

\section{UNIVERSITY OF CALIFORNIA LOS ANGELES}

SCHOOL OF LAW

LIBRARY 






\title{
THE CANADIAN TORRENS SYSTEM
}

WI'TH SPECIAL REFERENCE TO THE STATUTES OF MANITOBA, SASKATRHEWAN AND ALBERTA AND OF THE DOMINION OF CANAIA AND WITH A COLLECTION OF FORMS. STATUTES AND LEADING CASES

\author{
$\mathrm{BY}$ \\ DOLGLAS J. THON. B.A.
}

OF OSGOODE HALL, BARRISTER-AT-LAW, AND OF THE BAR OF SASKATCHEWAN

FORMERLY OF THE BAR OF THE NORTHWEST TERRITORIES

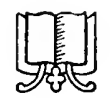

CALGARY

BURROUGHS AND COMPANY, LIMITED

LAW PUBLISHERS 
PRINTED BY

THE LEADER PCBLISHING COMPANY, LIMITED REGINA

COPYRIGHT, CANADA, 1912

BY BURROCGHS AND COMPANY, LIMITED 
To

THE HONOURABLE EDWARD LUDLOW WETMORE, LL.D.,

Chief Justice of Saskatchewan,

to whose learned and ceaseless industry during many years on the Bench the branch of law under discussion as well as the general law of Saskatchewan owes so much of its development, this work is (by his permission) dedicated by the author. 



\section{PREFACE}

The Torrens System of Land Transfer, while a product of Australia, has taken firm root in the provinces of Western Canada and, in fact, in two of these, the Provinces of Saskatchewan and Alberta, is being tested under the most satisfactory conditions, namely, where it is not only a system but the only system. The body of case law upon the system in Canada has of recent years, corresponding with the rapid development of Western Canada, been growing with great rapidity while, for the same reason, the attention not only of the legal profession but of the general public has been turned to a surprising degree to this branch of the law.

The time therefore seemed opportune for an attempt to collect and systematize the decisions on the Torrens Acts in Canada and to place side by side the various Acts so as to better understand them separately. A pioneer in such a work has no easy task with no prior work to build on except the annotations of Jones and Coutlee in the early days of the Acts in Canada. Mr. J. E. Hogg's masterly work on the Australian Torrens System has proved of invaluable assistance, but I have not attempted in the very limited time at my disposal the thorough analysis of the Canadian systems which that learned author has accomplished for Australia, and the scientific student of the Torrens System will not dispense with the careful reading of that work.

The reader will find explained in the first chapter why it is that only the Acts of Manitoba, Saskatchewan and Alberta and the Act of the Parliament of Canada governing the present Northwest Territories and the Yukon (referred to throughout the work as the "Dominion" Act) are dealt with. The latter Act, owing to the requirements of space and its close approxima tion to the Act of Saskatchewan, has not been set out in full.

I have to thank the many friends who have so kindly assisted me with valuable suggestions and criticism, my regret being that my desire to meet the requirements of the publishers 
in regard to time did not permit of more of such discussion and consideration. For assistance in the preparation of the converancing forms I am indebted to Mr. W. H. McEwen.

I fully realize the very many imperfections of the book. I trust, however, that the profession and my readers generally will take into consideration the difficulties already referred to and to some extent overlook and excuse. I venture to hope, however, that the practitioner will find useful suggestions for his work and that I have at least done a little toward the better general understanding of a system which is doing, and if built up on strong, broad lines, will continue to do so much for the rational and easy dealing with that kind of property, land, the law in regard to which has been so unreasonably intricate in the past under the Common Law as intermittently altered by statute.

DOUGLAS J. THOM.

Regina, July, 1912. 


\section{TABLE OF CONTENTS}

Preface.......................... v

Table of Contents . . . . . . . . . . . . . . . . . .

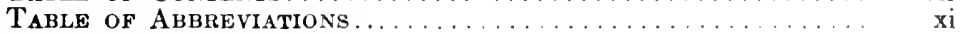

Table of Cases Cited ......................... xiii

\section{PART I.}

CHAPTER I.

INTRODUCTION.

Section 1. Estates in Land under Feudal System .............. 1

2. Method of Transfer under Feudal System......... 2

3. Effect of Statute of Uses. . . . . . . . . . . . . . . . 3

4. Effect of Later Statutes.................... 5

5. Defects of "Old System" ...................... 6

6. Origin and History of the Torrens System ......... 9

CHAPTER II.

The Machinery of the System.

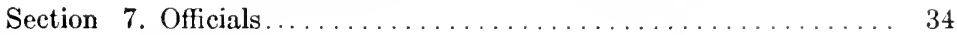

8. Books........................... 43

CHAPTER III.

Bringing Land Under the Systen.

Section 9. The Interests which Can be brought under the System ... 61

10. Proeedure on Application.................. 68

CHAPTER IV.

Registration.

Section 11. General Comments. . . . . . . . . . . . . . . . . . . . . 89

12. Functions of the Registrar ............... 92

13. Form and Contents of Instruments . . . . . . . . . 103

14. Necessity of producing Duplicate Certificate of Title .... 115

CHAPTER V.

The EFfect of Registration.

Section 15. Introduction....................... 118

16. The Effect of First Registration of Title ... . . . 122

17. The Effect of the granting of New Certificate of Title as against Unregistered Interests . . . . . . . . . . . . . 152

18. The Effect of the Registration of an Instrument . . . . . . 178 


\section{CHAPTER VI.}

\section{Remedies for the Recovery of LaNd.}

Section 19. Summary of Cases in which Land May be Recovered . . 194

20. Where Owner is Deprived of Land by Fraud......... 195

21. Where Owner is Deprived of Land by Misdescription . . . . 196

22. Where Registered Owner Claims under Instrument of Title Prior in Date . . . . . . . . . . . . . . . . . . 198

23. Where Persons Claim under Rights arising after Date of Certificate of Title of Registered Owner . . . . . . . . . . . 198

24. Where there has been Manifest Error . . . . . . . . . . . 199

\section{CHAPTER VII.}

The Assurance Fund.

Section 25. Nature of the Fund

27. Liabilities of the Fund

\section{CHAPTER VIII.}

Transfers.

Section 28. Purpose and Interpretation . . . . . . . . . . . . . . 228

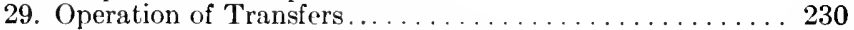

30. Interests which May be Transferred .............. 232

31. Distinguished from Conveyance.............. 232

32. Distinguished from Deed ................. 234

33. Implied Covenants. . . . . . . . . . . . . . . . . . 235

34. Necessity of Memorandum of Leases and Incumbrances. . 239

35. Restrictive Covenants in Transfers............. 240

\section{CHAPTER IX.}

Transmission.

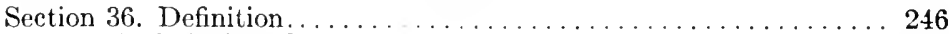

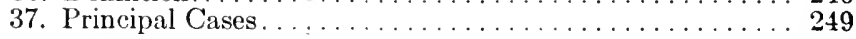

\section{CHAPTER X.}

Mortgages.

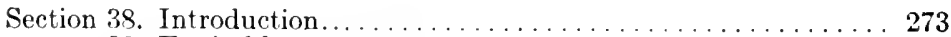

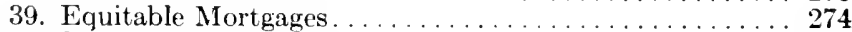

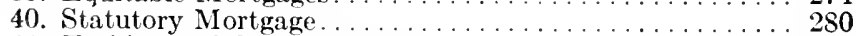

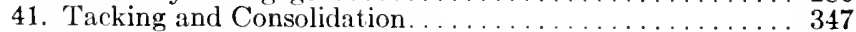

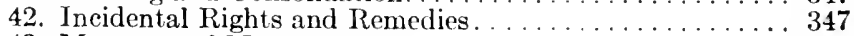

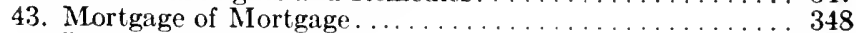

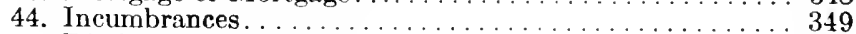

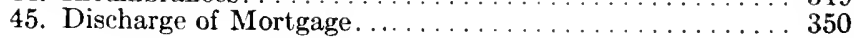

CHAPTER XI. 


\section{CHAPTER XII.}

\section{Caveats.}

Section 46. Purposes and Classes. . . . . . . . . . . . . . . 356

47. Caveats against Bringing Land under system . . . . . . 358

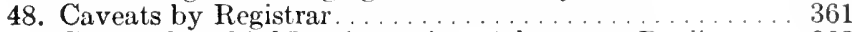

49. Caveats by Third Parties against subsequent Dealings... . 363

CHAPTER XIII.

Powers of Attorney.

\section{PART II.}

Appendix A. Statutes-Manitoba ................... 404

Saskatchewan ................. 465

Alberta....................... 551

Appendix B. Tariffs-Manitoba .................. 635

Saskatchewan................... 639

Alberta.......................6 645

\section{PART III.}

Appendix C. Additional Practice Forms . . . . . . . . . . . . . . 650

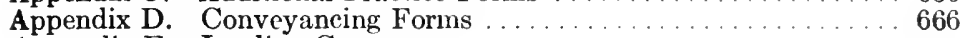
Appendix E. Leading Cases:

Gibbs v. Messer . ......... . . . . . . . . . . . . . . . . . . . . . . . 704

Assets Co. v. Mere Roihi ... . . . . . . . . . . . . . . 712

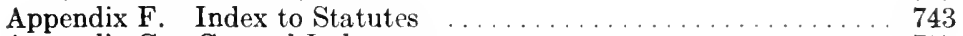

Appendix G. General Index . . . . . . . . . . . . . . . 757

Appendix H. Tabular Summary of Torrens Title Legislation:

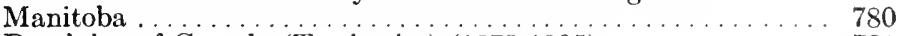

Dominion of Canada (Territories) $(1878-1905) \ldots \ldots \ldots \ldots \ldots 78$

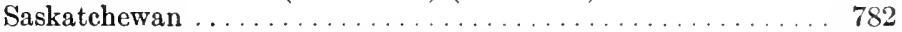

Alberta............................. 782

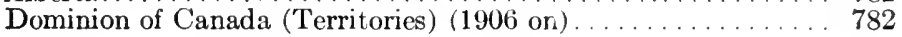





\section{TABLE OF ABBREVIATIONS}

[1...] A. C. Law Reports, Appeal Cases (1891 on).

A. L. R. Alberta Law Reports.

A. L. T. Australian Law Times.

A. R. Appeal Reports (Ontario).

A. J. R. Australian Jurist Reporta (Victoria, 1870-1874).

Amb. Ambler's Chancery Reports.

Anst. Anstruther's Reports, Exchequer.

B. C. R. British Columbia Reports.

Beav. Beavan's Rolls Court

Reports.

C. L. R. Commonwealth Law Reports (Australia).

C. L. T. or Can. L. T. Canadian Law Times.

C. O. Consolidated Ordinances (Northwest Territories).

Ch. D. Law Reports, Chancery Division (1875-1890).

[1...] Ch. Law Reports, Chancery Division (1891 on).

Cyc. Cyclopaedia of Law and Proeedure.

DeG. \& J. DeGex \& Jones' Chancery Reports.

Drew. Drewry's Vice Chancellor's Reports (1852-1859).

E. \& B. Ellis \& Blackburn's Queen's Bench Reports.

Ex. Welsby, Hurlstone \& Gordon's Exchequer Reports (18471856).

Ex. D. Law Reports, Exchequer Divisions.

F. C. Full Court.

Gr. Grant's Upper Canada Chancery Reports.

H. L. C. House of Lords Cases (1847-1866).

H. \& N. Hurlstone \& Norman's Exchequer Reports.

Ha. Hare's Chancery Reports. Hogg. Australian Torrens System, by J. E. Hogg.

Hunter. Hunter's Torrens Title Cases ('Toronto, 1898).

Jur. N. S. Jurist, New Series.
L. J. K. B. Law Journal, King's Bench.

L. J. Q. B. Law Journal, New Series, Queen's Bench (1831 on).

L. J. P. C. Law Journal, New Series, Privy Coumcil.

L. R. A. C. Law Reports, Appeal Cases.

L. R. (Ch.) Law Reports, Chancery Appeal Cases (1866-1875).

L. R. (Ch. D.) Law Reports, Chancery Division.

L. R. (Eq.) Law Reports, Equity (1866-1875).

L. R. (Ex.) Law Reports, Exchequer (1866-1875).

L. R. (H. L.) Law Reports, House of Lords.

L. T. Law Times Reports.

IM. L. R. or Man. L. R. Manitoba Law Reports.

M. \& G. Manning \& Granger's Reports, Common Pleas (1840$18+5)$.

M. \& W. Meeson \& Welsby's Exchequer Reports.

Madd. Maddock's Reports, Chancery.

Mac. \& G. Macnaghten \& Gordon's Chancery Reports.

Myl. \& K. Mylne \& Keens' Chancery Reports.

N. B. R. New Brunswick Reports.

N. S. W. or N. S. W. L. R. New South Wales Reports, Old and New Series.

N. S. W. Eq. or N. S. W. L. R. Eq. New South Wales Equity Reports.

N. W. T. Northwest Territories.

N. Z. Gaz. L. R. New Zealand Gazette Law Reports (1898 on).

N. Z. Jur. N. S. New Zealand Jurist Reports, New Series (18751878).

N. Z. L. R. New Zealand Law Reports.

N. Z. L. R. C. A. New Zealand Law Reports, Court of Appeal.

N. Z. L. R. S. C. New Zealand Law Reports, Supreme Court. 
O. A. R. Ontario Appeal Reports.

O. L. R. Ontario Law Reports.

O. R. Ontario Reports.

P. R. Practice Reports (Ontairio).

Phill. Phillipps' Chancery Reports

Q. B. Queen's Bench Reports (Adolphus of Ellis, New series, 1841-1852).

[1...] Q. B. Law Reports, Queen's Bench (1s91 on).

Q. B. D. Queen's Bench Division, Law Reports (1876-1890).

Q. L. J. Queensland Law Journal (Australia).

R. S. C. Revised Statutes of Canada.

R. S. M. Revised Statutes of Manitoba.

R. S. O. Revised Statutes of Ontario.

R. S. S. Revised Statutes of Taskitchewan.

S. A. L. R. South Australian Law Reports.

S. A. R. South Australian Register (newspaper).

S. C. Can. Supreme Court of Canada.

S. C. R. Supreme Court of Canada Reports.

S. C. R. [N. S. W.] Supreme Court Reports, New South Wales (1862-1876).
S. L. R. or Sask. L. R. Saskatchewan Law Reports.

S. R. [N. S. W.] State Reports, New south Wales.

S. R. [Q.] State Reports, Queensland (Australia).

T. A. D. Torrens Australasian Digest.

Tas. L. R. Tasmanian Law Reports.

Terr. L. R. Territories Law Reports (Northwest Territories of Canada).

U. C. C. P. Upper Canada Common Pleas Revorts.

U. C. R. L Lper Canada Queen's Bench Reports.

V. L. R. Victorian Law Reports (1575 on).

V. R. Vietorian Reports (18701572.

Ves. Tesey's Chaneery Reports. W. Bl. sir William Blackstone's King's Bench Reports.

W. L. R. Western Law Reporter Canada).

W. N. [N. S. W.] Weekly Notes, New south Wales (185t on).

W. W. and A'B. Wratt, Webb d A'Beckett's Reports (Australia).

W. W. R. Western Weekly Reports (Canada).

Wh. \& Tu. L. C. White \& Tudor's Leading Citses in Equity. 


\section{TABLE OF CASES CITED}

\section{A}

Acme Co. v. Huxley, (1911) 18 W. L R. 534: affirmer 20 W. L. R.

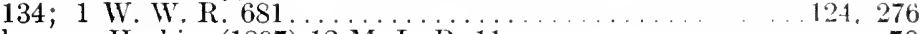

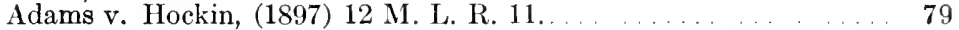

Agency Co. v. Short, 13 A. C. $793 \ldots \ldots \ldots \ldots \ldots \ldots \ldots \ldots$

Alder v. Lelion, (1909) 11 W. L. R. $23 \ldots \ldots \ldots \ldots \ldots \ldots \ldots \ldots \ldots 152$

Alexander v. Gesman, (1911) 17 W. L. R. 184; affirmed s. C. Can., I W. W. R. 873; T. A. D. 21; Hogg, 717; Hunter, 403. . 123, 392, 393

Alexander v. McKillop and Benjafield, 4 S. L. R. 111; affirmed 45 S. C. R. 551; 1 W. W. R. 873....123, 372, 381, 382, 392, 395, 397 Allen, In re, 22 V. L. R. 24 (full court) .......62, 125, 145, 149, 201 Alloway v. Rural Municipality of St. Andrews, (1905) 15 M. L. R.

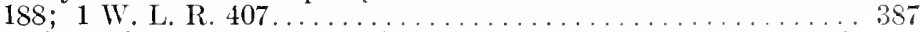

American Abell Engine \& Thresher Co. v. MeMillan, (1909) 10 W. L. R. 239 ; affimed 19 M. L. P. $97 ; 11$ W. L. R. 185; affirmed 42

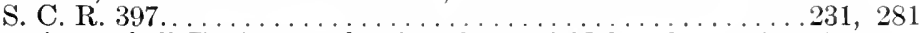
American Abell Engine \& Thresher Co. and Noble, In re, (1906) 3 W. L. R. 324; 6 Terr. L. R. 359

Anderton, In re, (1908) \& W. L. R. 319

Armitage, In re, 17 V. L. R. 17; Hunter, 393

Armstrong v. Auger, (1891) 21 O. R. 98.

Arnot and Smith v. Peterson, (1912) 2 W. W. R. 1 (Alta.) . . . . 177,

Assets Co. Ltd. v. Mere Roihi, 74 L. J. P. C. 49; (1905) A. C. 176; 92 L. T. $397 \ldots \ldots \ldots \ldots \ldots \ldots \ldots 66,69,96,102,120,153,157$,

Attorney General v. Montefiore, (1888) 21 Q. B. D. $461 \ldots \ldots . .210$

Attorney General v. Odell, $(1906) 2$ Ch. 47 ................ 191, 214

Attorney General v. Sibthorp, Mayor of, (1858) 3 H. \& N. 424 . . . 210

Auriol v. Alberta Land \& Investment Co., (1912) 1 W. W. R. 787:

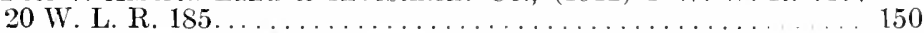

Australian Deposit \& Mortgage Bank v. Lord, 2 V. L. R. 31 . 237

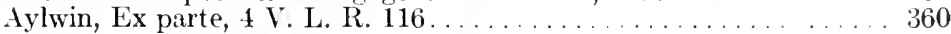

\section{B}

Babbitt and Boileau, In re, (1907) $6 \mathrm{~W}$. L. R. $260 \ldots \ldots \ldots \ldots . \ldots 283$

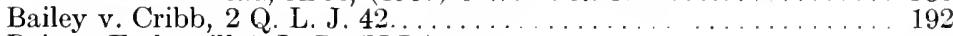

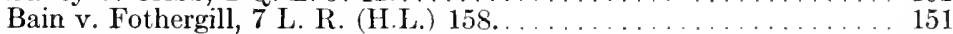

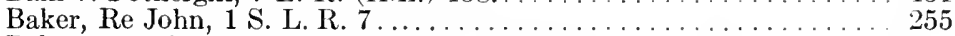

Baker v. Ambrose, 65 L. J. Q. B. $589 ;(1896) 2$ Q. B. $372 \ldots \ldots \ldots .114$

Baker v. Gillum, (1908) 9 W. L. R. 436................ 261

Baker Creek Gold Mining Co. v. Hack, 15 N. S. W. I. R. Eq. 207 . 175

Bank of Montreal v. Fox, 6 P. R. 217................ 50

Bank of Victoria v. McMlichael, \& V. L. R. 11; Hunter $406 \ldots \ldots \ldots 113$

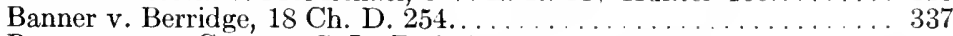

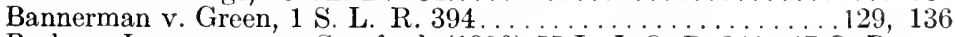

Barbers, In re, ex parte Stanford, (1886) 55 L. J. Q. B. 341 ; 17 Q. B.

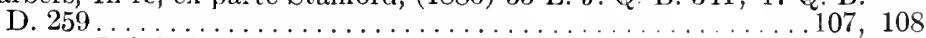

Barne v. Baird, (1904) 15 Man. L. R. $162 \ldots \ldots \ldots \ldots \ldots \ldots \ldots$. . . . . . . 344

Barthels, Shewan \& Co. Ltd. v. Winnipeg Cigar Co., (1909) 10 W. L. R. 263. 
Bartlett, In re, 4 Tas. L. R. $26 \ldots \ldots \ldots \ldots \ldots \ldots \ldots \ldots \ldots \ldots \ldots$

Bartlett v. Gibbs, 5 M. \& G $81 \ldots \ldots \ldots \ldots \ldots \ldots \ldots \ldots \ldots \ldots \ldots \ldots$

Bartlett v. Jull, 2S Gr. 140... . . . . . . . . . . . . . . . . 320, 323

Bashford v. Bott, (1909) 12 W. L. R. 42s; 2 s. L. R. $461 \ldots \ldots 390,391$

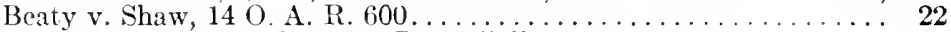

Beckett, In re, 15 N. S. W. L. R. 94 (full eourt) ........... 72

Beere v. Northern Bank, (1908) 7 W. L. R. 432 (Alta.) .......... 201

Belize Estate \& Produce Co. v. Quilter, 66 L. J. P. C. 53; (1897)

A. C. $367 ; 78$ L. T. $361 \ldots \ldots \ldots \ldots \ldots \ldots \ldots \ldots \ldots 2,125,143$

Bell, In re, Lake v. Bell, 34 Ch. D. $462 \ldots \ldots \ldots \ldots \ldots \ldots \ldots \ldots \ldots 38$

Bellamy v. Sabine, 1 DeG. \& J. $566 \ldots \ldots \ldots \ldots \ldots \ldots \ldots \ldots \ldots$

Benjamin, In re, (1S77) 2 N. Z. Jur. X. S. 163; T. A. D. $62 \ldots \ldots 200$

Bennett v. Gilmour, (1906) 4 W. L. R. 196; 16 M. L. R. $304 \ldots . . .230$

Bethune v. Porteous, (1S91) 14 A. L. T. 265; Hunter, 553...... 56

Bielfeld, In re, 12 N. Z. L. R. $596 \ldots \ldots \ldots \ldots \ldots \ldots \ldots \ldots \ldots \ldots . \ldots \ldots$

Bireh v. Ellames, 2 Anst. 428 . . . . . . . . . . . . . . . . . . 307

Blackwell v. Davy, \& N. Z. L. R. 129 …...........209, 218

Blanchard Estate, In re Land Titles Aet and, (1901) j Terr. L. R. 240

259,260

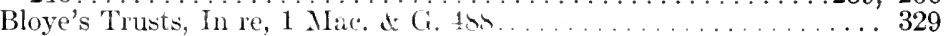

Blunt v. Marsh, (1sss) 1 Terr. L. R. 12t................278, 280

Boardman v. Handley, (1S99) 4 Terr L. K. $266 \ldots \ldots \ldots \ldots \ldots .278$

Boez v. Spiller, (1905) 1 IT. L. R. 366; affirmed 2 IT. L. R. 280...

$258,261,339$

Bond, Ex parte, (1s\$0) 6 V. L. R. 458; Hunter, 257 .......39, 94, 199

Bowman, Ex parte, 7 V. L. R. 314 (full court); Hunter, 383 . .66, 86, 102 Boyd v. MeFarlane, 1 N. Z. L. R. S. C. $347 \ldots \ldots \ldots \ldots \ldots \ldots \ldots$ Bradshaw v. Patterson, (1911) 18 W. L. R. 402...67, 6S, 141, 144, 146 Bradshaw's Title, In re, Master of Titles (Sask.), Aug, 16, 1910 . . . 66 67 Breithaupt v. Marr, 20 A. R. $6 \$ 9 \ldots \ldots \ldots \ldots \ldots \ldots \ldots \ldots . \ldots 264,339$ British Canadian Loan Co. r. Tear, (1S93) 23 O. R. 664........ 238 Brooks, In re, (1909) 2 S. L. R. 504; 12 W. L. R. 303....... 140, 270 Brooksbank v. Burn, 15 W. L. R. 661 (Alta.) ...............392-395 Brown, Ex parte, 5 V. L. R. (L) $5 \ldots \ldots \ldots \ldots \ldots \ldots \ldots \ldots \ldots \ldots$ Brown, In re, (1904) 3 s. L. R. 94; 12 W. L. R. 6s7; 7 Terr. L. R. 67268 Brown v. Dean, (1910) 79 L. J. K. B. 690 ... .............. 327 Brunswick, Mayor of, v. Dawson, (1879) 5 V. L. R. 2 ; Hunter, 179.241 Buchanan, In re, (1899) 12 N. L. R. 612.................. 200 Budgett, In re, Cooper r Adams, (1894) 2 Ch. $557 \ldots . . . \ldots . . .369$ Burton, In re, ex parte Union Bank of Australia Ltd., 27 V. L. R.

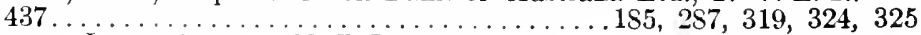
Bygum, In re, (1595) $13 \mathrm{X}$. Z. L. I. $270 \ldots \ldots \ldots \ldots \ldots \ldots$

Callaway v Platt, (1907) 17 M. L. R. 4S5; 6 W. L. R. $467 \ldots \ldots \ldots .67$

Cameron v. Mcllroy, 1 M. L. R. 242 . . . . . . . . . . . . . 330

Cameron v. Rutledge, (1905) 2 W. L. R. $473 \ldots \ldots \ldots \ldots \ldots \ldots \ldots \ldots . \ldots . \ldots 312$

Campbell v. Alloway, (1892) \& NI. L. R. 224 ............... 83

Campbell v. Auckland District Land Registrar, (1910) 29 X. Z. L. R.

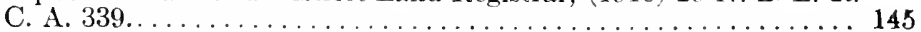

Campbell v. Bank of New south ir ales, 11 A. C. 192; affirming 16 N. S. W. Eq. $285 \ldots \ldots \ldots \ldots \ldots \ldots \ldots \ldots \ldots \ldots \ldots \ldots \ldots \ldots \ldots \ldots$

Campbell v. Commereial Bank of Sydney, referred to 4 L. R. (A. C.)

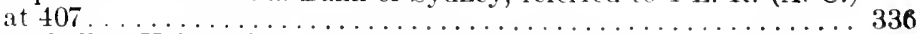

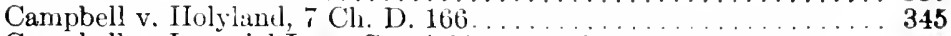

Campbell v. Imperial Loan Co., (1908) s Ki. L. R. 502 (IIan.) . . . . 146

Campbell v. Jarrett, 7 V. L. R. 137; Hunter, $313 \ldots \ldots . . . \ldots .149$ 
Canada Life Assurance Co. v. Registrar Assiniboia L. R. D., 21 II . I. R. 469

Canada Life Assurance Co. v. Vance, 12 W. L. R. $231 \ldots \ldots \ldots \ldots . .305$

Canada Permanent Mortgage Corporation r. Jesse, (1909) 11 W. L. R. 295.

Canada Permanent Mortgage Corporation $\mathrm{v}$. Martin, (1909) $2 \mathrm{~S}$. L. R. 472 .

Canadian Pacific Ry. Co., In re Land Titles iet and, (1899) 4 Terr.

L. R. 227 .

Canadian Pacific Ry. Co. v. Mang, (1908) 8 W. L. R. 774 (Sask).97, 319

Canadian Pacific Ry. Co. v. Silzer, (1910) 3 S. L. R. 162.

$258,261,262,401$

Canadian Pacific Ry. Co. v. St. Therese, (1889) 16 S. C. R. 606 .... 43

Canadian Pacific Ry. Co. and Doupe's Transfer, In re, unreported, Master of Titles, (Sask.) Feb. 6, 1911................... 241

Capital \& Counties Bank v. Rhodes, 72 L. J. Ch. 336; (1903) 1 Ch. $631 ; 88$ L. T. 255.

Carter v. Wake, 4 Ch. D. 605 .

Case Threshing Machine Co. and Fisher, In re J. I., (1911) 1 W. W. $129 ; 19$ W. L. R. 701 . . . . . . . . . . . 119, 131, 340, 341

Cass and Canada Traders Ltd., In re, (1910) 15 W. L. R. 194; 20

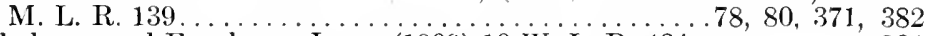

Chalmers and Freedman, In re, (1909) 10 W. L. R. $434 \ldots \ldots \ldots \ldots 304$

Chapman v. Edwards, (1911) 19 W. L. R. 266; 1 W. W. R. 59 . . . 167

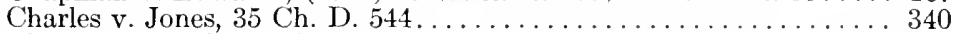

Chomley v. Firebrace, (1879) 5 V. L. R. (E) 57 ; Hunter, 98 . 105, 119, 157

City of Halifax v. James Reeves, (1894) 23 S. C. R. 340......... 43

Clagstone \& Hammond, In re, 2S O. R. 409 . . . . . . . . . . 363

Clarke, Ex parte, (1891) 17 V. L. R. 82; Hunter, 118. . . . . . . . . 152

Clarke v. Scott, (1888) 5 M. L. R. 2S1 . . . . . . . . . . . 79, 80

Claxton, In re, (1890) 1 Terr. L. R. 282 . . . 51, 53. 75, 100, 101, 259

Clendenan, In re, (1911) 18 O. W. R. $666 \ldots \ldots \ldots \ldots \ldots \ldots \ldots \ldots 256$

Codville v. Haygarth, 10 W. L. R. $35 \ldots \ldots \ldots \ldots \ldots \ldots \ldots \ldots \ldots \ldots$

Colechin v. Wade, (187S) 3 V. L. R. (E) 266 ; Hunter, $278 \ldots \ldots \ldots 140$

Coleman v. De Lissa, 6 N. S. W. L. R. Eq. $104 \ldots . . . . . . . . . . .269$

Coleman and Clarke v. Riria Puwhanga, 4 N. Z. L. R. S. C. $230 \ldots 192$

Colonial Bank v. Riddel, 19 V. L. R. $280 \ldots \ldots \ldots \ldots \ldots \ldots \ldots \ldots . \ldots . \ldots 269$

Colonial Investment \& Loan Co. v. Foisie et al., (1911) 19 W. L. R.

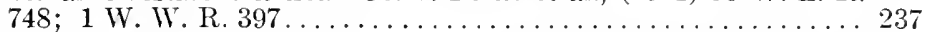

Colonial Investment \& Loan Co. v. King et al., (1902) 5 Terr. L. R. $371 \ldots \ldots \ldots \ldots \ldots \ldots \ldots \ldots \ldots \ldots$................. $312,315,316$,

Commercial Bank v. Breen, 15 V. L. R. 572 ; Hunter, 407. . . . . 299

Common v. Rees, 9 N. Z. L. R. C. A $555 \ldots \ldots \ldots \ldots \ldots \ldots \ldots \ldots \ldots 152$

Cooke v. Union Bank, (1893) 14 N. S. W. L. R. Eq. $280 \ldots \ldots \ldots \ldots 169$

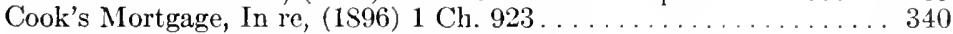

Cooper v. Anderson, (1912) 20 W. L. R. $347 \ldots \ldots \ldots \ldots \ldots \ldots 176,177$

Cote v. Olson, (1912) 20 W. L. R. 690 ; reversing 19 W. L. R. $364 \ldots 237$

Coventry v. Annable, (1911) 17 W. L. R. 577; 4S. L. R. 176; affirmed 1 W. W. R. 148; 19 W. L. R. 400; affirmed S. C. Can., 2 W. W. R. $816 \ldots \ldots \ldots \ldots \ldots \ldots \ldots \ldots 6,148,155,156,162,171,231$

Cowell v. Stacey, 13 V. L. R. 80 ; Hunter, $355 \ldots \ldots \ldots \ldots \ldots \ldots \ldots 175$

Cox v. Bourne, \& Q. L. J. $66 \ldots \ldots \ldots \ldots \ldots \ldots \ldots \ldots \ldots \ldots \ldots \ldots \ldots \ldots \ldots \ldots$

Crow v. Campbell, 10 V. L. R. (E) $186 \ldots \ldots \ldots \ldots \ldots \ldots \ldots \ldots \ldots$

Crowley v. Bergtheil, (1899) A. C. $390 ; 68$ L. J. P. C. $81 \ldots \ldots .131,134$

Cullen v. Thompson, (1879) 5 V. L. R. (E) 147; Hunter, $322 \ldots \ldots \ldots 167$

Cumberland v. Cairns, (1889) 18 O. R. 151; 17 A. R. 281 ....... 50

Cummings v. Semerad, (1908) 8 W. L. R. $644 \ldots \ldots \ldots \ldots \ldots \ldots \ldots . \ldots 329$ 


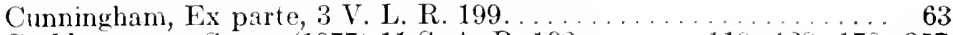

Cuthbertson Y. Swan, (1877) 11 S. A. R. 102......119, 128, 178, 357

D'Albedyhill v. D'Albedyhill, 3 N. Z. L. R. S. C. 391 ; T. A. D. 49. 365

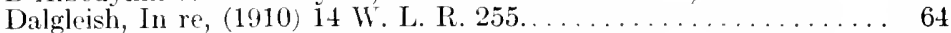

D'Arey v. Tamar, Kit Hill \& Callington Ry. Co., 2 L. R. (Lx.) 15S.. 113

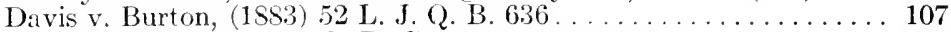

Davy, Ex parte, 6 N. Z. L. R. C. A. $760 \ldots \ldots \ldots \ldots \ldots \ldots . \ldots \ldots 2$

Dawkins v. Penrhyn (Lord), (1878) 4 A. C. 51 . . .......... 124

Dean and Chapter of st. John's Cathedral v. MacArthur, (is93) 9 M.

L. R. 391 .

Deane, In re, !) Q. L. J. 106.

Deering v. Gibbon, 7 W. L. R. 17s. . . . . . . . . . . 259

Derry v. Peek, (1s94) 14 A. C. 337 ; jo L. J. Ch. 864 ; 51 L. T. 265 . 167

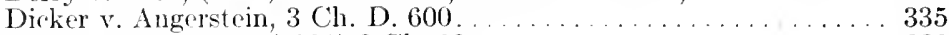

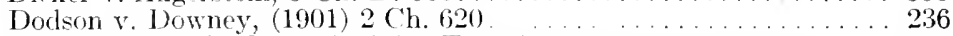

Donelly Tax suate, In re, (1902) 5 Terr. L. R. $270 \ldots \ldots \ldots \ldots .255$

Doupe's Transfer, In re, unreported, Master of Titles (Sask.), Feb. 6, 1911.

Downs y ( a

Drew's Estate, In re, Mason's Clain. 35 L. J. C'l. at5; 35 Bear. 343;

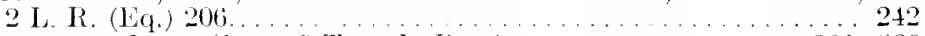

Dumaurez, In re, (1s99) 5 Terr. L. R. S . . . . . 261, 339

Dunn v. Alexander, (1912) 1 W. W. R 1117 ; 20 W. L. R. 902 . . . 150

\section{E}

Ebbing, In re, (1999) 2 ‥ L. R. 167; 11 II. L. R. 29 . . .75, 93, 101, $281,359,370-372,388,391,401$

Eeeles v. Hall, (1894) 13 N. Z. L. R. C. A. 433............... 169

Edmonds v. Ilamilton ['rovident \& Loan toriety, is A. R. $347 \ldots 303$

Edmonton Mortgage Co. v. (Gross, (1911) 15 W. L. R. 385. 140, 261, 339

Empire Loan ('o. and loung's Mort gage, In re, unreported (full court,

Sask.), Juiy 17, 1911, affirming Milligan, M. T.

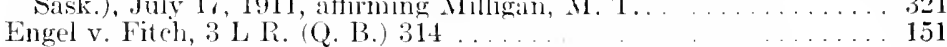

Entwisle v. Lenz, (1908) 9 W. L. R. 317; 1+ B. C. R. 51. . . . . 182

Equity Trustees Executors and Ageney (o. Ltd. and O'Halloran, Ex parte, (1911) V. L. R. 197.

Evans r. Postill, (1910) 3 A. 1. IR. 1tt. . . . 258, 339

\section{$F$}

Falkner v. Equitable Reversionary Śociety, 4 Drew. 352; 28 L. J. Ch. 132.

Fallis v. Bathatsar, (1912) 2 UI. II R. 132 (Altit.)

Farah v. Glen Lake Mining ('o., (1907) 17 O. L. R. 1

Farrars v. Farrars Ltd., 40 Ch. D). 395

Farrer v. Lary, Jartland \& Co., 25 L. R. (Cl. 1), 630 . . . . . 330

Farrington v. Smith. (1894) 20 V. L R. 90...

Fawkes v. Attorney General, (1903) 6 O. L. R. $490, \quad 209,215$

Featherstone v. Hanlon, (1Ssi) Barlger, Real Property Digest, 4; T. A. D. 9 .

Fels v. Knowles, 26 X. L. L. R. ( A. (6)t

Fernie v. Kennedv, (1910) 13 IT. L. R. 437

401

Fialkowski v. Fialkowsli and Traders Bank, (1911) 1 il. ii. R. 216; 19 W. L. R. $614 \ldots \ldots \ldots \ldots \ldots \ldots .177,192$

Fink, In re, (1910) V. L. R. 337. . . . . 140 
Fink v. Robertson, (1907) 4 C. L. R. $864 \ldots \ldots \ldots \ldots$

138,236

$305,315,316,345,346$

Finklestein v. Locke, (1907) 6 W. L. R. 173 (Man.) . . . . . . . . . 334

Finucane v. Registrar of Titles, (1902) S. R. (Q) 75 (full court) . . . . 209

Fish v. Bryee, (1909) 10 W. L. R. 616; 2 S. L. R. $111 \ldots .154,157,162$

Flannaghan v. Healey, (1900) 4 Terr. L. R. $391 \ldots \ldots \ldots \ldots \ldots \ldots 281$

Flureau v. Thornhill, 2 W. Bl. 1078... ............. 151

Fonseea v. Jones, (1910) 14 W. L. R. 14 S (Man.) . .... 157

Formby v. Barker, (1903) 2 Ch. $539 \ldots \ldots \ldots \ldots \ldots \ldots \ldots . \ldots \ldots$

Forster v. Ivey, (1901) 2 O. L. R. 480 _ _ _ 320

Foster v. Stiffler, (1910) 19 M. L. R. 533 _. . . $\quad 230$

Fowke v. Drayeott, 29 Ch. D. $996 \ldots 281$

Fox v. Hunter, (1909) 12 W. 1. R. \$7. . . 329

Franklin v. Ind., 17 S. A. R. $133 \ldots . . .57$

Fraser v. Douglas, (1908) 40 S. C. R. 34t … ‥ 140

Fredericks v. Northwest 'Thresher' Co., (1910) 3 s. L. R. 2s0; 15

W. L. R. 66; affirmed 44 S. C. R. 318 ...... 258-261

Freshfield v. Reed, 9 M. \& W. 404 .......... . 113

Frost v. Driver, (1894) 10 M. L. R. 209 _ . 387

Frost v. Driver, (1894) 10 M. L. R. 319... . 257

Fry v. Lane, 40 Ch. D. $313 \ldots \ldots \ldots \ldots \ldots \ldots$

$\mathrm{G}-$ In re, (1891) 21 O. R. 109

Gaar Scott Co. v. Giugere, (1909) 12 W. I. R. 245; 2 S. L. R. 374

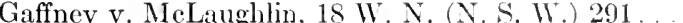

Galloway, In re, (1S98) 3 Terr. L. R S8 . . . . . 254. 255

General Finanee Ageney and Guarantee Co. of Australia Ltd. v. Perpetual Executors and Trustees Association of Australia Ltd., (1902) 27 V. L. R. 739 .

George v. Aust. Mutual l'rovident Soeiety, + N. \%. L. R. S. C. 165 172

Gibbs v. Messer, 60 L. J. P. C. 20; (1891) A. C. 248; 64 L. T. 237

Gilbert v. Bourne, 6 (2. L. J. 271 $91,124,139,160-162,191,214-216,235$

Gilbert v. Ullerich (Reeves \& Co.), (1911) 4 s. L. R. 56 ; 16 W. L. R. 490 ; affirmed 4 S. L. R. 97; 17 IV. L. R. $157 \ldots \ldots .119,128$, $129,132,275,321,339,387,392$

Giles v. Hamilton Provident \& Loan Society, (1895) 10 M. I. R. 567338

Gilmore v. Callies, (1911) 19 W. L. R. 545 ............... 261

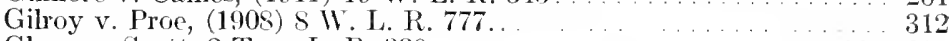

Glenn v. Seott, 2 Ter'r. L. R. $339 \ldots \ldots+238,239$

Goddard v. Slingerland, (1911) 18 W. L. R. $324 \ldots \ldots \ldots \ldots \ldots 1$

Graham v. Hamilton, (1892) \& M. L. P. $443 \ldots \ldots \ldots \ldots \ldots 2,83$

Grahn v. Litwin, (1911) 19 W. L. R. 144 (Sask.) . . . . . . . . 170

Grant v. Hunter, (1890) 6 M. I. R. $550 \ldots \ldots \ldots \ldots \ldots \ldots$

Grant v. Hunter, 6 M. L. R. $610 \ldots \ldots \ldots \ldots \ldots \ldots \ldots \ldots \ldots \ldots \ldots \ldots \ldots$

Grant v. II

Graves, Ex parte, 7 N Z. Gaz. L. R. 31 s … …

Graydon and Hanmill, In re, (1890) 20 O. R. 199 $\quad 30$

Great West Furniture Co. and Northern Crown Bank's Lease, Master of Titles (Sask.), Oet. 18, 1910 ........................ 108

Greenshields Co., In re, (1905) 6 Terr. L. R. 208 ; 2 W. L. R. $421 \ldots$

Gregory v. Alger, (1893) 15 A. L. T. 22; Hunter, 532 44, 110, 116

Grieg v Waten

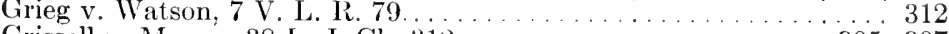

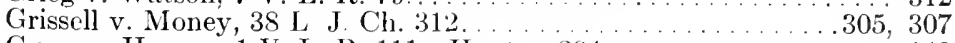

Gunn v. Harvey, 1 V. I. R. 111; Hunter, $294 \ldots \ldots \ldots \ldots \ldots \ldots \ldots . . . . .149$ 


\section{$\mathrm{H}$}

Halifax, City of, v. James Reeves, (1894) 23 S. C. R. 340. . . . . . 43 Hall v. Registrar Yorkt on L. R. D., (1911) 16 W. L. R. 568 (Sask.) 44, 218 Halsted v. Conklin, 3 M. L. R. \& . . . . . . . . . . . . . . 329 Hamilton, Ex parte, 3 S. C. R. (N. S. W.) 311 (full court); T. A. D. 2171 Hamilton v. Iredale, 3 S. R. (N. S. W.) $535 \ldots \ldots \ldots \ldots \ldots \ldots 197,220$ Hamilton v. MeCuaig, (1911) 18 IT. L. R. 84 (sask.) . . . . . . . 261 Hardy v. Desjarlais, (1892) 8 M. L. R. 670 . . . . . . . . . . 83 Harris v. Keith, (1911) 16 W. L. R. 431 (Alta.) ...........143, 144 Hart v. Stratton, (1873) 7 S. A. R. St _ . . . . . . . . 302 Hay v. Nixon, (1891) 7 M. L. R. $579 \ldots \ldots \ldots \ldots \ldots \ldots \ldots \ldots$ Hazen, Doe d. v. Hazen, 3 N. B. R. S7. . . . . . . . . . . . . 260 Heath v. Pugh, T Q. I3. D. 345..... . . . . . . . . . . 281 Hebert and O'Brien, In ro, (1907) 9 O. W. R. 172 . . . . . . . . 384 Henderson v. Astwood, (1594) A. C. $150 \ldots \ldots . \ldots . \ldots 329$ Herlert and Gibson, In re, (1889) 6 M. L. R. 191 ... . . . . . . 134

Hetherington, In re, $(1910) 3 \mathrm{~s}$. L R. 232 . . . . . . . . . . 261

Hextall v. I’. IBurns d Ston, unreported, Stuart, J., (Alta.), Sept. 23, 1911.

Hicks v. Laidlat, (1911) 1 W. W. IR. 293; 19 W. L. R. 525; affirmed 1 W. IV. R. $1009 ; 20$ W. L. R. $479 \ldots \ldots \ldots \ldots . . . . . .147,380,387$

IIobbs v. Ontario Loan \& Debenture Co., (1১90) 1s S. C. R. 483. . . 293

Hobson v. Mell, 2 Beav. $17 \ldots \ldots \ldots \ldots \ldots \ldots \ldots . \ldots \ldots . \ldots \ldots$

Hooper v. Smith, (1905) 2 W. L. K. $194 \ldots \ldots \ldots$. $153,172,173$

Horne v. Horne 26 X.Z. 1. IR. C. A. 120s …185, 189, 252, 355

Hosken $v$. Danaher, (1911) V. L. R. 214 . . . . . . . 255

Howard v. High River Trading Co., (1898) + Terr. L. R. 109. ..264, 339

Howell $r$. Montgomery, (1892) \& M. L. R. 499 ............. 80

Howell $v$. Cnion Bank of Australia Ltd., f N. Z. L R. S. C. 567 . . .386, 401

Hudson's Bay Co v. Kearns d Rowling, 3 B. C. R. 330; 4. B. C. R.

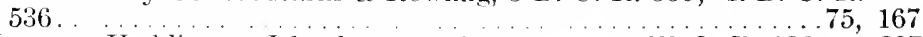

Huson v. Haddington Island ouary (o., (1911) 16 W. L. R. 226. . 327

Imperial Elevator ('o. v. Shere, (1910) 3. S. L. R. 197.

Independent Lumber Co. v. Bocz, (1911) $16 \mathrm{~W}$. L. R. 316 ; 4 S. L. R. 103 .

261

Independent Lumber ( o. v. David and Ifurlburt, (1911) 1 W. IV. R. 131 (Sask.)

Independent Lumber ( o. v. (iardiner, 3S. L. R. 140

Independent Lumber Co.'s Mechanics' Lien, In re, unreported, New-

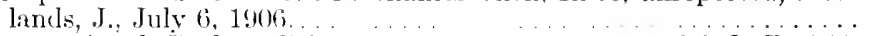

International Coal \& Coke (o. v. Lrans, (190s) y W. L. R. T11; affirmed 11 W. L. R. 463...................14, 241, 245

International coal \& coke Co. v. Trelle, $(1907)$ - W. L. R. $264 \ldots .240$

Iredale v. MeIntyre, (1901) 14 M. L. R. 20.5. . . . . . . . so so

Irish, In re, $(1855) 2$ M. L. R. $361 . \quad \ldots \ldots \ldots 63,69$

Irving r. Boyd, 15 (ir. $15 \%$.

\section{.}


John Abell Engine \& Machine Works Co. Ltd. v. Scott, (1907) 6

Terr. L. R. 302; 6 W. L. R. 272 .............. 42, 261, 268 Johnson, Ex parte, (1867) 5 W. IT \& A'B. 55 (Vic.); Hunter, 343

Jones v. Simpson, (1892) \& M. I. R. 124

$55,241.364$

Joyce v. Scarry, In re, (1ss9) 6 M. I. R. 2s1 . . . . . . . . . . 40

Kaihu Valley Ry. Co. and Owen, In re, s X. Z. L. R. C. A. 522 . . 95

Kay and White silver Co., In re, (1907) 90. W. R. 712. 372

Kearsley v. Phillips, 11 Q. B. D. 621..... . . . . . 293

Kelly v. Colonial Investment Co., (1906) ;) W. L. R. 62 . 108, 121, 237, 286

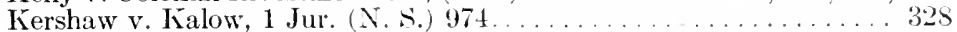

Kettleson's Transfer and La Corporation des Rev. Peres (Oblats, In re, unreported, Scott J., Feb. 26, 1897, (N. W. T. . . 112

Kingsland, In re, 8 P. R. $77 \ldots . . . .338$

Kinnaird v. Trollope, 39 Ch D. $636 \ldots \ldots \ldots \ldots \ldots \ldots \ldots$

Kintz Mortgage, In re, Master of Titles (Sask.) Dee. 14, $1911 \ldots . .109$

Kissling v. Mitchelson, 3 N. Z. L. R. C. A. 261; T. A. D. 172 . 38, 100

Kny v. Price et al., 24 N. Z. L. R. 291 .... . 172

Kolp v. Hunter, (1911) 19 W. I. R. 709 (Sask.) . . $\quad \ldots \quad \ldots 170$

La Corporation Episcopale Catholique Romaine de Saskatchewan, In re, unreported, Milligan, M. T., Dec. 21, 1910

Lake $\mathrm{V}$. Jones, $15 \mathrm{~V}$. $\mathrm{R}, 72 \mathrm{~S}$

Land Titles Act and Blanchard Estate, In re, (1901) 5 Terr. L. R.

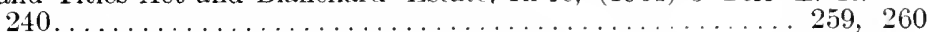

Land Titles Act and Canadian Pacific Ry. Co., In re, (1S99) 4 Terr. L.

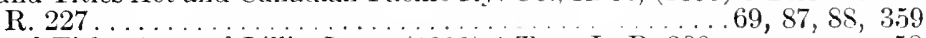

Land Titles Act and Lillis, In re, (1899) 4 Terr L. R. $300 \ldots \ldots \ldots . . .58$

Langan v. Newberry, (1911) 18 W. L. R. 458 ; reversed 20 W. L. R. $827 \ldots \ldots \ldots \ldots \ldots \ldots$

Lange v. Ruwoldt, (1872) 6 s A. R. 75; 7 S. A. R. 1 . . . .

$119,127,128,178,357$

LaValle v. Drummond, (1889) 6 M. L. R. 120 . $\quad ~ \& 33$

Lawrence v. Galsworthy, 3 Jur. N. S. 1049 $\quad 329$

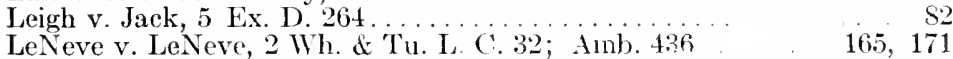

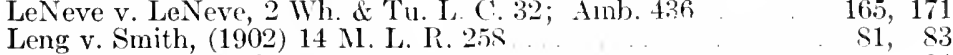

Lewis, In re, 5 M. L. R. $44 \ldots \ldots \ldots \ldots \ldots \ldots . \ldots \ldots$

Life Interest \& Reversionary Securities Corporation v. Hand in Hand Fire and Life Insurance Society, (1898) 2 Ch. $230 \ldots \ldots \ldots .335$

Lillis, In re Land Titles Act and, (1899) 4 Terr. L. R. $300 \ldots . . . . .58$

Limoges v. Campbell, (1896) 2 Terr. L. R. 356. . . . 258, 259, 260

Linstead v. Hamilton Provident d Loan society, (1896) 11 M. L. R. 199.

Liverpool Borough Bank v. Turnes, 7 Jur. N. S. 150

Lloyd, In re, (1903) 1 Ch. 385.

Locher v. Howlett (1895) 13 N Z I R is C 584

Lockhart, In re, (1912) 20 W. L. R. $413 \ldots \ldots \ldots \ldots \ldots 255$

London Chartered Bank v. Hayes, 2 A. J. R. $60 \ldots \ldots \ldots \ldots \ldots$

London \& S. W. Ry. Co. v. Gomm, (18s2) 20 Ch. D. 562 _ ‥ 134, 366

Long v. Town, 10 N. S. W. Eq. $253 \ldots \ldots \ldots \ldots \ldots \ldots \ldots \ldots \ldots \ldots \ldots \ldots$

Loudon v. Morrison, (1896) 14 N. Z. L. R. $245 \ldots \ldots \ldots \ldots \ldots \ldots 174$ 


\section{M}

MacCullough and Graham, In re, (1912) 2 W. IV. R. 311 (Alta.)... 368

MeArthur v. Glass, (1889) 6 M. L. R. 224 ........78, 83, 371, 376

McAndie v. Jackson, 1 II. IV R. 10

MeCarthy r. Badgley, 6 M. L. R. 370

McCaul and Bown's Note, In re, 9 Can. L. T. '27

McClellan v. Powassan Lumber Co., 17 O. L. R. 32; 12 O. W. R. 473

Meconaghy v. I)cmmark, + ‥ C. R. 6019

MeCue v. Smith, 17 II. L. R. 145.

MeDcrmott Caveat, In re, unreported, Newlands, J., (Sask.), May 3, $191^{2}$

MeDonald v. Rowe, :3 V. R. 143: Hunter, '3s

McDonald and sullivan, In re, 14 P. R. 60

MeDonald et al. v. Dunlop, (1898) 2 Terr. L. R. 238

McEarharn v. Colton, 71 L. J. P. C. 20; (1902) A. C. 104.

McCireery and Murray, in re, 19 W. L. R. 947.

McGregor v. Hemstreet, (1912) 20 W. L. R. 642; 2 W. W. R. 284... 348

Mcllvemna v. Goss, $2 \mathrm{~W}$. W. R. 2\$5

Mchay v. Nanton, (189I) 7 M. L. R. 250

$78,81,371,375,381$

MeTillop and Benjafield $v$. Alexamler. 4 s. L. R. 111 ; affirmed 45 S. C. R. 551; 1 W. W. IR. $\$ 73 \ldots . .123,372,381,382,392,395,397$

Mcleish v. Forrest, (1895) 21 V. L. R. 24t (full court)... . . . . . 302

Medicken v. Ontario Bank, 20 S. C. R. 54s. . . . . . . . 278

Mcגillan v. Gunn, 5 W. L. R. 479

MeNaughton, In re, (1909) V. L. R. 39to

Macuthy and Collins, In re, 19 N. Z. L. R. 545.

Magor v. Donald, (1857) 13 V. L. R. 255; Hunter, 266

$18 s, 216$

Mialoney v. Cimphell, 2s S. C. R. 22. . . . . . . . . . 238

Manahi Te Hiakai v. District Land Registrar, 29 X. Z. L. R. 130 . . 200

Mann v. Jsle of Wight liy. Co., 5 L. R. (Ch.) 416.

Mamning $\mathrm{v}$. Commissioner of Titles. $185959 \mathrm{~L}$. J. P. C. $59: 15 \mathrm{~A}$. C. $195 ; 62$ L. T. 373

Marks \& Butswolth, In re, 10 W. N. (.... IV.) 182 (full court); T. A. D. 37.

Martin v. MIorelen, (1s94) 9 M. L. R. 5ti.5

Martin v. Morden, (1s94) 9 II. L. R. 567

$78,191,371,382$

Martin v. IIall, 25 Gir. tis

Martinson v. Clowes, 21 ( h. D. . $\$ 57$

Massey, In re, 2 Terr. L. R. St.

Massey and Gibson, In re, (IS90) 7 M. L. R. 172

Matthew $r$. McLean, 11 W. I. IR. 630.

Maybery v. Williams, (1910) 15 W. L. R. 553

Mayor of Brunswick v. Dawson, (1879) 5 V. L. R. 2; Hfunter, 179 . 241

Mellor, In re, (1905) 2 11. L. R. 17 (I3. C.)

Melville v. Stringer, (1\$84) 53 L. J. (Q. B. 482

Merric v. Mckay, 16 N. \%. L. R. 124

Neunier v. Doray, (1905) 2 W. L. R. 231.

140,261

Milestone v. City of Moose Jaw, (1908) \& II. L. R.901 . . . . 113

Millard v. Cow drey, (1896) 14 N. Z. L. R 12 . _ . . . 174

Miller v. Dary, 7 N. Z. L. R. 515

Ninet v. Lemon, 20 Bear. 269

Mitchell, In re, Adam Caveator, 1t N. S. II. L. R. 12:3; T. A. D. 33. 373

Moore v. Dentice, 20 N. Z. L. R. 12s. 
Moore and Confederation Life Association, In re, (1893) 9 M. L. R. 453

Morice v. Baird, (1889) 6 M. L. K. 243

Morice v. Kernighan, (1908) 9 W. L. R. 307

$99,157,252$

Moritz v Christopherson, (1911) 18 II. L R. 63.

83,112

235

330

Morland v. Hales and Somerville, 30 N. Z. L. I. ('. A. 201 365

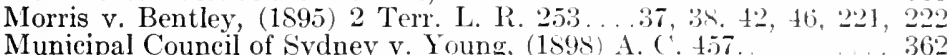

$\begin{array}{ll}\text { Municipal Council of Sydney v. Young, (1s98) A. ( . 457. } & 562 \\ \text { Municipal District of Coneord v. Coles, 3 C. L. R. } 96 & 35,362\end{array}$

Munsie v. Lindsay, 1 O. R. 164; 11 O. R. $520 \ldots \ldots 22$

Murphy v. Michel, $4 \mathrm{~W}$. W. \& A'J3. (Vic.) 13 . T. A. D. A 57,145

Mutual Assurance Society v. Registrar General, (18s3) 1 ( . L. J. 177. 96

National Bank v, Norrow, 13 V. L. R. 2; Hunter, 306

National Bank v. National Mortgage and Ageney Co., (185. $) 3$ X. Z L. R. S. C. 257.

National Bank of Australia v. United Hand in fland and Band of Hope

Co., 4 A. C. 391 .

$301,311,324,329,333,336$

National Trust Co. v. Caupbell, (1908) 17 M. L. R. 5si: 7 W. L. R. 754 .

National Trustees v. Hiassett, (1907) V. L. li. tot

Neal v. Adams, 4 N. Z. L. R. S. C. 177

Nelson Bros., In re, 5 N. Z. L. R. S. C. 111

Nicholson v. Bank of New Zealand, 12 N. Z. L. R. 4.7

Nicholson v. Drew and Norton, 2 W. IV. R. 295; 21 W. I. R. 1s9.

Nioa v. Bell, 27 V. L. R. S2

$41,96,212$

365

Nisbett and Potts Contract, In re, (1905) 1 Ch. 391 . 242, 243

Noble v. Campbell, (1911) 18 W. L. R. 591. . . . . . . 316

Norris v. Ainch, unreported, (Sask.) $1910 \ldots \ldots \ldots \ldots \ldots .125,145$

North British Canadian Investment Co. v. 'Trustees of st. John sichool

District No. 16 of the Northwest Territories, 35 S. C. R. 461 . 43, 255

North of Scotland Canadian Mortgage Co. v. Thompson, (1900) 13

M. L. R. 95 .

$.79,371$

Northwest Construction Co. v. Vaile, (1906) + II. L. R. 37; 16 M. L R. 201.

Northwest Telephone Co. Ltd., In re, (1909) 2 S. L. R. $379 ; 12$ W. L. R. 300 .

Oakden v. Gibbs, (1SS2) \& V. L. R. 380

O'Brien v. Pearson, (1912) 20 W. L. R. 510; 1 W. W. R. 1020.

Oceanic S. S. \& Navigation Co. v. Sutherberry, 16 Ch. D. $236 \quad 354$

O'Connor v. O'Connor, 9 A. L. T. 117

Oertel v. Hordern, 2 S. R. (N. S. WT.) Eq. 3i.

Ogle v. Aedy, 13 V. L. R. 461; Hunter, 28.5.

Oland v. MeNeil, (1901) 32 S.C. R. 23

O'Neill, Ex parte, 7 Q. L. J. 155.

O’Neil v. Drinkle, (1908) \& W. L. 12. 937

$6 \overline{7}, 142,149,201$

Orme v. Wright, 3 Jur. 19.

Ostad's Caveat, In re, Master of Titles (Nask.,) Nov. s, 1904) 366

Otis v. Weidmark, (1911) 1 W. W. R. 342; 19 W. L. R. 723 (s.ask. . 1S9 


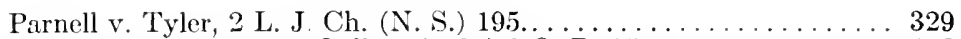

Parrott, In re, ex parte Cullen, (1891) 2 Q. B. $151 \ldots \ldots \ldots \ldots \ldots .113$

Pattullo v. Town of Orangeville, (1899) 31 O. R. $194 \ldots \ldots \ldots \ldots \ldots . \ldots 327$

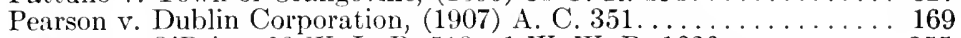

Pearson v. O'Brien, 20 W. L. R. 510; 1 W. W. R. $1026 \ldots \ldots \ldots .255$

Peek v. Sun Life Assurance Co., 11 B. C. R. 215; I W. L. R. 302 ...

Perpetual Executors \& Trustees Association Ltd., Ex parte, (1911)

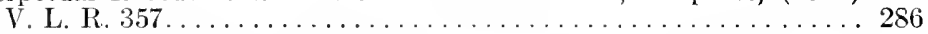

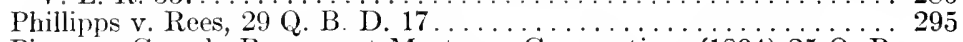

Pieree v. Canada Permanent Mortgage Corporation, (1894) $25 \mathrm{O} . \ddot{\mathrm{R}}$.

671 ; 23 O. A. R. $516 \ldots \ldots \ldots \ldots \ldots \ldots \ldots \ldots \ldots \ldots \ldots \ldots \ldots$

Plimmer Bros. v. St. Maur, $(1906) 26$ N. Z. L. R. $294 \ldots \ldots \ldots \ldots \ldots 385$

Ponton v. City of Winnipeg, 41 S. C. R. 1 S................ 256

Premier Permanent Building Association, (1S99) 25 V. L. R. $77 \ldots .346$

Publie Trustee v. Arthur, (1892) 25 S. A. L. R. $59 \ldots \ldots \ldots \ldots \ldots 176,335$

Public Trustee v. Registrar Gerteral of Land, (1899) 17 N. Z. L. R. C.

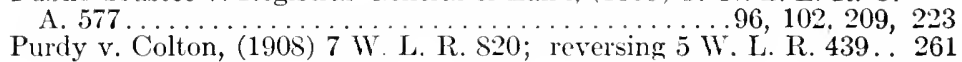

Pyrke v. Waddingham, 10 Ha. $8 \ldots \ldots \ldots \ldots \ldots \ldots \ldots \ldots \ldots \ldots$

Queensland Trustees Ltd. v. Registrar of Titles, 5 Q. L. J. $46 \ldots \ldots \ldots 193$ Quinn v. Leatham, (1901) A. C. $506 \ldots \ldots \ldots \ldots \ldots \ldots \ldots$. . . . . . . 160

\section{$\mathbf{R}$}

Ramsay v. MeDonald, (1Ss0) \& P. R 283.

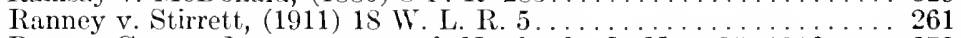

Ranney Caveat, In re, unreported, Newlands, J., Nov. 25, $1910 \ldots . .372$

Raymond Land Co. v. Knight Sugar Co.. (1909) 11 W. L. R. 693 (Alta.)

$49,119,152$

Reeves v. Konschur, (1909) \& W. L. R. 316; 1 S. L. R. 24; reversed $10 \mathrm{~W}$. L. R. $680 ; 2 \mathrm{~S}$. L. R. $125 \ldots .38,41,42,100,156,168,237,347$

Regina v. Fawcett, (1900) 13 M. L. R. $205 \ldots \ldots \ldots \ldots \ldots \ldots \ldots$

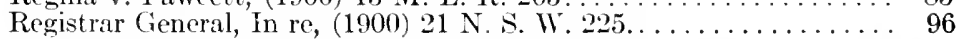

Reliance Gold Mining \& Milling Co. Ltd., In re, 13 B. C. R. 482 ;

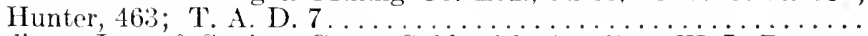

Reliance Loan \& Savings Co. v. Goldsmith, (1910) 15 W. L. R. 55. . 260

Renwick v. Berryman, (1886) 3 M. L. R. 385 . . . . . . . . 115, 189

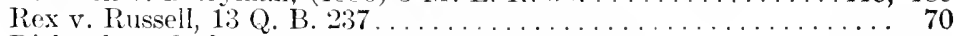

Richards v. Cadman, 17 T. L. R. 203; Hunter, $471 \ldots \ldots \ldots \ldots 262,264$

Richards v. Thompson, (1911) $18 \mathrm{~W}$. L. R. 179 ............ 346

Riddell, In re, (1907) 7 W. L. R. 301; i S. L. R. $24 \ldots \ldots \ldots 156,168,237$

Riddock and Chadwick's Contract, In re, $(1907) 6$ W. L. R. 360 ... 383

Rivers, In re, (1893) 1 Terr. L. R. 464 . . . . . . . 46, 228, 265

Roach v. McLachlan, 19 A. R. $4 \$ 6 \ldots \ldots \ldots \ldots \ldots \ldots \ldots \ldots$. . . . 339

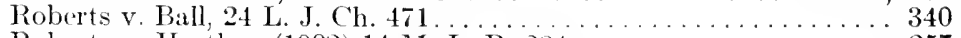

Roberts v. Hartley, (1902) 14 M. L. R. $284 \ldots \ldots \ldots \ldots \ldots \ldots \ldots \ldots .257$

Robertson v. Keith, (1870) 1 V. R. (E) 1 ; Hunter, $366 \ldots \ldots \ldots \ldots 146$

Rockwood Electoral Division Agricultural Society, In re, (1899) is

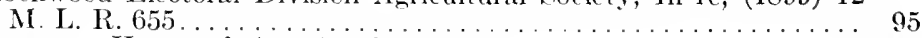

Rogers v. Hosegood, (1900) 2 Ch. $38 s_{\ldots \ldots \ldots \ldots \ldots \ldots \ldots \ldots \ldots \ldots \ldots \ldots \ldots .242}$

Rooker v. Hoofstetter, (1895) 26 S. C. R $41 \ldots \ldots \ldots \ldots \ldots \ldots \ldots \ldots \ldots \ldots \ldots \ldots$

Rorison v. Kolosoff, (1910) $15 \mathrm{~W}$ L. R. 497 (B. C.) . . . . . . . 5 S, 109

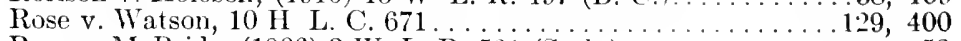

Ross v. MeBride, (1906) 3 W. L. R. 561 (Sask.). . . . . . . . . 53 
Smith v. National Trust Co., (1911) 20 M. L. R. 522; 17 IV. L. R. 354 ; affirmed 45 S. C. R. $618 ; 1$ W. W. R. $1122 \ldots . .57,143,145$,

$184,185,283,286,288,292,294,298,301,311,316,324,336$

smith v. Sugarman, (1909) 12 W. L. R. 585; reversed 13 IV. L. R. 671 .

Solicitor General v. Mere Tini (1899) $17 \mathrm{~N}$ Z L R C A $773 \cdots$

Solling v. Broughton, 63 L. J. P. C. 21; (1893) A. C. $556 \ldots \ldots \ldots$. . .

Spencer's Case, Smith's L. C. \& 15 R. C. $254 \ldots \ldots \ldots \ldots \ldots \ldots \ldots 241$

Spokane \& Eastern Trust Co.'s Mortgage, In re, (1910) 15 W. L. R. 637.

Sprague v. Graham, (1891) 7 M. L. R. 39S . . . . . . . . . 77

Standard Trust's Transfer, In re, umreported, Master of Titles (Sask.) Feb. 13, 1912 ......................... 200

Stanger and Mondor, In re, (1910) $15 \mathrm{~W}$. L. R. 346; affirmed $16 \mathrm{~W}$.

L. R. 53; 20 M. L. R. 280 . 2. 258; aftirmed 11 N. Z. L. R. C. A.
Staples v. Mackay, 11 N. Z. L. R.

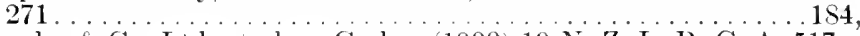

Staples \& Co. Ltd. et al. v. Corby, (1900) 19 N. Z. L. R. C. A. 517.

Stevens v. Ullerich, (1911) 17 W. L. R. $569 \ldots \ldots \ldots \ldots \ldots \ldots \ldots . \ldots . \ldots . \ldots$

Stewart v. Borm, (1911) 19 W. L. R. 166.

401

St. Germain v. Reneault, (1909) 12 W. L. R. $169 ; 2$ A. L. R. $371 \ldots$

185, 251, 354

Stockton Iron Furnace Co., In re, 10 Ch. D. 335 ... . . . . . . . . 293

Sunstrom's Transfer, In re, Master of Titles (Sask.), April 19, 1910 . 271

Swan v. Wheeler, (1909) 11 W. L. R. 730.

Swanson v. Getsman, (1908) \& W. L. R. 762.

Syndicat Lyonnais du Klondyke v. IIcGrade. (1905) 36 S. C. R. 251 $3 \varsigma, 158,167,172,188,366,383$

\section{$\mathbf{T}$}

Tanner, In re, 5 N. Z. L. R. S. C. $102 \ldots$

$72,103,361$

Tasker v. Carrigan, (1909) 11 W. L. R. 621

155,172

Tavender v. Edwards, (1908) S VI. L. R. $30 \mathrm{~s}$ 383

Taylor v. Land Mortgage Bank of Victoria Ltd., (1S86) 12 V. L. R. 748 ; Hunter, 168.

Taylor v. Robertson, (1901) 31 S. C. R. 615

Taylor v. sharpe, 3 M. L. R. 4.

Telfer Bros. $v$. Fisher, (1910) 15 W. L. R. 400

329

Tennant v. Trenchard, (1S69) + C'h. 537. .

Thomas v. Kelly, 58 L. J. Q. B. 66; 13 A. C. 506

Thompson, In re, 10 Can. L. T. 44.

Thompson v. Berglund, (1910) 3 S. L. R. $470 ; 16$ W. L. R. $154 \ldots$

$140,264,334$,

Thompson v. Finlay, 5 N. Z. L. R. S. C. 203 ..

Tierney v. Halfpenny, 9 V. L. R. 152.

Tierney v. Loxton, 12 N. S. W. L. R. 308 .

Tolley \& Co. Ltd. v. Byrne (Registrar), (1902) 28 V. L. R. 95

Toth 60, 209, 223,

Toth and Case Co., In re, (1910) 14 W. L. R. 704; 3 S. I. R. 270. .44, Trembath v. Carr, 23 V. L. R. 437

Trimble, In re, 1 B. C. R. 321

Trust \& Loan Co. of Canala v. Cook, $(1910) 3$ S. L. R. 210. . 260,

Trustee v. Registrar of Titles, 5 Q. L. J. 46

Tucker v. Armour, (1906) 6 Terr. L. R. $38 s ; 5$ V. L. R. 35 ; affirmed 6 W. L. R. 93. 
Tucker and Armour, In re, (1905) 4 W. L. R. 394.

Tudge Pork Packing Co., In re, (1908) 7 W. L. R. 507 _. 371, 381

Tulk v. Moxhay, 2 Phill. $774 \ldots \ldots \ldots \ldots \ldots \ldots \ldots \ldots \ldots .241,242$

Turner v. Clark, (1909) 2 S. L. R. 200; 10 W. L. R. 25. .116, 147, 155, 157

Union Bank v. Jordan, (1908) 8 W. L. R. 77 ...

Union Bank v. McElroy, (1909) 11 W. L. R. 259

261,339

312

Vale v. Blair, 9 A. L. T. 90 .

152

335

Van Damme v. Bloxam, 9 S. A. L. R. 27

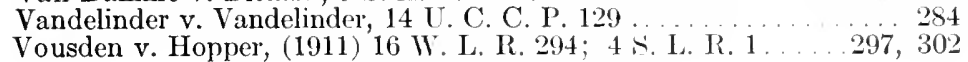

\section{W}

Wadham v. Buttle, 13 S. A. L. R. $1 \ldots \ldots \ldots \ldots \ldots \ldots \ldots \ldots \ldots$

Wallace v. Smart, (1912) 19 W. L. R. 787 (Man.) ... 175, 177, 264, 279

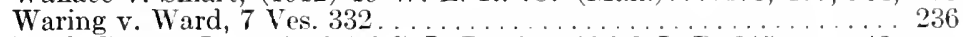

Wark Caveat, In re, (1909) 2 S. L. R. 431 ; 12 W. L. R. $245 \ldots 42$,

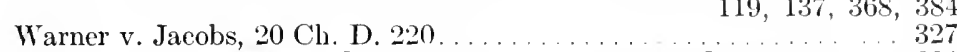

Waterous Engine Works Co. v. Weaver, (1908) \& W. L. R. 432 . . . 281

Watson v. Royal Permanent Building Societ y, 14 V. L. R. 283; Hunter,

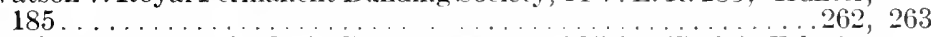

Webb, In re, Rumely Co.'s Caveat, Master of Titles (Sask.), Feb. 21,

$1911 \ldots . . . . .373$

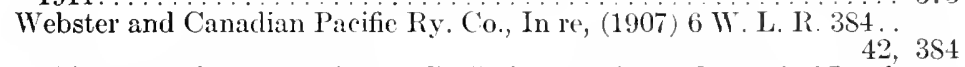

Wellington and Manawatin Ry. Co. Ltd. v. Registrar General of Land,

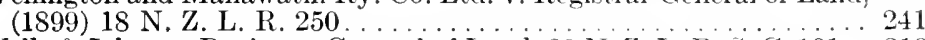

Wells \& Johns v. Registrar General of Land, 29 N. Z. L. R. S. C. 101 . 219

Western Canada Loan \& Savings Co. v. Court, 25 Gr. 151......... 341

Western Trust Co. v. Popham, (1912) 2 W. W. R. 297; 21 W. L. R.

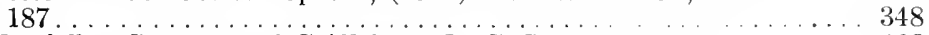

Westfall v. Stewart and Griffith, 13 B. C. R. $111 \quad \ldots \ldots .193$

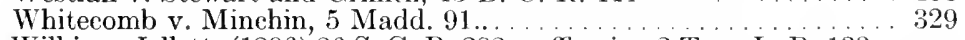

Wilkie v. Jellett, (1896) 26 S. C. R. 282 ; affirming 2 Terr. L. R. 133 .

$38,42,97,124,134-136,148,179,180,182,250,265,357,382,402$

Wilkins v. Deane, 6 N. Z. L. R. 425 ................... 108, 286

Williams v. Box, (1910) 44 S. C. R. 1; reversing 13 W. L. R. 451; 19 M. L. R. $560 \ldots \ldots \ldots \ldots \ldots \ldots \ldots \ldots \ldots \ldots 137,148,159,163$, $279,280,284,300,310,311,316,343-346$

Williams v. Papworth, 69 L. J. P. C. $129 ;(1900)$ A. C. $563 ; 83$ L. 'T.

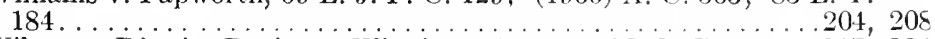

Wilson v. Distriet Registrar Winnipeg, (1S93) 9 AI L. R. 215. .217, 224

Wilson v. MeIntosh, 63 L. J. P. C. 49; (1894) A. C. 429 . . . 360, 377

Wisewould, Ex parte, (1890) 16 V. L. R. 149 (full court) . . . . . 37, 240

Wolfson v. Oldfield, (1911) 18 W. L. R. 449 _ _....... 167, 169

Wolters v. Riddiford, (1905) 25 N. Z. L. R. S. C. $532 \ldots \ldots \ldots \ldots 170$

Woodberry v. Gilbert, 3 Tas. L. R. $7 \ldots \ldots \ldots \ldots \ldots \ldots \ldots \ldots \ldots \ldots \ldots \ldots$

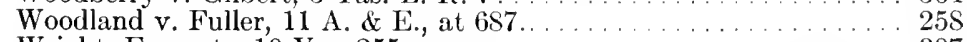

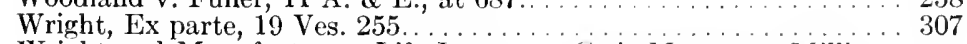

Wright and Manufacturers Life Insurance Co.'s Mortgage, Milligan, M. T., March $31,1910 \ldots \ldots \ldots \ldots \ldots \ldots \ldots \ldots \ldots \ldots \ldots \ldots$ 
Yemen v. Mackenzie, (1906) 7 O. I. R. $\$ 66 \ldots \ldots 384$

Yorkshire Guarantee \& Securities Co. v. Edmonds, 7 B. C. R. 348... 266

Yorkton Butter and Cheese Association, In re, (1899) 6 Terr. L. R.

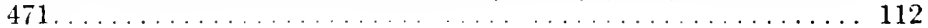


THE

\title{
CANADIAN TORRENS SYSTEM
}

\author{
PART I \\ CHAPTER I \\ INTRODUCTION
}

\$ 1. ESTATES IN LAND UNDER FEUDAL SYSTEM.

$\S 2$. METHOD OF TRANSFER UNDER FEUDAL SYSTEM.

3. EFFECT OF STATUTE OF USES.

$\$$ 4. EFFECT OF LATER STATUTES.

5. DEFECTS OF "OLD SYSTEMS."

6. ORIGIN AND HISTORY OF THE TORRENS SYSTEM.

\section{§ 1. ESTATES IN LAND UNDER FEUDAL SYSTEM.}

The system of holding and conveying land in: any country the basis of whose laws is the English common law, cannot be understood and appreciated. without going far back into the Middle Ages. The foundation of English law and of real property is in the feudal system, which the Norman Conquest introduced into England. Under that system the ownership of land was made ancillary to the purpose of the King and the great barons in levying assistance from their followers. Upon this basis grew up the system whereby absolute ownership in land in a subject is, in English law, unknown. The Crown is the owner of the soil of all land, and the subject. has only estates, greater or less, in the land. These estates are of varying extent. The smallest estate of freehold was the estate for life. Next to that came the estate tail, that is the estate given to a man and the heirs of his body. This was such an estate as would, if left to itself, descend, on the decease of the first owner, to all his lawful issue, children. and grandchildren and more remote descendants so long as his posterity endures, in a regular order 
and course of descent from one to another; and, on the other hand, if the first owner should die without issue, his estate, if left alone, would then determine. Estates tail might be either general or special or might be tail male or tail female Next in order was the estate in fee simple, the greatest estate or interest which the law of England allowed any person to possess in landed property.

"The tenant in fee simple is he that holds lands or tenements to him and his heirs; but so that the estate is descendible not merely to the heirs of his body, but to collateral relations according to the rules and canons of descent." 1

In the early days such an estate could not be alienated without the consent of the superior lord and the tenant, consequently, if he wished to dispose of part of his land, was obliged to create a tenure between his grantee and himself by reserving to himself and his heirs such services as would remunerate him for the services which he himself was liable to render to his superior lord. The immediate lord of the holder of any land had, however, advantages of a feudal nature which did not belong to the superior lord when any mesne lordship intervened, and the barons at the time of Edward I, to obviate this encroachment on their privileges, procured the prohibition of the practice of "sub-infeudation," as it was called, in the Statute of Quia Emptores." While thus intended to work to the immediate advantage of the superior lords, it was this statute which first secured facility of alienation of land.

\section{\$2. METHOD OF TRANSFER UNDER FEUDAL SYSTEM.}

These thrce are the chief estates in land, varied from time to time with an infinite variety of details. The system whereby these estates were created or transferred became not less elaborate and conventional than the system of the estates themselves.

1 Williams' Real Property, 9th Edition, page 59.

218 Edw. I, c. 1. 
The earliest form of transfer was the feoffment with livery of seisin, which was nothing more than a gift of an estate in the land with livery-that is, deliveryof the seisin or feudal possession. The seisin of land, the last vestiges of which have disappeared under the Torrens system, livery of which being entirely supplanted by registration, was under the feudal system a matter of great importance and much formerly depended upon its proper transfer from one person to another. Down to the time of King Henry VIII, nothing more was required for a valid feoffment than livery of the seisin and the limiting of the estate, but in the reign of that king an Act of Parliament of great importance was passed, known by the name of the Statute of Uses, and since that statute it became a further requisite to a feoffment, either that there should be a consideration for the gift or that it should be expressed to be made not simply "unto" but "unto and to the use of" the feoffee. It was not, however, till the Statute of Frauds in the reign of King Charles II $^{3}$ that writing was required in every case.

\section{§ 3. EFFECT OF STATUTE OF USES.}

The Statute of Uses just referred to followed upon the invention by the Court of Chancery of the use whereby the Court of Chancery administering equity held that the mere delivery of possession or seisin by one person to another, was not at all conclusive of the right of the feoffee to enjoy the land of which he was enfeoffed. Equity was unable to take from him the title which he possessed and could always assert in the courts of law, but equity could and did compel him to make use of that legal title for the benefit of any other person who might have a more righteous claim to the beneficial enjoyment. In the process of time such enfeoffment to one person to the

${ }^{3}$ Statute 29 Car. II, c. 3, Statute of Frauds. 
use of another became very common, for the Court of Chancery allowed the use of lands to be disposed of in a variety of ways, among others by will, in which a disposition could not then be made of the lands themselves.

By the Statute of Uses ${ }^{4}$ it was enacted that where any persons shall stand seised of any land or other hereditaments to the use, confidence or trust of any other person or persons, the persons that have any such use, confidence or trust (by which was meant the persons beneficially entitled) shall be deemed in lawful seisin and possession of the same lands and hereditaments for such estate as they have in the use, trust or confidence. The Statute of Uses was evidently intended to abolish altogether the jurisdiction of Courts of Chancery over landed estates by giving actual possession at law to every person beneficially entitled in equity; but this object has not been accomplished, for the Court of Chancery has since regained in a curious manner its former ascendency and has kept it to the present day. So that all that was ultimately effected by the Statute of Uses was to import into the rules of law some of the then existing doctrines of the courts of equity and to add three words, to the use, to every conveyance. This result was arrived at by the doctrine promulgated by the Court of Chancery that there should not be a use upon a use.

"The doctrine has much of the subtlety of the scholastic logic which was then prevalent. As Mr. Watkins says ${ }^{5}$ it must have surprised everyone who was not sufficiently learned to have lost his common sense." 6

Through this decision arose the modern doctrine of uses and trusts, the second use or trust being that over which the Court of Chancery assumed jurisdiction. The estate in fee simple which was vested

427 Hen. VIII, c. 10.

- Principles of Conveyancing, introduction.

6 Williams' Real Property, page 156. 
in the first trustee was the legal estate, being the estate to which the trustee was entitled only in contemplation of a court of law as distinguishable from equity. The interest of the cestui que trust was called an equitable estate, being the estate to which he is entitled only in the contemplation of the Court of Chancery, which administers equity. Thus grew up on the one hand the legal estates which have been mentioned, and equitable estates, the owner of which must have recourse exclusively to the Court of Chancery where he finds himself considered as owner according to the equitable estate he might have, and in dealing with which the Court of Chancery generally adopted the rules of law applicable to legal estates with certain exceptions based on a presumably more liberal system which it is not necessary at this point to discuss.

The Statute of Uses became the foundation for the whole system of English conveyancing and it may well be said that based on that statute the system grew to be one of great complexity and often of futile intricacy.

"There was nothing in China or Japan or any Eastern nation more absurd than the system of acquiring lands by fines and recoveries." 7

\section{§ 4. EFFECT OF LATER STATUTES.}

In modern times down to the year 1841, the kind of conveyance employed on every purchase of freehold estate was called a lease and release, and for such transaction two deeds were always required. In 1841 and again in 1845 changes were made in the law so that after the 1st of October, 1845,

"All corporeal tenements and hereditaments shall, as regards the conveyance of the immediate freehold thereof, be deemed to lie in grant as well as in livery,"

so that the simple deed of grant was sufficient to

${ }^{7}$ Professor Goldwin Smith, 12th Feb., 1890. 
grant the freehold or feudal seisin of all lands. The recording in any sort of a public office, of deeds, has been for centuries one of the strongest aversions of the English landowner. Shortly after the Statute of $U$ ses, it was required by Act of Parliament that every bargain and sale of any estate of inheritance or freehold should be made by deed indented and enrolled, within six months from the date, in one of the courts of record at Westminster or otherwise as there provided. The lease and release was an intricate device, particulars of which need not be entered into here, to aroid the necessity for such enrollment. After the Act of 1845 , the ordinary purchase deed became very much simplified, but even in the simplest ease, with its recitals, habendum clauses, covenants for title and other covenants, it was a very far eall from the "transfer" to which practitioners under the Torrens system are accustomed; and, in England, the fact that fees of solicitors and conveyancing counsel were based on the number of folios in the instrument, naturally did not tend towards eonciseness and brevity.

\section{DEFECTS OF "OLD SYSTEMS."}

In a srstem characterized by features such as have been shortly indicated, it is not surprising that the matter of the investigation of title involved labor and expense very far beyond the just proportion of the value of the property involved. There was, of course, no registry whatsoever of any sort. a thing which, to the Canadian practitioner, seems almost axiomatic. The very physical act of keeping together and preserving the documents of title, to say nothing of keeping track of their legal validity, was a serious question. The period for which title was investigated was sixty years and every rendor of freehold property was bound at his own expense to furnish the intending purchaser with an abstract of all the deeds, wills and other instruments which 
had been executed with respect to the lands in question during that period, and also to give him an opportunity to examine such abstract with the original deeds, and with the probate or office copies of the wills. On any sale or mortgage of lands, all the title deeds which related exclusively to the property sold or mortgaged were handed over to the purchaser or mortgagec. The possession of the deeds was of the greatest importance for (excepting in the register counties of Middlesex and York) if the deeds were not required to be delivered, it was evident that the property might be sold over again to different persons without much risk of discovery. The origin of the selection of sixty years as the period for search is not certain.

"The ordinary duration of human life is, if not the origin of the rule requiring the sixty years' title, at least a good reason for its continuance. For so long as the law permits of vested remainders after estates for life and forbids the tenant for life by any act to destroy such remainders, so long must it be necessary to carry the title baek to such a point as will afford a reasonable presumption that the first person mentioned as having conveyed the property, was not a tenant for life merely but a tenarit in fee simple." 8

The Statute of Limitations also was often a refuge in covering up errors and omissions.

In addition to all such difficulties was the fact already referred to of there being two estates recognized by law in the land.

"The coneurrent existence of two distinct systems of jurisprudence is a peeuliar feature of English law. On one side of Westminster Hall a man may sueeeed in his suit under eircumstanees in which he would undoubtedly be defeated on the other side; for he may have a title in equity and-not at law (being a cestui que trust), or a title at law and not in equity (being merely a trustee). In the former case, though he would suceeed in a Chancery suit he never would think of bringing an action at law; in the latter case he would suceeed in an action at law, but equity would take care that the fruits should be reaped only by the person beneficially entitled. An equitable

${ }^{8}$ Williams' Real Property, page 430. 
title is therefore the beneficial one, but if barely equitable it may occasion the expense and delay of a Chancery suit to maintain it. Every purchaser of landed property has therefore a right to a good title both at law and in equity; and if the legal estate should be vested in a trustee, or any person other than the vendor, the concurrence of such trustee or other person must be obtained for the purpose of vesting a legal estate in the purchaser, or, if he should please, in a new trustee of his own choosing." 9

It is apparent that as commerce advanced and people became restless under the fictitious forms and delays of the law, that the evils of this system became more apparent under the following heads:

(1) The uncertainty of the system owing to the difficulty of ascertaining and accounting for all interests which might have existed in the land.

(2) The division of estates into legal and equitable.

(3) The cumbersomeness and expense of the system.

From time to time systems have been devised for the overcoming of some or all of these evils. The systems may be classified under two general heads:

(1) Systems of registration of assurance.

(2) Systems of registration of title.

"A system of registration of title is a system of property law which provides for a register, entry upon which is essential to the passing of certain rights of property from one person to another in such a way that the latter's right in the subjectmatter of the transaction becomes complete and good against the world. *** Under a system of registration of assurance, entry on the register is not essential to the complete passing of rights of property, but such entry is in the nature of an additional safeguard, by the neglect of which rights acquired by the execution of an instrument assuring them may be lost as against a third person who does place an entry on the register in his own favor." 13

In Canada the two systems exist side by side in Ontario and in Manitoba, the "old system" in

9 Williams' Real Property, page 170.

${ }^{10}$ Hogg, Ownership and Encumbrance of Registered Land, page 3. 
Manitoba being a system of registration of assurances, the "new system" a system of registration of title.

\section{§ 6. ORIGIN AND HISTORY OF THE TORRENS SYSTEM.}

It will not be necessary or wise in this work to undertake a historical outline of the steps leading up to the English Acts of 1862, 1875 and 1897. The report of the Real Property Commissioners in 1830, the report by the Commission on Registration and Conveyancing of 1850 , the report by the Commission on Land Transfer and Registration in 1857, the report of another Commission on Land Transfer and Registration in 1870, and a still further report published in 1911 of the Land Transfer Commissioners appointed in 1908, all throw valuable light and suggestions on the construction of any Act for the registration of title. For a somewhat full analysis of these reports (except the last mentioned), the reader is referred to Mr. J. E. Hogg's exhaustive work on "Ownership and Encumbrance of Registered Land." The Torrens system itself, however, does not acknowledge as its foundation any of the English reports, although it undoubtedly must be the case that Sir Robert Torrens, the founder of the system, derived valuable assistance from them. The original Act was introduced in South Australia and the Act assented to on the 27th June, 1858, and in his essay, published a year after the introduction into South Australia of the system, Sir Robert Torrens, who was collector of Customs at Port Adelaide in South Australia, states that he took the Shipping Acts as his model, and that he intended to adopt the principle of conveyance by entry in a public office, and he expressly disclaims any indebtedness to the English report of 1857, and states that it only reached his hands on the eve of the second reading of his bill in the South Australian Legislature. Following the 
introduction of the Act into South Australia, it was introduced in the other Australian colonies and in New Zealand-in Victoria in 1862, in New South Wales in 1862, in Queensland in 1861, in West Australia in 1874, in Tasmania in 1862 and in New Zealand in 1870 .

In Canada the advantages of a system of registration of title, whether the Torrens system or the kindred English system, were first mooted in the early eighties. In the session of 1883 in the Dominion Parliament, an Act founded on the Torrens system and entitled "An Act for the Declaration of Titles to Land, and to Facilitate its Transfer in the Territories of Canada," compiled by Messrs. Beverley Jones and Herbert C. Jones, was introduced into the House of Commons at Ottawa by Mr. McCarthy, but went no further. In the spring of 1883 the Canadian Land Law Amendment Association was organized and by means of pamphlets, petitions and personal activity and interest, was able to make the benefits of the Torrens system known to the people and the Legislature. In view of the vast extension of the Torrens system in Canada at the present day, the address by Mr. J. Herbert Mason, President of the Canadian Land Law Amendment Association. delivered before the Canadian Institute on the 1st of December, 1883 , is of great interest as exhibiting the reasons why the system commended itself to the minds of the active business men in this new country. He stated in part:

"For a period of more than twenty-five years it has been my fortune to be in almost daily communication with professional conveyancers on subjects relating to the title and tenure of land. Seeing the difficulties they have to encounter, and the trouble, annoyince, and expense to which landowners are frequently subjected, and being often called upon to examine and weigh the rarious questions raised, and by balancing practical probabilities against legal possibilities, to determine whether the risk of accepting an imperfect title might be taken or not, I have been led to inquire why it is 
that real estate is burdened with a method of transfer so costly, dilatory, cumbersome, and uncertain, as compared with other kinds of property. 'That question has been askert in England, in every British Colony, in every state of the neighboring Republic, in fact wherever English law prevalis, and has failed to elicit a satisfactory answer. In default of other reason, in view of the antiquity of the system, and the immense amount of learned labor bestowed upon it, the conclusion generally accepted was that it must be one of the natural and unaroidable evils of life that had to be patiently endurerl; as inevitable as the flow of time, or the tides, or the payment of taxes.

"Modern inquiry, whieh has irreverently laid bare so many time honored delusions, refuses to aecept this theory, claiming that the system is of human invention, a relic of feudal and unenlightened times, and bears the impress of the comparatively absurd practices and customs of those days. High legal authorities now admit that the system is indefensible. As well might we imitate the soeial customs of centuries ago, instead of rejoicing in the superior civilization, culture and refinement of the present day. It would be interesting to treat the subject historically and trace how the present system of land transfer and tenure grew out of the old feudal system under which land was generally held as a fief for life, subject to the performance of military or other service. Time, however, will not permit. All I purpose to do is to take our system as we find it, and compare it, as briefly as may be, with the Torrens system, which it is proposed to introduee.

"Speaking generally, as the law now stands in Ontario and several other Provinces, no man can be sure that he is the owner of land muless he can show not only that he has paid for, and has possession of it and may be registered as owner, but that his deed is the last link in an unbroken chain of properly drawn, exeeuted, and registered eonveyances baek to the patentee of the Crown, or at least for sixty years back.

"To do this effectually his solicitor may have to critically examine hundreds of documents-as is the case with some properties in this city-many of which may not affect the property in question, and he may perhaps find after all, that he is unable to determine with certainty whether his elient has a good title or not. As a chain is no stronger than its weakest link, if one link is defective or missing, the title fails as far as the records are concerned and must be sustained by outside evidence, which after the lapse of years it is often difficult, and sometimes impossible, to obtain. A link may be missing in the registry office, owing to the title having been acquired by 
possession, by heirship, or by devise; for one of the anomalies of the system is, that while a will may be recorded in the lifetime of the maker, and while it is therefore inoperative, a will may be actually in force but not be registered on the land affected by it, and, as a matter of fact, many are not.

"Would such a system be endured if it applied to personal property, which can now be transferred in a few minutes and at little or no expense whatever? Let us suppose that every purchaser of registered Government, or municipal bonds, bank stock, or any of the rast railway, mining, shipping, mortgage, or other corporate interests, the outeome of modern civilization, was required to examine the chain of title from the first issue to the present ostensible owner, to see that every previous transfer had been properly drawn, properly executed by the proper parties, that it contained this particular property, and that other transfers recorded on the same page and mixed up with them did not; that each previous owner had paid his taxes; that he was of age; that he was unmarried, or if married, that his wife was twenty-one years of age and joined in the transfer; that if a previous owner died intestate, all his heirs joined in the transfer, that all were of age and unmarried, or if married, that their wives, or husbands were of age, and joined; and further that for several years at least, the sheriff had held no writs of execution against any of the owners; what, if all this were neeessary, would be the effect on the market value of such property? Ready convertibility, and certainty of ownership, being important elements in determining the worth of any investment, it is manifest that the effect would be to detract materially from its value. Yet all this troublesome, expensive, and time-consuming procedure, has to be undertaken at every transfer of real estate, no matter of how small extent, or of how little value.

* $\quad * \quad * \quad * \quad * \quad * \quad * \quad * \quad * \quad * \quad * \quad *$

"As a Canadian, I regret that it did not fall to the lot of one of our countrymen to discover and apply this great remedy. Neither can England, nor the United States, claim credit for it, though in both countries its neeessity and value have been recognized. To have been the inventor of the Torrens system is an honor any man might covet. However simple and selfevident, when propounded and understood, the original bright thought was as mueh an effort of genius as the invention of the steam engine or the telephone. Some seren and twenty years ago it occurred to a gentleman residing in Adelaide, South Australia, that there was no good reason why land should not be conveyed by registration in the same simple way 
that ships are transferred. The system then in operation there, and in the other Australian colonies, was one of conveyance by deed and registration, substantially the same as that now in force in Ontario. Upon promulgating his theory he was met with opposition and derision. Gentlemen learned in the law shook their bewigged heads, and said in effeet, 'Can any good thing come out of Nazareth?' For this bold innoviztor did not belong to the legal profession, but was simply an officer in Her Majesty's Customs. I awyers are naturally, and very properly, slow to adopt untried experiments in the laws affecting property, more especially when suggested by laymen, and perhaps there is no subject upon which they are more conservative than the laws affecting the tenure and transfer of land. These laws have been consecrated by antiquity, and the labors of the most eminent legal minds, and their ramifications affect in numerous ways the civil relations of a large proportion of the community. But with the spirit of a true reformer Mr. (now Sir Robert) Torrens resolutely persevered. Opposition rather stimulated than daunted him. Following up the original idea he elaborated what is known as the Torrens system. His arguments were unanswerable, and he soon convinced a majority of the people and of the Legislature that he was right. In 1858 the first crucle measure to give effect to his ideas was passed by both Houses of the Legislature of South Australia, and became law. In 1861 it was repealed to make way for an improved measure which time and experience had shown the necessity for. In 1878 further amendments were made, but since that date no further changes have been found necessary.

* * * * * * * * * * * * * * *

"In conclusion, I desire to impress upon every lover of his country: First-The paramount importance of each local Government providing, as speedily as possible, for the adoption of the principle of conveyance of land by registration of title in the several Provinces of the Dominion. Every year adds materially to the difficulty and expense of its introduction. And second-The urgent necessity there is for the Canadian Government to provide at the outset, a simple, safe, and inexpensive system of land transfer for the new territories of the Northwest. In the older Provinces a great portion of the public domain has been already alienated, and with regard to such lands, it would not be practicable for some time to make transfers under the new system compulsory. Landowners will soon see its advantages, and as opportunities occur, avail themselves of them; but it will probably be many years after 
the adoption of the Torrens system before a very large proportion of the alienated land is brought under it. In the Northwest the lands as granted by the Crown would at once be brought under the new system, and the trouble and expense of changing would be avoided. It will be a grave mistake, if not a lasting disgrace, if, now that an unquestionably better method is known, an antiquated and conclemned system, with all its uncertainties, and eumbrous and eostly machinery, be inflieted upon the virgin soil of the hope of our Dominion, the Great Northwest. Whoever shall emancipate land from this relie of feudalism; give legislative effect to the Torrens system of transfer by registration; simplify and make uniformly operative the law of descent; abolish general liens and all charges created by operation of law, without registration; and make land as safely and easily dealt with as registered stock or bonds, - will not only be entitled to the thanks of the present generation of his countrymen, but merit the gratitude of millions yet unborn."

The proceedings of a public meeting held in the City Hall, Toronto, on the 12th February, 1890, under the auspices of the Canadian Land Law Amendment Association, have recently been reprinted in pamphlet form and are not only useful as summarizing the advance made by the system in Canada up to that date, but exhibit in a popular manner the defects of the system of land holding and converancing then in vogue in Ontario and the features of the Torrens system which commended that system to practical men as overcoming these difficulties. Mr. J. Herbert Mason, the president of the Association, said in part:

"The reform of the present system of transferring title to landed property is one of the most important branches of the land problem, which, under various aspects, holds a foremost place among the great questions of the day, in all Englishspeaking communities.

$\begin{array}{lllllllllll}* & * & * & * & * & * & * & * & * & *\end{array}$

"There is, perhaps, no more potent factor in maintaining the permanence and stability of government than a wide distribution among the people of the omnership of the soil. A writer in the British Quarterly Reriew, referring to the large number of landowners in France, truly says: 'There can be no land agitation in that comntry beeause there the land is a 
veritable national possession.' There, as elsewhere, the dangerous classes are the landless and improvident.

"It is therefore in the public interest, and the well being of the State requires the removal of all unnecessary obstructions to the cheap, simple and safe acquisition, sale, and transfer of land, more especially of the homestead of the farmer, handicraftsman and laborer. Such obstructions proroke discontent and retard the prosperity of the people. Fortunately all political parties can consistently unite in promoting this great social and economical reform.

* $* * * * * \quad * \quad * \quad * \quad * \quad * \quad *$

"Before considering the relations of the Province of Ontario to this question, it may be interesting to refer briefly to the position in regard to it of other parts of the Empire and of the States of the American Union.

"In England, where the cost and delays of conveyancing are so great as to almost preclude small holdings of land, the subject has been long regarded by social reformers and statesmen as one of the first importance. After his return from Australia, Sir Robert Torrens strongly urged the adoption of a system of registration of titles upon public attention. One of the first to declare his adhesion to Sir Robert's views was Lord Coleridge, now Lord Chief Justice of England, who, in 1872, at a meeting at which Sir Robert had explained his scheme, spoke as follows:

"I have never been able to perceive the obstacle to applying to land the system of transfer which answers so well when applied to shipping; but, as my learned brethren, one and all, have declared that to be impossible, I had become impressed with the belief that there must be something wrong in my intellect, as I failed to perceive the impossibility. The remarkably clear and logical paper which has been read by Sir Robert Torrens relieves me from that painful impression, and the statistics of the successful working of his system in Australia amounts to demonstration; so that the man who denies the practicability of applying it might as well deny that two and two make four.'

"In 1875 Lord Cairns' Bill was passed, which provided for the permissive use of a scheme of registration of title; but, as the friends of that system pointed out, its provisions were in many respects objectionable, and comparatively little use has been made of it. ${ }^{11}$

"The Act of 1875 has since been superseded by the Act of 1897 and Land Transfer Rules of 1903 . The Act of 1897 , where in force, is compulsory and has met with considerably greater success than the entirely voluntary Act of 1875 . 
"The early settlers in the United States adopted the system of registration of deeds which, in 1704, was provided by Act of Parliament for the East Riding of the county of York, England. This system is still in force throughout the Union, and in the Maritime Provinces of the Dominion. Under it all instruments in each municipality are registered in their order, but no index is kept of the particular lot, block or parcel of land affected, as in Ontario. The chain of title is traced by means of an alphabetical index of the names of grantors.

"In populous districts there are many persons of the same name, and where subdivisions, changes of ownership, creation of liens, etc., are of frequent oceurrence, the great labor and the legal acumen required in traeing titles under this system. in course of time, may be readily imagined. The sums said to be paid to prominent converancers in the city of New York, and doubtless well earned, for investigating, elearing up and pronouncing an opinion upon a single purchase of property are almost incredible, passing sometimes into the thousands of dollars. The difficulties in the way of ridding the real estate of the country of this incubus, proteeted as it is by powerful vested interests, are such as have almost driven reformers to despair. In the State of New York, after years of agitation, the Land 'Transfer Reform Association, and its able and enthusiastic president, have sueceeled in getting an Act passed, which comes into force in January, 1S91, providing for a scheme of block indexing of instruments, somewhat similar to that now in force in Ontario, which, it is hoped, will pave the way for the Torrens system. In Illinois, Minnesota, Dakota and other States, the evils of the present system are admitted, and the subject is being discussed, but no practical measure of relief has yet been adopted. Failing any legislative remedy, and as a substitute for a more satisfactory system, land title guarantec companies have been devised, which, for a percentage on the value, indemnify purchasers and mortgagees against loss by defective title. Before the Torrens system was introduced, it was in contemplation to form sueh a company in Toronto. 'The necessity for these companies, and the fact that their transactions have become a large and regular branch of business, similar to life and fire insurance, in several of the larger eities of the Union, is a sad reflection on the practical intelligence of legislators in that country.

* $\quad \begin{array}{lllllllll}* & * & * & * & * & * & * & * & *\end{array}$

"Coming now to our own l'rovince of Ontario, and including therewith the Provinee of Manitoba and the Northwest Territories, all of which adopted the Ontario system we find 
that at a very early period in its history a system of registration of deeds was established which provided for the recording of memorials of all instruments affecting land in books to be provided for each municipality. The first Registry Act was passed at Newark (now Niagara) in 1795, in the Fourth Session of the First Parliament of Upper Canada. Registry of instruments was at first optional, but was made compulsory in 1851 No provision appears to have been made in that Act for keeping an index of the lot, block or parcel of land affected, but the practice of keeping such an index was generally followed, and in 1865 was made obligatory. This plan of lot indexing was a material improvement on the plan of a general registry, with an index of the names of grantors only-such as prevails in the United States and in the Maritime Provinces. After the lapse of years, however, from the subdivision of original lots, the multiplication of registries, death and intestacy of owners, incompetent conveyancing, and other causes, expense, delays, uncertainty and insecurity, in regard to land titles, gave frequent cause of complaint, sometimes of litigation. Various measures were from time to time passed by the Legislature, with a view to remedy some of the more prominent evils. Among these were the Act of 1865 , before referred to, which provided among other things for the registry of deeds in full, instead of by memorial; and the several Acts simplifying the barring of entails, providing short forms of conveyances, reducing the time when undisturbed possession constitutes a good title, and The Quieting Titles Act.

"Beneficial as these measures were in mitigating some of the causes of complaint, they did not reach the root of the evil. The inherent defects of a system which, before an opinion can be formed as to the validity of any title to land, necessitates an investigation by a professional expert into the validity $o$ every conveyance, or passage by devolution, or by legal process back to the issue of the patent, which must be repeated every time a transaction takes place, involving, may be, the examination of hundreds of entries; that surrounds the transfer of land with so many traps and pitfalls and uncertainties that sometimes nothing short of a judicial decision can conclusively determine the questions that arise; that preserves, in regard to the transfer of the smallest and most inexpensive piece of land, an elaborate verbiage, required for no other description of property, cannot be cured by stripping off some of its more obnoxious features. It must be entirely swept away.

*
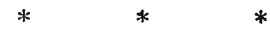

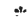

$*$

* 
"Although in successful operation for thirty years past in Australia, the Torrens system was first brought to the knowledge of the Canadian public in 1876, when two articles appeared in the Canadian Monthly Magazine, from the pen of Mr. George s. Holmested, whose attention had been drawn to the subject by Mr. Beverley Jones. To these two members of the legal profession, Canada is indebted, not only for initiating the movement for reform, but also for continued and efficient service in securing the adoption of the Torrens system. At first the announcement that such an improvement was possible seemed almost beyond belief. Gentlemen, learned in the law, ridiculed the idea, and others, whose experience had convinced them of the hardships attendant upon the old system, feared that the tidings were too good to be true. Subsequent investigation, the annual reports of the masters of titles in the Colonies where it was in operation, and the official returns to the Home Government, made by the Governors of these Colonies, soon left no room for unprejudiced doubt.

"In 1883, the Canada Land Law Amendment Association was formed for the avowed purpose of securing the abolition of some of the impediments to the safe holding and cheap and speedy transfer of land, and more especially to promote the introduction of the Torrens system. A prospectus was issued by the association and largely circulated. Were there time it would be amusing to read some of the able editorials and letters on the subject which appeared in the public press at the time. Some scoffed, others impugned the motives of the promoters. A large proportion of the members of the legal profession were either indifferent or hostile. Still, by many prominent and influential members of both the press and the legal profession the question was treated with candor, and even at this early date in some cases received a generous and hearty welcome and support. Notably among these distinguished members of the profession were Mr. Dalton McCarthy, Q.C., the Hon. Edward Blake, the Hon. Attorney General Mowat, and Mr. Meredith, Q.C.

"Deputations waited on the members of the three Gov(rnments of the Dominion and the Provinces of Ontario and Manitoba, to which the efforts of the association were chiefly directed, and were courteously received. But the subject was new, and very little hope was given of any immediate practical result. Several members of the Dominion Government, more especially Sir David Macpherson, then Minister of the Interior, and Sir John A. Macdonald, evinced a warm interest in the subject. 
"The Hon. O. Mowat, then, as now, Premier of Ontario, while personally sympathizing with the movement, on more than one occasion advised the officers of the association that in his judgment there was no sufficient expression of the popular will to warrant so radical a change as was proposed in the mode of land transfer. While admitting that there were grounds for this view, the officers of the association were convinced that the absence of any strong expression of popular opinion was not because the present system did not afford abundant cause for complaint, but because it was not generally known that any better system was available. The people had borne the burden so long that they supposed it to be inevitable. The association, therefore, took steps to bring the subject to the notice of various representative bodies and the general public. Deputations from the association waited on several of the city and county councils, Board of Agriculture, Grangers' Association, and Board of Trade. The prospectus of the association, an address delivered by myself before the Canadian Institute, and other literature on the subject were extensively circulated. The honorary secretary of the association visited Manitoba and organized a branch association in that Province. I myself, also, having other engagements in Manitoba, paid several visits to that Province. and also visited the Northwest Territories and the Provinces of Nova Scotia, New Brunswick and Prince Edward Island, and brought the subject before prominent representatives of each of these Provinces. Efforts, in many cases successful, were made to enlist the powerful aid of the press. As the result, the Ontario House of Assembly was flooded with petitions on the subject of land transfer reform, and at length cheering indications of ultimate success began to present themselves. The late Premier of Manitoba, Mr. Norquay, was from the first strongly in favor of the new method, and the Legislature of that Province enacted the first measure for adopting the Torrens system as a provincial scheme, which came into force on the 1st July, 1885. In the Province of Ontario the new scheme was inaugurated by the Hon. Mr. Mowat at the same date, but with a caution which was perhaps justifiable at the time, it was made applicable only to the city of Toronto and the county of York. Subsequently, in response to the urgent representations of the association, the outlying distriets of Muskoka, Parry Sound, Nipissing, Algoma, Rat Portage and Rainy River were brought by Mr. Mowat under the new system; optionally as far as land already patented is eoncerned, but compulsory in respect to all lands alienated by the Crown after the Aet came in force. The lands in these large districts comprise an extensive area, more than one-half 
of the whole Province, much of it still unpatented, which will therefore never be burdened with the old system of land transfer. Permission has also been given to counties, cities and towns in Ontario to adopt the Torrens system on certain conditions, which are, however, so onerous that not one of them has yet availed itself of the privilege. To obtain the benefits of the Torrens system each municipal council must pass a by-law declaring it expedient to extend the provisions of the Act to such municipality, and must undertake to provide proper fireproof and other accommodation for an office of land titles, provide books, furniture, stationery, lighting, etc., become responsible for the salaries of all officers, including the registrar or master of titles, and a proportion of the salary of an inspector. These appointments are all to be made and the salaries determined by the Government, the municipality having no voice, their sole duty being to provide the money. From sixty to seventy new offices to be built, and as many new officers to be saddled on the country. Can any scheme more extravagantly costly be conceived, or one less likely to be adopted? Instead of being surprised that no municipal council has adopted the scheme, the wonder would be if any one had done so.

"Next, and most important of all, the Dominion Government, after patient and painstaking investigation, decided on adopting the Torrens system of land transfer for the Northwest Territories, comprising all that vast region extending from the western boundary of Manitoba to British Columbia, and from the boundary of the United States to the Arctic Ocean. A bill with this object in view had been prepared some time before by Messrs. Beverley and Herbert C. Jones, and had been presented to Parliament in two previous sessions by Mr. Dalton McCarthy, Q.C., M.P. This bill, with some modifications, was adopted by Sir Alexander Campbell, then Minister of Justice, who introduced it in the session of 1884-1885. To give time for its full consideration, the bill was not enacted in that session; but in the following session, in the hands of Sir John Thompson, it was unanimously carried.

Mr. George S. Holmested, then inspector of titles of the High Court of Justice, in seconding the resolution favoring a simpler and less expensive mode of applying the Torrens system of land transfer to the whole province of Ontario, said in part :

"It is now fourteen years since I was first led to investigate that system, and from the time I came to understand it, 
until the present time, I have never wavered in my conviction of the great superiority of that system over that which prevails in Ontario.

"You have heard in the President's address that this Torrens system has been adopted by all the Australian Colonies, by the Parliament of Canada for the Northwest Territories, by the Legislature of Manitoba, and also partially by the Province of Ontario. The fact that it has been so adopted is strong prima facie evidence of its merits, but I should like, if possible, to convince everyone here present of the propriety of voting in favor of the Torrens system on its merits.

"In order that you may be able to give an intelligent opinion on the subject, it is necessary for you clearly to understand in what respect the Torrens system of registration differs from the system of registration of deeds which at present prevails in Ontario. People who look at the matter superficially may jump at the conclusion that there is no great difference between the two systems, but as a matter of fact they differ radically. It is quite true that under our present system of registration we talk of having 'a registered title,' meaning thereby that all the documents constituting the chain of title are registered. But if the Torrens system accomplished nothing more than that, no one would think it worth the trouble of making the change. Let us consider for a moment what the present system of registration is intended to do. It is simply this: To provide a public office in which all instruments affecting the title to land may be recorded. It does not pretend to provide any means whatever for determining the legal effect of instruments which are so recorded; and as a matter of fact instruments may be recorded against a pareel of land, which, though purporting to affect the title, have in reality no more legal effect on the title than a blank sheet of paper.

"Let us, in imagination, go for a moment to one of our registry offices. We want to ascertain the title to a lot of land. We are shown what is called an 'Abstract Index,' in which is set forth a list of all the instruments affecting the land we are inquiring about. From this it may appear that there is a perfect chain of titles, but no one is safe in relying on this index alone; he must examine each instrument indexed, and carefully consider whether it is made by proper parties, in proper form, and is duly executed. This he must do at his own risk. He must determine for himself the legal effect of each instrument at the risk that if he, or his legal adviser make a mistake, he may lose the land. And the great trouble is that after exercising all the eare and eaution possible, and procuring the best 
legal assistanee, some unexpected flaw may be discovered. Let me give you a few practical instances of the way in which our present registry system works.

"There was a ase of Nex V. Seddon before Mr. Justice Robertson lately. The action was brought to enforce a contract for the sale of a parcel of land. In this action it appeared that the rendor had a good registered title-no links in the chain were wanting, no flaws were apparent. It appeared that the vendor elaimed as devisee under his uncle's will and had effeeted loans on the property, and I believe had made one or two mortgages to loan companies. Now very few persons, I venture to think, would guess what was the objection to this title. The will under which the vendor claimed was in due form, duly executed, duly registered, and yet it was of no more value than a piece of waste paper. The difficulty was that after the testator had made his will, he married, which had the effect of revoking the will (see R. S. O., e. 109, \& 20), so that it was absolutely null and void; and yet, as you have seen, it was nevertheless registered.

"There was another ease not long ago before the courts of Munsie v. Lindsay (1 Ont. Reports, 164; 11 Ont. Reports. 520 ), in which the facts were as follows: In 1854 a man named Munsie died leaving a will whereby he devised his farm to his widow for her life, and then after her death to his son Robert. The will was cluly registered. Robert shortly afterwards purchased his mother's life interest, and then thinking himself owner of the lot absolutely, he sold it to his brother James, who subsequently sold it to the defendant Lindsay, who bought on the faith of his vendor having a good registered title. Lindsay lived on the lot and worked and improved it for a good many years, thinking, no doubt, to leave it as a provision for hi: family on his death. In 1874, lowever, the widow of the testator died, and within ten years afterwards the heirs at law instituted a suit against Lindsay and recovered the land from him, on the ground that the devise to Robert was void, he happening to have been a witness to the will. All the hardearned fruits of Linday's labor were thus taken from him without any compensation, except a lien for the value of the permanent improrements he had made, against which was set off an occupation rent for the premises since the widow's death. I think that you will eonfess that a registration system which leads to such results is, to say the least, not a very perfect or efficient system.

"I will give you anotler instanee of its effects. Some little time ago a ease was before the courts, Beaty v. Shau (14 Ont. Appeal Reports, 600), in which the following state of 
facts appeared: There were two persons, executor's and trustees of an estate. One of the trustees owed a sum of money to the estate, and executed a mortgage on a parcel of land to his cotrustee to secure its payment. The cotrustce died, and the other who owed the money survived him, and he then (without paying the debt to the trust estate) as surviving trustee and executor, dishonestly executed a discharge of his mortgage, which was duly registered. He then sold the land to the defendants in the action, who bought it in good faith. relying on the mortgage having been discharged. 'The purchasers worked it and made valuable improvements on it, and were somewhat astonished after the lapse of two years to learn that the discharge of mortgage was utterly worthless. The result of the suit was to take the land away from them, with all their improvements, without any compensation whatever; and yet you will be careful to observe that the discharge, or what purported to be a discharge, was duly registered.

"I remember another case where a man had laid out a farm lot as a village and cut it up into a number of small lots which he sold off. These lots passed through different hands, and some were sold for taxes. Unfortunately the village never got beyond the paper stage, and after some years all these lots got back into one hand, and were together used as a farm lot; but the land was practically unsaleable, for in order to investigate the title to this farm lot you had to examine and consider no less than 600 registrations, and the result was the owner had to spend over $\$ 1,000$ to quiet his title.

"But I will not weary you with further iliustrations of the hazards which people have to run under our present registry system. Let me, however, point out to you one other defect. Owing to the necessity of each link in the chain having to be perfect it is easy to see that the more transactions there are recorded, the greater is the number of defects likely to be found in the title; and the result is that the investigation of titles extends sometimes over months and even years. Some time ago there was a case before the courts in which no less than 144 objections and requisitions had been made on the title in question, and the investigation had been going on for four months; and all this means, I need hardly say, great expense.

"As the results of the present system of registry we have, therefore, great uncertainty of title and great expense and delay in investigating titles.

"Now let us see what the Torrens system is intended to do-but first I may tell you what it does not do. It does not pretend merely to record the fact that a deed or instrument 
has been made; and it does not permit instruments to be recorded as instruments affecting the title which are in fact of no more legal effect than mere waste paper, as we have seen that our present system of registry does. What the Torrens system aims at doing, and actually does, is to record the title, $i$. e., the legal effect of all instruments affecting the land. In order to bring property under this system, it is necessary that the title of the person claiming to be first registered as owner should be investigated by a public officer; the title having been proved to his satisfaction, it is then registered-not the string of deeds under which the owner claims, but the fact that the person who has thus established his title is the owner of the property; and if his title is subject to any qualifications, mortgages, or otherwise, these are also specially stated in the register."

The foregoing extracts set out with some fullness the steps leading up to the adoption of the Torrens system in Canada.

It will be noticed, however, that claim is made that the Torrens system was first brought to the notice of the Canadian public in 1876. Perhaps, strictly speaking, this is incorrect, for British Columbia had adopted a system drawn to a large extent from the Torrens system before its entry into the Canadian confederation. The history of the adoption of this system in British Columbia is given with some fullness in the judgment of Crease, J., in Re Shotbolt. ${ }^{12}$ The system was introduced by legislation into Vancouver Island as early as the 18th January, 1861. Vancouver Island was then a separate and distinct colony from the mainland known as British Columbia. When these were united on the 19th November, 1869, the Vancouver Island system was continued over the whole of the new colony, superseding the system of registration of assurances,

"Registration by copy; copving the deeds line for line, blot for blot, error for error."

and the system of the united colonies then confederated

121 B. C. R. Pt. 2 page 337. 
with the Dominion of Canada, was embodied in The Land Registry Ordinance, 18\%0. The draughtsman of The Vancouver Island Land Registry Act, 1861, had before him the draft of the bill to put the Torrens system into force in South Australia, which had reached British Columbia through the Imperial Colonial Office, but the system was adapted to meet the "peculiar circumstances of the eolony and the English system of conveyancing there." Registration was not made compulsory, and there was introduced into it a progressive feature which is not a feature of any of the Australian Aets, or of any of the Acts of Manitoba or of the former Northwest Territories, or the present Provinces of Saskatchewan and Alberta. The first title which could be registered was the "absolute" fee which was prima facie evidence of title only. After such a title had been on the register for seven years the owner might convert his absolute fee into an "indefeasible fee," obtaining a certificate of indefeasible title which corresponded very closely with the certificate of title under the true Torrens system. Progress was a principle of the Act. For some time it was the practice that each new owner, even though claiming under the owner of an indefeasible fee, could only perfect his own title into an indefeasible fee after the lapse of seven years and it was so judicially decided in Re Trimble, ${ }^{13}$ but the case of Re Shotbolt, ante, set this right, so that the holder of an indefeasible fee could pass a title of the same nature to his purchaser.

The requirement for the lapse of seven years has been abandoned, although in British Columbia the holder of an absolute fee may convert his title into an indefeasible fee, but only upon being able to satisfy the registrar that "a good safe holding and marketable title has been established," 14 and a person may, if he has the necessary title,

${ }^{13} 1$ B. C. R. Pt. 2, page 321.

${ }^{14}$ B. C. Act of 1906, e. 78. 
obtain an indefeasible fee without going through the intermediate stage. Neither was there in British Columbia any guarantee or assurance fund. This fund was established for the first time in British Columbia in 1898 and applies only to land on the register of indefeasible fees. Furthermore, the Act in British Columbia did not and does not now provide for, and, in fact, compel the use of the extremely simple forms for the passing or creation of interests in land under the Act as in the true Torrens Acts, and while such is not a necessity of a system of registration of title, it is one of the strong features which makes the true Torrens system so easily workable. This is in effect a great means of accomplishing the twofold object of the Act, namely, to simplify the law relating to the transfer and incumbrance of land and facilitate its transfer. It is a fact that by the successive amendments to the British Columbia Land Registry Act in recent years the register of indefeasible fees has been approximating more and more to the register under the Torrens system in the prairie provinces of Canada, but so long as there are so many and great differences in the working out of the two sets of Acts, it was found impossible and likely to lead to extreme confusion to attempt to include in this work a discussion of the British Columbia Act in all its bearings.

In regard to the Ontario Act, introduced in 1885 under circumstances which have been outlined. it has already been pointed out that this Act is based upon the English Act of 1875. That Act was adapted to the country where titles to land were growths of centuries and where custom and precedent exercised an extremely powerful, if not entirely dominating, influence. It is naturally to be expected that in such a case the framers of such an Act would not attempt to deal with land titles in the bold and thoroughgoing fashion adopted in the new colony 
of Australia, where a large part of the land had not passed from the Crown at all and where none of the titles had any history behind them eompared to what is to be found in the ease of any piece of land in England. The circumstances of the Provinee of Manitoba and of the Northwest Territories in 1885 and of the new provinces in 1906, corresponded much more closely with the state of affairs in Australia than with that in England and indeed in Ontario, and it is not surprising therefore to find a difference between the Acts in the prairie provinees and that of Ontario corresponding to that which is found between the Australian Acts and the English Acts of 1875 and 1897. The Ontario Act provides for three varieties of title, possessory, qualified and absolute. The absolute title corresponds to the title certified to under the ordinary certificate of title of land in fee simple under the Torrens systems in Australia and the prairie provinces of Canada. The term "possessory title" may be misleading to some, for, when used in ordinary legal parlance, it refers to a statutory title which the oceupant has acquired by length of possession, whereas in the Ontario Act it means simply the registration of the title of anyone in possession, and was adopted as the phraseology in the Ontario Act only because of a slavish copying of the English legislation. A possessory certificate does not obviate the necessity for searching the title prior to the time of the registration of the first certificate, but it prevents the formation of further links in the ehain of title except on the register and therefore in time, by the operation of the Statute of Limitations, ripens into as effective a title as an originally absolute title. Neither did the Ontario Act attempt to confine the creation of interests in land altogether to the register. Section 68 (1) of the present Act of that Provinee says: ${ }^{15}$

25 1 Geo. V, c. 28 (1911). 
"No person other than the registered owner thereof shall be entitled to transfer or charge registered freehold or leasehold land by a registered disposition."

Section 68 (2):

"Subject to the maintenance of the estate and right of such owner, any person having a sufficient estate or interest in the land may create estates, rights, interests and equities in the same manner as he might do if the land were not registered."

This provision, which also appears in the English Acts, as interpreted by Capital and Counties Bank v. Rhodes, ${ }^{16}$ has carried the theory of the Act in a divergent direction to that of the strict Torrens Acts. Notwithstanding the similarity in a great many ways between the absolute title of the Ontario Act and the registered title in the Acts of Manitoba, Saskatchewan and Alberta, the great differences in detail as in the case of the British Columbia Act, render it unwise to attempt to include the Ontario Act in this work, although the cases under that Act which, as compared with the body of law which has grown up around the system in the western provinces, are very few, will nevertheless be freely drawn upon for authority and analogy.

The progress and growth of the systems in the Provinces of Manitoba, Saskatchewan and Alberta and in the Northwest Territories, is set out in the Appendix. There is, however, one more province of the Dominion which has introduced a tentative system of registration of title. On the 3rd of March, 1904, The Land Titles Act of Nova Scotia was passed. ${ }^{17}$ By the last section of this Act it came into force for voluntary registration thereunder in any county only upon proclamation by the Lieutenant Governor in Council. Such orders have been made bringing the Act into force in the counties of Halifax, Colchester and Annapolis, but nothing has been done under it in any of them and the Act is practically

1672 L. J. Ch. 336 ; (1903) 1 Ch. 631.

${ }^{17} 3$ \& 4 Edw. VII, c. 47. 
a dead letter. In its outline it is more purely and simply an Act for the registration of title as distinguished from an Act having for its purpose also the simplification of title, than any other of the Torrens Acts. Statutory forms are prescribed by section 43. Any other forms in general use are equally acceptable. The titles are divided into "possessory," "qualified" and "absolute" as in Ontario. It is provided that:

"No instrument excepting a will or lease for a term not greater than three years, purporting to convey or affect any registered land, shall take effect so as to convey or bind the land but shall operate only as a contract between the parties and as evidence of authority to the registrar to make registration and the transfer or other conveyance shall not be deemed to be effected until registration is made."

Instruments, however, upon registration, appear to have the same effect as the same instruments where registration is not required. A mortgage is foreclosed in the same manner as a mortgage of unregistered land. A radical difference from the other Acts is that trusts are recognized. Trustees may be registered and referred to in certificates of title, and registered dealings may then be had with the land covered by such certificate only upon the terms of the trust.

The Torrens system has also been introduced to a small extent in the United States, but the question of constitutionality makes the progress of the system difficult. In 1895 an Act for the registration of titles was passed in Illinois but was declared unconstitutional by the Supreme Court on the ground that it conferred judicial powers on the registrars and the examiners of title. Another Act was passed in that State in 1897, which, as amended in 1907, constitutes the present basis of registration in Illinois. The California Act was passed in 1897 and has not been amended and very few registrations have been made under it. The Massachusetts Act 
was passed in 1898 and amended subsequently from time to time. The Oregon Act was passed in 1901, copied almost wholly from the Illinois Act of 1897. An Act was passed in Minnesota in 1901, in Colorado in 1903 and in Washington in 1907. The Philippine Islands adopted an Act in 1902, and the Territory of Hawaii in 1903. The indemnity fund provided by the Ohio Act was declared unconstitutional and the Act repealed in 1898.

It would perhaps not be out of place to add a few comments on the success of the system where it has seen its fullest development in Canada, namely in Manitoba, Saskatchewan and Alberta. Generally speaking, while from time to time there are occasions to find fault, often reasonably, with particular instances of mal-administration, it may safely be said that it would be hard, if not impossible, to find anyone who would revert to the old system of registration of deeds. The fact of the growth of the system in Manitoba where it is optional, the "old system" existing side by side, is striking evidence of the value of the Torrens system, especially where administered in a liberal spirit, untrammelled by unnecessary technicalities. The expense of bringing land under the "new system" has not proven a barrier, as against the increased salability of land under that system. It is not infrequent in contracts for a purchaser to stipulate for a Torrens title. This is notwithstanding the fact that, while Manitoba cannot show titles going back one hundred years, it has yet been in existence long enough to have produced titles of some complication and containing a very large number of instruments. The matter of expense in bringing land under the system is intimately connected with another feature, namely the attitude of the officials of the system toward technical defects. If that attitude be that the minutest objection unsatisfied is a bar to the registrar, and the assurance 
fund back of him, from accepting any responsibility, then the system becomes expensive and burdensome and to this attitude may probably be attributed the failure of the system to advance in some of the older jurisdictions. But if, as is the case in practice in Manitoba, the registrar is at liberty to substitute moral certainty for legal certainty where the latter is not available, acting on the view that the purpose of the Act, and of the assurance fund, is to facilitate the transfer of land, in that case the system becomes correspondingly advantageous and popular.

It is true also that the expense attached to operations under the system is higher than under the old system, especially in Saskatchewan and Alberta, where a percentage is payable to the assurance fund on each transfer, instead of only on the first bringing under the system, as in Manitoba. But laymen who have had experience with both systems are found to be the first to appreciate that, for this additional cost, they obtain in greater proportion, greater security of title on the one hand, and a title more easily disposed of on the other. From the point of view of the legal profession the time saved in searching and searching over again is inestimable. The other side of this is, of course, that a class of work for which considerable fees were collected under the old system is largely abol'shed under the new. But as in every other legal reform the general rule holds that in the long run the egal profession does not suffer in pocket, and cer ainly not in reputation, by the clearing away of "old lumber" and making access to the real benefits of the law more easy. Certainly the legal profession of these provinces would never willingly go back to the old, wasteful and wearisome system of searches back to the beginning on every succes:ive transaction.

An objection is sometimes made that operations under the new system are slower than under the old. 
Here again it is a question of a balance of conveniences. The culminating point of a sale transaction so familiar to conveyancing practitioners in the older provinces, when with all due form the solicitor for the vendor attended at the registry office with the deed, and at the same time the solicitor for the purchaser with the money, and having made final searches, deed and money were exchanged and the deed handed to the registrar with the assurance that such title as there was was thereby crystallized, has no counterpart under the new system. No matter how completely up to date a registry office under the new system may be the necessity for examination of instruments, having regard both to the form and contents of the instruments themselves and to the state of the register at the moment of registration, renders it in the nature of things impossible for the purchaser in such a case to know beyond peradventure that his transfer will obtain registration, and without that he cannot know he is getting what he is paying his money for. Therefore a practice of holding money in trust, either with solicitors or in banks, pending registration as agreed on, has grown up. It is true it is slower-varying from a day or two to as high as three weeks - a delay in such latter case which should be attributed to a poorly managed office where it occurs, and not put down as a necessary accompaniment of the system. But in any case, so satisfactory are the results of the unimpeachable title felt to be when obtained, that, as in the case of the cost, it is felt that the results justify the small disadvantage, and suggestions of reform are directed where necessary to the administration of the system, not to its abolition.

The administration of the system as distinguished from its general principles except in its broader outlines cannot be gathered with certainty from the Acts. Especially is this the case in Mani- 
toba. In that province, indeed, it is admitted that their legislation contemplates laying down the principles to be followed and results to be reached by the system, leaving out the details, so as to permit of elasticity in the everyday administration. In the other jurisdictions, a much greater acquaintance with the procedure thereunder can be obtained from a perusal of the Acts themselves. Both of these legislative views have something in them to specially commend them. But what is of more importance from the point of view of making the working of the Torrens system of the greatest advantage to the public generally is that the principle of administration should be the securing to all persons affected its benefits wherever possible and not its own technical perfection. Even the comparatively brief history of the system in Canada so far, shows that given this guiding principle in administration and on the other side an appreciation by the public and legal profession that the simplicity of the system does not mean laxity, and that accuracy in conveyancing is requisite for the satisfactory working of the system, it is bound to continue growing in public favor. 


\section{CHAPTER II}

THE MACHINERY OF THE SYSTEM

\section{$\S$ 7. OFFICIALS.}
a. In General.
b. Registrar General.
c. Master of Titles.
d. Inspector of Land Titles Offices.
e. Registrar or District Registrar.
f. Judges of Superior Courts.

§ 8. BOOKS.
a. In General.
b. Day Book.
c. General Register-Execution Register.
d. Certificate of Title.

(1) IN GENERAL.

(2) OIVNER.

(3) ESTATE.

(4) RIGHTS OLTSIDE THE CERTIFICATE.

(a) In General.

(b) Those Common to all Jurisdictions.

(c) Common to Alberta, Saskatcheuan and the Dominion.

(d) Peculiar to Manitoba.

(e) Peculiar to Saskatchewan.

(f) Pcculiar to Alberta.

(5) THE LAND.

(6) ADDREN OF OWNER.

(7) INCLMBRANCES.

e. Duplicate Certificate of Title.

\section{OFFICIALS. \\ a. In General.}

The administration of real property laws of all description is under section 92 of The British North America Act a matter for the provinces, and is in each province. in practice, placed under the control of the department of the attorney general. ${ }^{1}$

1 Sask. 21 ; Alta. 10; Dom. 28. 
Under this general control the actual working officers of the Torrens system in each province are ranged. In the Yukon and Northwest Territories the Dominion Government has the matter under its jurisdiction.

\section{b. Registrar General.}

In Manitoba a registrar general is provided for by section 8 of The Real Property Act, but so far no powers and duties have been prescribed by Order in Council under the Act pursuant to that section. In practice, however, the registrar general in Winnipeg has for many years been looked upon and consulted as the directing head of the system in Manitoba, with perhaps more real, if less nominal, authority than the head of the system in any other province. The registrar general must approve of all sales by executors or administrators where infants or lunatics are beneficially interested or where adult heirs or devisees do not concur and there are no debts. ${ }^{3}$

\section{c. Master of Titles.}

In Saskatchewan the head of the administration of The Land Titles Act is the master of titles. ${ }^{3}$ This officer has so far as the statutes show a much more extended jurisdiction than the corresponding officer in any of the other systems. In addition to having the general supervision of the work of the offices, he is constituted the appellate tribunal from the registrars, references and petitions from them or their rulings both being taken to the master, whereas in Alberta and Manitoba that jurisdiction is exercised by a judge, as defined in the Acts, acting as persona designata. ${ }^{4}$ The decisions, therefore, of the master of titles in Saskatchervan appear to be placed on a par with the decisions of the judge of the superior

25 \& 6 Edw. VII (1906); Man. c. 21, § 2.

3 Sask. 16.

${ }^{4}$ Sask. 146, 147; Man. 121; Alta. 112, 113; Dom. 152, 153. 
courts of the other provinces acting as such persona designata, and references are accordingly made to such decisions in this work.

\section{d. Inspector of Land Titles Offices.}

In Alberta the head of the system is the inspector of land titles offices. ${ }^{5}$ His duties correspond as far as they go to the duties of the master of titles in Saskatchewan, but he has not the very important powers of hearing references and petitions and of passing on the title of lands for which application to bring under the system has been made.

The inspector of land titles offices in the Territories has the same powers with the same limitations as the same officer in Alberta. ${ }^{6}$

\section{e. Registrar or District Registrar.}

Next to the foregoing officers comes the officer who is really the pirotal point of the system, the "registrar" or "district registrar," as the case may be..$^{7}$ The name "district registrar" is used in Manitoba to distinguish a registrar under The Real Property Act or "new system" from a "registrar" under The Registry Act or "old system."

The duties of the registrar are, speaking generally, to administer the Act within his district. The registrar or district registrar, in each case, must be a barrister, and to insure impartiality in the administration of the Acts, is expressly prohibited from engaging in any business that could conflict with his duties as registrar. ${ }^{8} \mathrm{He}$ is, however, protected from personal liability so far as regards all acts bona fide done by him in the exercise or the supposed exercise of his duties, which protection is likewise cast over all the officers administering the Torrens

- Alta. 7.

- Alta. 5; Dom. 23.

7 Man. 8; Sask. 18; Alta. 8; Dom. 25.

- Man. 16; Sask. 22; Alta. 18; Dom. 33. 
Acts. ${ }^{9}$ His duties, however, end with administering the Act strictly as he finds it. It has been laicl down by the Full Court of Victoria that he should not make a practice, even for beneficent ends, of protecting persons, for example creditors, where it is not so provided in the Act. The court pointed out that if he should at some time negleet so to do, a right might be set up against the assurance fund by such persons (ereditors in that ease) on the ground that the recognized practice had been departed from. ${ }^{10}$ For bona fide errors or omissions made by the registrar or by his elerks, for whose errors and omissions he is responsible, the assurance fund is provided. ${ }^{11}$ Upon the registrar is laid the duty in the first instance of examining the title to land for which application is made to bring the same under the Act. In British Columbia an examiner of titles is provided. ${ }^{12}$ There are also officials called examiners of title in Nanitoba, ${ }^{13}$ but they act merely through the registrar. It is also the duty of the registrar to pass on the fitness, or otherwise, for registration of all documents presented for that purpose. The principles upon which the registrar acts in bringing or refusing to bring land under the Act and in rejecting or passing instruments are discussed post pages 44 and 74 .

To what extent the functions of the registrar are purely ministerial, or, on the other hand, are discretionary or judicial, has been frequently the subject of judicial comment. Briefly, it may be said the functions of the registrar are strictly ministerial in so far as he can only carry out the terms of the Act; no judicial power, that is to say as affecting rights of parties outside of the Act, can be

${ }^{9}$ Man. 19; Sask. 23; Alta. 143; Dom. 34.

${ }^{10}$ Ex parte Wisewould, 16 V. L. R. 149 (full court).

"Morris v. Bentley, 2 Terr. L. R. 253, at page 272.

${ }^{12}$ B.C. 7.

${ }^{13}$ Man. 16. 
inferred; ${ }^{14}$ if it exists in any case, it must be expressly conferred. In Manitoba, such discretionary power has been expressly conferred to determine the right to priority of an instrument presented for registration over a prior registration of a certificate of judgment. ${ }^{15}$ On the other hand, in Manning v. the Commissioner of Titles, on appeal to the Privy Council from the Supreme Court of Western Australia, ${ }^{16}$ application had been made to bring land under the Act, and it was held that notwithstanding that the literal provisions of the Act had been complied with by the applicant, the commissioner of titles had a right to reject the title on account of certain depositions on oath, which he had taken, which tended to throw doubt on the applicant's possession. Commenting on section 18 of the Western Australia Act, Lord Hobhouse, delivering the judgment of the board, said.

"If the commisssioner finds that no transaction affecting the land has been registered under any general Act, section 18 says that 'he shall direct the registrar to bring the land under the operation of this Act by registering a certificate of title.' According to the literal force of sections 17 and 18 any person may appear claiming to be the owner of land alienated in fee by the Crown, and if there has been no previous registration the commissioner has absolutely nothing to do but to direct the registrar to enter a certificate of title. It is felt by all that such a conclusion is irrational and the appellant's counsel do not contend for it. They admit that the commissioner must have some power of inquiry and discretion to accept or reject an application, but they camnot point to any words of the Act which expressly confer those powers on him.

"As regards section 18 then it is not disputed that the commissioner is an official bound to exercise his intelligence and not a mere machine, as the literal force of the words would make him."

${ }^{14}$ Re Massey and Gibson, 7 Man. L. R. 172; Wilkie v. Jellelt, 26 S. C. R. 282, 2 Terr. L. R. 133; Reeres v. Konschur, 2 S. L. R. 125, 10 W. L. R. 680 ; Kissling v. Mitchelson, 3 N. Z. L. R. C. A. 261; Morris v. Bentley, 2 Terr. L. R. 253; Syndieal Lyonnais v. MeGrade, 36 S. C. R. at page 265.

15 Man. 87.

1615 A. C. $195 ; 59$ L. J. P. C. $59 ; 62$ L. T. 373. 
And in holding that a registrar had a judicial duty to examine into the validity of instruments presented to him for registration, in a Victorian case, ${ }^{17}$ Stawell, C. J., said:

"The judicial duty is imposed on him of examining into the validity of instruments presented to him for registration. He is to investigate them and all the facts presented to him and say whether such instruments are valid or not. * * * Section 135 provides that if the Registrar refuses to register he may be compelled to assign reasons; that is reasons in law as well as in fact. If merely the mechanical duty of registering instruments valid or invalid were imposed on him, the latter section would be scarcely necessary. *** He has therefore to discharge not merely ministerial but judicial duties."

The latter two cases, however, may be taken merely as instances where a judicial or discretionary power was read into the duties of the registrar by necessary implication. The former is an illustration of the very liberal interpretation placed upon the powers of the official whose duty it is to pass on titles submitted for first registration; while the latter merely excepts from the general rule the judicial power of the registrar, so far as it can be said to be a judicial power, of applying the law to the instruments and facts presented to him pursuant to the Act.

In addition to the registrar, deputy and assistant deputy. registrars are provided for by the Acts with powers as prescribed by the Acts. In addition there are in practice examiners, searching clerks, surveyors and clerks of various descriptions, all of which, however, is matter of internal administration, the registrar being the official responsible to the attorney general's department and to the public.

\section{f. Judges of Superior Courts.}

Excepting in Saskatchewan, where, as pointed out, ante, page 35 , the master of titles is the appellate tribunal on references or petitions from the registrar, the judges of the superior court in each

${ }^{17}$ Ex parte Bond, 6 V. L. R. 458. 
province are made officers for the administration of the Torrens Acts by reason of the powers conferred upon them as persona designata for the hearing of references or petitions. ${ }^{18}$

Under section 120 of The Real Property Act of Manitoba, 52 Vict. 1889 , c. $16, \S 120$, power of reference was provided by the registrar to a judge of the Court of Queen's Bench in chambers,

"Who shall allow any of the parties interested and the Attorney General for the Province to appear before him and summon any other of such persons to appear and show cause in relation thereto; and if upon such reference the said judge having regard to the parties appearing before him thinks proper to decide the question, he shall have power to do so or to direct any proceedings to be instituted for that purpose, or, etc."

Under that section where one of the parties asked leave to file an affidavit as to the facts Chief Justice Taylor held that the case stated, together with any documents transmitted by the registrar general should alone be dealt with. ${ }^{19}$ It may be noted that the power of reference to a judge has been abolished (an unwritten practice of referring to the registrar general having taken its place) in Manitoba, but continues in the other jurisdictions. With regard to petitions from a ruling of a registrar, $\overline{a s}$ distinct from a reference by the registrar, no power of receiving evidence is given beyond that prescribed in the case of references, except under section 122 of the Manitoba Act, and the preceding case would, therefore, seem to apply to all the petitions and references provided for in the present Acts of Saskatchewan, Alberta and the Dominion. It is true that in Re Massey and Gibson, ${ }^{20}$ Killam, C. J., held that, under the section the same as the present Manitoba section 121, he had power to take evidence upon a petition, but that dictum was not necessary to the decision arrived at, as the evidence taken was not

${ }^{18}$ Man. 121; Alta. 112, 113; Dom. 152, 153; compare $\$ \$ 146,147$.

19 Re Joyce v. Scarry, 6 Man. L. R. 281.

207 Man. L. R. 172 . 
acted on. The language of the Acts used in regard to the disposition of a petition is not substantially different from that used in regard to the disposition of a reference, under which Taylor, C. J., held as just previously stated. On a reference the only question before the judge is "whether or not the action of the registrar was right," 21 and that question being one of administration of the Act, not of rights of parties generally, it would seem proper that the appellate tribunal should place itself in the position of the registrar and from that point of view decide whether his action was right, rather than from evidence which he did not have and could not properly have had before him. The fact of the enactment of section 122 in Manitoba specifically providing for the hearing of evidence in such cases, as well as others, bears out the view that in the absence of such a section in the other Acts ${ }^{22}$ no such power is to be inferred. ${ }^{23}$

The term "judge" is defined in the Manitoba Act as a "judge of His Majesty's Court of King's Bench for Manitoba, and includes the Chief Justice," ${ }^{25}$ in Saskatchewan is a judge of the Supreme Court; ${ }^{26}$ in Alberta is "an officer" authorized in the province to adjudicate in civil matters in which the title to real estate is in question;" 27 and the definition in the Dominion Act corresponds to that in the Alberta Act. ${ }^{28}$ In Re Shere, ${ }^{29}$ the meaning of the present

$"$ Reeves v. Konschur, 2 S. L. R., Lamont, J., at page 133, and see Newlands, J., at page 131, that the judge on a reference is to "direct the registrar as to what his duties were"

22 A reference or petition is not an "inquiry" within the meaning of Sask. 173; Alta. 146; Dom. 178.

${ }^{23}$ But see what may be a contrary suggestion in Manning v. Commissioner of Titles, 15 A. C., at page 202
${ }^{25}$ Man. 2 (o).
${ }^{26}$ Sask. 2 (18) (19).

${ }^{27}$ Alta. $2(\mathrm{t})$.

28 Dom. $2(22)$.

${ }^{20} 4$ S. L. R. 51; 16 W. L. R. 277. In Saskatchewan the Rules of Court do not extend so as to confer on local masters of the Supreme Court the jurisdiction of a judge of the Supreme Court acting as persona designata under The Land Titles Act. Re Saskatoon Caveat, 2 WV. W. R. 523, 21 W. L. R. 575. Nor does any other Act, unless by express words overriding The Land Tilles Act. Nicholson. v. Drew, 21 W. L. R. 189. 
definition of "judge" in the Alberta Act was discussed in Saskatchewan, the definition in The Land Titles Act 1906, Saskatchewan, being the same as in the present Alberta Act, and it was held that the definition did not extend to a District Court judge acting as a local master of the Supreme Court.

The jurisdiction of a judge under the Acts being that of persona designata is strictly confined to the powers conferred by the Act. Thus on a reference or petition (and in discussing references and petitions the same rules apply to the case of the master of titles in Saskatchewan) the judge has jurisdiction only to make the order which the registrar should have made. ${ }^{30}$

"Where equitable or beneficial rights are sought to be enforced, the equitable jurisdiction of the court must be invoked in some cause or matter in the court and cannot be raised on a reference to a judge is to a registrar's duty." ${ }_{31}$

The general rule is that wherever a judge as persona designata is made an officer for the administration of the Torrens Acts, he will not on such proceedings or on a chamber application decide important or involved questions of law or disputed questions of fact. ${ }^{32}$ But a judge acting as persona designata is not as strictly bound by technical rules as he would be if dealing with a matter in court. ${ }^{33}$

An appeal to the supreme Court of Canada eventually lies in the ordinary way from proceedings originating before a judge acting as persona designata; thus the confirmation of a tax sale transfer by a

${ }^{30}$ Recves v. Konschur, 2 S. L. R. 125; Morris v. Bentley, 2 Terr. L. R. 253 ; Hilkie v. Jellett, 2 Terr. L. R. 133, 26 S. C. R. 252; Hassey v. Gibson, 7 Man. L. R. 172.

s1 Reeres v. Konschur, supra, at page 134.

${ }^{32}$ Re Vellor, 2 W. L. R. 17: Re Roumd and Strathcona, 5 W. L. R. 450; In re Wark Caweat, 2 S. L. R. 431; Gaar Scott v. Guigere, 2 S. L. R. 374; Re Hofreevy and Murray, 19 IV. L. R. 947; Re Webster and C.P.R., 6 W. L. R. 384.

sa John Abell Engine and Hachine Works Co. Ltd, v. Scolt, 6 Terr. L. R. 302 , at page 308 .

For further comments and cases upon the powers of a judge acting as persona designata, see page 67 . 
judge of the Supreme Court of the Territories under Section 97 of The Land Titles Act 1894, was held to be a matter or proceeding originating in a court of superior jurisdiction, and an appeal was held to lie to the Supreme Court of Canada from a final judgment of the full court affirming the same. ${ }^{34}$ The grounds of the above decision are unfortunately not given in the judgment of the court, and the decision does not appear to throw any light on whether such an appeal to the Supreme Court of Canada would now lie from a proceeding originating by reference or petition to the master of titles in Saskatchewan.

\section{§. BOOKS.}

\section{a. In General.}

Under a system of registration of instruments and of titles thereby, a first requisite is a system of books which shall conveniently classify and systematize the instruments so registered. Correlative with that is the requirement of keeping a strict chronological record of all instruments which are presented for registration, and, in more convenient form, those which, after having been so presented, have been examined and found in proper form for actual registration. The objects to be accomplished in all the Acts are the same, the methods of accomplishing them differ in detail in practice.

\section{b. Day Book.}

The "day book" is the one name common to all the jurisdictions as the important book in the preliminary stage of registration. Consistently with the general scheme of their system, the Act in Manitoba leaves much more detail to be filled out in the

* The North British Canadian Investment Co. v. The Trustes of St. John Sehool District No. 16 of the Northwest Territoris, 35 S. C. R. 461 ; and see City of IIalifax v. Jas. Reeres, 23 S. C. R. 340; C.P.R. v. Ste. Therese, 16 s. C. R. 606. 
actual working of the system than in the others. When an instrument is presented for registration a record of it is immediately taken, together with the actual time of presentation. In Manitoba this entry is made in the fee book at once, and if the instrument is subsequently rejected a note of that fact is made opposite the entry. The "fee book" is deemed part of the day book. The actual day book as known to the office practice is a mere record of totals. Into the transfer journal, or the caveat book, or as the case may be, are carried forward from the fee book particulars of all instruments actually registered. In the other provinces it is into the day book that the record of all instruments actually registered or filed is carried forward, this book containing in chronological order a record of all instruments registered or filed of whatever nature. The time of entry in the day book under the Acts fixes the priority of registration, and priority of registration priority of the instruments, so that the important thing is not the names of the books kept but the fact of their being kept in some way to permit of easy reference from the books to the instruments themselves, which are retained in the office upon registration, and to the certificates of title and abstract books.

Only those instruments which are in proper form for registration under the system can be entered in the day book. ${ }^{35}$ Any other instrument which may come into the hands of the registrar is, for the purposes of the Act, treated as if it had never been received by him ${ }^{36}$ and the registrar owes no duty to it but to reject it, and return it to the person presenting it for registration.

35 Sask. 29 (2); Man. 83; Alta. 46; Dom. 74.

${ }^{3 i}$ Re American Abell Engine of Thresher Co. and Noble, 6 Terr. L. R. 359, 3 W. L. R. 324; Re Greenshields Co., 6 Terr. L. R. 205, 2 W. L. R. 421; Re Toth and Case, 3 S. L. R. 270; Hall v. Registrar of the Yorkton Land Titles Distriet, 16 IT. L. R. 565. 
Those instruments which appear on the day book are said to be "registered" or "filed," as the case may be. "In Saskatchewan, Alberta and the Dominion a "registered" instrument is one which is not only entered in the day book, but which affects land for which a certificate of title has been granted, and consequently which has a memorandum thereof entered upon a certificate of title; while a "filed" instrument is one referring to lands without specific description, or to lands for which no certificate of title has been granted, and which, therefore, can only be entered in the day book and not on any certificate of title. In Manitoba although the word "file" is used, ${ }^{38}$ it has not a technical meaning as in the other jurisdictions, and any instrument which is entered in the day book is said to be registered, although the distinction necessarily exists between the two kinds of instruments. In Manitoba an instrument is deemed to be "registered" as soon as a memorial thereof indorsed thereon shall have been signed and sealed by the district registrar, ${ }^{39}$ but in the other jurisdictions every instrument (except a grant, which stands by itself) is deemed to be registered as soon as a memorandum thereof has been entered in the register upon the folio constituted by the existing certificate of title of the land; in Manitoba every registered instrument shall, for the purpose of the Act, be deemed and be taken to be embodied in the register as part and parcel thereof. ${ }^{40}$ Registration in Manitoba includes what is called "filing" in the other jurisdictions. There are, however, even in Manitoba certain instruments, as for example, a notice of exercising power of sale, which are directed to be filed. A note of such instrument should be made in some way upon the certificate of title of the land affected, as otherwise the

${ }^{37}$ Sask. 2 (13); Alta. 2 (m); Dom. 2 (13).

${ }^{38}$ Man. 12, $109 . \quad 30$ Man. 65.

${ }^{6}$ Man. 81. 
instrument would be for all practical purposes lost in the day book, a search through that book being impossible for the purpose of discovering filed instruments. ${ }^{41}$ For a discussion of the principles upon which the registrar acts in determining whether an instrument is suitable for entering in the day book see post, pages $92-117$.

\section{c. General Register-Execution Register.}

These books are provided for by the Act in Saskatchewan, ${ }^{42}$ and while no statutory provision is made in the other jurisdictions, it may be said, generally, that the Acts imply the power in the registrar to keep such books as may be necessary for the efficient working of the system, and the earrying out of duties cast on the registrar. Thus, for example, in each jurisdiction it is customary to keep what is called the power of attorney book. ${ }^{43}$ In Manitoba a book called the deposit book is kept, in which are entered, numbered and indexed matters of evidence, such as marriage certificates and companies' charters. In any jurisdiction where registration under the system is compulsory to permit of dealings, a land index must be kept on which are noted all filed instruments affecting land prior to the issue of a certificate of title, and such index is also kept in any case for convenience as an index to certifieates of title.

\section{d. Certificate of Title.}

(1) IN GENERAL.

The certificate of title may be deseribed as the pivotal point in the Torrens system of land transfer, and consequently the certificate of title together with its comnterpart, the cluplicate certificate of title, and the register, which is nothing more than the original

${ }^{41}$ Re Rivers, 1 Terr. L. R. 464, at 475, is not followed. Morris v. Bentley, 2 Terr. L. R. 253.

${ }^{42}$ Sask. 34 and 35. ${ }^{43}$ Sask. 106; Dom. 112. 
certificates bound together in volumes, ${ }^{44}$ justify a scrutiny of their contents with considerable care.

The certificate of title is in its simplest form, merely a certificate provided by statute and signed by the registrar, certifying that the party named therein is the owner of the land described for the estate also named therein, and subject to the incumbrances appearing on it. Around the effect given by the various Torrens statutes to this certificate centres the whole value of that system.

(2) OWNER.

The name of the holder of the certificate, together with his address and occupation, appears first on the certificate. It is important for the proper working of the system that these should be set out with great care and accuracy. Where the actual creation and transfer of estates in land lie in the hands of the registrar by reason of the effect given to registration, it is important that he should have, to guide him, full particulars, and a registrar might reasonably reject an instrument which would call for the issue of a certificate of title in the name of a person giving initials only, for example, or without any address or description, as the registrar is entitled to these full particulars for use when he is again required to pass on an instrument dealing with the land. If, however, an error shall have crept into a name in a certificate of title, it has been held in Saskatchewan that the registrar has power to receive evidence and to correct the name. ${ }^{45}$ Owners and mortgagees may be required to deliver to the registrar a memorandum of some post office address within the province at which notices may be served. ${ }^{46}$

(3) ESTATE.

Following the name, address and description comes the limitation of the estate certified to. The

44 Man. 2 (x); Sask. 2 (12); Alta. 2 (1); Dom. 2 (12).

${ }^{45}$ Re Smith, 8 W. L. R. 131. ${ }^{46}$ Sask. 186; Alta. 38; Dom. 192. 
intention of the system is to permit only a few simple estates and interests in land to have the benefit of registration under the system. So far as recognition by the system is concerned, trusts are done away with, ${ }^{47}$ and in Saskatchewan, Alberta and the Dominion fee tail estates, except possibly upon first registration, are abolished. ${ }^{45}$

(4) RIGHTS OLTSIDE THE CERTIFICATE.

(a) In General.

The certificate of title, however, does not purport to be a complete symopsis, as it were, of the title of the holder. There are certain rights in land which attach entirely independently of mention or otherwise in the certificate, which, therefore, transfers and the issue of new certificates cannot defeat as they are expressly exempted from the operation of the system, and continue their existence quite independently of the machinery of the system. These are the statutory exceptions to which the certificate of title granted by the Acts is by implication and without any special mention therein subject. ${ }^{49}$ The sections setting these out are in Manitoba and Alberta printed on the margin of the duplicate certificates of title as warnings to the unwary. There are two other classes of interests or rights to which the certificate is subject, namely, the incumbrances appearing thereon, and competing rights, arising through fraud or error, misdescription or double grants. These, however, are more properly treated subsequently in studying the operation of the system. What we are concerned with now is the machinery of the system, what it prima facie purports to cover, what, quite independently of rights arising in its operation, it purports to touch and what to leave alone. The Acts exhibit a great

47 Man. 92; Sask. 68; Alta. 47; Dom. 75.

48 Sask. 6, 7; Dom. 7; Alta. 1906, c. 19, \$ 9.

4 Man. 70; Sask. 66; Alta. 43; Dom. 73. 
similarity in the enumeration of these incidents or "inherent rights" 50 in property not thus affected by the system and they may advantageously be treated together. They are:

\section{(b) Those Common to all Jurisdictions.}

1. Any subsisting reservations (or exceptions) contained in the original grant from the Crown.

In the Manitoba Act the words "Or exceptions" are omitted. "An exception" is always part of a thing granted and only a thing in esse can be excepted; a reservation is of a thing not in esse, but newly created or reserved out of land or a tenement upon a grant thereof. Thus upon the grant of land there may be an exception of a specified part, and then this is not included in the grant at all. Trees or minerals may be excepted.

Strictly the term "reservation" implies a right of the nature of rent reserved to a lord or landlord of a manor, but the term is frequently used to denote some incorporeal right over the thing granted of which the grantor intends to have the benefit, such as the right of sporting, fishing or right of way. ${ }^{51}$ But such implied restrictions upon the estate specified in any certificate of title do not extend to the description of the same land in ordinary dealings. Thus in Raymond Land Co. v. Knight Sugar Co. ${ }^{52}$ Mr. Justice Stuart said:

"It has also since suggested itself to me that it might be argued that under our system of registration of titles every agreement for sale of land generally should be implied subject, to the reservations contained in the original grant from the Crown. But I see no reason why such an implication should be imposed in this jurisdiction any more than in any other."

2. All unpaid taxes.

${ }^{50}$ So aptly called by Mr. Hogg in his work on the Australian Torrens System.

"Halsbury, Laws of England, Vol. 10, p. 471.

6211 W. L. R. 693. 
This is taken in practice to carry with it transfers issued by duly constituted authorities by reason of unpaid taxes, which are regularly treated as valid notwithstanding subsequent registered dealings. In Saskatchewan, Alberta and the Dominion provision is made for the purchaser filing a caveat at any time after the sale, ${ }^{53}$ suggesting by implication that in the absence of such caveat, a bona fide purchaser from the registered owner might take free of any rights in the land of such tax purchaser under his tax transfer. Those sections of the Act referred to have not been the subject of judicial construction on this point and their effect is bound up with the whole question of the relation of Torrens Acts to other statutory enactments which will be found more fully discussed on page 139. In Manitoba, in addition to "any municipal charge, rate or assessment at the date of the certificate or which may thereafter be imposed on the land," there is added the words "or which has theretofore been imposed for local improvements and which is not then due and payable." The latter words formerly appeared in The Land Titles Act 189.4 of the Dominion, but were repealed in 1898. In Ontario it has been held that local improvement rates not yet due are incumbrances on the land and must be removed by the vendor under an open contract.54 Whether or not under the Acts of the western provinces other than Manitoba local improvement rates are a mere incumbrance from which by virtue of The Land Titles Acts a bona fide transferee will take free has not been the subject of judicial decision. In Manitoba upon any transfer by the owner of land mentioned in any certificate which has been furnished pursuant to section 46 , the district registrar requires

${ }^{53}$ Sask. 12.1; Alta. \$2; Dom. 130.

${ }^{54}$ Bank of Montreal v. Fox, 6 P. R. 217; Cumberland v. Cairns, 18 O. R. 151, 17 A. R. 2\$1: Armstrong v. Auger, 21 O. R. 98; Re Graydon and Hamill, 20 O. R. 199. 
the taxes in arrears to be paid before registering the transfer.

3. Any public highway.

4. Any subsisting lease or agreement for lease for a period not exceeding three years where there is actual occupation of the land under same.

This exception obviates the great practical inconvenience which would be produced if all short leases were liable to be defeated by a bona fide transfer under the Act duly registered. A possible case of confusion might be, however, where in a contract for sale there was a valid tenancy created, as can be done, ${ }^{55}$ in which case the contract might be defeated and the lease continue.

5. a. Any decrees, orders or executions against or affecting the interest of the owner in the land which have been filed and maintained in force against the owner. (Saskatchewan.)

b. For "filed" read "registered." (Alberta and Dominion.)

c. (Manitoba) Any order of attachment, judgment, decree or order for payment of money against the registered owner of the land which may have been respectively registered since the date of the certificate of title, and which order of attachment, judgment, decree or order has been maintained in force under the provisions of any statutes of this province from time to time relating thereto.

The use of the word "registered" in the Alberta and Dominion Acts is misleading, as under these Acts if an instrument is registered it must necessarily be actually entered on the certificate of title. The purpose of this section is not to absolve the assurance fund from liability for ignoring any such existing instruments in the registration office upon transfer, ${ }^{56}$

${ }^{5}$ Independent Lumber Co. v. David and Hurlburt, 1 W. W. R. 134.

${ }^{5 f}$ Re Claxton, 1 Terr. L. R. 2S2; Sievell v. Haultain, 4 S. L. R. 142. Compare Canada Life Assurance Co. v. Registrar Assiniboia L. R. D., 21 W. I. TR. 469. 
but merely to meet the practical necessity arising from the fact that instruments without a specific description of the land cannot be entered up against particular land till the registrar has occasion to deal with the land owned by the person against whom the decree, order, judgment or attachment is directed. In the case of executions, by subsequent sections ${ }^{57}$ the registrar is directed, in cases of executions in Saskatchewan, Alberta and the Dominion, to enter these up on any new certificate of title granted pursuant to the transfer from the registered owner against whom the execution is directed, but in case of onission to do so, will the new owner nevertheless hold subject to the execution with a claim against the assurance fund? In James v. Stevenson, ${ }^{58}$ the Victorian Act was under consideration by the Privy Council. An easement had been omitted from a certificate of title upon its issue. By the 49th section of The Transfer of Lands Statute, it was provided that "land included in any certificate of title should be subject to any easement acquired by enjoyment or user or subsisting over, or upon or affecting such land," and by a subsequent amending Act it was provided that "notwithstanding the reservation of any easement subsisting over or upon or affecting any land comprised in any grant or certificate of title, the registrar shall specify upon any future certificate of such land and the duplicate thereof as an incumbrance affecting the same, any subsisting easement, orer or upon or affecting same which shall appear to have been created by any deed or writing." The easement in question, a right of way, had been created by deed.

Sir Edward Fry, delivering the judgment of the Privy Council, said:

"But their lordships agree with the judgment of the Full Court of Victoria that the omission by the registrar to enter an b7 Sask. 118 (4); Alta. 77; Dom. 124.

${ }^{58}$ (1893) A. C. 162; 62 L. J. P. C. 51. 
easement as an incumbrance on the certificate of the servient tenement under this provision would not relieve the servient tenement of its liability."

In Re Claxton, supra. Wetmore, J., was evidently of the same opinion. He said, at page 286:

"I am of opinion that section 61 was framed with a view of providing for the ease where executions may be registered after the certificate of title has issued; and I am also inclined to the opinion that even in a ease like the present, if the registrar issued a certifieate of title without indorsing a memorial of the execution, the owner would nevertheless hold the certifieate subject to the execution."

This, however, is not the generally accepted construction of the provision in question at the present day. James v. Stevenson may be distinguished. An easement remains an easement whoever may be the owner; but as soon as a new certificate of title is issued an execution against a former registered owner ceases to be "an execution against the registered owner." The Manitoba section makes this very clear, for as soon as a new certificate is issued only those judgments issued since the date of that certificate attach without special mention-the "date" being moved forward with each successive registration (section 68). This view is, it is submitted, more consonant with the principle of the Acts than the view that an execution or judgment, an incumbrance, on the one hand well fitted for registration and, on the other hand, not discoverable by any examination of the actual visible land, should be singled out for special favors under the Acts.

The words "decree or order" are very wide. In practice, however, the courts reduce their possible content. The court will not make a roving decree. In Ross v. McBride, ${ }^{59}$ Wetmore, C. J., said:

"I am also asked to make a declaration that the plaintiffs have a lien upon any other land the defendants now own or hereafter may own or be interested in. There is not a particle of material before me showing that the defenclants are now

${ }^{59} 3$ W. L. R. 561. 
interested in any other land. That being so, I am of the opinion that I am not able to make a declaratory decree of the roving character (if I may so describe it) asked for. No authority has been cited to me for any such decree."

6. Any right of expropriation by statute.

(c) Common to Alberta, Saskatchewan and the Dominion.

7. Any public right of way or other public easement howsoever created upon or over or in respect of the land.

In these jurisdictions an easement created in favor of private individuals has no special consideration under the Act.

\section{(d) Peculiar to Manitoba.}

8. Any unregistered subsisting right of way or other easement howsoever created upon, over or in respect of the land.

In the other jurisdictions only public easements and easements acquired through some statutory right are granted exceptional protection. An easement may be defined to be "a privilege without profit which the owner of one neighboring tenement hath of another existing in respect of their several tenements by which the servient owner is obliged to suffer or not to do something on his own land for the advantage of the dominant owner." fo

James v. Stevenson, ${ }^{61}$ in the Privy Council, is of little or no value in the construing of Canadian Acts owing to the difference in the statutory provisions. $^{62}$ Unity of ownership extinguishes all preexisting easements. ${ }^{63}$ Eascments are to be distinguished on one hand from "natural rights," as for example, the right of the riparian owner to a natural flow of water past his land, and on the other hand

${ }^{60}$ Termes de la Ley tit. Easements. Gale on Easements, 8th Ed. 8.

6162 L. J. P. C. 51; (1893) A. C. 162.

2 See page 52.

63 McClellan v. Powassan Lumber Co., 17 O. L. R. 32, 12 O. W. R. 473. 
from mere personal rights which do not partake of the nature of an interest in the land. As to the former rights, the land under the Torrens Act is subject to this as part of the general law. As to the latter their treatment is varied and will be found more fully discussed post under "transfer." The court, however, will not preserve a right by calling it an easement which has none of the incidents of an easement. Thus a grant of the right of way in gross will not be protected under these provisions: ${ }^{64}$ there being in law no such thing as "an easement in gross" where the essential element of two distinct tenements, the dominant and servient, are absent. ${ }^{65}$

9. Any certificate of lis pendens issued out of any court of competent jurisdiction in the province and duly registered since the date of the certificate of title, and caveats registered since the date of the certificate of title.

These are specially mentioned, in Manitoba, as under that Act the duplicate is equally efficacious with the certificate in the register and necessarily the duplicate cannot have entries of such instruments since the last dealings.

10. Any mechanics' liens affecting the land.

In the other jurisdictions unregistered mechanics' liens have to take their chance with other unregistered interests, as against parties acquiring an interest in good faith. ${ }^{66}$

11. The title of any person adversely in actual occupation of and rightly entitled to the land at the time when such land is brought under the "new system" and who continues in such occupation. ${ }^{67}$

The same exception appears in British Columbia, ${ }^{68}$ except that the date at which the possessor must

${ }^{64}$ Ex parte Johnson, 5 W. W. and A'B. 55.

6s Gale on Easements, 8th Ed. 14; Municipal District of Concord v. Coles, 3 C. L. R. 96; Staples \& Co. Ltd. v. Corby, 19 N. Z. L. R. 517.

Independent Lumber Co. v. Bocz, 4 S. L. R. 103.

67 Man. 74.

${ }^{68}$ B. C. 81 (1). 
be rightly entitled is fixed as the time of application instead of the time when the land is actually brought under the Act. The same exception also arises under the Ontario Act. ${ }^{69}$ In the other jurisdictions such rights are not preserved and the right of a person in possession would disappear on issue of certificate of title to a bona fide owner in the same way as any other unregistered interest. The person in possession should, nevertheless, notwithstanding that his rights would be preserved, oppose the granting of a certificate of title. In Bethune v. Porteous, ${ }^{70}$ in the Full Court of Victoria (Australia) A'Beckett, J., delivering the judgment of the court upon an application for injunction against the issue of a certificate of title, said:

"Another objection which might have been, but was not raised to granting the injunction was that according to the decision in Ex parte Broun, 5 V.L.R. (L) 5, a person who has acquired title by adverse possession has no right to restrain a person having title by deed from applying for a certificate of title, because if the certificate should issue it would be subject to all rights subsisting by adverse possession. We do not agree with this decision. If the title by adverse possession has matured the applicant for a certificate has no title which the commissioner ought to recognize, and giving him a certificate would enable him to harass the rightful owner."

The person in possession who obtains the benefit of the exception must show that at the time of the bringing of the land under the Act he was in a position to claim the protection of the statutes of limitation; anything less would be of no avail. This must be the construction to be placed on the word "rightly," although the use of that word in connection with adverse possession seems anomalous. The old doctrine of "adverse" possession was put an end to by the Act $3 \& 4$ William IV, c. 27 , and the use of the word "adverse" is not to be taken as

69 1 Geo. V, c. $28, \S 29$, as regards "possessory" titles.

70 14 A. L. T. 265. 
reviving the old doctrine. In Staughton v. Brown, in the Full Court of Victoria, Fellows, J., said:

"It was, however, contended by the plaintiff that *** the expression 'rightly subsisting under adverse possession' had re-established the doctrine of non-adverse possession. I cannot adopt that construction. The Transfer of Land Statute contains nothing to show that it was intended to revive that doctrine, and I must, therefore, suppose that the Legislature was satisfied with the meaning which the court put upon the words, and used them accordingly, rather than that they intended the old doctrine to apply to lands brought under the Act and the new doctrine to all other lands. I therefore come to the conclusion that the word 'adverse' must be read in its popular sense. The Transfer of Land Statute is far from technical and I am of the opinion that when the wrong man is in, and the right man is out of possession, the possession is adverse within the meaning of that Act." 71

(e) Peculiar to Saskatchewan.

12. Any right of way or other easement granted or acquired under the provision of The Irrigation Act.

(f) Peculiar to Alberta.

13. Any right of way or other easement granted or acquired under the provision of any Act or law in force in the province.

The Alberta provision is wider than the Saskatchewan provision, which is confinéd to the one Irrigation Act. The rights of way or easements under headings 12 and 13 are to be distinguished from those under heading 8 . In the former cases they may be private rights of way or easements, but cannot have been acquired by grant but only under the provisions of a statute.

\section{(5) THE LAND.}

Following the estate certified to in the certificate of title comes the description of the land. In a

${ }^{71} 1$ V. L. R. 150; and see post page 67. See, also. Franklin v. Ind., 17 S. A. R. 133; Murphy v. Michel, 4 W. W. \& A'B. (V) 13 . 'The Manitoba Act was not "framed in ignorance" of these Australian decisions. Duff, J., in Smith v. National T'rust, 1 W. W. R. 1122. 
document of such great efficacy as a certificate of title, the description of the land should be set out with accuracy. ${ }^{72}$

\section{(6) ADDRESS OF OWNER.}

The address of the owner, ${ }^{73}$ in view of other provisions for notice being served by mailing the same to the owner at the address set out in the certificate, as for example notices relating to tax sale and forfeiture proceedings, is a requirement which should be insisted upon by the registrar, and to which interested parties would do well to give careful attention.

\section{(7) INCUMBRANCES.}

Following the signature of the registrar there appear on the certificate in chronological order memoranda of all instruments registered against the land described in the certificate. In Manitoba the practice is to indorse on the back of the certificate of title all mortgages, incumbrances, charges, mechanics' liens, etc., and on the face of the certificate to enter only memoranda of cancellations in whole or in part in addition to incumbrances existing at the time of bringing the land under the new system. In Saskatchewan and Alberta the practice is to indorse on the certificate the memoranda of registration strictly in chronological order. The difference, however, would appear to be a matter of practice only.

\section{e. Duplicate Certificate of Title.}

The idea of a duplicate certificate of title was suggested by the fact that upon land being brought under the system, the applicant is required to deliver up, and the registrar retains, all documents of title.

72 In re Land Titles Act \& Lillis, 4 Terr. L. R. 300; Rorison v. Kolosoff, 15 W. L. R. 497.

${ }^{73}$ Sask. 186 ; Dom. 192. 
A registered owner has not, therefore, the practical convenience which arose through the possession of title deeds, which could be deposited by way of equitable mortgage. In order that a registered owner might have some efficacious evidence of title, the duplicate certificate of title was evolved. A duplicate certificate of title is issued on bringing the land under the system ${ }^{74}$ and upon each subsequent transfer. ${ }^{75}$ The duplicate is nothing more than its name imports, merely an exact replica of the certificate of title bound in the register. In Manitoba the certificate bound in the register and that not bound have each the like force and effect of the other, ${ }^{76}$ and either is conclusive evidence that the person named therein is entitled to the land for the estate therein specified. ${ }^{77}$ In the other jurisdictions the duplicate and certificate are distinguished to a great extent in the terminology of the respective Acts. ${ }^{78}$ It is evident, however, that the efficacy of a duplicate certificate of title depends upon its being shown at any particular time that it is the actual literal duplicate of the certificate of title in the register. The document in possession of a registered owner may, for various reasons, cease to be a duplicate of any certificate of title then existing in the registry office. For the purpose of rendering the duplicate as conclusive as possible, the registrar is forbidden to accept, for registration, any documents unaccompanied by a duplicate certificate of title ${ }^{79}$ except in certain specified cases. ${ }^{80}$ The possibilities of the actual duplicate certificate of title to any parcel of land differing from the exist-

74 Man. 66, 45; Sask. 61; Alta. 36; Dom. 67.

${ }^{75}$ Man. 66; Sask. 75; Alta. 37; Dom. 82.

${ }^{76}$ Man. 66.

77 Man. 71.

${ }^{78}$ Sask. 2 (15), (16), 169, 170; Alta. 2 (o), 136; Dom. 2 (15), (16), $174,175$.

${ }^{79}$ Man. 82 ; Sask. 31 ; Alta. 20 (2); Dom. 42.

${ }^{80}$ Man. 82; Sask. 32; Alta. 20 (2); Dom. 42. 
ing certificate of title to the same parcel in the register may be classed under the following headings:

(1) By reason of a registration affecting the particular piece of land made other than by the registered owner or some person having a registered interest, $e . g$. a caveat, mechanic's lien, order of the court or judge, lis pendens.

(2) The cancellation of the certificate of title corresponding to the duplicate by reason of some dealing in invitum, e. g. transfer on sale of land for taxes, vesting order of the court, transfer on sheriff's sale, transfer or order of foreclosure under mortgage.

(3) The issue of a new certificate of title on proof (fraudulent or erroneous) of loss of the old certificate, ${ }^{81}$ consequent upon which the owner may register dealings, requiring the production of the duplicate by production of the new certificate so issued. The registrar should exercise great care in the issue of such new duplicates to protect the assurance fund, which, however, may be liable in cases of the improper issue of title notwithstanding the apparent sufficiency of any proceedings taken by the regis$\operatorname{trar}^{82}$

It is the duty of any party having executed and delivered a transfer or mortgage which requires the production of the duplicate for its registration to deliver up that duplicate to the registrar for the purpose. ${ }^{83}$

81 Man. 54; Sask. 159; Alta. 123; Dom. 164.

${ }^{82}$ Cf. Tolley do Co. Lid. v. Byrne (Registrar), (1902) 28 V. L. R. 95.

${ }^{83}$ Sask. 74; Alta. 50; Dom. 81; Man. 90. The right to registration would appear to include and imply the right to demand the requisites for registration. 


\section{CHAPTER III}

BRINGING LAND UNDER THE SYSTEM

\section{§ 9. THE INTERESTS WHICH CAN BE BROUGHT UNDER THE SYSTEM.}

$\S 10$. PROCEDURE ON APPLICATION.

\section{§ 9. THE INTERESTS WHICH CAN BE BROUGHT UNDER THE SYSTEM.}

"Bringing land under the system" may be described broadly as having land placed on the register in such a way that, as a result of its being so placed, estates and interests in it, so long as the land remains on the register, are held by an indefeasible title, and can only be created and transferred by entry on the register.

In order to understand clearly the force and effect of land being brought under the system, the fundamental basis of the title to all land under the English law regarding property must be kept in mind. All land is in theory held from the Crown for a greater or less estate, and all ownership of land is really an ownership of an estate in the land. To bring land under the system does not mean, therefore, that a particular piece of material earth is set apart and dealt with under a peculiar system of law, but merely that the title to a certain estate in a certain piece of land is placed on the register, and thereafter such title can only be dealt with, transferred and modified in the manner provided by the respective Acts governing the system. As a matter of practice in Western Canada, practically all land is held in fee simple, and an application to bring a limited estate of freehold under the operation of the 
system is almost unknown. In Manitoba, in fact, the registrar is empowered to refuse to entertain an application unless all parties, other than the applicant, consent, the result of which would ordinarily be that the "whole title" would be brought under the Act, that is to say, the fee simple. To this extent, however, it may be said "bringing land under the Act" refers to the actual material land, $i$. e., once the fee simple in land has been brought under the Act, the registration of all other interests is acquired as a modification of the registered title, the land not reverting when the interest originally brought under the Act fails for lack of an owner, or by reason of the title being extinguished. Thus, where a person claimed by possession for the period required by the limitation Acts the application was refused and the registrar's action was affirmed by the Full Court of Victoria. The court said that it had been argued:

"That when the Act speaks of bringing land under its operation, it means bringing the title to the land under its operation, and, therefore, when the old title is destroyed, a new one may be brought under the Act. We think that the Act does not allow of this, and that in fact there is no jurisdiction in the registrar to grant an application made to him for the purpose. The sections referred to prescribe precisely what land may be brought under the Act, and we think that when land is brought under the Act it remains under the Act."'

In Belize Estate v. Quilter" the Privy Council said "a registered title might come to an end, through the death of a proprietor intestate and without leaving heirs. * * * The Crown might make a new grant of the land to a subject who, if he desired to possess a registered title, would be under the necessity of making a fresh application under the Act." This decision, however, was under The British Honduras Act, which is not available to the author. but which is stated to "differ somewhat from the Torrens Statutes"' in this respect.

\footnotetext{
${ }^{1}$ Re Allen, 22 V. L. R. $24 . \quad 2(1597)$ A. C. 367.
}

${ }^{3}$ Hoggr, p. 719 , note. 
The provisions of the Acts relating to the interests which may be registered are very broad. In Manitoba, "the owner of any estate or interest in land, whether legal or equitable," ${ }^{4}$ may apply for the registration of his interest. In Saskatchewan, and Alberta, and in the Dominion Act, the words are added "letters patent for which issued from the Crown before the first day of January, 1887, or otherwise had prior to that date passed from the Crown." This was the date of the coming into force of The Territories Real Property Act, R. S. C. 1886, c. 51. Since the coming into force of that Act upon the issue of all letters patent, the letters patent have been sent to the proper registry office and a certificate of title is forthwith, or upon payment of the necessary fee where required, issued upon the grant. In Re Irish, ${ }^{5}$ it was held that unpatented land could be brought under the new system as in a case of a homestead or" pre-emption after "recommendation for patent." Dubuc, J., said:

"In such case the certificate of the registrar general would not deceive the public or any party who might take a conveyance from the holders of said certificate because such certificate would not show an absolute title in fee simple but only such title or interest as he appears to have at the time."

The word "land" under the various interpretation sections of the Acts is given a very wide meaning. ${ }^{6}$ In Ex parte Cunningham, ${ }^{7}$ it was suggested that a rent charge issuing out of land not brought under the Act could be made the subject of a certificate of title, but an easement over land not brought under the Act could not be registered along with the title of the dominant tenement. The basis of the latter part of this decision has, however, disappeared by reason of statutory provision in Saskatchewan

${ }^{4}$ Man. 28; Sask. 49; Alta. 27; Dom. 5i.

52 Man. L. R, 361. This case would not now be followed in the same circumstances.

${ }^{6}$ Man. 2 (a); Sask. 2 (1); Alta. 2 (a); Dom. 2(1)

73 V. L. R. 199. 
and Alberta, and the same change has been made in the Dominion Act. ${ }^{8}$ In practice, however, the interest which is almost invariably brought under the Act is the fee simple. In Manitoba the registrar may, in his discretion, refuse to entertain such an application unless all persons, other than the applicant, who are interested in the land shall be consenting parties to the application. ${ }^{9}$ Under this provision the registrar may practically force the registration of the fee simple in every case, excepting in the case of leaseholds for long terms of years to which there seems to be no objection to issuing a certificate of title independently of the fee. An application for an undivided interest in land will not be entertained in Nanitoba, ${ }^{10}$ nor, in any jurisdiction, should an application be entertained for bringing under the Act an interest, the registration of which is provided for in the Act, as for example, that of a mortgagee.

In Manitoba the registrar must be satisfied that the title is "safe holding." In Saskatchewan and Alberta there is no definite standard set; the master of titles or the judge must be "satisfied with the applicant's title." In British Columbia for a certificate of indefeasible title the registrar must be satisfied that the title is "a good safe holding and marketable title." Absence of covenants for title in a deed presented as a link is not a defect in title, ${ }^{11}$ but a sale under power in a mortgage without notice might be such. ${ }^{12}$ Under The Real Property Act of Manitoba 1855, $\$ 110$, it was provided that the examiner of titles in investigating the title might receive and act upon any evidence which was receivable in any court of the province. In Re Lewis, ${ }^{13}$ Taylor, C. J., pointed out that this did not.

\footnotetext{
8 Sask. 73; Alta. 49; Dom. 80.

${ }^{9}$ Man. 28 .

10 Man. 32.

${ }^{11}$ Re Dalgleish, 14 W. L. R. 255.

12 Re Shore, 6 Man. L. R. 305.

135 Man. L. R. 44.
} 
permit the registrar to act on evidence which the practice of English conveyancers authorizes to be received on an investigation of a title out of court, and consequently he could not accept letters of administration as evidence of intestacy. But in Acts intended to simplify the laws relating to the transfer of land and to facilitate its transfer, it is evident that it was not intended that the registrar or the judge or master should reduce their usefulness to the extent which neutralized the value of the English Acts of 1862 by insisting on a "marketable" title, that is, "one which so far as its antecedents are concerned may at all times and under all circumstances be forced on an unwilling purchaser."14 To quote the author of Coutlee's Real Property Statutes, at page 87:

"A substantially good title regardless of technicalities is all that is required to have land brought under the Statute. Nothing more is necessary in any case than any solicitor or conveyancer ought to require in duty to his client, and in many cases less is required, as safe holding titles ean be passed and an absolutely marketable title does not need to be made out to obtain a certificate. On the other hand, as the province becomes an insurer against adverse claims, care has to be exercised in the examination of the title, and if a purchaser has bought a piece of land, voluntarily incurring the risk of taking a defective title by submitting to conditions which prevent objections being taken, he ought not to expect the public to adopt his bargain without due investigation."

In Ontario it is provided that in the examination of title the master may receive and act upon any evidence which is received in court on a question of title, or any evidence which the practice of conveyancers authorizes to be received on an investigation of a title out of court, or any other evidence, whether the same is or is not receivable or sufficient in point of strict law, or according to the practice of conveyancers, if the same satisfies him of the truth of the

1 Pyrke v. Waddingham, 10 Ia. 8.; Fry on Specific Performance, par. 833. 
facts intended to be made out thereby. ${ }^{15}$ The registrar, master of titles, or judge acting as persona designata, has on the one hand to protect the assurance fund, ${ }^{16}$ and on the other hand, has the same fund to justify him in extending the beneficent operation of the Act, and so granting a certificate of title with the correctness of which he is morally satisfied, ignoring a possible but negligible defect. ${ }^{1 \text { i }}$

Land may be brought under the system on evidence of possession sufficient to bar the title of the rightful owner under the Statutes of Limitations in force in the province where the land lies. In discussing title by possession care must be taken to distinguish such titles as are now under consideration from the "possessory titles" of the Ontario Land Titles Act and the English Land Transfer Act. Under those systems the registration of the possessory title is nothing more than the registration of the title of the person in possession, whatever that may be, and, as it were, for what it is worth, and such registration does then prejudice the enforcement of any estate right or interests adverse to or in derogation of the title of such first registered owner, and subsisting or capable of arising at the time of registration of such owner, but otherwise (that is to say, as regards subsequent dealings) has the same effect as the registration of an owner under the systems in the prairie provinces. This possessory title seems further to be analogous to the registration of an absolute fee in British Columbia, as distinguished from the registration of an indefeasible fee, and to entry on the "provisional" as distinguished from the "permanent" register in New Zealand, to which reference is made in the leading case of Assets Co. v. Mere Roihi. ${ }^{18}$

${ }^{15}$ Land Titles Act, 1 Geo. V, c. $28, \S 22$ (e)

${ }^{16}$ Ex parte Bowman 7. V. L. R. 314.

17 Re G- 21 O. R. 109.

18 (1905) A. C. 176. 
Evidence of actual, visible and undisturbed continuous possession, ${ }^{19}$ or of "an actual possession, an occupation exclusive, continuous, open or visible and notorious" 20 for the statutory period as prescribed by the law of the province in which the land may lie, accompanied by evidence of the state of the title at the beginning of the possession, in order to satisfy the official examining the title that there are no persons in existence against whom the statute has begun to run at a later period than the beginning of the possession, is sufficient, not only to extinguish the title of the owner, but to entitle the applicant showing such possession to the issue of a certificate of title in his favor. ${ }^{21}$

The matter of jurisdiction in such applications is not settled outside of Manitoba, where the registrar does not assume any jurisdiction and the question is one for an issue ${ }^{22}$ or for statement of claim. In Alberta under the very wide powers conferred on a judge acting as persona designata for the examination of titles, ${ }^{23}$ Mr. Justice Stuart examined into a possessory title offered ${ }^{24}$ assuming that he had jurisdiction to order the issue of the certificate of title provided the evidence as to possession satisfied him. In Saskatchewan under the exactly similar section covering the same jurisdiction in the master of titles (section 56), the master of titles has held that he had not the power to order the issue of a certificate of title on evidence of possession only ${ }^{25}$ and subsequently an action in court was brought for declaration of the same title, in which action an order was made declaring that the rights of the defendant

${ }^{19}$ McConaghy v. Denmark, 4 S. C. R. 609.

${ }^{20}$ Sherren v. Pearson, 14 S. C. R. 585.

${ }^{21}$ Re Anderton, 8 W. L. R. 319; Bradshaw v. Patterson, 18 W. L. R. 402;

Ogle v. Aedy, 13 V. L. R. 468; E.x parte O'Neill, 7 Q. L. J. 155.

${ }^{22}$ See Callaway v. I'latt, 17 Man. L. R. 485.

${ }^{23}$ Alta. 31.

${ }^{24}$ Re Anderton, supra.

${ }^{25}$ Re Bradshaw's Title, Master of Titles, 16th Aug. 1910 (Sask). 
were extinguished, and the matter was then remitted to the master to be dealt with on the strength of the decision of the court. ${ }^{26}$ The wording of the section in question is very wide, and the reason for limiting the full jurisdiction granted is not apparent. In an Australian case from Queensland, it was held by the full court that where on an application to bring land under the Act the applicant's title arises from adverse possession, the registrar of titles should deal with the application in the ordinary way. He could not refuse to inquire into the evidence in support of the application, although he might, if not satisfied with the evidence, refuse to go on with the application. ${ }^{27}$

The present position of the matter in Saskatchewan is in line with the generally accepted maxim that a judge acting as persona designata or on a chamber application will not dispose of important questions of law or fact, but seems to be a straining of that maxim in this instance in view of the prima facie intention of the Acts that all matters of title in applications shall be disposed of under the Act and the very positive language that the master shall "examine" all titles and "shall when necessary hear" all persons and "shall hear and consider the claims" and shall have all the powers for compelling attendance of persons and the production of documents which usually appertain to courts of civil justice. Why are these powers granted if not to be exercised?

\section{§10. PROCEDURE ON APPLICATIONS.}

Where registration is compulsory, as in Saskatchewan, Alberta and the Dominion, the patents for all lands granted are sent to the proper registry office, and a certificate of title is granted to the patentee forthwith, or in case payment of a fee is required,

${ }^{26}$ Bradshaw v. Patterson, 18 W. L. R. 402.

${ }^{27}$ Ex parte $\mathrm{O}^{\prime} \mathrm{Neill,} 7$ Q. L. J. 155. 
upon the payment of the proper fee. ${ }^{28}$ Prior to the issue of such certificate of title the land cannot be said to be under the system. ${ }^{29}$ The certificate of title is issued "with any necessary qualification." Where there have been registrations under former registry laws, an entry on the certificate of title of these registrations is a necessary qualification. ${ }^{30}$ As to qualifications arising within the grant itself, the Crown is bound by the limitations of the statute, nor does the fact that the land granted in the prairie provinces, or at least the greater part of it, is granted by the Crown in the right of the Dominion of Canada, affect this position, as, within their own jurisdictions the provinces are supreme in the matters of title to land, and cannot be bound by the Dominion, nor even, unless by express reference, by the Imperial Parliament. ${ }^{31}$ Thus, on a reference to the master of titles in Saskatchewan where a grant was made to a corporation "in trust for the purposes of the congregation of the Roman Catholic Church of the Parish of St. Anne," it was held that the trust could not be expressed in the certificate of title, as pursuant to section 79 of The Land Titles Act 1906 no entry of any trust should be made upon a certificate of title. ${ }^{32}$

In Manitoba, and in cases of land patented prior to 1st January, 1887, in the other provinces, the first step to bring land "under the new system," as it is called in Manitoba, "under the Act" in the

${ }^{28}$ Dom. 41; Alta. 26 (1); Dom. 49.

${ }^{23}$ Coventry v. Annable, 1 W. W. R. 148; 19 W. L. R. 400; Re Irish, 2 Man. L. R. 361; Re Thompson, 10 Can. L. T. 44. But see contra Re MeCaul and Bown's Note, 9 Can. L. T. 27; Re Boyle, 9 Can. L. T. 506, and 10 Can. L. T. 73.

${ }^{30}$ Re Land Tilles Acl and C. P. Ry., 4 Terr. L. R. 227. In New Zealand, on the contrary, held only those incumbrances should be brought forward which could be registered. Staples v. Corby, 19 N. Z. L. R.

C. A., at 52:3.

31 Assets Co. v. Mere Roihi, (1905) A. C. 176.

${ }^{32}$ Re La Corporation Episcopale Catholique Romaine de Saskatchewan, Master of 'Titles, 21st Dec., 1910 (Sask). 
other jurisdictions, is to make an application to the registrar in the form prescribed or, in Manitoba, in a form similar to that prescribed in the other provinces.

The application is made by the owner, or in Manitoba and Saskatchewan by his duly authorized agent or attorney. In Alberta and the Dominion provision is not made for application by the agent or attorney, ${ }^{33}$ but in Form $\mathrm{F}$ to the Alberta Act and Form $\mathrm{F}$ to the Dominion Act, paragraph 1 of the affidavit reads "that I am the owner (or agent for the owner)." Where an Act provided that all informations exhibited before any justice or justices of the peace for any offence against the customs should be drawn in the form or to the effect in the schedule annexed to the Act, and the form in the schedule used words indicating that the information was supposed to be made before two justices, it was held that this circumstance did not override the provisions of the Act, that the information might be made before one justice and that the form might be modified accordingly. ${ }^{34}$ In view of the powers conferred upon an applicant, it would seem to follow that the statutes must be construed strictly, and that, therefore, a variation in the form could not be held to repeal or amend the statute. Although not specifically prescribed, it must be assumed that the agent or attorney must be duly authorized in writing verified by affidavit of execution in the manner prescribed for any other instrument under the system, and in the same manner as the consent of an interested party is required to be evidenced. ${ }^{35}$ The bringing of the land under the system is not only a very important step as regards the law to which all subsequent dealings will be subject, but the

${ }^{3}$ Alta. 27; Dom. 55.

\& Rex v. Russell, 13 Q. B. 237. See Endlich, Interpretation of Statutes, section 71 , and cases cited.

35 Sask. 54; Alta. 29 (5); Dom. 60. 
applicant has extensive powers of eonveyance ${ }^{36}$ which cannot be held to be conferred upon any agent for the purposes of the Act, except by some such authority as outlined.

In Manitoba a power of attorney authorizing the sale of the land is held sufficient to authorize an application to bring the land under the Aet, unless the power contains an express prohibition. In all jurisdictions in regard to persons under disability, the guardian of such person may make the necessary application, and in Manitoba the father, or mother, if the father be dead. ${ }^{37}$

The possession called for in the applicant by the forms preseribed in Saskatchewan and Alberta is the constructive possession of the rightful owner, and not necessarily actual possession. This is implied by the subsequent paragraphs requiring information as to whether or not the land is oceupied, and has been the subject of judicial decision in Australia, where it was held that an application to have the land brought under operation of The Real Property Act 1862 (New South Wales), must be entertained by the registrar, although it appears by the terms of the application that the lands in question are as a matter of fact in the adverse occupation of some other person. ${ }^{38}$

The only limitation placed on the amount of land to be included in any application is in Manitoba where the amount of land is restrieted to two thousand acres of contiguous country lands, or any number of lots under the same plan of subdivision (section 30). In the same jurisdiction it is provided that no applieation shall be entertained for an undivided interest without the remaining undivided interests being brought under the new system.

${ }^{20}$ Man. 35; Sask., Form B.; Alta., Form I.; Dom., Form F.

7 Man. 33, 164; Sask. 160; Alta. 133; Dom. 165.

${ }^{8}$ Ex parte Hamilton, 3 S. C. R. (N. S. W.) 311 (full court). 
The forms call for a full disclosure by the applicant of all mortgages or incumbrances affecting the land, or of any estate or interest therein at law or in equity, in possession, reversion or expectancy, which may be within the knowledge of the applicant other than his own. Nevertheless an applicant is not required to specify in his application everything done, honest or dishonest, well founded or ill founded, which may possibly at any time be set up in opposition to his title. He need not state an alleged interest in respect of which no claim has ever been made on him, nor any action commenced, ${ }^{39}$ nor need he disclose in his application the fact that a trespasser claims the land. ${ }^{40}$ From a practical point of view, however, the applicant will do well to make the fullest disclosure, and not attempt to make himself the judge as to how far, or otherwise, it may be evidence of fraud in a subsequent proceeding that he has had knowledge of a claim and concealed it, with the intention of thereby defeating the claim.

The applicant has power to direct the issue of a certificate of title in a name other than his own. This direction is made in Saskatchewan, Alberta and the Dominion by request in the application (see forms) and in Manitoba may be made either in the application or by special request. ${ }^{41}$ In the jurisdictions other than Manitoba, the only provision for such a direction is in the form prescribed. As to whether or not such a clause in a form is sufficient to prescribe a statutory method of transfer, see Hardcastle, Construction of Statutes, third edition, page 233 , and antc page 70 . In Manitoba such a person named as transferee in the application is joined as a party plaintiff with the applicant in an issue pursuant to a caveat ${ }^{42}$ and the consent of such a party

\footnotetext{
In In Tamner, 5 N. Z. L. R. S. C. 102.

${ }^{40}$ In re Beckett, 15 N. S. W. L. R. 94 (full court).

${ }^{41}$ Man. 35.

42 Hay v. Nixon, 7 Man. L. R. 579.
} 
is required for the withdrawal of an application (section 39).

In Manitoba upon the filing of an application, the land named in the application becomes "subject to" the new system, although the land is not fully "under" the new system until the certificate of title is actually granted (section 2 (u). Such a provision is required to fix a point of finality and to prevent another registration being made under the old system while an application to bring under the new is pending, but in the other jurisdietions where no registration system is provided except the Torrens system, no such starting point other than the actual issue of the certificate is necessary and no provision is accordingly made for that purpose. The applicant merely takes his chances on any registration, such as a caveat or execution, being made prior to the actual issue of the certificate of title and any such registration up to that moment must be taken into account. In view of the fact, however, that no such registration can be made of any incumbrance or transfer by any person claiming the land, the practical inconvenience is very slight.

The application is to be accompanied by all deeds, if any, in possession of the applicant, and a certificate showing all registrations affecting the title down to the time when the application is filed; in Alberta, in addition, by a certificate from the sheriff showing that there are no executions in his hands against the applicant's land, or presumably, if there is any execution, particulars of it; and in the Dominion, in further addition, a certificate of the payment of taxes if the land is within any organized municipality. ${ }^{43}$ In Manitoba similar full production of the evidences of title is required by necessary implication, in order to enable the registrar to properly examine the title. All documents produced

${ }^{43}$ Sask. 50 (2); Alta. 28; Dom. 56. 
on the application are retained by the registrar in his office in case of a certificate of title granted. In Manitoba the documents are retained in the offices of the old system, but such retention does not constitute a registration of the documents under the old system as to land not included in the application. ${ }^{44}$

The registrar then proceeds to examine the title, and if the applicant is the original grantee from the Crown of the land, and no deed, transfer, mortgage or other incumbrance or instrument or caveat affecting the title thereto appears to have been recorded, or, if not the original grantee, all the original title deeds are produced, and no person other than the applicant is in actual possession of the land, and no caveat has been filer, the registrar, if he entertains no doubt as to the title of the applicant, shall grant a certificate of title. ${ }^{45}$ If any person other than the applicant is interested in the land by way of mortgage, incumbrance, lease or charge under a recorded or produced instrument, the registrar may grant a certificate of title subject to such interest, if he entertains no cloubt as to the nature and extent of the interest, or of the title of the applicant. ${ }^{46}$ In Manitoba, however, such other person may be required to consent (section 28), and in all jurisdictions is required to consent if his interest is otherwise than the foregoing.

The nature of the title to be shown has already been discussed. In Manitoha the registrar must be satisfied "that the title to the land is safe holding" (section 45), and in the other jurisdictions "must entertain no doubt" as to the title. The title to be made out is, therefore, practically the same in all jurisdictions. The registrar discharges nearly the same duties in demanding the production of deeds

4 Re Stanger and Mondor, 15 W. L. R. 346; affirmed 16 W. L. R. 53.

4 Sask. 51; Alta. 29 (1); Dom. 57.

${ }^{46}$ Sask. 53; Alta. 29 (4); Dom. 59. 
as were formerly cast on an intending purchaser of the fee simple ${ }^{47}$ and must be satisfied according to the practice of conveyancers. The registrar, however, seems to have a wider scope in the examination of titles than in the examination of instruments for registration under the Act after a certificate of title has been granted. In such case the registrar can act only on information disclosed by the documents presented to him, ${ }^{48}$ but in applications for certificate of title the registrar is more than "a mere machine for registration," he is "bound to exercise his intelligence" and may take notice of objections to title not raised by any opponent of the application. ${ }^{49}$ In Municipal District of Concord v. Coles ${ }^{50}$ Griffiths, C. J., delivering the judgment of the High Court of Australia, said:

"I make these preliminary observations for the purpose of adding that the registrar is not bound to give effect to an application if he has information from some trustworthy source that the statements of the applicant are not true in fact; on the contrary, it is the duty of the registrar, if he has reason to believe that giving effect to the application in compliance with its terms would do an injustice to the public, or to an individual, to stay his hand until the matter is properly investigated. That is not only what he is justified in cloing, but what he is bound to do."

And the registrar may withhold registration in the interests of the rights of the third parties or of the assurance fund. The court will not order a district land registrar to bring land under the Act involving the decision of the rights of third parties in their absence, and also involving liabilities on the part of the assurance fund, unless clearly satisfied that such a title has been shown as will be forced upon an unwilling purchaser. ${ }^{51}$ And where a district land

\footnotetext{
47 Hudson's Bay Company v. Kearns and Rowling, 3 B. C. R. 330.

${ }_{48}$ In re Ebbing, 2 S.L. R. 167; 11 W. L. R. 29; Re Claxton, 1'Terr. L. R. 288.

${ }^{49}$ Manning v. Commissioner of Titles, 15 A. C. 195.

${ }^{\text {so }} 3$ C. L. R. 96 ; on appeal from New South Wales.

61 Ex parte Smith, 7 N.Z. Gaz. I. R. 567 ; In re Nelson Bros., 5 N. Z. I. R. S. C. 111.
} 
registrar refused to proceed with an application to bring land under The Land Transfer Act of 188.5 in New \%ealand, on the ground that it was not vested in the applicant, but in some other person not before him, the court would not order the registrar to proceed if such procectings could involve either the rights of the absent person or the assurance fund, unless it could clearly see that the title was one which would be forced on an unwilling purchaser. ${ }^{52}$

Adrancing a step beyond the simple and certain title referred to, the powers of the registrar differentiate in the various jurisdictions. In Manitoba the registrar continues the proceedings, or as registration is not compulsory to permit of dealings, if the registrar meets what he considers a serious defeet in the title, which is not cleared up when the parties are hoth before him, all he is required to do is to reject the application, and the parties are still at liberty to make such registrations as they see fit under the old system, or to resort to the coun ts for a settlement or declaration of the rights of parties. In the other jurisdictions, as no instrument can be registered unless the land be brought under the Act and none is effectual without registration, the interests of opposing parties must necessarily be disposed of in some way and the master of titles or judge has specific power to adjudicate on or dispose of adverse claims. ${ }^{53}$ In the other jurisdictions, therefore, the registrar gives to the applicant a certificate of the filing of his application, and, in Saskatchewan, transmits the application with all the evidence to the master of titles, and in Alberta and the Dominion to a judge. In the latter three jurisdictions the power of the master of titles and the judges under the Act is enlarged beyond that of the registrar in Manitoba. Those officials have and evercise all power for

52 Smith v. Auckland District Land Registrar, 24 N. Z. I. R. \$62.

${ }^{53}$ Sask. 56, 58, 173, 174; Alta. 31, 33, 146; Dom. 62, 64, 178, 179. 
compelling the attendance of persons and production of documents which usually appertains to courts of civil justice, and to judges thereof in civil actions brought therein, ${ }^{54}$ and examine into and adjudicate on all adverse claims.5 In Manitoba, while the registrar retains control in a manner of the proceedings, his powers are confined to serving notices (in Form 1, App. C.) on persons adverse in interest to the applicant, and to granting title if no procecdings are taken by such persons to protect their rights, although, even with that, the registrar requires to be satisfied that the title is safe holding in addition to evidence of the proper service of notices. ${ }^{56}$

In Manitoba a party notified of an application, or becoming aware of it in any way, maveither file a caveat forbidding bringing the land under the new system or may proceed at once by statement of claim (section 145). After the receipt of such caveat the registrar cannot bring the land under the new system until the caveat has been disposed of (section 128), but such caveat automatically lapses at the expiration of one month from its filing unless the caveator takes proceedings in court to establish his title to the land or his right set out in the caveat and files evidence thereof with the registrar (section 129). The caveator may nevertheless take proceedings at any time under his caveat, provided the registrar shall not have disposed of it as lapsed before the evidence is filed (section 137), which disposal would in case of application to bring the land under the new system consist in the issue of the certificate of title. In a petition brought more than one month after the filing of a caveat it should be alleged that certificate has not issued. ${ }^{57}$ Proceedings may be

\footnotetext{
Sask. 56; Alta. 31; Dom. 62; and compare the general power, Man. 49 (c).

${ }^{65}$ Sask 58; Alta. 33; Dom. 64.

se Man. 40, 41, 42, 43, 43a, 45.

${ }^{67}$ Sprague v. Graham, 7 Man. L. R. 398.
} 
taken either, as is ordinarily done, by petition under rules prescribed in Schedule $\mathrm{L}$ to the Act, or in court.

The basis of proceedings either by petition or in court is the caveat. "The filing of a caveat that complies with the directions of the statute is a condition precedent to the court having any jurisdiction in the matter," ${ }_{58}$ and section 156 of the Act does not specifically refer to, and does not seem to apply to caveats. ${ }^{59}$ Thus where an affidavit, filed in support of a caveat, did not state that in the opponent's belief the applicant had a good and valid claim upon the land, the petition was dismissed with costs; ${ }^{60}$ where the name of the applicant was A. M. Nanton and in the caveat he was described as A. M. Newton, this was held not fatal, but in the same case where the caveator "appointed A. N. M. Commissioner of Railway Offices in Winnipeg my agent on whom notices and proceedings may be served" in pursuance of the statutory requirement that the caveat should state "some address or place within the province at which notices may be served," this was held to be fatal, as the caveator had named a person and not a place. ${ }^{61}$ Where the affidavit verifying the caveat was neither fully a declaration nor an affidavit, the petition was dismissed, ${ }^{62}$ and where the caveat gave no addition of the caveator, although the affidavit in support of the caveat described him as an accountant, Bain, J., was of opinion that the omission was fatal to the validity of the caveat, but the case actually turnerl on the fact that the interest claimed was set out in the words "I have an attachment against T. M. who owns or has a personal interest

${ }^{88}$ McArthur v. Glass, 6 Man. L. R. 224; Schultz v. Archibald, 8 Man. L. R. 284; Martin v. Mordcn, 9 Man. L. R. 565; Re Cass and Canada

- Traders, Ltd., 15 W. L. R. 194.

${ }^{59}$ Martin v. Morden, 9 Man. L. R. 565.

${ }^{60}$ McArthur v. Glass, 6 Man. L. R. 224.

${ }^{61}$ McKay v. Nanton, 7 Man. L. R. 251.

${ }^{62}$ Schultz v. Archibald, 8 Man. L. R. 284. 
in land described," which statement was held not to "particularize the estate or interest claimed." 63 A corporation, however, does not require to give an addition as it has none. ${ }^{64}$

Where the objections to the caveat were of a highly technical character, the rights of the caveator have been preserved by leave granted to file a new caveat. ${ }^{65}$

The petition must closely follow the rules prescribed in Schedule $\mathrm{I}$ to the Act, although it would appear that section 156 applies to the petition and, therefore, somewhat more latitude is allowed than in the case of the caveat. ${ }^{66}$ Where a petition did not allege the date of the filing of the caveat, it was held that it was for the party opposing the petition to show that the caveat had lapsed, if such was the fact. $^{67}$ In the petition it is not necessary to allege all the details required to make a good caveat, it being sufficient to allege that the "caveator filed a caveat in the prescribed form." 68 The petition must state specifically what estate, interest or charge the caveator claims, but where the petition did not in so many words set out the nature of the estate claimed, but did set out the facts from which it could be gathered, this was considered to be, if not a strict compliance with the Act, a technical irregularity which was cured by the present section $156,{ }^{66}$ and in the same case it was held that neither the residence or addition of the petitioner was required to be stated in the petition. But where a petition goes further than setting up the title of the petitioner, and also sets up the title of the cavcator, to make out a case, the petitioner must allege defects in the

${ }^{63}$ Jones v. Simpson, 8 Man. I. R. 124.

${ }^{64}$ North of Scotland Canadian Mtge. Co. v. Thompson, 13 Man. L. R. 95.

${ }^{65}$ McKay v. Nanton, Schultz v. Archibald, supra.

${ }^{66}$ Adams v. Hockin, 12 Man. I. R. 11.

${ }^{67}$ Clarke v. Scolt, 5 Man. L. 1R. 281.

${ }^{68}$ Downs v. Campbell, 7 Man. L. R. 34. 
caveatce's title sufficient to displace it. ${ }^{69}$ Where the claim in the petition differs from the claim set forth in the caveat, the petition was dismissed..$^{70}$

On the hearing of the petition it is for the caveatee to show cause why the prayer of the petition should not be granted, and the court has power. if it shall think fit, to dismiss the petition or make an order establishing the right of the caveator, but unless satisfied beyond a doubt will direct an issue and should do so rather than rely on affidavits where important questions of fact are involved. ${ }^{71}$ In such issue, pursuant to Rule 6 , the caveator is plaintiff and the careatee defendant, unless, upon proper cause shown, a judge directs that the issue be tried with the caveatee as plaintiff and the caveator as defendant. The principle on which a judge acts in determining whether or not a departure should be made from the rule that the caveator should be plaintiff, is clearly laid down in Howell v. Montgomery. ${ }^{72}$ Mr. Justice Killam there said:

"If, then, the cause shown is not by disputing the allegations of the petition, but by raising and asserting independent facts, the omus falls upon the caveatee, and he should naturally be the plaintiff in an issue the affirmative of which it is necessary for the support of his case to establish. To point this out is to show proper cause for directing that the issue be tried with the caveatee as plaintiff."

The general rule was applied where the caveator claimed under conveyance from the patentee from the Crown, and the applicant made application under a tax deed,$^{73}$ but this is contrary to the general rule subsequently approved by the full court in Howell v. Montgomery of making the tax purchaser plaintiff.

${ }^{69}$ Iredale v. McIntyre, 14 Man. L. R. 205.

${ }^{70}$ Re Cass and Canada Traders, Ltd., 15 W. L. R. 194.

7 Clarke v. Scott, 5 Man. L. R. :81.

i2 8 Man. L. R. 499.

${ }^{73}$ McCarthy v. Badgley, 6 Man. L. R. 370. 
Where one B purchased land from the Government of Canada and paid certain instalments and then gave the defendant (applicant) a quit claim deed of the land, and the defendant upon patent granted to him, applied for certificate of title under The Real Property Act, and the caveator alleged that he had bought the land at a tax sale, and that the moneys paid by the defendant belonged to $\mathrm{B}$, the caveator was made plaintiff and the caveatee defendant as the only case made was to have the caveatee declared a trustee for the caveator $;^{74}$ and where the claim of the caveator was under a mortgage on which he claimed a certain amount was due, he was made plaintiff. ${ }^{75}$ The fact of the caveator being in possession does not necessarily alter the general rule. Thus in New South Wales, where the applicant claimed the land by documentary title and the caveator claimed by possession, the court ordered the caveator to be plaintiff, ${ }^{76}$ and where the defendant applied to bring the land under The Real Property Act of New South Wales and showed a complete documentary title, and that he had been in possession within twenty years before such application, it was held by the Privy Councili that the onus was on the caveator, though in possession, to show that the applicant's title had been defeated. Lord Macnaghten, in delivering the judgment of the board, said:

"The first ground of complaint is that they ought not to have been made plaintiff in the trial of the issues, but that they ought to have had such advantage as a defendant in possession has in an aetion for recovery of land. *** It is stated in the judgment under appeal that it has been held in New South Wales that a eaveator in possession is not in the same position as a defendant in ejectment and authority was cited in support of that view. Their lordships do not desire to

${ }^{74}$ Ruddell v. Georgeson, 8 Man. L. R. 134.

${ }^{75}$ Leng v. Smith, 14 Man. L. R. 258.

${ }^{76}$ In re Marks and Buttsworth, 10 W. N. (N. S. W.) 182 (full court).

77 Solling v. Broughton, (1893) A. C. 556. 
throw any doubt upon this proposition which in itself does not seem unreasonable or, indeed, to express any opinion on it as the point is not properly before them. But it may be observed in the present case the caveators would have gained no advantage by being made defendants. The applicant comes forward and shows a complete documentary title, and proves that he was in possession within a period of twenty years before the commencement of the proceedings. Then the burden of proof is shifted, (Leigh v. Jack, 5 Ex. D. 264) and it lies upon the caveators to show that the applicant's original title has been defeated, $\mathrm{Or}^{\circ}$ in other words, that the entry in 1875 was not effective."

On the other hand the caveatee was made plaintiff where both parties claimed under conveyance from the patentee; the caveatee, having initiated 'proceedings by applying for the certificate of title and thus claiming the land as against the world, having reference to the questions in dispute between the parties, must be taken as substantially in the position of a plaintiff toward the caveator. ${ }^{78}$ And where the applicant claimed title by a tax sale deed and that in any case the land was the homestead and exemption of $M$ he was made plaintiff as against the caveator who claimed a charge under a writ of execution against the lands of $\mathrm{M}^{79}$

The proceeding by way of petition is purely statutory and the powers of a judge thereon are strictly limited to those prescribed in the rules; 80 nevertheless, within those limits the court on proceedings by way of petition follows the practice of - a superior court as far as permissible. For the purpose of determining that practice, proceedings by way of petition have been usually considered as analogous to interpleader proceedings; thus, a defendant out of the jurisdiction was refused security for costs on the ground that he was the real plaintiff, and by analogy with interpleader. ${ }^{81}$ A commission

\footnotetext{
${ }^{78}$ Grant v. Hunter, 6 Man. L, R. 550.

${ }^{79}$ Martin v. Morden, 9 Man. L. R. 567.

${ }^{80}$ Graham v. IIamillon, 8 Man. L. R. 443.

${ }^{81}$ McCarthy v. Badgley, 6 Min. L. R. 370.
} 
to examine a witness abroad was refused on similar grounds. ${ }^{82}$ Documents are ordered produced following the ordinary procedure of the courts ${ }^{83}$ and security for costs is granted as in proceedings in court. The caveatee is entitled to demand security for costs from a petitioner resident out of the jurisdiction upon the hearing of the petition, but if that application is allowed to be made, such caveatee loses his right to security if he be subsequently made plaintiff in the issue. ${ }^{84}$ Security for costs may subsequently be granted with regard to the issue. ${ }^{85}$ Affidavits need not be filed with the petition, ${ }^{86}$ although this may be done if desired. The affidavits may be filed at the hearing.

The court may order costs even as against the Crown, ${ }^{8 i}$ but has no power to stay a petition until the costs of a prior action in court relating to the same matter have been paid..$^{88}$ An appeal lies from the verdict of the court on a petition ${ }^{89}$ and a new trial may be granted for sufficient cause shown. ${ }^{90}$ The issue should be confined strictly to the question to be tried and should reserve all other questions, and the question of costs, until after the trial of the issue. ${ }^{91}$ The decision of the issue determines nothing but the actual question directed to be tried, ${ }^{92}$ so that, where a petition was filed claiming land in fee simple and the caveatee (tax purchaser) was made plaintiff and subsequently nonsuited, there was no jurisdiction whereby to direct an issue of certificate of title

${ }^{82}$ Grant v. II unter, 6 Man. L. R. 610. See, also, Grant v. Hunter, 8 Man. L. R. 220.

${ }^{83}$ IIardy v. Desjarlais, 8 Man. L. R. 670.

${ }^{84}$ Ross v. Morgan, 7 Man. L. R. 593. But see contra McCarthy v. Badgley, 6 Man. L. R. 370; Leng v. Smith, 14 Man. L. R. 258.

${ }^{85}$ Grent v. II unter, 6 Man. L. R. 550.

${ }^{86}$ McArthur v. Glass, 6 Man. L. R. $3(01$.

${ }^{87}$ Reginat v. Fawcett, 13 Man. L. 1R. 205.

${ }^{88}$ Graham v. IIamilton, 8 Man. L. R. 443.

${ }^{89}$ Morice v. Baird, 6 Man. L. R. 243.

${ }^{90}$ Grant v. II unter, 8 Man. L. R. 220.

${ }^{91}$ La Valle v. Drummond, 6 Man. L. R. 120.

${ }^{92}$ Campbell v. Alloway, 8 Man. L. R. 224. 
to the caveator, as the nonsuit determined nothing. except that the caveatee did not take advantage of the opportunity given to establish his title. Whether or not a second petition may be allowed where the first was not heard on the merits, does not appear to have been determined. In Schultz v. Frank, ${ }^{93}$ Dubuc, J., thought that proceedings should be stayed for a week, to allow the careator to file a new petition. Killam, J., said:

"The statute says nothing about a second petition. It may be that a second can be filed when the first fails on grounds which do not amount to a decision on the merits. It may be that this can be done when the first is dismissed without prejudice to the filing of a second or with leave reserved for the purpose."

And Bain, J., said:

"If there are no provisions in The Real Property Act that stand in the way of a petitioner filing another petition, the court has no power that I know of to grant leave to file one.'

Where an application was made for a new trial on the ground of discovery of further evidence, Killam, J., refused the application under the circumstances, but said that he should be sorry to see a rule absolutely laid down that such an application could not be made. ${ }^{94}$ In McKay v. Nanton ${ }^{95}$ the petition was dismissed "without prejudice to the caveators' right to apply to file another caveat," and in Schultz v. Archibald ${ }^{96}$ leave was granted in the same proceedings to file such other caveat.

Caveats having been disposed of, the registrar is yet not necessarily compelled to grant certificate of title, though such is the almost invariably proper course. He must always be satisfied that the title is safe holding. ${ }^{97}$ In Manning v. The Commissioner of Titles, on appeal to the Privy Council from

93 8 Man. I. R. 345.

94 Grant v. Hunter, S Man. L. R. 220.

957 Man. L. R. 250.

96 \& Man. L. R. 284.

97 Man. 45. 
Western Australia, ${ }^{98}$ the commissioner of titles had indicated that his requisitions had been satisfactorily answered. Advertising according to the Act was thereupon completed and afterward no caveat was filed. The section in question, No. 21, reads:

"If before the expiration of the time limited in the notice aforesaid for lodging a caveat, the registrar shall not have received a caveat forbidding the bringing of the land in question under the operation of the Act, he shall bring such land under the Act by registering in the name of the applicant, etc."

In the meantime, however, the commissioner had taken certain depositions on oath without notice to the applicant and thereupon notified the applicant that his application was rejected. It was held by the Privy Council that the action of the commissioner was right. Lord Hobhouse, delivering the judgment of the board, said:

"As regards section 18, then, it is not disputed that the commissioner is an official bound to exercise his intelligence, and not a mere machine as the literal force of the words would make him. Now, when we have once reached the conclusion that such a meaning must be read into section 18, we cannot refuse to read it into section 19 , and then it is for those that insist on his mechanical action to show at what point his discretion ceases and his obligation to follow a rigid rule begins."

And referring to the notices:

"They may not necessarily produce caveats for those can only be lodged by persons making claims on their own behalf, but they may produce information showing that registration of the application would not be right.'

Other cases from Australia bear out the rule that the registrar or official examining titles will be supported by the court in suspending the issue of a certificate of title until a disputed question of title can be tried, notwithstanding that no caveat has been lodged, if the result of the action might be to endanger the assurance fund. ${ }^{99}$ It is his duty to protect the assurance fund and he should not allow

9 (1890) 15 A. C. 195.

"Re Nelson Bros., 5 N. Z. L. R. S. C. 111. 
it to be subjected to avoidable risks. ${ }^{100}$ On the other hand, as has been pointed out, the same assurance fund only attains its greatest utility when its existence is taken as permitting the registrar to ignore trifling defects in title or defects which he is morally certain do not indicate the defeat of bona fide rights. While the courts, on appeal, probably could not order such a title to be registered, it may well be that, as has been the case in Manitoba, a registrar would be acting properly in extending the benefits of the system to such a case.

In Saskatchewan, Alberta and the Dominion, if no title is shown within the few simple cases referred to ante page 74, the jurisdiction of the registrar ceases. He does not seem to have power even to reject the application, although it is to be presumed that in a very obvious case he should exercise that right. The applicant might then take a "petition," the hearing of which would come before the same tribunal as would the examination of the application for title, but in the ordinary case the registrar gives to the applicant a certificate of the filing of his application, the purpose of which does not appear, and then transmits the papers, in Saskatchewan to the master of titles, and in Alberta and the Dominion to a judge. The jurisdiction of the master of titles in Saskatchewan on the one hand and of the judge on the other is co-terminous.

The judge or master of titles

(a) examines without delay all titles submitted to him;

(b) when necessary hears all persons interested or claiming to be interested;

(c) hears and considers the claims, as against the applicant, of any person who is in possession of the land;

${ }^{100}$ Ex parte Bowman, 7 V. L. R. 314; Hunter, 383. But see page 65 ante. 
and he has all the powers for compelling attendance and production of documents which usually appertain to courts of civil justice and the judges thereof in civil action. ${ }^{101}$ He would appear also to be acting properly to issue a notice similar to that issued by the registrar in Manitoba, and to treat failure to appear or to file an adverse claim in response to that notice, as an admission of the claim of the applicant and a bar to any adverse claim by the party notified, ${ }^{102}$ or the judge or master if he have any reason to suspect that any parties having claims would not thus receive notice and thereby leave the assurance fund open to a claim, may direct notices of the application to be published in some newspaper or newspapers in such form or for such periods as he deems expedient. ${ }^{103}$ Any person having an adverse claim or one subject to which the certificate is not applied for, protects himself by filing with the registrar a statement of his claim verified by affidavit, upon which the judge or master examines into same and disposes of the claim one way or another, ${ }^{104}$ and in addition to the preceding powers further powers are given subsequently in the Acts for compelling attendance of witnesses. ${ }^{105}$

The registrar, master or judge in each and all jurisdictions on being satisfied as to the title, issues or directs the issue of a certificate of title to the applicant, and thereupon the land becomes "under the system," and is dealt with as prescribed by the Act of the province governing the system, though for some period of time

101 Sask. 56; Alta. 31; Dom. 62. See ante page 76 for a discussion as to how far the judge or master should go into the investigation of facts and law.

${ }^{102}$ In re Land Titles Act and Canadian Pacific Ry. Co., 4 Terr. J. R. 227 (full court), at 240.

103 Sask. 59; Alta. 34; Dom. 65.

104 Sask. 57-58; Alta. 32-33; Dom. 63-64. See ante page 76.

${ }^{105}$ Sask. 173-174; Alta. 146; Dom. 178-179. 
traces, as it were, of the former system appear. For example on the first certificate of title there can appear indorsements or memoranda of instruments not otherwise registerable under the Act, such as contracts of sale ${ }^{106}$ and in Manitoba an old system instrument carries forward its rights and incidents as the land passes under the operation of the new system. ${ }^{107}$

${ }^{106}$ Re Land Titles Act and C.P.R., 4 Terr. L. R. 227.

${ }_{107}$ Man. S3 proviso. 


\section{CHAPTER IV}

REGISTRATION

\section{GENERAL COMMENTS.}

12. FUNCTIONS OF THE REGISTRAR.

a. Examination of Instruments.

b. Questions of Priority.

c. Limitations of Inquiry.

\section{\$13. FORM AND CONTENTS OF INSTRUMENTS.}

a. In General.

b. Names and Descriptions.

c. Affidavit of Execution.

\$14. NECESSITY OF PRODUCING DUPLICATE CERTIFICATE OF TITLE.

\section{§ 11. GENERAL COMMENTS.}

Registration and its effect are the outstanding features of all Torrens systems. Under a system of registration of assurances or deeds as distinguished from registration of title, the registration of an instrument gives no validity to the instrument itself, but is merely a notice to parties dealing subsequently with the land; and failure to register does not in any way confer or take away the effect of the instrument, excepting so far as by statute it is provided that such unregistered instrument shall not prevail over a subsequent registered instrument. But in the Torrens system registration is that which gives validity and operation to instruments ${ }^{1}$ and until registered no instrument affecting land under the system is effectual to pass any estate or interest in the land ${ }^{2}$ except as against the person making the

1 Man. 81; Sask. 69; Alta. 41; Dom. 71.

2Alta. 41. 
same $^{3}$ or any estate or interest as against any bona fide transferec. ${ }^{4}$ The qualifications of this general statement are discussed post page 164 .

The physical process which fixes the moment of registration of an instrument is, in Manitoba, the signing and sealing of a memorial thereof indorsed thereon by the registrar. ${ }^{5}$ Such instruments are then constructively embodied in the register, a memorial thereof being entered in the register in all cases where the instrument refers to any land by specific description. In Saskatchewan, Alberta and the Dominion, the physical act which determines the moment of registration of all instruments (except grants) is the entry of a memorandum thereof in the registel upon the folio constituted by the existing certificate of title. ${ }^{6}$ This definition of registration requires a further provision for the entry of those instruments that do not refer to land by specific description; such instruments are therefore said to be "filed," which means entered in the day book. ${ }^{7}$

The registration of instruments divides itself naturally into two headings:

(a) Those registrations which result in the issue of a new certificate of title, such as transfers, vesting orders of the court, final orders of foreclosure, tax sale transfers, sheriff's transfers, etc.

(b) Those registrations which result merely in the entry of a memorandum or memorial of an instrument on an existing and continuing certificate of title.

In the first case the effect of registration so far as the act is concerned is merged in the new certificate of title. The instrument itself drops out of

3 Sask. 64.

4 Man. 83; Dom. 70; Sask. 67.

5 Man. 65.

${ }^{6}$ Sask. $37(2)$; Alta. 22; Dom. 45; Sask. 2 (13); Man. 2 (m); Dom. 2 (13).

7 Sask. 2 (13); Alta. 2 (m); Dom. 2 (13). 
consideration except so far as any claim may be made by reason of anything contained therein for errors in the new certificate of title; or such instrument may be referred to afterwards in an action as evidence. ${ }^{8}$ But in the greater number of cases the rights of the parties are determined with reference to the new certificate of title, and not with any further reference to the instrument itself.

With regard to instruments the registration of which falls into class $(b)$, it may be stated as a general proposition that they obtain equally effectively the benefit of the Act. In effect, every authoritative statement by the registral as to an interest being registered, is equivalent to a certificate of title ${ }^{9}$ that is to say that the parties claiming under those instruments, which are merely noted on a continuing certificate, stand in the same position as to the interest claimed as if the certificate of title were cancelled and a new one issued to them for the interest or charge which they have, subject only to the prior incumbrances and implied reservations appearing on the existing certificate of title. The sections of the Acts establishing the conclusiveness of certificates of title do not limit the persons in whose favor such conclusiveness is to be presumed, but rather on the other hand extend it to all persons dealing on the faith of the register. ${ }^{10}$ And in Gibbs v. Messer, ${ }^{11}$ Lord Watson, delivering the judgment of the Privy Council, said:

"In the course of the argument it was maintained on his (the registrar's) behalf that the protection given by the statutes to proprietors of a mere interest in land, such as is claimed by a statutory mortgage, which does not operate as the transfer of a legal estate, is less extensive than the protection afforded to proprietors of the land itself. Their lordships do not find it necessary to determine that point, although, prima facie,

${ }^{8}$ Man. 160; Sask. 172; Alta. 134; Dom. 177.

${ }^{9}$ Hogg, page 760.

${ }^{10}$ Man. 71,91; Sask. 65, 162, 169; Alta. 42, 44, 135; Dom. 72, 174, 167.

11 (1891) A. C. 248, at 254. 
it does appear to have been the intention of the Act to confer the same lind and degree of security upon all persons who, transacting in reliance on the register, acquire either proprietary rights or mere interests in land, in good faith or for valuable consideration. They assume, for the purpose of this case, that the statute in that respect makes no distinction between these two classes of proprietors; that the McIntyre's mortgage is not liable to impeachment upon grounds which would have been unavailing against a transfer of this land obtained by them in similar circumstances, from the same author."

Registration, in the Torrens system, being the act which gives operation to instruments, requires a more careful delimitation of the powers of the registrar in regard to same and the nature of the instruments which may be registered than under a mere system of registration of deeds where registration is a matter of notice only. The question will be discussed (a) with regard to the functions of the registrar and (b) with regard to the requisites of instruments.

\section{\$12. FUNCTIONS OF THE REGISTRAR.}

\section{a. Examination of Instruments.}

He examines all instruments presented to him for registration, meaning, of course, either personally or by members of his staff for whom he is responsible. ${ }^{12}$ A certain statutory discretion as to the form and contents permissible in instruments is given to the registrar in Manitoba (section 83b), which discretion, however, in practice is not used freely, but only where the registrar is satisfied that it is a proper case to prevent hardship, as, for example, where he is satisfied that a party to a conveyance of land under the new system has paid his money in good faith on the strength of a conveyance under the form of the old system and is unable to get another one. But, independently of that section, the registrar must be more than a mere machine for comparing and checking up instruments with the

${ }^{2}$ Man. 83; Sask. 29 (2); Alta. 46; Dom. 74. 
forms, and with the certificate of title and documents already in his office. He has, within the limits of the Act, certain judicial duties. The tendency in Saskatchewan and Alberta is not to enlarge the scope of his judicial discretion. For example, on a reference as to whether a mechanics' lien received at the land titles office was on the face of it presented within the time for registration prescribed by The Mechanics' Lien Ordinance, Newlands, J., said:13

"I think the lien made by the Independent Lumber Company should be registered if it otherwise complies with the Land Titles Act. I do not think it is any part of the registrar's duties to construe instruments; that should be left to the courts."

On the other hand, in Australia, before the Full Court of Victoria, where the question was which of two sheriff's transfers should have priority and the registrar gave as his reasons for registering the first (a) that it was his duty to register instruments in the order in which they were lodged with him for registration; (b) that a special clause in the lease restricting the right of sale under execution of the lessee's interest did not relate to or affect the registration of instruments under The Transfer of Land Statute, the Full Court upheld the registrar, but gave their views upon his duty, having regard to the first reason given. Stawell, J., said:

"But if he meant that this second reason was only subsidiary to and supporting the first and that he was simply to accept all instruments in the order in which they were lodged, without reference as to whether they were valid instruments or not, he was, I venture to think, in error, and it is only right that he should be put in possession of the views of the court on the point. $* * *$ The judicial duty is imposed on him of examining into the validity of instruments presented to him

${ }^{13}$ Re Independent Lumber ('o.'s Mechanic's Lien, unroported, July 6, 1906. Compare In re Ebbing, 2 S. L. R., at page 173: "Nor does our Act in my opinion cast upon him the obligation of determining whether or not that instrument be valid or invalict under Dominion legislation. The question whether or not the registrar should accept a document for registration must be determined by the provisions of the Land Titles Act alone." 
for registration. He is to investigate them and all the facts presented to him and say whether such instruments are valid or not. $* * *$ The registrar is constituted the authority, subject to an appeal against his decision, to determine the validity of the instrument as well as the priority of registration in point of time."

Higinbotham, J., said:

"It is the duty of the registrar to exercise a judicial opinion on the validity of this proviso; being invalid he could not give effect to it." "14

And in British Columbia a district registrar was held correct in construing a quit claim deed. ${ }^{15}$ It must be kept in mind that the discretion here under discussion is not in reference to the powers of a registrar to decide on conflicting rights between parties, but merely as to his judicial discretion in construing instruments as actually presented for registration.

The functions of the registrar in this respect have been much under discussion in regard to the registration of instruments to and from incorporated companies. The statutory provisions in this regard vary. It is provided in Saskatchewan, but not in the other jurisdictions, that the assurance fund shall not be liable by reason of the improper use of the seal of any corporation or company (section 155). It is open to question whether cven this language, which apparently distinguishes between the improper use of the seal and actual incapacity in a company to hold or deal with the interest involved, does not refer only to the formal execution of instruments under the company's seal and is only declaratory, placing the registrar in the same position as a grantee under such instrument by reason of the rule in Royal British Bank v. Turquand. ${ }^{16}$ In practice, in Saskatchewan, this section is construed as absolving the assurance fund from all liability whatsoever

${ }^{14}$ Ex parte Bond, 6 V. I. R. 45 s.

${ }^{15}$ In re Reliance Gold Minirg and Milling ('o. Ldd., 13 B. C. R. 4S2.

${ }^{16} 6$ E. \& 13. 327; Palmer, Co. Law, 5th Ed., page 34. 
by reason of dealings to or from corporations, and accordingly the registrar raises no question of capacity. The section, however, does not seem to authorize the registrar to accept an instrument in favor of a corporation without some evidence that the corporation is entitled to take under that instrument. In Manitoba, where there is no statutory provision on the point, it is assumed, and in practice regularly acted on, that the registrar must be fully satisfied that a company is entitled to take or grant the interest in question in any instrument, and for that purpose evidence is required to be produced as to the charter of the company, by-laws, and as to the proper passing of all necessary authorizations, excepting in the case of instruments affecting land executed by companies licensed under The Act Respecting Licensing of Extra Provincial Corporations other than companies incorporated under The Companies Act (Dominion). ${ }^{17}$ The propriety of the registrar demanding such evidence in case of companies was assumed in Re Rockwood Electoral Division Agricultural Society by the full court. ${ }^{18}$

In New Zealand, The Land Transfer Act 1885 contains (section 185) a clause exactly similar to Saskatchewan (155d) and the Court of Appeal there, negatively, at least, held that that proviso was requisite in order to absolve the registrar from the necessity of examining into the powers of companies, and, positively, that the section had that effect. Dealing with a petition to compel registration of a mortgage by a company, Williams, J., delivering the judgment of the court, sajd: ${ }^{19}$

"Section $\mathbf{1 8 5}$ is sufficient protection to the assurance fund if it turns out afterwards that the seal was not properly affixed or that the instrument was not binding."

1812 Man. L. R. 655.

${ }^{19}$ Re Kaihu Valley Ry. Co. and Owen, 8 N. Z. L. R. C. A. 522. 
On the other hand, in Queensland and New South Wales, even in the absence of such statutory provision, it has been held that it is no part of the registrar's duty to inquire into the powers of a company..$^{20}$ On principle, where under the terms of the Act, registration itself is the passing of the estate, it seems reasonable that the registrar should be bound to inquire whether or not his machinery is being used by what for the purpose of the Act is a legal entity, that is to say, a person or corporation entitled to hold and dispose of interests in land, or whether he is being asked to lend the protection of the Act to mere nullities. The registrar is entitled to evidence in the affidavit of execution of instruments and, if desired, otherwise, ${ }^{21}$ as to the age of a party executing an instrument. This is a question of the legal status of such party, differing from the question of the status of a corporation to use the machinery of the Act only in difficulty of determination.

Into the validity of one class of instruments presented to him the registrar is (with one exception to be mentioned) precluded from inquiring, that is to say, into the validity of orders of a court having prima facie jurisdiction ${ }^{21 a}$ over the matter involved. In the leading case of Assets Company, Limited v. Mere Roihi, ${ }^{22}$ Lord Lindley delivering the judgment of the judicial committec, said:

"It by no means follows that errors in procedure even in matters which in one sense affect jurisdiction, need be noticed, or ought to be noticed, by other persons whose duty it is to act on orders brought to them. It is not their duty to attend to such matters; if it were, their action would be paralyzed. What they have to look to is the order and if that is good on the

${ }^{20}$ Mutual Assurance Society v. Registrar General, 1 Q. L. J. 177; In re Registrar General, 21 N. S. W. 225.

${ }^{21}$ Man. 86; Sask. 189; Man. 145; Dom. 195.

21a The registrar makes a "mistake" where he decides wrongly as to jurisdiction. Nicholson v. Drew and Norton, 2 W. W. R. 295.

22 (1905) A. C. 176, at page 203. See, also, Public Trustee v. Registrar General of Land, 17 N. Z. L. R. C. A. 577. 
face of it, it is their duty to act upon it; and it must be treated as a sufficient foundation for what they do. Not only are they protected from liability if the order turns out to have been improperly obtained, but if what they do under it is made conclusive on questions of title, a title which might otherwise be impeachable must be treated as valid."

In Saskatchewan where on a reference the registrar raised as a reason against registering a transfer by order of the court and order confirming, that he had no evidence that the preliminaries to the sale had been properly taken, Wetmore, C. J., said: ${ }^{23}$

"In my view of the case, all this proof of the preliminaries" having been properly taken is a matter for the court-not a matter for the registrar. The judge is to determine whether the proper steps have been taken, not the registrar, and when the judge says they have been and confirms the sale and the order confirming the sale is filed with the registrar, that is all it is necessary he should have."

In Manitoba, however, by statutory provision (section 52 proviso) the registral is not thus bound by any order, obedience to which would result in the issue of a new certificate of title, until by his own investigation he has satisfied himself that the title is safe holding.

An order to be recognized by the registrar must be an original under seal; service of a copy on the registrar in the same manner as on the solicitor for a party is of no effect. ${ }^{24}$

\section{b. Questions of Priority.}

The registrar has no power to determine questions of equitable priority or other equities between instruments presented to him for registration. This has been laid down repeatedly in a number of cases and is conclusively settled by the Supreme Court of Canada in the case of Willie v. .Jellett. ${ }^{25}$ That was a case where the E. and $\mathrm{S}$. Land Company executed

${ }^{23}$ C.P.R. v. Mang, 8 W. L. R. 774.

${ }^{24}$ Shattuck v. McRae, (Sask.) Master of Titles, 12 th Aug 1910.

${ }^{25} 26 \mathrm{~S}$. C. R. 282 , affirming 2 Terr. I. R. 133. 
transfers in favor of the plaintiff Wilkie. Subsequent to the date of the completion of the transfers, but before their registration, an execution was filed against the lands of the E. and S. Land Company at the suit of Jellett, the defendant, an execution creditor. In the case four actions were consolidated, the facts being similar in each. At the trial the action was dismissed, but on appeal to the Full Court of the Northwest Territories the judgment of the trial judge was reversed and judgment entered declaring that the executions registered were clouds on the title of the plaintiffs and that the registrar should be and was ordered to cancel and remove from the register of the lands in question the entries made by him of the executions. On appeal to the Supreme Court of Canada under the name of Jellett v. Wilkie, the order of the Full Court of the Northwest Territories was affirmed. The question before the court was really twofold. First, was the registrar right in refusing to register the transfer, except subject to the lien or charge of the execution creditor; and secondly, whether the execution creditor was entitled to sell the lands so as to cut out the title of the plaintiff. The Chief Justice in the Supreme Court of Canada in affirming the judgment of the court below stated that the reasons given in that court by Mr. Justice McGuire "were entirely right." In that judgment, in holding that without doubt the transferee had equitable priority, Mr. Justice McGuire said:

"One must not forget, however, that the Act is largely framed for the guidance of registrars and that as far as that officer is concerned, the meaning of the Act is that he should regard only instruments such as he is directed to receive or register, and when substantially in accordance with the provisions of the Act, and when brought in and presented for registration or delivered to him as provided, and I think that the positive language employed was not intended to prevent $\boldsymbol{a}$ court from giving effect to rights equitable or otherwise." 
The question had previously come up in Manitoba under a similar state of facts. ${ }^{26}$ In that case the transferee attempted to dispose of the execution by a petition from the registrar under section 118 of The Real Property Act 1889, corresponding to section 121 of the present Act. The Full Court of Manitoba, while agreeing that equitable rights could exist under the Act, held that the registrar could not take notice of them.

Killam, J., said:

"Under provisions to which I have referred, and particularly the sections of the Act of 1885 , of which I have given the substance, it appears to me that the registrar general could not inquire into the existence of beneficial interests apart from the registered title in order to ascertain whether the writ of execution bound the lands. The remedy, if any, of Herbert was to be found only in a court of equity."

And Bain, J., said:

"He (the registrar), I thought and still think, could not inquire into or recognize any interest in the land in anyone but the registered owner."

And in Re Moore and the Confederation Life, ${ }^{27}$ Killam, J., delivering the judgment of the full court, said:

"The district registrar has assumed to go behind this certificate and find that Mrs. Moore had a power of sale as executrix which enabled her to sell the property for the purpose of paying debts and legacies, and thus to cut out the two latter of these incumbrances. In Re Massey and Gibson, 7 M. R. 172, we held that the registrar general under the old Acts could not inquire into the existence of a beneficial interest, apart from the registered title, in order to ascertain whether a writ of execution against the registered owner bound the lands as against an alleged beneficiary. Here the district registrar has found in the registered owner a power inconsistent with two of the incumbrances named, which seems to us wholly opposed to the principles of The Real Property Act, as that Act makes a certificate of title final at each stage."

In Saskatchewan it was held by the full court that where the wording of an instrument read along

${ }^{26}$ Re Massey and Gibson, 7 Man. L. R. 172.

${ }^{27} 9$ Man. L. R. 453. 
with the sections of The Land Titles Act in point, evinced a merger, the registrar could not receive evidence of a contrary intention so as to keep alive the security of the plaintiff on the register, but the court alone had that jurisdiction and ordered accordingly. ${ }^{28}$ The rule in this regard is the same in Australia. ${ }^{29}$

To this general rule there are, however, three notable statutory exceptions. By section 69 of the Manitoba Act (introduced as to executors and administrators with will annexed in 1890 , and as to all cases of representatives or trustees in 1900) before registering any dealing with the land by an executor or administrator or trustee under a will, the district registrar shall satisfy himself that such dealing is in accordance with such trust or purposes. By section 87 he is expressly given the power denied him under the previous state of the law as laid down in $R e$ Massey and Gibson, supra, and by section 143 of the Manitoba Act and the corresponding section 97 of the Alberta Act, the registrar has a discretion to allow the withdrawal of a caveat and permit the registration in lieu thereof of the instrument under which the person on whose behalf such caveat was lodged claims his title or interest, provided such instrument is an instrument that may be registered under the Act.

\section{c. Limitations of Inquiry.}

The registrar must pass on the fitness of instruments for registration from the material in his office or properly presented to him under the Act only. $\mathrm{He}$ cannot of his own motion gather information elsewhere. Thus on a reference to the Full Court of the Northwest Territories as to the power of the

${ }^{28}$ Reeves v. Konschur, 2 S. L. R. 125 (full court), 10 W. L. R. 680. Reversing 1 S. L. R. 24, S W. L. R. 346 . See, also, Re Seaborn and Harsberger, 8 W. L. R. 71; Re Claxton, I Terr. L. R. 282.

${ }^{29}$ Kissling v. Mitehelson, 3 N. Z. L. R. C. A. 261. 
registrar to issue a certificate of title of exempt land free from a registered execution, Wetmore, J., delivering the judgment of the court, said:

"Suppose the sheriff presents the documents and seeks to have the charge entered and states that the land is not the homestead of the execution debtor, exempted under the ordinance, that he has another property that is his homestead. Is the registrar to run around the country and find out if this is true or not? I think not. I think he has merely to receive the papers and deal with them as the law directs." ${ }^{30}$

And where the question coming before the Full Court of Saskatchewan by way of an appeal on a petition was as to the right to file a caveat against land claimed under mortgage, the patent for the land not being issued, and where it appeared that the registrar had made inquiries himself by letter from the Dominion lands agent, Prendergast, J., said:

"I may say at once that I will deal with the matter on the assumption that this is all the information that the registrar was possessed of as I deem it useless to take notice of certain correspondence which he had with the Dominion lands agent at Humboldt."

\section{And Lamont, J., said:}

"I agree with the contention of the counsel for the appellants, that under our Act, no duty is cast upon the registrar to make inquiries outside of his own office as to whether or not an instrument is a proper one for registration." 31

It seems, however, to be an open question as to what, if any, jurisdiction the registrar has to act on extraneous evidence coming in fact before him, either through his own efforts or incidentally, which would show, for example, that a fraud was being committed, or that an improper registration was being attempted, which might result eventually in a claim against the assurance fund. The registrar,

${ }^{30}$ Re Claxton, 1 Terr. I. R. 282, at 288.

${ }^{21}$ Re Ebbing, 2 S L. R. 167, at 170 and 173. 
as stated in an Australian case, "has a duty to protect the assurance fund, and not to allow it to be subjected to risks which may be avoided." 32 The Court of Appeal in New Zealand has indicated that even where the duty of the registrar is admittedly purcly ministerial, some effect may be given to notice of improprieties. They said:

"The duty of the registrar to issue a certificate of title upon receipt of a warrant from the Governor is merely ministerial-and his duty to register transfers upon such certificatesat all events so long as he has no notice that they have been wrongly issued-is also ministerial." 33

The cases seem to establish a very considerable discretion in this regard in applications to bring land under the Act, and in some respects at least there is no "distinction between the first registered owner and any other," 34 and it may be urged, therefore, that there is no distinction between the powers of the registrar on presentation of papers for registration in the ordinary way after a certificate of title and on an original application for a certificate of title. On the other hand, the doctrine of the inviolability of the assurance fund may be pressed too far. The assurance fund is itself a device to render the Torrens system practicable and easily workable, and to unduly extend the powers of the registrar to protect this fund is to greatly limit the usefulness of the very system it is designed to assist. It is further evident from the provisions of the various Acts that a much more extended, rigorous and judicial investigation is expected in cases of original applications than in cases of subsequent registration, where

Lx parte Bowman, 7 V. L. R. 314; Hunter, 3S3. See, also, Re Nelson Bros., 5 N. Z. L. R. S. C. 111.

-s Iublic Trustee v. Registrar Gencral of Land, 17 N. Z. L. R. C. A. 577 , at 593 .

M Assets Co. Ltd. v. Mere Roihi, (1905) A. C., at 202. 
subject to the rules now under consideration, the duty of the registrar is more largely ministerial and the "assurance fund must take its chance." 35

\section{$\S$ 13. FORM AND CONTENTS OF INSTRUMENTS.}

\section{a. In General.}

Having considered the question of the fitness of instruments for registration from the point of view of the duties of the registrar, it remains to consider the same question from the point of view of the contents of the instruments themselves.

The instrument must be one "whose registration is provided for and in form and execution conforms to the requirements of the Act." ${ }^{36}$ In Manitoba this is subject to the statutory provision for the allowance of variations as found in the provisions of section 83 of the Manitoba Act. In the Northwest Telephone Company case ${ }^{36}$ a mortgage was presented for registration attached to which was an instrument called a mortgage trust deed which was referred to in the mortgage as annexed to and embodied in and made part of the mortgage. In the trust deed the mortgagor did "grant, and convey unto the trustee, etc.," and furthermore included all the lands which the company had or might acquire. Registration of this instrument was refused by the registrar, his decision affirmed by the master of titles and his decision again affirmed by the Full Court (Sask.), on the ground that to register this instrument would be to ignore the provisions of The Land Titles Act.

The effect of forms was fully discussed by the Full Court of Saskatchewan in Re M. Rumely Co. and Registrar of the S. L.R. D. ${ }^{37}$ In that case an instrument presented for registration contained first, an agreement to give a mortgage upon the land, describing it, and then concluded with words in the

\footnotetext{
${ }^{25}$ Re Tanner, 5 N. Z. L. R. S. C. 102.

${ }^{36}$ In re Northwest Telephone Co. Limiled, 2 S. L. R. 379.

भ 17 W. L. R. 160.
} 
form of a statutory incumbrance incumbering "the said land for the benefit of the said company with the said sum to be paid as above set forth." Registration of this instrument was refused by the registrar, on petition, by the master of titles, and on appeal, by the full court, on two grounds: first, that in the circumstances of the case it was not a proper ease for the use of the incumbrance form, with which grounds we are not here concerned; and secondly, because, in any case, the instrument did not comply with any form prescribed in the Act. It was held that under The Land Titles Act compliance with the forms, "or to the like effect," was mandatory and not directory, and that the document in question varied from any form prescribed in a matter of substance by reason of containing "an equitable mortgage carrying with it rights and remedies not obtainable under a simple incumbrance in Form $\mathrm{J}$," and consequently that the instrument was misleading to anyone not trained in the interpretation of legal documents.

"The impression that a perusal of the document would create would be that it was an agreement simply that he would give a mortgage when called upon, and not that it was in itself a registerable incumbrance upon the land."

This holding suggests a rule of construction for instruments under The Land Titles Act which if carried to its logical conclusion would be of radical and far-reaching effect, namely, that a test of the fitness for registration under the Acts of an instrument should be its ready intelligibility to the lay mind.

Somewhat along the same lines was the suggestion made in a recent judgment of the majority of the Full Court of New Zealand, where it was said:

"The object of the Act was to contain within its four corners a complete system which any intelligent man could 
understand and which could be carried into effect in practice without the intervention of persons skilled in the law." 38

But fortunately no such rule of construction has as yet been unequivocally laid down. In the Full Court of Victoria it was said:

"I do not know what the policy of the statute is except so far as can be legitimately concluded from the statute itself, and judging from it I do not think there has been any intention manifested that professional persons were not to be employed on one side or the other." 39

In Manitoba the only reported case under The Real Property Act of a discussion of the forms is that of Shore v. Green. ${ }^{40}$ In that case the defendant, the owner of the land subject to The Real Property Act, executed a lease according to the form given in The Act respecting Short Forms of Indentures except that it purported to be made in pursuance of The Act respecting Short Forms of Leases. Killam, J., thought that the instrument was a registerable instrument. He said:

"It appears to me that the instrument in question was substantially in conformity with the form in Sehedule M. It did not describe the lessor as registered owner, etc., as in the form, but that appears to be a mere matter of description not affecting the validity of the instrument. The operative word of the form in the schedule is 'lease;' the word is used as well as 'demise' in this instrument. The instrument is a little more extended but substantially the same as the form in all important respects. The form says that special covenants may be inserted."

But Bain, J., and with him Dubuc, C. J., concurring, said:

"The lease could not have been registered under The Lands Registration Act and it was not registered under The Real Property Act and its form is so different from the form of a lease given in the latter Act that it is questionable if the registrar could properly have registered it had it been presented for registration."

${ }^{38}$ Fels v. Knowles, 26 N. Z. J. R. 604, at 620.

${ }^{39}$ Chomley v. Firebrace, 5 V. I. R. 57; Hunter, 98, at page 117.

${ }^{40} 6$ Man. I R. 322. 
Forms have, under some statutes, been held to be "inserted merely as examples and only to be followed implicitiy so far as the ease of each can or may permit," "41 but under Torrens Acts as the instruments take effect not by virtue of the use of ordinary conveyancing words but by virtue of statutory effect given them, the requirements as to following forms provided are more strict. In the Liverpool Borough Bank v. Turner, ${ }^{42}$ on appeal, where the question was as to the validity of a mortgage under The Merchants Shipping Act 1854, section 55 thereof provides that "A registered ship when disposed of $* * *$ shall be transferred by bill of sale and such bill of sale shall contain such description of the ship as is contained in the certificate of the surveyor or such other description as may be sufficient to identify the ship to the satisfaction of the registrar, and shall be according to the form marked ' $\mathrm{E}$ ' in the schedule hereto, or as near thereto as circumstances permit, and shall be executed by the transferrer in the presence of and be attested by one or more witnesses."

\section{The Lord Chancellor on appeal said:}

"I will only add that if Statutes 17 and 18 Victoria, c. 104, had been the first and only legislation respecting the transfer and mortgage of a British ship I should have held that the forms of transfer and mortgage required by sections 55 and 66 must be substantially followed although there be no negative words declaring that all transfers or mortgages in any other forms shall be null and void. No universal rule can be laid down for the construction of statutes as to whether mandatory enactments shall be considered directory only or obligatory, with an implied nullification for disobedience. It is the duty of courts of justice to try to get at the real intention of the legi:lature by carefully attending to the whole scope of the statute to be construed. Looking to the great peculiarities of the forms of transfer and mortgage here required and the purpowe which they were to serve, I cannot doubt that the legislitture intended that these and no other forms were to be nsed."

By The Bills of Sales Act 18is Amendment Act in England, a form of bill of sale made or given by

1 Barllett v. Gibbs, 5 M. \& G., at 96.

427 Jur N.S. 150, 17 and 18 Vict., c. 104. 
way of security for payment of money was set out and it was provided by section 9 that the bill of sale shall be void unless made in accordance with the form in the schedule to the Act. Under this Act parties have been held to a very strict compliance with the form. ${ }^{43}$

In Thomas v. Kelly ${ }^{44}$ the House of Lords laid down rules for the testing of instruments as to their compliance with the forms in The Bills of Sales Act. Lord Fitzgerald said:

"I do not think that the legislature intended by the words 'in accordance with' a literal conformity with the statutory form of the bill of sale. I agree with the view of Lord Justice Bowen, that it is sufficient if the bill of sale is substantially in accordance with and does not depart from the prescribed form in any material respect."

\section{And Lord Macnaghten said:}

"It has been held-and I think rightly-that section 9 does not require a bill of sale to be a verbal and literal transeript of the statutory form. The words of the Act are, 'in accordance with the form', not 'in the form.' But then comes the question, when is an instrument which purports to be a bill of sale not in accordance with the statutory form? Possibly when it departs from the statutory form in anything which is not merely a matter of verbal difference. Certainly I should say when it departs from the statutory form in anything which is chara ateristic of that form."

Lurd Fitzgerald stated that he did not wish to be taken as adopting in all its terms as affording an inclusive as well as an exclusive test the rule of construction as laid down in Ex parte Stanford by the Court of Appeal there. as follows:

"Its divergence only luecomes substantial or material when it is calculated to give the bill of sale a legal consequence or effect either greater or smaller than that which would attach to it when drawn in the form which has been sanctioned. *** We must consider whether the instrument as drawn will

${ }^{13}$ Davis v. Burton, 52 L. J. Q. B. 636; Melville v. Stringer, 53 L. J. Q. B. 482

"Thomas v. Kelly, 58 L. J. Q. B. 66. 
by virtue of either addition or omission have any legal effect which either goes beyond or falls short of that which would result from the statutory form." 45

A covenant by a mortgagor to observe all the rules and by-laws of a loan company would not have the effect of incorporating them in the mortgage. ${ }^{46}$ A mortgage conveying the estate to the mortgagee and containing a habendum clause was refused registration. ${ }^{47}$ And where a fire year lease to a bank contained also the provision that "for the better securing of the said Northern Crown Bank, the peaceful enjoyment of the said term and the repayment by way of rent of the moneys so advanced, the company mortgages to the bank its estate and interest in the lands above described," the master of titles in Saskatchewan properly held that the instrument was neither a lease nor a mortgage in the form of the Act, but a combination of instruments, and not a single instrument in any form provided which it was possible to register by a single registration. ${ }^{48}$

The result of the cases, having in view also the provisions of the interpretation acts of the various jurisdictions, ${ }^{49}$ seems to be fairly summed up by Lamont, J., in Re Rumely and Registrar, ante:

"An exact verbal compliance is not necessary, but the document must be in substance the same as the form prescribed. And it is not the same in substance when the divergence in form gives to one or more of the parties to it rights or remedies or imposes upon them duties or obligations which would not result from the use of the prescribed form." 50

${ }^{45}$ In re Barber, Ex parte Stanford, 55 L. J. Q. B. 341; 17 Q. B. D. 259.

40 Kelly Y. Coloninl Investment Co., 3 W. L. R. 62; Wilkins v. Deane, (i) N. Z. I. R. 425

${ }^{47}$ Re Sipokane and Eastern Trust Co.'s Hortgage, 15 W. L. R. 637.

${ }^{15}$ Iir Cireat West Furniture Co. and Northern Crown Bank's Lease, Master r, 'Titles, Sask., Isth Oct., 1910, and compare Re Rumely Co. and Registrar, 17 IV. L. R., at 167.

${ }^{40}$ I. s. s. 1909 , c. $6, \$ 6$ (3S); R. S. N. 1902, c. $89, \S 8$; R. S. C. 1906 , c. $1, \S 31$ (d); 1906 , Alta., c. $3, \S 7$ (39).

so 17 W. L. R. 160 at 166. Compare Halsbury Laws of England, Vol. 3, page 35. 


\section{b. Names and Descriptions.}

The instrument must be technically correct according to the records in the land titles office, that is to say, all names and descriptions of persons and all lands concerned must be capable, by means of the papers presented, of identification with the corresponding names and descriptions on the register. In regard to the identity of the makers of instruments with the registered owners of the interest dealt with, the registrar in Manitoba requires affidavits in Form 2, App. C, under section 86 of the Act, and in this affidavit it must be distinctly stated whether the party is registered owner or is only entitled to be registered owner. The same affidavit has been approved of for use in Saskatchewan to satisfy the registrar as to small variations, for example, to show that an initial on the register stands for a certain name. ${ }^{51}$ The description of property must be capable of exact identification with the description in the certificate of title ${ }^{52}$ and particularly the instrument must be registerable as against every part of the property and every interest described in it. In Re Northwest Telephone Company Limited, ante, the trust deed stated to be embodied in the mortgage purported to mortgage all or any of the lands of the company. Newlands, J., delivering the judgment of the full court, said:

"I think it would be unnecessary for me to discuss what would be the effect of the registrar ignoring the Act and registering an instrument such as this one. I need only say that for his action the assurance fund woukd be responsible and a subsequent transferee of the mortgage, if not the mortgagees themselves, might have an action against that fund beeause the registrar did not, when he registered the instrument, register it against all the property of the mortgagors, in the event of the specifically described lands not being all their property."

${ }^{61}$ Re Kintz Mortgage, Master of 'litles (Sask) 14 th Dec., 1911.

${ }^{62}$ Rorison v. Kolosoff, 15 W. L. R. 497. 
This case, therefore, so far as Saskatchewan is concerned, must be taken to expressly overrule Re Greenshields and American Abell Engine and Thresher Co. v. Noble, ${ }^{53}$ in so far as they approved the registration of a document as against part of the land described therein only. And the practice, and undoubtedly the proper practice, is both in Alberta and in Manitoba as in Saskatchewan. All reservations and exceptions should similarly be inserted, so that a party holding a registered instrument may merely read his instrument and know without searching the register that he has a registered interest in all the property described in his instrument. ${ }^{54}$

There is one exception to this general rule in practice (outside of Manitoba, where section 84 is an express prohibition), which is, that where an instrument refers to land in more than one land registration district it may be registered, on the practical ground that no person can claim to be misled by the non-registration of an instrument against land outside of the territorial limitations of the district in which the instrument is registered. In practice, the registrars adopt the wise precaution of indorsing on the certificate of registration of the instrument, a limitation to the land in the registration district in question only. The registrations of this sort were approved in Saskatchewan on a reference to the master of titles. ${ }^{55}$

As a sub-rule to that laid down in the preceding paragraphs, it may be said that, as a safe rule of practice, the registrar is not only dealing with the present instrument before him, but may look ahead and take into consideration that he is creating interests which he may subsequently have to deal with,

\footnotetext{
b3 Re Cireenshields, 6 Terr. L. R. 20s; American Abell Engine and Thresher Co. v. Noble, 6 Terr. L. R 39

${ }^{54}$ Russell v. The Registrar General of Land, 26 N. Z. L. R. C. A. 1223.

Bs Re Wright and Manufacturers Life Insurance Co. Mortgage, Master of

Titles, 31st Mareh, 1910.
} 
and he may require precision with that end in view; thus it is submitted that a registrar would be justified in refusing to register a transfer or a mortgage to a transferee or mortgagee where initials only are given, or where an address and description is omitted, or he may refuse to register an instrument in favor of a partnership, as it is no part of his subsequent business to inquire as to whether all members of the partnership have executed any subsequent instruments. For convenience, where descriptions by metes and bounds would be cumbersome and render his office liable to mistake in subsequent dealings with the land, the registrar may require an owner to file a plan of the land. ${ }^{56}$

\section{c. Affidavit of Execution.}

The instrument must be properly attested and verified by an affidavit of execution..$^{57}$ In Manitoba the requirements of an affidavit of execution extend only to instruments executed by the registered owner, but in the other jurisdictions the requirements extend to all instruments except those falling under certain specific exceptions, and, therefore, include instruments such as mechanics' liens, which in Manitoba would require nothing further than as provided in The Mechanics' and Wage-Earners' Lien Act. In the jurisdictions other than Manitoba, an instrument executed under seal of any corporation is one of those specifically exempted from being attested by a witness and accompanied by an affidavit of execution. In practice, however, without specific statutory provision it is held in Manitoba that the seal of a corporation proves itself and does not require attestation. There does not seem to be an authoritative judgment upon whether or not a corporation is necessarily so exempted from the requirement of attestation, but the weight of opinion

${ }^{\text {bs Man. 61, 62; Sask. 76; Alta. 53; Dom. } 83 .}$

${ }^{87}$ Man. 86; Sask. 134, 135; Alta. 102, 103; Dom. 140, 141. 
seems to be in favor of the view that it is so exempted. ${ }^{58}$ 'The question of the right of a corporation to execute an instrument as distinct from whether or not such exccution has been properly effected has alroady been considered (page 94). As to the manner of execution, "it may be open to question whether the registrar should not accept a document under the seal of a corporation, even where it does not have the signature of any of its officers." 59 But the scal must be a seal. Where the testimonium clause to a mortgage by an incorporated association read "In witness whereof we by our president and secretary have hereunto subscribed our names and affixed our seals this 3rd day of May, 1899," and the instrument was signed by the president and secretary and opposite to the name of each a small common red seal was pasted, and there was an affidavit of the subscribing witnesses verifying the execution by the president and secretary and verifying the fact that they respectively were the president and secretary, the execution of the mortgage was held invalid and the registrar was upheld in his refusal to register the same, and it was pointed out that The Land Titles Act 1894, contemplates that instruments mentioned in that Act, executed by a corporation, shall be executed "under its common seal." 60 The evidence requisite to prove the seal of a corporation is discussed in Morice v. Baird. ${ }^{61}$ It may be assumed that even where, as in Saskatchewan, the assurance fund is specifically absolved from liability by reason of improper use of the seal of any corporation, nevertheless the registrar would be acting properly in withholding registration where it appeared prima

59 IIogg, page 915.

${ }^{53}$ Re Ketllesor's Transfer and La Corporation des Peres Oblats. Unreported, Scott, J., 26th Feb., 1897 (N. W. T.)

${ }^{60}$ Re Yorkton Buller and Cheese Manufacturers Association, 6 Terr. L. R. 471.

${ }^{61} 6 \mathrm{Man}$. L. R, 243. 
facie that it had been improperly used, but in the ordinary case it is not to be presumed that what has been done is ultra vires, and, therefore, when an instrument is produced under seal of the company, it is prima facie to be taken that the seal was properly affixed. ${ }^{62}$

The better opinion seems to be that an attesting witness should not be a party to an instrument. This is the common law rule. In Seal v. Claridge, in the Court of Appeal in England, Lord Selborne, L. C., said:

"The first question is of more general interest. I was at first surprised that no authority could be found direetly in point; but no doubt the eommon sense of mankind has always rejected the notion that a party to a deed eould also attest it. I do not pay much attention to the old rule of evidence whereby interested persons were rendered incompetent as witnesses; it has now been done away with by statute. What is the meaning of the word 'attestation,' apart from Bills of Sales Act 1878? The word implies the presence of some person who stands beside, but is not a party to the transaction." 63

The Full Court of Victoria has held that there was no proviso in the Act restraining an interested party from attesting an instrument, ${ }^{64}$ but in that case this was a mere dictum, as there was sufficient ground in fact for holding as they did in the result, because the mortgage in question was attested by the manager of the mortgagee bank, this not being the same as a party to an instrument; and the rule laid down that attestation by a party is allowable, unless restrained by the Act, is distinctly at variance with the general rule of construction that wherever applicable, and except so far as repealed by necessary implication in any Act, the common law rules apply.

${ }^{62}$ Milestone v. Moose Jaw, 8 W. T. R. 901, quoting Bramwell, B., in $D^{\prime}$ Arcy v. Tamar, Kit II ill and Callington Ry. Co., L. R. 2 Ex. 158.

${ }^{63}$ (1881) 7 Q. B. D. 516. See, also, Freshfield v. Reed, 9 M. \& W. 404. Seal v. Claridge was approved and followed in Re Parrott, Ex parte Cullen, (1891) 2 Q. B. 151.

4 The Bank of Victoria v. McMichael, 8 V. L. R. 11; IIunter, 406. 
In Saskatchewan, Alberta and the Dominion, it is provided with particularity before whom affidavits of execution may be sworn. In regard to all affidavits it is further provided, in Saskatchewan, that they shall be subject to the practice governing affidarits in the Supreme Court (section 180); in Alberta, to the practice governing affidavits in the Supreme Court of the Northwest Territories at the date of the passing of the Act (May, 1906) (section 142); and in the Dominion to the practice governing affidavits in the court (section 185) In Alberta, by section 142 (2), it is made clear that the restriction in the rules of the court against the swearing of affidavits by the solicitor of the party, does not apply in cases of affidavits of execution.

The corresponding provision which appeared in The Land Titles Act 1906, of Saskatchewan, section 190 (1), carried forward from The Land Titles Act 1894, was dropped in the revision of 1909 . Under the English Bills of Sales Act 18\%8, it was provided that "every affidavit required by or for the purposes of this Act may be sworn before a master of any division of the High Court of Justice, or before any commissioner empowered to take affidavits in the Supreme Court of Judicature," and in Baker v. Ambrose, ${ }^{65}$ it was held that an affidavit of execution to a bill of sale sworn before the solicitor of the grantee was insufficient, and the registration of the bill invalid. In Alberta, Beck, J., declined to follow this case. ${ }^{66}$ It is evident, moreover, in Saskatchewan that sections 134 and 135, prescribing the persons before whom affidarits are to be taken, are intended to be a complete code in that respect as the master of titles and the registrar and deputy registrar are

${ }^{65} 6.5$ L. J. Q. B. 589.

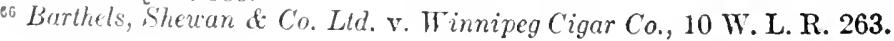


included in that tabulation, and in no case could those officials take affidavits as such for use in the supreme court.

Affidavits of execution are further subject to the general sections of the Act curing invalidity for an informality or technical irregularities, or any mistakes not affecting the substantial justice of the proceedings. ${ }^{67}$ Under The Registry Act in Manitoba it was held that where the affidavit of execution omitted the addition or calling of the subscribing witness to the plaintiff's mortgage, it was an omission rendering the registration invalid. ${ }^{68}$ Other cases along the same lines to be found in the reports under various Registry Acts, Bills of Sale and Chattel Mortgage Acts, are not in point under the Acts being considered in this work, so far as they affect the validity of the registration of the instrument (see page 106.) On the other hand, although they may not affect the validity of an instrument once it has been registered, they may be taken as a guide to registrars in passing on the fitness or otherwise of an instrument for registration, and a registrar, in his discretion, is entitled to insist upon a very full compliance with the forms and provisions of the Act in regard to affidavits of execution.

\section{$\S$ 14. NECESSITY OF PRODUCING DUPLICATE CER- TIFICATE OF TITLE.}

The instrument must be accompanied by the duplicate certificate of title unless it fall among the statutory exceptions to that rule in Saskatchewan and Alberta, or unless it be an instrument which, in Manitoba, from the nature of the case does not require to be indorsed on the certificate of title, such as, for example, a certificate of judgment. ${ }^{69}$ The

\footnotetext{
${ }^{07}$ Man. 156; Sask. 184; Alta. 142; Dom. 190.

${ }_{68}$ Renwick v. Berryman, 3 Man. I. R. 387.

${ }_{69}$ Man. 67; Sask. 32; Alta. 22; Dom. 42.
} 
registrar may dispense with the production of the duplicate in Manitoba where it would otherwise be required (section 67) or may replace a lost duplicate (section 54), but in the other jurisdictions the production of the duplicate can only be dispensed with by a judge. ${ }^{70}$ But a judge should not, except on very clear evidence, exercise this power, or at all if the rights of third parties may be thereby interfered with. ${ }^{71}$ The registrar is not the person who requires the duplicate, it being simply his duty to register, other things being correct, if the duplicate is presented with the instrument, or to reject if not, so that he should not use the machinery of the Act to assist a party presenting an instrument to call in the duplicate. $^{72}$ In such case it will appear that the only remedy of the party requiring the duplicate is by ordinary action. Registration, under the Act, being that which passes the estate or interest, a grantee under an instrument is entitled, as against the grantor, to performance of all such acts as are necessary to effectuate the grant, and among these is the production of the duplicate to permit of registration. As between competing instruments presented otherwise simultaneously for registration priority is granted to the holder of that instrument who presents with his instrument the duplicate certificate of title $;^{.3}$ and it would appear that except in the case where an incumbered certificate of title is retained in the land titles office for the benefit of all persons interested in the land,$^{74}$ the mere physical possession of the certificate of title would not justify

Sask. 31; Alta. 22; Dom. 41 .

"T urner v. Clark, 2 S. L. R. 200, 10 W. L. R. 25.

i2 Re Toth and Case, 14 W. L. R. 704.

is Re Greenshields, supra, American Abell Engine and Thresher Co. v. Noble, supra.

is Man. 118; Sask. 90; Alta. 71. 
the registrar in using it for the purposes of registration of an instrument presented where the certificate is not presented for the purpose of effecting such registration, or is in the possession or control of some other person. ${ }^{75}$

7i Swanson v. Getsman. , W. L. R. 762. 


\section{CHAPTER V}

THE EFFECT OF REGISTRATION

$\S$ 15. INTRODUCTION.

§ 16. THE EFFECT OF FIRST REGISTRATION OF TITLE.

a. Nature and Permanency of the Registered Estate.

b. Unregistered Interests.

c. Relation of the Registered Estate to the General Law.

d. Jurisdiction of the Court.

c. Conveyancing Practice.

§ 17. THE EFFECT OF THE GRANTING OF NEW CERTIFICATE OF TITLE, AS AGAINST UNREGISTERED INTERESTS.

§ 18. THE EFFECT OF THE REGISTRATION OF AN INSTRUMENT.

a. Effect of Unregistered Instruments.

(1) REGISTERABLE INSTRUMENTS AS AGAINST UNREGISTERABLE INSTRUMENTS.

(2) UNREGISTERED INSTRUMENTS AS BETIVEEN THE PARTIES.

(3) UNREGISTERED INSTRUMENTS AMONG THEMSELVES.

b. Registration as Giving Operation to an Instrument.

(1) SPECIAL CLAUSES IN THE INSTRUMIENT.

(2) IRREGULARITIES IN THE REGISTRATION OF THE INSTRUMENT.

(3) FORGERY.

(4) OPERATION AGAINST EXECUTION CREDITORS AND ASSIGNEES FOR THE BENEFIT OF CREDITORS.

\section{INTRODUCTION.}

Under a system, the cardinal principle of which is the passing of the only estate in land recognized by the law under that system by registration in a 
public office rather than by execution and delivery of a deed or instrument, the analysis of the effect of such registration evidently goes to the root of the understanding of the whole system. The results of the changes in the substantive law and in the rules of conveyancing practice are so varied that it is impossible in a few words to summarize the effect of the Torrens system; and judicial comment on the scope of the Acts exhibits great variation, and points to the fact that the effects of the introduction of the system cannot be summed up in any set formula. On the one hand we are told that

"one must not forget that it is a registration system and nothing more,"

and that

"The Land Titles Act is an Act which deals with and is intended particularly to deal with matters of registration.,"2

On the other hand we are told that there has been so great a substantive change in real property law that no interest in land off the register can be enforced $^{3}$ and that the person holding an agreement to give a mortgage on land is

"as to the land itself in no better position than any other simple contract creditor of the mortgagor.",

The truth lies between these two extremes. The Act deals with more than matters of registration and to a considerable extent with questions of title. ${ }^{5}$ The purpose of the Acts may be to facilitate conveyancing transactions, even to the extent of acting without solicitors, ${ }^{6}$ and

"to simplify the laws relating to the transfer and incumbrance of freehold and other interests in land,"

${ }^{1}$ Raymond Land Co. v. Knight Sugar Co., 11 W. L. R., at page 698.

${ }^{2}$ In re Wark Caveat, 2 S. L. R. 431.

${ }^{3}$ Lange v. Ruwoldt, 7 S. A. R. 1; overruling on this point Cuthbertson v. Swan, 11 S. A. R. 102.

4 Gilbert v. Reeves and Ullerich, 4 S. L. R. 97, at page 102. See, also, In re Case, 1 W. W. R. 129.

- Canada Permanent Mortgage Corporation v. Martin, 2 S. L. R. 472.

- Suggested by Mlolesworth, J., Chomley v. Firebrace, 5 V. L. R. 7. Not concurred in by the Chief Justice on appeal.

7 Title of the original Torrens Act of South Australia 1858. 
but in effecting this purpose changes had to be made in the method of transferring and incumbering land which certainly might well be called drastic if not revolutionary. The desire for simplification of procedure necessarily involved, perhaps not changes in substantive rights of property, but certainly changes in the methods of securing and enforcing these rights, and some of these changes are of such a nature that the statute introducing them cannot be said to be a registration system and nothing more.

For the convenience of discussion, the subject of the effect of registration under the Acts will be divided under three heads: title.

(1) The effect of the original registration of a

(2) The effect of the registration of a new title upon the cancellation of a former certificate of title.

(3) The effect of the registration of an instrument entered upon an existing certificate of title.

As stated, this division of the subject is for convenience only and for the purpose of classifying the questions naturally arising. It is not a strictly logical classification, but it is under these heads that in the actual working of the Act points of difficulty seem to naturally present themselves. Upon the strict theory of the Act, all registration is one. There is no difference in effect between the first registration of a title and any subsequent registration. ${ }^{8}$ But the transition of land from one system to another raises questions not raised upon the mere transfer of registered land from one person to another. And again, the registration of a new certificate of title is not in theory different from the registration of an instrument. In strict theory, in

Assets (o. Ltd. F. Here Roihi, (1905) A. C. 176, at page 202: "In dealing with action between private inctividuals, their lordships are unable to draw any distinetion between the first registered owner and any other." "But this is apparently not the rule under the Ontario Act. Farah v. Glen Lake Mining Co., 17 O. L. R. 1. 
a system of registration of title, it is the register itself that is conclusive, and as soon as the instrument has produced the entry in the register, the instrument has served its purpose and is of no further use unless as evidence in an action ${ }^{9}$ or unless some collateral question, such as that of forgery, arises. Thenceforth the instrument itself should disappear into the recesses of the registry office, the register being the whole evidence of title; and in case of a transfer or other instrument resulting in the issue of a new certificate of title, such is the practice as well as the theory, but in the case of an instrument such as a mortgage, the difficulties of having indorsed in the memorandum placed upon the certificate of title all the particulars of the instrument, as for example the powers of sale, powers of distraint, powers to insure, and so on, which the parties to such instruments, even under a system which insists upon simplicity of instruments, are entitled to make, has resulted in the practice of there being entered on the certificate of title short entries only, being merely for the identification of the instrument, to which itself reference is necessarily made for further particulars. As a result, "special covenants" are often allowed which carry the instrument very far from the simple document, not requiring legal assistance to understand, which only, it has been said, is contemplated under the system. There seems indeed a tendency in practice and in the decisions ${ }^{10}$ to restrict this liberty, but having opened the door thus to special covenants and powers, the lines of demarcation seem hard to draw. This fact, however, in practice makes an apparent difference in the effeet of the registration of an instrument resulting in a certificate of title, and the

- Sask. 170; Alta. 136; Dom. 175.

10 helly v. Colonial Investment Co., 3 W. I. R. 62; Re Northwest Telephone Co. Ltd., $2 \mathrm{~S}$ I. R. 379; Re Rumely Co. and Registrar S. L. R. D., 17 W. L. R. 160. 
effect of one resulting only in the entry of a memorandum upon a continuing certificate of title.

The effect of original registration will first be considered.

\section{§16. THE EFFECT OF FIRST REGISTRATION OF TITLE.}

a. Nature and Permanency of the Registered Estate.

In one sense the registration of a title may be said to be merely the establishing of a title already existing, adverse interests by virtue of the force given to priority of registration under the Acts having been cut out, and the certificate of title granted upon such registration merely cértifying that the registered owner is the owner of such an estate in fee simple or for life or for a term of years, as the case may be, in a certain piece of land. This is the prima facie meaning of the words used in a certificate of title. There may appear to be nothing in this to affect the nature of the estate so certified to be held by the registered owner, but, as already pointed out, the effect of radical changes in the law of disposition of property and the requiring of the registration of the interests which can modify or take away from the registered estate, do result in effecting a very real difference in the nature of the estate held by the registered owner from either a "legal" or an "equitable" estate as known to English law. For convenience the estate of a registered owner is called the "registered estate." "Put in the most general words, the registered estate is a group of statutory rights which are new, in the sense that they do not exactly correspond in their juridical theory with the rights in property as known to the ordinary law, though designed to preserve and confer the same or analogous rights in their practical result. The Acts have conferred on the registered proprietor of land what may be called a statutory estate, which 
is not merely a legal right, but a right both legal and equitable, which courts both of law and equity must recognize. The interest conferred is indeed expressly called an 'estate,' and consists of rights as nearly as possible resembling the rights of persons who have what is ordinarily called an 'estate' in the land, but the new registered, or statutory, estate does not operate in the same manner, or on the same principles, as the ordinary estate." 11 The registered estate is not the strict "legal" estate, for land may be brought under the Act subject to a mortgage, in which case the actual legal estate is outstanding in the mortgagee; nor is it an equitable estate as known to English law, as it does not depend for its support on any other estate, and is not liable to destruction for loss of that support, and, indeed, the equitable estate may be outstanding in cestuis que trustent when the land is brought under the Act.

In the reported cases, however, from a practical point of view, the registered estate is treated as the legal estate, and in one case at least in the statutes, namely sections 106 and 108 of the Manitoba Act, the words "legal estate" are used in such a way as to mean the registered estate. The Supreme Court of Canada has referred to the person who holds the contract from the registered owner as one who has "a better right to call for the conveyance of the legal estate," 12 and in the same case in the court below Newlands, J., said that "Under The Land Titles Act, as no instrument takes effect until registered, the only way to get in a legal title to land is to obtain a certificate of title;"13 and, in another case, where it was argued that an unregistered lessee had no status

${ }^{11}$ Hogg, Ownership and Encumbrance of Registered Land, page 90.

${ }^{2}$ Alexander v. MeKillop and Benjafield, 45 S. C. R., per Anglin, J., at page 582 .

${ }^{13}$ Alexander v. Gesman and MeKillop and Benjafield, 4 S. L. R. 111. See, also, Sawyer Massey Co. v. Bennell, 2 S.' L. R. 516, where the registered owners, the Canadian Pacifie Railway, are called "the holders of the legal estate in the said property." 
to bring an action touching his lease, Newlands, J., delivering the judgment of the Full Court of Saskatchewan, said, referring to section 54 of The Land Titles Act 1894 (see Alberta, 41):

"This section is similar to section 59 of The Territories Real Property Act, under which Willie v. Jellett was decided. There it was held that though a registered owner was the legal owner of the lands, he was a bare trustee for an unregistered transferee, and that the courts would give effect to the title of the equitable owner;"

the analogy between a legal and an equitable estate on the one hand, and registered and unregistered estate on the other, being very sharply drawn. ${ }^{14}$

That the result of the registration of a first certificate is something more than to declare a certain estate in a certain person, and to make it the legal estate, whether it was previously so or not, is shown by the cases holding that once land has been brought under the system, it is always under the system. If the certificate of title were merely an entry in a register of a certain existing title, there appears to be no reason why, in those systems where registration is not compulsory, upon the title certified to or its successor by transfer or transmission ceasing to exist, the registration of that title should not, as it were, lapse, and the new title upon coming into existence, should require to be brought anew under the system in the ordinary way. But, for example, upon the adverse occupant being in possession of land for the statutory period required by the Act enforced in the particular jurisdiction where the land lies, the title of the first owner is actually extinguished, ${ }^{15}$ and although no reported Canadian case directly in point can be cited, in such a case in Australia it has been held that a new application to

${ }^{14}$ Tucleer v. Armour, 6 Terr. L. R. 38s. See, also, Gibbs v Messer, (1S91) A. C., at page 254; Short v. Craham, 7 W. L. R. 7S7; Acme Co. v Huxley, 20 W. L. R., at page 139 .

${ }^{16}$ Dawlins v. Penrhyn (Lord), (1S78) 4 A. C. 51; Sanders v. Sanders, (1881) 19 Ch. D. 373. 
bring the land under the Act in the name of the adverse occupant would not be entertained. ${ }^{16}$ In the judgment of the Full Court of Victoria it was said that it had been argued:

"That when the Act speaks of bringing land under its operation, it means bringing the title to the land under its operation, and that therefore when the old title is destroyed, the new one must be brought under the Act. We think the Act does not allow of this, and that in fact there is no jurisdiction with the registrar to grant an application made to him for the purpose,"

and

"we think that when land has been brought under the Act it remains under the Act."

There is nothing to be found in the Canadian Acts to indicate what becomes of the title to land when it escheats or is surrendered to the Crown. The question, indeed, may be complicated by the fact that in the western provinces, the original grantor of the land is the Crown in the right of the Dominion, while land would escheat to the Crown in the right of the particular province. The Crown in the right of the provinces very regularly accepts certificates of title in its own favor and considers itself bound by them as in the case of forfeiture of land for non-payment of taxes in Saskatchewan and Alberta. There is a dictum on this point by the Privy Council in Belize Estate Co. v. Quilter. ${ }^{17}$ Discussing the acquirement of title by possession under The British Honduras Act and the absence of provision for putting on the register any entry of rights acquired by adverse possession their lordships illustrate how, in other ways, without special mention, a registered title may come to an end. They say:

"The adoption of The Land Titles Registry Act by proprietors is permissive; and it is not made imperative that,

\footnotetext{
${ }^{16}$ Re Allen, 22 V. I. R. 24. In Norris v. Ainch, Sask. 1910 unreported, an old certificate was cancelled and a new one granted, on evidence of possession.

${ }^{17} 66$ L. J. P. C. 53.
} 
when a title has once been put upon the register, it shall thereafter continue to be registered in the name of each successive owner. A registered title may come to an end, through the death of a proprietor intestate, and without leaving heirs. In that erent, the land would revert to the Crown, who presumably would not, as there is no provision made for its so doing, put its name on the register. The Crown might, and probably would, make a new grant of the land to a subject, who, if he desired to possess a registered title, would be under the necessity of making a fresh application under the Act."

But Mr. Hogg in his discussion of the question for Australia is unable to come to a definite conclusion in the absence of judicial decision (Hogg, page 719). The practical considerations referred to would no doubt result, in the jurisdictions under discussion in this work, in the Crown accepting a certificate of title for escheated land. It is evident, therefore, that the bringing of the land under the system is more than a mere certification or registration of a particular title. A new variety of estate is created and the ownership of the land itself, whether it be the ownership of a subject of an estate only in the land, or the ownership of the Crown, which theoretically is the only absolute owner, remains permanently subject to the rules of the Torrens system.

\section{b. Unregistered Interests.}

While on the one hand the nature of the registered estate is thus incapable of exact definition in terms of ordinary English law, the nature of unregistered interests in the land is not more capable of exact delimitation in similar terms. The existence of two estates side by side, the "legal" and the "equitable" in English law, was one of the great causes of evil in the existing system of land holding and conveyancing which the Torrens system was designed to remedy. To obtain full ownership in land, a person was required to "get in" both the legal and the equitable estates, both of which, the equitable not less than the legal, were surrounded 
by a growth of rules and precedents which made their easy and safe transfer impossible. The intention of the founder of the Torrens system was to establish one estate in land only, to have it certified in a public register and to provide that, subject to a few specified exceptions, any person who acquired that registered estate bona fide, should by the act of registration acquire the full ownership of the land free from any other estate or interest. The foregoing sentence is, itself, not quite accurate. There were to exist no other estates or interests. What would formerly have been an "equitable estate" was to be only a "right" which some third person had against the registered owner. The registered transferee was not under the provisions of the Acts to be considered in any case as defeating an equitable estate, in the sense understood under the rules of equity touching such an estate. He would simply be taking land free from certain personal rights enforceable in equity against the last owner, and which under certain circumstances the court would consider it inequitable for the new owner to ignore, and would, therefore, acting on him in personam, compel him to give effect to. So far was the doctrine that there was to be no such thing as an estate in land other than the registered estate carried, that in South Australia an ordinary written contract for the sale and purchase of land was held unenforceable. ${ }^{18}$ The plaintiff had entered into such a contract and had paid the whole of his purchase money to his vendor. The vendor died without executing a statutory transfer or any formal conveyance, leaving his heir-at-law an infant and having made a general devise of his property to his. widow and children, who were the defendants. The plaintiff claimed that either a statutory transfer should be executed or a vesting order made. By the South

${ }^{18}$ Lange v. Ruwoldt, (1872) 6 S. A. R. 75, 7 S. A. R. 1. 
Australian Act no estate or interest in land passed until registration, and it was contended for the plaintiff, that, although the written contract conferred no estate or interest at law or in equity in the land, it yet gave the purchaser a right in personam against the vendor or his heir, which the court of equity would enforee. The court, and on appeal, the full court, held that the effect of the eontract, had the land not been under the system, would have been to pass an equitable fee simple to the purchaser, but that under the Torrens system no such estate or interest could pass, the contraet not having been registered and being incapable by reason of its not being in statutory form, of being registered; that the power of the court to decree specific performance depended on an equitable estate having been eonveyed to the purchaser; that the provisions of the statute effectually prevented any separation of the legal and equitable estates; and that the plaintiff was not entitled to have the land conveyed to him but merely had a right to recover his purchase money. Gwynne, J., said:

"The contract had no binding effect on the land and was only a personal obligation."19

This decision, however, was subsequently specifically stated to be overruled by the judgment of the same court, ${ }^{20}$ where it was laid down that

"The system of trusts, except so far as is necessary for the maintenance of the one principle involved in The Real Property Act, namely, the indefeasibility of title on a sale to a bona fide purchaser is not swept away by The Real Property Act."

The Canadian courts, as is evidenced by a perusal of any report one may care to pick up, has followed the latter and overruling case, Cuthbertson v. Swan, rather than the former, Lange v. Ruwoldt.

19 Compare Gilbert v. Ullerich, 4 S. C. R. 97.

${ }^{20}$ Cuthbertson v. Swan, 11 S. A. R. 102. 
In Bannerman v. Green, ${ }^{21}$ Johnstone, J., adopted as applicable to a contract of sale of land under the system, the language of the House of Lords in Rose v. Watson, ${ }^{22}$ where the Lord Chancellor said:

"When the owner of an estate contracts with the purchaser for the immediate sale of it, the ownership of the estate is in equity transferred by that contract. Where the contract is an executory contract, in this sense, namely, that the ownership of the estate is transferred subject to the payment of the purchase money, every portion of the purchase money paid in pursuance of that contract is a part performance and execution of the contract, and to the extent of the purehase money so paid, does in equity finally transfer to the purchaser the ownership of a corresponding portion of the estate."

Bannerman v. Green was decided, it should be noted, even before the addition of the words "except as against the person making the same" to section 64 of the Saskatchewan Act.

The nearest approach to a literal following of the doctrine of no estate except on registration in the Canadian jurisdictions is the case of Gilbert v. Ullerich. ${ }^{23}$ This case, however, is in itself an excellent illustration of the difficulty of adhering to the fine distinction suggested between rights and estates. The facts were, that Ullerich, being the registered owner of certain lands, mortgaged them to the plaintiff who registered his mortgage; he subsequently gave an agreement to mortgage the same lands to Reeves \& Co., who filed a caveat claiming under that agreement. Subsequently again to this, he gave another mortgage of the land to the plaintiff, who registered this mortgage. The land having been sold under the plaintiff's first mortgage, the question at issue was the distribution of the purchase money. It was held by the full court that Reeves $\&$ Co. not having any registered interest as to the land itself, were in no better position than any

211 S. L. R. 394.

2210 H. L. C. 671.

${ }_{23} 4$ S. L. R. 56 ; affirmed, 4 S. L. R. 97. 
simple contract creditor of the mortgagor and that before they could have a lien on the land itself, and share in the proceeds, they must prosecute their claim to judgment, and either obtain an order of the court making their claim a lien on the land, or obtain judgment and execution for the amount due them and file an execution in the land titles office. In that particular case, as appears in the reports, Reeves \& Co. had demanded a mortgage and it had been refused them and they no doubt would have had an action against Ullerich to compel him to give a mortgage, or a declaration that they were entitled to the same, and there is no doubt that on a summons for the payment of money out of court, such questions could not have been tried out in chambers between Reeves \& Co. and Ullerich, nor for that matter could any disputed questions of fact as to the amount owing or the signature of parties or the bona fides of the transaction have been tried out ${ }^{24}$ but it does not appear from the report and the fact is, that Ullerich did not appear and contest the claim of Reeves \& Co., nor did Gilbert contest the amount owing or that any of the allegations made by Reeves \& Co. were incorrect, and the decision is left therefore to stand on the bare fact that Reeves \& Co. had no registered interest. In case Reeves \& Co. had been claiming under an unregistered mortgage which was not overdue or in default, it is a fair question to ask, what action could they have brought? The courts have jurisdiction to enforce rights, not to make them, and if in such a case Reeves \& Co. had no interest in the land unless they had got it by registration, it does not appear in the Act by what authority the court could have usurped to itself power to create a lien which the Act as interpreted in this case says can only arise upon registration.

${ }^{24}$ Independent Lumber Co. v. Gardiner, 3 S. L. R. 140. 
So far as the report shows the caveators in this case got no moneys at all, but in a subsequent case, pressed no doubt by the injustice of carrying Gilbert v. Ullerich to its logical conclusion, the Chief Justice in Saskatchewan directed that the proceedings in the distribution be stayed, pending the prosecution of an action by the caveators ${ }^{25}$ in other words, directed that opportunity should be given for the insertion of a lien on the title, which according to the logic of Gilbert v. Ullerich was not there at the time of the sale.

The decision of the Privy Council in Crowley v. Bergtheil, ${ }^{26}$ draws attention to the distinction between equitable rights and equitable estates. The present writer not having access to the laws of Natal, from which Colony the appeal was taken, is not in a position to state to what extent the words of the Judicial Committee are applicable here. In that case Bergtheil purchased from one Smith under contract and had paid his purchase money in full. Smith having died, his executor fraudulently disposed of the property adversely to the agreement. Fraud having been found on the facts, their lordships continued:

"The defendant's counsel argue that though the heirs of Smith might set the sale aside, the plaintiff, not having any specific property in the land, but only contractual rights against Smith, has no such status as entitled him to sue. This however, is a misapprehension of the plaintiff's position.

"It is true that by the law of Natal the purchaser of land, though he may have paid the price, is not, until regular legal transfer, the owner of the land, but is only one who has a claim against the vendor. To speak of him as the true owner in the language of an English court of equity, though the expression may be used in speech for brevity's sake, is not correct, and if there were other claimants against Smith or his estate, it would be misleading; but the plaintiff's claim against Smith is beyond dispute, so that as between those two, the plaintiff must have become the owner of the estate at his own will and at any moment."

${ }^{25}$ Re J. I. Case Threshing Machine Co. and Fisher, 1 W. W. R. 129, 19 W. L. R. $701 . \quad 26(1899)$ A. C. $390 ; 68$ L. J. P. C. 81. 
Whatever may be the law in Natal, this would throw little light on the case of a purchaser under an agreement who has not paid his last instalment but nevertheless is not in default. The truth is, as said by another writer, that:

"The logical principle of title registration is that no estates or interests in land may be registered except those which are authorized by statute, and that no estates or interests need be noticed except those which are registered. It will be little practical good to regard an equitable estate as an 'equitable right, rather in the nature of an incumbrance on the estate of the registered proprietor than part of the ownership of the land,' and it seems vain to hope that such a distinction will remove 'many difficulties which exist in the practice and theory of the system.' In practice the unregistered equitable right in the nature of an incumbrance on land, is quite as dangerous and burdensome as an unregistered equitable estate in land. The doctrine of an estate in land will not be relieved of its many difficulties unless and until the legislative tendency of the people reaches the point where all equitable estates and rights in land are swept away. Unfortunately for the complete development and success of the system, neither the legislative nor the judicial tendency seems to be towards the recognition of the registered estate only in land." 27

The Acts themselves recognize the impossibility of keeping away entirely from the ordinary doctrine of courts administering equity, of equitable estates. Section 73 of The Land Titles Act 1906 of Saskatchewan, referred to in Gilbert v. Ullerich, was amended in the revision of 1909 coming into force March 5, 1911 , by the addition to section 64 of the words "except as against the person making the same," recognizing between the parties at least, even under the statute, the equitable estate; and in Manitoba the corresponding section 83 enacts that no instrument may be effectual to pass any interest in land, until registered "as against any bona fide transferee" of such land.

Again in regard to caveats, the persons who may caveat are, in Manitoba, the persons "claiming

${ }^{27}$ Niblack, Analysis of the Torrens System, § 163. 
an estate or interest in land;" in Saskatchewan, any person "claiming to be interested in any land," and by the form the caveat is directed to state "with particulars the nature of the estate or interest claimed," and the persons who may move to strike off the caveat are any persons "claiming an interest in the land" (section 129). In Alberta the wording is a combination of the wordings of the Manitoba and Saskatchewan Acts. The person who may caveat is any person "claiming to be interested in any land," and by the form he forbids the registration of any instrument affecting the said "estate or intere.t." And again, except in case of fraud, the person taking bona fide from the registered owner is not affected by notice, direct, implied or constructive, of any trust or "unregistered interest." 28 The statutes seem to have in many cases preferred, possibly with the idea of avoiding the word "estate," to use the word "interest," but little force can be attached to this fact. "Interest" in its legal signification, means the estate or property which a man possesses in lands or chattels, and so accurate a writer as Mr. Williams in his authoritative work on Real Property, in opening his remarks on equitable estates, says:

"We have now arrived at a very prevalent and important kind of interest in landed property, namely an estate in equity merely, and not at law. The owner of such an estate has no title at all in any court of law, but he must have recourse exclusively to the Court of Chancery, where he will find himself considered as owner according to the equitable estate he may have." 29

This last quotation might very well be adapted and transposed to read that the owner of such an estate, while he has no title under the Torrens system, may have recourse to the courts where he

${ }^{28}$ Man. 91; Sask. 162; Alta. 135; Dom. 167.

${ }^{29}$ Williams, Real Property, 9th Ed., page 157. 
will find himself considered as owner according to the equitable estate he may have.

Referring to the decision in Crowley v. Bergtheil, supra, it has well been said that:

"It is difficult to distinguish this 'right' from what would be ealled by English lawyers an equitable interest in the land."

In London and Southwestern Railway v. Gomm, ${ }^{30}$ Jessell, M. R., says:

"The right to call for a conveyance of the land is an equitable interest or equitable estate."

The leading case on the point of equitable estates or interests in the Canadian courts is the decision of the Supreme Court of Canada in Wilkie v. Jellett. ${ }^{31}$ That case was a consolidation of four actions. In three of them the registered owner of land had executed a transfer to the plaintiffs, and in the fourth case had given him an agreement of sale. Subsequently, but before the registration of the transfers, the defendant, Jellett, recovered judgment and registered exccutions against the lands of the company. The action was for a declaration that the transfers and agreements took priority to the executions. The Territories Real Property Act, under which the case arose, contained the section:

"After a certificate of title has been granted for any land, no instrument, until registered under this Act, shall be effectual to pass any estate or interest in any land (except a leasehold interest not exceeding three years) or render such land liable as security for the payment of any money."

At the trial the plaintiff's action was dismissed. Mr. Justice Roulcau, following In re Herbert and Gibson, ${ }^{32}$ held that the unregistered transfer could not take effect as against the registered execution. but on appeal to the full court in the judgment delivered by Mr. Justice McGuire--of which it was said in the judgment of the court in the Supreme

${ }^{30} 20 \mathrm{Ch}$. D. 562, page 581 .

${ }^{31} 26 \mathrm{~s}$. C. R. 282, affirming 2 Terr. L. R. 133.

${ }^{32} 6$ Man. L. R. 191. 
Court of Canada, that "the reasons given for it in the opinion of the court written by Mr. Justice McGuire, were entirely right" - it was held that the Act was largely framed for the guidance of registrars and was not intended to prevent a court from giving effect to rights, equitable or otherwise, whether evidenced by any instrument or by one not capable of being registered or by one which has been merely omitted to be registered. The language of Bain, J., in Massey v. Gibson, ${ }^{33}$ was quoted with approval:

"Equitable interests can be created and will arise by implication in these lands just as in the case of lands that have not been brought under the Act, and courts of equity, acting upon the registered owner in personam will still recognize and give effect to them."

He points out that an executor under the Act was deemed to be the owner against all persons whomsoever, but that it would not be contended for a moment that if an executor contemplated dealing with the land contrary to the interests of the devisee, the latter could not by injunction or order restrain him from so doing.

"This, I think, illustrates how the general words of section 59 (above quoted in Sask. 64 with last elause off and Alta. 41 last part) and 62 (Man. 71; Sask. 169; Alta. 44) may be given effect to as being addressed to the registrar and to be observed by him so far as he is concerned in the performance of his duties."

As against the execution creditor of the registered owner, he

"has become a mere trustee for someone else who is the real and beneficial owner."

In the face of such language it seems hopeless to deny the practical existence of "equitable estates" in land as well as the registered estate. It is true that the equitable estate is enforced by an action on the equity side, if the expression may now be used, of the court, and in personam, but it is as much an

${ }^{33} 7$ Man. I. R. 172.

${ }^{34}$ Wilkie v Jellett, 2 Terr. L. R., at 149. 
estate in the land as was the old "equitable" estate as distinguished from the "legal" estate, and differing from that estate only as necessarily modified by the rules of the Torrens Act as to notice and defeasibility. This view has been acted on throughout the decisions. In Tucker v. Armour ${ }^{35}$ the unregistered assignee of a lease brought action against the landlord for possession. Scott, J., delivering judgment for the Full Court of the Northwest Territories, said:

"The appellant contends that the assignment by Herbert Tucker to plaintiff not having been registered, did not operate as a transfer of any interest in the lease to plaintiff and he is, therefore, not entitled to claim under it. I am of opinion that the trial judge was right in the view he expressed that the principle laid down in Willie v. Jellett is applicable as well to The Land Titles Act as to The Territories Real Property Act and that therefore the assignment, though unregistered, transferred to the plaintiff all the interest of the original lessee."

Bannerman v. Green, ${ }^{36}$ where the view of a contract for sale of land at a price pavable in instalments as transferring with each instalment the ownership of a corresponding portion of the estate was adopted without question in regard to land under the Act, has been referred to. On this point Mr. McCaul, in his Notes on the Remedies of Vendors and Purchasers, ${ }^{37}$ says:

"Consequently, where, as in Alberta, agreements of sale are not 'instruments' capable of registration, it may well be argued that the intention of the Act is to prevent any estate or interest, legal or equitable, resting in the purchaser by such an agrement. So far as the writer is aware, the courts have never considered this difficulty but have dealt with the remedies of rendors and purchacer-e. g. relief against forfeiture, enforcement of rendor's lien, atc.-as if they were unaffected by the Act; except, of course, so far as they notice caveats that may have heen registered in respect of such agreements of sale."

It is perhaps not going too far to say that as the courts construe the Acts at the present time, interests in land ancillary to a registered interest maly be created as fully as cquitable interests or

$$
{ }^{35} 6 \text { W. L. R. } 93 .
$$

${ }^{37}$ Note page 10. 
estates had been engrafted on the legal estate. As regards his records the registrar is absolved from and in fact forbidden to pay any attention to such estates, but as regards parties they stand in the same position as under the former law, excepting as regards the nature and effect of the priorities created under the Acts, and their liability to be defeated, as discussed post page $164 .^{38}$ This is not to be understood as necessarily identifying equitable interests with unregistered interests. One of the distinctive instruments of the system is the mortgage. By statute it does not operate as a transfer of the land (Manitoba) and of any estate or interest therein. In other words, the registered interest itself is made analogous to the equitable charge or lien. And, again, the registered transferee by way of security, is also in the position of an equitable mortgagee. ${ }^{39}$ What is meant is simply that, as a result of the cases, the law relating to equitable interests where the land is not under the system is applicable to unregistered interests where the land is under the system, except where necessarily altered by the specific language, read in the light of the general intendment, of the Acts. As the old courts of equity acting in personam finally established interests which in equity were treated as interests in the land itself, though at law they would have had no standing, so our courts administering both law and equity, may, and generally do, recognize unregistered interests as interests in the land, wherever in doing so they need not do violence to the principles and purposes of the Acts.

c. Relation of the Registered Estate to the General Law.

It is not to be supposed that the Torrens Acts are a complete code of real property law and contain all the law relating to that kind of property.

${ }^{38}$ See, also, Williams v. Box, 44 S. C. R. 1; Barnes v. Baird, 15 Man.

L. R. 162; Sawyer Massey Co. v Waldell, 6 Terr. L. R. 45; In re

Wark Caveat, 2 S. I. R. 431.

${ }^{39}$ Independent Lumber Co. v. Bocz, 4. S. J. R. 103. 
"The Act was not intended to be a complete self-sufficing code of law in its operation." 40

Sueh language as that of Edwards, J., delivering the majority judgment of the Full Court of New Lealand, where he said:

"The object of the Aet was to contain within its four corners a complete system which any intelligent man could mulerstand and which could be carried into effect in practice without the intervention of persons skilled in the law,"

must be taken to be intended to exclude the operation of rules of law at variance with the plain meaning of the Torrens Acts, but not as excluding the operation of a creat deal of law and a great many statutes not referred to or touched in the Torrens Aets at all. 'This has been well illustrated in the disenssion just had of the nature of unregistered interests. The Acts say that no action for the recorery of any land shall be sustained against the owner execpt in ecrtain specified interests. None of these specified cases is that of a vendor who has received all his purchase money, or of an executor who by the terms of the sale is bound to transfer the land to a certain bencficiary, but the courts would exercise their right to enforec these remedies. In Saskatchewan and Alberta, the jurisdiction of the court is continued by special sections. ${ }^{42}$ The corresponding scetion 126 in Manitoba is now repealed, but the law is as statcd in that scetion in any case (see page 147). The section appears in only two of the Australian ilets.

In considering the relation of the Torrens Acts to the general law, it must be kept in mind that the two main objects of the Aets are to give facility of transfer and security of title.

"The main ohject of the Act, and the legislative scheme for the attainment of that object, appear to be equally plain.

4" Per lliggins, I., Fink v. hobertson, 4 C. L. R. Sot.

"Fels r. Knowles, 26 N. \%. L. R. C. 1. 60t, at page 620 .

. Sask. t; Alta. 139. 
The object is to save persons dealing with registered proprietors from the trouble and expense of going behind the register in order to investigate the history of their author's title and to satisfy themselves of its validity." 43

It does not conduce to such greater facility or security that a registered owner should not be bound by a contract made by him, or that an executor should not be compellable by a court of equity acting upon him in personam to use his registered ownership for the benefit of the person entitled, and accordingly the Acts are construed with reference to these purposes, and are to be taken merely as a part of the general body of law and not superseding it, except by necessary intendment read in the light of these main purposes of the Acts. It will be seen clsewhere how the general law relating to mortgages and leases is applicable to mortgages and leases of land under the system.

The question of the applicability of other particular statutes to the land under the system is to be viewed somewhat differently in Manitoba than it is in the other jurisdictions. In these latter all land is, or, before being dealt with, must come, under the system. There is no question but that all legislation relating to land passed since the coming into force of The Territories Real Property Act 1886, applies to land under the Acts. The only questions arise as to previous legislation and imported English law. In Manitoba, prima facie all acts of legislature relating to land, include and apply to land under the system; but in accordance with the maxim generalia specialibus haud derogant, the special provisions of The Real Property Act will take effect so as to exclude the operation of the general statute, whenever such exclusion is essential to the due operation of the special enactment.

As regards matters dealt with under the Act, the Torrens Act is an overriding act. To such a 43 Gibbs v. Messer, (1891) A. C. 218, at page 254. 
case the language of Edwards, J., in Fels v. Knowles, ante, ${ }^{41}$ applies. Where the provisions of other statutes can be given effect to without doing violence to the principles of the Act, such other statutes will be given their effect. Thus in Re E.J. Brooks ${ }^{44}$ there was an assignment for general benefit of creditors and a transmission of certain property to the assignee, to register which the registrar claimed he must indorse on the certificate of title issued to the assignee for the general benefit of creditors memoranda of all executions against the assignor; Lamont, J., delivering the judgment of the Full Court of Saskatchewan pointed out that the registrar must issue a new certificate of title "subject to the rights of the execution creditors," and for the delimitation of those rights the registrar was entitled to read The Assignments Act. The Creditors Relief Acts ${ }^{45}$ The Assignments Acts and the statute 13 Eliz. c. 5, apply to lands under the system, ${ }^{46}$ but where the interest of a bona fide purchaser intervenes, who has obtained a certificate of title, his title is read as governed by the Torrens Act. In regard to trustees, The Trustee Acts providing for the appointment of new trustees apply, notwithstanding that trustees for the purposes of the Act are deemed to be absolute and beneficial owners. ${ }^{47}$ And notwithstanding that executors are deemed to be the absolute owners, the ordinary rule is followed that upon the death of one, the other may act alone. ${ }^{48}$

The Mechanics' Lien Acts form another instance where charges on land are established entirely out-

41 S. L. IR, 504.

${ }_{45}$ Thompson v. Berglund, 3 S. L. R. 470; Edmonton Mortgage Co. v. Gross, 18 W. L. R. 385.

${ }^{46}$ Perk v. Sun Life Assurance Co., 11 B. C. R. 215; Meunier v. Doray, 2 W. L. R. 231; Codville v. Haygarth, 10 W. L. R. 35 ; Smith v. Sugarman, 13 W. L. R. 67 I; Fraser v. Douglas, 40 S. C. R. 384; and also Statute 27 Eliz. c. 4; Colcchin v. Wade, 3 V. L. R. (E) 266.

"7 Sask 68 (2); Man. 92; Alta. 47; Dom. 75; Re Fink, (1910), V. L. R. 337. And see, Sask. 115; Alta. $76(2)$; Dom. 155.

48 lie Roueche, 7 W. I. R. 278. 
side of the Torrens Acts, and are consistently and without question enforced; but where they come into conflict with the Torrens Acts the latter prevail. While a lien may be good against the owner for thirty days, the purchaser, outside of Manitoba, where the certificate of title is without special mention subject to the lien, is not bound to go beyond the register to ascertain the extent or existence of a lien; $;^{49}$ but in the case just cited, and in practice, it is assumed, though nowhere specifically decided, that the provision that a lien holder has a charge on the increased value in priority to a mortgagee, is not so repugnant to the provisions of the Torrens Acts as to be nugatory. In such a case the mortgagee has acquired all the benefits intended by the Act when he takes his mortgage upon the land as it exists at the time of the registration thereof.

A registered title may be founded upon a title gained by the length of possession required under the Statute of Limitations in force within the jurisdiction. That is to say, a person on making an original application to bring land under the Act, may submit as evidence of title continuous and uninterrupted possession for the period of time required by the Statute of Limitations in force in the jurisdiction in which the application is made. ${ }^{50}$ The effect, however, of the granting of a certificate of title upon other evidence as against the title of a person who has at the time of such granting been in uninterrupted possession for the required statutory period, varies. In Manitoba, but not in Saskatchewan, Alberta and the Dominion,

"every certificate of title shall be void as against the title of any person adversely in actual occupation of and rightly entitled to the land at the time when such land was brought under the new system, and who continues in such occupation." 51

${ }^{19}$ Independent Lumber Co. v. Bocz, 4 S. L. R. 103.

${ }^{50}$ Re Anderton, 8 W. L. R. 319 ; Bradshaw v. Patterson, 18 W. I. R. 402.

61 Man. 74. 
The right of such a person therefore is safe in the same way as the rights to which a certificate of title is subject by implication and without special mention under the Act. The full period required by the statute must, however, have expired prior to the bringing of the land under the new system, that is, to the actual issue of the new certificate, as otherwise all such adverse occupiers could not be said to be "rightly entitled," the use of the word "rightly" under such circumstances being at best a rather anomalous use of the word.

In the other jurisdictions possession even for the statutory period is an adverse interest which is "cut out" by the certificate of title under the general sections making the certificate conclusive with certain exceptions. ${ }^{52}$ The registrar, however, is only permitted to pass on an application where the applicant is the original grantee of the Crown and no instrument has been recorded, or, if not the original grantee, all the original title deeds are produced and no person other than the applicant is in actual possession of the land $;^{53}$ and in all cases the applicant is required by the form to state the name and addition of the occupant and the nature of his occupancy. It is hardly conceivable, therefore, that in fact an adverse occupier for the statutory period could be overlooked so as to be deprived of an opportunity of establishing his title except by reason of affidavits so incorrect as to be fraudulent, and therefore rendering the certificate of title granted voidable at least in the hands of the first holder. ${ }^{54}$

Once land has come under the new system, the question then arises, is the registered title liable to be defeated by adverse occupancy for the statutory period? Or, in other words, must the Acts be

52 Sask. 65; Alta. 42; Dom 72.

${ }^{53}$ Sask. 51; Alta. 29 (1); Dom. 57.

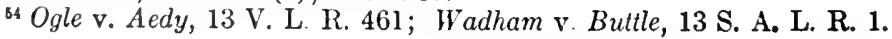


amended, as it were, by adding another instance to the statutory cases in which an action for ejectment or recovery of land will lie, namely, by the holder of a "title by possession?" In Saskatchewan, Alberta and the Dominion, in a sense, yes; but this case is nothing more than an instance of the general rule laid down elsewhere, ${ }^{55}$ that a certificate of title was not intended to be a continuing charter of title in favor of the owner named therein, but in his favor only a certificate that, upon its date, the registered owner was the holder of the title therein specified. This is the view supported by the Privy Council decision in Belize Estate and Produce Co. v. Quilter. ${ }^{56}$ This was a case under The British Honduras Land Registry Act, but is decided upon the general principles of the Act which appear to apply equally to the Canadian Acts. ${ }^{57}$ It was held that adverse possession for the statutory period since the registration of the registered owner's title, extinguished that title. Their lordships said:

"If that enactment (referring to the limitation provisions of the Code) had been inserted in The Land Titles Registry Act their lordships do not think there would have been the least color for the contention that it was repugnant to any of the other provisions of the statute. In their opinion the fact that the clause occurs in another statute forming part of the same Code of laws makes no difference in result."

The decision, however, does not touch the further question, if question it be, whether upon the registered title being extinguished, a new certificate to the adverse possessor may be issued. The form of the question submitted to the court for answer and which their lordships upheld the trial judge in

${ }^{65}$ See pages 56 and 164 .

${ }^{56} 66$ L. J P C. 53

${ }^{67}$ Harris v. Keith, 16 W. L. R. 433. In Smith v. National Trust Co., 17 W. L. R., at page 368, Perdue, J. A., doubted that even in the absence of section 75 of the Manitoba Act the decision would be applicable to Manitoba. No detailed reasons are given and the doctrine was as stated by Perdue, J. A., himself, "a question which is beside the present issue." On appeal in the Supreme Court of Canada the decision was held applicable. 45 S. C. R. 618. 
answering in the affirmative, if taken by itself, would seem to settle the question. It was:

"Whether twenty years' possession will establish a title adverse to the registered owner of lands registered under The Honduras Land Titles Acts."

But the action was by the registered owner against the adverse occupier for trespass not by the occupier for a certificate, and the question and answer of the court should be read in the light of the facts of the case. ${ }^{58}$ But in Re Anderton, ${ }^{59}$ Stuart, J., in Alberta, after an exhaustive examination of the authorities, came to the conclusion that:

"The balance of opinion and of practice is very strongly" in favor of the doctrine that a title in fee simple, or what we would consider equivalent thereto, can be acquired, not indeed by virtue of any express words contained in the statute, but as a logical consequence of the effect resulting from its operation,"

and brought land under the Act by the issue of a certificate of title to an applicant claiming title by possession. But in Harris v. Keith ${ }^{60}$ the same learned judge raised and left unanswered the question of whether the court could order a new certificate of title and the cancellation of an existing certificate in such case. But it is submitted that if a first registered owner may have his certificate of title on evidence of title by possession, and the Canadian and Australian courts agree that he may, there is no reason why in this respect there should be any difference between the first and any other registered owner. If one registered owner's title be extinguished, as may be the case, unless another title can be registered, the title to the land is, as it were, "in the air," for there is no title except the registered one. It would seem to be a logical

${ }^{68}$ Ouinn v. Leatham, (1901) A. C., at page 506.

${ }^{59} 8$ W. L. R. 319, at page 333, approved in Bradshaw v. Patterson, 18 W. L. R. 402. See, also, International Coal and Coke Co. v. Evans, 9 W. L. R. 711, at page 716.

6016 W. L. R., at 433. 
necessity of the system, at least where there is no other system, that the title should be somewhere, and if it is not in the existing registered owner, the court has power in the proceeding in which it so finds, to declare its existence in some other. ${ }^{61}$ This was so held by the Full Court of Victoria, ${ }^{62}$ where it was said that the possessor may go to the court and compel the person who appears on the register to transfer to him. The statute runs against the holder of each successive certificate of title from the issue of such certificate, ${ }^{63}$ at least to a bona fide purchaser. To hold otherwise would be an unwarranted infringement of the conclusiveness of the certificate in the hands of such purchaser.

In Manitoba it is provided by section 75 that "after land has been brought under the Act no title adverse thereto or in derogation to the title of the registered owner shall be acquired by any length of possession merely."

The same provision also appears in the Ontario and British Columbia Acts. The word "merely" may for all practical purposes be read out of the statute $^{64}$ and consequently a mortgagee who has entered into possession under his mortgage is debarred equally with an ordinary trespasser from claiming title by occupation for the statutory period..$^{65}$ By the amendment of 1908 , c. 52, $\S 6$, the same immunity from defeat by reason of the Statute of Limitations was conferred on the mortgagee as had been conferred on the mortgagor, making the rights of the two parties reciprocal. It is possible that in view of the decision in Campbell v. District Land Registrar of Auckland ${ }^{66}$ the law

'Sask. 150; Alta. 116; Dom. 156. This was done by Johnstone, J., in Saskatchewan, in Norris v. Ainch (1910), unreported.

62 In re Allen, 22 V. L. R. 24.

${ }^{63}$ Featherstone v. Hanlon, (1886) Badgers' R. I'. Dig. 4 ('T'asmania). Re Bartlett, 4 Tas. L. R. 26; but contra Murphy v. Michel, 4 W. W. \& A'B. 13.

os Smith v. National Trust Co., 17 W. L. R. 35t. The word does not appear in the Ontario Aet.

65 Smith v. National Trust, supra, affirmed 45 S. C. R. 618.

66 N. Z. L. R. C. A. 339. 
might, at least as to first mortgagee, having regard to section $10 S$ of the Manitoba Act, have been held to be the same in any case.

Throughout the foregoing remarks and in section 74 of the Manitoba Act, the word "adverse" has been freely used as applied to possession. That word has not, however, its former technical meaning, which was abolished under the general law in 1833, by 3 and 4 William IV, c. 27 . The doctrine is not reestablished by the use of the word in the Manitoba Act. And referring to the corresponding section of the Victoria Act, Barry, J., in the Full Court of Victoria, said:

"I therefore come to the conclusion that the word 'adverse' must be read in its popular sense. The Transfer of Land Statute is far from technical and I am of opinion that when the wrong man is in and the right man is out of possession the possession s adverse within the meaning of the Act." 67

The possession which is required under the statutes, where possession is of any avail, must be actual "open, risible and notorious," not constructive possession. There must be both absence of possession by the person who has the right, and actual possession by another, whether adverse ${ }^{68}$ or not, to be protected to bring the case within the statute. ${ }^{69}$

\section{d. Jurisdiction of the Court.}

This matter is referred to under a separate heading rather than left, as might perhaps be expected, to be covered through the discussion of the rights and liabilities arising in the operation of the Acts, on account of certain special sections in the Acts. These sections provide that nothing in the

${ }^{67}$ Staughton v. Brown, 1 V. L. R. (L) 150 , overruling on this point Robertson v. Keith, 1 V. L. R. (E) 1.

68 The word is used here in its former technical sense.

${ }^{69}$ Bradshaw v. Patterson, 18 W. L. R. 402; McConaghy v. Denmark, 4 S. C. R. 609 ; sherren v. Pearson, 14 S. C. R. 585 ; Campbell v. Imperial Loan Co., 8 IV. L. R. 502; Agency Co. v. Short, 13 A. C. 793; Smith v. Lloyd, 9 Ex. 562. 
Acts shall take away or affect the jurisdiction of the court on the grounds of fraud or over contracts for the sale or other disposition of land, and, in any proceedings respecting land or any transaction relating thereto or any instruments, the judge may direct the registrar to cancel, correct or substitute any certificate or entries thereon. The sections referred to are noted below. ${ }^{70}$

These two sections were commented on in Turner v. Clark ${ }^{71}$ by the Chief Justice of Saskatchewan as follows:

"These sections are intended to preserve the jurisdiction of the court to deal with questions of fraud, and al:o with other equities that may arise affecting land and which would be properly cognizable on the equity side of the court."

The first of the sections, formerly 126, in the Manitoba Act, has been repealed, and in Australia a corresponding section is to be found only in the Queensland and South Australian Acts. The law as settled by judicial decision is the same even in the absence of any such statutory provision. ${ }^{72}$ Prima facie no matter is deemed to be beyond the jurisdiction of a superior court unless it is expressly shown to be so, and particularly in view of the repeated declarations of the purpose of the Act as not being to abolish equitable rights, it would seem to have required specific language to oust the jurisdiction of the court rather than to require such a section to continue it. In other words, wherever there are rights, either in personam or in rem, the court is the place to enforce them. This is the very essence of courts, and when equitable rights have not been excluded it seems unnecessary to say that

${ }^{70}$ Man. 126, now repealed; Sask. 4; Alta. 139; Dom. 4; Man. 52; Sask. 150; Alta. 116; Dom. 156.

${ }^{71} 2$ S. L. R. 200.

${ }^{72}$ Hogg. page 779 and note 37 . In Manitoba the repeal of seetion 126 has not resulted in any cessation by the court of the exereise of their power to deal with disposition of land, e. g. IIicks v. Laidlaw, $1 \mathrm{~W}$. W. R. 293. 
the courts may enforce them. This was the conclusion reached by the Court of Appeal in Manitoba in Williams v. Box. Cameron, J. A., says: ${ }^{73}$

"The conclusion therefore is, that section 126, without the amendment, adds nothing whatever to the jurisdiction of the court, and that, in its absence, the law would be held to be what the section declares.'

It is true that this holding is weakened by the decision of the Supreme Court of Canada, which hinged on there being some meaning where the Court of Appeal in Manitoba had likewise found no meaning, namely in the words of the amendment "or over mortgages," thereby indicating that probably the remainder of the section likewise had some meaning. And in Coventry v. Annable, ${ }^{74}$ in the Full Court of Saskatchewan, Wetmore, C. J., implies that the corresponding section in the Saskatchewan Act adds a great deal to the Act - that without that part of the section enacting that nothing should take away the jurisdiction of the court "over equitable interests," the court had no such jurisdiction. But, for example, "surely it would not be contended for a moment that if an executor contemplated dealing with land contrary to the interests of the devisee, the latter could not by injunction or order, restrain him from doing so," ${ }^{75}$ even in the absence of such a section. The question of the jurisdiction of the court over land resolves itself into this: Are the courts prevented from applying the ordinary rules of law and equity to land under the system? and can they only apply what they find within the four walls of Torrens Acts, and so far as jurisdiction is given them by these sections in regard to fraud and contracts? or, on the other hand, do courts apply to land under the system the ordinary principles of law and equity, except where prevented by the

"13 W. L. R., at page 472 .

74 1 W. W. R. 148.

is Quoted from McGuire, J., in Wilkie v. Jellett, 2 Terr. L. R., at page 144. 
direct language and necessary intendment of the Acts, taking into consideration this scope and object discussed ante page 138? It is submitted that the latter is the correct view and that only on such a view do the decisions approach any appearance of consistency.

The second of the sections referred to under this heading is one of procedure only. ${ }^{76}$ The convenience of the section may be realized when it is pointed out that under the Victorian (Australian) decisions where there is no such section, the registrar is a necessary party to any action in which the cancellation of a certificate is one of the reliefs sought, ${ }^{77}$ and in case of rectification of the register, the registered owner is ordered to execute a transfer. ${ }^{78}$ The Australian practice is the logical practice if it be attempted to adhere rigidly to the view that unregistered interests are mere rights in personam against the registered owner and in no sense a right in the land itself. If these unregistered interests are mere rights against the registered owner it is evident that the logical course is to compel the registered owner to execute such instrument as may be requisite, and thus create the interest by registration, the one means provided by the Acts for establishing interests in land cognizable by the registry offices. But if these unregistered interests be rights in the land itself, inchoate it is true, and ineffectual in many cases against the registered interest, the statutory procedure in these sections permitting the court for the purpose of establishing those rights to operate directly upon the registered title is the proper course. In this is to be found another statutory recognition of the unregistered interest as taking effect in some way on the land itself.

${ }^{76}$ Re Smith, 8 W. L. R. 131.

$\pi$ Ogle v. Aedy, 13 V. L. R. 461.

78 Gunn v. Harvey, i V. L. R. 111; Campbell v. Jarrett, 7 V. L. R. 137; Re Allen, 22 V. L. R. 24. 


\section{e. Conveyancing Practice.}

(1) As regards the production of an abstract on a treaty for sale. Maybery v. Williams ${ }^{79}$ was an action by a vendor for the balance of purchase money and the first ground of defence set up was that no abstract of title was produced before the action was brought. Wetmore, C. J., after dealing with the contention adversely from the point of view of the general law, goes on to add:

"Dealing with this question of abstract oc title, I must say that, in my opinion, the conditions are not the same $\mathrm{n}$ this province as they are in England or in Eastern Canada. In England there is no general system of registration and I would be disposed to call what regi:tration they have of rather an inconclusive character. *** Here tne reyistration is conelusive to a certain extent. *** In this case if he defendant had expressed himself dissatisfied with the title which the plaintiff had to offer, it was quite open to him to ask for a reference, as has been done in the courts of Ontario, and I apprehend that if he had asked for it, there would have been no difficulty in getting it."

And dealing with the same question under the British Columbia Act, Clement, J., says: ${ }^{0}$

"In conclusion upon this point I venture to express very grave doubts of the wisdom of importing into our land law, with its system of registration and certification of title, an implied obligation, under an open contract of sale, to show title' in the English sense by delivery of a solicitor's abstract of title. 'Naking title' is of course a different matter."

But on appeal Macdonald, C. J. A., expressed the opinion that this practice had been imported with the common law and was always in force in British Columbia. ${ }^{\text {1 }}$

(2) As to damages upon breach of contract. This matter was considered by Lamont, J., in Saskatchewan in O'Neil v. Drimles. ${ }^{82}$ The question

${ }^{79} 15$ W. L. R. 553 followed A uriol v. Alberta Land and Inestment Co., 1 II. W. R. 787. See, also, Mcllenna v. Goss, 2 II. W. R. 285.

so Largan v. Texberry, 1s IV. L. R. 458 .

$\$ 120 \mathrm{~W}$. L. R. 827 followed Durn v. Alexander, $1 \mathrm{~W} . \mathrm{W} . \mathrm{R} .1117$.

s2 8 IV. L. R. 937 . 
was as to whether damages could be collected for loss of bargain where the sale went off by reason of lack of title in the vendor. After quoting from Bain v. Fothergill ${ }^{83}$ as to the grounds of the rule in the uncertainty and complication of the law of real property, the learned judge adds:

"In this province, however, the reasons for the adoption of this exception to the common law as to damages do not exist. Instead of the complieated law as to the title of real estate which they have in England, we have a very simple system of land transfer, under which the person having the certificate of title holds an indefeasible title to his and, which is not subject to those uneertainties and defects which led to the establishment of the exceptions as laid down in Flureau v. Thornhill and as was said by Cockburn, C. J., in Engel v. Fitch, ${ }^{84}$ 'The limit of the exception is to be found in the reason on which it is based; the reason ecasing, the rule should also cease.'

"Therefore, I am of opinion that the conditions being entirely different here and the reasons which led to the establishment of the exception being entirely absent, there is no reason why a different principle should be adopted in assessing damages for breach of contract for the sale of land, than that adopted for the breach of other contracts."

The effect of this language, however, is weakened by the subsequent comment, that upon other grounds it became unnecessary for the judge in that case to pronounce upon the point; and in McAndie v. Jackson, ${ }^{85}$ Scott, J., in Alberta, in a judgment reported without the reasons, declined to follow O'Neil v. Drinkle.

(3) As to the duties of vendors in regard to registration. As it is registration that is the passing of the title and not the execution of a document, it is arguable that the vendor should procure the registration. This matter is important in the matter of fees, especially where the fees payable to the assurance fund are chargeable on a sliding scale in every transfer, but in practice, except in the case of

\footnotetext{
${ }^{83}$ L. IR. 7, II. I. 158.

${ }^{84}$ L. R. 3, Q. B. 314.

851 W. W. R. 10.
} 
borrowers, such a rule is not adopted. The view as to the vendor's responsibility has been suggested in Victoria, ${ }^{86}$ but in New Zealand it was said that "it has always been the business of the purchaser to take his transfer to the registry office and procure himself to be registered as proprietor." 87

The vendor in any case is required to see to it that the purchaser upon the registration of his transfer will be able to have issued to himself a certificate of title free of incumbrances or as agreed on between the parties. The purchaser is not bound to dispose of caveats or other clouds on the title, ${ }^{88}$ but either party has the right to proceed against the parties causing that cloud. ${ }^{\$ 9}$ The vendor is bound to deliver a registerable transfer from the registered owner and if he does not do so any expense incurred by the purchaser in making his transferor the registered owner, is chargeable to the vendor. ${ }^{90}$

(4) The exceptions and reservations to which a certificate of title is inherently subject, do not extend so as to be read into a description of land in an instrument between parties. ${ }^{91}$

\section{\$ 17. THE EFFECT OF THE GRANTING OF NEW CER- TIFICATE OF TITLE, AS AGAINST UNREGISTERED INTERESTS.}

As already pointed out, this heading is adopted not because it corresponds accurately to any real distinction in the effects of different certificates, but because by the consideration of it by itself, attention may be directed to the indefeasibility of the certificate of title itself, independently of considerations as to the land just having emerged into the operation of the system. As a matter of fact, in actions

\footnotetext{
${ }^{86}$ I'rle v. Blair, 9 A. L. T. 90.

87 Common v. Rees, 9 N. Z. L. R. C. A. 555.

${ }_{8}$ Taylor v. Land Mortgage Bank of Victoria, Ltd., 12 V. L. R. 748.

${ }^{89}$ Ex parte Clarke, 17 V. I. R. 82.

${ }^{90}$ Alder v. Lelion, 11 W. L. R. 23.

${ }_{91}$ Raymond v. Knight Sugar Co., 11 W. L. R. 698.
} 
between private individuals "there is no distinction between the first registered owner and any other." This refers to any distinction there may have been thought to be as regards the relationship of the title of the registered owner to defects and invalidities and equities claiming to affect the same. The courts act on the same principle in regard to the first registered owner as in regard to any other owner. There are certain statutory exceptions, however, from the conclusiveness of a certificate of title in favor of the holder thereof.

The first is those matters to which the certificate of title is subject by implication and without special mention therein. The second, the case of a person deprived of or claiming any land included in any grant or certificate of title of other land by misdescription of such other land or its boundaries as against the owner of such other land, and, in Manitoba, adding "not being the transferee thereof bona fide for value." Thirdly, the case of an owner claiming under the instrument of title prior in date of registration, in any case where two or more grants or two or more certificates of title may be issued under the Act. Fourthly, the case of fraud. The first, second and third cases are dealt with under their appropriate headings elsewhere in the book. The fourth case is the one which leads to the greatest amount of uncertainty and variation of judicial decision. The sections involved in the consideration of the question of fraud are given below. ${ }^{93}$ Before attempting to reach a definite conclusion as to the meaning of fraud and its effect on a certificate of title it would be well to run over the facts of the Canadian cases.

Hooper v. Smith ${ }^{94}$ was a motion by one defendant to dissolve an injunction against him. He had

${ }^{22}$ Assets Co. Ltd., v. Mere Roihi, (1905) A. C. 176.

${ }^{93}$ Man. 76, 91, 71; Sask. 65, 136, 162, 169; Alta. 42, 104, 135; Dom. 72, $142,167,174$.

${ }^{94} 2$ W. L. R. 194. 
purchased and obtained a certificate of title for land from his co-defendant, who, it was admitted, was selling in fraud of the persons having a beneficial interest in the land. Fraud on the part of the applicant was alleged but none was proved, unless his purchasing from his co-defendant, knowing that the co-defendant did not possess the whole interest, was such fraud. Nevertheless Scott, J., continued the injunction until the trial.

In Shaw v. Bailey, ${ }^{95}$ one James, being the owner of certain land under the old system, sold the land to the plaintiff. Subsequently he sold the same land to the defendant. The defendant had heard of an alleged sale to the plaintiff but made inquiries and search at the registry office, and finding no agreement registered, took a deed and subsequently obtained certificate of title. It was held that specific performance could not be decreed against him at the suit of the prior purchaser and although apparently, the land was not under the new system when Bailey bought, he was given the advantage of section 91, providing for the validity of dealings with registered owners, as well as of section 71 .

Fish v. Bryce ${ }^{96}$ was a case where certain lands were sold by the trustees from the Crown to the predecessors in title of the plaintiff. The same and other lands were then transferred voluntarily and without consideration to the trustees for the local Presbyterian Church.

\section{Johnstone, J., said, at page 118:}

"There is no distinetion between a proprietor who has got on the register by fraud and one who has got there under a voluntary transfer as against the rightful owner. In either ease the registered owner may be deelared a trustee for the rightful owner," ${ }_{97}$

and the existing trustees were ordered to carry out the sale made by the first trustees.

${ }_{95} 17$ Man. L. R. 97.

962 S. L. R. 111.

97 See Hogg, page 825 . 
This case, however, on this point may be said to have been overruled in Coventry v. Annable, post.

In Turner v. Clark ${ }^{98}$ the facts are not important as clear fraud was found, but Wetmore, C. J., said:

"I do not wish to express any decided opinion upon the subject, but I am inclined to think that unless fraud or collusion is brought home to the defendant McMillan, that is, if he was the bona fide purchaser for value, his title would be good, but if there was collusion or fraud or the conveyance to him was without consideration, I am of the opinion that I have jurisdiction to deal with the matter, notwithstanding the fact that a certificate of title was issued to him."

This dictum also may be said to have been overruled in Coventry v. Annable, post.

In Tasker v. Carrigan, ${ }^{99}$ Carrigan sold land to the plaintiff for $\$ 2,700$, under an unregistered agreement, receiving $\$ 100$ down. Subsequently Carrigan mortgaged the same land to the defendants, the Northwest Thresher Company, for $\$ 4,100$, which mortgage was registered. It was found by the trial judge that the company had notice that the land had been previously sold and on this sole finding the company's mortgage was postponed to the plaintiff's rights under his agreement, with costs.

In Independent Lumber Co. v. Gardiner, ${ }^{100}$ one Gardiner, the registered owner of certain land, made a mortgage to the plaintiffs, which was registered. At the time of giving the mortgage Gardiner told the plaintiffs that his brother owned a half interest and he expressly but verbally excepted it from the mortgage. The court en banc hold that it was not necessary to determine whether or not the accuuiring of the registered mortgage with the knowledge of the brother's half interest and that the registration of the mortgage would defeat the interest, would

\footnotetext{
${ }_{98} 2$ S. L. R. $200 ; 10$ W. I. R. 25.

${ }^{99} 11$ W. L. R. 621.

1003 S. L. R. 140.
} 
amount to fraud, as the circumstance itself of taking the mortgage in the face of the exception made by the defendant of his brother's half interest, necessitated its being fraud in the plaintiff to insist on having the mortgage enforced on the whole interest.

In Reeves v. Konschur, ${ }^{101}$ one Riddell, being the mortgagee of land by way of assignment of mortgage from Konschur, took and registered a transfer of the same land to herself. The plaintiffs were second mortgagees of the land. Upon the registration of the transfer the registrar, holding that the plaintiffs' mortgage was merged on the registration, issued a certificate of title to Riddell showing the mortgage of Reeves \& Co. as a first charge. The action of the registrar upon the evidence before him was right ${ }^{102}$ and Reeves \& Co. had taken no steps to bring about the issue of the certificate of title in the form in which it was issued. The court en banc, however, taking into consideration the facts as found, namely, that it was not the intention of Riddell that her mortgage should merge, reinstated the mortgage on the register as a first mortgage.

In Coventry v. Annable ${ }^{103}$ the facts were that in 1902 , one White, for value, agreed to sell certain lands to the plaintiff Coventry. In 1904 the defendant Annable, under circumstances clouded in uncertainty, and without consideration, obtained a transfer of the same land (for which patent from the Crown had not then issued and which therefore was not under The Land Titles Act) to himself but, as found

1012 S. I. R. 125.

102 Re Riddell, 7 W. L. R. 301.

${ }^{103} 1 \mathrm{~W}$. W. R. 148 ; 19 W. L. R. 400; affirming 17 W. L. R. 577 . Since the text was written the decision of the Full Court of Saskatchewan has been affirmed by the Supreme Court of Canada, 2 W. W. R. 816 . The court unanimously found fraud and refrained from expressing any opinion on the point of law here under discussion. Idington and Anglin, JJ., without committing themselves, used language which would indicate that on the question of the right of the court to set aside a certificate of title on grounds other than fraud their views accorded with those of the trial judge rather than of the full court. 
by the trial judge, without fraud. The learned trial judge held that having taken transfer without consideration, following the Australian decisions of Chomley v. Firebrace ${ }^{104}$ and Crow v. Campbell, ${ }^{105}$ Annable was trustee for the same persons as was his transferor and therefore, through his transferor, for Coventry. On appeal to the full court the decision was affirmed but on different grounds. Wetmore, C. J., Lamont, J., and Brown, J., all disagreed with the finding of fact of the trial judge and found actual fraud. Wetmore, C. J., and Lamont, J., held that had they not found such fraud they would have been compelled to hold the certificate of title issued in the name of Annable indefeasible as against the plaintiff; following their view of the decision in Assets Co. v. Mere Roihi, ${ }^{106}$ Wetmore, C. J., distinguished Fish v. Bryce, ante, on the ground that the present section 4 of The Land Titles Act as it appeared in the Act of 1894, under which Fish v. Bryce was decided, concluded with the words "or over equitable interests therein" instead of with the words "for which certificate of title has been granted," and dissented fr.mm his own dictum in regard to the position of a voluntary transferee in Turner v. Clark, ante. Johnstone, J., agreed with Wetmore, C. J., and Lamont, J., that the certificate of title in the hands of a rolunteer without fraud, was indefeasible, but, not differing from the trial judge as to his finding of fact in regard to fraud, dissented from the majority in the full court, and moved to dismiss the appeal.

Re Moore v. Confederation Life Association ${ }^{107}$ is important in this discussion in view of the dictum

\footnotetext{
1045 V. L. R. (E) 57.

10510 V. L. R. (E) 186.

${ }^{100}$ (1905) A. C. 176. The dictum of Mathers, C. J., in F'onseca v. Jones, 14 W. L. R. 148 , at page 156 , as to the applicability of the doctrine of resulting trusts to lands under the system, is wider than necessary for the decision of that case, when read out of connection with the actual facts.
}

1079 Man. I. R. 453. 
that The Real Property Act "makes a certificate of title final at each stage." In that case the certificate of title in favor of Emma Beall, executrix and devisee in the will of William Beall, was subject first to incumbrances made by William Beall, deceased, and subsequently to two incumbrances being a charge on the interest of Emma Beall as devisee only. The full court held that the district registrar could not go behind the certificate and find in the executrix a power of sale which enabled her to sell the property for the purpose of paying debts and legacies and thus cut out the two latter incumbrances.

In Syndicat Lyonnais Du Klondyke v. McGrade, ${ }^{108}$ McCrade as a creditor brought action to set aside a transfer of certain lands standing in the name of the defendant L. D. McConnell, wife of the defendant Edward McConnell. The action was brought under 13 Eliz. c. 5, and a certificate of lis pendens was filed, after which the Syndicat purchased from Mrs. McConnell. It was held that the registrar had no authority to file a certificate of lis pendens, but nevertheless the Syndicat had notice of the claim of the plaintiff, and on the pleadings as they stood, it was taken necessarily to have admitted the allegation of the debt and that McConnell's deed to his wife was for the purpose of defrauding the plaintiff and the other creditors. Nesbitt, J., with whom Sedgewick and Davies, JJ., concurred, adopted the language of Bump on Fraudulent Conveyances that "if another receives the property with notice of the fraud, he is aiding the debtor to cheat his creditors and this the law never tolerates."

The case was remitted to the trial court to allow the plaintiffs to plead the renial of the debt sued on and of the fraudulent intent, but unless this were established the plaintiff's action was to succeed. Idington, J., intimated that the doctrine of lis pendens still 
applied to transactions under The Land Titles Act, that

"it is scareely correct to speak of lis pendens as affecting the purchaser through the doctrine of notice, though the language of courts often so deseribes its operation. It affects him not beeause it amounts to notice but beeause the law does not allow litigant parties to give to others pending the litigation rights to the property in dispute, so as to prejudice the opposite party." 109

But this observation is probably one of those with which Nesbitt, J., stated he did not agree.

In Williams v. Box ${ }^{110}$ the defendant was the holder of a certificate of title obtained through an order of foreclosure in proceedings taken under section 109 and the following sections of The Real Property Act. This foreclosure was opened up and the plaintiff allowed to redeem, not on the ground of fraud, but purely on the ground that in the circumstances of that case equity would have enabled the mortgagor so to claim redemption after a judgment of foreclosure of land under the old system. The decision turned largely upon the presence in section 126, at the time the case was decided, of the words "or over mortgages," but Anglin, J., with whom the Chief Justice and Girouard, J., agreed, intimated that in his opinion the court would have the right upon equitable grounds outside of sections 76 and 71

"to order the cancellation of a certificate, at all events where rights of a third party holding the status of a bona fide purchaser for value, had not intervened."

No attempt will be made here to quote the Australian decisions which are numerous and some of which will be referred to incidentally in the following pages. They exhibit the same divergent views as do the Canadian cases. ${ }^{111}$

${ }^{109}$ Quoted from Bellamy v. Sabine, 1 DeG. \& J. 566.

11044 S. C. R. 1.

11 See Hogg, page 825 and following. 
The facts in Gibbs v. Messer ${ }^{112}$ will be found by reference to the case in the Appendix. For the purpose of this discussion the important feature of the case is the statement therein contained of the scope of the Acts on page 254 of the report, as follows:

"The main object of the Act and the legislative scheme for the attainment of that object, appear to them (their lordships) to be equally plain. The object is to save persons dealing with registered proprietors from the trouble and expense of going behind the register in order to investigate the history of their author's title and to satisfy themselves of its validity. That end is accomplished by providing that everyone who purchases, bon a fide and for value, from a registered proprietor and enters his deed of transfer or mortgage on the register, shall thereby acquire an indefeasible right, notwithstanding the infirmity of his author's title."

The facts in Assets Co. v. Mere Roihin ${ }^{113}$ are lengthy and complicated and the reader is again referred to the report of the case in the Appendix. This decision is a veritable mine of dicta on the construction of the Torrens Acts. ${ }^{114}$ That part of the decision particularly in point in this discussion is in regard to Waingaromia No. 3, where "the company produced to the district land registrar a warrant from the Governor of the Colony on May 7, 1889 ," and obtained the registration of their title. It was contended that the warrant was invalid because founded on an invalid order made by the Native Land Court. The Assets Company were the first owners to obtain registration on the permanent register. Their vendors had been registered on the provisional register, in which case

"the estate or interest of a proprietor of any estate or interest

112 (1891) A. C. 248.

113 (1905) A. C. 176.

114 The language of Lord Halsbury in Quinn v. Leatham, (1901) A. C., at page 506, as follows: "The judgment must be read as applicable to the principal facts proved or assumed to be proved, since the generality of the expressions which may be found there are not intended to be expositions of the whole law but governed and qualified by the particular facts of the case in which such expressions are to be found," should be kept in mind. 
on the provisional register shall be indefeasible only against the person named in the original receipt or order," 115 and it was therefore contended and held in the court below that if the first title on the provisional register was voidable by the natives, those natives retained that right against each successive owner in the provisional register and the Assets Company, obtaining title from a person on that register, obtained no better title than such person as against the natives; that the mere fact of the issue of a certificate of title on the permanent register to the company gave them no such additional protection against these original invalidities. But in the absence of actual fraud, the meaning of which will be discussed later, their lordships held that the certificate of title issued to the company was unimpeachable. They said:

"The sections making registered certificates conclusive evidence of title, are too clear to be got over,"

and that

"in dealing with actions between private individuals, their lordships are unable to draw any distinction between the first registered owner and any others;"

and in regard to the judgment of Lord Watson in Gibbs v. Messer,

"there is nothing in his judgment in favor of the view that the original registered owner elaiming from a real person, does not get a good title against everyone, except in the cases specially mentioned in the Act, fraud being one of them,"

and

"this provision taken in connection with those already referred to, went far to show that except in the excepted cases, the registered certificate was to be conclusive and that the remedy of persons wrongfully deprived of their property was to obtain damages from the wrong-doers."

115 Section 45, Lamd Transfer Act 1885, New Zealand. The provisional register in New Zealand corresponds in effect to the register of possessory titles in Ontario and of absolute fees in Britisl Columbia; while the "permanent register" is identical with the "register" in the prairie provines, the recrister of "absolute fees" in Ontario and of "indefeasible fees" in Britisl Columbia. 
The question at issue, as it were, in regard to the effect and meaning of a certificate of title is between two opposing views - or at least opposing in the sense that one goes further than the other. The first view fixes attention upon the transaction between the registered owner and the person about to acquire his registered interest, and holds that in such transaction the holder of the certificate of title is enabled, if the nature of the transaction according to the ordinary rules of equity and law permits it, to confer on the holder of the new certificate of title indefeasibly as good a title as the holder of the first mentioned certificate had prima facie on the register; but this view does not touch, in the hands of the holder of the new certificate of title, any equities arising in the transaction itself. As the bona fide purchaser for value without notice is the only person against whom no equity in such a transaction can arise, this view or theory is often called the "bona fide purchaser" theory. The second or "absolute" theory, which is not really opposed to the first view, but includes it and goes farther, fixes attention not on the transaction and upon the relation of one certificate to its successor, but upon the new certificate of title as evidence of the absolute and indefeasible title of the holder thereof which cannot be attacked except upon grounds specifically stated in the Act. The charter, if it may be so called, of the first viow, is found in the last cited quotation from Gibbs v. Messer, and of the second view in quotations cited from Assets Co. v. Mere Roihi. The difference in the two views may perhaps be clearly pointed out by reference to the case of Cocentry v. Annable, ante. There Annable, according to the facts as found by the trial judge, obtained his certificate of title without giving value, but without fraud. Upon the first theory, following the language used in Fish v. Bryce, ante, Annable, being 
a volunteer, was in no better position than his transferor, who was a trustee for Coventry, and hence also was Annable. But the Full Court of Saskatchewan adopted the second theory, holding in effect that they were not at liberty to examine, on equitable grounds, the transaction by which Annable got his certificate of title, but that they were bound by the fact that he had a certificate of title, and that it could only be attacked on the grounds mentioned in the Act. Hence to let in the plaintiff to recovery of the land they reversed the findings of fact by the trial judge, and found actual fraud. In taking this view of the Act they felt themselves bound by the decision in Assets Co. v. Mere Roihi, and it is evident, therefore, that unless the New Zealand Land Transfer Act 1885, under which that case arose, can be distinguished from the Canadian Acts, there is no object in going back of this Privy Council decision. An examination of the Acts will disclose the fact that in principle they are the same, and that the differences in wording are not sufficient to effect any radical difference in construction. And it is submitted that in the same way as the Privy Council found

"the scctions making the registered certificates conclusive evidence of title are too clear to be got over,"

the rules laid down by the Privy Council for the construction of the Act are likewise too clear to be got over.

It must, however, be admitted that the view here suggested, that is to say, the second of the theories just discussed, as being the proper view to be adopted under the construction of the Torrens Acts, did not appear to commend itself to the Supreme Court of Canada in Williams v. Box, ante. That decision, however, turned on the specific language of The Real Property Act in regard to mortgages. The Assets Co. v. Mere Roihi decision was 
not referred to in the judgment, although it was discussed on the argument and in the court below.

Adopting for the purposes of discussion the second theory and in view, therefore, of the numerous decisions already referred to on pages 134-7 holding that equitable rights are still available under the Act, the question then arises, what are those rights and equities which may be enforced against the registered owner?

First, there is nothing either in the Acts or in any of the decisions to suggest that a certificate of title is intended to be, as it were, in the nature of a continuing charter of rights in favor of the registered owner, cnabling him to defeat interests, equitable or otherwise, arising by his o:in acts. The certificate is only conclusive in Manitoba as of its date, and in the other jurisdictions as of the date of the last registration thereon, which is the same period of time as the date of the certificate in Manitoba. To hold otherwise would in effect render the certificate of title a thing to be aroided, as it would render it impossible for a registered omner to bind his interest in the land excepting by a registered disposition. But secondly, as of the date of the certificate, there are only three grounds on which action can be taken to affect the interest of a registered omner. They are:

(1) Tnder any of the exceptions, reservations or special cases mentioned in the Acts.

(2) Under any of the incumbrances entered on the certificate of title.

(3) Cpon grounds of fraud.

Until placed under one of these heads, no unregistered equity can find, as it were, a footing to attack the registered interest, and the only heading under which an "equity" may come is under the heading of fraud. In other words, "equities," 
"equitable interests" or "rights" arising against or attaching to the interest of the prior owner, or arising in connection with the transaction whereby the owner of the certificate of title acquired his interest, can only be let in to attach themselves to the estate of the present registered owner on the ground of fraud on his part or that it would be fraudulent on his part to defeat them.

This involves careful consideration of what is fraud under the Acts and particularly of the relationship beween notice, or knowledge, and fraud. The difficulties arising in this connection under the Acts were stated so excellently in an early New Zealand decision that we give a rather extended quotation. ${ }^{116}$

"But the title has been registered under the provisions of The Land Transfer Aci 18\%0; and the plaintiff company invokes the protection of section 119 as a bona fide transferee under that section. That section provides that transferees shall not 'be affected by notice direct or constructive of any trust or unregistered interest $* * *$ except in the case of fraud; and further that the knowledge that any such trust or unregistered interest is in existence shall not of itself be imputed as fraud.' It is apparent from these terms that whilst the legislature does not intend to confer immunity in all cases on purchasers who are guilty of what in reference to transactions of this nature has been hitherto considered as fraud, yet it does intend to narrow the class of cases in which fraud is imputable to a purchaser. Since the decision of Le Neve v. Le Neve, 2 Wh. \& Tu. L. C. 32; Amb. 436, nearly 140 years ago on the English Lands Registration Acts, it has been established law that, in the words of Lord Hardwicke, 'the person who purchases an estate (although for valuable consideration) after notice of a prior equitable right makes himself a mala fide purchaser;' and through the doctrine of constructive notice, courts of equity have extended the legal imputation of fraud to cases in which no actual fraud exists. Section 119 clearly expresses the intention to alter the rule of equity. The term 'fraud' as used in the section must be understood as meaning actual fraud, and as excluding at least all those cases in which neither the

${ }^{116}$ National Bank v. National Morlgage and Agency Co., 3 N. Z. L. R. S. C. 257 , Richmond, J. 
purchaser nor his agent in the purchase has actual knowledge of any prior equitable title. Therefore to a large extent (whether altogether or not I need not consider) the statute puts an end to the operation of the doctrine of constructive notice. Beyond this, section 119 in express terms does away with the legal inference of fraud from knowledge of the mere existence of a prior equitable interest. But after excluding all cases of mere constructive notice and all cases where the knowledge of the purchaser does not extend beyond information that some equity exists in third parties which may not be consistent with the proposed transfer, the language of the section seems to require that to some extent other cases of actual, or, as the statute calls it, 'direct notice' which have heretofore been regarded as cases of fraud shall no longer be deemed to have that character. The difficulty lies in determining the exact limit in this respect of the operation of the provision. Cases of bona fide mistakes seem to come within the protection of the clause. But amongst the residuary cases, after excluding all which have been mentioned, it is to be remembered there may be transactions involving gross actual fraud on the part of both transferor and transferee. In many instances the rule of equity that notice is fraud, must be recognized as consentaneous with the principles of common morality; for it may be an act of downright dishonesty knowingly to accept from the registered owner a transfer of property which he has no right to dispose of. A transfer by the trustee whose name is on the register may even be a fraudulent conversion of a criminal character, and the purchaser may be actually confederated with the vendor to effect the fraud. Such a purchaser as this it was certainly not intended to shelter. Between an extreme case of this kind, and one in which the purchaser has a mere hint of some possible irregularity in the execution of a trust, there may be an indefinite number of cases differing in their circumstances, and ranging from a high degree of moral turpitude to transactions which in a moral point of view are unobjectionable. All the cases where there is notice are treated as fraudulent by the former rule of equity. But this rule being abolished for the purpose of the Act, it will be at some time necessary to settle what is to be the new criterion of fraud, and the line will have to be exactly drawn. The statute absolutely requires that a new rule shall be followed, but unfortunately leaves it to the judicial interpreters of the Act to define the terms of that rule as they best can within the limits vaguely indicated by the exception of fraud." 
From this decision to the last pronouncement of the highest court of the Empire is not as great an advance as might be supposed.

"Further, it appears to their lordships that fraud which must be proved in order to invalidate the title of a registered purchaser for value, whether he buys from a prior registered owner or from a person claiming under a title certified under The Native Land Acts, must be brought home to the person whose registered title is impeached, or to his agents. Fraud by persons from whom he claims does not affect him unless knowledge of it is brought home to him or his agents. The mere fact that he might have found out fraud if he had been more vigilant and had made further inquiries which he omitted to make, does not of itself prove fraud on his part. But if it be shown that his suspicions were aroused and that he abstained from making inquiries for fear of learning the truth, the case is very different and fraud may properly be ascribed to him."'117

This latter decision forms an excellent basis from which to work in any given case. Fraud under the Acts means actual moral fraud involving some actual turpitude or dishonesty. ${ }^{118^{\circ}}$ It is safe to say that there will never be, and it would be most unwise to attempt, a complete analysis and classification of all possible cases of fraud. At best one may attempt only a classification of such cases as may be gathered from the reported decisions.

1. Fraud must be brought home to the registered owner. Fraud by the persons from whom the registered owner claims does not affect him unless knowledge of it be brought home to him or his agents. ${ }^{19}$ In so far as Gibbs v. Messer, where the mortgagee under a forged mortgage from a registered owner who had also been registered through forgery, was held to have no valid title, although no fraud or mala fides was brought home to him,

117 Assets Co. v. Mere Roihi, (1905) A. C. 176.

118 Syndicat Lyonnais v. McGrade, 36 S. C. R. 251; Independent Lumber Co. v. Gardiner, 3 S. L. R. 140; Wolfson v. Oldfield, 18 W. L. P. 449; Chapman v. Edwards, 1 W. W. R. 59; Hudson's Bay Co. v. Kearns and Rowling, 4 B. C. R. 536. And compare Derry v. Peek, 14 A. C. 337.

${ }^{119}$ Assets Co.v. Mere Roihi, 74 L. J. P. C., at page 60. Cullen v. Thompson, 5 V. L. R. 147. 
is opposed to this view, it is explained in the decision in Assets Co. v. Mere Roihi on the grounds that "forgery is more than fraud and gives rise to considerations peculiar to itself." Persons dealing on the faith of the register with real registered owners come within the protection of the section providing that "except in the case of fraud of such person, no person contracting or dealing with or taking or proposing to take an instrument from a registered owner, shall be required or in any manner concerned to inquire into or ascertain the circumstances under or the consideration for which such owner or any previous owner is or was registered in order so to be affected by notice, direct, implied or constructive of any trust or unregistered interest." 120

2. Upon this riew of the effect of the certificate of title the decision in Reeres $v$. Konschur, ante, ${ }^{121}$ must be supported on the grounds that it is fraudulent to rely on the title conferred by a certificate of title in relation to what might be called an accidental accretion to or betterment of the interest of any party thereto, lnowing that others are thereby deprived of their rights, although no active steps have been taken to keprive them of such rights. In that case Reeves \& Co., through the action of the registrar, which action so far as the registrar was concerned, was right, ${ }^{122}$ found themselves first mortgagees by reason of the fact that the defendant Lavinia Riddell, the first mortgagee, had taken a transfer to herself and the registrar had merged her first mortgage, leaving the former second mortgage of Reeves \& Co. as a first mortgage. The basis of the actual decision was that Reeves \& Co. were not acting on the faith of the register. This ground of decision is satisfactory upon the view of a certificate

\footnotetext{
${ }^{120}$ Man. 91; Sask. 162; Alta. 135; Dom. 167.

1212 S. L. R. 125. Sce page 156.

${ }^{122}$ Re Riddell, 7 W. I. R. 301.
} 
of title as conclusive only in favor of a bona fide purchaser for value, but upon the view of its absolute conclusiveness excepting from attack on one of the grounds specifically pointed out in the Acts, it is more consistent to read fraud into any attempt on the part of Reeves \& Co. to rely on such new certificate of title. But in an Australian case, where A was in possession of one piece of land and $B$ of another, but by mistake the registered ownership was reversed and $B$ was the registered owner of A's land, which was a more valuable piece, and thereupon $\mathrm{B}$ sold the land of which he was the registered owner to $\mathrm{C}$, who had full knowledge, and $\mathrm{C}$ brought an action of ejectment against A, A'Beckett, J., said:

"The conduct of the plaintifs in buying that interest I think was not fraud. The conduct of White and the persons who bought from him might indicate a very low moral perception, but I do not think it was fraud within the meaning of section 50 of The Transfer of Land Statute No. 301."123

3. The principal is affected by the fraud of his agent, not on the ground of notice, but because he cannot retain the benefit of the transaction which his agent has obtained by fraud. "The principal and the agent are one, and it does not signify which of them made the incriminating statement, or which of them possessed the guilty knowledge."124 This statement of the law is also implied rather than directly stated in a passage from the decision in Assets Co. $\mathrm{v}$ Mere Roihi:

"Fraud by persons from whom he (the registered purchaser for value) claims, does not affect him unless knowledge of it is brought home to him or his agent."

4. The person claiming bona fide under an invalid court order cannot have his title defeated on the

${ }^{123}$ Lake v. Jones, 15 V. I. R. 728. And see Cooke v. Union Bank, 14 N. S. W. Eq. 280.

${ }^{124}$ Wolfson v. Oldfield, 18 W. L. R. 449, at page 455 . Robson, J., quoting from Pearson v. Dublin Corporation, (1907) A. C. 351. See, also, Carden v. Gillett, 13 N. Z. L. R. C. A. 457 ; Eccles v. Hall, 13 N. Z. L. R. C. A. 433. 
grounds of fraud or otherwise. This is clearly laid down in the decision in Assets Co. v. Mere Roihi. ${ }^{125}$ In Manitoba by reason of the proviso to section 52 , such an irregular order has small chance of registration.

5. Duress and undue influence are species of the actual fraud required under the Acts to invalidate a certificate of title. In Grahn v. Litwin ${ }^{126}$ while the certificate of title was held good, Wetmore, C. J., said that

"apart from undue influence, no fraud was proved;"

but then proceeded to find that there was not undue influence, evidently implying that had he found such undue influence, he would have had to set aside the certificate of title. In Kolp v. Hunter ${ }^{127}$ the actual word "fraud" is not used. Lamont, J., found that the transfer was executed under duress and at an undervalue, and therefore the transaction could not stand, and the plaintiff transferor was entitled to have the certificate of title of the transferee cancelled and a new certificate issued to himself. It is submitted that it is quite within the definition of "fraud" under discussion, to class the obtaining of a transfer by duress under that heading, but in the same case Lamont, J., intimated that even without duress the transaction could not have stood. The plaintiff was a woman in distress, had no independent advice and sold at an undervalue, and the learned judge quoted with approval, as applicable to the case, the dictum that

"where a purchase is made from a poor and ignorant man at a considerable undervalue, the vendor having no independent advice, a court of equity will set aside the transaction."128

It may be that undervalue and lack of independent advice may be evidences of actual fraud, but it is

${ }^{125}$ Followed in Wolters v. Riddeford, 25 N. Z. L.R. S. C. 532.

12619 W. L. R. 144.

12719 W. L. R. 709.

${ }^{129}$ Quoted from Fry v. Lane, 40 Ch. D. 313. 
submitted that the setting aside of a certificate on those grounds alone, not considered as fraud but purely by reason of their application in equity, is going far, in view of the holding of the same judge a month previously in Coventry v. Annable reason of the provisions of The Saskatchewan Land Titles Act the court was powerless to apply the doctrine of equity that a voluntary transferee held the land upon the same trusts as his transferor.

6 . The most serious question in regard to fraud under the Acts, is the effect of notice as evidence of fraud. As already stated, since the decision of Le Neve v. Le Neve, ante, the maxim upon which courts of equity have acted is that "notice is fraud." On the other hand, the Acts say that a person acquiring an interest from a registered owner shall "not be affected by notice direct, implied or constructive of any trust or unregistered interest, any rule of law or equity to the contrary notwithstanding,"

and that

"the knowledge that any trust or unregistered interest is in existence, shall not of itself be imputed as fraud."'130

It is clear that, whatever this enactment may mean. although it may not be the mere fact of notice which imputes the fraud, still

"there can be no question. If there is a valid contract affecting an estate and the estate is sold expressly subject to that contract it would be a distinct moral fraud in the purchaser to repudiate the contract and the Act does not protect moral fraud;"'131

and without going so far, if a purchaser acquires an interest with knowledge that some other interest theretofore acquired will be defeated, or

"with knowledge that another person is also taking steps to effect registration in respect to the same property, he can hardly, under any circumstances, be otherwise than dishonest and fraudulent." 132

${ }^{129} 1$ W. W. R. 148.

${ }_{130}$ Man. 91; Sask. 162; Alta. 135; Dom. 167.

131 Thompson v. Finlay, 5 N. Z. L. R. S. C. 203.

${ }^{132}$ Hogg, Ownership and Encumbrance of Registered Land, page 151, quoted with approval in Independent Lumber Co. v. Gardiner, $3 \mathrm{~S}$. L. R' 140. 
In Hooper v. Smith, ante, page 153, the effect of notice was not decided. Tasker v. Carrigan, ante, is an extreme case of the effect of notice, and unless a finding of fraud, though nowhere mentioned, is to be implied, the decision seems to run contrary to the plain and unequivocal wording of the Acts and cases. The decision of the Supreme Court of Canada in Syndicat Lyonnais v. McGrade ${ }^{133}$ turned on the pleadings. The defendant Syndicat, registered owner, on the pleadings as they stood was necessarily taken to have admitted that the land was transferred by the defendant McConnell to his wife in fraud of creditors, and it was held by the Supreme Court of Canada that by the registered owner taking with knowledge of these facts, he made himself an abettor of the fraud. On the other hand, in Shaw v. Baily, ante, notice which would have been sufficient in a court of equity under the old law was held ineffective as against the registered owner. Independent Lumber Co. v. Gardiner, ante, adds little to the discussion of the subject, except the approval of the dictum already quoted, that it is difficult to understand how the taking with notice that another person is attempting to register an adverse interest can be otherwise than fraudulent.

Constructive fraud based on a presumption of knowledge of the law is insufficient. ${ }^{134}$

"The mere knowledge that a claim has been made which might or might not prove valid, but which the claimant has taken no steps to make good, is not fraud within the meaning of the section."

Mere notice of irregularities accompanied by a presumption of knowledge of the law is insufficient. ${ }^{136}$ In the Australian jurisdictions and New Zealand a very considerable number of cases are reported

13336 S. C. R. 251.

${ }^{134}$ Nicholson v. Bank of New Zealand, 12 N. Z. L. R. 427; Gregory $\mathbf{}$. Alger, 15 A. L. T. 22.

${ }^{135}$ George v. Aust. Mutual Provident Socicty, 4 N. Z. L. R. S. C. 165;

Kny v. Price and others, 24 N. Z. L. R. 291. 
dealing with the question of notice and fraud. It seems often hard to harmonize the decisions in the light of the facts, but it will be found that the same principle runs consistently throughout the decisions whatever may be the apparent conflict in the result. ${ }^{136}$ That principle is that fraud means actual moral fraud, moral turpitude, active dishonesty - not even passive dishonesty, if the term may be used, unless such amount to a wilful determination not to know the truth; and unless the notice in question, in any given set of facts, is such as to render the conduct of any party ignoring it fraudulent within the meaning of fraud so defined, it is unavailing.

Illustrative of the difficulty in harmonizing the eases it may be pointed out that in Hooper v. Smith, ${ }^{137}$ Gregory v. Alger, ante, in Victoria is set over against Locher v. Howlett ${ }^{138}$ in New Zealand as authority, the former against the latter, that "in the absence of fraud on the part of the holder of a certificate of title, his title will prevail over an unregistered interest, even though he had notice of such interest before he obtained the certificate of title." But while in the Victorian case the judges carefully explained that they found the conduct of the defendant, though exhibiting ignorance of the law, not fraudulent as above defined, on the other hand in the New Zealand case, it is evident that it was not intended to give effect to the knowledge of the mere existence of a trust. While, on the facts, the case reads like one of constructive notice, the problem which the judge set himself to solve in that case was:

"I now come to the defence raised by the defendant (ioteh under section 189 of The T'ransfer of Land alct 1885. It may be

136 "A decision that any particular facts amount to fraud, so as to satisfy one particular tribunal dealing with facts, camnot bind another like tribunal even though dealing with similar facts." Per Hood, J., in Gregory v. Alger, 15 A. L. T. 22 (Full Court Victoria).

1372 W. I. K. 194.

${ }^{138} 13$ N. Z. L. R. S. C. 584 . The italies in the quotation are mine. 
settled as the settled construction of this enactment that a purchaser is not affected by knowledge of the mere existence of a trust or unregistered interest, but that he is affected by knowledge that the trust is being broken or that the owner of the unregistered interest is being improperly deprived of it by the transfer under which the purchaser himself is taking. The question then is did the defendant Gotch know that Locher was being improperly deprived of his equitable interest."

Knowingly to "improperly deprive" a person of a rightful interest is surely actual fraud. The cases all turn on a finding of some such actual fraud. ${ }^{139}$

It is a question not free from difficulty how far the protection given to purchasers from the registered owner extends to purchasers claiming under unregistered instruments only, so long as those instruments are unregistered. The language of the section is very broad. Does it mean that a person purchasing, say, under contract from the registered owner, knows for a certainty that he can beyond a doubt compel that owner to convey the land to him upon payment of the purchase money provided in the agreement? It cannot mean that, for a purchaser the previous day may have acquired the same right, and as both cannot get the land the first in time will prevail. But assume, to cover this simple case, that the purchaser has filed his caveat on a clear certificate, can he then be absolutely certain of getting his land upon fulfilling the covenants of his agreement? If he can, the court may be confronted with enforcing a breach of trust. The court will enforce a breach of trust in favor of the holder of a registered interest, on the ground that they are enforcing a statutory right, ${ }^{140}$ but are they compelled by the statute to do so-for the court will not enforce a breach of trust unless compelled-in faror of an unregistered claimant?

139 See, also, Smith v. Essery, 9 X. Z. L. R. C. A. 449; In re Bygum,

13 N. Z. L. R. 270; Loudon v. Morrison, 14 N. Z. L. R. 245; Millard v. Coudrey, 14 N. Z. L. R. 12; Werrie v. WcKay, 16 N. Z. L. R. 124.

140 Fels v. Fnoules, 26 N. Z. I. R. C. A. 604. 
By a trust is meant here a trust in the popular sense - the interest of a cestui que trust as against an express trustee. The case of a prior purchaser which has been eliminated by the presumption of a caveat having been filed, was in a sense a case of trust but is the kind of trust of which the Privy Council in Assets Co. v. Mere Roihi ${ }^{141}$ said:

"But if the alleged cestui que trust is a rival elaimant, who can prove no trust apart from his own alleged ownership, it is plain that to treat him as a cestui que trust is to destroy all benefit from registration."

Assiume a case of real trust-say that the registered owner is trustee under a written instrument whereby he is to administer the land for the benefit of certain infant children. Will the court enforce his contract to the detriment of the infant children?

that:

In Cowell v. Stacey, in Victoria, Webb, J., held

"The principle of notice still exists as it did before the Act. Notice of an equitable interest in another given to a purchaser before he has completed his title by procuring a conveyanee was sufficient under the old law, and under the new law until a person has completed his title by getting his transfer registered he is just as amenable to notice." 142

And dealing with the similar section of the New Zealand Act the Court of Appeal said:

"We think, however, that this seetion must be read with sections 36,56 and 190 ; and so read it appears to us that only those elaiming under registered instruments can rely upon the statute in eases in which it proves that the title of those with whom they contract can be successfully impeached." 143

In Manitoba the same view was followed in Wallace v. Smart. ${ }^{144}$ There a purchaser under contract from a registered owner, apparently absolute, but who unknown to the purchaser at the time of

14174 L. J. P. C., at page 57.

14213 V. L. R. 80.

${ }^{143}$ Solicitor General v. Mere Tini, 17 N. Z. L. R. C. A. 773 . And also

Baker Creek Gold Mining Co. v. Hack, 15 N. S. W. L. R. Eq. 207;

Oertel v. Hordern, 2 S. R. (N. S. W.) Eq. 37; London Chartered Bank v. II ayes, 2 A. J. R. 60.

1419 W. L. R. 787 . 
purchase and payment of deposit was a mortgagee without power of sale, had a claim only to the extent of his deposit paid as against a judgment creditor of the beneficial owner, but had not a right to have his contract carried through.

On the other hand beginning again in South Australia, in Public Trustee v. Arthur, ${ }^{145}$ the court said that

"the application of the section is to be taken right down to registration from the initiation of the dealing."

In Manitoba, in Cooper v. Anderson, ${ }^{146}$

"The plaintiff's counsel contended that the contract was not completed, and cited English cases to show that notice to an intending purchaser, before completion, that equities existed in favor of third parties, was sufficient to intercept the contract, and prevent the intending purchaser from acquiring title." Robson, J., said:

"This argument is fraught with great possibilities. Carried to its legitimate extent, it means that, even after payment of the purchase money, perhaps to assignees, and up to the time of the registration of a transfer to them, the agreement held by the 'Trust Investment Company may, simply by notice of the supposed cquity of the plaintiff, be subject to be defeated thereby. That such a result is possible, at all events where The lieal Property Act is involved, is difficult, I must acknowledge, for me to magine. That many large transactions have no stronger foundation need hardly be said. In many cases, contract- have been made for sales again, in reliance on such agreements with the registered owner, supported by the usual caveat.

"It seems to me that sections 71 and 91 of the Act conclusively establish the right of the Trust Investment Company. Section 91 means nothing if it does not mean that an innocent person may safely contract or deal with a registered owner without inquiry. It certainly cannot mean that, though he need not inquire at the time of innocently contracting, yet, if he gets the notice later and before completion, his contract shall be affected, possibly nullified, thereby. In short, I take it that the contract is protected throughout, from its inception to its termination, by completion or otherwise. If the Act were meint to protect only such transactions as are specifically

${ }_{145} 25$ S. A. L. R. 59.

14620 W. L. R. 347. 
dealt with in the Act, e.g., actual transfers, mortgages, incumbrances, and leases, the words 'contracting or dealing with' would not be merely surplusage, but would be misleading."

And in Alberta, in Arnot and Smith v. Peterson, ${ }^{147}$ Beck, J., held that the purchaser from the registered owner, who was in reality a mere mortgagee, took priority to a prior purchaser from the beneficial owner by reason of section 135 . Whatever may be said of that decision in so far as it refer's to the priority gained by a caveat, need not affect the weight to be attached to the dictum of the learned judge that

"that section (135) refers not merely to a purchaser from the registered owner who gets a transfer and registers it, but to a person 'contracting or dealing with, or taking or proposing to take a transfer from the owners of any land for which a certificate of title has been granted." "

And in Fialkowski v. Fialkowski, ${ }^{148}$ Scott, J., in Alberta, had enforeed a mere equitable mortgage by deposit of certificate of title by the owner named in that certificate, who had obtained it by forgery, against the real owner.

The decision in Wallace v. Smart, ante, may perhaps turn on the fact that prior to notice of the adverse claim the registered owner had paid only a small deposit, and not a substantial payment on account of the purchase money. If so, it may be said without hesitation that the effect of the Canadian decisions is to round out the system by extending the protection granted to purchasers from the registered owner right down to the inception of the contract, for the reasons clearly stated by Robson, J., in Cooper v. Anderson, ante. 'This would undoubtedly bring the system into harmony with prevailing methods of dealing in land in Western Canada, and as against the advantage thereby gained would only

${ }^{147} 2$ W. W. R. 1.

1481 W. IV. R. 216. 
require that all cestuis que trustent of any description must resort to the caveat for their protection if they consider they require any.

\section{§ 18. THE EFFECT OF THE REGISTRATION OF AN IINSTRUMENT.}

a. Effect of Unregistered Instruments.

(1) REGISTERABLE INSTRUMENTS AS AGAINST UNREGISTERABLE INSTRUMENTS.

We have seen that apart from the question of statutory form, agreements and instruments inter partes generally confer the same rights as would instruments and agreements in equity, whether or not, with reference to land under the system, these rights be called an interest in the land. Thus, under the ordinary agreement for sale, the rights of parties to specific performance, rescission, cancellation and refund of moneys paid, are treated as identical, whether the land in question be under the system or not. But in regard to an instrument in statutory form, it is specifically provided in the Acts that its operation is by reason of registration. In the Australian case of Cuthbertson v. Swan, ${ }^{149}$ overruling Lange v. Ruwoldt, ${ }^{150}$ it was held that an equitable estate would pass by virtue of an ordinary written contract, notwithstanding that an instrument in statutory form would be ineffectual to pass any such estate until registration. This distinction has not, however, been followed either in the Australian or Canadian cases, but a statutory instrument, unregistered, is given the same efficacy as between the parties as any other instruments in passing an equitable interest. In McEllister v. Biggs, before the Privy Council,151 it was contended that the plaintiff who held under an unregistered transfer had no interest in the lands and could not bring an

14911 S. A. R. 102 . See ante, pages 119, 128.

1507 S. A. R. 1.

1518 A. C. 314 . 
action to set aside a certificate of title obtained by fraud. Their lordships were of opinion that:

"Although the deeds did not pass an interest in the land, still they passed to the plaintiffs the equitable right which Guthrie had to set aside the certificate of title to McEllister on the ground of fraud."

In Wilkie v. Jellett, ${ }^{152}$ three of the parties whose rights, obtained from the registered owner, were held to take precedence over those of the execution creditor, held under transfers which only required registration for their completion. One held under an agreement of sale. All the parties were treated as standing in exactly the same position. The transfer was treated as an agreement binding on the vendor. McGuire, J., in delivering judgment of the Territorial Full Court, said:

"There is in reality no difference between Erratt's case (Erratt held the contract for sale) and the others, except that they are $\mathrm{n}$ a position at once to apply their registered title, whereas Erratt must first procure a transfer and may possibly have to bring an action to compel the company to give him one."

In Tucker v. Armour, ${ }^{153}$ the plaintiff bringing an action to recover possession was the unregistered assignee of a registered lease and the objection that he had no standing was overruled on the authority of Wilkie v. Jellett. Referring to that case Newlands, J., said:

"There it was held that though the registered owner was the legal owner of the lands, he was the bare trustee for an unregistered transferee and that the courts would give effect to the title of the equitable owner."

And in full court it was held that

"the assignment though unregistered, transferred to the plaintiff all the interest of the original lessee." 154

In Shore v. Green, ${ }^{155}$ an unregistered lessee was held to have a status to bring an action for breach

16226 S. C. R. 282, affirming 2 Terr. L. R. 133.

${ }^{163} 6$ Terr L. R. 388.

tos 6 W L R. 93, at page 94

tos 6 Man. L. R. 322 . 
of the covenant for quiet enjoyment. The lease under which the action was brought was in this case a prior lease which had been defeated by the granting of a subsequent lease. It was pointed out that had the position arisen under common law, the first lease would have been effectual as against the lessor and anyone acquiring title from him subsequent to the demise. Such an interest, in the nature of an interest at law as distinguished from one in equity, which, as it were, inheres in the land and defeats a person subsequently acquiring an interest even for value and without notice, undoubtedly does not pass under the Acts without registration.

An unregistered registerable instrument confers in Manitoba the right to registration (section 90) and in the other jurisdictions is equiralent to an agreement binding on the vendor (Wilkie v. Jellett, supra). This is an equitable interest.

"The court of equity will treat the subject matter of a contract or agreement in the same manner as if the act thereby contemplated was already donc." 156

"Equity will treat the sulject matter, as to collateral consequences and neidents, in the same manner as if the final acts contemplated by the parties had been done exactly as they ought to have been." "157

These registerable and unregisterable instruments are alike treated as passing no interest in the land analogous to the legal estate or interest which could defeat a subsequent grant, but registerable and unregisterable instruments alike are treated as passing rights in such a way as to be indistinguishable from the equitable estate or interest of ordinary English law.

(2) UNREGISTERED NATRUMENTS AS BETWEEN THE PARTIES.

Generally speaking the Acts do not concern the relations between parties to unregistered instruments

166 Snell, Principles of Equity, page 19.

167 Halsbury, Laws of England, Vol. 13, page 73. 
where no competing rights arise. So far as they do the topic has necessarily been referred to fully in the discussions on the nature of the registered estate as against unregistered interests (ante page 152) and in the preceding paragraphs upon the distinction between registerable and unregisterable instruments. Such parties are treated as they would be in a court of equity.

(3) UNREGISTERED INSTRUMENTS AMONG THEMSELVES.

The position of the holders of unregistered interests as among themselves independently of the register, has not often been considered. Goddard v. Slingerland ${ }^{158}$ arose under section 74 of the British Columbia Act. ${ }^{159}$ Two owners of adjoining lots, both holding under agreement of sale, were in dispute as to rights under an alleged easement over one lot in favor of the other. The Full Court in British Columbia decided the case on the ground that neither party had any interest. McDonald, C. J. A., said:

"I think the sale and purchase agreements fall within section 74 of The Land Registry Act 1906, and as they were not registered at the time of the alleged wrongful acts, neither the plaintiff nor the defendant with respect to his or her complaints against the other had any interest at law or in equity in the properties in question. Each was in possession as purchaser under an unregistered agreement and in no other rapacity. *** Each was a stranger to the other in the legal sense,"

and Martin, J. A., said:

${ }^{158} 18$ W. L. R. 324.

${ }_{159}$ "No instrument * * * purporting to transfer, charge, deal with or affect land or any estate or interest therein (exeept a leasehold interest in possession for a term not exceeding three years) shall pass any estate or interest, either at law or in equity, in such land, until the same shall be registered in compliance with the provisions of this Act, but such instrument shall confer on the person benefited thereby, and on those claiming through or under him, whether by descent, purchase or otherwise, the right to apply to have the same registered. The provisions of this section shall not apply to assign ments of judgment." 
"In the face of that very unusual and positive enactment, the result of which is to declare that at the time of the matters complained of, neither of the parties had obtained any estate or interest at law or any equity under their similar agreements for sale from their common vendor, I confess I cannot see how the plaintiff is to succeed against the defendant who was and is an absolute stranger to him in the legal sense.

"In my opinion this court cannot recognize any right in the plaintiff to complain of interference with an easement appurtenant to property which the said section declares he had not 'any estate or interest in' at the time of such interference."

The beneficial owner in possession may maintain an action for damages for trespass on his property; and it is submitted that this decision, based as it is, not on any question of either party having a better equity than the other, carries the theory of no estate under unregistered instruments further than is justified by the decisions in those cases where creditors holding executions against registered owners were held not to have any claim on such land where, prior to the filing of the executions, the registered owners had disposed of the land by unregistered dispositions. ${ }^{160}$ If against such a person as an execution creditor, who does not rely on the register, an unregistered instrument creates sufficient interest in the land to defeat him, in principle there seems no reason why, as between two parties claiming under unregistered instruments but independently of the register, the Act should be called in to alter the ordinary principles of equity relating to such dealings. For example, if two adjoining owners, both claiming under bona fide agreements of sale from the respective registered owners, become involved in litigation to prevent the one injuring the land of the other by the flow of water from the land of the first

${ }^{160}$ Re Massey and Gibson, 7 Man. L. R. 172; Wilkie v. Jellett, 26 S. C. R. 282; Entuisle v. Lenz, 14 B. C. R. 51; Sauyer Massey v. Waddell, 6 Terr. L. R. 45; Yorkshire Guarantee \& Securities Co. v. Edmonds 7 B. C. R. 348. 
to the land of the second, there seems no reason why the Torrens Acts should be held in any way to interfere with or affect the rights of the parties.

b. Registration as Giving Operation to an Instrument.

(1) SPECIAL CLAUSES IN THE INSTRUMENT.

On this point a marked difference appear's between those instruments the indorsement of which continues on the existing certificate of title in the register, and those which result in the issue of and are merged in a new certificate of title. In a transfer or instrument of transmission the contents of the instrument drop out of consideration; but, on the other hand, a party dealing with land is treated as having knowledge of and being bound by the contents of a prior instrument indorsed on the existing certificate of title under which he claims. This raises the question of the effect of registration on the contents of an instrument. In Manitoba every registered instrument is "for the purposes of the Act deemed and taken to be embodied in the register as part and parcel thereof, and such instrument when so constructively embodied, shall thereupon create, transfer, surrender, or discharge, as the case may be, the lien, estate or interest therein mentioned in the land mentioned in the said instrument," 161 and registration must be taken to have a similar effect in the other jurisdictions. ${ }^{162}$ On examination of the forms of instruments prescribed-and only instruments complying with the statutory forms can be registered - it will be found that in the case of transfers or instruments of transmission, there is no place for personal or special covenants and the registrar is, by the Acts, specifically directed to ignore any notice of trusts, implied or constructive; while in the case of an instrument, memorandum of which is indorsed on the register without producing:

161 Man. 81.

162 Sask. 69; Alta. 41; Dom. 71. 
the issue of a new certificate of title, provision is made for special covenants. In the first case, how'vel, the instrument is given its complete statutory effect by the issue of a new certificate of title, but in the sccond case the question which arises is, what is the effect of registration on these special covenants? ${ }^{163}$ Does it give them any special efficacy or opcration? That these special covenants may in some way be said to be "registered" is evident from the care with which any improper covenant is kept off the register. An agreement, contained in an incumbrance, to give an ordinary mortgage, was not allowed to be read as a "special covenant" in $R e$ Rumely Co. and Registrar of Sasliatoon L.R.D. ${ }^{164}$ In a New Zealand case where in a mortgage of a leasehold to a brewer, a covenant was inserted that the mortgagor" would "at all times during the continuance of the term of years granted in the memorandum of lease" purchase from the mortgagee all ale, stout, ete., used upon the prenises, this covenant, on the ordinary principles governing mortgages, was held void, and Richmond, J., the trial judge, and Connolly, $J$, in the Court of Appeal, which confirmed the trial judge, Fere both of opinion that the district land registrar ought to refuse to register as a mortgage an instrument containing such a provision. ${ }^{165}$ But in no reported case can authority be found to the effect that upon the registration of an instrument containing special corenants or any clause granting any special rights or powers under the instrument, any rability is given to such clauses analogous to the effect given to the instrument itself by registration; or; to state the question in another way, it

${ }^{153}$ In Simith v. Nutional Trust Co., $1 \mathrm{~W}$. W. R., Idington, J., in his dissenting judguent, at page 1138 , expresses the opinion that a mortgagee arrquires an "indefeasible title" to all the powers contained in a regisarererl nortegere.

$16117 \mathrm{~W}$. L. R. 160.

105 Sitrples r. Hackay, 11 N.Z. L. R. S. C. 258 ; affirmed 11 N.Z. I. R. C. A. 271. 
does not appear that the whole contents of an instrument come within the operation of the sections enacting that instruments "take effect" upon registration $^{166}$ so as to result in registration giving validity and binding effect to such covenants in favor of the covenantee, defeasible only on the grounds of fraud or grounds similar to those upon which a certificate of title may be set aside. The cases cited wherein instruments containing certain objectionable clauses were forbidden, or where stated should have been forbidden registration, would seem to indicate that had they been registered some such special effect would have been given, to those clauses. But covenants and powers in a mortgage have frequently been held nugatory. ${ }^{167}$ The registrar's duty cannot well be said to consist in keeping his register as free as possible from objectionable instruments which, however, if they do get on, can give no special effect and therefore do no damage. In St. Germain v. Reneaulitis an option given by an executor of which under the ordinary law a court of equity would not compel specific performance, was held not to have acquired any greater validity because contained in a registered lease. In similar circumstances the Full Court of New Zealand has held that such an option in a registered lease can be enforced. In the latter case Edwards, J., delivering the majority judgment of the full court, divided four to one, said:

"The right to purchase is an integral part of the lease and registration of the lease is registration of every right given by it. The court is not enforcing a breach of trust but an indefeasible legal right lawfully created in the plaintiffs." ${ }^{169}$

166 Man. 81; Sask. 69; Alta. 41; Dom. 71.

${ }^{167}$ Smith v. National 'Trust Co., 1 W. W. R. 1122; Staples v. Mackay, 11 N. Z. L. R. C. A. 271; In re Burton, 27 V. L. R. 437.

1682 A. J. R. 371 .

${ }^{169}$ Fels v. Knowles, 26 N. Z. L. R. C. A. 604; followed and approved IIorne v. IIorne, 26 N. Z. L. R. C. A. 1208. 
It is apparent, however, that for the reason suggested in the quotation just given, power to grant such option being one specially provided for by the statutes, ${ }^{170}$ this clause may be distinguished from the case of a special covenant pure and simple, not referable to any of the provisions of the Acts. It would certainly seem to be giving extraordinary efficacy to a proceeding effected by the registrar, usually without hearing either party, and, indeed, usually in practice by an examining clerk in the office, if it were to be held to give any special validity to covenants and powers spread on the face of the instruments and open to inspection by all parties interested, continuing embodied in the register so long as it is the intention to give them any force, that is to say, unless released or discharged. The registrar, it is submitted, is not concerned what mere personal covenants are allowed in. They take their chance as under the ordinary law. What he must guard against is an attempt to create estates or interests in the land differing from that created by the instrument being registered.

(2) IRREGULARITIES IN THE REGISTRATION OF THE INSTRUMENT.

The decisions and dicta on this point cannot be said to be either conclusive or consistent. The instrument does not take effect under the Act until registration, but upon registration it creates, transfers, surrenders, charges or discharges, as the case may be, the land or lien, estate or interest therein mentioned. In Manitoba an instrument is deemed to be registered as soon as a memorial thereof indorsed thereon shall have been signed and sealed by the district registrar (section 65), and a certificate to that effect on the instrument is conclusive evidence that such instrument was duly registered (section 82). In the other jurisdictions an instrument is 170 Sask. 81 (3); Alta. 51; Dom. 88 (2). 
deemed to be registered as soon as the memorandum of it has been entered in the register upon the folio constituted by the existing certificate of title of such land, ${ }^{171}$ and a memorandum on the duplicate certificate of title to that effect shall be received in all courts of law as conclusive evidence that the instrument of which it is a memorandum has been duly registered under the provisions of the Act. ${ }^{172}$ From these sections it prima facie appears that when the act of registration as defined by the Acts is actually effected, the registration has accomplished its results, and at least as against parties relying on the registration, the result is what they look to, not the action producing the result, and therefore technical irregularities in the registration, as they do not fall under any of the substantive grounds whereby registrations are invalidated as against third parties, would not have any result in vitiating the registration. If more were required the statutes provide that:

"No petition, order, affidavit, certificate, registration or other proceeding under this Act, shall be invalid by reason of any informality or technical irregularity therein or of any mistake not affecting the substantial justice of the proceeding."

Consistently with this view, in a Victorian case where in an action for trespass the defendant claimed under a registered grant of right of way executed under power of attorney, which power of attorney, it was admitted, did not authorize the creation of such a right of way by the attorney, the full court held that on registration the right of way passed to the defendant. The court said:

"We are of opinion that this instrument purporting to transfer and grant an incorporeal hereditament, is an instrument purporting to affect land under the operation of the Act, within the meaning of the Act, and that uron registration of the said instrument in the manner preseribed by section 36

171 Sask. 37 ; Alta. 22; Dom. 45.

172 Sask. 40; Alta. 25; Dom. 48. 
and in the absence of fraud, the defendant Peter Donald became, by authority of sections 36 and 49, the duly registered proprietor under the Act of the easement or right of way mentioned in the instrument, and entitled to exercise the rights of such registered proprietor." 173

Syndicat Lyonnais v. McGrade $e^{174}$ supports the view that registration gives operation to an instrument even though the registration itself be improper. In that case a lis pendens had been filed claiming that a prior transfer made to the then registered owner was a fraud on creditors under 13 Eliz. c. 5. Subsequent to the filing of the lis pendens, a transfer for valuable consideration was registered in favor of the Srrndicat. The trial judge held that the law and practice of the Yukon Territory did not authorize the filing of a notice of lis pendens, that the purchaser for valuable consideration with notice under such cireumstances ras subject to have his contract roided, but that notice having reached the Syndicat through a defective or irregular document, it was not an effectual notice and could not bind the parties. The Full Court of the Iukon reversed that judgment and the Supreme Court of Canada upheld the Full Court of the Iukon. Nesbitt, J., delivering the judgment of three out of fire of the judges, said:

"I do not think that the registrar had any right to register the lis pondens, nor do I think the form of certificate issued by hin could have the effect of eutting down the effect of section $126 . " 115$

Nevertheless, the Supreme Court held that the conveyance to the syndicat was void as being taken with knowledge of the fraud and therefore aiding and abetting it, although it appeared there was no eviclence whatsoever of any notice on the part of the Syndicat except that conveyed to them by this lis pendens. The conclusiveness of the decision, however, on this point is greatly reduced by the fact

173. Magor r. Donald, 13.T. L. R. 255.

$1{ }^{14} 36$ s.s. C. R. 251.

${ }^{175}$ For section 126 of the Land Titles Act, 1894, see Alta. 135. 
that the Supreme Court found that having such notice, to allow the Syndicat to retain its title would have been an actual fraud within the rules laid down in Assets Co. v. Mere Roihi, and to hold their title good would have been to make an Act of Parliament an instrument of fraud, which the courts will not do. In Otis v. Weidmarliti the registration of a seed grain lien against land did not prevent a vendor showing that the registration was improper, and thereby defeating the claim of a purchaser, who had paid the lien, for reimbursement under the heading of money paid on account of the vendor. Lamont, J., said:

"I am of opinion that registration of the lien against the title of the said land was without authority and was therefore of no validity as a lien."

In the Full Court of New Zealand, in Horne v. Horne, ${ }^{177}$ the registration against land under the system of a lease covering land both under The Land Transfer Act and under the general law was held to show on its face that it was improperly registered and therefore conveyed no interest.

The cases cited refer more particularly to irregularities going further than mere technical irregularities. In regard to this latter, the language of the validating sections previously quoted ${ }^{178}$ is very broad. Even under the Registry Acts where registration is not the creation of an interest but is merely the giving of notice, and under which formerly unless such notice was giren in strict compliance with the provisions of the Act it was held to be invalid, ${ }^{179}$ the rule has become much less stringent. In Rooker v. Hoofstetter, ${ }^{180}$ there was an irregular

${ }^{176} 1 \mathrm{WV} . \mathrm{W} . \mathrm{R} .382$.

17726 N. Z. L. R, C. A. 1208 .

${ }_{178}$ Man. 156; Sask. 184; Alta. 142; Dom. 190.

${ }^{179}$ e. g. Renwick v. Berryman, 3 Man. I. R. 387, where the registration was held invalid beeause the occupation of the witness in the affidavit of execution was omitted.

10026 S. C. R. 41. 
affidavit of exceution. Gwynne, J., delivering the majority judgment of the court and speaking of the Registry Act in Ontario, said:

"The object of the statute is to make every purchaser of an interest in land, in order to establish his own security, search the register of titles established by law. If he does so and finds a document in point of fact upon the register relating to the lands he is about to acquire an interest in, he seems to me to acquire thereby actual notice of such document by which he must be bound, although he may discover some informality in the mode of proof which may have escaped the notice of the registrar."

And

"He must accept the effect of registration as equivalent to notice unless at least the objection taken constitutes an absolute defect in the proceeding, as for example, the absence of an affidavit of execution would perhaps ${ }^{181}$ have to be held to be a defect constituting nullity of registration."

Analogies are somewhat difficult to find. There are other statutes where registration or the lack of it makes the instrument sometimes void, sometimes voidable, as for example the English Bills of Sales Act. These are not statutes under which registration is an act of an official which in itself gives operation to the instrument in such a way that a party looking to the register is not concerned with the steps up to registration but with the effect of registration. In the English Bills of Sales Act, for example, an affidavit filed on registration must contain a description of the residence and occupation of the grantor and of every attesting witness of the bill of sale in order that the creditors and others may make inquiries before dealing with the grantor; ${ }^{182}$ but where the registration is the important point as giving operative effect, not merely notice, it is submitted that no registration should be invalid, unless, at least, by reason of such an apparent irregularity

181 The italies are mine.

${ }^{152}$ Halsbury, Laws of England, Vol. 3, page 48. 
as must necessarily force itself upon the attention of every person acting on the faith of such registration.

The foregoing discussion applies particularly to instruments which create, transfer, surrender, charge or discharge an estate or interest. One very important class of instruments is not dealt with, that is to say, caveats. These do not come under the provisions of the sections referred to. ${ }^{183}$ The irregularities in caveats for which they have been held invalid have already been fully discussed. ${ }^{184}$ It is perhaps, however, not going too far to say that the tendency of the courts is to exercise growing care not to take away substantial rights by reason of merely technical defects not affecting the substantial justice of the proceedings, even in regard to caveats.

\section{(3) FORGERY.}

Forgery has been referred to (page 168). The registered transferee or mortgagee, even though bona fide and for value, obtains no rights under a forged transfer or mortgage.

"The protection which the statute gives to persons transacting on the faith of the register, is by its terms limited to those who aetually deal with and derive rights from a proprietor whose name is upon the register. Those who deal, not with the registered proprietor, but with a forger who uses his name, do not transaet on the faith of the register; and they eannot by registration of a forged deed acquire a valid title in their own person, although the fact of their being registered will enable them to pass a valid title to third parties who purehase from them in good faith and for onerous consideration." 185

There is a passage in the decision of Assets Co. v. Mere Roihi which scems to throw some doubt on the foregoing statement of the law. Speaking of the

${ }^{183}$ Schultz v. Archibald, 8 Man. L. R. 284; Martin v. Morden, 9 Man. I. R. 565 .

134 See page 78 .

${ }^{135}$ Gibbs v. Messer, (1891) A. C. 248, at page 255; Attorney General v. Odell, (1906) 2 Ch. 47. 
fraud "which must be proved in order to invalidate the title of a registered purchaser for value" their lordships said:

"A person who presents for registration a document which is forged or has been fraudulently or improperly obtained, is not guilty of fraud if he honestly believes it to be a genuine document which could be properly acted upon."186

Certificates of title issued immediately on forged documents have been held to be unimpeachable where taken in good faith ${ }^{187}$ and again to confer no title. ${ }^{188}$ Gibbs v. Messer has settled the law in favor of the latter view, and so far as the passage quoted from Assets Co. v. Mere Roihi appears to be opposed to Gibbs v. Messer, it may be pointed out that that passage, so far as it refers to fraud, is a mere dictum and subsequently in the same decision, their lordships pointed out that "forgery is more than fraud."

It has never been disputed, however, that while a certificate of title issued on a forgery may not be good in favor of the owner through the forgery, even though bona fide and for value, the real person holding such certificate of title may pass a good title to a third person, and, apparently, even the person acquiring an interest through an unregistered dealing is entitled to treat his grantor's certificate of title as unimpeachable. ${ }^{189}$

\section{(4) OPERATION AGAINST EXECUTION CREDITORS AND ASSIGNEE FOR THE BENEFIT OF CREDITORS.}

Registration does not give a registered execution or judgment creditor priority over an unregistered equitable interest; ${ }^{190}$ nor over an assignment for the

18674 L. J. P. C., at page 60.

187 Coleman and Clark v. Riria Puwhanga, + N. Z. L. R. S. C. 230; O'Connor v. O'Connor, 9 A. L. T. 117 (Vict.); Bailey r. Cribb, 2 Q. L. J. 42.

${ }^{188}$ Ex parte Davy, 6 N. Z. I. R. C. A. 760.

${ }^{189}$ Fialkowski v. Fialkousti, 1 IV. W. R. 216, 19 IV. L. R. 644.

190 See pages 179 and 265. 
general benefit of creditors. ${ }^{191}$ Neither is registration notice to all the world. A mortgagee may make further advances as provided by his mortgage without being affected by the subsequent registration of another mortgage, unless he had actual notice thereof, as distinguished from any constructive notice by reason of registration. ${ }^{192} \mathrm{~A}$ mortgagor may make his payments to the mortgagee safely, notwithstanding the registration of an assignment of the mortgage unless he has had actual notice of the assignment ${ }^{193}$ and a purchaser having registered his contract (in British Columbia) may make payments thereon to his vendor without being affected by intervening registrations, ${ }^{194}$ and it is submitted that the same rules would hold in other jurisdictions after the filing of a caveat.

${ }^{191}$ Westfall v. Stewart and Griffith, 13 B. C. R. 111.

192 Queensland Trustees Ltd. v. Registrar of Titles, 5 Q. L. J. 46 . And compare under the Registry Act of Ontario, Pierce v. Canada Permanent L. and S. Co., 25 O. R. 671, 23 O. A. R. 516.

${ }^{193}$ Nioa v. Bell, 27 V. L. R. 82.

194 Peck v. Sun Life Assurance Co., 11 B. C. R. 215 ; 1 W. L. R. 302. 


\section{CHAPTER VI}

REMEDIES FOR THE RECOVERY OF LAND

\section{§ 19. SUMMARY OF CASES IN WHICH LAND MAY BE} RECOVERED.

§20. WHERE OWNER IS DEPRIVED OF LAND BY FRAUD.

\$21. WHERE OWNER IS DEPRIVED OF LAND BY MISDESCRIPTION.

§ 22. WHERE REGISTERED OWNER CLAIMS UNDER INSTRUMENT OF TITLE PRIOR IN DATE.

§ 23. WHERE PERSONS CLAIM UNDER RIGHTS ARISING AFTER DATE OF CERTIFICATE OF TITLE OF REGISTERED OWNER.

\$24. WHERE THERE HAS BEEN MANIFEST ERROR.

\section{\$ 19. SUMMARY OF CASES IN WHICH LAND MAY BE RECOVERED.}

The preceding chapter dealing with the conclusivencss of a certificate of title, suggests a chapter summarizing the cireumstances under which an action of "ejectment or other action for the recovery of any land" may be brought against a registered owner. As the only estate in land is a registered estate, such an action is tantamount to an action to set asicle the existing certificate of title and issue a new one in the name of the plaintiff. The matter may, perhaps, be most satisfactorily approached by an annotation on section 76 of the Manitoba Act ${ }^{1}$ prescribing the cascs, which are more or less seattered through the other Acts.

The cases in which land may be recovered are:

(1) The case of a mortgagee or incumbrancee against a mortgagor or incumbrancer in default.

${ }^{1}$ Compare Sask. 130; Alta. 101; Dom. 112. 
(2) The case of a lessor as against a lessee in default.

(3) The case of a person deprived of any land by fraud as against a person registered as owner through fraud or as against a person deriving his right or title otherwise than bona fide for value from or through a person so registered through fraud.

(4) The case of a person deprived of any land included in any certificate of title of other land by misdescription of such other land or its boundaries, as against the owner of such other land.

(5) The case of a registered owner claiming under the instrument of title prior in date of registration under the provisions of this Act in any case in which (two or more grants or) two or more certificates of title may be issued under the provisions of the Acts in respect of the same land.

(6) Where persons claim under rights arising after date of certificate of title of registered owner.

(7) The case of the inherent rights or exceptions to which a certificate of title is impliedly subject without special mention therein, to the extent of such rights.

(8) Cases of manifest error.

\section{§20. WHERE OWNER IS DEPRIVED OF LAND BY FRAUD.}

A person deprived of any land by fraud may recover it as against a person registered as owner through fraud or as against a person deriving his right or title otherwise than bona fide for value from or through a person so registered through fraud. The meaning of fraud, under the Acts, has been discussed in the preceding chapter, as also the effect of this subsection in letting in all those equities to defeat which would, under the circumstances of each particular case, be fraud. This subsection also shows that although the volunteer may in some circumstances be entitled to rely on a certificate of 
title as fully as a bome fide purchaser for value, nevertheless the position of the volunteer is in one important easc inferior to that of the boma fide transferee for value, that is to siy, if the holder of the certifieate of title from whom the rolunteer took, was himselt the owner through fratud, the voluntere is in no betfer position, while in such ease upon the basie prineiple of the Act, the owner through fraud would be alble to eonfer upon a boma fide purchasel for value a better title thatn he himself had.

\section{\$ 21. WHERE OWNER IS DEPRIVED OF LAND BY MISDESCRIPTION.}

In Manitoba. but not in the other jurisdictions, a porson deprived of any land included in any certifieate of title of other land hy misdescription of such ofher land or its boundaries, has no right of recovery andinst the owner if the owner is the transferee of such other land or deriving from or through the transferes thereof boma fide for value. In Satiomal Trusteses r. Herestl." by an error in the survey, land under the general law, owned and ocempied by 13, was included in a ecetificate of title issucel to $i$. It was held that $A$ did not thereby acquire any estate or intrerst in such land. It was pointed ont that where the same piece of land is included in two ecrtiticates, ordinarily the prior certifieate is eonchusire, but this is not so where the land has been included in the prior certificate through a wong description of boundaries.

The deseription of a section of land which does not follow the original survey pess is a misdeseription. In husell v. Muller, in Now Zealand," Stout, ('. J., silid:

"I am of opinion that the original survey pegs must be follewed. I have alleaty dealt with this matter in the ease of Heore v. Dentice, 20 X. \%. 1.. R. 12s, and in that decision previous decisions of the supreme Court were followed. What

$=(10(0))$ Y. . L. R. 40.4 .

3.5 x. 2. L. li. 25 . 
the land transfer certificates in this case purport to give are seetions of land, and these sections are marked out on the ground by the surveyor hy proper survey pegs, and the measurements given in the land transfer certificates are all said to 'be the same, a little more or less.' 'The variations between the eertifieate measurements and the measurements on the land may come within that phrase. To hold that a person who enters and takes possession by the survey pegs is not entitled to hold that possession, but only to hold possession of what the land transfer eertificate ealls the section, not what the survey pegs mark it out to $b e^{2}$, would be to introduce confusion into all the surveys of the colony. In fact section 423 is the section that the surveyor surveyed and pegered. 'To follow the land transfer eertificate would be to give the owner of section 421 part of that portion of land which the surveyor inclucled in section 423 in his survoy."

The meaning of misdescription was considered in a New South Wales case, ${ }^{4}$ where it was held that:

"There is no 'wrong description of parecels or of houndaries' within the meaning of section 42, subsection (c), of The Real Property Act 1900, where the description in the application for the certificate and in the certificate of title includes only the tand in respeet of which the applieation was intended to be made. Wrong description is where an applicant intending to deseribe Blackacre, describes Whiteacere, or so deseribes blackacre as to make it inelucke Whitcacre. It is not wrong description where the applicant correctly deseribes the land he is applying for, though the land is not his. It is then a case of no title and the efficacy of the certilieate of title depends upon the bona fides of the applicant."

An unreported decision of Stuart, J., in Alberta, ${ }^{5}$ exhibits the working of the rule. In that case there was a grant to the predecessor of the plaintiff of that part of the south half of a certain section lying west of the Bow River, as shown on Deville's plan, containing a specified number of acres, and another grant to the predecessor in title of the defendant of that part of the same south half lying cast of the Bow River, according to Deville's plan, containing a specified number of acres. As a matter of fact,

- Iamillon v. Iredale, 3. S. R. (N.S.W.) 53.5.

'Ilextall v. P'. Burns and Son and Denton, Sept. 23, 1911. 
Deville's plan was incorrect. The Bow River ran much further east than shown on it and there were about 40 acres more west of it than as mentioned in the plaintiff's grant and shown on Deville's plan, and the corresponding amount less lying east of the Bow River than as shown on the plan and mentioned in the grant. The Bow River was taken as the correct boundary and the certificates were amended, giving the plaintiff the additional acreage.

The exception in favor of a bona fide transferee is also contained in most of the Australian and New Zealand statutes in the same way as it appears in the Manitoba statutes.

\section{\$22. WHERE REGISTERED OWNER CLAIMS UNDER INSTRUMENT OF TITLE PRIOR IN DATE.}

In any case in which (two or more grants or) two or more certificates of title may be issued under the Acts in respect of the same land, the prior certificate as defined in the Acts ${ }^{6}$ prevails. Such duplicate grants in practice are not infrequently issued. If the index books of the registry offices are carefully kept, the issue of duplicate certificates of title will be guarded against, but through mistakes of one sort or another, such as the omission to cancel a certificate of title of which the owner has executed a transfer, or otherwise, it sometimes happens that there are two existing certificates of title for the same piece of land.

\section{§ 23. WHERE PERSONS CLAIM UNDER RIGHTS ARIS- ING AFTER DATE OF CERTIFICATE OF TITLE OF REGISTERED OWNER.}

We have already seen that the intention of the Acts is to assure to a party a good title, but having done that, it was never intended to totally abolish all transactions touching land otherwise than by the register. It was never intended that a registered

'Man. 72; Sask. 3; Nlta. 42; Dom. 3. 
owner by exhibiting certificate of title from time to time, could defeat all claims arising against himself.

"But although The Transfer of Land Act, for the preservation of the simplicity of its scheme, excludes the registration or recognition of trusts in such scheme, it nowhere indicates any such revolutionary intention as to abolish rights under trusts, and this court has always recognized and insisted that persons legally in the position of trustees, though they do and must appear on the register as the representatives of the legal estate in land untrammelled by a declared trust on the register, must nevertheless execute the trust of which they are trustees as the court directs according to the trust, and so the scheme of the Act and the law of trusts travel smoothly side by side." 7

And the same holds with regard to contracts of sale or other unregistered dispositions made by the registered owner as against himself and also with regard to statutory rights acquired against a registered owner.

\section{§24. WHERE THERE HAS BEEN MANIFEST ERROR.}

A further case implied but not specifically mentioned is that of manifest error where by mistake parties improperly appear on the register as entitled to certain rights or priorities. The registrar has certain powers of colrection. ${ }^{8}$ In all the Acts, the registrar, if it appear that any certificate or other instrument has been registered in error or contains any misdescription, or that any entry has been made in error ${ }^{9}$ or that the duplicate certificate has been fraudulently or wrongfully obtained or retained, may, in Manitoba, summons, in the other jurisdictions serve demand, requiring the person in whose possession such certificate is to deliver it up to be cancelled or altered. ${ }^{10}$ In Manitoba, ${ }^{102}$ it is

${ }^{7}$ Rowe v. Equity Trustees and Executors, 21 V. I. R. 762 (full court), Madden, C J., at page 775 .

${ }^{8}$ Re Smilh, 8 W. L. R. 131.

- Including mistake of law as well as mistake of fact. Ex parte Bomel T.V.T.R. 458.

${ }^{10}$ Man. 49 (b) (d); Sask. 148; Alta. 114; Dom. 154.

$10_{a}$ C'f. Alta. $114(2)$. 
provided that if such certificate be in his custody or be delivered up on such summons, the registrar may so far as practicable without prejudicing rights conferred for value cancel or correct any error in such certificate (section 49d). Such a power though not specifically granted in the other Acts is to be presumed. ${ }^{11}$ The mere possession, however, of the certificate of title in Saskatchewan, impounded under section 90 , does not give the registrar jurisdiction to treat that certificate as in his possession for cancellation or amendment, at least where the registered owners in response to the demand make objection. ${ }^{12}$ But the registrar should only alter or amend in the clearest cases. Unless the erroneous certificate or instrument is delivered up the registrar is powerless and must apply ${ }^{13}$ to a judge in chambers, in Manitoba by notice of motion, in the other jurisdictions for a summons, calling on the holder of the erroneous certificate or instrument to deliver it up. Upon the appearance before the judge of the person notified or summonsed, either voluntarily in response thereto, or brought up on warrant in case of neglect, the judge examines such person on oath, and, if it appear right to do so, may order such person to deliver up such certificate or instrument. In such proceedings. however. the judge applies the usual rule that in chamber applications he will not decide important questions of law or complicated and contested issues of fact. ${ }^{14}$ In case the person so before the judge is ordered to and does deliver up the certificate or instrument, the registrar's implied power of correction again comes into play, but if such person has absconded or cannot be served, or goes to jail in preference to delivering up the document in his

"Re Smith, supra.

12 Re Standard Trust's Transfer, Master of Titles, Sask., 13th Feb., 1912.

${ }^{13}$ Man. 51, 52; Sask. 148, 149; Alta. 114, 115; Dom. 153, 154.

${ }^{14}$ In re Buchanan, 12 Man. L. R. 612; In re Macarthy and Collins, 19 N. Z. L. R. 545; In re Banjamin, 2 N. Z. Jur. N. S. 163; Manahi v. District Land Registrar, 29 N. Z. L. R. 130. 
possession, or, in the jurisdictions other than Manitoba, does not respond to the demand inside of three months, the judge may make the necessary order cancelling or amending the certificate or instrument.

Aside from this statutory proceeding for correction of the register, which, while on its face is very wide, in practice, owing to the rule of construction quoted, is of little value except in uncontested cases, and easily balked, the ordinary remedy for recovery of the land is by ordinary action, based on one or more of the cases set out in this chapter, the action being for rectification of the register, and if desired in addition, possession of the land. In such action the judge may by decree or order

"direct the registrar to cancel, correct, substitute or issue any certificate of title or make any indorsement or entry on any instrument or otherwise to do every such act and make every such entry as may be necessary to give effect to the judgment, decree or order of the court." is

The registrar need not be a party to the action, ${ }^{16}$ thereby differing from the Australian practice, where it is customary to correct the register by ordering the parties on the register to execute the necessary transfers, or, if not, the registrar must be a party. ${ }^{17}$

The alternative rights to damages, where by reason of the provisions of the Acts the remedies for the recovery of the land itself are barred, will be considered in the next chapter.

${ }^{15}$ Man 52. Cf. Sask. 150; Alta. 116; Dom. 156.

${ }^{16}$ Beere v. Northern Crown Bank, 7 W. L. R. 432. The same rule is followed in all jurisdictions.

เ7 Ogle v. Aedy, 13 V. L. R. 461; In re Allen, 22 V. L. R. 24. See ante, page 149. 


\section{CHAP'TER VII}

THE ASSURANCE FUND

\section{$\S 25$. NATURE OF THE FUND.}

$\S 26$. SOURCES OF THE FUND.

$\$ 27$. LIABILITIES OF THE FUND.

a. Introduction.

b. Liability of Assurance Fund in Saskatchewan, Alberta and the Territories.

(1) IN GENERAL.

(2) INDIRECT LIABILITY OF FUND.

(a) Ground of Liability.

(b) Against Whom Iction for Damages may be Brought.

(c) When Assurance Fund is Liable.

(d) When Assurance Fund is Not Liable.

(3) DIRECT LIABILITY OF FUND.

c. Liability of Assurance Fund in Manitoba.

\section{NATURE OF THE FUND.}

The assurance fund is the special fund created under the Torrens system for the compensation of certain persons for losses sustained by operations under the system. If the person rightfully entitled to any interest in land has lost it owing to another person having obtained a registered interest, which is, as against the rightful owner, indefeasible, provision is made for pecuniary compensation by way of damages, being in certain cases made payable to the person so deprived of his property. The creation of such a fund is often said to be, but is not necessarily, essential. There is no such fund in the Fiji Ordinance 1876 , nor in the English Act of 1875 , nor as to "absolute" fees in British Columbia, but the doctrine of the indefeasibility of a registered title, and the policy of protecting the bona fide purchaser for value from a registered owner, in some 
cases must divest estates and interests from innocent persons, and work hardship in the operation of the system, and the indemnity or assurance fund is necessary to round out the system, although it may be carried on without such a fund. The reason, indeed, for the creation of such a fund is obvious. The act of registration is the operative act, and the transfer and vesting of the title is effected, not by the execution of an instrument of transfer, not by the act of the owner of the land, not by the transfer of a valid title from the transferor, but by the state acting through its officer, the registrar; and because it transfers and vests the title by the issue of a certificate which is declared by statute to be conclusive evidence of an indefeasible title to the land, the state creates a fund for the compensation of such persons as may be injured by the divesting and cutting off of rights and interests under this statutory declaration. The purpose of the Acts is twofold: to give certainty to the title to estates in land by registering a title after it has been examined into and established by proofs which are deemed to be requisite by the registrar, and also to facilitate the proof of titles and the tronsfer thereof by issuing to the owner a certificate which is conclusive evidence of the ownership and character of the title as registered, except in certain specified cases. No action of ejectment or other action for the recovery of the land shall lie or be sustained against the registered owner except in certain specified cases mentioned in the preceding ehapter, and except in these cases the production of a certificate of title is made an absolute bar to any such action, any rule of law or equity to the contrary notwithstanding. The legislatures foresaw that, in some instances, the creation of an indefeasible title in the registered owner might occasion hardship, for, despite every precaution, mistakes might be made in passing such a title, and, 
as ancillary to the scheme, they provided that in certain cases, such as fraud, error or misdescription, a right of action should accrue to injured persons against persons causing the injury, or against the fund directly, and that an assurance fund should be created, out of which in certain cases, either in the first instance or in default of obtaining satisfaction from the person primarily liable, compensation should be made to those who might suffer loss by the divesting of estates and interests under the operation of the Acts. The fund is intended to relieve innocent persons suffering loss by reason of the fact that the certificate is a conclusive evidence of an indefeasible title to land, and from any injustice which may arise to them by operations under the Act, making for the conclusiveness of a certificate, whether such injustice arise from the fraud or error of someone connected with the registry office, or of some third person dealing with the land. It is not intended to relieve from the legal consequences of his act any third person who perpetrates a fraud or commits an error, nor is it intended, except in Manitoba, to relieve a person who is injured by operations under the system from the burden of first prosecuting the remedies given to him by the general laws or by the Act establishing the system.

"The statutes give a right of action to any person deprived of an interest in land through the bringing of such land under the provisions of the Act. The remedy is a statutory remedy. It is to be worked out by an action, not against individuals competing for possession of land, but against a fund specially provided by a system of insurance in order to compensate persons who, without any fault of their own, may have been deprived of their property in the course of carrying out a new scheme."

It might be well to note that, while in common parlance, the system of titles created under the Torrens Acts is often called a system of "guaranteed

${ }^{1}$ Williams v. Papworth, (1900) A. C. 563; 69 L. J. P. C. 129. 
titles," this must be carefully distinguished from the system of guaranteed titles which, owing to the necessity of the case, is growing in favor in the United States. Under that system a title guaranty company issues a "title insurance" policy, in consideration of a certain sum, and gives a certificate of the standing of title in question at the time of the certificate. Payment is made to the holder thereof when it is determined that he is not seized of some interest or estate in land with respect to which he was guaranteed or insured. Under the Torrens system, the holder of a certificate of title, except as to the statutory exceptions, needs no guaranty or insurance because it is declared by statute to be, and therefore is, conclusive evidence of title. Speaking generally, where under the American system the opposing party would get the interest in land and the holder of the guaranteed certificate of title would get his claim against the guaranty company, under the Torrens system the holder of the certificate of title keeps the interest in land and the opposing party has his claim against the assurance fund.

\section{\$26. SOURCES OF THE FUND.}

In Manitoba the fund is constituted by a levy of one-tenth of one per cent. upon the first bringing of the land under the new system in the case of an original grantee where no transaction or instrument affecting the land has been registered except mortgages or leases, but in other cases one-fourth of one per cent. of the value thereof."

In Saskatchewan, Alberta and the Dominion, ${ }^{3}$ the fund is constituted by a levy upon the registration of every grant of incumbered land and upon every absolute transfer of land of one-fifth of one per cent. of the value of the land transferred if such value is five thousand dollars or under, and one-tenth of

${ }^{2}$ Man. 154.

${ }^{3}$ Sask. 151-154; Alta. 117-120; Dom. 157-160. 
one per cent. when such value exceeds five thousand dollars; and upon every subsequent transfer there shall be paid upon the increase of value since the granting of the last certificate one-fifth of one per cent. if the increase is not more than five thousand dollars, and one-tenth of one per' cent. on any excess over five thousand dollars. In these jurisdictions statutory provision is made that if the registrar be not satisfied with the correctness of the value sworn to by the applicant, owner, person acquiring the land or person whom the registrar believes to be acquainted with the value of the land, he may require such owner, applicant or person acquiring the land to produce a certificate of the value under the hand of a sworn valuator, appointed in Saskatchewan by himself or a judge, and in Alberta and the Dominion by a judge, which certificate shall be received as conclusive evidence of the value for the purposes aforesaid. In Manitoba a permanent valuator is employed, generally a practical land expert. It will be observed that the liability in every case is against the assurance fund, and only in Manitoba is it provided that if there shall not be sufficient funds at the credit of the assurance fund to satisfy the claim, then the amount shall be satisfied out of the public funds of the province (section 148). As a matter of fact, however, while the assurance funds in Saskatchewan and Alberta have grown to large proportions the claims proved against them have been comparatively small, and the question of the payment of claims in excess of the amount of the fund does not look to be a practical question at the present time; and if the present ratio between the growth of the fund and the amount of claims proved continues, it will become all the time a less practical question. In Saskatchewan as against $\$ 527,021.11$ collected, $\$ 5,406.51$ has been paid in claims, and in Alberta the figures are $\$ 375,915.35$ collected and $\$ 575.00$ paid in claims. 


\section{§ 27. LIABILITIES OF THE FUND.}

\section{a. Introduction.}

The reported cases in Canada upon the construction of the sections of the Acts referring to the assurance fund are surprisingly few, and, therefore, so far as case law is concerned, to aid in the construction of these sections we must draw upon the Australian cases. As this book does not pretend to be an exhaustive review of the case law in that country, an attempt can only be made to analyze briefly the sections of the Canadian Acts as they actually appear, in a way which it is hoped will be suggestive to the practitioner in considering the application of the liability of the assurance fund to concrete cases as they may arise.

The Saskatchewan, Alberta and Dominion Acts are under this heading almost identical, and differ from the Manitoba Act in that the latter provides in all cases a direct remedy against the fund. In the former jurisdictions the remedy is, in a very great many cases, secondary only.

The Manitoba section, while in practical effect very often the same as the other Acts, is differently constructed and therefore to avoid, if possible, some confusion, the Manitoba Act and the other Acts will be taken up separately. The Acts of Saskatchewan, Alberta and the Dominion will be considered first, as they are longer and more complicated, and will cover the majority of the points to be referred to in considering the Manitoba Act.

b. Liability of Assurance Fund in Saskatchewan, Alberta and the Territories.

\section{(1) IN GENERAL.}

In order to understand ${ }^{4}$ the liability of the assurance fund, it should be observed that the scheme of these Acts is:

"These sections, it has been truly said, are "extremely confused and difficult to construe." Ilogg, page 852. 
(1) To give a right of action for damages for deprivation of land in certain cases to certain persons, and secondarily in certain of these cases to give a remedy over for recovery of the damages recovered in such action from the assurance fund.

(2) To give direct remedy against the assurance fund where:

(a) Pecuniary loss has been sustained by any omission, mistake or misfeasance by any of the officials, or

(b) Where deprivation of land has been suffered but the remedy for recovery of the land is barred by the Act, and

(c) In either case, where the remedy for damages is barred.

(2) INDIRECT LIABILITY OF FUND.

\section{(a) Ground of Liability.}

This liability arises upon deprivation of land. Land pursuant to the interpretation section of the Acts, includes every estate or interest therein, whether that estate or interest is legal or equitable. In the Acts of New South Wales, Tasmania, Victoria and Western Australia, which each contain sections almost identical with Saskatchewan 137 and Alberta 105, the words are, "any person deprived of any land or of any estate or interest in land." Referring to the New south Wales section where parties claiming against the assurance fund were cestuis que trustent, Lord Macnaghten, delivering the judgment of the judicial committee, said:

"It could not, of course, be clisputed that the expression 'interest in land,' unless there was something to restrict the meaning, must include equitable as well as legal interests. But it was argued that the scope of the Act rightly understood requires such a restriction; otherwise it was said the labor thrown upon the office woukl be enormous, if not intolerable. It seems rather difficult to support that contention, etc. (eiting other sections of the Act)."

${ }^{5}$ Williams v. Papuroth, (1900) A. C. 563. 
And the interest must be a beneficial interest of some appreciable value, not a bare legal estate. ${ }^{6}$ An equitable mortgagee by way of deposit of title deeds, was allowed to prove a claim against the fund where the owner obtained the issue of a new duplicate certificate of title by affidavits and proceedings regular on their face, but which affidavits were false. A'Beckett, J., said: Act" 7

"I think the plaintiff had an interest in land under the and the mortgaging of land constitutes a deprivation thereof pro tanto.

A restriction upon the meaning of the word "deprived" has been suggested in Ontario in the case of Fawkes v. Attorney General. ${ }^{9}$ Here the plaintiff had been induced to transfer her land in consideration of receiving certain stock certificates, which turned out to be valueless. As against the original transferees the transaction was fraudulent and voidable, but through a series of transfers, all fraudulent and voidable, the land passed until by a final transfer it got into the hands of a bona fide purchaser for value, one Clark. Boyd, C., says:

"Clark being registered as owner did not deprive the plaintiff of the land; it may have prevented her recovering the land; she had ceased to be owner under the Act when her transfer was registered to Deacon and the land was transferred in due course to Clark."

And again:

"Now, I think the word 'deprivation' is used in contradistinction to another word in the Act, 'disposition.' The plaintiff's dealing with the land falls under section 124; she made a transfer, which was a 'disposition' of the land, that if properly attacked, would be declared fraudulent and void. Her act was a disposition of the land, a voluntary thing, and it is not to be called a deprivation of it.

'Blackwell v. Davey, 8 N. Z. L. R. 129.

7 Tolley and Co. Ltd. v. Byrne, 28 V. L. R. 95.

8 Finucane v. Registrar of Titles, (1902) S. R. (Q.) 75.

${ }^{9}$ Fawkes v. Attorney General, (1903) 6 O. L. R. 490. And compare Public Trustee v. Registrar General, post, page 223. 
"According to the Oxford English Dictionary, "to deprive a person of a thing, is to take it away from him.' Sub voce it imports wrongful action, or action in invitum, and in the statute, I think, it intends some transaction ex parte, or behind the back of the true owner, or wherein his existence is concealed, whereby he, being in ignorance of what is going on, is deprived of his property. As contrasting 'disposition' and 'deprivation' refer to Attorney General v. Montefiore, (1888) 21 Q. B. D. 461 and The Attorney General v. Mayor of Sibthorp, (1858) $3 \mathrm{H}$. and N. 424, at page 453. In such a case the provisions of the Act have been employed to do wrong against the real owner, and if he suffers the loss of the land thereby, yet shall amends be made to him out of the fund, if the personal remedy is fruitless."

If such distinction, however, is well drawn, certain sections of the Acts would seem to be useless and unneccssary, for example:

"No bona fide purchaser * * * of land for valuable consideration shall be subject to an action for recovery of damages as aforesaid *** on the ground that his transferor * * * has been registered as owner through fraud or error * * * or has derived from or through a person registered as owner through fraud or error." (Sask. 138.)

Now if "deprivation" applies only to the original filching, as it were, of the land from the rightful owner, there is nothing in the Acts to give any right of action for recovery of damages against such bona fide transferee, while if the bona fide transferee by his application to be registered, contributes to the deprivation, the section has a plain meaning. It is submitted that the Acts should be given a liberal construction, and that all persons who contribute in removing owncrship of the land from the rightful owner to its last owner, contribute to the deprivation.

The persons so deprived of land who may sue are:

(i) Any person deprived thereof by fraud.

Fraud as a specific cause of loss of land for which damages may be recovered is omitted from the Manitoba section 146, though assumed as a cause later in the section. Every certificate of title obtained by fraud is voidable on that ground, unless in the case of a subsequent registered owner bona fide for value 
and except in such case the land itself would be recoverable, and therefore damages are unnecessary; and if the land cannot be recovered, every case of fraud necessarily involves liability under some of the other headings, fraud being only the element of mala fides, the machinery, as it were, of the fraud being found under some other heading.

(ii) Any person deprived thereof by the registration of any other person as owner of such land.

This must be considered to cover also the first registration, that is to say, "bringing land under the system," which in Manitoba and in the Australian jurisdictions is made a separate ground of damages.

(iii) Any person deprived in consequence of any fraud, error, omission or misdescription in any certificate of title or in any memorandum thereon or in the duplicate thereof, or otherwise.

(b) Against Whom Action for Damages may be Brought.

(i) Against the person upon whose application the erroneous registration was made.

(ii) Against the person who acquired title to the land in question through such fraud, error, omission or misdescription.

(iii) In Alberta, in case the land has been included in two or more grants from the Crown, against such person as the judge appoints.

There does not seem to be any distinction between the person who applies for registration, and the person who acquires title. The enumeration of the two classes suggests the possible view that by the first is meant a vendor, on the strict view of the Act that registration being that which passes the interest, it is the vendor's duty to obtain such registration, but the following subsection of the Act which provides that "such person shall upon a transfer of such land bona fide for value cease to be liable" negatives this view. 
(c) When Assurance Fund is Liable.

(i) Where damages are recovered and the sheriff makes a return of mulla bona or certifies that any portion thereof with costs awarded cannot be recovered from the defendant.

(ii) Where the person against whom the action for damages (a) is dead; (b) cannot be found in the province, and $(c)$ an action has been brought and judgment recovered against the registrar as nominal defendant.

(iii) Where the person primarily liable was not so liable by reason of fraud or error occasioned by any omission, misrepresentation or misdescription in his application to be registered as owner of the land or in any instrument executed by him, and has transferred the land bona fide for value, in which case an action may be brought against the registrar as nominal defendant. ${ }^{9 a}$

\section{(d) When Assurance Fund is Not Liable.}

(i) Where the land itself has been recovered or is recoverable.

(ii) Where damages can be recovered from the person who caused the loss, no damages are recoverable from the assurance fund.

Where a person has been deprived of land by fraud and the actual and immediate perpetrator of the fraud has died, absconded, or become insolvent, his right to recover against the assurance fund is complete, and is not affected by the fact that a third person was also party to the fraud, and derived benefit from it, and in such case a plaintiff need not first proceed against such third person. ${ }^{10}$

(iii) Where the loss has been caused or contributed to by the owner's negligence.

9a Nicholson v. Drew and Norton, 2 W. W. R. 295.

10 Cox v. Bourne, 8 Q. L. J. 66. 
This is an elementary principle of law, but is further emphasized by certain statutory provisions regarding this defence. If the party damnified or attempting to recover the land, had notice of "such delay" and wilfully or collusively omitted to lodge a caveat, or allowed the caveat to lapse, such plaintiff shall be nonsuited." The meaning of "such delay" is not clear as there does not appear to be any case of delay necessarily referred to in the context; but the effect of the section is no doubt intended to be the same as that of section 153, Manitoba, namely to cover the case where the plaintiff had knowledge that the registrar was about to commit an act through which he claims to have been damnified, with this additional term added instead of implied, as in Manitoba, namely that having notice of the impending commission of such act, the plaintiff omitted the obvious remedy of filing a caveat, whereby anything so improperly done would nevertheless be subject to his rights. It would appear that such might very well be held to be negligence, even without statutory provision to that effect. ${ }^{12}$

This, however, is only one instance of possible negligence. A person depending on a search and registering documents without making allowance for the possibility of documents produced for registration but not entered in the register in the ordinary course at the time of search, has no claim against the fund..$^{13}$ A party defrauded who omitted to search the register when he might have found out the fraud by so doing, has no recourse against the fund; ${ }^{14}$ but this does not apply where some act or thing done by the registrar has itself induced the omission to scarch. Thus a memorial of registration on an instrument is evidence of its registration, and that all the consequences of

${ }^{11}$ Sask. 143; Alta. 110; Dom. 149.

12 Northwest Construction Co. v. Valle, 4 W. L. R. 37.

${ }^{13}$ In re. Jackson, 10 N. Z. L. R. $14 \%$.

"In re Scanlan, 3 Q. L. J. 43; Miller v. Davy, 7 N. Z. L. R. 515. 
and conditions precedent to registration have been fulfilled, and the assurance fund is not relieved because the party relied thereon and did not in such case search the register, though such a search would have disclosed a defect. So where a lease was registered against the land which the lessors did not own, and buildings were erected thereon by the plaintiffs who relied on the certificate of registration indorsed upon the memorandum of lease, it was held that it was no negligence on the part of the plaintiffs not to search the register, and the assurance fund was held liable. ${ }^{15}$

Under this heading may be said to fall the case of forged instruments. ${ }^{16}$ The leading case on this point is the decision of the judicial committee of the Privy Council in Gibbs v. Messer. In that case Mrs. Messer was entered in the register as owner of certain parcels of land. Her solicitor forged a transfer to one Hugh Cameron, a fictitious person, and thereupon arranged a loan for the supposed Cameron with the McIntyres. The solicitor signed the document, witnessed it and swore the affidavit of execution all himself. The judicial committee, reversing the Supreme Court of Victoria, held that the mortgage purporting to be executed by Cameron to the defendants McIntyre was invalid and did not constitute an incumbrance upon the title of the plaintiff, Mrs. Messer; that the certificate of title issued in the name of Hugh Cameron should be cancelled and the former certificate in the name of Mrs. Messer restored. The result was that the plaintiff, Mrs. Messer, did not recover against the fund because, instead, she got her land back; but, of the parties relying on the forged instruments, Lord Watson, delivering the judgment of the court, said:

${ }^{15}$ Russell et al. v. Registrar General of Land, 26 N. Z. L. R. C. A. 1223.

${ }^{16}$ Gibbs v. Messer, (1891) A. C. 24S; Attorney General v. Odell, (1906) 2 Ch. 47. 
"The protection which the statute gives to persons transacting on the faith of the register is, by its terms, limited to those who actually deal with and derive right from a proprietor whose name is upon the register. Those who deal, not with the registered proprietor, but with a forger who uses his name, do not transact on the faith of the register; and they cannot by registration of a forged deed acquire a valid title in their own person, although the fact of their being registered will enable them to pass a valid title to third parties who purchase from them in good faith and for onerous consideration."

And again:

"In the opinion of their lordships the duty of ascertaining the identity of the prineipal for whom an agent professes to act with the person who stands on the register as proprietor, and of seeing that they get a genuine deed exeeuted by that principal, rests with the mortgagees themselves; and if they accept a forgery they must bear the consequences."

The duty thus being cast on the party taking an interest to ascertain the identity of his transferor or mortgagor, it follows, conversely, that such transferee or mortgagee can have no claim on the assurance fund for failing in that duty. This, however, is very different from saying, as is frequently inaccurately stated as a result of Gibbs v. Messer, that the assurance fund is not liable for forgery. A title conferred upon a person under a forged instrument, even though void as against the rightful owner, if further transmitted to a subsequent purchaser bona fide for value, becomes indefeasible in the hands of such bona fide purchaser, ${ }^{17}$ and where the rightful owner is thus deprived of his remedy to recover the land and is unable to recover damages against the forger, there is no reason why he should be deprived of his remedy against the assurance fund.

But the reasoning of Gibbs v. Messer in dicta already quoted would apply, as against the party taking under the instrument, to all invalidities in the instrument itself as distinct from infirmities in his transferor's title. Thus a person taking a bona

${ }^{17}$ Gibbs v. Messer, supra; Fawkes v. Attorney General, 6 O. L. R. 490. 
fide registered interest under registered power of attorney, might nevertheless, in case that power of attorney were insufficient to support the authority exercised thereunder, get nothing, and such person would have no claim against the fund. ${ }^{18}$ The case of power of attorney, however, at least where the power is already registered, and not registered by the person claiming under it, is not so clear as the case of forgery and the cases about to be mentioned, for if a registrar indorsed on the register a memorandum that the owner has granted to the agent a power of attorney to transfer certain land, upon the strict theory of the system the owner is entitled to rely upon the entry in the register and should not be required to search the instrument, the registrar being responsible if he makes an incorrect memorandum.

On the principles stated in Gibbs v. Messer, a certificate of title granted upon a transfer executed by an infant or a mortgage made by an infant or other person under disability, would in the hands of the transferee or mortgagee be invalid, with no recourse against the assurance fund, notwithstanding that it might have been registered on a false affidavit by the witness to the fact that the party executing was of full age or otherwise had the necessary capacity. This doctrine leaves undisturbed the general law as to the validity between the parties of instruments executed by companies. A registered instrument executed by a company which is ultra vires of the company, is invalid in the hands of the taker under that instrument, but there is of course nothing to throw a greater duty on a person taking an instrument under a Torrens Act than under the general law, in which latter case the person contracting with

18 The contrary was held in Magor v. Donald, 13 V. L. R. 255. This decision was relied on by the court below in Messer v. Gibbs, that decision again being reversed by the Judicial Committee of the Privy Council on appeal as Gibbs v. Messer, supra. 
a company and dealing in good faith, may assume that acts within the powers of the company have been properly and duly performed and is not bound to inquire whether the acts of internal management have been regular. ${ }^{19}$ In Saskatchewan, indeed, in regard to disability and incapacity in a company, the Act goes further in providing with regard to these invalidities that in no case shall the assurance fund be liable for compensation by reason of the improper use of the seal of any corporation or by reason of the registration of any instrument executed by any person under a legal disability unless the fact of such disability was disclosed on the instrument by virtue of which such person was registered as owner. (Section $155 d$.)

The doctrine, however, of the responsibility of takers under instruments to see to the status and capacity of the maker of the instrument and the consequent immunity of the assurance fund - must not be carried too far. It would seem to extend to a status or capacity but not to a mere restriction by contract or otherwise of the power of the maker of the instrument to effect the purpose which he purports to effect. ${ }^{20}$

It is not necessary in an action against the assurance fund to negative all defences of this nature, ${ }^{21}$ and it apparently is a peculiarity of the Acts in Saskatchewan and Alberta and the Dominion that the assurance fund may not in every case have the advantage of these defences. Where the fund is reached by reason of judgment having been obtained against the party primarily liable for damages under the Act, to the suit ior which judgment the registrar is not necessarily a party, and where after such judgment the sheriff returns a writ mulla bona, the assurance fund is liable to pay the claim without,

${ }^{19}$ Royal British Bank v. Turquand, 6 E. \& B. 327.

${ }^{20}$ McEacharn v. Colton, (1902) A. C. 104.

${ }^{21}$ Wilson v. District Registrar Winnipeg, 9 Man. L. R. 215. 
apparently, having had an opportunity to raise all possible defences.

(iv) Damages are not recoverable where no actual damage of a money value has been suffered.

This may appear axiomatic when stated in its bald form. Where the action was brought by the plaintiff for deprivation of a bare legal estate by the bringing of land under the Act, the registrar in his defence relied merely on the fact that the plaintiff was not a beneficial owner and did not set up that the parties who got the certificate of title were. Richmond, J., delivering judgment, said:

"It was contended that the registrar was bound to show an equitable title in the persons to whom he issued certificate of title. In my opinion this is not so. The plaintiff is bound to establish affirmatively that he has been damnified by the improper use of the certificate of title. In order to do this he must show that he has been deprived of a raluable estate in the land."' 22

Where the plaintiff's mortgage was registered to secure a past indebtedness, and by an oversight the abstract furnished showing the registration omitted to show a large prior mortgage, the plaintiff failed to obtain judgment on this score against the assurance fund, for the reason that the evidence did not show that the mortgagor had any other security which he could have given to the plaintiff nor that he had any estates out of which the plaintiff could have realized had he taken proceedings to collect; in other words, that the evidence did not show that the plaintiff had sustained any pecuniary loss by reason of the failure of the registrar to show the prior mortgage on the abstract. ${ }^{23}$

But in an action against the registrar as nominal defendant for damages for omission to indorse the plaintiff's second mortgage on a new certificate of title, the value of the land was fixed at a higher sum

${ }^{22}$ Blackuell v. Davy, \& N. Z. L. R. 129.

${ }^{23}$ Hall v. Registrar Yorkton L. R. D., 16 W. L. R. $56 \mathrm{~s}$. 
than the purchase price at a forced sale under a first mortgage, this not being considered conclusive evidence of the value. ${ }^{24}$

(v) Damages cannot be recovered against the assurance fund in an action brought after six years from the date of the deprivation of the land or the lifting of a disability. In the Australian jurisdictions this limitation is also placed on the action for damages against the person liable. Such is not the case in Saskatchewan and Alberta, and furthermore there is nothing to limit the liability of the assurance fund after an unsatisfied execution against a person primarily liable, even though six years have elapsed. Still further, this limitation does not apply to the actions of persons sustaining loss or damage through any omission, mistake or misfeasance of the registrar. The date of "deprivation of the land" is the date of the issue of the certificate of title. ${ }^{25}$

(vi) No damages against the assurance fund can be recovered by reason of the breach by the owner of any trust whether expressed, implied or constructive. ${ }^{26}$ This, of course, does not in any way infringe upon the right of the cestui que trust to enforce upon his trustee observance of the trust or for damages in case of breach thereof, which rights still exist as under the general law. The beneficiary can always file a caveat, but the whole scheme of the Acts is to dissociate trusts entirely from the registry office. ${ }^{27}$

(vii) The assurance fund is not liable for loss occasioned by the same land being included in two or more grants from the Crown. ${ }^{28}$ In Australia, in such cases, the actions are brought against such persons as the judge may direct, and this is the procedure in Alberta. In such cases the action for

${ }^{24}$ Wells and Johns v. Registrar General of Land, 29 N. Z. L. R. S. C. 101.

${ }^{25}$ Rulu Peehi v. Davey, 9 N. Z. L. R. 134.

${ }^{26}$ Sask. 155 (a); Alta. 121 (a); Dom. 161 (a).

${ }_{27}$ Sask. 68; Alta. 47; Dom. 75.

${ }^{28}$ Sask. 155 (b); Alta. 121; Dom. 161 (b). 
damages may be brought, but there seems little scope for such an action, as a prior claimant (as defined in section 3 of the Saskatchewan Act and section 44 of the Alberta Act) may always recover in ejectment, while the claimant in a subsequent grant is not in a position to claim that the prior grantee's application was erroneous or that such prior grantee first acquired title through fraud, error, omission or misdescription.

(viii) The assurance fund is not liable in any case in which loss has been occasioned by any land being included in the same certificate of title with other land through misdescription of the boundaries or parcels of any land, unless it is proved that the person liable for compensation and damages is dead, or has absconded from the province, or has been adjudged insolvent, or the sheriff has certified that he is not able to realize the full amount of costs awarded in any action for compensation. ${ }^{29}$

"Wrong description is where the applicant, intending to de-cribe Blackacre, describes Whiteacre, or so describes Blackacre as to make it include Whiteacre. It is not wrong description where an applicant correctly describes the land he is applying for, though the land is not his. It is then a case of no title and the efficacy of the certificate of title depends upon the bona fides of the applicant." ${ }^{30}$

In the case of misdescription, the rightful owner is not barred from recovering the land ${ }^{31}$ in Saskatchewan and Alberta, and the necessity for any action for damages is not apparent.

\section{(3) DIRECT LIABILITY OF FUND.}

There are many cases of loss or damage sustained in the administration of the Acts where there are no persons from whom the damages may be recovered. In such case a remedy is provided against the 29 Sask. 155 (c); Alta. 121; Dom. 161 (c).

${ }^{30}$ Hamilton v. Iredale, 3 S. R. (N.S.W.) 535.

अ1 Sask. 136 (e), 137 (2), 135; Alta. $101(2), 105,106$; Dom. 142 (e), $143(2), 144$. 
fund in the first instance. Those persons who have such a direct remedy against the fund are:

(i) Any person sustaining loss or damage through any omission, mistake or misfeasance of any officer or clerk under the system.

(ii) Any person deprived of any land by the registration of any other person as owner thereof, or by any error, omission or misdescription in any certificate of title or in any memorandum upon the same or upon the duplicate thereof, and who by the provisions of the Act is barred from bringing an action of ejectment or other action for the recovery of the land.

(iii) And being in either case, a person who is barred from bringing an action for the recovery of damages as provided for in the Act. ${ }^{32}$

It is not easy to rigidly distinguish between "loss or damage" on the one hand and "deprivation of land" on the other; but it would seem to be evident that, by a recital of the two grievances of loss or damage on the one hand and deprivation of land on the other, it is intended to avoid the effect of an Australian decision in which, construing the section of the Victoria Act corresponding to but slightly different in wording from sections 140 Saskatchewan and 108 Alberta, it was held that the loss or damage referred to must be in the nature of a loss of an interest in land and that a purely money loss could not be compensated for. ${ }^{33}$ In the Canadian jurisdictions there is now no reason for claiming that once it be proved that a party has suffered loss on some ground coming within the category of any omission, mistake or misfeasance of any of the officials of the system, such person cannot claim damages, even although he may not have reached

${ }^{32}$ For this construetion of the section see Morris v. Bentley, 2 Terr. L. R. 253.

${ }^{33}$ Oakden v. Gibbs, 8 V. L. R. 380. 
the point of having acquired an interest in the land recognizable as such under the Acts, or of having lost the same. For example, there is no reason to suppose that a person purchasing land on the strength of a clear abstract and general register certificate would not be able to hold the assurance fund, notwithstanding his purchase had never resulted in a registered interest.

The necessity in the case of an action for deprivation of land of the remedy for the recovery of the land being barred, and, in all cases, of the remedy in damages being barred, was considered in Morris v. Bentley, supra. It was there held that in order to enable the plaintiff to recover in an action for damages, it was not necessary that all his remedies, whether direct or indirect, should be barred, and that it was sufficient to show that his principal remedy, that is the remedy against the registrar, had been barred; and there it was held sufficient that the remedy had been barred under the general section exempting from liability any registrar in respect of any act bona fide done or omitted to be done in the exercise or supposed exercise of the powers given by the Act. ${ }^{34}$ It will be observed that the persons who may bring an action against the fund directly for deprivation of land, are the same persons as those who by the preceding sections may bring an action for damages in certain cases. That action, however, being barred by other provisions in certain cases, this direct remedy against the assurance fund is provided.

The liability of the assurance fund does not require before it may arise any actual culpable negligence on the part of the registrar. He may have merely registered documents perfectly regular on their face and in regard to which in registering he may have been performing a purely ministerial.

${ }^{34}$ Sask. 23; Alta. 143; Dom. 34; Man. 19. 
act, but if, in the result, he has registered documents which should not have been registered, the fund may be liable. In Public Trustee v. Registrar General of Land: ${ }^{35}$ before the Court of Appeal in New Zealand, land properly vested by law in the public trustee had been granted to individuals by void Governor's warrants. The land had gotten into the hands of bona fide purchasers for value whose title was unimpeachable. It was contended that as the district registrar had, as was admitted, no discretion in action upon the warrants or the transfers presented subsequent thereto, the assurance fund was not liable. But Edwards, J., delivering the judgment of the court holding the fund liable, said:

"It is observed moreover that section 185 of the Act ${ }^{36}$ defines certain cases in which the assurance fund shall not be liable for compensation, and that the cases so defined do not include such a ease as the present. It seems to us therefore plain that it was intended that every person who is deprived of his land through the bringing of the same under the Act and the issue of a certificate of title to another should be enabled to bring his action for the recovery of damages from the assurance fund. The scheme of the Act is to provide a fund for compensating all persons who are deprived of their land by the operation of the Act, and reason and justice require that no qualification should be put upon the rights so given which is not in express terms imposed by the statute."

The defences of the action against the registrar as nominal defendant for recovery of damages payable out of the assurance fund, are so far as they go

${ }^{35} 17$ N. Z. L. R. C. A. 577. Compare Tolley v. Byrne, 28 V. I. R. 95

${ }^{36}$ Section 185 of the New Zealand Act reads:

"No person shall, as against the registrar general or the assurance fund, be entitled to recover any greater amount for compensation in respect of the loss or deprivation of any land, or of any estate or interest therein, than the value of such lind, estate, or interest at the time of such deprivation, together with the value of the messuages and tenements ereeted thereon and improvements made thereto (if any) prior to the time of such deprivation, with interest at the rate of five per contum per annum to the date of judgment recovered; and in case the assurance funt for the time being shall be insufficient to satisfy any claim, the deficiency shall be paid out of the consolidated revenue of the colony, and shall be a first charge upon the assurance fund." 
the same as those defences which may be raised in case of action for damages and against the registrar as nominal defendant where the party otherwise liable is dead or cannot be found within the province, and which remedies have already been fully considered. The defences are:

(i) Where the land itself has been recovered or is recoverable. Ex hypothesi, in case of the proceedings under discussion this is not possible.

(ii) Where damages can be recovered from the person who caused the loss; this defence similarly is not available.

(iii) Where the loss has been caused or contributed to by the owner's negligence. This defence is fully available.

(iv) Where no actual damage of a money value has been suffered. This defence is also available.

(v) When the action is brought more than six years from the date of deprivation of the land or the lifting of the disability. This defence is available in case of deprivation of land, but apparently not available in case of loss or damage sustained through any omission, mistake or misfeasance of the officials.

Defences vi, vii and viii, ante, are also available.

(ix) There is further in the action against the registrar for recovery against the fund direct, the requirement that notice in writing of every such action and the cause thereof shall be served upon the attorney general at least three calendar months before the commencement of the action, and failure to serve such a notice is a defence to the action. In the pleadings it must be distinctly alleged that the action is brought under the statute and that the act complained of was done contrary to the provisions of the statute. ${ }^{37}$

Upon the payment of any such claim, the amount paid out on account of any person may be

${ }^{37}$ Wilson v. Districl Registrar Winnipeg, 9 Man. L. R. 215. 
recovered from him or his estate by action against his personal representative in the name of the registrar and provision is made for speedy judgment and issue of execution in the case of absconders. ${ }^{38}$

\section{c. Liability of Assurance Fund in Manitoba.}

After attempting to set out in some sort of orderly fashion the intricacies of the machinery for an attack on the assurance fund in Saskatchewan, Alberta and the Dominion, it is somewhat of a pleasure to turn to the comparative simplicity of the scheme under the Manitoba Act (sections 146-155). First, it should be noted that the scheme in that Act does not depend in any way upon any primary statutory right to damages against any other person. Where there is any such right to damages on ordinary principles of law, there is nothing in the Act to take away such right from any person injured, but the scheme of the Act is simply that where any person has suffered loss or damage or deprivation of land through and by reason of the operations of the Act, he may recover his damages against the assurance fund by action against the registrar as nominal defendant. The persons who may bring the action are:

(i) Any person sustaining loss or damage through any omission, mistake or misfeasance of the district registrar (which would include any deputy, official or clerk in his office for whose acts the registrar is responsible) in the execution of his duties under the Act.

(ii) Any person deprived of any land, mortgage, incumbrance, or of any estate or interest therein:

(a) Through the bringing of the same under the new system, or

(b) By the registration of any other person as owner of such land, mortgage or incumbrance, or

${ }^{38}$ Sask 144, 145; Alta. 111; Dom. 150, 151. 
(c) By any error, omission or misdescription in any certificate of title, and

(d) Who in any case is by the provisions of the Act barred or in any way precluded from bringing an action for the recovery of such land, mortgage, incumbrance or interest therein.

It is not open to the registrar to plead that the loss was suffered through the fraud or wrongful act of some other person, but in such case, or in case the loss has been suffered jointly through the fraud or wrongful act of some other person and the omission, mistake or misfeasance of the district registrar, then the action is brought both against the registrar and such other person, and in that case judgment shall not be entered against the district registrar until it be ascertained that the money cannot be made out of the goods or lands of such other person. The scheme of this Act was evidently adopted from the scheme of the New Zealand Act, while the more complicated scheme of Saskatchewan, Alberta and the Dominion corresponds rather closely with the scheme in New South Wales and some other of the AustraJian jurisdictions. The present sections of the Saskatchewan and Alberta Acts appeared almost verbatim in the Manitoba Act up to the revision of 1900, when the simpler scheme of the present Manitoba Act was introduced.

While the Act says that the persons mentioned may bring an action for damages, there is nothing in the Act to negative the right of the registrar to raise ordinary defences in an action for damages, so that the principles of the defences already referred to are available in Manitoba. The defences so available are:

(i) That the land, mortgage or incumbrance of which the person is deprived may itself be recovered.

(ii) The negligence of the person sustaining loss or damage or deprived of the land, mortgage or 
incumbrance. Under this heading in addition there is the statutory negligence established by section 153, whereby it is a bar to the bringing of an action against the district registrar that the plaintiff or the person through whom he claims was served under the provisions of the Act with notice, or not being served with notice, had knowledge that the district registrar was about to bring the land, in respect to which the action was brought, under the Act, or was about to commit the act through which the plaintiff claims to have been damnified.

(iii) The statutory period of limitation is ten years from the date of deprivation, or in the case of disability, within five years from the lifting of the disability, whichever shall be the later.

(iv) Notice of action and the cause thereof must be served on the district registrar and the attorney general at least one calendar month before the bringing of the action. (Section 147.)

(v) The district registrar shall not under any circumstances be liable for any loss, damage or deprivation occasioned by the breach by a registered owner of any trust, whether expressed, implied or constructive. (Section 151.)

(vi) That no actual damage has been suffered.

Provision is also made by section 152, and regularly acted upon, whereby the provincial treasurer, if satisfied that the claim for loss $\mathrm{Or}^{\circ}$ damage is a fair and reasonable one and upon report of the attorney general and the registrar general and the district registrar advising such payment, may pay such claim without putting the plaintiff to the necessity of a formal action. 


\section{CHAPTER VIII}

TRANSFERS

28. PURPOSE AND INTERPRETATION.

29. OPERATION OF TRANSFERS.

$\$ 30$. INTERESTS WHICH MAY BE TRANSFERRED.

31. DISTINGUISHED FROM CONVEYANCE.

32. DISTINGUISHED FROM DEED.

33. IMPLIED COVENANTS.

34. NECESSITY OF MEMORANDUMOF LEASES AND INCUMBRANCES.

§35. RESTRICTIVE COVENANTS IN

\section{§28. PURPOSE AND INTERPRETATION.}

The instrument by which registered ownership is passed roluntarily from one person to another is the transfer. This instrument, probably more than any other, is characteristic and typical of the essential features of the Torrens system of real property law, and of the changes made in the law of real property and of conveyancing by the Torrens Acts. It is "an instrument introduced by the Act, and would not apart from the Act have been sufficient to pass any title in the land." All the complicated accumulation of law concerning the delivery of seisin, uses, conveyancing words and limitations of estate, is wiped away, and the law of transfer of real property assimilated to that of the transfer of personal property as nearly as the actual and permanent difference between the two classes of property permits.

While the Torrens Acts on the one hand do not profess formally to abolish "estates" in land, the fundamental basis of the English common law of

${ }^{1}$ Re Rivers, 1 Terr. L. R. 464, at page 474. 
real property based on the feudal system, and while they still refer to such estates, equally often they refer to dealing with the actual land itself as if under a system of allodial ownership. In Manitoba according to the interpretation section 2 (a) "land means and includes land, messuages *** of every kind and description whatever the estate or interest therein may be, or whether legal or equitable. * * * But in the body of the Act no care is taken to distinguish between "land" and "an estate in land," as for example section 89, which speaks of "every instrument transferring an estate or interest in land," while in section 78, the expression used is "land" simply. In the other jurisdictions the word "land" means "lands, messuages * * * and every estate or interest therein," and no care is taken throughout the Acts to distinguish between the actual land and an estate therein. In all the Acts use is made of the expression "absolute owner," which, literally, is only applicable to a system of allodial ownership corresponding to the omnership of personal property. Thus, in Manitoba, an assignee is deemed to be the "absolute" owner of the land (section 120) and in the other jurisdictions no entry of trusts is to be made upon a certificate of title, but the trustees are deemed to be the "absolute and beneficial owners of the land" for the purpose of the Act.? Consistently with this evident intention, if not actual legislation, to approximate the law of personal property, the Manitoba Act provides (section 79) that any registered owner of land may make a valid transfer to himself jointly with any other person, and registered owners may make a valid transfer to one of their number, either solely or jointly with some other person. In the other jurisdictions, although there is no corresponding definite enactment, such a right in owners and joint

${ }^{2}$ Sask. 68; Alta. 47; Dom. 75. 
owners is properly assumed: and for the same reason words of limitation, so essential under the old system to define the estates passed to a grantee, are entirely unnecessary. ${ }^{3}$

The statutory instrument of transfer is in form nothing but a quit claim, as said by Richards, J., in the Court of Appeal in Manitoba:4

"A grant under the old system with such words of description would be only a quit claim. I know of no rule of law by which they should be differently interpreted when contained in a Real Property Act transfer."

So far as a transfer under the system is more than a quit claim it is by virtue of specific provisions in the Act. It is not to be construed as a deed of land under the old system. For example, it does not imply any covenants for title. ${ }^{4}$

\section{§29. OPERATION OF TRANSFERS.}

The only person whose transfer is registerable under the Act is the registered owner of the land intended to be transferred. It is a common practice, and it would seem unobjectionable in principle, ${ }^{5}$ for a statutory instrument to be executed by a person who has not yet become the proprietor of the land, as where a purchaser executes a mortgage before his own transfer is registered, intending that transfer and mortgage shall be registered simultaneously. It would appear that as the form of transfer requires that the transferor shall represent that he is the registered owner of the estate or interest about to be transferred, such transfer, if the transferor is not the registered owner at the time of execution but subsequently becomes such, may be said upon presentation for registration to operate by estoppel

${ }^{3}$ Man. S0; Sask. 72; Dom. 79; Alta. 1906, c. $19, \S 3$.

4 Bennett v. Gilmour, 16 Man. L. R. 304, 4 W. L. R. 196; Foster v. Stiffer, 19 Mlan. L. R. 533.

${ }^{5}$ Hogg, page 912 . 
and be therefore valid. ${ }^{6}$ In Coventry v. Annable a transfer was executed in July, 1903, patent was not issued and certificate of title granted to the transferor until March, 1904, but no suggestion was made by the Full Court of Saskatchewan that this constituted any objection to the validity of the transaction, except that the transferee, taking before the land came under the Act by the issue of patent, did not obtain the protection of section 162 of The Land Titles Act.

The view, based upon a very literal interpretation of the Acts, whereby the passing of the estate for all purposes lies not in the execution of the instrument of a transfer, but in the registration of it, has led to a holding in a Queensland case ${ }^{8}$ to the effect that, at least as against a volunteer, the transferee was not entitled to have his transfer registered where the transferor had died before presentation for registration. But in Victoria it was held that a transfer executed by the transferor, but not registered before his death, was nevertheless valid, and passed the estate in the land to the transferee upon registration." "The view that the death of the transferor" after authorizing the change of proprietorship on the register is ipso facto to annul the authority thus given, possibly for valuable consideration, seems both inconvenient and by no means a necessary consequence of the registration principles of the system."10 In view of the repeated holdings of the Canadian courts that an unregistered instrument does create rights in the transferee against the transferor, and especially in Manitoba, where the "right to registration" is the statutory effect of an unregistered statutory instrument (section 90), it

- Man. 80; Sask. 72; Dom. 79; Alta. 1906, c. 19, \$3; American Abell v. McMillan, 19 Man. L. R. 97, at page 101.

71 W. W. R. 148 ; 19 W. L. R. 400.

Re Skinner, 6 Q. L. J. 68.

9 T'ierney v. Halfpenny, 9 V. L. R. 152.

${ }^{10} \mathrm{Hogg}$, page 917. 
would appear unreasonable to hold that these rights once conferred are taken away from the holder of the instrument merely by the death of the maker of the instrument.

\section{\$30. INTERESTS WHICH MAY BE TRANSFERRED.}

The transfer is a flexible instrument. While unless a contrary intention is expressed it operates as transferring all the interest which the transferor has, nevertheless, if specifically stated, a less interest may be transferred, excepting only a fee tail. A conveyance under the general law conveyed only such interest as was stated in the conreyance. A grant to $A$ under the general law gives to A a life estate only; a transfer to A under the Torrens Acts conveys all the interest the transferor has, which is usually a fce simple. To convey a life estate special words must be used. These words would not be necessarily or even properly the habendum clauses and technical words used in a conveyance under genelal law, but would simply be the ordinary colloquial but accurate phrases necessary to convey the required meaning.

\section{\$31. DISTINGUISHED FROM CONVEYANCE.}

A distinction has been dram between a transfer under the system and a converance under the general law in that such a converance is the creation of a new estate rather than merely the passing from one person to another of one already in existence, as is prima facie a transfer. "Notwithstanding that conveyance by way of sub-infeudation can no longer be made, the ordinary form of conveyance of fee simple does not purport to pass the whole estate of the alienor to the alience, but rather to confer on the alience an estate in the land, that is an estate similar to the estate held in the same land by the alienor." The transfer under the system, on the 
other hand, is nothing but a substitution of the alienee in place of the alienor, in the same manner as in case of transfer of personal property. The Acts recognize this distinction, but provide nevertheless that the transfer is to be the instrument for the creation of an interest as well as merely for transferring. Section 78 of the Manitoba Act provides that the transfer shall contain an accurate statement of the estate, interest or easement intending to be transferred or created. Section 71 of the Saskatchewan Act provides that when land is intended to be transferred or any right of way or other easement is intended to be created or transferred, the transfer shall be used, and section 48 of the Alberta Act is the same as the Saskatchewan Act. The grant of an easement is necessarily the creation of an interest, as the law does not recognize the existence of an easement where the owner of the dominant and servient tenements are the same persons. This has been clearly laid down by the Court of Appeal in Ontario in the following language:

"This seems to imply that the way had in some way, in the meantime, continued to exist during the unity of ommership and possession which continued down to the date of the last mentioned transfer. For that position I can find no ground in or out of The Land Titles Act. *** A right of way is an easement, and an eascment requires for its legal construction a dominant and servient tenement, a condition which, of eourse, does not exist where the whole is in one hand." 11

For the creation of a right of way or an casement, the form of transfer provided by the Act is the proper instrument. By this use of the transfer form instruments commonly known as party wall agreements, which in essence are mutual grants of easements but which in the ordinary forms in use do not make that fact apparent, can obtain actual registration instead of registration by way of caveat only.

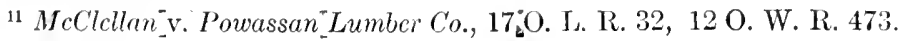




\section{§ 32. DISTINGUISHED FROM DEED.}

A transfer is not a deed nor do the Acts profess to give it the effect of one. In all the Australian jurisdictions statutory instruments are, upon registration, given the effect of deeds under seal between the parties.

"Upon registration, every instrument drawn in any of the several forms in the schedule hereto $* * *$ shall be deemed to be embodied in the registry book as part and parcel thereof, and such instrument when so constructively embodied and stamped with the seal of the registrar general shall have the effect of a deed duly executed by the party signing the same." New South Wales Act, 1900, section 36 (4). Similarly New Zealand.

"So soon as a memorial thereof shall have been entered in the register book, every instrument drawn in any of the several forms provided in the schedule hereto $* * *$ shall create and impose the like obligation on the person signing the same, and for the like period of time as if the same had been sealed and delivered." Queensland Act, 1861, section 35.

"Every instrument shall when registered $* * *$ have the effect of and be deemed and taken to be a deed duly executed by the parties who have signed the same." South Australia Act, 1886, section 57 .

"Every transfer or other instrument shall be deemed of the same efficacy as if under seal; and when signed by the proprietor and registered shall be valid and effectual as a deed duly executed." Victoria Act, 1890, section 92.

No such language appears in the Canadian Acts, the object in view being left to be accomplished pro tanto by the ordinary provision that upon registration the instrument shall create, transfer, surrender, (charge or) discharge the (land or) lien, estate or interest therein mentioned. ${ }^{12}$ The instrument having thus been given its full operation, no question arises as to whether any of the law peculiar to deeds as distinct from ordinary writing under hand, has been incorporated in the statutory instruments. In the Canadian jurisdictions they are not deeds either before or after registration, nor are they in any way

${ }^{12}$ Man. 81; Sask. 69; Nlta. 41; Dom. 71. 
by implication or otherwise made such, consequently they are not to be interpreted or construed by any of the rules applicable to deeds only. Statutory instruments have, however, even in decisions of the highest courts, as in Gibbs v. Messer, been referred to as "deeds." Of the Australian law on the point it has been said that "in the absence of authority it would be impossible to lay down a rule with any confidence as to how far a stipulation which under general law would depend for its efficacy upon being embodied in a document under seal would be valid as contained in a registered statutory instrument." 13 Thus on the question as to whether a statutory instrument can be signed in blank or whether it is subject to the rule which would make a deed a nullity if executed in blank, there are dicta both ways, but no actual decision. ${ }^{14}$ In Alberta it has been expressly held that such an instrument signed in blank is perfectly valid, ${ }^{15}$ and under the Canadian Acts there would appear to be no ground for holding that the law applicable peculiarly to deeds applies to these purely statutory instruments which are not under seal.

\section{§33. IMPLIED COVENANTS.}

From the foregoing it is evident that the transfer implies no covenants by reason of the nature of the instrument itself or by reason of the efficacy of any words contained in it, whatever implied covenants a court of equity may raise by reason of the nature of any new legal relationships established. The implied covenants in the Acts arise by virtue of registration. They are, firstly:

"That the transferor or incumbrancer will do such acts and execute such instruments as in accordance with the provisions of the Act are necessary to give effect to all covenants,

13 Hogg, page 908.

${ }^{14}$ Trembath v. Carr, 23 V. L. R. 437; Gilbert v. Bourne, 6 Q. L. J. 271.

15 Arnot and Smith v. Peterson, 2 W. W. R. 1. 
conditions and purposes expressly set forth in such instrument or by the Act declared to be implied against such person in instruments of a like nature."16

Further that:

"In every instrument transferring land *** subject to a mortgage, there shall be implied a covenant by the transferee"-

Manitoba, "with the transferor."

Saskatchewan, "with the transferor, and so long as such transferee shall remain the registered owner, with the mortgagee or incumbrancer."

Alberta, "both with the transferor and the mortgagee."

"That the transferee will pay the principal money, interest, annuity or rent charges secured by such mortgage or incumbrance at the rate and at the time specified in the instrument crenting the same, and shall indemnify and keep harmless the transforor from and against the principal sum or other moners secured by such instrument, and from and against all liability in respect of any of the corenants therein contained or under the Act implied, on the part of the tran-feror." 17

This provision, so far as it implies a corenant only between the transferor and the transferee, does not secm to cnact any new law beyond what has alwars been cnforeed in the court of equity. As far hack as 1802 Lord Chancellor Eldon said:

"It he (the purchaser of an equity of redemption) enters into no obligation with the party from whom he purchased, neither $3, y$ hond nor covenant of indemnity to save him harmless from the mortgage, vet this court if he receives possession, and has the profits, would, independent of contract, raise upon his conscience an obligation to indemnify the vendor against the personal obligation to pay the money due upon the vendor's transiction of mortgatge: for being become owner of the estate, he must be sipposed to intend to indemnify the vendor against the mortguge."

The question as to whether this implied covenant reads also by the transferee in faror of the original mortgagee, has been set at rest by the insertion of expless words to that effect in the Acts of

16 Sisk. 62; Alta. 41); Dom. 69.

1. Man. s9; Fiskl. 63; Alta. 52; Dom. 69.

is Waring v. Ward, 7 Ves. 332. Soe, also, Dodson r. Douney, (1901) 2C Ch. 620 ; Fint v. Robertson, + C. L. R. sot. 
Saskatchewan and Alberta, inserted in 1909 and 1906 respectively. Where the Act, as in Manitoba, does not expressly enact an implied covenant between the transferee and the original mortgagee, no such covenant could be implied. ${ }^{19}$ The Alberta section appears to have gone further than the Saskatchewan Act and established an unlimited covenant between the transferee and the mortgagee. In equity such a covenant, in any case, would not have been enforced, except during the ownership of the transferee. But the implied covenant does not include a covenant to obey the rules and by-laws for the time being of the mortgagees who were an incorporated company. ${ }^{20}$ When an action is brought against a transferee of land subject to a mortgage and personal judgment is sought against him under these sections, "there should be an express claim setting forth that such transferee is so liable." "The liability is statutory and nerr; but under any circumstances the defendant sought to be charged ought to be distinctly informed as to how and by what authority he is alleged to be held personally liable. $: 21$

The effect of this implied covenant is to produce a merger wherc a mortgagee of land becomes the owner thereof,,$^{22}$ but evidence may be given to the court to show a contrary intention and the merger does not necessarily follow. ${ }^{23}$ Where a transferee is taking a transfer to himself of the land, upon which there is a mortgage, it is essential, if it is not the intention to merge the mortgage, to negative or modify the implied covenant for payment under the provisions of the Act allowing such implied covenants

${ }^{19}$ Australian Deposit and Mortgage Bank v. Lord, 22 T. L. 1R. 31; Cote v. Olson, 20 W. L. R. 690.

${ }^{20}$ Re Kelly and Colonial Inestment end Loan Co., 3 W. L. R. 62.

${ }^{21}$ Colonial Investment and Loan ('o. v. Foisie, 1 W. W. R. 397, 19 W. I. R. 748. Compare Man. 157.

${ }^{22}$ Re Riddell, 7 W. L. R. 301, 1 S. L. li. 24.

${ }^{23}$ Reeves v. Konsehur, 2 S. L. R. 125. 
to be modified or negatived. ${ }^{24}$. This is the only evidence of contrary intention the registrar may consider. Even where there has been a merger, courts of equity have relieved against it upon equitable considerations, and where it appeared that consequences resulting from the mode of dealing with the estate in question were not foreseen. ${ }^{2 \overline{5}}$ For though the implied covenant in a transfer may be negatived by express declaration in the instrument, ${ }^{24}$ it would appear that this is not the only method of so negativing this corenant which the court can consider. In Short v. Graham ${ }^{2}$ the transfer was proved to have been executed and registered by way of security and it was held that in such case the implied covenant did not arise. Mr. Justice Stuart said:

"I am very strongly of the opinion that the application of the statute should, therefore, be restricted entirely to the case where there has been a real purchase by the transferee and a complete parting with all his interest on the part of the transferor, and that whenever it is impossible for the vendor, the transferor, to take advantage of the covenant declared to be implied in his favor, that is, wherever he would have had before the statutes no right against a purchaser capable of assignment to the mortgagee, which is admittedly the case here, then the covenant should not beimplied in faror of the mortgagee either."

This decision is referred to with apparent approval in a case where on the facts the transfer was found to be absolute in Manitoba. ${ }^{27}$

The benefits of the implied covenants in a transfer are assignable. In Glenn v. Scott, ${ }^{28} \mathrm{Mr}$. Justice Richardson said:

24 Man. 157; Sask. 167; Alta. 131; Dom. 172.

${ }_{25}$ The Dean and Chapter of St. John's Cathedral v. McArthur, 9 Man. L.R. 391 , where the law as stated in the text is laid down and the authorities discussed.

26 H. L. R. 787.

${ }^{27}$ Morice v. Kernighan, 9 W. L. R. 307.

2 Morice v. Kernighan, supra; Glenn v. Seott, 2 Terr. L. R. 339; Maloney v. Campbell, 2s S. C. R. 22; Irving v. Boyd, 15 Gr. 157; British Canadian Loan Company v. Tear, 23 O. R. 664; Ball v. Tennant, 21 O. A. R. 602. 
"This undertaking or covenant by Scott is a chose in action assignable, and being assigned as shown, the privity which otherwise was wanting supports the plaintiff's action as mortgagee against Scott's estate in the hands of his representative to compel the payment of the outstanding money by the estate."

\section{§ 34. NECESSITY OF MEMORANDUM OF LEASES AND INCUMBRANCES.}

The case of Glenn v. Scott (supra) is also suggestive on a point in regard to the form of transfer which does not appear to have been the subject of express decision. Pursuant to the Manitoba Act the transfer must contain

"a memorandum of all leases, mortgages, or incumbrances to which the same may be subject" (section 78).

In Alberta the transfer must contain

"a memorandum of each lease, mortgage or incumbrance to which the land is subject" (section 48),

and similarly in the Dominion Act (section 78). This direction was formerly in Șaskatchewan, and is now partly in Alberta, more honored in the breach than in the observance, for which reason probably the corresponding words were struck out of The Saskatchewan Land Titles Act 1906, by Statutes of 1909 , c. $20, \$ 6$. Is such a memorandum requisite for the validity of a transfer? If no such memorandum is made on a transfer, or if the memorandum does not agree with the actual registrations, does this render the instrument unfit for registration and a proper subject for rejection by the registrar? Does the omission of such a mcmorandum affect the rights of the parties? In this case of Glenn v. Scott, it was argued that the implied contract to indemnify does not arise unless the mortgage is specified in the transfer and the latter is made subject to the mortgage, but on this point the learned judge stated:

"It was then urged by Mr. Hamilton, Q.C., for the contesting defendants, that because in the transfer put in from Thompson to Scott, the incumbrances existing, and to which 
the land was subject, were not notified by memorandum as provided by section 65 of The Territories Real Property Act, the action failed. True, the section cloes so provide, but the Act does not make a transfer without this void, or disallow its registration."

If, then, this statement be correct-and, as a matter of fact, the law there stated has been assumed to be the law in several offices for years - the omission of this memorandum has no effect; and it may be that the practice so adopted for many years has established its own propriety. The possibility of so establishing rights by long practice in the registry office has been suggested by the Full Court of Victoria, Australia. ${ }^{29}$ In Manitoba, however, and to some extent in Alberta, the direction is closely followed and an instrument not setting out the incumbrances as on the register is rejected, with the idea of making each instrument as far as possible a complete record as regards the interest thereby created.

\section{RESTRICTIVE COVENANTS IN TRANSFERS.}

The use of the transfer for the creation of easements has already been referred to (page 233). An easement is a well recognized legal interest in land as distinct from an equitable interest only, and therefore raises no special questions as to its nature and effect under the Torrens system, in which system the registered estate takes the place, speaking broadly, of the legal estate. But there is a quasi interest in land which has created some difficulties, that is to say, the interest (if any) created by covenants frequently contained in deeds and mortgages under the general law, restricting the use of property.

In Alberta, such a covenant has been indorsed on a certificate of title as an incumbrance, ${ }^{30}$

${ }^{29}$ Ex parte Wisewould, 16 V. L. R. 119.

${ }^{30}$ See International Coal and Coke Co. v. Trelle, 7 W. L. R. 264. 
which is still the practice in the Calgary office, though not at Edmonton, and it has been suggested in a Victorian case ${ }^{31}$ that this was a proper course. In Manitoba such covenants cannot be indorsed by memorandum on the certificate, but the covenantee may file a caveat to protect his interest thereunder, and the rule is the same in Saskatchewan. ${ }^{32}$ The covenant if contained in a separate instrument could not be registered, and there is no reason why it should receive better treatment because inserted in a transfer. And going further, in an earlier Victorian case a caveat claiming under a grant of a right of way to $\mathrm{W}$, his heirs or assigns - a mere easement in gross-was struck off, ${ }^{33}$ and in New Zealand the covenantee in a covenant contained in a former conveyance whereby the purchaser covenanted not to purchase alcoholic liquors from any other brewer than the plaintiff, was held neither entitled to have notice of the covenant appear on the certificate nor to enter a caveat to protect his rights. ${ }^{31}$

The authoritics upon the construction and effect of such covenants under the general law, in a long series of often apparently conflicting deeisions, ${ }^{35}$ are now fairly well settled so far as affects the principles governing the recognition of such interests under the system. It is not necessary to go back into a discussion of covenants rumning with the land at law and those which do not. Such an inquiry is relevant to the case of landlord and tenant. To arrive at what effect the covenants under discussion may have

${ }^{31}$ Mayor of Brumswick v. 1)awson, i) V. L. R. 2. To the contrany in New Zealand, Wellington and Humbutin Ry. r"o. v. Bisgistrar Generul, 18 N. Z. I. R. 250.

32 Re Canadian Pacific Railway Co. and Doupe's Transfor, Master of Titles, 6th Feb., 1911.

${ }^{33}$ E'x parte Johnson, 5 IV. W. and A'B. 5i).

${ }^{34}$ Staples v. Corby, 19 N. Z. T. R. ( . А. 517.

${ }^{35}$ See notes to Spencer's Case, Sinith's Leading Cases and 15 Ruling Cases 254 ; Tulk v. Moxhay and Austerberry Corporation of Oldham, 2 Phill. 774; also International Coal and colic ro. v. Evans, 9 W. L. R. 711 ; affirmed 11 W. L. R. 469. 
in case of assignment of the interest subject to the burden of the covenant, we must look to the equitable jurisdiction of the court.

"There appears to be no authority which has decided, apart from the equitable cloctrine of notice, that the burden of a covenant will run with the land in any case, except that of landlord and tenant." 33

In other words the interest created in favor of the covenantee by such a covenant in the land bearing the burden thereof is, if any at all, an equitable interest and consequently, in the absence of express provision in the Acts, bas no place as a qualification of or incumbrance on the registered-or legal ${ }^{37}$ - estate. The means provided for the protection of such interests is the caveat, and it would appear, therefore, that the person entitled to the benefit of such covenant has, if any, a right to attach the land subject to the burden, by way of caveat. Now beginning with Tulk v. Moxhay ${ }^{38}$ the decisions establish with increasing clearness that such a covenant is not only one which it would be inequitable to allow a purchaser with notice to ignore, but is something which creates an actual interest in the land which can only be defeated-as can any equitable interest-on the ground of purchase bona fide for value without notice. The climax, as it were, of these decisions is in the cases of Rogers v. Hosegood ${ }^{39}$ and In re Nisbett and Potts. Contract. ${ }^{40}$ Rogers v. Hosegood was an application for an injunction against the breach of what are known as building covenants, made by the successor in title to certain land originally belonging to the original covenantee. The plaintiff had purchased without notice at the time of his purchase of these

\footnotetext{
${ }^{36}$ Smith's Leading Cases, 11th Ed. Vol. 1, page $8 S$, and cases there cited. Cf. Re Drew's Estate (Mason's claim), 35 Beav. 343, under Englisb Act of 1862 .

37 See paxe 123 .

382 Phill. 774.

${ }^{39}$ (1900) 2 Ch. 388.

${ }_{40}(1905) 1 \mathrm{Ch} .391$.
} 
covenants, but it was held that he was entitled to an injunction. Collins, M. R., reading the judgment of the Court of Appeal, after summing up the authorities, said:

"These authorities establish the proposition that, when the benefit has been once clearly annexed to one piece of land, it passes by assignment of that land, and may be said to run with it, as well in contemplation of equity as of law, without proof of special bargain or representation on the assignment of it. In such a case it runs not because the conscience of either party is affected, but because the purchaser has bought something that inhered in or was annexed to the land bought. This is the reason why, in dealing with the burden, the purchaser's conscience is not affected by notice of covenants which were part of the original bargain on the first sale, but were merely personal and collateral, while it is affected by notice of those hat touch and concern the land. The covenant must be one that is capable of running with the land be ore the question of the purchaser's conscience and the equity affecting it can come into discussion."

In Re Nisbett and Potts Contract, the question was as to the burden of covenants, and it was held that where a squatter has been in possession of land for the statutory time provided in the Statute of Limitations, he acquired whatever title he had, subject to the burden of a restrictive covenant in favor of the owners of adjoining land, although he had no actual notice of such covenant; and the purchaser from the squatter was similarly bound by such covenant, it being one which he would have become acquainted with if he had made reasonable inquiry into the title prior to that of the squatter. Collins, M. R., in the Court of Appeal, said:

"It seems to me, therefore, that the principal point of the discussion here is whether or not Sir George Jessel was right in the view that he took that an obligation created by a restrictive covenant is in the nature of a negative easement creating a paramount right in the person entitled to it over the land to which it relates. If that is so, then this gentleman by his squatting simply acquired a right to land subject to this incident." 
"The right created is an equitable right, and is one capable of bcing defeated by a person who acquires the legal estate for value; and the question therefore arises whether, in the circumstances of the case, there is something which would make it inequitable for that person to avail himself of his legal estate. That, as counsel for the respondent pointed out, is an inquiry which is inevitable in cases where we are dealing with equitable rights and legal estates. But that does not in the least prevent the right in question being what Sir George Jessel considered it to be-namely, a burden imposed upon the land, and passing with the land, subject, of course, to this-that it might be lefeated by a purchaser for value without notice, but, in order to defeat it, the burden would be upon the person who took the land to show that he had acquired it under such conditions as to defeat the right as against him-namely, that he had acquired it for value and without notice."

"Therefore, it seems to me that the law is clearly established in accordance with Sir Cicorge Jessel's view of that matter, and therefore that this burden did remain on the land binding upon any person who could not show that he had bought for value and without notice."

And Romer, L. J., said:

"I think the law is that such a covenant, when validly created, binds the land in rquity, and can be subsequently enforeed as against subsequent owners of the land, subject only to the limitation, that, heing equitable, it cannot be enforced as against a bona fide purchaser of the legal estate without notice."

Cozens-Hardy, L. J., also delivered a judgment entirely concurring in the same view, making the court unanimous.

These cases show clear ground for caveat on the ground of the covenantee having an equitable interest in the lands, but on the other hand, being equitable rights only, they are not entitled to indorsement on the certificate of title.

It will be observed that the two foregoing cases are both cases where the burden of the covenant is treated as a "negative easement" so that there were always two pieces of land involved. What the position would be where the covenant was merely 
personal, as in Formby v. Barker, ${ }^{41}$ is not so clear. In International Coal \& Coke Co. v. Evans, ${ }^{42}$ Stuart, J., at the trial considered it necessary to make an amendment to the claim alleging that the plaintiffs were owners of property entitled to the benefit of the covenant, in order that they might obtain an injunction, and the full court seemed to acquiesce in this view. It would appear that if there be not sufficient interest in the land to support an injunction, the case is not one for a caveat. But in the practice of the registry offices the view is accepted that as, under the old system, even such a covenant could have obtained the protection of notice by being contained in a registered deed, or where there is no registration system, by being contained in one of the title deeds, so under the Torrens system such rights should as far as possible be kept intact, and to permit such to be done by means of a caveat is doing no violence to the system.

It would seem to be the proper practice to reject such a transfer containing improper matter for registration in the shape of restrictive covenants, rather than to register the transfer ignoring the covenants. ${ }^{43}$

41 (1903) 2 Ch. 539.

${ }^{42} 9$ W. L. R. 711, affirmed 11 W. L. R. 463.

${ }^{43}$ Re Rumely Co. and Registrar Saskatoon L. R. D., 17 W. L. R. 160. 


\section{CHAPTER IX}

\section{TRANSMISSION}

§3. DEFINITION.

\section{\$ 37. PRINCIPAL CASES.}

a. Common to All Jurisdictions.

(1) CHANGE OF OWNERSHIP ON DEATH.

(a) In General.

(b) As Regards Estate and Beneficiaries.

(c) As Regards Third Parties Acquiring Rights from Personal Representatives.

(d) As Regards Registrar.

(2) CHANGE OF OWNERSHIP UPON SALE FOR TAXES.

(3) CHANGE OF OWNERSHIP UPON SALE UNDER EXECUTION AND JUDGMENT.

(4) CHANGE OF OWNERSHIP CONSEQUENT UPON THE ORDER OF THE COURT, OR OTHER ACT OF LAW.

b. Peculiar to Manitoba and Saskatchewan.

(1) CHANGE OF OWNERSHIP CONSEQUENT UPON ASSIGNMENT FOR GENERAL BENEFIT OF CREDITORS.

c. Peculiar to Manitoba.

(1) CHANGE OF OWNERSHIP UNDER FORECLOSURE OR SAIE UNDER MORTGAGE OR INCUMBRANCE.

d. Peculiar to Alberta, Saskatchewan and the Dominion.

(1) CHANGE OF OWNERSHIP CONSEQUENT UPON LUNACY.

(2) CHANGE OF OWNERSHIP UPON ANY SETTLENIENT.

§ 36. DEFINITION.

The term "transmission" under the Acts is used, generally speaking, in contrast to the term "transfer." The most comprehensive and at the same time, the 
most logical definition of the term is that found in The Real Property Act 1886 of South Australia, where transmission is defined as

"the passing of title to land in any manner other than by transfer."

The definitions in the Canadian Acts approach this meaning but in each case fall in some respects short of it. In Manitoba transmission applies to "every change of ownership under assignment for benefit of creditors or under foreclosure or sale under mortgage or incumbrance and to every involuntary change of ownership of land, mortgage or incumbrance." 1

In Alberta and the Dominion transmission applies to

"change of ownership consequent upon death, lunacy, sale under execution, order of court, or other act of law, sale for arrears of taxes or upon any settlement or any legal succession in case of intestacy,"

and in Saskatchewan the definition is the same as in Alberta with the addition of "assignment for the general benefit of creditors." ${ }_{2}$ In those latter jurisdictions the expression "transfer" is interpreted to mean

"the passing of any estate or interest in land under the Act whether for valuable consideration or otherwise."

This definition would include transmission and seems unnecessarily broad, and the Acts do not seem to disclose where anything would have been lost by distinguishing carefully between transfer and transmission. The Acts other than Manitoba lose in accuracy by attempting to define transmission, simply by tabulating the cases to which the word applies without attempting to lay down any principle of distinction. If there is to be a difference between transfer and transmission, change of ownership under statutory order of foreclosure or statutory transfer under power of sale should be included in

1 Man. 2.

${ }^{2}$ Alta. 2 (u); Dom. 2 (23); Sask. 20. 
transmission, while on the other hand the use of the word "gettlement" is confusing. If a "settlement deed" in the ordinary meaning of that word were presented to the registrar for registration, it would assuredly and properly be rejected, either, on the one hand as declaring trusts, which the registrar could not recognize, or on the other hand as not being in any form prescribed by the Acts. The word has probably been taken from certain of the Australian Acts, which have established provision for the "deposit for safe custody and reference" of such trust deeds and deeds of settlement, which practice has no counterpart in the Canadian Acts. ${ }^{3}$

The distinction in any case between transmission and transfer is rather one of terminology, as there does not appear to be any feature common to all cases of transmission. In some cases the holder of a new certificate of title, as for example, a purchaser under execution, would have all the protection yranted to a registered owner bona fide for value. In other cascs, such as an executor or administrator, the new registered nwner holds subject to all cquitios binding the prior registered owner. It has been suggested that the difference lies in the fact that transmissions are not mere matters of routine in the registry office but require more deliberation on the part of the registrar. This is the result of the distinction rather than the distinction itself, so far as it is true at all. Transmission is effected in Manitoba upon an application, which in itself is not of any conveyancing value except to set clearly before the registrar the documents produced, and the nature of the request. In the other jurisdictions there is no general provision as to the method of transmission, each case depending on the statutory rules relating to it.

${ }^{3}$ New South Wales 1900, § 36; Queensland 1861, § 35; New Zealand 1885, § 33; South Australia 1886, § 57. 


\section{§ 2. PRINCIPAL CASES.}

\section{a. Common to All Jurisdictions.}

\section{(1) CHANGE OF OWNERSHIP ON DEATH.}

\section{(a) In General.}

In all the jurisdictions land, upon the decease of the owner, passes to his personal representative. ${ }^{4}$ While this is not a necessary adjunct to the system on principle, nevertheless in practice it conduces very greatly to the simplicity and workability of the scheme of the Acts. In jurisdictions other than Manitoba, the evidence of intestacy and the appointment of the personal representative required is specifically prescribed in the Act itself, and provision is made for the acceptance of probate or letters of administration either granted by the proper court of the province or resealed by that court. The original or an exemplification thereof is presented to the registrar together with a sworn copy, the original being returned to the applicant and the sworn copy being retained. In Manitoba the acceptance of letters probate or of administration follows from R. S. M. 1902 , c. $41, \S 9$.

The ownership of the executor or administrator may be considered from three points of view. First, as regards the estate and the beneficiaries; secondly, as regards third parties; thirdly, as regards the registrar.

\section{(b) As Regards Esiate and Beneficiaries.}

First, as regards the estate and beneficiaries, "any person registered in place of a deceased owner shall hold the land in respect of which he is registered upon the trusts and for the purposes to which the same is applicable by this Act or by law and subject to any trusts and equities upon which the deceased owner held the same." 5

${ }^{4}$ R. S. M. 1902 , c. $48, \S 21$; R. S. S. 1909 , c. $43, \S 21$; L. T. Act, $\S 108$; Alta. 1906, c. $19, \S 2$; Dom. L. T. Act, $\S 5$.

- Sask. 114; Alta. 70. In Manitoba necessarily implied by the absence of any provision to the contrary, and by section 69 . 
And in Saskatchewan, Alberta and the Dominion, it is provided in the Acts that upon application by any person beneficially interested, the court or judge having jurisdiction may take the land out of the hands of the trustee having charge by law and transfer it to some other person or persons who shall give security, and the judge may then order the certificate of title to the old trustee to be cancelled and a new one issued. There is nothing, therefore, in the Act to relieve the executor or administrator or his bondsmen from the ordinary liability to parties interested for breach of duty. As stated by McGuire, J., delivering the judgment of the Territorial Court on appeal in Willie v. Jellett, ${ }^{6}$

"The Act provides for a person having no beneficial interest in the land being registered as owner; for example, section 91 allows the personal representative of a deceased owner to apply for and obtain a certificate of title of such land and he is thereupon 'deemed to be the orner.' Now then, for the purpose of registration, doubtless, he would be treated as the owner, so that if he executed a transfer or mortgage, such instrument would be dealt with by the registrar exactly as if he were the absolute beneficial owner But it would assuredly not be contended for the moment that if an executor contemplated dealing with the land contrary to the interests of the devisee, the latter could not by injunction or order, restrain him from so doing."

(c) As Regards Third Parties Acquiring Rights from Personal Representatives.

In the Acts other than Manitoba it is distinctly provided that upon the memorandum of transmission being made, the executor or administrator shall "be deemed to be the owner of the land," the certificate of title of the land shall be issued to him and for the purpose of any registered dealings with such land he sha!l be deemed to be the absolute and beneficial owner.7

s 2 Terr. L. R., at page 144.

Sask. 109, 111, 114; Alta. 74, 76. Dom. 115, 117, 121. 
In an Australian case in the Supreme Court of Victoria ${ }^{8}$ where the position of the executor under their Act is similar to that in Saskatchewan and Alberta, the plaintiff, one of the next of kin, brought an action to set aside a mortgage made by the administratrix to secure her own personal debt and the supreme court held that it was incumbent on the plaintiff to show actual dishonesty on the part of the mortgagee. Williams, J., said:

"The question to be asked in these cases is this-Did the defendant purchase honestly (bona fide) and for valuable consideration? If he did, he acquires an indefeasible right. Except for the contention of constructive notice of a breach of trust, there appears to be no ground whatever for arriving at the conclusion that the defendant in this case did not deal honestly and for valuable consideration. He may have acted in ignorance of the law, he may have had unsound legal advice as to his legal position, and yet may have acted in perfect innocence of the fact that he was running any risk of making himself privy to a breach of trust."

The person acquiring an interest from the executor is protected unless he deliberately and knowingly makes himself a party to a breach of trust.

In Alberta the question has been considered by Mr. Justice Stuart in St. Germain v. Reneault. ${ }^{9}$ In that case an executor had given an option in a lease which the learned judge found, independently of The Land Titles Act, would have been incapable of being ordered to be specifically performed. The lease was registered and the option was contained in the lease under the provisions of section 54. Dealing with section 76 , the learned judge said:

"As regards him (the lessee) the administratrix could not be deemed to be the absolute and beneficial owner of the land, because the dealings between him and the administratrix were not 'registered dealings' at all until he by his own act only had made them so. It may indeed be the ease, that a person pui chasing the lease from Boudreau, after it had heen registered,

8 Gregory v. Alger, 15 A. L. T. 22.

912 W. L. R. 169. 
a person finding it so registered and containing that clause, and acting upon the faith of such registration would be entitled to claim the benefit of the section and to say that for the purposes of this registered lease with the option clause contained in it, the administratrix must, in his (the purchaser's) favor, be deemed the absolute and beneficial owner of the land, and so fully competent to grant the option."

This decision, however, seems to establish an extraordinary division of transactions at the moment of registration. It seems to overlook the fact that for the purpose of The Land Titles Act, the registration is the dealing and that the instrument has not taken effect or the estate been created till registration. It would in effect repeal The Land Titles Act so far as it abolishes the doctrine of constructive notice. The rights of a bona fide purchaser would first be determined, upon general principles of equity, prior to registration, when the claim of such purchaser might be unenforceable by reason of some equitable doctrine, such as that of constructive notice. Such purchaser would then register his transfer, but, according to this decision, he cannot "by his own act" tum a roidable title into an unimpeachable one. But this is to nullify the Act. In the Court of Apjeal in New Zealand under similar circumstances, the enforcement of such an option has been held to be the enforcement of a statutory right lawfully created and not the enforcement of a breach of trust. Edwards, J., delivering judgment of the court, said:

"The mere fact that a person dealing with a registered proprietor linows that such registered proprietor is a trustee under a will certainly does not make it necessary to make inquiry as to his powers unless there is something in the nature of his dealings with the trust property to give notice of the fact that he is dealing fraudulently with it." 10

And this decision was expressly approved in Horne v. Horne. ${ }^{11}$

${ }^{10}$ Fels v. Knowles, 26 N. Z. L. R. 604.

1126 N. Z. L. R. C. A. 120 S. 
In Manitoba (section 69) the executor or administrator by specific enactment holds subject to the trusts of the will or administration even for the purposes of the Act. The law therefore in regard to dealings by such with third parties is the ordinary law without special reference to The Real Property Act.

\section{(d) As Regards the Registrar.}

The position of the registrar with reference to a certificate of title in the name of a personal representative is radically different in Manitoba from that in the other jurisdictions. In Manitoba it is specifically enacted (section 69) "that before registering any dealings with the land, the district registrar shall satisfy himself that such dealing is in accordance with such trusts or purposes," that is to say, the trusts and purposes for which the land is subject in the hands of the personal representative. The duty of the registrar in Nanitoba, therefore, in passing upon a transfer or mortgage made by an executor or administrator, is determined by the principles of law governing the dealings of executors with the estate, ${ }^{12}$ and is not in any way peculiar to the Torrens system. The registrar, under the Act, must make further inquiries than would be necessary by a bona fide mortgagee. For example, such a mortgagee would be entitled to assume, in the absence of notice to the contrary, that there were debts for which it was necessary that the personal representative should mortgage the estate. The registrar on the other hand must satisfy himself that there are in fact such debts, and that the personal representative is acting within his rights, independently of any presumption that may arise in favor of a third party. In the result in Manitoba, as instruments take effect only from registration, the bencficiaries of an estate ${ }^{12}$ Re Simon, 14 W. L. R. 56. 
obtain apparently a greater protection than, for example, in Ontario where all lands pass in the first instance to the personal representative, but without his transactions necessarily having to pass the scrutiny of a district registrar.

The extreme in the other direction is reached in Saskatcherran, Alberta and the Dominion. In those jurisdictions "for the purpose of any registered dealings with the land, the executor or administrator shall be deemed to be the absolute and beneficial owner thereof." 13 The extent to which this f:eedom of action by the personal representative in the registry offices is carried, is well illustrated by a case where the executor was also the beneficiary of land under the same will. There was filed in the land titles office at the time an execution against the executor personally. A transfer from the executor as such was produced to a third party and registered free of the execution, and on reference to the full court this action was sustained..$^{14}$

In Victoria it was provided that "executors shall become the transferees of the equity or interest of the deceased proprietor, and shall hold the same subject to equities upon which the deceased held the same, but for the purpose of any dealings with such land every executor, administrator or curator shall be deemed to be the absolute proprietor thereof." 15 But notwithstanding these apparently very distinct words, the Full Court of Victoria has taken into consideration the right of an administrator to sell, the case in point deciding that the registrar had no right to raise an objection not disclosed by the papers before him. ${ }^{16}$ And notwithstanding these words the Acts recognize some distinction in the ownership

${ }^{13}$ Sask. 114; Alta. 76; Dom. 121.

14 Re Galloway, 3 Terr. L. R. ss.

15 Transfer of Land Act, 1990 (Victoria), \$ 193.

18 Ex parte the Equity Trustee and Agency Co., Ltd. and O'Halloran (1911) V. L. R. 197. 
of an executor and that of an owner personally. The description of a party as executor is more than a mere addition. An administrator may make a transfer to himself to get a clean certificate. ${ }^{17}$

(2) CHANGE OF OWNERSHIP UPON SALE FOR TAXES.

The proceedings for the registration of a title gained through a tax sale differ radically in Manitoba from the proceedings in the other jurisdictions. $^{21}$ In Manitoba the registrar examines the tax title and notifies the party interested, and in fact carries on all the proceedings with a view to redemption or disclosing any irregularity in the title of the purchaser. In the other jurisdictions, on the other hand, the whole question of the validity of the proceedings is taken out of the hands of the registrar and placed in those of a judge acting as persona designata under the Acts. All that the registrar has to do in such case is to read the order of the judge, when made, confirming the transfer. In Manitoba the registrar gives notice to the parties to redeem the land, if it is open for redemption. In Saskatchewan redemption may be effected upon the confirmation proceedings before the judge, and the general Act is sufficient to extend the privilege of redemption to all cases, ${ }^{22}$ but redemption must be offered before the actual hearing. ${ }^{23}$ After the tax transfer has been confirmed in Saskatchewan and Alberta it must be presented for registration within two months, unless the period be extended by order of the court or judge, ${ }^{24}$ and upon being deposited in

${ }_{17}$ Iosken v. Danaher, (1911) V. L. R. 214 (full court); Re Lockhart, 20 W. L. R. 413; Re Galloway, 3 Terr. I. R. 88. Compare Re Moore and Confederation Life Association, 9 Man. L. R. 453, as explained in Pearson v. O'Brien, 1 W. W. R. 1026; 20 W. L. R. 510.

${ }^{21}$ Man. 46, 47, 48; Sask. 124; Alta. 82; Dom. 130.

${ }^{22}$ North British Investment Co. v. St. John School District, 35 S. C. R. 461.

${ }^{23}$ In Re John Baker, 1 S. L. R. 7.

"Sask. 122; Alta. 80; Dom. 128; Re Donnelly Tax Sale, 5 Terr. L. R. $27 \mathrm{C}$. 
the land titles office, the transfer must lie there for a period of four weeks before the purchaser is registered as absolute owner. This four weeks, however, is not to extend the period of redemption, but merely to permit of appeal and an order stopping registration in the meantime; neither does it permit of other registrations coming ahead ${ }^{25}$ - that is to say, the purchaser's transfer, when registered, operates on the register as it stood at the time of the original deposit of the tax transfer.

The rights of a purchaser, as against the holder of a tax transfer unconfirmed, have already been touched on. A sale for taxes pays the taxes, ${ }^{26}$ and it would seem, therefore, to be reading a great deal into the words "unpaid taxes" in Saskatchewan and Alberta"i to say that these words include "transfers under sale for taxes." especially in view of the fact that in those jurisdictions it is specifically enacted that a tax purchaser may, further, after his purchase lodge a careat. If such a purchaser be protected in any case, it is hard to understand why this special provision should be enacted providing that he may lodge a careat.

(3) CHANGE OF OWNERAHIP UPON SALE UNDER EXECLTION AND JUDGIENT.

Here again the practice differs in Manitoba on the one hand, and in the remaining jurisdictions on the other.

In Manitoba the writ of execution or fier i facias is not used to reach land. By The Judgments Act, R. S. M. 1902, c. S0, it is provided that immediately upon any judgment for parment of money being entered or recovered in the Court of King's Bench a certificate of such payment may be recorded in any and all the registry offices or land titles offices of the

${ }^{25}$ Re Clendenan, 1s O. W. R. 666.

${ }^{26}$ Ponton v. City of ITimipeg, 41 S. C. R. 18.

27 Sask. 66; Alta. 43; Man.70. 
province, "and, from the time of the recording of the same the said judgment shall, except as thereafter mentioned, bind and form a lien and charge on all the lands of the judgment debtor in the several districts in the registry offices and land titles offices in which such certificate is recorded the same as though charged in writing by the judgment debtor under his hand and seal." The judgment upon the filing of this certificate is made a lien by The Judgments Act and attaches all land, exempt and otherwise. $^{28}$ Proceedings to realize on the lien so created are taken by separate action and when the property is sold and vesting order obtained the order is brought into the district registrar's office if the land sold is under the new system, and if regular (section 52 proviso) is registered. So far as The Real Property Act is concerned the lien is treated in the same manner as any other lien and the effect of filing the certificates is merely to preserve the priority of the lien.

In Saskatchewan and Alberta ${ }^{29}$ the writ of fieri facias directed against lands is used. The local registrar or clerk issues the writ, directed to the sheriff, who upon its delivery to him is required to transmit forthwith a copy thereof to the registrar, the costs of which are included in the costs of writ in the clcrk's office. In Alberta "no lands shall be bound by any such writ until the receipt by the registrar for the registration district in which such land is situated, of a copy thercof" (section 77), and in Saskatchewan "such writ shall bind the land covered thereby only from the time of the receipt of a certified copy thereof by the registrar for the registration district in which such land is situated" (section 118, par. 2). The wording of the Saskatchewan Land Titles 4 ct 1906 was the same

${ }^{28}$ Frost v. Driver, 10 Man. L. R. 319; Roberts v. IIartley, 14 Man. L. R. 284.

${ }^{29}$ Sask. 118 and following; Alta. 77 and following. 
as that of the Alberta Act prior to the amendment of 1908 , c. $29, \S 10$, but the meaning of the two sections appears the same. The filing of a copy of the writ in the land titles office is that which gives the writ its effect as against land:

"In the Territories a judgment is not a lien upon land. Whatever effect it obtains is through the filing of the execution in the land titles office." 30

"As I pointed out in Bocz v. Spiller, 1 W. L. R. 366, a judgment is not a lien upon land in this province, and it is only by virtue of an execution against land that such a lien can be ob̆tained." 31

The dictum of Scott, J., delivering the judgment of the full court in Limoges r. Campbell must be taken to be overruled, where he said:

"I see no reason why lands could not at the time The Territories Real Property Act was in force, have been sold under execution and a certificate of title issued to the purchaser from the sheriff without a copy of the execution having been delivered to the registrar under section 94, provided, of course, the land had not been dealt with by the judgment debtor prior to the registration of the transfer from the sheriff." ${ }_{32}$

Upon being so filed the writ "binds" the land covered thereby-(being all the land of the execution debtor within the bailiwick of the sheriff to whom the writ is directed) -- that is to say; "creates a charge" upon it.

"In my opinion the delivery of an execution to the sheriff to be executed creates a lien upon the execution debtor's property, or, to adopt the wording used in Woodland r. Fuller, $11 \mathrm{~A}$. and E., at pages 687,688 , 'a charge.' The lien of an execution, like other liens, does not of itself transfer title. It does not change the right of property and rest it at once in the plaintiff in execution, nor in the officer charged with the execution of the writ. It confers, however, the right to levy on the property, to the exclusion of all transfers and liens made by the

${ }^{30}$ Bocz v. Spiller, 1 W. L. R. 366, affirmed 2 W. L. R. 2S0. See, also, Evans v. Postill, 3 A. L. R. 141.

${ }^{31}$ Frederieks v. Northwest Thresher Co., 3 S. L. R. 280, Newlands, J.; Canadian Pacific Railway Co. v. Silzer, 3 S. L. R. 162, at page 169. See, also, Evans v. Postill, 3 A. L. R. 141.

322 Terr. L. R. 356, at page 374 . 
defendant subsequent to the commencement of the execution lien, subject to some statutory exceptions." 33

"In the next place it provides that "no land shall be bound by any such writ or process until such copy and memorandum have been so delivered.' Surely that must mean that when the copy and memorandum are delivered the land shall be bound. What is that but charging the land?" "34

It has been laid down in the recent decision of Fredericks v. Northwest Thresher Company ${ }^{35}$ that the effect of the filing of the execution in the land titles office is to constitute a seizure of all the lands of the execution debtor which may be subject to the writ. Mr. Justice Newlands said:

"I can, therefore, come to no other conclusion than that by delivering a copy of the writ to the registrar the sheriff seized all the land of the judgment debtor, and that the registrar by making the memorandum required by the Act on the certificate of title is notifying the judgment debtor that that piece of land has been seized by the sheriff under the writ."

This holding is at variance with a number of reported decisions touching the same point. In McDonald v. Dunlop, Scott, J., said:

"Such registration cannot be construed as a seizure or anything equivalent thereto." ${ }^{36}$

In Re Land Titles Act and Blanchard Estate, McGuire, J., delivering the judgment of the Territorial Full Court, said:

"The sheriff in delivering copy of execution to the registrar does so, not with any intention of seizing the land, but simply in compliance with The Land Titles Act. I cannot consider such an act as a seizure or an inception of execution of the writ and especially is this clear since The Land Titles Act of 1894 , because under that Act the sheriff is not required to specify the land intended to be bound as was the case under The Real Property Act." 37

${ }^{33}$ Deering v. Gibbon, 7 W. L. R. 178, Beck, J., at page 180.

${ }^{34}$ Re Claxton, 1 Terr. L. R. 282 (full court), Wetmore, C. J., at page 287.

See, also, Limoges v. Campbell, 2 Terr. L. R. 356 . See, also, for the effect of the word "bind," 11 Ruling Cases 549-621.

${ }^{35} 3$ S. L. R. $280 ; 15$ W. L. R. 66 , affirmed 44 S. C. R. 318.

3s 2 Terr. L. R. 238 , at page 243 .

${ }^{37} 5$ Terr. L. R. 240 , at page 244 . 
And in Rcliance Loan and Savings Company v. Goldsmith, Harvey, J., said:

"It is clear, however, from Re Blanchard, 5 Terr. L. R. 240, that such filing, even if the debtor owned the land at the time, would not constitute a seizure or inception of execution of the writ." 38

And in Trust and Loan Company of Canada v. Cook, Lamont, J., said, referring to certain executions which had been filed as required by The Land Titles Act:

"In this case the sherifi made no seizure whatever." 3

And subsequently to the decision under discussion, Wetmore, C. J., in an application to confirm the sheriff's transfer upon a sale under execution, laid down what, it is submitted, is the correct view:

"The deputy sheriff in his affidarit stated that the property in question was seized on 29th September, 1910. That happened to be the day of the sale. There must have been some mistakr on the part of the deputy unless he imagined that there was no scizure until the date of the sale. I am of op:nion that in the case of lands no corporal seizure is necessary, and, if it were necessary, the seizure, or what was equivalent thereto, in this case, was made in June, when the advertisements were posted and published-whichever may have happened first. Doe d. Hazen v. Hazen, 3 N. B. R. 87." ${ }^{40}$

The decision of the learned trial judge in Fredericlis v. Northucest Thresher Company was confirmed on appeal to the Supreme Court of Canada, but Idington, J., delivering the judgment of the same court, ${ }^{41}$ entirely refrained from basing his judgment upon that part of the reasoning of the judgment of the trial judge regarding the effect of filing the execution as a seizure or from discussing the appellant's counsel's argument on this point.

${ }^{38} 15$ W. L. R. 55, at page 57.

393 S. L. R. 210 , at page 212 .

${ }^{40}$ Re Shere, 16 W. L. R. 27. The same practice was laid down by the same judge in Limoges v. Camplell, 2 Terr. L. R. 356, at page 367, where lie carcfully distinguished between the seizure by advertisemont and the "binding" previously, up to the filing of the writ.

${ }^{41} 44$ S. C. R. 318, under name Northwest Thresher Co. v. Frederichs. 
And it is submitted that the reasoning of the learned trial judge in Fredericks v. Northwest Thresher Company is unnecessary in view of the ratio decidendi of the long line of cases which have held that a homestead may be sold or claimed by the execution debtor, free of execution, not because it has not been seized, but because, being incapable of being seized while a homestead, the execution does not bind or form a lien on it; or as stated in Bocz v. Spiller, by Newlands, J.:

"As the execution creditors could not seize this land under the writs of execution, I do not think that they have any rights therein with which this land can be charged under The Land Titles Act, and therefore, although registered under it, these executions are not incumbrances to which it is subject and on the sale of the same under mortgage the land would vest in the purchaser, free from incumbrance." ${ }^{42}$

If it is the actual seizure only which gives an execution any "binding" effect, how can it arise that the execution attaches a homestead when the exempt owner abandons it? ${ }^{43}$ It can hardly be that the sheriff unconsciously in the night watches, as it were, makes a seizure by reason of some act done by an utter stranger to him far away from his office and of which he may be in entire ignorance for years.

It has been held in Saskatchewan that executions bind only registered interests in land, and do not bind or affect an equitable interest, as, for example, one held by way of contract from the registered owner. ${ }^{44}$ This conclusion was

${ }^{42}$ Bocz v. Spiller, 1 W. L. R. 366, at page 367. See, a!so, Re Dumaurez, 5 Terr. L. R. 84; Meunier v. Doray, 2 W. I. R. 231; John Abell Engine and Machine Works Co. v. Scolt, 6 Terr. L. R. 302; 6 W. L. R. 272; Purdy v. Colton, 7 W. L. R. 820; Union Bank of Canada v. Jordan, 8 W. L. R. 77; Baker v. Gillum, 9 W. L. R. 436; Gilmore v. Callies, 19 W. L. R. 545; IIamilton v. MeCuaig, 18 W. L. R. 84, as to what is a homestead within the meaning of The Exemption Ordinance: Re John Abell Engine and Machine Works Co., supra; Imperial Elevator Co. v. Shere, 3 S. I. R. 197; In re IIetherington, 3 S. L. R. 232.

${ }^{43}$ Gilmore v. Callies; In re IIetherington, ante.

* Canadian Pacific Railway Co. v. Silzer et al., 3 S. L. R. 162. Approved Ranney v. Stirrett, 18 W. L. R. 5. 
arrived at by an examination of sections 118-123 of the Act, from which the learned judge gathered that the intention was to deal in those sections with the registered interest only. As touching, however, section 125 of the Act, permitting an execution creditor to file a caveat against land in which the execution debtor is interested beneficially, but which stands in the name of some other person, the reasoning is not satisfactory. To file a caveat, the caveator is required to state that he claims an interest in the land, and to swear that the allegations are true, and it could hardly be supposed that the legislature would suggest that a party may make such a claim on affidavit, when as a matter of fact he had no claim or interest in the land whatsoever. It has been previously pointed out, that there is a distinction between the "binding" effect of an execution and a "seizure" under an execution. Admitting, therefore, that the sheriff cannot seize an equitable interest, it does not seem unreasonable to hold that the filing of an execution may "bind" such equitable interest, while at the same time, as regards the registrar, who ean only deal with registered intcrests, the memorandum of the execution can only be made where the execution debtor appears as having a registered interest.

On the other hand it must be admitted that the reasoning in C.P.R. v. Silzer is closely parallel with that in two Victorian cases, neither of which, however, appear to have been cited either on the argument or in the judgment..$^{55}$ The Tictorian Act prorides for the entering of the writ on the "register," that is the certificate of title, having no provision for "filing" as in Saskatchewan; and it has no such indication of the scope of an execution as in section 125 of the Saskatchewan Act. But the principles of

15 Watson v. Royal Permanent Building Socicty, 14 V. L. R. 283; Richards v. Cadman, 17 V. J. R. 203. 
the Canadian and the Australian decisions are largely the same. The latter cases arose under the section of the Victorian Act, so far as material, as follows:

"No execution registered prior to or after the commencement of this Act shall bind, charge, or affect any land or any lease, mortgage or charge; but the registrar on being served with a copy of any writ of fieri facias issued out of the Supreme Court or of any decree, or order of the Supreme Court (or of a. county court in its equitable jurisdiction), accompanied by a statement signed by any party interested or his attorney, solicitor, or agent specifying the land, lease, mortgage, or charge sought to be affected thereby, shall, after marking upon such copy the time of such service, enter the same in the register book; and after any land, lease, mortgage, or eharge so specified shall have been sold under any such writ, decree, or order, the registrar shall, on receiving a transfer thereof in such one of the forms in the Fifteenth Schedule hereto as the case requires (which transfer shall have the same effect as if made by the proprietor), enter such transfer in the register book; and on such entry being made the purehaser shall become the transferee and be deemed the proprietor of such land, lease, mortgage, or eharge."

In Watson v. Royal Permanent, S. E. Smith, being owner of land, had mortgaged it to the defendant loan company, giving an absolute transfer, which was registered, and taking back a deed of defeasance. Her interest was therefore equitable. On the 22nd of July, 1888, a writ of execution against S. E. Smith was served on the registrar mentioning "the equity of redemption of S. E. Smith" in the land, describing it. On August 20, 1888, S. E. Smith sold to M. E. Smith, a bona fide purchaser. On August 31st the plaintiff bought the equity of redemption at the sheriff's sale. M. E. Smith filed a caveat and the plaintiff brought his action to compel the defendant loan company to convey to him, and M. E. Smith to withdraw her caveat. The action failed on the ground that the mortgagor's interest could not be affected by any proceedings by the execution creditor under section 106 - the section quoted. Subsequently, 
in Richards v. Cadman, the same judge affirmed his previous conclusion that until there was a folio of the register upon which to enter it, in other words, until there was a registered interest on which to operate, proceedings by the creditor under the section quoted were inoperative.

In Manitoba, on the other hand, the meaning of "land" as set out in the interpretation section of The Judgments Act has been accepted as the test of the interests which are bound by a judgment, and consequently where the interest of a debtor in land held by another under certificate of title but by way of mortgage, was sold under a judgment, the judgment took priority over a sale made by the mortgagee owner, except as to the deposit paid before notice. ${ }^{46}$

Notwithstanding that instruments shall be entitled to priority, the one over the other, according to the time of registration, the provisions of The Creditors Relief Act apply to executions against lands, which share pro rata and in order of priority; ${ }^{47}$ but only as regards those executions standing consecutively on the register. Where, by an intervening instrument, the creditor has mortgaged or incumbered his land, a subsequent execution creditor has not a charge on the same interest in the land as the prior execution creditor, and the first execution creditor is paid in full, then the incumbrancee, and then the subsequent execution creditors, pro rata $;^{48}$ and much more, if the execution debtor has disposed of his land, the subsequent execution creditors do not come in under the first execution. ${ }^{49}$

45 Wrallace v. Smart, 19 W. L. R. 7S7.

${ }^{47}$ Thompson v. Berglund, 3 S. L. R. 470, 16 W. L. R. 154.

${ }^{48}$ Edmonton Mortgage Co. v. Gross, is W. L. R. 385, applying the principles involved rather than the precise reasons adduced in the cases of Roach v. McLachlan, 19 A. R. 486; Breithaupt v. Marr, 20 O. A. R. 689 ; Re Massey, 2 Terr. L. R. S4; Howard v. High River Trading Co., 4 Terr. L. R. 109.

${ }^{49}$ Trust and Loan Co. of Canada v. Cook, 3 S. L. R. 210. 
The execution, or in Manitoba, the certificate of judgment, binds only the actual interest of the execution debtor in the land, notwithstanding the execution debtor may have the whole registered interest. The contrary was originally laid down as the law in Re Rivers. ${ }^{50}$ In the foot note to that case in the report, it is pointed out that, even in the light of subsequent cases, the decision in that case was correct, being merely a matter of direction to the registrar. But, as explained in Taylor v. Robertson, ${ }^{51}$ it is evident that the case was looked on as authority in the matter of substantive law, and not merely as a matter of practice. Davies, J., delivering the judgment of the Supreme Court of Canada in the latter case, said:

"At the time the action against Jellett and Robertson was brought and up to the delivery of judgment therein by the Supreme Court of the Territories, the case of Re Rivers was supposed to have correctly declared what the law was as to the effect of registered executions upon unregistered cleeds. Mr. Justice Rouleau, who was himself a party to the judgment in Re Rivers, in giving judgment on the trial of the case now before us in appeal, says:

"'In Re Rivers, the language of the court, as expressed by Wetmore and McGuire, J. J., is not equivocal. It was held that an unregistered transfer had not passed or affected the land and that an execution registered against the registered owner had priority and that such transfer could not be registered afterward, except subject to such exccution."

The subsequent case, however, of Willie v. Jellett, ${ }^{52}$ has finally and effectually settled the law on this point; and the law as decided in Wilkie v. Jellett remains the same notwithstanding the change in the wording of the section prescribing the effect of the filing of an execution. ${ }^{53}$ The same law had

${ }^{50} 1$ Terr. L. R. 464.

6131 S. C. R. 615.

${ }^{62} 26$ S. C R. 282 , affirming 2 Terr. L. R. 133 ; citing and approving National Bank v. Morrow in the Supreme Court of Victoria, Australia, 13 V. L. R. 2.

${ }^{53}$ Sawyer and Massey v. Waddell, 6 Terr. L. R. 45. 
previously been laid down in Manitoba in Re Massey and Gibson ${ }^{54}$ though in that case the actual result turned on the lack of jurisdiction of the registrar to entertain the application; and in British Columbia the same conclusion was arrived at in Yorkshire Guarantee and Securities Corporation v. Edmonds. ${ }^{55}$

Upon the question of procedure the law as laid down in the case of Re Massey and Gibson, supra, is still the law in Saskatchewan and Alberta, that is to say, the registrar "cannot inquire into the existence of a beneficial interest apart from the registered title in order to ascertain whether the writ of execution binds the land. The remedy is to be found only in a court of equity.'

In Manitoba, by section 87 of the Act, the registrar has been given jurisdiction to take evidence upon oath to decide whether the certificate of judgment does or does not affect the land, the proceedings being begun in practice by a notice to the execution creditor to show cause why the transfer or incumbrance presented for registration should not be registered in priority to his execution.

An exceution in Saskatchewan and Alberta is registered, strictly speaking, as distinguished from being filed, only upon being indorsed on a duplicate certificate of title, ${ }^{56}$ which is required to be done upon the granting of any certificate of title or registration of any transfer, mortgage or other instrument executed by the execution debtor. It is at this point that the execution creditor in practice runs considerable risk of losing the benefit of his exccution. If the memorandum of execution be not indorsed on a new certificate of title the new owner would be entitled to rely on his duplicate certificate of title as evidence of his ownership of the land, free

${ }^{54} 7$ Man. I. R. 172.

557 B. C. R. 34 S.

${ }^{56}$ Sinvyer and Massey $\nabla$. Waddell, 6 Terr. L. R. 45. 
of the execution. In Saskatchewan it has been determined that the assurance fund will not be liable to the execution creditor unless there be a very exact similarity between the name and address of the execution debtor and the name and address of the transferor. Thus, it has been held that the registrar was not liable for an omission to register an execution against W. A. Matheson of Denver, Colorado, upon land owned prior to the transfer thereof by William A. Matheson, of Westview, Saskatchewan. ${ }^{57}$ It may be admitted that this decision is strictly logical, but were it to be closely followed, as is fortunately not the case, it would be extremely desirable that there should be some legislation whereby execution creditors' rights, in a new country with a migratory population, should be given reasonable protection. It is submitted that the actual practice of the registrars in assuming an identity of parties, till the contrary is shown, from a substantial similarity of name or address, is more in accordance with a reasonable protection of creditors' interests, even if an innocent party, as often happens, may suffer annoyance from being confused with one of a similar name, than to demand actual identity of name and address.

Renewal of the execution must be filed within two years of the date of the receipt of the execution, otherwise the same ceases to bind the land, and so on with each successive period of two years, and upon the satisfaction or withdrawal thereof the sheriff is required to file a certificate thereof in the land titles office, and the registrar shall mark the execution as withdrawn. In Alberta, section 78 is not quite so clear as the corresponding scetion 120 of the Saskatchewan Act, as although the sheriff is not directed to forward a certificate of expiration of a writ, the registrar is directed

57 Sievell v. Haultain, 18 W. I. R. 388. 
to enter a memorandum of expiration upon production of the certificate thereof. In practice, however, it is not customary to forward any such certificate of expiration, merely relying on the provisions of the Acts, which automatically render the execution of no effect after the expiration of two years from the filing thereof. The costs of such certificate of withdrawal or satisfaction must be paid by the creditor, ${ }^{58}$ unless the money has been made out of the land, or unless the certificate is sent at the request of the debtor under circumstances which did not require the sheriff to have filed such certificate.

The procedure to sell under execution is a matter of the general law, but before any sheriff's transfer can be registered the same must be confirmed by a judge acting as persona designata under The Land Titles Act. Confirmation against an owner will be refused unless all the formalities have been strictly complied with. ${ }^{59}$ The proceedings for confirmation are proceedings under the Act but they may, nevertheless, be intituled in the court. Affidavits, however, must be taken before the persons prescribed in The Land Titles Act and not pursuant to The Judicature Act. ${ }^{60}$ And in the case last cited, Wetmore, J., allowed an affidavit sworn before a wrong party to be resworn, saying:

"Sitting as I am in this matter as persona designata, I am not as strictly bound by the technical rules as I would be if I was dealing with a matter in the court."

The transfer must be registered within a period of two months from the date of the order or within such period as may be prescribed by an order of the court or judge filed with the registrar within such period of two months. The costs of the confirmation proceedings are borne out of the purchase money.

${ }^{58}$ In re Brown, 3 S. I. R. 94.

${ }^{59}$ Re Shere, 4 S. L. R. 51.

${ }^{60}$ John Abell Engine and Machine Works Co. v. Scott, 6 Terr. L. R. 302. 
The transfer together with the order of confirmation must remain in the registry office for a period of four weeks, which four weeks form part of the two months within which the transfer must be registered. The transfer relates back to the date of the registration of the writ. ${ }^{61}$

(4) CHANGE OF OWNERSHIP CONSEQUENT UPON THE ORDER OF THE COURT OR OTHER ACT OF LAW.

This case calls for no special treatment.

b. Peculiar to Manitoba and Saskatchewan.

(1) CHANGE OF OWNERSHIP CONSEQUENT UPON ASSIGNMENT FOR GENERAL BENEFIT OF CREDITORS.

Provision is made in the Acts for the registration of the assignee for the general benefit of creditors. ${ }^{62}$ Such an assignment may be registered and is noted in a special book kept for the purpose. This first deposit of the assignment is inaccurately called "registration" in Alberta, the better term being "filed," as in Saskatchewan, as the document is not at this stage indorsed upon any certificate of title. It is specifically prescribed in the Saskatchewan Act that from and after the receipt by the registrar of such assignment, he shall not permit any dealings with any such land, mortgage or incumbrance by any person making such assignment, and although not as specifically enacted, this may be assumed to be a rule in the other provinces by necessary implication. At any time after, the assignee may make an application to be registered as the owner of any particular piece of land or any mortgage or incumbrance. The assignee does not in Saskatchewan

${ }^{61}$ Coleman v. De Lissa, 6 N. S. W. Eq. 104; In re Deane, 9 Q. L. J. 106; In re Shears and Alder, 17 V. L. R. 316; Colonial Bank v. Riddel, 19 V. I. R. 280.

${ }^{62}$ Man. 120; Sask. 117; Alta. 83 (a). 
take free of executions unless evidence be produced to show that the costs of all execution creditors for which they have a lien are paid, and the registrar is entitled to accept evidence that all such costs have been paid. ${ }^{63}$ The Manitoba and Alberta Acts go on to provide that the assignee for the purpose of the registered dealings, shall be deemed to be the absolute owner, and for greater certainty no reference to his capacity is to be inserted in his certificate. No such provisions appear in the Saskatchewan Act, which simply enacts that the assignee "shall become the owner thereof." In practice, however, the effect of the Saskatchewan Act is treated as the same as the other Acts, and, indeed, once having provided that the assignee shall be the owner, he comes within section 68 of the Saskatchewan Act, which provides that "the registrar shall treat any instrument containing any such notice (of trusts) as if there were no trust and the trustees therein named shall be deemed to be the absolute and beneficial owners for the purposes of the Act." The Saskatchewan Act also contains specific provisions for the claiming of exemptions by the assignor. It is provided that the statutory claim (section 117 proviso) shall be filed within thirty days. Whether or not after this period of time the assignor is debarred from claiming exemption or whether this time limit is merely for the purpose of restraining the registrar from permitting dealings with assigned lands until thirty days after the filing of the assignment, has not been before the courts. It has been held on petition, by the master of titles in Saskatchewan, that where an assignment was filed in December, 1907, and in January, 1910, a transfer to the assignor and a further transfer from the assignor to S., these transfers might be registered, as the assignment did

${ }^{63}$ In re E. J. Brooks, Insolvent, 2 S. L. R. 504, 12 W. L. R. 303. 
not affect after acquired property, so far as the land titles office was concerned..$^{64}$

\section{c. Peculiar to Manitoba.}

(1) CHANGE OF OWNERSHIP UNDER FORECLOSURE OR SALE UNDER MORTGAGE OR INCUMBRANCE.

The inclusion of this case under "transmission" in Manitoba makes the content of the word more logically complete. The law in this connection will be treated fully in the chapter on "Mortgages."

d. Peculiar to Alberta, Saskatchewan and the Dominion.

(1) CHANGE OF OWNERSHIP CONSEQUENT UPON LUNACY.

The case of change of ownership consequent upon lunacy in Saskatcheran and Alberta seems to be quite unnecessary. The guardian of a lunatic has no right to deal with the lunatic's real estate except by order of the court, in which case the transmission would fall under change of ownership by order of the court. Section 160 of the Saskatchewan Act and section 133 of the Alberta Act do not extend to authorizing the registrar to transmit ownership to a guardian or committee of a lunatic, and thus permit the guardian to do untrammelled what the courts would only allow him to do upon its approval and the giving of bonds.

(2) CHANGE OF OTNERSHIP UPON ANY SETTLEMENT.

The meaning of this case is uncertain, as already discussed in $\$ 1$ of this chapter. In practice no such case of transmission ever arises and there is therefore no case law on this point.

${ }^{64}$ Re Sunstrom's Transfer, Master of Titles, 19th April, 1910. 


\section{CHAPTER X}

\section{MORTGAGES}

\section{\$3. INTRODUCTION.}

\section{\$3. EQUITABLE MORTGAGES.}

a. In General.

b. Agreement to Give Mortgage.

c. Deposit of Certificate of Title as Security.

d. Transfers Absolute in Form.

\$4. STATUTORY MORTGAGE.

a. Compared with Legal and Equitable Mortgages Under the General Law.

b. Form of the Statutory Mortgage.

(1) IN GENERAL.

(2) INSERTION OF SPECIAL COVENANTS.

(3) IMPLIED CONENANTS.

(4) SHORT FORAIS.

c. Remedies of Mortgagee.

(1) SLMNARY.

(2) IEMEDIES ATAILABLE TO MORTCiAGEE OF HIS OVN MIOTION.

(a) Cieneral Comments.

(b) In .1lberta, Saskatcheuran and the Territories.

(c) In Menitoba.

(d) Conclusion.

(3) REMEDIES THROLGH THE COURTS.

(a) Sule.

(b) Foreclosure.

(I.) In Alberta, Saskatchewan and the Territories.

(II.) In Maritoba.

(III.) Assumption of Jurisdiction by Courts.

(c) Action for Possession.

(d) Action on the Corenant for Payment.

(e) Appointment of Receiver. 
(4) PROCEEDINGS AVAILABle TO MIORTGAGEE THROUGH REGISTRY OFFICE.

(a) Summary.

(b) Foreclosure and Sale.

(I.) In Manitoba.

(II.) In Alberta and Saskatchewan.

(III.) Application to Mortgages on Register when Land is Broughi Under Act.

(IV.) Procedure.

(aa) General Rule.

(bb) Notice-Parties.

(cc) Notice-Form of.

(dd) Notice-Filing of.

(ee) Notice-Service of.

(ff) Directions and Conditions.

(gg) Rights Arising upon the Sale.

(hh) Distribution of Procceds.

(c) Foreclosure.

(d) Entering into Possession and Leasing Property.

$\S 41$. TACKING AND CONSOLIDATION.

$\S$ 42. INCIDENTAL RIGHTS AND REMEDIES.

a. Acceleration.

b. Insurance Against Hail.

c. Covenant to Repair.

§43. MORTGAGE OF MORTGAGE.

$\S$ 44. INCUMBRANCES.

$\S$ 45. DISCHARGE OF MORTGAGE.

a. In General.

b. In Alberta and Saskatchewan.

c. Absence of Mortgagor from Province.

\section{§ 38. INTRODUCTION.}

A perusal of the reports will show that under other names the long recognized division of mortgages into legal and equitable mortgages still applies where the land being dealt with is under the Torrens system. 
These particular words in such cases may not be strictly accurate, suggesting as they do, a mortgage conveying the legal estate, as distinct from a mortgage enforceable in equity only, for a mortgage of the land under the system is in no case a conveyance, nor is there a "legal" estate. The intention of the Acts is to abolish the common law legal estate, substituting therefor the registered estate. The division of mortgages into statutory and nonstatutory would be the parallel and more accurate division. The statutory mortgage is so far removed from the conveyance of the legal estate by way of mortgage that the term "legal mortgage" is practically never used, but the term "equitable mortgage" persists with great frequency and in common parlance the main division of mortgages may be said to be into "statutory" and "equitable."

\section{§39. EQUITABLE MORTGAGES.}

\section{a. In General.}

Before entering into the study of a statutory mortgage under the system it might be well to classify briefly cases where land under the system has been held to be subject to an "equitable" mortgage. It will be found that, considering for the purpose only of this classification the statutory mortgage as equivalent to the old mortgage of the legal estate, equitable mortgages of land under the Torrens system exist in practically the same circumstances as in the case of land not under the system, with this important exception, that a second mortgage under the old system was an equitable mortgage, the mortgagor not having the legal estate, while under the Torrens Acts a second and subsequent mortgage is of exactly the same nature as a first mortgage, except perhaps in Manitoba where, by statute, the first mortgagee has conferred upon him the same rights as a mortgagee of the legal 
estate under the old system of conveyancing (section 108).

\section{b. Agreement to Give Mortgage.}

An agreement to give a mortgage or to charge any moneys on land is an equitable mortgage. ${ }^{1}$

In Sawyer and Massey v. Waddell the lien claimed was set out in an agreement in the following words:

"And the purchasers hereby further agree with the said company that they shall have a charge and specific lien for the amount of the said purchase money and interest upon the said land or any other lands the purchasers now own or shall hereafter own."

Of these words Newlands, J., said:

"The language in my opinion creates an equitable mortgage on the land described in the document. In Robbins on Mortgages, page 50, it is stated 'Any agreement in writing and properly signed, however informal, by which any property real or personal is to be a security for a sum of money owing or advanced, is a charge and amounts to an equitable mortgage."”

\section{c. Deposit of Certificate of Title as Security.}

The deposit of a certificate of title by way of security operates as an equitable mortgage. This is statutory under the Ontario Act, section 93 of which enacts that:

"Subject to any registered estates, charges or rights, the cleposit of the certificate of ownership in the case of freehold land, and of the office copy of the registered lease in the case of leasehold land for the purpose of creating a lien on the land to which such certificate or lease relates, shall be deemed equivalent to a deposit of the title deeds of the land."

Outside of Ontario the only Canadian case directly on the question of the deposit of the certificate of title is that of Fiallowski v. Fialkowski. ${ }^{2}$ This is the decision of a single judge in Alberta. Mr. Justice Scott there said:

1 Sawyer and Massey Co. v. Waddell, 6 Terr. L. R. 45; Gilbert_v. Ullerih 4 S. L. R. 97, 17 W. L.'R. 157.

21 W.W. R. 216, 19 W. L. R. 644. 
"Under the Victoria Act as well as under other Australian Acts it has been repeatedly held that the deposit of a certificate of title as security for a loan constitutes an equitable mortgage *** I have not been referred to, nor can I find any case in this country in which the effect of such a deposit has been considered. In the absence of any such authority I think that the construction that has been placed upon the effect of the Australian Acts, from which our Act was practically taken, should be adopted."

The case of Tolley and Co. Ltd. v. Byrne ${ }^{3}$ was relied on. In that case the depositee of the certificate of title as security was held to have an action for compensation against the assurance fund where a new certificate of title had been issued upon proof of loss by advertising and declarations in the regular way. A'Beckett, J., said:

"I think the plaintiff had an interest in the land under the Act. The Act itself seems to recognize and certainly the court has in a series of decisions recognized that a right may be conferred by the deposit of a certificate of title."

As under the system the duplicate certificate of title takes the place of the title deeds as evidence of ownership in the hands of the owner, and as it bears further analogy to title deeds in that it must be delivered up on transfer or mortgage of the registered estate in the same way as title deeds were required to be delivered up on conveyance or mortgage of the legal estate, to hold otherwise than that the deposit of the duplicate creates an equitable mortgage would be to abolish, for the land under the system, the larger part of the benefit law of equitable mortgage by a deposit of the title dceds. ${ }^{4}$

An equitable mortgage may also be created by deposit of some of the title deeds and this doctrine has bcen carried very far in relation to land under the system in Albcrta in the case of Acme Co. v. Huxley ct al. ${ }^{5}$ In that case the defendant Huxley,

3 28 V. T. R. 95.

- See, also, Hogr, page 787 , and cases there cited.

- Acme Co. v. II uxley, 18 W. L. R. 534, affirmed 20 W. L. R. 134, 1 W. W. R. 681. 
the husband, bought a business from the plaintiffs and to secure the deferred payments therefor handed to the plaintiffs a transfer under The Land Titles Act from his wife to himself, expressed to be in consideration of one dollar, of certain land of which his wife was the registered owner. It was found by the trial judge that this transfer had in fact been given by the wife to the husband to pledge as security for the first deferred payment of four hundred dollars and interest only. This first payment was in fact made, but becoming further involved, the husband made a settlement in which, among other things, he executed a further transfer of this land from himself to the plaintiffs, and delivered same to the plaintiffs with the intention of conveying to them the land absolutely. The plaintiffs proceeded by way of originating summons to compel the defendant wife to deliver up her duplicate certificate of title to permit them to register their transfers. It was held by the trial judge (a) that the deposit of the transfer from the wife to the husband, unaccompanied by the duplicate certificate of title, constituted an equitable mortgage, (b) that the plaintiffs having no notice of the limitation of the husband's authority, the wife was bound by the terms of the actual deposit. On appeal the court was evenly divided, and the judgment consequently upheld. Mr. Justice Stuart, however, in giving reasons on several grounds for reversing the judgment, relied strongly on the fact that the unregistered transfer passed no estate from the wife to the husband. He said:

"Can it be said, then, after all, that an equitable mortgage can be ereated in such a way? Once again, I emphasize the question-whose estate was being mortgaged or pledged? If it was the husband's, he clearly had none to pledge or mortgage. If it was the wife's, then, was any title deed of hers deposited at all? Clearly not. The transfer from herself to her husband was no part of her muniments of title. So far from showing any title in her it actually spealis of a 
transference of her title to her husband but it does not, however, effect such transference. Examine the matter as you will, I cannot see that the defendant did anything more than at most give a written expression of intention to transfer her legal estate to her husband, and say verbally to him: 'You may pledge this agreement I give you as security for your debt.' It is impossible to hold that this is an equitable mortgage by means of the deposit of title deeds. No title deeds of the defendant were ever deposited."

The decision in the result undoubtedly goes very far in giving effect to a statutory instrument as a muniment of title independently of registration.

\section{d. Transfers Absolute in Form.}

A transfer absolute in form may be proved to be a mortgage. ${ }^{6}$ But to induce a court to declare such transfer absolute on its face to have been intended to operate as a mortgage only, the evidence of such intention must be of the clearest, most conclusive and unquestionable character. ${ }^{7}$

The position of the transferee under such transfer operating as a mortgage only, as to such transferee being bound by the implicd covenant to indemnify, has already been discussed (page 238).

In McMillan v. Gumn in Nanitoba, Mathers, J., held that under the circumstances of that case, a right to sell without notice might be inferred from the circumstances but such a power does not follow necessavily. In Oland r. McNcil, ${ }^{8}$ Sedgrick, J., delivering the judgment of the court said:

"It is urged that the transfer to MicNeil, though absolute in form, is in fact a mortgage or pledge, in which case the subject of the transfer cannot be sold without notice to the equitable owner. That cloubtless is true in the case of an instrument on its face of such a character. But the proposition does not apply where an instrument is absolute on its face and is made

s Bhent v. Marsh, 1 Terr. L. R. 126; Mc.lHillan v. Gunn, 5 W. L. R. 479: Short v. Graham, 7 W. L. R. 7 S ; McCue v. Smith, 17 W. L. R. 145; Ruthcrford v. Mitchell, 15 Mlan. L. R. 390.

7 McMicken v. The Ontario Bank, 20 s. C. R. 548; Boardman v. Handley, 4 Torr. I. R. 266.

${ }^{8} 32$ s. C. R. 23. 
for the very purpose of enabling the apparent legal owner to give to another the beneficial or equitable as well as a legal title."

The rule, therefore, may be stated to be that a power of sale is not implied where a transfer absolute in form has been given by way of mortgage unless the circumstances of the case warrant the inference that such was the intention of the parties. ${ }^{9}$

The effect of such a transfer has been well laid down by Richards, J., in Rutherford v. Mitchell:10

"The rules of law and equity, governing a bare mortgage under the old system, were developed from the position in which the parties to it were placed owing to its being a bare conveyance of the legal estate, absolute in form but intended in effect merely to secure a debt. That is precisely the position in which the plaintiff and Howard E. Mitchell were placed by transfer to the latter and the issue of the certificate of title to him. Therefore, the true position of the parties here seems to differ in no respect for the purpose of this action from that of the parties to a mortgage under the old system, without redemise clause, covenants or provisos."

It has been suggested in Manitoba that the jurisdiction of the court in regard to the treatment of such transfers as mortgages lay only in the former section 126 of the Manitoba Act, and particularly in the amendment thereto of 1906.

"Nothing contained in this Act shall take away or affect the jurisdiction of any competent court on the ground of fraud, or over contracts for the sale or other disposition of land, or over equitable interests therein, or over mortgages, nor shall anything contained in this Act affect the right of the mortgagee to foreclose or sell through any competent court, which right it is hereby declared may be excrcised in such court." 1906.)

(The words in italics were added by the amendment of

In Williams v. Box, ${ }^{11}$ Perdue, J. A., said:

"The conclusion, therefore, is that the general declaration in section 126, that nothing in the Act shall take away or affect the jurisdiction of the courts orer mortgages does not affect

- Wallace v. Smart, 19 W. L. R. 787.

1015 Man. L. R. 390, at pag( 397.

119 Man. L. R. 560, at page 589. 
the particular enactment as to statutory proceedings for foreclosure. *** Adopting this interpretation there would still remain many branches of jurisdiction over mortgages to which the amendment might be applied. As instances of this I might mention * * * suits to declare that transfers absolute in form are in effect mortgages.

The judgment of the Court of Appeal in Manitoba in that case was, it is true, reversed by the Supreme Court of Canada, ${ }^{12}$ but Anglin, J., in that court, with whom the Chief Justice and Girouard, J., concurred, agreed that the words "or over mortgages" must have some meaning.

In Alberta, however, where Short v. Graham ${ }^{13}$ was decided, the Alberta section 139 contains no such words referring to mortgages, and in Victoria, where a transfer has been given similar effect under similar circumstances, there is no section corresponding to the former Manitoba section 126 and the present Alberta section 139. For a fuller discussion, however, of the effect of this section see page 146 .

\section{\$40. STATUTORY MORTGAGE.}

a. Compared with Legal and Equitable Mortgages under the General Law.

The division of mortgages into "legal" and "equitable" under the general law has already been referred to. An ordinary legal mortgage was "a debt secured on land, the legal ownership of the land becoming rested in the crectitor, and the equitable ownership of the land remaining rested in the debtor," 14 and

"the essence of a legal mortgage is the resting of the legal estate in the mortgagee, together with the right of possession even though it contained a corenant for quiet enjoyment after default." 15

1244 S. C. R. 1.

${ }_{13} 7$ W. L. R. TS7. Compare, also, Land Titles Act 1894 under which

Blunt v. Marsh was decided, and Rutherford v. Mitchell in Manitoba prior to 1906

14 Snell. Principles of Equity, 15th Ed., page 259.

${ }^{15}$ Fisher on Mortgages, Can. Ed., page 7 . 
In equity on the other hand, the mortgage was treated as being a security only. ${ }^{16}$ The Torrens system dispenses with the fictions surrounding a legal mortgage through the growth of centuries and makes a mortgage in form and operation what it actually had come to be considered by reason of practice of the court of equity. Continuing to its logical end, the work of the judicature acts by which "the rights of a legal mortgagee are to be assimilated to the rights of an equitable mortgagee" rather than those of an equitable mortgagee to those of a legal mortgagee, ${ }^{17} \mathrm{it}$ is provided that "a mortgage shall have effect as security but shall not operate as a transfer of the land thereby charged or of any estate (or interest) therein."18 Not only have the Acts adopted the equitable view of a mortgage, as a charge only, but they have gone a step further by stripping from it the trappings, as it were, of the legal estate, with results which, as will be seen, carry the doctrine of the mortgage as a charge only, much beyond the signification of that phrase as touching the treatment of a former legal mortgage in a court of equity.

In one respect the statutory mortgage has been held to be of the nature of a transfer, that is to say, for the purpose of the section of The Dominion Lands Act, which makes void every assignment or transfer of a homestead, purchased homestead, or preemption right prior to patent. ${ }^{19}$ In American Abell v. McMillan, supra, the question was as to the effect of a document by which a purchaser of machinery did "hereby incumber, charge and create a lien upon

${ }^{16}$ IIeath v. Pugh, 6 Q. B. D. 345.

17 Fouke v. Draysent, 29 ('h. D. 996, at page 1003.

${ }^{18}$ Man 100; Sask. 91: Alta. 1 : Dom. 98. The concluding words, "or of any estate or interest therein," oreur in the Manitoba Act only.

19 190א, 7 \& 8 Edw. VII c. :0, \$21; R. S. C. 1906, c. 55, \$142; Americon Abell Engine \&. Thres' er Co. v. Mr.Millan, 10 W. L. R. 239, 11 W. L. R. 185, 42S.C R. 397; Re Ebsing, 2S. C. R. 167; Flannaghan v. Healey, 4 T ir L. IR. 391; I'arli v. L n, 1S. L. R.:31, 7 W. L. R. 309; Sonwyer Massey ('o. v Demis, 7 W. I. R. 272; Waterous Engine Works Co. v. Wiaver, 8 W. L. R. 432. 
the said land," for which land he had not at the time obtained his recommendation for patent. Davies, J., in the Supreme Court of Canada, said:

"Then, upon the question which Mr. Chrysler seemed chiefly to rely, I cannot doubt that what the statute intended to prevent was, as expressed, any transfer or assignment, or agreement to transfer or assign, as well as anything which would or could have the legal effect of transferring away from a homesteader and giving to another his rights as such or of having the same done by process of law. In other words the language used was large enough, in the connection in which it was used, to cover indirect as well as direct transfers and so to cover a charge such as this under which a sale of the homesteader's rights could be decreed and transferred from him by a sale of the land under the decree,"

and the Supreme Court unanimously held the instrument in question to fall within the prohibition of The Dominion Lands Act. It will be noticed that this meaning is given to a mortgage for this purpose quite independently of section 60 (subsection 3) of the present Alberta Act, section 100 of The Saskatchewan Land Titles Act 1906, or section 73 (3) of The Land Titles Act 1894, as enacted by 61 Vict. c. $32, \S 9$. By these sections a statutory mortgage was expressly declared to be in the nature of an assignment or transfer prohibited by The Dominion Lands Act.

Although a mortgage under the new system is more akin to an equitable mortgage than to an ordinary conveyance of the legal estate by way of mortgage, a perusal of the reports and an acquaintance with the actual practice shors that in dealing with the law relating to the rights and liabilities of mortgagees and mortgagors, the law which has grown up around the ordinary mortgage of the legal estate is constantly applied. To attempt to tabulate the cases in support of this proposition would be merely to summarize the succeeding pages of this book. In Alberta and Saskatchewan, indeed, it may be said that statutory recognition has been given to this practice. It is enacted that proceedings to enforce 
payment, observance of covenants for sale or foreclosure, or to redeem or discharge, may (shall) be had and taken in the supreme court under the practice and procedure of such court; although referring, for example, to foreclosure, as will be seen, the supreme court in neither of these provinces has strictly speaking a practice or procedure over the foreclosure of an interest in land which is by way of charge only, unless there be something in the charge which entitles the holder to call for a complete legal security. ${ }^{20}$ In the case of the vendor's lien being a charge in equity there is no right to foreclose. ${ }^{21}$ The same sections speak of redeeming a mortgage, which word is strictly applicable only where the legal estate has passed to the mortgagee. And further, in the statutory short covenants, in case they are inserted, the mortgagor is in Saskatcherran made to covenant that he has good right, power and authority to convey the lands and tenements and that he has not done anything whatsoever whereby the lands conveyed are in any wise impeached, charged, affected or incumbered.

In determining the rights of the parties in mortgage actions the courts have consistently and without hesitation drawn on the practice with regard to mortgages under the general law. ${ }^{22}$ "The rights and powers of the mortgagee rest directly upon the provisions of the statute itself." ${ }_{23}$ But whenever either by the express terms of the statute, or by implication, or by covenant permissible to be inserted in a statutory mortgage, a right arises either the same as or similar to a right existing or which might arise in a mortgage under the general law, that law

${ }^{20}$ Fisher, on Mortgages, Can. Ed., 1002. See, also, post page 305.

${ }^{21}$ Mann v. Isle of Wight Railway Co., L. R. 5 Ch. 416; Storey, Equity Jurisprudenee, 2nd Eng. Ed., page 1217; Sanderson v. Burlett, 16 Gr. 129.

22 See, also, similar Australian practice referred to; Hogg, Australian Torrens System, page 942.

${ }^{23}$ Smith v. National Trust Co. (Duff, J.), 1 W. W. R., at 1126. 
is drawn upon for the details in connection with the working out of that right. Thus in Williams v. $B o x,{ }^{24}$ where the ordinary jurisdiction of the court was extended "over mortgages," it carried with it the right to reopen a statutory foreclosure upon the same principles as under the general law.

\section{b. Form of the Statutory Mortgage.}

\section{(1) IN GENERAL.}

The form of mortgage is purely statutory, except where under the discretionary power in the proviso to section 83 of the Manitoba Act, a registrar may permit an old system mortgage to be registered. No words which even purport to bind the land are used, excepting only the words at the close of the form "do hereby mortgage." Although unusual for that purpose, these words would have created an equitable mortgage in any case.

"Any agreement in writing and properly signed, however informal, by which any property real or personal is to be a security for a sum of money owing or advanced, is a charge, and amounts to an equitable mortgage." 25

But the operation of the instrument as a charge is by virtue of the Acts, and it takes effect as such upon registration. ${ }^{26}$

The skeleton of the mortgage consists of the parties, a description of the land to be mortgaged and a statement of the interest therein of the mortgagor, a covenant to pay and the mortgaging words, just mentioned, at the end.

The requirements of an accurate description of the parties and estate and of a memorandum of incumbrances have already been dealt with in the chapter on transfers, page 109 . The principles in regard to mortgages are exactly the same and need

2444 . C. R. 1.

${ }^{25}$ Robbins, on Mortgages, page 50; Sawyer Massey Co. v. Waddell, 6

Te r. I. R., at page 4S; Doe d. Ross v. Papst, 8 U. C. R. 574;

Vandelinder v. Tandelinder, 14 U. C. C. P. 129.

${ }_{26}$ Man. 100, 81; Sask. 91, 69; Alta. 61, 41; Dom. 98, 71. 
not be repeated. The question of what variations from the form are permitted has also been dealt with (page 103). Any instrument which departs from the statutory mortgage in any essential feature is not registerable. A mortgage in which it is set forth that "the mortgagor has granted, bargained, sold, remised, released, conveyed, assigned, transferred and set over and by these presents it has according to the bargain, sold, remised, released, conveyed, assigned, transferred and set over unto the mortgagee, all and singular the property described therein," is neither "in the form prescribed in Schedule N (Alberta) or to a like effect." The document has an entirely different and much wider effect and purports to do something which, according to section 61 , a mortgage or incumbrance is not supposed to do, and a registrar is right in refusing registration of such an instrument. ${ }^{27}$ And a mortgage which refers to and embodies into itself a trust deed, which trust deed grants and conveys unto the trustee the mortgaged land, is likewise unfit for registration. ${ }^{28}$

(2) INSERTION OF SPECIAL COVENANTS.

The form of mortgage also permits the insertion of special covenants, and it is customary in any well drawn mortgage to find a greater or less number of additional covenants and powers limiting or enlarging the rights of the parties pursuant to this license to insert special covenants. The varieties of special covenants are numerous, and so long as they do not conflict with the nature of the instrument, are permissible. They cannot in any case override the express provisions of the Acts. It is a frequent practice to join another party in a mortgage for the sake of his personal covenant or guarantee of payment. This is permissible. Where in Australia a

${ }^{27}$ Re Spokane and Eastern Trust Co.'s Mortgage, 15 W. I. R. 637.

${ }^{28}$ Re Northwest Telephone Co., Ltd., 2 Sask. L. 1R. 379 (full court). 
mortgage was rejected on the ground of containing such covenant, it was subsequently directed to be registered. ${ }^{29}$ But the rules of a loan society cannot be incorporated into a mortgage. ${ }^{30}$ An àgreement to give a mortgage, inserted in an incumbrance, is not such a special covenant, ${ }^{31}$ nor is a contractual power of sale independent of the Act, such being an "agreement authorizing the mortgagee to deal with the title in a manner which the Act itself not only does not provide for, but which appears to do violence to some of its express provisions." 32 Where there was a covenant in the mortgage that "the Crown grants, etc., for the time being of the land hereinafter described shall at all times during the continuance of this mortgage remain in the custody of the mortgagee," it was held that this covenant did not absolve the mortgagee from the necessity of compliance with section 134 of the (Victoria) Act requiring the first mortgagee to produce the duplicate certificate of title at the registry office to permit of registration. A'Beckett, J., said:

"The terms of that section amount to a positive enactment and I think this enactment overrides the covenant in this case, which provides that the mortgagees are to retain the custody of the documents." ${ }_{33}$

And where there had been a mortgage sale under power in which a notice was served on the mortgagor, but not on the registered assignee relying on a covenant in the mortgage, foreclosure was refused and the refusal upheld by the Full Court of Victoria, which said:

"The Act controls the instrument of mortgage, you cannot draw up an instrument so as to control the Act.

${ }^{29}$ F.x parte the Perpetua? Executors and Trustecs Association, Limited, (1911) V. L. R. 357.

so Re Kelly and Colonial Investment and Loan Co., 3 W. L. R. 62; Wilkins v. Deane, 5 N. Z. I. R. 425.

${ }^{81}$ Re Rumely Co. and Registrar of Saskatoon L. R. D., 17 IV. L. R. 160.

${ }^{32}$ Simith v. National Trust Co., I IV. W. R. 1122 (Duff, J.), at page 1129.

${ }^{33}$ In re Arnitage, 17 V. I. R. 17. 
The strictest procedure is intended to be followed in regard to foreclosure." 34

(3) IMPLIED COVENANTS.

The only covenant implied in an ordinary mortgage was the covenant for payment; the mortgage implied a loan and, therefore, a debt recoverable by action and bearing interest as a simple contract debt. $^{35}$ This covenant under the system ceases to be an implied covenant by reason of the form itself, and is necessarily an expressed covenant. In Saskatchewan, Alberta and the Dominion there is implied against the mortgagor remaining in possession a covenant that he will repair and keep in repair all buildings or other improvements erected and made upon the land and that the mortgagee may at all convenient times until the mortgage is redeemed, be at liberty, with or without surveyors or others, to enter into and upon the land, and view and inspect the state of repair of the buildings or improvements. ${ }^{36}$ All other covenants must come in, if at all, under the heading of "special covenants," ante.

(4) SHORT FORMS.

The Acts other than in Manitoba also contain a set of statutory short forms. ${ }^{37}$ These forms are not in any way incorporated by implication in the mortgage, but it is merely provided that where a short form is used in a mortgage it means the long form. Neither do the statutes give any special validity to the long forms. In fact they do not appear to be either appropriate or necessary. It is registration which gives effect to the mortgage, and the effect of registration is defined by the Act. The mortgagee gets a statutory mortgage of the registered estate, and no covenant is required to protect or enlarge that interest. The language in the

In re Burton, 27 V. L. R. 437.

25 Fisher, on Mortgages, Can. Ed., section 8 and cases there cited.

${ }^{36}$ Sask. 102; Alta. 69; Dom. 108. ${ }^{37}$ Sask. 103; Alta.70; Dom. 109 
covenants themselves is inappropriate. They speak of "heirs" when "heirs" as such inherit no rights or liabilities in land in Saskatchewan, Alberta and the Dominion. In Saskatchewan and the Dominion the forms are subject to a further defect which has been cured in the Alberta Act, namely that they speak of "conveying" the land, and further in all three Acts there is provided a form of covenant for entry into possession on default, when, except in Saskatchewan under the amendments of 1908, a mortgagee has no power of his own motion and without the aid of the court to enter into possession for the purpose of realizing his security (see page 298).

\section{c. Remedies of Mortgagee.}

(1) SUMMARY.

The remedies of the mortgagee may be classed under three heads: (a) Those available to the mortgagee directly through his own action by reason of his position as mortgagee. (b) Remedies available to the mortgagee through process of the court. (c) Remedies available to the mortgagee by special procedure prescribed in the Acts.

The leading case in Canada concerning the rights and powers of a mortgagee under the system is the recent case of Smith v. National Trust Co., on appeal to the Supreme Court of Canada from the Court of Appeal in Manitoba. ${ }^{38}$ The specific point decided was that in Manitoba there can be no power of sale in a mortgage apart from the statutory power. In arriving at this conclusion, affirming the judgment of the Court of Appeal in Manitoba, the Supreme Court considered the position of a mortgagee as to his rights and remedies generally. As to these rights under the statutory mortgage, the viewpoint was accepted by three out of the five judges (Duff, J., with whom Davies and Brodeur, JJ., concurred, Anglin and 
Idington, JJ., dissenting) of considering this instrument not as the common law mortgage necessarily modified to a certain extent, but as a new statutory instrument, to arrive at the effect of which one must look primarily at the statute. To reach a conclusion as to any particular right or power being enforceable or exercisable under a statutory mortgage, the method is not first to consider the same right under the common law mortgage, and then see whether there is anything in the Act which forbids the existence or exercise of that right, as suggested in the dissenting judgment of Mr. Justice Anglin, where he says:

"But can the owner of land registered under the 'new system' give to his mortgagee a power of sale other than the statutory power and exercisable without observance of the requirements of sections 109 and 110 of the Act? There is no clause in The Real Property Act which forbids him doing so;"

but the statute should primarily be resorted to, and examined to see whether the enforcement of the right arises either (a) by express words or (b) by implication. And in considering whether a right arises by implication, regard must be paid to the "essential difference" between the common law and statutory mortgage, namely the vesting of the legal and equitable estate in the mortgagee under the common law, as against the transference of no estate under the statute. If the power being considered is not found under either of these heads it does not exist. This is the resultant of the principle laid down by Mr. Justice Duff and summed up in language so clear that, though at some length, we quote:

"It is argued that the view thus stated is too narrow; and another view is put forward, which is this: that the mortgage authorized by the Aet is to be regarded as having annexed to it all the legal incidents which by law belong to a mortgage at common law, and as being capable of having annexed to it by contract all the incidents which maty by contract be annexed to a mortgage at common law in so far as such ineidents are not expressly or by necessary implication excluded. I think 
in either view the practical result of this appeal must be the same: but I must say that it seems to me to be an artificial and unnatural reading of the statute to regard the mortgage contemplated by it as primarily a common law mortgage, and I think that in adopting such a reading one incurs some risk of losing the point of view from which the legislator envisaged the problem to which he was addressing himself. There is much in the Act to indicate an intention on the part of its authors that under the statutory mortgage the powers and rights of the mortgagee should in substance be economically equivalent to those possessed by the mortgagee under a common law mortgage; ret juridieally considered there is-as I have indicated-this essential difference between the two instruments, viz.: that at common law the rights and powers of the mortgagee as such in respect of the mortgaged property are rights and powers which are ineidental to the legal or equitable estate vested in him as mortgagee, while under the statutory instrument the rights and powers of the mortgagee do not and cannot take their efficaey from any such estate beeause none is vested in him, and his rights and powers must consequently rest directly upon the provisions of the statute itself.

"This view, of course, does not involve the consequence that the mortgagee's rights are those only which the statute expressly gives him. It is obrious that many things are left to implieation; and where in any partieular ease it appears that the rules governing reciprocal rights of the mortgagor and mortgagee under the mortgage contract in relation to the mortgaged property are left to implication then it is a question to be determined upon an examination of the statute as a whole, how far the rights of the partics are to be governed by the rules of law whieh, apart from the statute, are applieable as between mortgagor and mortgagee."

The rights expressly conferred by the statute on the mortgagee involve, of course, no questions as to their existence, but merely as to the mode of their exercise; and as to those arising by implication, it is submitted that it is a fair method, in view of the principle of the decision, to consider the statutory mortgage from the point of view of what it actually is, apart from any inference by association with the common law mortgages, namely, an equitable mortgage by way of charge only, and having determined whether any right or power in question could be enforceable 
under such an instrument, to determine whether the same power, whether contained in a "special covenant" or in the statutory covenant to pay, is repugnant to any other provision of the Acts.

(2) REMEDIES AVAILABLE TO MORTGAGEE OF HIS OWN MOTION.

(a) General Comments.

Following out the line of investigation suggested these are, prima facie, such remedies as are prescribed by the Acts or as would be available to an equitable mortgagee by way of charge only by reason of his equitable mortgage, or by reason of any covenants which could be entered into in such a mortgage and enforceable by such mortgagee without the assistance of the courts. The proceedings which have ordinarily been taken to enforce the payment of money secured by an ordinary mortgage of the legal estate, and which could be taken by the mortgagee in the ordinary way without outside assistance (in the absence, of course, of physical opposition) were (i) distress under a license clause; (ii) distress under an attornment clause; (iii) taking possession; (iv) making leases; (v) sale under power in the mortgage; (vi) appointment of a receiver. These remedies may be classified into (a) those arising as pure matter of contract, as to which the only inquiry will be whether they are repugnant to any of the provisions of the Acts; (b) those dependent on the creation in the mortgagee of an estate or interest in the land, which are of no avail under the statute; $(c)$ those created by the statute.

(a) Under the first class would fall (1) the license to distrain; (2) the appointment of a receiver, and perhaps (3) the right to take possessionwhich may be viewed, quite aside from the mortgagee having or not having any estate or interest in the land, as merely a conferring by contract on the mortgagee by the mortgagor of a right 
to take possession of his, the mortgagor's land, and to receive the rents and profits thereof, if certain moneys, the mortgage moneys, are not paid as provided.

(b) Under the second class would fall (1) sale under porrer. The common understanding of a power of sale is that the mortgagor conveys his estate in the land to the mortgagee as security and then gives him power to sell it to realize the debt. Another view, under which, if correct, this power might have been inserted in elass $(a)$ has been expressly negatived in Smith v. National Trust Co., ante. This is the view expressed by Anglin, J., in his dissenting judgment:

"If the mortgagees neither had themselves, nor had the right, by a contract made in the exercise of their power of sale, to create in this purchaser an equitable interest in the land, which the mortgagor or his representatives might be compelled to perfect by a transfer or conveyance, they were at all events empowered to confer on him a right to claim such a transfer or conveyance which a court exercising equitable jurisdiction will enforce."

But this view is expressly negatived by the majority judgment delivered! by Duff, J.:

"It is to be fremised generally that the statute nowhere countenances the idea that a registered owner can, except under the authority of some specifie provision of the Act, by instrument inter vivos confer unon another the porrer to defeat or override his title by transferring a registered title to his property without constituting the clonee of the power his agent for that purpose and without transferring any interest to the donee himself."

The suggestion that the same purpose might be aecomplished by making the mortgagee the agent or attorney for the mortgagor for sale, is probably not of great practical importance. An instrument containing such a creation of agency or power of attorney would fall within the evil aimed at by the Full Court of Saskatchewan in Re Rumely Co. and Registrar Saskatoon L. R. D., ${ }^{39}$ and would be rejected,

2917 I. L. R. 160. 
on presentation for registration, as attempting to combine two instruments of different natures in one. (2) Distress under an attornment clause. An attornment creates an actual tenancy, ${ }^{40}$ and in every case where such a tenancy has been held to exist, the mortgagee landlord had an estate or interest in the land before assuming to rent it back to the mortgagor. If it be argued that this remedy can arise merely by virtue of contract, it is carrying the theory of contract very far to say that parties can by contract agree that relationships and interests exist without laying the elementary foundations in law for the existence of those relationships or interests. This view has been clearly set forth in a New Zealand case where a land mortgagee who had distrained brought action for conversion against a chattel mortgagee who removed part of the goods so distrained. It was held that as between the parties the attornment clause created a tenancy, but by estoppel only, which accordingly was not binding on third parties - and in actual practice it is when the mortgagor has become involved with third partics that the utility of a real tenancy arises. It was there said:

"If therefore an actual tenancy existed by virtue of the attornment clause there must be judgment for the plaintiff. But the status of a mortgagee under The Land Transfer Act is such that, in my opinion, no actual tenancy can have been created by the clauses. Section 94 enacts as follows: 'A mortgage under this Act shall have effect as security but shall not operate as a transfer of the estate or interest so charged.' It is plain therefore that the mortgagee has a mere charge. The fee simple whether it be legal or equitable remains in the mortgagor. There can be no reversion in the mortgagee and therefore no actual tenancy by the mortgagor. The attornment clause cannot operate as a demise by the mortgagee to the mortgagor for the mortgagee has no demisable estate." 41

(3) The right to take possession, in so far as it arose, independently of contract, in the fact of the

${ }^{10}$ Kearsley v. Phillips, 11 Q. B. D. 621; In re Stockton Iron Furnace Co., 10 Ch. D. 335; Hobbs v. Ontario Loan and Debenture Co., 18 S. C. R. 483.

${ }^{41}$ Jellicoe v. Wellingion Loan Co., 4 N. Z. L. R. S. C. 330. 
legal estate being in the mortgagee. (4) The right to make leases. This is commonly understood as the mortgagee leasing by virtue of having an estate in the land, and that estate, by reason of default, paramount to that of the mortgagor. To treat the right to make leases in any other way, is, it is submitted, to fall into the same error as was condemned in Smith v. National Trust Co., ante, in regard to powers of sale. The language in that case extends, it is true, only to the attempt to create a freehold estate under a bare license, but though a leasehold estate be a lesser interest the principle is the same. Such could only be done by the mortgagee as agent or attorney, and not under a "power."

(c) Under the third class fall in Manitoba, and to a smaller extent in Saskatchewan, certain statutory remedies given to the mortgagee for exercise by himself-power to enter into possession and distrain (section 106, Manitoba), to distrain on the occupier (section 107, Manitoba), enter into possession, receive the rents and profits and make leases (Manitoba, section 109, and Saskatchewan, section 93 (2).

These considerations raise a number of questions in regard to the remedies of a mortgagee under the system, which under the former law were in the mortgagee's hands for execution. (1) Are any such remedies available now? (2) If so, may those which are available be enforced $(a)$ by the mortgagee following the mortgage powers only, or (b) by the mortgagee, after taking the preliminary steps provided by the Acts, or (c) through the courts only? (3) Are such remedies displaced by or merged in the corresponding statutory remedies, if any?

(b) In Alberta, Saskatchewan and the Territories.

In Alberta and the Dominion and in Saskatchewan (except as modified by section 93 (2), Sask., and following subsections), the language of the Acts seems broad enough to throw the mortgagee on the 
courts for the smallest exercise of any powers or the enforcement of any rights under the mortgage. It is enacted in the two first named jurisdictions that:

"Proceedings to enforce payments of moneys secured by mortgage or incumbrance, or to enforce the observance of the covenants, agreements, stipulations or conditions contained in any mortgage or incumbrance, or for the sale of the lands mortgaged or incumbered, or to foreclose the estate, interest or claim of any person in or upon the land mortgaged or incumbered, as also proceedings to redeem or discharge any land from such mortgage or incumbrance shall be had and taken-(in Alberta) in the Supreme Court-(in the Dominion) before a stipendiary magistrate- (and in the Northwest Territories) in the Territorial Court of the Yukon." "42

The word shall is mandatory, so that the effect of this section, apparently, is to drive the mortgagee to the courts in order to enforce even his smallest right under his mortgage or anything contained in it. In Saskatchewan, in the corresponding section 93 (1), the words used after reciting the same proceedings are "may be had and taken in the Supreme Court of Saskatchewan." The effect of this section in Saskatchewan, however, does not appear to be substantially different except that it lets in the statutory powers set out in the following subsections. "In order to construe the section we are entitled to consider the state of the law at the time it was passed," 43 and "the general words of a statute are not to be construed so as to alter the previous policy of the law, unless no sense or meaning can be applied to those words consistently with the intention of preserving the existing policy untouched. $* * * *$ This principle of construction, as a general proposition, cannot be disputed." 44 Now in both The Land Titles Act 1894, section 75, as enacted by 61 Vict. (Dom.) c. $32, \S 11$, and in The Land Titles Act 1906 (Sask.),

${ }^{42}$ Alta. 62; Dom. 99.

${ }^{43}$ Phillipps v. Rees, 29 Q. B. D. 17, at page 20.

${ }^{4}$ Minel v. Lemon, 20 Beav. 269, at page 278. 
the word used was shall. The word may was introduced in the Saskatchewan Act by the amendments of $1908-9$, c. $9, \quad 7$, providing for statutory sale proceedings, and construing, therefore, the present section in the light of the rule just stated and the circumstances of its amendment, it is evident that the word may was introduced merely so that there should not be an inconsistency between subsection 1 of section 93, and the succeeding subsections which provided a method of sale and foreclosure without resort to the courts, and was not intended otherwise to relax the monopoly which the courts had of proceedings under the mortgage.

To confirm the view taken of the meaning of the main enactment, one may carry back the same line of reasoning a step further, that is in regard to the amendment of 1898 of The Land Titles Act 1894 (Dom.). The position was that, prior to that amendment, there were in that Act provisions for sale and foreclosure by statutory proceedings (sections $74,75,76,77$ and 78 ), but no reference whatsoever was made to any other remedies under a mortgage. By the amendment of 1898 the statutory proceedings for sale and foreclosure were abolished and a new section 75 was enacted, gathering up, as it were, not only sale and foreclosure proceedings, but, specifically, all other proceedings "to enforce payment of moneys secured by mortgage or incumbrance, or to enforce the observance of the covenants, agreements, stipulations or conditions contained in any mortgage or incumbrance," and by the use of the word "shall" confining the mortgagee for all his remedies-sale, foreclosure and every other description of remedyto the courts.

But it is a common practice in Saskatchewan and Alberta for the mortgagee to distrain both under a license to distrain and under an attornment clause, to take possession and even to make leases. These 
proceedings are undoubtedly proceedings to enforce payment of the mortgage money. For example, the distress or the rent, whichever it may be, is applied on and becomes payment of the mortgage money. Although the point does not appear to have ever been up for express decision, the Full Court of Saskatchewan has considered the propriety, under the circumstances there found, of a distress made by a mortgagee, assuming without question the right of the mortgagee so to distrain, but questioning only whether the distress in this particular instance was properly made upon a tenant of the mortgagee. ${ }^{45}$ But with regard to others of the covenants and powers, the rule of all jurisdiction in courts is closely adhered to. There is no reported case of a sale having been made pursuant to powers of sale, which have, in practice, regularly been inserted in a great number of mortgages (apparently in the hope that at some time they would become useful), followed by an application to the courts not to sell, but to declare that a valid sale had been made, and to vest the title in the purchaser by an order which the registrar would be bound to recognize.

In Saskatchewan the restriction of all remedies to the courts is relaxed by statute. There is, first, the statutory power of sale which, however, as will be seen, is not so much a release of this power to the mortgagee personally as to him under direction of the registrar. Secondly, upon serving and filing notice upon the same persons and in the same manner as in case of exercising power of sale, the mortgagee may (a) enter into possession of the lands and receive and take the rents, issues and profits thereof and $(b)$ whether in or out of possession make any lease of the same (section 92, subsec. 4). Now it has been held in Manitoba that where in a mortgage under the

${ }^{46}$ Vousden v. Hopper, 4S. L. R. 1. 
system there was a power to sell the lands these words should not

"be held to create a power of sale apart from that provided by the statute,"

but that

"The Real Property Act creates a method for realizing by sale or foreclosure in case of mortgages under it, which method is clearly meant to be exclusive unless otherwise permitted by the Act itself. It is a full and sufficient method and its enactment impliedly repeals, as to such mortgages, any powers of sale given by the previous Acts, including Lord Cranworth, if it would otherwise have applied." 46

The same rule should logically be applied to powers to take possession and lease contained in the same paragraphs of the Acts, that is to say, the right to take possession and to make leases must be exercised by the mortgagee pursuant to the provisions of The Land Titles Act so far as they go, by service and filing of notice. Furthermore, the proceedings under the Act are authorized only in pursuance of a covenant, necessarily implying that without such proceedings under the Act the covenant is unenforceable; and, carrying the inference a step further, confirming the view that no other covenants and powers are enforceable by the mortgagee directly, but only through the courts.

\section{(c) In Manitoba.}

In Manitoba in regard to these powers and remedies of a mortgagee no question arises with reference to any exclusive jurisdiction of the courts. No special jurisdiction is conferred on them and they have therefore only, and in the absence of its being by express language taken away, all the inherent jurisdiction of superior courts to enforce all existing rights and remedies. But the statutory powers are much fuller than in other jurisdictions.

46 Smith v. National Trust Co., 20 Man. I. R., at pages 533 and 534; affirmed Supreme Court of Canada, 1 W. W. R. 1122. 
The question for determination is, therefore, reduced to the question whether the covenants of the mortgagor in favor of the mortgagee create rights and powers independently of those set out in the Act. Except in regard to sale proceedings, specific authority covering the point is again lacking. But as the sections providing for sale form a complete code, as has been seen, so likewise do the same sections 106 , 107 and 109 bear evidence on their face of being a "complete method for realizing" in any permissible manner under the mortgage on the mortgaged land under the system, and any other covenant can at best be valid only in so far as it can be construed as a valid "modification," pursuant to section 157, of the statutory power.

In Manitoba technical objections to the enforcement of covenants formerly depending on the possession of the legal estate are cleared away by statute; but as, in any case, the first mortgagee for the time being only had the legal estate, the benefit of the statutory provision extends only to the first mortgagee, for the time being. He has the same rights and remedies at law and in equity as he would have had or been entitled to if the legal estate in the land had been actually vested in him (section 108). A section in similar terms in the Victorian Act was considered by the Supreme Court of Victoria (Australia) in the Commercial Bank v. Breen. ${ }^{47}$ That was an action for possession upon default in a mortgage in which the mortgagor covenanted to pay the mortgagee the mortgage money, on demand in writing served personally or through the post. The mortgagor was dead and notice was sent by registered letter in accordance with the mortgage. It was argued that the mortgagee had no right to take possession, because it had not complied with the provisions of the Act prescribing that the notice to

${ }^{47} 15$ V. I. R. 572. 
pay was to be directed to the then proprietor of the land, he being dead. It was held, however, that the mortgagee was within its rights by reason of the 93rd section of the Victorian Act, corresponding to section 108 of the Manitoba Act. The court, referring to the powers of the mortgagee, said:

"The previous sections, commencing from section 84 , confer certain powers and rights on a mortgagee who holds a mortgage in statutory form of land registered under the Act, as if the rights and powers were inserted in the instrument itself in the first instance. Then the ninety-third section comes in as a drag net securing to the mortgagee, in addition to his rights and powers under the instrument, all the rights and remedies he would have had as owner of the legal estate under the old law, concurrently with a right in the mortgagor to enjoy the mortgaged land quietly until default. We are of the opinion that in this case the mortgagee would have been able to eject the mortgagor.'

Consequently the effect of the words was held to be to constitute a redemise to the mortgagor if there be a fixed period of payment, otherwise, there being, as in this case, no fixed period of payment, there was no redemise and the mortgagee was entitled to possession at any time even without any demand. And in Farrington v. Smith ${ }^{48}$ the same section was held to be construed as implying a redemise for a period terminating at the date so fixed subject to a proviso permitting the mortgagee to re-enter on default in payment of interest or on any other breach of covenant. In Williams v. Box, in the Court of Appeal in Manitoba, Perdue, J. A., said: ${ }^{49}$

"It appears to me that this section 108 was passed for the purpose of enabling the mortgagee, in case of default, to enter upon the mortgaged land and receive the rents and profits, to bring ejectment against the mortgagor and to distrain for arrears of interest, without technical objections being raised in regard to such proceedings by reason of his not having the legal estate, his mortgage being only a charge on the land, while the real ownership and legal estate remained in the mortgagor."

4920 V. I. R. 90.

$4320 \mathrm{M}$ an. L. R., at page $58 \mathrm{~S}$. 
The section does not extend to conferring actual powers such as a contractual power of sale on a first mortgagee but not on others. In Smith v. National Trust Company, ante, the same court of appeal held that no power of sale could be operative in a mortgage outside of the statutory power, notwithstanding that the mortgagee of the legal estate under the old system had such a power of sale if there were a covenant to that effect in the mortgage. This decision was affirmed by the Supreme Court of Canada, where the effect of section 108 was carefully considered. It was contended that the mortgagee by virtue of that section was in the same position for all purposes as if the legal estate were vested in him and therefore that it followed that contractual power of sale conferred upon the statutory mortgagee the same powers of disposition over the mortgagor's title as would be vested in a legal mortgagee at common law. Duff, J., delivering the majority judgment of the court, though admitting that this might be the literal meaning of the words, did not think that taken along with other sections of the Act they could be given this construction. To arrive at this conclusion, he relied first, on National Bank of Australia v. The United Hand in Hand and Band of Hope,$^{50}$ decided under an Act which contained the same provisions, and, secondly, was of opinion that as the section dealt with the rights of the first mortgagee only, it indicated that those rights only were contemplated with which the law would invest a legal mortgagee as peculiarly incidental to his possession of the legal estate.

"If rights of foreclosure and sale independently of the other provisions of the Act were in view there appears to be no explanation why the benefit of such rights was withheld from the holders of mortgages subject to the first."

${ }^{50} 4$ A. C. 391 . 
And Anglin, J., in his dissenting judgment, referring to this section, says:

"I rather think, however, that this provision is intended to preserve to, or to confer upon the mortgagee, for the protection of whatever interest he may have under the terms of the statutory form of mortgage, rights and remedies other than the power to convey the land and that it would not enable him in the exercise of a power of sale other than that conferred by the statute to give a conveyance which nould have the effect of vesting in his purchaser the mortgagor's title and estate in the mortgaged registered land. I am confirmed in this view of the scope and purpose of section 108 by the fact that, notwithstanding its presence in the statute the legislature deemed it necessary to make special provisions to give to the conveyance of a mortgagee exercising the statutory power of sale the effect of resting in the transferee the mortgagor's title and estate (sections 111, 112)."

The actual enacting sections are, as has been pointed out, sections 106, 107 and 109 of The Real Property Act. These contain a summary of the rights and remedies which are conferred on a mortgagee. Section 107 extends the right of distress beyond the goods of the mortgagor, to which only the contractual right extends. ${ }^{51}$ The "occupier" mentioned in section 107 is not the mortgagor. ${ }^{52}$

\section{(d) Conclusion.}

In the present work the only question at this point for discussion is as to whether or not any powers and remedies under mortgages and covenants therein are enforceable by the mortgagee of his own motion. If it be held that there are such so enforceable, their scope, operation and interpretation fall under the general law of mortgages. Thus in Vousden $\mathrm{v}$. Hopper ${ }^{51}$ the defendant was the mortgagee under The Land Titles Act (Sask.) of certain land under a mortgage made by James Vousden, the father

"1 Tousden v. Hopper, 4 S. L. R. 1

${ }^{52}$ Hart v. Stratton, 7 S. A. R. S4; In re Ross and Mc.Veil, 5 N. Z. L. R. S. C. 322. But contra McLeish v. Forrest, 21 V.L. R. 384. And see Hogg, page 957 . 
of the plaintiff. The mortgage contained an attornment clause with reservation of a rental equivalent to the interest, and also a license to distrain for principal and interest. James Vousden after the execution of the mortgage, leased the land to the plaintiff, Walter Vousden. Having fallen into arrears the defendant distrained on the crop of the plaintiff who thereupon brought an action claiming damages for unlawful seizure. Judgment was given for the plaintiff by the district court judge, and on appeal this judgment was upheld by the full court. Mr. Justice Johnstone quoted the English cases to show that if a lease be made subsequent to a mortgage, the mortgagee may treat the lessee and all those who may be in possession, as wrong-doers, and may bring an ejectment, but he cannot distrain or bring any action for the rent they have contracted to pay, and added:

"Although the effect of a mortgage under The Land Titles Act would not be to vest all interest in the mortgagee, yet I think the result would be the same, and the only recourse the mortgagee would have as against the sub-tenant woule be that of an action or proceeding for the recovery of possession."

In the same case Chief Justice Wetmore, with whom Lamont, J., concurred, followed the Ontario courts on the question of whether the restriction of the right of a mortgagee to distrain upon the goods of the mortgagor or his assigns contained in the Act respecting extra judicial seizures ${ }^{53}$ extended to a distress where a mortgagee made such as landlord under the attornment clause. He said:

"In Edmonds v. Hamilton Provident and Loan Society, 18 A. R. 347, Osler, J. A., at page 358, referring to the Ontario provisions states: 'I think the intention was to reach every case in which the mortgagee, whether in the character of landlord or licensee, but still under and for the purposes of the mortgage, had the right to distrain.' I am entirely in accord with what that learned judge so laid down."

${ }^{53}$ R. S. S. 1909 , c. $51, \S 5$. 
In Linstead v. Hamilton Provident and Loan Society, ${ }^{54}$ in Manitoba, Killam, J., declined to follow this Ontario case, and held that the corresponding section of The Distress Act ${ }^{55}$ did not apply where the distress was for rent as landlord. But in Re Chalmers and Freedman, ${ }^{56}$ McDonald, J., without, so far as the report shows, discussing the foregoing authorities, said:

"The object of the attornment clause, was, no doubt, to entitle a mortgagee to an additional remedy by distress, but this does not entitle him to distrain upon the goods other than those of the mortgagor (The Distress Act, R. S. M. 1902, c. 49). This effectually disposes of the claim of the landlord to the remedy thus sought."

The foregoing cases, however, and the comments thereon have not been cited with the intention of purporting to make a study of the rights of a mortgagee under these covenants, but rather to illustrate the applicability of the general law of mortgages to the remedies of the mortgagee. To attempt to set out the comparatively few cases decided under mortgages actually made under the Torrens Acts with the idea of thereby setting out the whole law on that subject would only be misleading and is better, therefore, left unattempted.

\section{(3) REMEDIES THROUGH THE COURTS.}

The remedies for which a mortgagee under the general law ordinarily had resort to the courts are (a) Sale, (b) Foreclosure, (c) Action for possession, (d) Action on the covenant for payment, (e) Appointment of receiver.

\section{(a) Sale.}

So far as the jurisdiction of the courts to sell land by virtue of a mortgage under the Torrens

${ }^{64} 11$ Man. L. R. 199.

${ }^{65}$ Now R. S. M. 1902 , c. $49, \S 2$.

${ }_{56}^{56} 10$ W. L. R. 434. 
system is concerned, it is treated as standing on the same footing as foreclosure and for the purpose of considering whether or not such a jurisdiction is available to a mortgagee under the system the following remarks under the heading "Foreclosure" are in that case equally applicable. It is open to question, however, whether there is not a distinction between the power of the court to sell and to foreclose under such an instrument as the statutory mortgage. In equity, entirely independently of registration under the system, such a mortgage would have amounted to an equitable charge, for which sale and not foreclosure is the proper remedy. ${ }^{57}$ A contrary opinion was expressed by the High Court of Australia in Fink v. Robertson, ${ }^{58}$ based on James v. James. ${ }^{59}$ This latter case, from the headnote, is clearly a case of equitable mortgage by way of deposit of title deeds, and in such case equity will foreclose by ordering the mortgagor to convey the property, but on the ground that such a mortgage is more than a mere charge or lien, and implies an agreement to give a legal mortgage. ${ }^{60}$ In the meantime, however, the courts in Manitoba do not now exercise the jurisdiction in sale at all and in the other provinces exercise it freely, upon the same grounds as govern in case of foreclosure. The remedies are treated as bearing the same relation to one another as under the old law; thus a mortgagee may demand foreclosure unless properly required to sell under The Chancery Procedure Act, 15 \& 16 Vict. c. $86, \S 48 .{ }^{61}$

\section{(b) Foreclosure.}

The jurisdiction in foreclosure is correlative to the jurisdiction in sale.

\footnotetext{
${ }^{87}$ Grissel v. Money, 38 L. J. Ch. 312; Tennant v. Trenchard, (1869) 4 Ch. 537.

${ }_{88} 4$ C. L. R. 864.

${ }^{69}$ L. R. 16 Eq. 153.

- Carter v. Wake, 4 Ch. D. 605.

'Canada Life Assurance Co. v. Vance, 12 W. I. R. 231.
} 


\section{(I.) In Alberta, Saskatchewan and the Territories.}

In Saskatchewan, Alberta and the Dominion in the sections providing generally for mortgage proceedings already referred to, it is enacted that "proceedings *** to foreclose the estate, interest or claim of any person in or upon the lands mortgaged or incumbered, shall (in Saskatchewan may, but see page 295) be had and taken in the Supreme Court *** under the practice and procedure of such court."

The meaning of this enactment so far as regards foreclosure is not entirely free from difficulty. Prima facie it means that if a mortgagee desires to foreclose his mortgage he must resort to the courts and there use the practice and the procedure which he finds for that purpose. It requires, however, specific language in statutes to establish a jurisdiction which had not previously existed. ${ }^{62}$ If the courts independently of this enactment did not have jurisdiction to grant foreclosure of a statutory mortgage, the section is very awkwardly worded to establish a new jurisdiction for that purpose. In fact, it seems to imply the previous existence of a jurisdiction, and merely enacts that proceedings for foreclosure are confined to that jurisdiction. The section in question first appeared in the amendment to The Land Titles Act 1894 (Dominion) of 1899 (61 Vict. c. 32, \$11). Up to that time there had been in The Land Titles Act 1894 statutory provisions for sale and foreclosure. These, by the same enactment were repealed and the mortgagee thrown upon the courts entirely for his remedies. Now a statutory mortgage is a mere charge or lien. For the purposes of this discussion it is not and must not be considered under the general caption of an equitable mortgage. Deposit of title deeds created an equitable mortgage

${ }_{62}$ Maxwell's Interpretation of statutes, 3rd Ed., page 412. 
and foreclosure was a suitable remedy thereunder, but on the ground that it "has always been considered as an imperfect mortgage, which the mortgagee is entitled to have perfected, or rather as a contract for a mortgage which according to the well known doctrine of courts of equity would give to the party claiming the benefits of such a contract all such rights as he would be entitled to if the contract had been completed." 63 And on the same ground, an equitable mortgage by way of agreement to give a mortgage carried with it the right of foreclosure. The essence of foreclosure in equity of a mortgage of the legal estate, was that the mortgagee had vested in him the legal estate, which could be redeemed on payment of the mortgage money. Equity had said that "once a mortgage, always a mortgage" to do justice to the mortgagor; but in order to do justice to the mortgagee it had then further said, in effect, that the mortgagee might after default bring the mortgagor into a court of equity, which court would limit the time within which the mortgagor might pay his mortgage money and get back the legal estate in the land, but in default of so doing the mortgagor was foreclosed of his right to do so, that is, the legal estate stayed where it was, in the mortgagee, who was then considered the absolute owner in equity also. Under the Torrens Acts the mortgagee never has any estate or interest in the land and the mortgage "has effect as security" only, and where the security is a mere charge or lien and not in the nature of a mortgage (in the sense of the general law) or an agreement for mortgage, the proper remedy is an action for sale to realize the security, and not foreclosure. ${ }^{64}$ Unless, therefore, the inscrtion of the clause at the

${ }^{63}$ Parker v. Housefield, $2 \mathrm{Myl}$. \& K. 419. See, also, Fisher, on Mortgages, par. 511; Birch v. Ellames, 2 Anst. 428; Ex porte Wright, 19 Ves. 255.

-Ternant v. T'renchard, 4 Ch. 537; (írissel v. Money, 38 I. J. Ch. 312; Bell \& Dunn, Mortgages, nage 206; Mamn v. Isle of Wight Railway Co., L. R. 5 Ch. 416; Storey's lefuity Jurisprudence, Eng. Ld., page 1217. And see notes 57, 58 and 59 ante. 
end of the mortgage form whereby the mortgagor "mortgages" all his right, title and interest in the land to secure the money, has a very far-reaching effect in introducing into the statutory mortgage all the effect of a legal mortgage, the statutory mortgage must be considered as a mere charge or lien in equity. It cannot fairly be argued that the insertion of this wrol "mortgage" can have such effect, for this would he to practically repeal the plain language of the Acts making a mortgage have effect as security only and not operate as a transfer of the land. The difference between the mortgage of the legal estate and the statutory mortgage was clearly seen by Mr. Justice MicGuire of the former Supreme Court of the Northwest Territories in Colonial Investment and Loan Company v. King et al. ${ }^{65}$ This was an action upon the corenant after foreclosure. At page 379 he said:

"I may observe, en passant, that the word 'foreclose' as applied to proceedings to enforce a mortgage under The Land Titles Act in the Territories, is apt to mislead if it is sought to treat those proceedings as identical with 'foreclosure' proceedings where the mortgage conveys an estate in the land to the mortgagee with a defeasance clause in case payments are made as provided. In such a mortgage the mortgagee has only an 'equity of redemption' after the time for payment has expired without payment, that is, he is held in equity entitled to come in and redeem after default upon certain terms, but no particular time has been fixed within which he must exercise that right. In order, therefore, that the mortgagee may not be kept indefinitely in suspense he is allowed to call upon the mortgagor to exercise his right within a limited time. The amount the mortgagor must pay to redeem is ascertained by the court. He is notified that unless he pays that amount by the day named his right to redeem will be barred, and in the event of his not arailing himself of this final opportunity, the court declares that his right to redeem is gone-the mortgage is foreclosed. But under our Land Titles Act the mortgage does not operate as a transfer of title but only as security. The mortgagor remains the owner of the legal estate. The mortgagee

es 5 Terr. L. R. 371. 
merely has a lien until payment, and in case of default he can proceed to get an order either to sell the land or to have the title thereto vested in himself. Upon getting a final order vesting the title in him he can obtain from the registrar of land titles a certificate which gives him an absolute title freed from all claim by the mortgagor.

$* \quad * \quad * \quad * \quad * \quad * \quad * \quad * \quad * \quad * \quad * \quad * \quad *$

"A certified copy of that judgment (of foreclosure) was put in by the defendant King, from which it appears that 'It is ordered that the defendant do stand absolutely debarred and foreclosed of and from all right and title, interest or estate, or right or equity of redemption of, in or to the above deseribed lands.

"And it is further ordered that all the estate and interest of said George Clift King, or of anyone claiming through or under him in the said lands (describing the land in the $\$ 2,600$ mortgage) be and the same is vested in the said plaintiffs (the mortgagees) free from all right or equity of redemption on the part of the defendant King or anyone claiming through or under him.'

"This judgment or order was registered in the proper land titles office and a certificate of title thereon issued vesting the title in the land in the mortgagees.

"It will be noticed that while the person who drafted the judgment has used the word 'foreclosed' he has also used words apt and necessary to vest the title in the mortgagees. The ordinary judgment in a foreclosure action under a mortgage which passes the legal estate to the mortgagee is usually in this form (Seton):

" 'It is ordered that the defendant A. B. do from henceforth stand absolutely debarred and foreclosed of and from all equity of redemption of, in and to the said mortgaged premises'; that is, the relief given by the equity courts is now taken away from him. There is nothing here as to vesting in the plaintiff the defendant's title in the land, because the mortgage had already passed the legal estate. In the Territories it was necessary to do more than bar the defendant. An order in the terms of a foreclosure order in the form taken from Seton would not have satisfied the registrar or warranted him in issuing a certificate of title. The judgment had to vest the title to the land in the plaintiffs, and that is the material and indispensable portion of the judgment. 'The 'deharring and foreclosing' paragraph is probably not at all essential, however prudent it may have been deemed to insert it." 
In this case a foreclosure order had been made and it was not incumbent on the learned judge to discuss the propriety of it or otherwise. Had it been so, upon the reasoning so well set out, Mr. Justice McGuire might have come to some more definite conclusion than at page 379 :

"Under these eireumstances one must be eareful when endeavoring to apply to mortgages here the rules and prineiples laid down, say, in England or Ontario, as governing the rights of parties to a mortgage there."

The logical conclusion from the language of Mr. Justice McGuire is that there is no practice and no procedure in the Supreme Courts of Saskatchewan or Alberta (then of the Northwest Territories) for foreclosure of a statutory mortgage, and, secondly, that an enactment declaring that proceedings to foreclose a statutory mortgage shall be taken "under the practice and procedure" of that court was nugatory.

\section{(II.) In Manitoba.}

There is not and never was in Manitoba any section corresponding to 93 (1) of the Saskatchewan Act or 62 of the Alberta Act. In Williams v. Box, ${ }^{66}$ Richards, J. A., who dissented from the Court of Appeal in Manitoba and whose judgment was upheld in the supreme rourt of Canada, said, at page 573 of the report:

"When our first Real Property Aet was passed, it made no provision for foreclosure of any kinel. It expressly provided that the legal estate did not pass to the mortgagee. The only remedy which a mortgagee possessed under it was to sell the property under the provisions of the Aet."

And Perdue, J. A., at page 586, said:

"Before the introduction of this provision (1887 Man. (c. $11, \$ 44,45)$ I think a court of equity could only enforce the charge against the land created by a mortgige under the new system as any other charge, such als a registered judgment might be enforeed, that is by a sale of the land."

ef 19 Ninn. L. R. 560. 
And Cameron, J. A., at page 597, said:

"Now let us examine briefly the meaning of the words, 'Nor shall anything contained in this Act affect the right of the mortgagee to foreclose or sell through any competent court, which right it is hereby declared may be exercised in such court.' This branch of inquiry is not essential to a determination of this case, but is incidental to it. What was the existing right to foreclose 'through any competent court' in the case of mortgages under the new system prior to the enactment of the amendment? We know precisely what a mortgagee is, for the expression 'means the owner of a mortgage registered under this Act' section $2(e)$. There was no right to foreclose such a mortgage through any competent court existing prior to the amendment, and, therefore, no right to be affected thereby."

While the Manitoba Court of Appeal was reversed in the result, the Supreme Court of Canada did not negative the foregoing statements of law. ${ }^{67}$ Idington, J., at page 11, said:

"Mr. Justice Perclue explains that under this registration system the mortgagee never has vested in him the legal estate, never has and cannot get more than a charge upon the land, and then, he suggests, foreclosure never could exist as a method of procedure in regard to such a form of mortgage.

"I will assume that to be so without entering into that which is a wide fielel in some aspects of it, and certainly do not question the general principle. See the judgment of Sterling, $J .$, in Re Lloyd ${ }^{68}$ at page 397 , speaking for the ecurt,"

and nothing to cause doubt on this statement of the law is found in any of the other judgments. The subsequent decision of the Supreme Court in Smith v. National Trust Company, ante, may, it is submitted, be applied mutatis mutandis, substituting "foreclosure under statutory provisions" for "sale under statutory provisions," and "foreclosure through the courts" for "sale under contractual powers." The decision there cited of the Privy Council in National Bank of Australia v. United Hand in Hand and Band of Hope Company, ${ }^{69}$ is also directly in point. To the

6744 S. C. R. 1.

${ }^{68}$ (1903) 1 Ch. 385.

${ }^{\text {e9 }}$ I. R. 4 A. C. 391. 
same effect are the Australian decisions, holding that foreclosure of the statutory mortgage can only be effected through the statutory proceedings. ${ }^{70}$

It is evident, then, that aside from some statutory jurisdiction expressly conferred, the courts have no power to grant foreclosure of a registered statutory mortgage as such, and whether or not the courts can now grant foreclosure depends on the wording of the Acts.

(III.) Assumption of Jurisdiction by Courts.

The fact is, however, that for years the courts, both in the old Northwest Territories and to a limited extent in Manitoba, were, and in Saskatchewan and Alberta are, in the habit of assuming without question, presumably because no question had ever been raised, that the courts had authority to make what are called foreclosure orders, resting the land in the mortgagee and directing the registrar to cancel the existing certificate of title and issue a new one to the mortgagee. Such orders can be found registered in the land titles offices, and foreclosure actions can be found scattered through the reports where the jurisdiction is assumed..$^{71}$

In Saskatchewan and Alberta the propriety of assuming, as do the courts in those provinces, that section 93 (1) and 62 respectively confer a jurisdiction in foreclosure, would be stronger had it not been the case that there undoubtedly was no jurisdiction in foreclosure of a statutory mortgage prior to the 13 th of June, 1898, the date of the first enactment of the present sections 93 (1) (Saskatchewan) and 62

${ }^{70}$ Gricg v. Watson, 7 V. L. R. $79 ;$ Long v. Toun, 10 N. S. W. L. R. Eq. 253

${ }^{11}$ Colonial Investment and Loan Co. Y. King et al., 5 Terr. L. R. 371; Comeron v. Rutledge, 2 W. L. R. 473; Gilroy v. Proe, 8 W. L. R. 777; Suan v. Wheeler, 11 W. L. R. 730; Matthew v MeLean, 11 W. L. R. 360; Union Bank v. 1feElroy, 11 W. L. R. 259; Canada Permanent Mortgage Corporation v. Jesse, 11 IT. L. R. 295. See, also, Wetmore, C. J. (obiter), in C. P. R. v. Mang, S W. L. R., at page 775 . "Tho court, however, has yet authority beyond all question to make decrees of foreclosure." 
(Alberta). It is evident that the draftsman of that section assumed that there was a jurisdiction in the courts. Whether or not, there being in reality no such jurisdiction, the legislature succeeded in establishing one has never been raised as a serious question in Saskatchewan and Alberta, and the courts have regularly and without question continued to make foreclosure orders from that day to the present. In no case does it appear that the jurisdiction of the court to grant such an order was ever a point at issue.

In Manitoba the jurisdiction in the courts was first doubted in Barnes v. Baird, ${ }^{72}$ consequent upon which the amendments of 1906 to sections 108 and the former 126 were enacted specifically declaring the right of the courts to exercise jurisdiction in foreclosure. These amendments having been repealed by Statutes of 1911, c. $49, \S 7$, the position in Manitoba is now back to what it was before 1906, as outlined in the preceding cases, except that the right of the court to grant such an order has been adversely passed on by the courts, has been declared by statute, and the declaration subsequently repealed, so that the lack of jurisdiction of the courts in such case is now made quite plain.

The practice in actions for foreclosure in the courts where the right is treated as existing is not a matter for discussion in such a book as the present, but for a work on mortgages or on court practice. Only one important statutory change will be referred to, that is, in Manitoba the lengthening of the period of redemption from the ordinary period of six months to twelve months ([1908] Edw. VII c. 13).

\section{(c) Action for Possession.}

The nature of the action for possession will differ somewhat in the different jurisdictions. Under

7215 Man. L. R. 162. 
sections 106 and 108 of the Manitoba Act, possession by the first mortgagee on default is a statutory right, the first mortgagee being in the same position as if he were the owner of the legal estate and the owner of the legal estate being entitled to possession on default. But under any subsequent mortgage in Manitoba, and in the other jurisdictions, the action for possession is merely the enforcement of a contractual right. There being a statutory method provided for taking possession in Manitoba, it is to be presumed the courts would not enforce possession except as ancillary to these proceedings. In Saskatchewan by analogy with the view taken by them in regard to foreclosure the courts would endeavor to enforce a covenant for that purpose independently of any proceedings under the Act; while in Alberta there is no reason to suppose that the courts would hesitate at all to enforce a covenant for possession after default.

\section{(d) Action on the C'orenant for Payment.}

The action on the covenant is not a proceeding affecting the land, and consequently is not subject to any limitation as to jurisdiction by reason of other powers in the Acts. In Saskatchewan and Alberta apparently the action must be brought in the supreme courts of those provinces, notwithstanding the amount claimed may otherwise be within the jurisdiction of the district courts.

In one particular the action on the corenant has given rise to difference of judicial opinion. Under the general law, after a foreclosure, an attempt by the mortgagee to enforce payment under the personal covenant results in reopening the foreclosure, that is, the court as a condition of recovery under the covenants, permits the mortgagor to redeem the mortgaged lands, and if the mortgagee has so dealt with the lands that he cannot convey the legal estate 
in them back to the mortgagor, he cannot recover at all on the covenants. In Colonial Investment and. Loan Company v. King, ${ }^{73}$ MeGuire, C. J., in the former Territorial Supreme Court, held that the effect of taking and registering a foreclosure order in court, was for the mortgagee voluntarily to put himself in the position of a transferee who impliedly covenanted to indemnify the mortgagor, and thereby abandoned the covenant to pay, which consequently could not thereafter be sued on. He expressed an opinion contrary to the possibility of reopening a foreclosure after registration thereof under the Act, but did not rest his decision thereon. This decision is in line with what has been held in a comparatively recent case in the High Court of Australia, on appeal from the Supreme Court of Victoria. ${ }^{74}$ It was there held that after a statutory foreclosure, the court could not compel its reopening on mere equitable grounds, but that, nevertheless, the right to sue on the covenant was not necessarily for that reason alone extinguished. The fact of the mortgagor being unable to open up the foreclosure, was held not to be conclusive either way as to the right to sue on the covenant, as the court could still impose terms, but examining various provisions of the Act, which, in the Victorian Act as in the Canadian Acts, are very specific in placing the mortgagee in case of an order of statutory foreclosure in the position of a transferce - and certainly much more so than in case of a court order in regard to which Colonial Investment v. King was decided - they arrived at the conclusion that there was nothing to negative the implied covenant of the transferee to indemnify the transferor against the mortgage moneys, and that therefore the mortgagee could not sue the mortgagor on the very covenant against which he had covenanted to indennify him.

${ }^{73} 5$ Terr. L. R. 371.

it Fink v. Rotherlson, (1907) 4 C. L. R. 864. 
In Noble v. Campbell, ${ }^{75}$ Robson, J., in Manitoba, held that the covenant to pay was not extinguished by a statutory foreclosure, distinguishing Fink v. Robertson, supra, on the general ground that, followin Williams v. Box, "the principles of equity in respect of mortgages were preserved unaffected" in Manitoba as was not the case in Victoria. Williams v. Box is more fully discussed ante pages 310-13 where it was pointed out that the words of the Manitoba Act upon which that case largely turned have, since the circumstances of Noble v. Campbell arose, been repealed. In view of the more recent decision in Smith v. National Trust Company it seems unlikely that the Supreme Court would now extend the principle of Williams v. Box to cover the Manitoba Act as amencled, and, therefore, in all probability the law as stated in Colonial Investment Company v. King and Fink v. Robertson correctly states the present law in regard to enforcement of the covenant after foreclosure in all Canadian jurisdictions, namely, that such corenant is extinguished upon the registration of a foreclosure order.

\section{(e) Appointment of Receirer.}

The principles on which such an action will be entertained or otherwise are to be gathered from the foregoing discussions. In cases where the action is maintainable the rights of parties are the same as in case of a mortgage under the general law.

\section{(4) PROCEEDINGS AYAILABle TO MORTGaGEE THROUGH REGISTRY OFFICE.}

(a) Summary.

These are: (I) Entering into possession and leasing property. (II) Foreclosure. (III) Foreclosure and sale.

7518 W. L. R. 591.

is 44 S. C. R. 1. 
These will be considered in the reverse order. To some extent these different remedies run concurrently with one another.

\section{(b) Foreclosure and Sale.}

\section{(I.) In Manitoba.}

The earliest Real Property Act of Manitoba, that is, the Act of 1885, contained provision for sale only, by the mortgagee, corresponding substantially with sections 109 and 110 of the present Act, with this important exception, that the sale was subject to such conditions as the mortgagee might think fit, the mortgagee having entire control over the proceedings and not requiring any directions from the registrar, except that the registrar general on summary application ex parte might direct the manner of service on a mortgagor or incumbrancer who could not be found. The Act of 1889,52 Vict. c. 16, introduced proceedings for foreclosure, subsequent on abortive proceedings for sale, in substantially the same manner as now provided. The next important change in the proceedings was the Act of 1900 , which cast the Act into its present shape and directed the sale to be subject to such conditions as the registrar might think fit.

(II.) In Alberta and Saskatchewan.

The present provinces of Alberta and Saskatchewan were subject to The Territories Real Property Act of 1886, and The Land Titles Act 1894, until the taking effect of the new Acts of the provinces in September, 1906. The Territories Real Property Act, being 49 Vict. c. 26 (Dom.), provided for a method of sale the characteristic of which was that all the steps had to be taken under the close supervision of a judge. There was from the first a proceeding for obtaining foreclosure order upon an abortive sale, such proceeding being almost identical with the 
present procecding for foreclosure under the Saskatchewan Act, except that the application was made to a judge as persona designata under the Act and not to the registrar. These provisions were carried forward into The Land Titles Act 1894, but were repealed in toto by (1898) 61 Vict. c. 32 (Dom.), and a new section enacted, being the present 62 of the Alberta Act, and 93 (1) of the Saskatchewan Act (but reading shall for may in the latter Act). So far as Alberta is concerned no subsequent Act has been passed re-establishing anything in the nature of sale proceedings under the Act, but in Saskatchewan by 1908-09, c. 9, proceedings for sale and foreclosure through the land titles office were re-established, the distinguishing characteristic as compared with its predecessor being that the registrar and not a judge was the supervisor of the proceedings.

The history of sale and foreclosure proceedings under the present Dominion Act corresponds identically with that under the Alberta Act.

(III.) 1 pplication to Mortgages on Register when Land is Brought Under Act.

It has been held in Australia that the statutory proceedings for sale and foreclosure do not apply to mortgages on the register at the time the land is brought under the Act, and to which the first certificate of title is made subject. ${ }^{77}$ There a mortgagee purported to sell under a power in the mortgage, and then applied for foreclosure which was refused on the ground that:

"There is no provision in the Act enabling such a mortgagee to foreclose under the procedure prescribed by the Act for foreclosure of mortgages under the Act or enabling the commissioner to make the order applied for; and seetion 135 of the Act assumes that hefore a mortgagee can become a registered proprietor on foreclosure of land under the Act, subject to a

"In re Smith, 15 A. L. T. S5. 
mortgage under general law, he has first to foreclose under general law."

The question, however, is not one of practical importance in the Canadian jurisdictions, as in Manitoba the proviso to section 83 expressly extends the proceedings under the Act to such cases; and in Saskatchewan, where registration under the Torrens Act has been compulsory since the 1st of January, 1887, the lapse of time has for practical purposes disposed of any mortgages to be found on land now brought under the Act for the first time, under which a mortgagee might possibly proceed.

\section{(IV.) Procedure.}

\section{(a) General Rule.}

It may be laid down as a basic principle in discussing the statutory remedies of sale and foreclosure, that the sections enacting them are interpreted strictly and must be closely followed:

"The strictest procedure is intended to be followed in regard to foreclosure." $7 \mathrm{~s}$

\section{(bb) Notice-Partics.}

The proceedings are set in motion by a notice given by the mortgagee. For form of notice see Form 3, App. C. The direction to the parties required to be served is usually at the head of the notice, though there is nothing in the Act requiring that every copy of the notice shall be directed to all the parties. These parties are:

(a) The mortgagor, his executors or administrators. There is no provision in the Acts for the appointment of an administrator ad litem. In Manitoba, under section 43, the registrar has power to grant all order for service as therein provided where notice is required and it appears that the party who should get the notice has been dead for

\footnotetext{
${ }^{78}$ In re Burton, 27 V. L. R. 437.
} 
the space of one year and no will for his estate has been proved. In Saskatchewan, the mortgagee finding any of the parties to h s notice dead with no administration or probate taken out, is blocked unless he can persuade some person so entitled to take out administration; or the mortgagee may himself take such administration as a creditor, when, it is submitted, he may add his cost of so doing to the mortgage account, or failing either of these courses he may resort to court proceedings.

(b) Assigns of the mortgagor. In case the original mortgagor has sold the mortgaged property he does not require to be served with notice, but the new registered owner must be served. The statutory requirement is for service on the mortgagor, his executors, administrators or assigns, not and assigns. ${ }^{79}$ The proceeding in the registry office is strictly one for making title only, and the registrar is not concerned with anything but the title to the land. A mortgagor who has sold the equity of redemption is not entitled to redeem, nor is he a party to a foreclosure action. ${ }^{80} \mathrm{He}$ has, therefore, no interest in the land, and whatever his rights may be where he has had no notice in case of being subsequently sued on the covenant, the business of the registrar is to assure the titie only, and not to protect the mortgagor personally in circumstances which may or may not arise. This practice has been approved on appeal from a registrar by the master of titles in Saskatchewan. ${ }^{81}$ The mortgagee, however, if he wishes to preserve intact his covenant against the original mortgagor in such case, should serve him with the notice.

${ }^{79}$ See Bartlett v. Jull, $2 \mathrm{~S}$ Gr. 140, for construction of a direction where the word was "and."

${ }^{80}$ Coote, on Mlortgages, 7 th Ed., page 1027: Kinnaird v. Trollope, 39 Ch. D. 636 ; Forster v. Ivey, 2 O. L. R. 480.

${ }^{81}$ Re Rouan to Trust and Loan Company Mortgage, Milligan, Master of Titles, March 10, 1910. 
(c) Every other person appearing at the time of the filing of the notice in the land titles office, to have any mortgage, incumbrance or lien upon, or estate, right or interest in or to the land subsequent to the first named mortgage. The holders of a certificate of judgment, or execution creditors against the registered owner, are entitled to be served under this heading. Caveators are also served, notwithstanding that they have not under the Acts any interest in the land and "as to the land itself are in no better position than any other simple contract creditor of the mortgagor." 82 The registrar will not assume that the caveator's interest claimed in the caveat is not such as gives him a right to redeem. A mere covenantor in the mortgage is not entitled to notice, ${ }^{83}$ and the omission of such notice in itself would appear not to release the covenantor, but the mortgagee selling is liable to him for the full value of the property. ${ }^{8 t}$

(cc) Notice-Form of.

The notice is not necessarily a formal document, but for greater certainty in practice it is usual to adopt the form set out in Appendix C (No. 3). This form, in addition to notifying the parties of the intention to sell covers also the intention to exercise all other powers which may be exercised upon such notice, and further contains the declaration of intention to apply for foreclosure, in case the sale be abortive. The notice may be signed by the party, or in practice is accepted when signed by the solicitors of the party; there being nothing "either in the

${ }^{82}$ Gill,erl v. Rccres \& Co., 4 S. L. R. 97 (full court).

${ }^{83}$ Re Empire Loan Co. and Young's Morlgage, Master of Titles (Sask.), February 9, 1911, affirined by the full court, July 17, 1911, unreported.

${ }^{84}$ Marlin v. IIall, 25 Gr 471. 
language or in the body of the statutes which showed that a personal act was intended." 85

$$
\text { (dd) Notice-Filing of. }
$$

The notice requires to be filed with the registrar, but nothing is stated in the Acts as to the time at which the notice must be filed. The notice is not intended to pass any estate or interest in the land, and its validity, therefore, is not governed by those sections of the Acts which enact that

"no instrument until registered shall be effectual to pass any estate or interest in the land." 86

The effect of filing the notice is to close the list of subsequent incumbrancers who must be served, and in view of that effect of filing it is wise on the part of the mortgagee to file at once on beginning proceedings. The practice of the registrars is also to insist, as far as possible, on filing as the beginning of the proceedings. There is, however, in Saskatchewan, an informal regulation that a notice filed within thirty days of serving will be considered to be properly filed.

\section{(ee) Notice-Service of.}

The notice requires to be personally served, ${ }^{87}$ but in case of impossibility the registrar is given a discretion to direct otherwise. He has a general power under section 113 (a) Manitoba, and 93 (7) Saskatchewan, to order substitutional service in case any person requiling to be served cannot after due diligence be found. Such an order is granted upon similar evidence to that which would be required to obtain such an order in court. The notice not being the command of the King, nor of any tribunal purporting to exercise authority, no question

\footnotetext{
${ }_{80}$ See Maxwell, Interpretation of Statutes, 4th Ed., page 110, and cases there cited; McDonald v. Rowe, 3 V. R. 143.

${ }^{36}$ Man. 83; Sask. 64, 67.

${ }^{87}$ Man. 113 (a); Sask. 93 (7).
} 
of the propriety of service out of the province in which the land lies arises.

The notice may be served on a party wherever he can be found. Where a minor or person of unsound mind is to be served, his guardian may be served (Man. \$164; Sask. \$160), or if he have none, in Manitoba the district registrar may appoint the official guardian ad litem or other person as guardian upon whom service may effectively be made, and in Saskatchewan the court or judge may appoint a guardian for the purpose of the proceedings. These provisions will supersede the old law under which it was no objection to a service of a notice that a party who receives the notice may be an infant or of unsound mind or otherwise incapable of understanding it. In Bartlett v. Jull, ${ }^{88}$ Spragge, C., said:

"I find no case in which it has been held or in which it has been contended, that where, by the terms of the contract, notice is required to be given, notice will be dispensed with because the person to whom it is intended to be given is not of capacity to understand it. It does not follow from the heir in this case being so young, that the placing of a proper notice in his hands directed to him as heir-at-law would necessarily have been an idle form. It might have drawn the attention of the child's mother, who was, I apprehend, his guardian in socage, to his rights and to her duties in that relation; but whether practically useful or not it was a something without the doing of which the mortgagee had not the power to sell."

It is a common practice to insert in mortgages directions customary and effectual under the former system of conveyancing providing for service of the notice being effectual by the performance of specific actions, such as by posting a copy of the notice on the land. While it is submitted that the registrar is entitled to read these provisions as suggestive in giving directions when required by reason of their having been the agreement of the parties, nevertheless the sections of the Acts

${ }^{88} 28 \mathrm{Gr} .140$. 
"contain a code that *** is required to be followed in realizing under any power of sale, in a mortgage of land under the Act. whether that power remains undisturbed by express declaration in the instrument or is 'modified' by such a declaration. The intent of the Act to hold statutory control over exercise of such powers is shown (in Manitoba) by the fact that, where a mortgage provides for a sale without notice, section 110, nevertheless, safeguards the owner against abuse of such provisions by requiring an order of the district registrar to be got allowing the sale.

"Except where otherwise permitted by the Act itself, as in the provisions allowing foreclosure by sale or court process, compliance with the statutory procedure seems to me indispensable to valid sale of the land under the power." 89

And in Australia, where, on a sale under power, notice was served on the mortgagor, but not on the registered assignee, Holroyd, J., said:

"The Act controls the instrument of mortgage. You cannot draw up a mortgage so as to control the Act. The strictest procedure is intended to be followed in regard to foreclosure." 90

That part of the judgment of the Privy Council in National Bank of Australia v. United Hand in Hand, ${ }^{91}$ in which they approved a covenant in the mortgage as shortening the time for service of the notice is not in point, as under the Tictorian Act, upon which that case was decided, the parties are expressly permitted to fix, in the contract, the length of default permitted and the length of notice required. In Saskatchewan, indeed, that part of the reasoning of Richards, J. A.. in Smith v. National Trust, supra, in which he determines that the execution of the power of sale may not be modified by declaration in the mortgage, arguing from the insertion of the proviso to subsection 110 , is not applicable, as there is no such proviso to the corresponding section, 93 (3), while on the other hand, the statutory power of sale is expressed only to arise where there is a contractual power of sale in

89. Simith v. National Trust, 17 W. L. R. 354; Richards, J. A., at page 363.

${ }_{90}$ In re Burton, 27 V. L. R. 437 , at page 441 , and see ante page 285 .

91 L. R. 4 A. C. 391, at page $40 \%$. 
the mortgage (section 93 (2), and is expressed to be pursuant to that power of sale (section 93 (3). The fact, however, of the Saskatchewan Act making the statutory power of sale depend on the covenant in the mortgage seems merely to be to require such a covenant as a peg, as it were, upon which to hang the proceedings. Once a covenant for sale in favor of the mortgagee is found in the mortgage, no matter how simple or how comprehensive the terms may be in which it is expressed, the intention of the Act appears to be, as in Manitoba, to carry out the sale under the terms of the Act and under the direction of the registrar. In only one case is any direct reference made in the Act to the provisions of the mortgage as determining the details of carrying out the power; that is in section 93 (2), which provides for lengthening the period of defau't before notice if such period be lengthened in the mortgage, and section 93 (3), which provides for lengthening the time for continuation of default after the notice, if so provided in the mortgage. But these two specific references to the mortgage provisions would indicate that, otherwise, these provisions are of no avail. It is evident, therefore, that section 157 of the Manitoba Act and section 167 of the Saskatchewan Act declaring that

"every covenant and power declared to be implied in any instrument by virtue of this Act may be negatived or modified by express declaration in the instrument,"

do not apply to the power of sale proceedings under the Acts. The same section, moreover, was also in the Australian Act when In re Burton, ante, ${ }^{90}$ was decided.

The notice cannot be served before the expiration of one month after default, and service of notices in connection with any mortgage is only complete when all the necessary parties have been

${ }^{90} 27$ V. L. R. 437 , at page 441 ; and sce anle page 286. 
served, and time begins to run in favor of the mortgagee from the date of the last service. After that date the mortgagee must wait, one month in Manitoba, and two months in Saskatchewan, before selling. The sale is presumably the actual sale of the property, and does not include all the preliminaries of the sale. But nevertheless, the practice is the same as has been the case in Ontario in proceedings under the general law by reason of the statutory provision there that

"in order to prevent the making of unnecessary and vexatious costs in respect of mortgages *** where pursuant to any condition or proviso contained in a mortgage there has been given a demand or notice, either requiring payment of the moneys or any part thereof secured by such mortgage or declaring an intention to proceed under and exercise the power of sale contained in such mortgage, no further proceedings and no action either to enforce such mortgage $* * *$ shall until after the lapse of the time at or after which according to such demand or notice payment of the moneys is to be made or the power of sale is to be exercised or proceeded under, be commenced or taken, etc." ${ }_{92}$

Under that section it was held that advertising was a proceeding and could not be carried on during the period. ${ }^{93}$

\section{(ff) Directions and Conditions.}

At the expiration of the period prescribed in the notice for default continuing, the mortgagee applies to the registrar for direction for sale. It is usual for the mortgagee's solicitor to submit directions, conditions of sale and poster in draft form. Suggested forms will be found in Appendix C (Nos. $4,5$ and 6$)$. The registrar revises these $n$ his discretion to suit the particular case, the sale being subject to such terms and conditions as the district registrar may think fit. The discretion thereby allowed to the registrar is a "judicial discretion 
regulated according to the known rules of law and not a mere whim or caprice of the person to whom it is given on the assumption that he is discreet." 94 "In other words, while caprice is excluded the judges must exercise their own discretion with regard to its object and the known rules of law and not merely copy the decisions of others." 95

In order, therefore, to fully understand the method of sale under the Acts reference should be made to the practice under the general law of mortgage sales as set out in works on mortgages.

In Manitoba the registrar may if provided in the mortgage, but apparently not otherwise, direct a sale without notice.

In prescribing conditions the general duty of a mortgagee selling under power of sale should be regarded:

"While the cases show that the mortgagee or assignee of the mortgagee is not a trustee for the mortgagor, yet they show that the power of sale ought to be exereised with due regard to the mortgagor's interests, and the sale ought to be made in the manner that it would be made by a reatsonably prudent man selling his own property." 96

The mere fact that a condition may be conceived to be such as might depreciate the price is not conclusive that the condition is improper, if it be such as a prudent vendor selling his own property might insert. Where there was a condition of sale entitling the vendor to rescind the contract in case he should be unwilling or unable to answer any requisition, Vice Chancellor Kindersley said:

"Now let us consider what are the rights of a mortgagee under a power of sale, more especially when the mortginge has given him an express power to sell under such speeial condlitions as he may think fit. I am not disposed to sily that any condition, whatever be its nature, would be justified under this

94 Encyclopaedia Laws of England, 2nd Ed., Vol. 4, page 610.

${ }_{95}$ Sharp v. Wakefield, (1891) A. C. 17:); P'ullullo v. Toun of Orangeville, 31 O. R. 194; Brown v. Jean, (II. L.) 79 L. J. K. B. 690.

${ }_{98}$ II uson v. IIaddington Island Quarry ('o., 16 W. L. R. (I3. C.) 226;

Warner v. Jacobs, 20 Ch. I). 220. 
special power; but I do say that the effect of the power is that any condition, whether special or not, that a prudent and reasonable owner, selling in his own right, would impose, is a condition justified by this power.

"Now, even without that special clause in the power, what are the relative positions of the mortgagee and the mortgagor when the mortgagee is selling? A mortgagee is certainly not a mere trustee; he stands in a very different position; he has his rights, viz., a beneficial interest in realizing the security so as to get his principal, interest and costs. It is that the court will not allow him to exercise that right without a due regard to the interest of the mortgagor; and the interest of the mortgagor requires that the sale shall take place as beneficially for the mortgagor as if he were himself selling. This, however, must be borne in mind, that though of course the object of the mortgagor is to realize the largest amount that can be got, yet it does not follow that conditions of sale, the effect of which would be to obtain the largest possible amount at the sale, are always the best for the mortgagor; for they may be such that, after selling at a good price, immense expenses may afterwards occur, and after you may fail in enforcing the contract, which would be to the detriment of the mortgagor. It does not follow, therefore, that because the conditions do to some extent tend to depreciate the price that will be offered at the sale, they are conditions that are really to the detriment of the mortgagor. If such condition as this were to the detriment of a mortgagor, it would be equally so when the absolute owner is selling; and yet we find that it is in practice a very ordinary and reasonable condition for an absolute owner to introduce in his condition of sale, and one that, without saying all conveyancers, but at any rate many leading conveyancers, consider extremely proper to be introduced when a mortgagee is selling under a power. The strong impression upon my mind is this, that the question is not simply whether such a condition may tend to diminish the number of buyers, or the sum which any bidder may be disposed to give; but whether it would tend to the detriment of the mortgagor or of an absolute owner, or be prudent in any absolute owner. If it would be prudent in an absolute owner, it is not imprudent as affecting a mortgagor." 97

It is to be kept in mind, however, that it is the mortgagee who sells and not the registrar. In case of difference in practice, the proceedings by a mort-

${ }^{97}$ Falkner v. The Equitable Reversionary Society, 4 Drew. 352, 2S I. J. Ch. 132. See, also, Hobson v. Bell, 2 Beav. 17; Kershaw v. Kalow, 1 Jur. (N. S.) 974 . 
gagee under power of sale are followed in preference to the practice under proceedings in court, where it is an official appointed by the court for the purpose who sells. Thus in a sale by the court where the ordinary practice is to appoint a third party to conduct the sale as an officer of the court for the purpose, the mortgagee may bid at the sale though not if the plaintiff himself has the conduct of the sale $;^{98}$ or the court may fix the reserve bid or upset price at sufficient to cover the claim. ${ }^{99}$ But in sale proceedings by the mortgagee he cannot under any circumstances bid nor can his solicitors or agent, nor can the registrar authorize him to do so. ${ }^{100}$ In Farrars v. Farrars, Limited, supra, it was said:

"A sale by a person to himself is no sale at all, and a power of sale does not authorize the donee of the power to take the property subject to it at a price fixed by himself, even although such price be the full value of the property. Such a transaction is not an exercise of the power and the interposition of a trustee, although it gets over the difficulty so far as form is concerned, does not affect the substance of the transaction."

The mortgagee may fix a reserve bid, and the better practice is on the sale to have it produced in a sealed envelope, which envelope is opened after the bidding is concluded, and if the highest bid has not reached the reserve bid, the property will then be put up again, beginning at the reserve bid. The fixing of this reserve bid does not appear to be a matter for the registrar. The mortgagee is entitled to realize his debt out of the property, and is not required to fix the reserve bid by reference to the value of the property. The registrar's duty is to see that the

${ }^{98}$ Ramsay v. McDonald, 8 P. R. 283; Taylor v. Sharpe, 3 Man. I. R. 4; Halsted v. Conklin, 3 Man. L. R. 8; Cumings v. Semerad, 8 IW. L. R. (Alta.) 644 .

${ }^{09}$ Fox v. In

100 National Bank of A ustralia v. United IIand-in-Hand Co., L. R. 4 A. C. 391; Farrars v. Farrars, Ltd., 40 Ch. D. 395; Orme v. IVright, 3 Jur. 19: Whitcomb v. Minchin, 5 Madd. 91; In re Bloye's Trusts, 1 Mac. and G. 488; Lawrence v. Galsworthy, 3 Jur. N. S. 1049; Marlinson v. Clowes, 21 Ch. D. 857; Henderson. v. Astwood, (1894) A. C. 150; Parnell v. Tyler, 2 L. J. Ch. N. S. 195. 
sale is conducted fairly and openly under reasonable conditions, and having done that the mortgagee may sell below his claim and costs if he wishes to. If he thereby directly or indirectly gains an advantage, the sale may be set aside; while on the other hand, if he sets the reserve bid above his claim and costs, and the bids run above his claim and costs, but not to the amount of the reserve bid, the mortgagee thereby deprives himself of the opportunity of making an application for foreclosure based on such abortive sale. It is doubtful whether the cost of a sale abortive for such reason would, as between the mortgagor and mortgagee, be chargeable to the mortgage account, although, as a general rule, the mortgagee is entitled to the costs of sale proceedings taken reasonably which prove abortive. ${ }^{101}$

The practice in court proceedings is to sell subject to all prior incumbrances, including taxes, seed grain liens and any other such charges. ${ }^{102}$ This practice, however, is not generally adopted in the registry offices where the view is taken that, so far as possible, to avoid the reluctance of the buyer which necessarily accompanies uncertainty, the bidding should be on a basis of a title free of incumbrances. An exception is necessarily made in the case of a prior registered incumbrance, but so far as possible the amounts of such incumbrances should be stated.

The conditions and poster and newspaper advertising should be such as to give fair notice of the sale. The usual practice under sale proceedings is to advertise for three or four weeks once a week, and to fix a date a week or two after the last advertisement. There is no fixed rule as to where the advertising should be done, the general principle

101 Cameron v. Mcllroy, 1 Man. L. R. 242; Farrer v. Lacy, Hartland \& Co., L. R. 25 Ch. D. 636.

${ }^{102}$ Canada Permancnt Mortgage Corporation v. Martin, 2 S. L. R. 472; Moriiz v. Christopherson, is W. I. R. 63. 
being that the property should be advertised where the advertisement would best reach that section of the public liable to buy the property being sold.

The registrar has power under the Acts to authorize a private sale at the beginning, but except in very exceptional circumstances the registrar will not depart from the long established practice of, in the first place at least, allowing the fullest opportunity of purchase, so as to avoid so far as possible a sale at an under value.

The approval of conditions by the registrar and the directions of sale given by him should not be considered in effect as analogous to an order of the court, so as to make invalid any thing done otherwise than in strict accordance with the order. In Manitoba the practice was at one time for the mortgagee to sell first, and bring in his proceedings completed to the district registrar subsequently, relying on their being reasonable and in general conformity with the practice of the registry office and consequently such as would commend themselves to and be passed by the district registrar. The sale is by the Act directed to be

"subject to such conditions as the district registrar may think fit,"

not "may order." There is no time specified at which the registrar may "think fit." It is the present practice, however, in both Manitoba and Saskatchewan, to take directions from the registrar first, but they are not construed as an order. Small variations therefrom arising from emergencies are not ground for refusing to pass the proceedings upon being subsequently presented, although the mortgagee or his solicitor makes such variations at his own risk. The registrar may approve the variations subsequently. Thus the mortgagee may, and probably should, even at the last moment, grant an adjournment of the sale at the request of the 
mortgagor, to give him an opportunity to complete a bona fide proposal for payment. In such cases if the bidders had gathered, a mere announcement of the postponement to such a date and time would seem sufficient, while if an adjournment is granted because of extraneous circumstances preventing all or any likely bidders assembling, or a full opportunity of a fair sale, further advertising should be done.

\section{(gg) Rights arising upon the Sale.}

It is usual after the property has been knocked down at an auction sale, for the purchaser to sign the agreement at the foot of the conditions of sale, which agreement is also signed by the same person as representing the mortgagor. The rights of the vendor, mortgagee, and the purchaser, as between themselves, depend on one hand on the conditions and on the other hand on the statute.

Sections 111, Manitoba, and 93 (4), Saskatchewan, raise questions not without difficulty, as to the rights among themselves of mortgagor, mortgagee and purchaser after a sale but before registration of transfer under power of sale. Without those sections the position of the mortgagee was simply that of one selling by virtue of a statutory right something he did not own, and, if he sold as provided by the statutes throughout, the registrar would register his transfer, and upon registration as provided in the next following section, the estate or interest of the owner of the land would vest in the purchaser free from all liability on account of such mortgage. It seems, however, that by the sections in question some further effect as against the land is given to the mortgagee's contracts and conveyances and a corresponding right is conferred on the purchaser prior to issue of the certificate of title in his name, if meaning is to be given to words of the section. If the purchaser 
"shall not be obliged to inquire as to the faet of any default or notice having been made or given,"

the inference is that he may have certain rights, even though such default or notice has not been given, and independently of his rights under the certificate of title when issued, which certificate by reason of the other provisions of the Acts, would in any event be sufficient to protect a bona fide purchaser from any liability on account of improper exercise of the power of sale.

As to the effect of the sale, against the mortgagor, there is a dictum of the Privy Council which suggests that the mortgagor's rights in the land remain, up till the time of registration of the transfer in favor of the purchaser. In National Bank of Australia v. United Hand in Hand, ${ }^{103}$ where there had been a sale purporting to be an exercise of a power, their lordships said:

"Again it follows from both the forty-second and eightyseventh seetions of the Act under consideration that whether the transaction with Lakeland be regarded as a sale by absolute owners, or as one by mortgagees under the statutory power, no interest in the mine could effeetually pass to the purchaser until registration, and consequently that the agreement of 15 th of September, 1857, was a mere agreement for sale which, whatever equities it ereated between the bank (selling mortgagees) and Lakeland (purchaser) left the prior equity of the company untouehed."

In Saltman v. McColl, ${ }^{104}$ this case was presented as authority for the proposition that a mortgagor is entitled in all cases to redeem before the sale is completed by complying with the conditions of sale and by the registration of transfer. Macdonald, J., distinguished the Privy Council case on the ground that "in that case there was collusion and pretended and fictitious sales," and held that where the vendors were in a position to make an effective sale and did so, in the absence of fraud or irregularity in

${ }^{103}$ L. R. 4 A. C. 391.

10412 W. L. R. 146. 
proceedings the purchaser was entitled to become registered owner. And in Thompson v. Berglund, ${ }^{105}$ where an execution creditor, whose execution had been filed subsequent to the day of the sale, wished to share in the proceeds, Wetmore, J., said:

"I hold that they had no right in the distribution, for the simple reason that when these executions were lodged there was no property against which they could attach; the property had been sold.'

In that case there was no question as to any irregularity in the sale. In Finklestein v. Lock, ${ }^{106}$ the sale proceedings were set aside, but on the ground of irregularity, and

"on the ground that they were conducted with the avowed purpose of the defendant (the beneficial owner of the mortgage) himself becoming the purchaser through the medium of the trustee,"

and also on the ground of an irregularity in the advertisement.

So far, therefore, at least as to the relations between mortgagor and mortgagee, it appears evident that upon a sale made regularly the interest of the mortgagor ceases upon the property being knocked down, or at least, upon the agreement being signed immediately after the property has been knocked down. The subsidiary rights, for example as to possession, depend on the conditions. ${ }^{107}$

The words of The Imperial Conveyancing and Law of Property Act 1S81, to which sections 111, Manitoba, and 93 (4), Saskatchewan, are analogous, and which reads as follows:

"Where conveyance is made in professed exereise of the power of sale conferred by this Act, the title of the purchaser shall not be impeached on the ground that no ease had arisen to authorize the sale, or that due notice was not given or that the power was otherwise improperly or irregularly exercised; but

1053 S. L. R. 470.

1066 W. L. R. 173.

${ }_{107}$ Stevens v. Ullerich, 17 W. L. R. 569. 
any person damnified by the unauthorized or improper or irregular exercise of the power shall have his remedy in damages against the person exercising the power,"

standing by themselves, are wide enough to give effect in favor of purchasers to an irregular sale under the general law, the person damnified having his remedy in damages against the person exercising the power. ${ }^{108}$ In an early case under the Victorian Act in Australia, ${ }^{109}$ an action was brought by the mortgagor against the mortgagees and the purchaser restraining them from dealing with the mortgaged land. The injunction was refused against a bona fide purchaser of part of the land wishing to register his transfer under power of sale. It was admitted that the notice was an improper notice and the service was not properly proved, but as regards the defendant purchaser, Molesworth, J., said:

"The eighty-fifth section (corresponding in Canada to the sections in question) appears to me to validate the contracts, not merely conveyances or transfers, without registration under the Act, and to protect contractors knowing nothing to impugn the propriety of the sale when contracting."

The same judge, however, afterwards doubted the correctness of this view, ${ }^{110}$ while on the other hand again, subsequently, in South Australia, an opinion in favor of the purchaser's protection from the date of the contract was expressed. ${ }^{111}$

There are no Canadian cases where it appears that a purchaser has attempted to rely on this section to enforce his rights under a sale admitted or proved to be irregular. In any case the registrar must reject any transfer under power of sale unless the regularity of every step is shown to his satis-

${ }^{108}$ Dieker v. Angerstein, 3 Ch. D. 600; Life Interest \& Reversionary Securities Corporation v. IIand-in-IIand Fire and Life Insurance Society, (1898) 2 Ch. 230; Bailey v. Barnes, (1894) 1 Ch. 25.

${ }^{109}$ MeDonald v. Roue, 3 V. R. 143.

"10 Ross v. Victorian Permanent Building Society, 8 V. L. R. 254.

${ }^{11}$ Public Trustee v. Arthur, 25 S. A. L. R. 59. See, also, Van Damme v. Bloxam, 9 S. A. I. R. 27. 
faction. ${ }^{112}$ It is not the duty of the registrar to hear evidence upon the purchaser being such without notice of irregularity. A dictum from the judgment of Richards, J. A., in Smith v. National Trust Company, ${ }^{113}$ indicates that the section only extends to sales otherwise regular under the Act. He said:

"Section 111 contains a proviso that the purchaser shall not be obliged to inquire as to the fact of notice having been given. But a perusal of the section shows that such proviso only applies where the requirements of sections 109 and 110 have otherwise been complied with."

Upon the payment in full of the purchase price the purchaser receives his transfer under power of sale (Form No. 7, App. C). The effect of this transfer is purely statutory, as the mortgagee, aside from the statute, has not the land to convey. The transfer operates, but upon registration only, to vest the land in the purchaser freed from all liability on account of the mortgage and of any mortgage, lien, charge or incumbrance created by any instrument registered subsequent thereto. The usual practice is for the purchaser to attend to the registration of his transfer in the same way as does a purchaser under an ordinary transfer.

In Manitoba, the documents when placed in the registry office are accompanied by an application for transmission, in Form No. 8, App. C, pursuant to section 119. The change of ownership under sale or foreclosure, falls under the definition of "transmission" (section 2, page 246). In Saskatchewan, however, such passing of ownership does not fall under the interpretation of "transmission" (section 2 (20).

Upon registration of the transfer the purchaser is entitled to receive a certificate of title for the land and thereupon is protected not only by the specific provisions of the Act in regard to a purchaser already

${ }^{112}$ Camplll v. Commercial Bank of Sydney, referred to in National Bank v. United Hand-in-Hand, L. R. 4 A. C., at page 407 .

i3 20 Man. L. K. 522, at page 534. 
discussed (Man. 111; Sask. 93, 94), but he relies for his protection upon the effect of a certificate of title, being in the same position as any other registered owner bona fide for value.

(hh) Distribution of Proceeds.

Express provision is made in the Acts for the distribution of the proceeds of a sale. The provision is substantially identical with that which it is customary to set out in mortgages under the general law under the ordinary practice of conveyancers, and also with that contained in the power of sale in The Short Forms Acts of the various provinces of Canada and particularly of Revised Statutes of Manitoba 1902, c. 157, Second Schedule, Form 13. The mortgagee is constituted by statute an express trustee for the mortgagor and other persons interested in the sale. The absence of the word "trust" does not alter the relationship of the parties nor prevent an express trust arising. ${ }^{114}$ In Banner v. Berridge, ${ }^{115}$ there was a sale of a ship under the power of sale contained in The Merchants Shipping Act as follows:

"Every registered mortgagee shall have power absolutely to dispose of the ship or share in respect of which he is registered and to give effectual receipts for the purchase money; but if there are more persons than one registered as mortgagees of the same ship or share, no subsequent mortgagee shall, except under the order of some court capabie of taking cognizance of such matters, sell such ship or share without the concurrence of every prior mortgagee,"

as to which, Kay, J., said:

"It is plain that there is a mere expression that the registered mortgagee shall have power to sell and to give receipts and certainly there is no express trust for all purchase moneys."

And on page 269 of the report, he pointed out that where no trust is expressed, none arises until it is

114 Lewin, Trusts, 11th Ed, page 1100.

118 Ch. D. 254. 
shown there is a surplus, in which case a constructive trust arises, that is to say,

"a case of trust which only arises on proof of the fact that there was a surplus in the hands of the mortgagee after paying himself."

But under the Acts express provision is made as to the application of the whole of the proceeds sufficient to create the mortgagee an express trustee of the surplus for the mortgagor or other persons interested. ${ }^{116}$

If the mortgagee undertakes to pay out the claims upon the surplus on his own responsibility, he is entitled to strict proof from subsequent incumbrancers as to the validity of their claims. Thus in Re Kingsland, ${ }^{117}$ a subsequent incumbrancer produced in support of his claim a copy of an assignment purporting to have been made to him by the mortgagor of his interest in the surplus proceeds. The trustees refused to pay to the claimant the surplus, in the absence of instructions to do so from the original mortgagor, on the ground that the original assignment should be produced and proof given that there was no existing prior assignment, and also that his claim had not been otherwise satisfied, as the assignment to him had been expressly made to secure payment of a debt. They also asked for a bond of indemnity against any loss they might sustain from being compelled to pay the surplus twice. The claimant refused to give any further proof and the money was paid into court. The claimant presented a petition for payment out and for costs. Spragge, J., said:

"No question of bona fides had been raised. The question simply was, whether the proof required by the trustee before paying over the money was reasonable,"

and he thought it was.

wo In re Bell, 34 Ch. D. 462 ; Gilles $v$. The Hamilion Provilent \& Loan Society, 10 Man. I. R. stiz'

11: S P.tR. 77. 
An execution or a judgment creditor who files his execution or judgment subsequent to the filing of the notice of exercising power of sale, but prior to the date of the sale, is entitled to share in the proceeds, but a creditor under an execution or judgment lodged after the date of the sale has no right to share in the distribution. ${ }^{118}$ A creditor under an expired execution has no claim. ${ }^{119}$ The Creditors Relief Act. applies to distribution of proceeds among execution creditors, supra, and where subsequent to the mortgage there are executions, then a second mortgage and then further executions, the surplus not being sufficient to pay off the incumbrances, the executions prior to the second mortgage are paid in full first, then the second mortgage, then the executions subsequent to the second mortgage pari passu. ${ }^{120}$ In Saskatchewan, in the case of lands exempt from executions, the execution filed in the land titles office is not a lien on the land and consequently an execution creditor does not share in the distribution of surplus proceeds in case of such exempt land. ${ }^{121}$ In Gilbert v. Ullerich, ${ }^{122}$ it was held that a mere caveator had under the claim in his caveat no lien on the land, and until he prosecuted his claim to judgment and obtained an order of the court making his claim a lien on the land, he had no claim on the land in question, nor on the moneys derived from the sale. This case is discussed elsewhere as an illustration of the difficulties in a literal interpretation of The Land Titles Act as to its effect in the passing

${ }^{118}$ Thompson v. Berglund et al., 3 S. I. R. 470, 16 W. I. R. 154.

119 Evans v. Postit, 3 A. I. R. 141.

120 Edmonton Mortgage Compamy v. Gross, 18 W. L. R. 385, "applying the principles involved rather than the precise reasons adcluced" in the case of Roach v. Mclachlan, 19 A. R. 486; Breithaupt v. Marr, 20 A. R. 689; Re Massey, "2 Terr. I. I. 84; Howard v. High River Trading Co , 4 Terr. L. R. 109.

${ }^{12 t}$ Re Dumaurez, 5 Terr. L. R. S4; Bocz v. Spiller, 1 W. T. R. 366, affirmed 2 W. L. R. 280; Union Bank v. Jordan, \& W. 1. 12. 77.

122 Gilbert v. Ullerich, 4 s. L. R. $56,16 \mathrm{~W}$. I. R. 490 , affirmed 4 S. L. R. 97,17 W. L. R. 157. 
of interests in the land. The decision would be easily intelligible if its effect was merely that on a chamber application for payment out a contested claim under a caveat could not be tried out. But there was no contest in that case as to the fact alleged by the caveator. In the meantime, it is safe to say that the presence of a caveat subsequent to the mortgage under which sale is made in Saskatchewan is justification to a mortgagee with surplus moneys in hand, unless he can obtain full consents from all parties interested, for taking proper proceedings through the courts to determine the parties entitled to surplus money. On such a proceeding the court in Saskatchewan will stay the distribution to permit the caveator to bring an action to establish his lien. ${ }^{123}$

For a suggested form of release to be taken by the mortgagee from subsequent mortgagees on receipt of surplus proceeds allotted to them, see Form No. 9, App. C.

In case of doubt arising in the distribution of the proceeds in the hands of the mortgagee, he may call the court to his assistance in the matter. The practice under this head in the Canadian courts does not appear to be accurately settled. In Coote on Mortgages, page 932, under the English practice it is laid down that "where it does not appear who is the proper person to receive the surplus proceeds the mortgagee may pay the money into court," and there are reported cases where this course has been adopted under The Trustee Relief Act, ${ }^{124}$ and in another instance an originating summons was granted on the application of the mortgagee to determine how a balance of purchase money was divisible. ${ }^{125}$ In The Western Canada Loan and Savings Company

${ }^{123}$ In re J. I. Case Threshing Machine Co., 1 W. W. R. 129, 19 W. L. R. 701.

${ }^{124}$ Roberts v. Ball, 24 L. J. Ch. 471 ; Charles v. Jones, 35 Ch. D. 544.

${ }^{125}$ In re Cook's Mlortgage, (1896) 1 Ch. 923. 
v. Court, ${ }^{126}$ a bill was filed for an interpleader between the defendants, both of whom claimed to be entitled to the surplus money in the hands of the plaintiff, arising from the sale of the lands under the ordinary statutory power in a mortgage. One of the defendants set up by his answer that the plaintiff should have paid the money into court under The Trustee Relief Act. Proudfoot, V. C., said:

"I do not think that this is such an express trust as to come within the meaning of The Trustee Relief Act and enable the plaintiff to pay the money into the court, and the course they have taken in filing a bill is proper."

The mortgagee is, however, an express trustee, ante page 337. In Re J. I. Case Company and Fisher, ${ }^{127}$ Wetmore, C. J., in Saskatchewan, diseussed the right of the mortgagee to pay into court under The Trustee Relief Act, not, however, conclusively. The learned chief justice admits that in that ease, owing to the presence of a caveat, there was sufficient uncertainty as to the persons entitled to justify the payment into court under section 28 of The Saskatchewan Trustee Act (being in the same words as The Imperial Trustee Relief Act of 184\%, 10 and 11 Vict. c. 96), but he indicated that the propriety of payment into court under this Act may depend on the difficulty of the questions at issue, and he suggested an application under section 49 of The Trustee Act (compare Revised Statutes of Manitoba 1902, c. 17.0, $\$ 42$ et seq.). The greater number of cases seem to indicate payment into court under The Trustee Relief Act as a proper course for the mortgagee, but if in the opinion of the judge such payment has been unnecessary, he may be deprived of his costs of such payment in.

\section{(c) Foreclosure.}

The proceedings in foreclosure under the Acts are identical with the proceedings in sale up to the $12525 \mathrm{Gr} .151$.

${ }^{127} 1$ W. W. R. 129; 19 W. I. R. 701. 
moment preceding the property being knocked down to the highest bidder at an auction sale. If this highest bid is equivalent to the reserve bid, it is a sale. If there is no bid in amount equal to the claim and costs, the foundation for foreclosure has been laid. The notice of exercising power of sale, if properly drawn in anticipation of such a possible failure of bidding, has in order to complete the statutory foundation for foreclosure to contain a declaration of the intention of the mortgagee to make an application for foreclosure in case the sale prove abortive. Before such application can be made default must have continued for six months. which time, however, may run simultaneously with the time sale proceedings are being carried on. Therefore, in the ordinary case the mortgagee is almost, if not quite, at the point where he can make his application for foreclosure at a very early date after an abortive sale. The application may be made in Form 10 and is accompanied by the same proof of the regularity of the sale proceedings as is required in case of a transfer, and in addition by an affidavit of continued default which may be in Form 11. Upon such application in Manitoba notice is required to be served of the time within which redemption may take place, ${ }^{128}$ which time shall be not less than one month from date of the serving of notice. The notice may be in Form 12 and is required to be serred in the same way as an original notice of exercising porrer of sale. In Saskatcheran there is no statutory requirement calling for any such notice. but the practice has been to require a month's notice of the application to foreclose to be given, the notice having been usually held sufficient when given by registered letter. The question of the necessity of such a notice independently of such a provision as now appears in the Manitoba Act

128 Section 113 (a), amendment of 1911. 
of 1911, was very fully discussed in Williams $v$. Box. ${ }^{129}$ The Court of Appeal in Manitoba held that such a notice was not necessary and the Supreme Court of Canada did not reverse this holding. Anglin, J., in the Supreme Court, with whom the Chief Justice and Girouard, J., agreed, expressly refrained from dealing with the question; Idington, $J$, used very strong language in condemning the practice of doing without such a notice, but did not go so far as to hold that it was necessary, but only that in the case at bar it was so oppressive a proceeding to dispense with it, that a court might on that ground exercise its inherent power respecting mortgages in the way desired, that is to open up the foreclosure; and Davies, J., said that in his opinion it had been shown that the proceedings (which had not included such a notice) were in strict conformity with the Act. The registrar may also cause notice to be published offering the land for private sale, implying that the power of the registrar to approve conditions of sale is not exhausted by the approval of the conditions of an auction sale, and that a private sale may be made carrying with it in favor of a purchaser all the rights he would have obtained by purchase at the sale by auction.

In default of redemption or sale the order of foreclosure goes. A certificate of title is issued to the mortgagee, and "every such order of foreclosure under the hand of the district registrar and entered in the registry shall have the effect of vesting in the mortgagee or his transferee the land mentioned in such order, free from all right and equity of redemption on the part of the owner, mortgagor or incumbrancer, or of any person claiming through or under him subsequent to the mortgage or incumbrance, and such mortgagee, incumbrancee or transferee shall upon such entry being made be decmed a transferee 
of the land, and become the owner thereof and be entitled to receive a certificate of title for the same" (Man. 114; Sask. 93 (8). The Acts thus seem to pile up clause upon clause fortifying the position of the mortgagee under a certificate of title so obtained, and utterly extinguishing any rights by reason only of the relationship theretofore existing of mortgagor and mortgagee. Under a foreclosure order granted by the court there is no doubt but that the jurisdiction existed to open up the foreclosure, even after the issue of a certificate of title.

"An election on the part of the mortgagee, therefore, to inroke that jurisdiction involved necessarily a right to redeem on the part of the mortgagor. The mortgagor could not invoke the jurisdiction of the courts with respect to foreclosure without accepting that jurisdiction in full, involving the mortgagor's right of redemption in accordance with the ordinary practice and rules of the court."'130

In Barnes v. Baird, ${ }^{131}$ Perdue, J., reopened a foreclosure under the Act, saying:

"The foreclosure proceedings which are conducted by the district registrar in the ease of lands which have been brought under the operations of the Act, cannot be considered as being more binding between mortgagor and mortgagee than a decree or order of foreclosure made by the court,"

but the learned judge had not at that time before him the decision in Campbell v. Bank of New South Wales, ${ }^{132}$ and in Williams v. Box, ${ }^{133}$ the same judge stated in regard to his former decision:

"I am conscious now after having the opportunity of perusing a full report of Campbell v. Bank of New South Wales, and of comparing the statutes, that I expressed myself too widely in regard to the power of the court to open statutory foreclosures."

In Williams v. Box the plaintiff brought an action for redemption after an order for foreclosure under the Act and the issue of certificate of title. The case

130 Williams v. Bor, 44 S. C. R. 1 (Davies, J.), at page 7 .

13115 Man. L. R. 162.

13211 A. C. 192 , affirming 16 N. S. W. Eq. 285.

13319 Man. L. R., at page 590. 
was one where admittedly under the equitable jurisdiction of the court ${ }^{134}$ in case of an old system mortgage the foreclosure would have been reopened. Upon the construction of the statute and the effect given to such order of foreclosure, the action was dismissed by the trial judge, who was upheld by the Court of Appeal in Manitoba, but that court was reversed by the Supreme Court of Canada, which allowed the mortgagor to redeem. The decision in the Supreme Court of Canada, however, turned on the then section 126 of the Manitoba Act, which read:

"Nothing contained in this Act shall take away or affect the jurisdiction of any competent eourt on the ground of fraud or over contracts for the sale or other disposition of land or over equitable interests therein or over mortgages. Nor shall anything contained in this Act affect the right of the mortgagee to foreclose or sell through any competent court which right it is hereby declared may be exercised in such court."

The decision in the Supreme Court turned on the words "or over mortgages." 135 The Court of Appeal in Manitoba had treated these words as practically adding nothing to the Act. Section 126 of the Manitoba Act has been repealed by Statutes 1911, c. 49, $\S 7$, and it would appear therefore that the decision of the Court of Appeal in Manitoba is now good law for Manitoba and for Saskatchewan, where section 4 of the Act does not contain these words.

This conclusion is fortified by the decision in Fink v. Robertson, ${ }^{136}$ where the High Court of Australia held that a statutory foreclosure could not be reopened. Griffiths, J., delivering the judgment of the majority of the court said:

"In our opinion the title of the mortgagee, when so registered as proprietor, is absolute and unimpeachable except on the ground of fraud."

${ }^{134}$ Campbell v. IIolyland, 7 Ch. D. 166.

$13544 \mathrm{~S}$. C. R. (Davies, J.) at page 8, (Idington, J.) at page 15, (Anglin, J., with whom the Chief Justice and Girouard, J., concurred) at page 24.

1364 C. L. R. 861. 
In re Premier Permanent Building Association ${ }^{137}$ was expressly overruled. In that case it had been held that a statutory foreclosure could be reopened, Madden, C. J., saying:

"It was argued that the principle as to a foreclosure being reopened was a creature of the court of equity, and if the former state of things existed it would be different, but that where you have a statute of this kind declaring that this is an absolute estate, then equity had no right to intervene. But the principles of equity are part of the general law of the land, and unless the Act of Parliament showed clearly that it intended that as to land brought under its operation the ordinary equitable principles should not apply, it would be wrong to raise such a new position between the parties."

While this statement of the law is incontestable, the result of Fink v. Robertson was that just such a clear intention to exclude equitable principles was evident in this case.

As to the effect of a foreclosure in the courts, in Colonial Investment Company v. King, ${ }^{138}$ McGuire, C. J., in the Supreme Court of the Northwest Territories, had expressed the opinion as an obiter that a foreclosure pursuant to order of the court could not be opened up. In view of what was said in Williams r. Box, supra, this cannot be said to be good law. ${ }^{139}$

\section{(d) Entering into Possession and Leasing Property.}

The right of the mortgagee to enter into possession and make leases of the property independently of the proceeding through service of notice as prescribed, authorized by the Torrens Acts, has already been considered, ante page 298. both as regards the practice and the law. As no questions in regard to the statutory powers of entering into possession and

13725 V. L. R. 77 ; In Re Fink v. Robertson, the court stated that it concurred in and followed Campbell v. Bank of New South Wales, $11 \mathrm{~A}$. C. 192 .

${ }^{133} 5$ Terr. L. R. 371.

139 Compare the remarks, obiter, of Wetmore, C. J., in Richards v. Thompson, 18 W. L. R. 179. 
leasing have been the subject of reported decisions, it is not necessary at this point to do more than refer the reader back to that discussion.

\section{$\S$ 41. TACKING AND CONSOLIDATION.}

The equitable doctrine of tacking has been abolished and all instruments take priority the one over the other according to the date of their registration. ${ }^{140}$ In regard to consolidation as between the two original parties there seems no reason why the doctrine should be abolished, but any rights which might be so aequired as against third parties relying on the register are excluded.

\section{§ 42. INCIDENTAL RIGHTS AND REMEDIES.}

\section{a. Acceleration.}

There are in the Acts a number of covenants and powers provided which, while bearing no special relation to the statutory mortgage, as such, are referred to here merely because they are contained in the Acts.

In case of default and the whole principal and interest thereby becoming due and payable by reason of an acceleration clause in the mortgage, the mortgagee may, notwithstanding any provisions to the contrary, perform such a covenant or pay such arrears as may be in default under the mortgage, and shall thereupon be relieved from the consequence thereof. ${ }^{141}$ This sect on is applieable in Manitoba to all mortgages whether registered under The Real Property Act or under the old system. Mather's, J., in National Trust Company v. Campbell, ${ }^{142}$ said that:

"It would be difficult to assign a reason why a mortgagor under one system should be entitled to relief against an acceleration clause and a mortgagor under the other system not so entitled."

140 Reeves v. Konschur, $2 \mathrm{~S}$. L. R. 125.

${ }^{141}$ Man. 117; Sask. 93 (10).

${ }^{142}$ National Trust Co. v. C'amplell, 17 Man. L. R. 587, 7 W. L. R. 754. 
On the other hand, in McGregor v. Hemstreet, ${ }^{143}$ Brown, J., in Saskatchewan, instead of extending the beneficial operation of the same section in the Saskatchewan Act, limited it to cases where proceedings were taken under the provisions of The Land Titles Act, on a ground equally available under the Manitoba Act, namely, that the section names the registrar of land titles as the person who shall tax costs. It is submitted that the interpretation of the Manitoba court is more consonant with the principle of construction of remedial statutes.

\section{b. Insurance Against Hail.}

In Saskatchewan only, there is implied a covenant that the mortgagee may in certain circumstances insure against hail (section 92).

\section{c. Covenant to Repair.}

In Saskatchewan only, there is implied against the mortgagor remaining in possession a covenant that he will repair, and that the mortgagee may enter upon the land to view the state of repair (section 102).

\section{§ 43. MORTGAGE OF MORTGAGE.}

In Saskatchewan, and Manitoba, provision is also made for the mortgage of a mortgage in the same form as a mortgage of land adapted to su:t the circumstances (see Form No. 12). While this form is not specifically prescribed in the Saskatchewan Act, it is to be assumed the same form would be used. The mortgagee of a mortgage has all the rights of the original mortgagee upon default in the original mortgage (Man. 102; Sask. 98 (4), and on the other hand is entitled to treat the original mortgage itself as the mortgaged property and presumably on default is entitled to sell the same.

${ }^{148} 20$ W. L. R. 612. But see Hestern Trust Co. v. Popham, 2 IV. IV. R. 297. 


\section{$\S 44$. INCUMBRANCES.}

The instrument called "mortgage" under the Acts is that which is used when the land is intended to be charged for the purpose of securing a debt or loan. For charging the land for other purposes a slightly different form of instrument called "incumbrance" is provided by the Act. By the interpretation clause a mortgage is defined to mean "any charge on land for the purpose of securing a debt or loan," but it was at one time customary to use the incumbrance form very frequently for the purpose of securing a mere debt. This, however, has been held to be an improper use of the incumbrance form and the registrar is entitled to refuse registration of such a purported incumbrance, ${ }^{144}$ and the law as so laid down has been put into a statutory enactment in Saskatchewan, in section 87 (2). It is to be presumed, however, that although such an instrument would not be a registerable instrument, it creates an equitable mortgage ${ }^{145}$ and may be marle the ground of a caveat.

The statutory form of incumbrance differs from the mortgage in that it does not contain a covenant for payment, but aside from that difference, no further differences may be gathered from the language of the statutes themselves. A perusal of the sections dealing with mortgages and incumbrances discloses the fact that the remedies under the two instruments are substantially identical. The provisions of section 108, Manitoba, conferring on a first mortgagee the same rights and remedies as he would have been entitled to if the legal estate had been vested in him, do not extend to an incumbrance, indicating, as indeed does the statutory form of the instrument itself, that the incumbrance is to be treated in case of difference as more strictly

${ }^{144}$ Re Rumely Co. and Registrar of Saskatoon L. R. D., 17 W. L. R. 160) (Sask. full court).

145 Sawyer Massey v. Waddell, 6 Terr. L. R. 45. 
analogous to an equitable mortgage by way of charge only rather than to a mortgage of the legal estate. By a peculiarity of the Saskatchewan Act the statutory proceedings for sale or foreclosure are made applicable apparently to mortgages or incumbrances, but in the additional words inserted in those provisions, which do not appear in the Manitoba provisions, riz., that such remedies shall be pursuant to any corenant in the instrument, the mortgage only is referred to and not the incumbrance. Reading the sections, however, as a whole there is no reasonable cloubt but that these provisions for sale and foreclosure will extend also to an incumbrance, if there be a corenant for that purpose therein.

\section{DISCHARGE OF MORTGAGE.}

\section{a. In General.}

A mortgage is discharged in Manitoba by an instrument of discharge in Form 14 (section 104), accompanied by the certificate of charge, if any, or proof of its loss, and also by the mortgage or proof of its loss; and in Saskatchewan and Alberta by a receipt exccuted and attested as an ordinary instrument, accompanied by the original mortgage (Sask. 94; Alta. 63) or proof of its loss, and in Alberta, also, by the certificate of charge issued, if any, or proof of its loss (Alta. 71). In practice the discharge form is used in Saskatchewan and Alberta in the same manner as in Manitoba.

\section{h. In Alberta and Saskatchewan.}

In Saskatchewan and Alberta a mortgage may be discharged by the certificate of a judge showing that proof has been made to his satisfaction of the parment of all or part of the moneys. This certificate is usually obtained ex parte, and in accordance with the general practice under the Act there is no doubt that, even did the parties appear, 
where the questions under consideration are contested or involved, an application under this provision would not be entertained.

It is also provided in Saskatchewan that where a mortgagor is entitled to redeem, he shall have power to require the mortgagee, instead of discharging the mortgage, to transfer to a third party (section 93 (10).

c. Absence of Mortgagor from Province.

In the case of the absence of the mortgagor from the province, provision is made in Manitoba for payment to the provincial treasurer (section 116), and in Saskatchewan (section 96 ( 7 ) and Alberta (section 65), for payment to a bank on the order of a judge, and in either case for the entry of the certificate of payment with the same effect as a discharge. 


\section{CHAPTER XI}

LEASES

A lease under the Torrens system need not be by deed, thereby exhibiting the general tendency of the Torrens Acts to give statutory effect to equitable rules, but otherwise does not differ in essence, as does a mortgage, from the corresponding instrument under the general law. If the lease be for a term of three years or under, it need not conform to the forms in the Acts, ${ }^{1}$ and if there is actual occupation of the land under such a lease the certificate of title will be impliedly subject thereto notwithstanding the same be not registered. ${ }^{2}$ But in case of a lease for a term of over three years the registration makes the lease effective. ${ }^{3}$ Considerable latitude is allowed as to the form of the document. ${ }^{4}$ Certain covenants are implied by the Acts on the part of the lessee and on the part of the lessor. ${ }^{5}$ These may be read into a lease purporting to be made under the Act, even though not registered, and for a term less than three years. ${ }^{6}$ The lessee covenants that he will pay the rent reserved and all rates and taxes which may be payable in respect of the demised property during the continuance of the lease. This latter covenant is contrary to the actual practice in perhaps the majority of cases, and should, therefore, be negatived unless the lessee's special agreement is to saddle himself with the taxes. The lessee also covenants to keep and yield up the property in good

1 Man. 93; Sask. 81; Alta. 54.

${ }^{2}$ Man. 70 (d); Sask. 66 (d); Alta. 43 (d).

3 Shore v. Green, 6 Man. L. R. 322.

${ }^{4}$ Shore v. Green, supra.

- Man. 94, 95; Sask. 82, 83; Alta. 55, 56.

- Telfer Bros. v. Fisher, 15 W. L. R. 400. 
and tenantable repair. There is, by the general law, implied in all leases, a stipulation that the tenant will use the demised premises in a tenantlike manner. ${ }^{7}$ There is implied a power on the part of the lessor to enter and view the state of repair and to serve upon the lessee a notice in writing of any defect, requiring the tenant within a reasonable time to repair the same so far as the tenant is bound so to do; and further, a power that in case the rent or any part thereof be in arrears for two months, or default be made in the covenants and continued for two months, or in case the repairs are not made according to the notice, the lessor may enter upon and take possession of the demised premises. Upon proof to the district registrar of lawful entry and recovery of possession, the registrar shall treat the lease as at an end. ${ }^{8}$ The provisions in this regard in Saskatchewan and Alberta differ in a very material point from that in Manitoba, that is by the insertion after the words "re-entry and recovery of possession" of the words "by a legal pròceeding." In Re Tucker and Armour," the lessor, by his bailiff, peaceably entered on the land and took possession and submitted evidence of such taking possession to the registrar. The registrar thereupon cancelled the lease and the lessee took a petition from this action to a judge, who referred it to the full court. The full court directed the registrar to restore to the register the memorandum of the lease, on the ground that the simple act of taking possession on the part of the lessor by his bailiff was not a legal proceeding within the meaning of the section. Legal proceeding means

"any civil or criminal proceeding or inquiry in which evidence is or may be given."

7 Woodfall, Landlord and Tenant, 17th Ed., page 669.

${ }^{8}$ Man. 96 ; Sask. 84; Alta. 57.

- 4 W. L. R. 394. 
The court further threw out a suggestion, which would be equally in point in Manitoba where these words do not occur. Harvey, J., delivering the judgment of the court, said:

"The consequences of the registrar's act point also to the conclusion that Parliament could not have intended to permit the cancellation of the lease on the bare taking possession perhaps without the knowlerlge of the lessees. For many years the courts have relieved against the consequences of forfeiture for nomperformance of covenants, and particularly the covenant to pay rent, but in the present case, how could the lessee, assuming that he had the right to relief, obtain redress and repossess himself of the property? His lease being cancelled and his estate in the land being determined, he is prohibited by section 102 (of The Land Titles Act 1894, see Sask. 136) from maintaining an action for ejectment, without which he could not regain possession against a resisting lessor."

It is also provided in Alberta and Saskatchewan that a right for the lessee to purchase the land therein described may be stipulated in the instrument, and in case the lessee pays the purchase money stipulated and otherwise observes his covenants expressed and implied in the instrument, the lessor shall be bound to exccute a transfer to such lessee of the land and to perform all necessary acts prescribed for the purpose of transferring the land to the purchaser.

In St. Germain v. Reneault, ${ }^{10}$ an executor had given such an option under a lease. An action was brought by one of the beneficiaries interested in the estate asking that the option clause be declared null and void. It was pointed out that an executor cannot give an option, " and that, therefore, independently of the effect of the Act, the plaintiff was entitled to succeed. Mr. Justice Stuart considered the section of the Act making an executor the absolute owner of the land for the purpose of registered dealings, and held that, as the option would have been invalid in the hands of the lessee up to the

${ }^{10} 12$ W. L. R. 169.

11 Oceanic Steamship and Narigrtion Co. v. Sutherberry, 16 Ch. D. 236. 
moment of registration, the lessee could not by registration of his lease make that which was before void, valid and binding in his favor. An exactly similar state of facts has been considered by the Full Court of New Zealand in Fels v. Knowles, ${ }^{12}$ which court came to the contrary opinion. They held that the right to purchase was part of the lease, and the registration of the lease is the registration of every right given by it, and that the court was not enforcing a breach of trust, but an indefeasible legal right lawfully created in the plaintiffs, and this case was approved by the same court subsequently in Horne v. Horne. ${ }^{13}$

1226 N. Z. L. R. C. A. 604.

${ }^{13} 26$ N. Z. L. R. C. A. 1208. 


\section{CHAPTER XII}

CAVEATS

\$ 46. PURPOSE AND CLASSES.

$\$$ 47. CAVEATS AGAINST BRINGING LAND UNDER THE SYSTEM.

\$ 48. CAVEATS BY REGISTRAR.

\$ 49. CAVEATS BY THIRD PARTIES AGAINST SUBSEQUENT DEALINGS.

a. Persons Who May Caveat.

b. Form and Contents of Caveat.

c. Cessation of the Caveat.

(1) SUMMARY OF CAUSES.

(2) LAPSE OF TIME.

(3) NOTICE BY REGISTRAR AND LAPSE THEREAFTER.

(4) NOTICE BY ANY PERSON.

(5) SUMIMONS TO DISCHARGE CAVEAT.

(a) In General.

(b) Technical Objections.

(c) Objections on the Merits.

(6) WITHDRAWAL BY CAVEATOR.

d. Second Caveat.

e. Effect of Caveat.

(1) SUMMARY.

(2) EFFECT ON CLAIM MADE THEREIN.

(3) EFFECT AS AGAINST THIRD PERSONS.

(4) INCIDENTAL EFFECTS OF CAVEAT.

\section{\$46. PURPOSE AND CLASSES.}

The cavcat is an instrument peculiar to the Torrens system of registration, or at least to a system of registration of titles. As already explained, the scheme of the Acts is to recognize only registered interests in land, but it is equally as impossible to 
confine all interests in land to registered interests as it was, under the old system, to confine all estates in land to the legal estate. While it is true that the Acts state that no instrument until registered shall be effectual to pass any interest therein as against a bona fide transferee, or except as against the parties thereto, and only certain instruments ean be registered, nevertheless the courts administering equity recognize that "equitable interests and estates can be created and will arise by implication in these lands, just as in the case of lands that have not been brought under the Act, and the eourts of equity acting upon the registered owner in personam will still recognize and give effect to them." 1 Now, where there was no system of registration at all, such equitable rights merely stood their chance as such under the rules of equity, and where there was a system of registration of deeds it was, in addition, generally possible to register the actual instrument raising the equity, but under the Torrens Aets, the only instruments capable of actual registration are a few simple instruments passing a registered estate or effecting a registered charge on land. In an early Australian case ${ }^{2}$ it was held that no other instruments were effectual between the parties or enforeeable either at law or in equity, but fortunately this view of the Acts has not been generally adopted, as it would be impossible to confine dealings in and dispositions of land to the narrow limits of registerable instruments and the Acts themselves now impliedly recognize that such unregistered instruments do have some effect. On the other hand, the bona fide purchaser from the registered owner, even with notice not amounting to fraud, gains absolute protection by

I Bain, J., in Re Massey and Gibson, 7 Man. L. R., at page 180, approved Wilkie v. Jellett, 2 Terr. L. R., MeGuire, J., at page 143, whoso reasons were entirely right; $26 \mathrm{~S}$. C. R., at page 288.

${ }^{2}$ Lange v. Ruwoldt, 7 S. A. R. 1, overruled Cuthbertson r. Stoan, 11 S. A. R. 102 . 
registration. To take a middle course, as it were, between practically nullifying unregistered or unregisterable instruments on the one hand, and, on the other, permitting their actual registration and thus destroying the simplicity and workability of the system, the caveat was devised, with what effect it is the purpose of this chapter to elucidate.

Caveats are of three sorts:

(i) Caveats against bringing land under the system.

(ii) Caveats filed by the registrar.

(iii) Careats by third parties against subsequent dealings.

\section{\$47. CAVEATS AGAINST BRINGING LAND UNDER THE SYSTEM.}

The practice in regard to these necessarily differs in Manitoba from that in the other jurisdictions, for the reason that, in Manitoba, if land is not under the new system it may be dealt with under the old system, while in the other jurisdictions if land is not under the Acts, it may not be dealt with at all until brought under. It is therefore sufficient in Saskatchewan and Alberta and the Dominion to file a caveat in the ordinary way in the only registry office existing, even though there be no registrations under the Acts. The caveator has the assurance that before the land can be dealt with on the register, that is to say, at all, the careat must be disposed of. The claim of a caveator in these latter jurisdictions, thus to file a caveat prior to any certificate of title for the land having been issued, raises the question as to whether any land before the issue of certificate of title can be said to be under the system, and whether, therefore, the registrar is justified in clouding the title to such land or dealing with it in any way, 
even to the extent of filing a caveat. In Re Ebbing, ${ }^{3}$ the report shows that this contention was raised, but while in that case the registration of the caveat before patent was forbidden, it was distinctly based on the prohibition against the mortgage of a homestead before the issue of patent, and not on the general ground above suggested. The Acts themselves, however, recognize the propriety of filing a caveat before the issue of any certificate of title, ${ }^{4}$ and as the filing of the caveat is not actually dealing with land, but rather a restriction upon dealing, there seems no objection in principle to such filing, and certainly where there is no other possibility of registration, the protection of the public demands it. Under the law, prior to The Territories Real Property Act of 1886, instruments affecting land, whether patented or not, might have been registered."

But in Manitoba, where if land has not been voluntarily brought under the Act it may be dealt with under the old system, to file a careat under the new system against land which might or might not ever come under the operation of that system would be meaningless, and there is, therefore, special provision for the filing of caveats against bringing land under the new system when an application for the purpose has been actually made. Such a caveat may be filed upon a party having an adverse interest becoming aware in any manner of the fact that such an application is being made, but is ordinarily the first step taken by a party having an interest adverse to that of the applicant when such party has been notified by the registrar pursuant to section $4 t$ of the Manitoba Act.

The persons who may file a caveat against bringing land under the new system in Nanitoba are

32 Sask. L. R. 167. Sere, also, page 370.

Sisk. 127 (2); Alta. st; 10om. 133.

- In re Land'T'illes Act and C'anadian l'acific Railuay ('o . I'T.r.' 1. R., at page 243. 
the same persons as may file a caveat against dealings with registered land; that is to say, any person claiming an estate or interest in the land. These words will be more fully discussed post page 363 . A caveat against bringing land under the Act, unlike the ordinary caveat against dealings, operates as an injunction, and the district registrar after the receipt of the caveat shall not bring the land under the new system until such careat has been disposed of (section 128). But though more effective than the caveat against dealings in this respect, its efficacy is much less in the fact that it automatically lapses at the expiration of a month from the filing thereof, unless the person by whom or on whose behalf it has been lodged shall, within that time, have filed with the district registrar evidence that he has taken proceedings in court to establish his title to the land or his right as set out in such careat (section 129). After the lapse of the caveat forbidding the bringing of land under The Transfer of Land Statutes in Victoria, it was held that the court or a judge had no power to make an order restraining the registrar from bringing the land under the Act, ${ }^{6}$ but such time limitation is introduced for the benefit of the caveatee and may be waived by him. ${ }^{7}$ The proceedings to establish the claim in the careat may be taken either under Schedule L (section 144) or by statement of claim followed by the filing of a lis pendens (section 145). The caveat and proceedings thereunder depend for their existence on the continued existence of the application pursuant to which they are filed, and upon the withdrawal of such application the caveat and proceedings taken thereunder cease to have any effect, and do not operate so as to restrain the registrar from bringing the land comprised in the application under the Act if a second application

- Ex parté Ayluin, 4 T. L. R. 116.

7 Wilson v. McIntosh, 63 L. J. P. C. 49, (1594) A. C. 429. 
be made for that purpose. ${ }^{8}$ And where, pursuant to a caveat, writ was issued and an order for security made and compliance therewith defaulted in, an application to remove the caveat was granted by the Full Court of Victoria, Australia, which stated that it might do otherwise, but only in very special circumstances, if some fraud or oppression were shown. ${ }^{9}$ The proceedings based upon a caveat against bringing land under the new system have been discussed, ante page 77 .

\section{§ 48. CAVEATS BY REGISTRAR.}

Such a form of caveat is provided for in Manitoba and Alberta only; and, it may be added, in all the Australian jurisdictions. The jurisdiction of the registrar to file caveats is prescribed by section 49 (a) Manitoba and section 100 Alberta. Even for the purposes prescribed by these sections the registrar will exercise his jurisdiction cautiously. In New Zealand, where a caveat was filed by the registrar because an action had been brought calling in question the title of the registered owner, in order to protect the assurance fund in case the land got into the hands of bona fide purchasers, the court refused to discuss the rights of the claimants and the caveat was struck off. Richmond, J., said:

"The assurance fund must take its chance. It is contrary to the whole spirit and policy of these Acts, as I read them, to allow transfers by the registered owner to be inhibited upon a mere quia timet of the district registrar or his official superior." 10

On the other hand, where, before the High Court of Australia, on appeal from the Supreme Court of New South Wales, the question was as to the protecting of the rights of a municipality in certain lands under which they had acquired a statutory

- Gaffney v. McLaughlin, 18 IV. N. (N. S. W.) 291.

- In re McNaughton, (1909) V. L. R. 398.

1. Re T'anner, 5 N. Z. L. R. S. C. 102. 
right to construct gas works and lay pipes, it was held, following Municipal Council of Sydney v. Young, ${ }^{11}$ that this gave the municipality in question no interest in the land sufficient to qualify them to file a caveat, but O'Connor, J., said:

"The registrar, if he is of opinion that there was a highway or road dedicated properly, and that the applicant has taken a step which might put the municipality and other persons who wish to use the road in a difficulty by the issue of a certificate, has power under section 12 to enter a caveat immediately on the issue of the certificate of title." 12

A caveat filed by the district registrar does not lapse after the expiration of notice as provided in the case of a caveat filed by a private person, but only upon special proceedings for the purpose, taken in Manitoba upon notice of motion (section 141) and in Alberta by originating summons (section 96). Nor is the district registrar liable for filing or continuing any caveat wrongfully (Man. 135; Alta. 94).

The present sections of the Saskatchewan Act, numbers 161 and 177, which have no counterpart in the Alberta and Manitoba Acts, were taken from subsection 10 of the general section providing for and relating to caveats in The Land Titles Act 1894. section 99 reading:

"The judge, on application for that purpose, on behalf of any peron who is under the disability of infancy, lunacy, unsoundness of mind or absence from the Territories, may, by order lirected to the registrar, prohibit the transfer of or dealing with any land belonging to such person, and the dealing with any land in any casce in which it appears to him that an error has been made by misdescription of such land or otherwise in any certificate of title or other instrument, or for the prevention of any improper dealing."

There was no caveat by the registrar provided for in that Act. In the new Alberta Act of 1906 that subsection did not appear, but the careat by the

11 (1898) A. C. 457.

12 Municipal District of Concord v. Coles, 3 C. L. R. 96 ; see 12 (e) of the New south Wales Act 1900 is almost identical with 49 (e) Manitoba. 
registrar was introduced, copied probably from Manitoba. Sections 161 and 179 of the Saskatchewan Act, in view of sections 4 and 150, without some explanation appear somewhat as surplusage. It is submitted that it is the intention of these sections to provide an easy method whereby any person interested (in the widest sense of that word), or the registrar himself, may obtain an order, under circumstances where in Manitoba or Alberta the registrar, either on application or of his own motion, would file a caveat.

\section{§49. CAVEATS BY THIRD PARTIES AGAINST SUBSE- QUENT DEALINGS.}

\section{a. Persons Who May Caveat.}

The provisions of all the jurisdictions follow in a general way much the same lines in regard to these caveats. In Manitoba and Alberta the cavcator may caveat not only against land but against any mortgage or incumbrance. In Saskatchewan and the Dominion the power to caveat is confined to persons claiming an interest in land. In Manitoba, the words descriptive of persons who may file caveats are general, that is to say, any person claiming "an estate or interest in land" (section 130). Under the Ontario Act the power to caution, as it is called there, is extended to "any person interested in any way in any land." This phrase, which is substantially identical with the one adopted in the Saskatchewan and Alberta Acts, is wider than "claiming an interest in land." Whatever dealing gives a valid claim to call for or receive a conveyance of land is an interest within the scope of the statute. ${ }^{13}$ In Municipal District v. Coles, in Australia, ante, wherein a municipality claimed certain land as a street, it was held that it had no such interest in the land as entitled it to enter a caveat merely because it

${ }^{13}$ Re C'lagstone and IIammond, 28 O. R. 409. 
had the care, control and management of the road, or because of the power to construct gas works and lay pipes through the streets, or on the ground that a right of public passage is an easement.

"The intention of the Legislature in using the word 'interest' was that only a person having or claiming to have some legal or equitable interest in the land partaking of the character of an estate or of an equitable claim upon the land, can be a caveator." 14

The most important cases on the dividing line are those touching the question of the right to file a caveat under instruments containing covenants restricting the use of land. The effect of these covenants as running with the land, and being of the nature of an interest in the land, has already been discussed (ante page 244), and it may be stated that the practice in all the jurisdictions, whether in Manitoba, where the person who makes the caveat is one "claiming an interest," or in the other jurisdictions, where the caveator need only "claim to be interested," has been to allow the filing of caveats protecting rights under such instruments. The Australian cases to the contrary have not been followed, e. g. Ex parte Johnson, ${ }^{15}$ where a caveat under a covenant to grant a right of way was removed on the ground that the deed conveyed only an easement in gross which was a mere personal right, not assignable; Staples v. Corby, ${ }^{16}$ where a covenant in a mortgage not to purchase alcoholic liquors for sale on the premises from any other brewer than the plaintiff company was held not to entitle the plaintiffs to protect their right by a caveat; Woodberry v. Gilbert, ${ }^{17}$ where a covenant not to carry on a business in the particular

${ }_{14}$ Tierney v. Loxton, 12 N. S. W. L. R. 308, referring to section 24 of the New South Wales Act. Quoted with approval in Municipal District of Concord v. Coles, supra, section 24 reads: "Any person having or claiming an interest in any land may lodge a caveat, ete."

15 $5 \mathrm{~W}$. W. and $A^{\prime} B .55$.

1319 N. Z. L. R. 517.

173 Tas. L. R. 7. 
locality and not to let certain stables on certain land, was purely personal and would not run with the land or entitle the covenantee to enter a caveat against dealings; Ex parte Graves, ${ }^{18}$ where the right of a lessee to apply to the supreme court to be relieved from forfeiture of a lease was held not to be a beneficial interest in land which could be protected by caveat. The Canadian registrars have acted on "the broad principle, which appears to govern so many decided cases, of preserving rights in land which has been brought under the system as nearly as possible by analogy to rights which would exist in the same land if held under the general law."

A caveat may be filed by a cestui que trust even upon an unwritten trust. Thus, a wife, alleging that her husband had invested her money held upon trusts not committed to writing in the purchase of land, has a right to enter a caveat to protect her interests, the court saying:

"I think the caveat is rightly lodged. I am of opinion that cestuis que trustent have a right to caveat with a view to protecting their interests." 20

And an equitable mortgagee by deposit of title deeds has a claim on which to file a caveat, ${ }^{21}$ and likewise a person having an interest in the proceeds of the sale of land, ${ }^{22}$ and a person claiming under twenty years' adverse possession. ${ }^{23}$ In Fels v. Knowles, ${ }^{24}$ it was suggested by the High Court of New Zealand that a mere option would not entitle the holder thereof to file a caveat, but the same court subsequently, in Morland v. Hales and Somerville, ${ }^{25}$ decided

\footnotetext{
187 N. Z. Gaz. L. R. 318.

${ }^{19}$ Hoge, page S03.

${ }^{20} D^{\prime}$ Albedyhill v. Albctyhill, 3 N. Z. L. R. S. C. 391.

${ }^{21}$ Neal v. Adams, 4 N. Z. L. R. S. C. 177.

22 In re Bielfeld, 12 N. \%. L. R. 596.

22 Boyd v. Marfurlane, $1 \mathrm{~N}$ \%. I. Ii. S. C. 347.

2426 N. \%. L. R C. A., at page 613: merely that a caveat claimed under an option was assumed as molojectionable in Fallis v. Balthasar, $2 \mathrm{~W}$. W. IR. $1: 32$.

2630 N. Z. L. R. C. A. 201.
} 
that an option would pass an interest in the land sufficient to found a caveat upon, following London and South Western Railway Company v. Gomm. ${ }^{26}$

In the case of restrictive covenants in Manitoba the legislature has itself, in a manner, approved the filing of such agreements by way of caveat by such sections as 1908 , c. $52, \S 7$, altering by legislative authority the effect of certain agreements theretofore filed by way of caveat, and thus assuming the propriety and effectiveness of the filing.

As to the right of a creditor having a clain under 13 Eliz. c. 5, to set aside a certificate of title in the name of a registered owner, to file a caveat to protect such right, Dugas, J., at the trial in McGrade v. Syndicat Lyonnaise, ${ }^{27}$ intimated that in his view the creditor had such right. Idington, J., in the Supreme Court of Canada, dissented from this view. ${ }^{28}$ The latter view would seem to be supported by the Full Court of British Columbia in Peck v. Sun Life Assurance Co. ${ }^{29}$ where Duff, J., said:

"The creditors * * * had a statutory right to invoke by appropriate proceedings a judicial declaration of the facts which the provisions of 13 Eliz. c. 5, made void ab initio the conveyance from the debtor to his wife. The statutory right was neither an unregistered title nor an unregistered interest nor an unregistered disposition."

In Saskatchewan, owing to the peculiar wording of section 125 of the present Act, the power to caveat is held to be confined to persons claiming under an instrument in writing, according to a practice as established by a decision of the master of titles on a petition from a registrar. ${ }^{30}$ He there pointed out that of the specific documents under which it is provided that a person may file a caveat the most general is "any unregistered instrument."

${ }_{26} 20$ Ch. D. 562.

27 Sce 36 S. C. R. 251 , at page 255 .

${ }_{28} 36$ S. C. R., at page 275 .

${ }^{29} 11$ B. C. R 215.

${ }^{30}$ Re Ostad's Caveat, Master of Titles, Sask, Sth November, 1909. 
Instrument, according to the interpretation section, does not extend to any documents but those in writing. The specific enumeration of instances under which a person may file a caveat (section 125) is followed by the words "or otherwise," but it was held that these words "or otherwise" were either ejusdem generis with the preceding enumeration so as to be confined to instruments in writing, or referred to the words immediately preceding, so that in the latter case, that part of the section in question should read "under an execution where the execution creditor seeks to affect land in which the execution debtor is interested beneficially, but the title to which is registered in the name of some other person or the title to which is registered otherwise." Prima facie it would appear that the title to any land is either registered in the name of any given person or is not so registered, and that therefore such an enumeration is so unnecessary as to be meaningless, but the Full Court of Saskatchewan has, in effect, approved of this latter interpretation of the words "or otherwise." That was in a case where land was registered in the name of Prudent Guigere; the execution under which the caveator claimed was against James Gear, in fact the same person. Newlands, J., delivering the judgment of the court said:

"Now this land was not, strictly speaking, registered in the name of some other person, but as far as the land titles office was concerned, it was registered in the name of "some other person,' as they could not recognize these two names as belonging to one and the same person, and, therefore, as to the execution against James Gear, the land which was registered in the name of Prudent (iuigere, was registered in the name of some other person. Besides, the words 'or otherwise' must be given some meaning, so that if in this case the land was not actually registered in the name of some other person, it seems to me that these words extend the right to file a caveat to cases where the execution creditor is interested in land the title to which is registered otherwise than in the name of some other 
person, which would make the provision applicable to this case, and give the Gaar Scott Company the right to file this caveat."31

The language of Wetmore, C. J., in Re Wark Caveat, as follows: ${ }^{32}$

"The expression in section 136 of the Act of 1906 that 'any person claiming to be interested in the land may lodge a caveat with the registrar' is not governed by section 79 . The word 'claiming' gives this section a wider significance and I apprehend that it is good, therefore, to enable any person claiming a beneficial interest of any sort to lodge his caveat so as to prevent the land being disposed of,"

can be taken to be subject to the limitation under discussion, and apparently, therefore, in Saskatchewan a claim such as under a vendor's lien or an equitable mortgage by way of deposit of certificate of title without written memorandum, or, as were the facts in the case decided by the master of titles, ante, a claim by the prior registered owner that the present registered owner had obtained the land fraudulently and without consideration, are not grounds for filing a caveat in Saskatchewan. With reference to this result, it may be pointed out that in the Australian and in the other Canadian jurisdictions no such restriction has been established. It will be observed that in the Manitoba Act (section 130), the language is general. In the Alberta Act (section 84), the language corresponds very closely to that of the Saskatchewan Act (section 135), but the addition of the word "howsoever" after "otherwise" seems to indicate that the words "or otherwise" are not to be restricted in their meaning in the manner which is held to be the case in Saskatchewan. ${ }^{32 a}$ In The Territories Real Property Act 1S86, the words were:

"Any person claiming to be interested under any will, settlement or trust deed, or any instrument of transfer or transmission, or under any unregistered instrument, or otherwise howsoever, in any land may lodge a caveat, etc."

${ }^{31}$ Gaar Scott Co. v. Guigere, 2 S. L. R. 374.

3212 W. L. R. 245, 2 S. L. R. 431 . Sections 136 and 79 referred to are sections 125 and 68 of present Act.

${ }^{32 a}$ Re MacCullough and Graham, 2 W. W. R. 311. 
The meaning of this section is clear, viz.: that any interest however created may be the foundation for a caveat. This section was carried forward into The Land Titles Act of 1894 as follows:

"Any person claiming to be interested under any will * * * or under any unregistered instrument, or under an execution where the execution creditor seeks to affect land in which the execution debtor is interested beneficially but the title to which is registered in the name of some other person, or otherwise howsoever in any land, may lodge a caveat, ete."

And in 1898 this section was amended to read:

"Any person elaiming to be interested under any will * * * or under any unregistered instrument, or under an execution where the execution ereditor seeks to affect land in which the execution debtor is interested beneficially but the title to which is registered in the name of some other person, or otherwise, in any land, may lodge a eaveat, ete."

And in The Land Titles Act of 1906 the section appears as section 136 in its present form. It is legitimate, if not conclusive, to look at these prior sections for the purpose of ascertaining the meaning of the present section..$^{33}$ Assuming, as apparently is quite justifiable, that in its original form the section was intended to permit the filing of a caveat under any state of facts which in law or equity raised any estate or interest in land, upon the ordinary principles of construction of statutes, ${ }^{34}$ in none of these changes does an intention appear to alter the law so as to abolish the right in a considerable number of cases where it previously existed, nor to restrict the words "or otherwise," which have always appeared in the section and which appear in the corresponding: section of the Australian Acts, to a modification of

${ }^{33}$ Re Budgett, Cooper v. Adams, (1894) 2 Ch. 557.

* Maxwell, Interpretation of Statutes, 3rd lid. 113; Hardeastle. Construction of Statutes, 3rd Fd. 113. Minet v. Leman, 20 Beav. 269, at page 278 , where Romilly, J., said:

"The general words of an Act are not to be so construed as to alter the previous policy of the law unless no sense or meaning cail be applied to these words consistently with the intention of preserving the existing policy untouched. "This principle of construction as a general proposition cannot be disputed." 
the specific case of execution creditor's rights in execution debtor's lands, which first appeared in The Land Titles Act of 1894.

A further restriction of the power to caveat has been established in Saskatchewan by the decision in Re Ebbing, ${ }^{35}$ in which ease the Full Court of Saskatchewan determined that a eaveat claiming under a mortgage executed before recommendation for patent could not be filed. This decision, however, is not free from difficulty so far as it is based, as it appears to be, upon the fact that the mortgage was not accompanied by the statutory affidavit in Form K. The logical result of the decision is that no caveat can be filed under an instrument which might be registered, as the party so filing would be "cloing indirectly by means of the careat, what was prohibited under the Act," thus forbidding, for example, a party to file a caveat under any unregistered mortgage made by the registered owner, because the certificate of title might be produced and the mortgage itself registered. If it be urged that, in this case, the land was homestead land, the answer is from the decision itself that "the registrar has no duty to make incuiries outside his orn office 2.5 to whether or not an instrument is a proper one for registration."

There is a further statutory restriction in all jurisdictions upon the right to file a caveat, that is to say, that no caveat may be lodged based on a claim contained in the instrument commonly known as a lien note, hire receipt, written order, contract or agreement for the purchase or delivery of any chattel or chattels, ${ }^{36}$ and any such instrument so far as it purports to affect land is declared roid, in Manitoba from and after March 11, 1893, in Saskatchewan from January 1, 1910, and in Alberta from December,

35 2.S. L. R. $16 \pi, 11 \mathrm{IV}$. L, R. 29.

${ }^{30}$ R. S. NI. 1902, c. 99, 4: sask. 125 (2). amendment of 1910-1911, c. 12 \& \&; Alta. 1910 (2nd siess.), c. 5. 
1910. These provisions were discussed by the Manitoba Court in Smith v. American Abell Engine and Thresher Company, ${ }^{37}$ where it was held that a separate document charging land for the purpose of securing the purchase price of chattcls ordered by such an order form is nevertheless valid and may be the foundation of a careat.

\section{b. Form and Contents of Caveat.}

- The form of caveat is prescribed by the Acts. In Manitoba a separate form is prescribed for a caveat against bringing land under the system, but there has been no distinction made in principle between the two sorts in the treatment of the requisites to the form and contents thereof. It has been laid down that a strict compliance with the forms prescribed is required..$^{38}$

The form begins with the name and addition or description of the caveator. "Where the caveat gave no addition of the caveator, although the affidavit in support of the caveat described him as accountant, in Jones v. Simpson, ${ }^{38}$ Bain, J., was of the opinion that the omission was fatal to the validity of the caveat although the actual decision in this case turned on another point; but this dictum was approved in Martin v. Morden. ${ }^{38}$ A corporation, however, has no addition. ${ }^{39}$

The land must be accurately described, and not merely incorporated by reference to some other document. ${ }^{40}$ The forms in Alberta and Saskatchewan call for a reference to the certificate of title, but

${ }^{37} 5$ W. L. R. 329; affirmed 6 W. L. I. 179.

${ }^{38}$ McArthur v. Glass, 6 Man. I. R. 244; Meliay v. Vanton, 7 Man. I. R. 250; Jones v. Simpson, 8 Man. L. R. 121; Schultz v. Archibald, 8 Man. L. R. 28t; Martin v. Worten, 9 Man. I. R. 5tis; Re Cass and Canada Traders Limitod, 15 W. L. R. 194; Re Ehbing, 2 S. L. R. 167; Re Tudge Porl: Packing ('o., 7 II. L. L. 507.

a3 North of Scotland Mortgage Co. v. Thompson, 13 Man. L. R. 95.

${ }^{40}$ Martin v. Morden, 9 Man. L. R. 565. 
"if a caveat enables the registrar to identify the land in respect of which it is lodged * * * he properly receives it." ${ }^{41}$

A caveat must state, in Manitoba, the nature and particulars of the title, estate, interest or lien under which the claim is made; in Saskatchewan, the nature with particulars of the estate or interest claimed (Form T), and in Alberta the nature of the interest clained and the grounds upon which such claim is founded.

In reard to the nature of the estate claimed, it is not necessary that the caveator should give the technical name, in legal parlance, of the estate or interest claimed so long as he sets out facts which may establish an interest and sufficiently indicate what that interest is. Where the caveator claimed to be

"the owner of (naming the land) under and by virtue of an agreement of sale in writing of the said property to me from (naming the vendor),"

it was held by Anglin, J., in the Supreme Court of Canada in the decision last cited, a sufficient compliance with the requirements. The same thing was well stated by Newlands, J., in an unreported decision, where he said:

"Now the caveator has not stated that he elaims an estate in fee simple, or an equitable interest, or any other particular estate or interest, but he does say that he elaims as purchaser under an agreement of sale made between himself and George Sterrett, giving the date of same, the deseription of the lands and the consideration. This, it seems to me, complies with the provisions of the Act, as it shows both the nature of the interest and the ground upon which it is founded." +2

The registrar before registering a caveat should determine that the facts set out do establish an interest. He must sec that altogether idle instruments are not put on record, ${ }^{43}$ and a caveat will be struck off

${ }^{41}$ Ackillop and Benjaficld v. Alexander, 45 S. C. R., at page 580.

${ }^{42}$ In re Ranney Caveat, unreported, Newlands, J., November 25, 1910.

${ }^{43}$ In re Ebling, 2 S. L. R., at 171. 
at once on application where, for example, the caveator is merely claiming a commission for the sale of the land; ${ }^{44}$ and a caveat claiming as "estate or interest" a "documentary title" was held bad for not setting out the nature thereof. ${ }^{45}$ It will have been seen that to some extent the nature of the estate and the particulars overlap, or at least the particulars may furnish sufficient information in regard to the nature of the estate, but the nature of the estate alone would not necessarily have divulged the particulars. In order that parties claiming to file caveats might not be permitted to cloud the title of a registered owner without showing some bona fide claim affecting him, the words "and particulars" were added to section 133 of the Manitoba Act by the amendment of 1908 and the words "and the ground upon which such claim is founded" to the Alberta Act in 1912, bringing the Acts all in line, were it not for the more recent amendment in Saskatchewan to be referred to. Under these requirements registrars demand that before the title of a registered owner may be clouded some interest moving from him, and transmitted in some way, either by assignment or chain of contracts, or by statutory right or otherwise, to the caveator or in favor of the caveator, must be shown. ${ }^{46}$ By a still more recent amendment of the Saskatchewan Act, namely, the proviso to section 125 (1) enacted by 1912 , c. $16, \S 5$,

"No caveat shall be deemed to be insufficient for the purpose of the lodgment thereof merely on the ground that the interest claimed therein is not shown to be derived from the registered owner of the land affected."

The effect of the proviso is that in passing upon the

14 Re Kay and White Silver Co., 9 O. W. R. 712, as explained by In re Skill and Thompson, 17 O. L. R. 186, at page 190.

4s In re Mitchell (Adam Caveator), 16 N. S. IV. I. R. 123.

${ }^{48}$ Jones v. Simpson, 8 Man. I. R. 124; Re Webb, Rumely Co.'s Caveai, Master of Titles, Sask., 21st Feb., 1911. 
fitness of a caveat presented for registration in Saskatchewan, the registrar is not entitled to demand such particulars as show the claim of the caveator to be derived directly or indirectly from or through the registered owner, and thus to entitle the caveator to cloud that omner's title, but he must be satisfied if such particulars are shown as could be the foundation of an interest in land assuming that further links exist. But such a caveat would not by reason thereof be continued by a judge in the absence of showing some claim direct or indirect as against the registered owner.

The caveator by the form used in Saskatchewan forbick, in effect, that any dealing shall be made while the caveat is in force unless expressed to be subject to the claim of the caveator, and in Manitoba and in Alberta ( $a$ ) forbids the registration of any person as transferee or owner of the estate or interest claimed by the caveator, or $(b)$ the registration of any instrument affecting such estate or interest unless the instrument is expressed to be subject to the claim of the caveator. In the Australian jurisdictions other than Victoria and Western Australia the caveat does always operate as an absolute prohibition, and in those excepted jurisdictions may and apparently generally does so operate. But notwithstanding the wording of the form in Manitoba and Alberta as actual prohibitions, the actual provisions of the statutes of those provinces do not give to caveats any such operation, but merely provide (Manitoba 132; Alberta 87) that so long as a careat remains in force the registrar shall not register any instrument purporting to affect the land, mortgage or incumbrance in respect of which the careat is lodged unless such instrument be expressed to be subject to the claim of the caveator.

The caveat must state some address within the province at which notices of proceedings relating 
to such caveat may be served. The omission to give such an address is fatal to the validity of a caveat and a caveat with such an omission will not be cortinued; and where the caveator appoints "A. N. MePherson, commissioner of railways office, Winnipeg, my agent on whom notices and proceedings thereto may be served," this was held to be a fatal defect as naming a person and not a place. ${ }^{47}$ Prior to the amendment of 1912 in Saskatchewan, the address required to be given was within the registration district, but by that amendment the Saskatchewan Act has been brought into line with the other provinces. The requirement, however, of an address for service of papers in connection with the caveat, is not a positive enactment that all papers and documents required to be served in connection with the caveat may be served by leaving the same at such address, and in fact the use of that address for service is only permissible where elsewhere specifically provided for in the Acts, or ordered pursuant to powers contained in the Acts. In regard to summonses taken out in proceedings on the caveat or notices of motion, personal service is, by the well established practice in all the courts in the Canadian jurisdictions, required in the ordinary way. ${ }^{48}$

The caveat must be signed by the caveator, his attorney or agent. The evidence which shall be produced to the registrar to satisfy him that a person so signing is the attorney or agent is not prescribed. In Saskatchewan and Alberta the affidavit of the attorney or agent is accepted as proof of his authority.

${ }^{47}$ Mckiay v. Narton, 7 Man. L. R. 250.

48 See statutes, Man. 41; Sask. 166; Alta. 144 (2); Dom. 171; and in Vietoria, Re Slack and IV inder, 1 V. L. R. 319; IIunter, 24s; Stephen, J., delivering the judgment of the full coupt, sitiul: "It is a rule too important and well cstablished to admit of the least infrartion, that no man is to be condenned, punished, or deprived of lis property in any judieial proceeding, unless he has had an opportmity of being heard; and a comt camnot be sat isfied that sucl opportunity has heen afforded, mnless it clearly sees that there bas been a proper service o the process requiring appearance." 
In Manitoba the agency is usually required to be established by more complete evidence. The authority is there ordinarily required to be in writing, though not necessarily in the shape of a formal attested document. A caveat by a corporation must be executed under the seal of the corporation or by some one authorized under such seal, or satisfactory reason for dispensing with the seal must be shown. These rules, however, are office rules and may be relaxed. The general rule upon which the registrar acts - and this rule applies equally well to all jurisdictions - is that since the Act gives a party injured by the wrongful filing of a caveat a right to damages, the registrar should not nullify that right by accepting for registration caveats where he is not reasonably satisfied that it would be impossible for the caveator, principal, to repudiate responsibility for the caveat on the ground of lack of authority in the agent.

The careat does not require to be witnessed nor accompanied by an affidavit of execution, but must be accompanied by an affidavit of the caveator or his agent in the form prescribed by the Act. The absence of, or a material omission in, this affidavit invalidates the caveat. ${ }^{49}$ The affidavit cannot supply an omission in the caveat, ${ }^{50}$ and although under the Manitoba or Alberta Act the eridence in support of the caveat may be either by an affidavit or declaration, a writing which is neither an affidavit nor a declaration, but a combination of both, will render the caveat ineffectual. ${ }^{51}$

\section{c. Cessation of the Caveat. \\ (1) SUMMARY OF CAUSES.}

A caveat may expire or cease to be of any effect by reason of: (1) Lapse of time.

(2) Notice given by

49 Mc.4rthur y. Glass, 6 Man. L. R. 224.

so Jones r. Simpson S Man. L. R. 124.

51 Schultz v. Archibald, \& Man. L. R. $2 \$ 1$. 
the registrar and lapse thereafter. (3) Notice by any person. (4) Proceedings by way of motion or summons to discharge same. (5) Withdrawal by the caveator.

(2) LAPSE OF TIME.

Under The Territories Reul Property Act of 1886 and The Land Titles Act 1894, a caveat was effective during a period of three months only, and automatically expired at the expiration of that period unless proceedings had been taken to establish the caveator's title to the claim or interest specified and an injunction granted restraining the registrar from granting a certificate of title or otherwise dealing with the land; and this is still the law under the Dominion Act (section 136), and in British Columbia, in which latter province the caveat operates in the meantime as an absolute prohibition against dealings. In the Dominion, the caveat lapses at the expiration of three months; such limitation is introduced for the benefit of the caveatee and may be waived by him. ${ }^{52}$

(3) NOTICE BY REGISTRAR AND LAPSE THEREAFTER.

This procedure is peculiar to Saskatchewan. The owner or other person claiming an interest in the land may require the registrar to notify the caveator by registered letter at his address for service set forth in the caveat, that such caveat shall lapse at the expiration of thirty days from the mailing of the notice unless in the meantime a judge's order be obtained continuing the caveat. The registrar at his discretion may demand satisfactory evidence that any person, other than the owner, who requires him to serve such notice has an interest in the land. The request, being an instrument, should be attested in the ordinary way (for form see No. 15, App.C.). The customary procedure by the eaveator on receipt of

${ }^{52}$ Wilson v. McIntosh, 63 L J. P. C. 49, (1894) A. C. 429. 
such a notice is to prepare an affidavit setting out all the facts of the case and verifying the interest of the caveator, upon which affidarit, accompanied by an abstract and copy of the caveat, a summons from the judge is obtained, calling upon the person making the request and all persons interested as disclosed by the register to show cause why the caveat should not be continued, and such summons embodies an order continuing the careat temporarily until further order; or under the practice introduced by the rules of 1911 this might more properly be done by order and notice of motion to continue, following the analogr of an interim injunction and notice of motion to continue in an ordinary action.

Upon the return of such summons or notice of motion, cause is shown by the caveator why his caveat should not lapse. Except as to the party who begins, the practice and principles invoked on the return of a summons under this section are, for all practical purposes, the same as on a summons taken out by the party adverse in interest in the first case against the careator for the careator to show cause why the caveat should not be withdrawn, as to which see post, page 380 . The filing of the judge's order continuing the careat within the thirty days is a requisite for the validity of such order, and an order received after the expiration of the time will not be registered. ${ }^{53}$ In Manitoba, pursuant to the statute (section 1:37), proceedings may, apparently, be taken under the carcat at any time after the expiration of the time limit, but before the district registrar shall have disposed of the careat as lapsed.

A qualification of the generality of the capacity of any person claiming "any interest in the land" to require the registrar to serve the notice under this section is provided by the amendment of 1912, enacting the proviso to section 130 . The purpose of

53. Shattuck v. McCrae, Master of Titles, Sask., 12th Aug, 1910. 
this amendment is to enable the registrar to check capricious steps to remove bona fide caveats where third parties' rights are involved. Thus, where a caveat is filed under a party wall agreement, or under an easement or restrictive agreement, the original caveator may long have ceased to have any interest in the land, and to permit of his eaveat being lapsed by reason of his indifference to a registered letter in the contents of which he took no interest, if he ever received it, would be a serious flaw in the usefulness of a caveat. A party claiming he is improperly refused such a notice has still, however, his remedy under the ordinary summons, which must necessarily come before a judge, before whom the interest of the third person will be disclosed by the abstract, and who will accordingly under the general power given him in section 129 require such third persons to be heard before discharging the caveat.

\section{(4) NOTICE BY ANY PERSON.}

Somewhat analogous to the proceedings provided by section 130 of the Saskatchewan Act are the proceedings provided by section 131 of the Manitoba Act and section 89 of the Alberta Act. These sections, are very general in their phraseology. In Manitoba the section does not say under what circumstances the notice shall be given and the practice therefore, in Manitoba, has been to refuse to recognize notices under this section unless the party requiring it to be served shall satisfy the registrar beyond any doubt that he is entitled to have the caveat discharged, and the district registrar, in such cases, will not take upon himself to adjudicate the contested facts, but the evidence furnished, in view of its being given ex parte, must be of the clearest and most unequivocal character to show that the caveat is or remains wrongly filed and that the caveator has absolutely no grounds which he could show why his eaveat should not be discharged. Consequently, 
for all practical purposes, the remaining practice as set out in section 131 of the Manitoba Act is unused. In Alberta, on the other hand, the procedure is used more freely; a notice served by the registered owner, or by any other person upon a judge's order so permitting, is accepted as sufficient.

\section{(5) SUMMIONS TO DISCHARGE CAVEAT.}

\section{(a) In General.}

In all jurisdictions a proceeding is provided for summary application to the court or judge calling upon the caveator to show cause why his caveat should not be discharged. ${ }^{54}$ In Manitoba the proceedings are by way of motion; in Saskatchewan by way of summons, and in Alberta by way of originating summons. In Manitoba and Alberta such application may be made by the applicant, in the case of a caveat against bringing land under the Act, or by the owner, that is to say, the registered owner. ${ }^{55}$ In Saskatchewan the owner or any person claiming an interest may take out the summons. The summons must be served personally and not merely at the address given for service in the caveat. ${ }^{56}$ On the return of the summons objections may be urged against the caveat under two heads, first, technical objections; secondly, objections on the merits.

\section{(b) Technical Objections.}

First, in regard to technical objections, it may be argued that a caveat which is bad for one purpose is bad for another, and consequently the line of cases where, in Manitoba, petitions to establish the claims of caveators against bringing land under the new system have been dismissed by reason of not being founded on caveats complying with the provisions of the Act (ante page 371), are in point as showing where

${ }^{54}$ Man. 138; Sask. 129; Alta. 91; Dom. 135.

ss Hicks v. Laidlaw, 19 W. L. R. 525, affirmed 20 IT. L. R. 479.

${ }^{56}$ Re Slack and Winder, 1 V. L. R. 319. 
a caveat will not be continued upon the same grounds of mere technical irregularity. Against this view, however, is the fact that whereas, upon a petition under a caveat against bringing land under the new system being dismissed, the court may permit the filing of a second caveat, ${ }^{57}$ and, the first caveat having prohibited the registrar proceeding in the meantime, no substantive right would be defeated; in the case of a caveat against dealings, new registrations may in the meantime have been madc, or a new certificate of title issued, in respect to which the new caveat would be subsequent, instead of prior, as was the first, and thus the effect of a lapse of the first caveat would be possibly to defeat actual rights. It is submitted that the courts at the present day lean against such a construction which would defeat substantive rights by reason of mere technical defects in form. ${ }^{58}$ But where an objection, while technical in the sense of being based on a noncompliance with the Act, is not a mere matter of form, the case is different. Where a second caveat was filed without permission contrary to the provision of the Act, the judge refused to continue it, holding that it was "improperly lodged and of no force or effect." ${ }_{59}$ The same case held that a person interested is not estopped from taking such objection by reason of having set the registrar in motion under section 130 of the present Saskatchewan Act. And by statute in that province, a caveat lodged contrary to the provisions of section 125 is by subsection 4 thereof absolutely null and void to all intents and purposes whatsoever. Where the caveatees by notice under section 131 of the Manitoba Act required the caveators to take proceedings upon their caveat, and the caveators filed their petition but the claim made therein differed from that in the caveat, the

${ }^{57}$ Mckay v. Nanton, 7 Man. L. R. 250.

${ }^{5}$ MeKillop and Benjafield v. Alexander, 45 S. C. R. 551.

${ }^{50}$ Re Tudge Pork Packing Co., Lud, 7 W. L. R. 507. 
petition was dismissed and, consequently, the caveat lapsed. ${ }^{60}$ And it is submitted the result would be the same in any jurisdiction if the caveators' material upon the hearing of a summons to strike off was either inconsistent with the claim or failed prima facie to establish it. In all the Acts there is what appears to be at first glance a general section curing all inralidities by reason of any informality or technical irregularity or of any mistake not affecting the substantial justice of the proceedings. ${ }^{61}$ This section does not expressly refer to careats, and, it has been held, does not apply to them so as to cure such informality or irregularity. ${ }^{62}$ But since the decision in Me Killop \& Benjafield $\mathrm{v}$. Alexander ${ }^{63}$ the law must be taken to be the same as if that section did specifically apply. The irregularities there complained of were that the careat did not show the interest of the caveator, not describing him as "purchaser" or otherwise, but merely stating that he claimed to be the owner under a certain agreement, describing it, and secondly, that the caveat did not give the number of the certificate of title as prescribed in the form. Anglin, J., said:

"The provisions of section 137 (now 126) should, I think, be regarded as directory and intended for the guidance of registrars (Willie $v$. Jellett). If a caveat enables the registrar to identify the land in respect of which it is lodged and if the interest claimed is stated with reasonable certainty, he properly receives it and when duly lodged it has the effect contemplated by the statute, although in some particular it should not be in strict compliance with the prescribed form."

This decision is not to be taken as operating to cure all defects once the instrument has been registered, as has been suggested is the result of the decision of the Supreme Court of Canada in Syndicat Lyonnais

${ }^{60}$ Pe Cass and Comada Traders Limited, 15 IV. L. R. 194.

61 Nan. 156: Nask. 184; Alta. 142; Dom. 196.

62. Schullz v. Archibald, 8 Man. L. R. 2S4; Martin v. Morden, 9 Man. J. R. R65.

63 45 S. C. R. 551 . 
du Klondike v. McGrade ${ }^{64}$ on appeal from the Yukon Territorial Court under The Land Titles Act 1894. There the registrar had registered a certificate of lis pendens and while holding that there was no provision for such registration, still having been in fact registered, that court dealt with it as effective against purchasers for the purpose for which it was registered, that is, to give notice. If that case be taken as an authority beyond its own facts as relating to a $l i$ s pendens, the principle laid down seems capable of indefinite extension. It is submitted, however, that that case decides only that the courts will not permit a party to assist in a fraud, through reliance on technical irregularities.

(c) Objections on the Merits.

Secondly, as to the merits. Where all parties consent the court has gone fully into the merits of the question at issue between the parties and tried it out. ${ }^{65}$ And upon another application a proceeding was devised for the filing of pleadings in the application itself, and the trial of the issue thus raised at the next sittings of the court. ${ }^{66}$ It is submitted the proper practice is to hear the summons on the material filed, and if the rights of the parties be clear, to either discharge ${ }^{67}$ or continue the caveat, or if there be questions of fact or important questions of law to determine, to continue the caveat meanwhile, and leave the partics to their ordinary remedy, that is, by writ of summons or statement of claim, or, in Manitoba, by proceedings by way of petition as prescribed under the Act. In the Full Court in Saskatchewan in Gaar Scott v. Guigere, Newlands, J., delivering judgment of the court, said:

6436 S. C. R. 251.

${ }^{65}$ Re Babbit and borlenu, 6 W. L. R. 260) (Altit., Stuart, J.); Tavender v. Edwards, \& W. I. R. 30s (Alta., Stmart, J.).

${ }^{66}$ Re Riddock and 'hadwick's C'omtract, 6 W. I. R. 360.

${ }^{67}$ Re Sanyer Massey and Dennis, 7 W. L. R. 272; Fallis v. Ballhasar, $2 \mathrm{~W}$. W. R. 132. 
"As to the first and second grounds of appeal, section 140 (now 129), provides "that the judge may upon proof that the caveator has been summoned and upon such evidence as he requires, make such order in the premises as to him seems fit.' Although this section gives a very wide discretion to the judge, it does not, in my opinion, confer upon him the powers of the supreme court to decide upon legal or equitable rights between the parties, but only the jurisdiction to decide whether the caveator had any right to file the caveat in question, and if he had at the time of filing such right, whether he had at the time of application the right to have the caveat continued against such property. If there is a bona fide question of law or equity as to the right of the caveator to the estate or interest which he claims under the careat to be decided, the supreme court is the proper place for such question to be disposed of, and the careat should be continued a sufficient time to allow an action to be brought in which to decide such a question." 68

In Manitoba, where issues of fact are involved a summons to discharge a caveat is dismissed absolutely, leaving the party to his ordinary remedy at law. ${ }^{69}$ In Ontario, under a somewhat similar procedure in the hands of the master, an order was made that entry of the cessation of the caution be made, upon the registered owner giving security for the amount claimed by the cautioner against the land, payment to be made according to the result of an action then pending. ${ }^{70}$ The caveator must, however, show some substantive right to have his caveat continued. The mere fact of the caveator having already brought an action to establish the same claim is not in itself sufficient to justify the continuation of the caveat. ${ }^{11}$ Where a prima facie right to only part of the interest is claimed, the caveat will be continued, but as to that

\footnotetext{
${ }^{68}$ Gaar Scott v. Guigere, 2 S. L. R. 374, at 376. See, also, Re Webster and C'anadian Pacific Railuay Co., 6 W. L. R. 384; Re Wark, 2 S. L. R. 431; In re Skill and Th mpson, 17 O. L. R. 1S6; Re Rowand and Strathcona, 5 W. L. R. 450; Re Yemen and Mackenzie, 7 O. W. R. 866.

${ }^{69}$ Re McGrecvy and Murray, 19 W. L. R. 947.

${ }^{70}$ Re McDonald and Sullivan, 14 P. R. 60.

${ }^{71}$ Re Hebert and O'Brien, 9 O. W. R. 172.
} 
part only. ${ }^{72}$ The rule as to the duty of the judge in such cases is in Australia and New Zealand, generally speaking, the same, although where the judge was satisfied that the delay had been so great as to bar an action for specific performance, the caveat was ordered struck off summarily. ${ }^{73}$

In case of proceedings being directed to be taken. the matter of who should be the plaintiff and who should be the defendant is important. If the caveator be the plaintiff the form of order is that the caveat will expire unless proceedings be taken within a certain time. If the caveatee be the proper plaintiff the order is that unless proceedings be taken within a certain time the caveat shall be continued indefinitely, otherwise to abide the result of the action. The principles invoked in determining this point will be the same as the principles invoked in determining in Manitoba whether the caveator or the eaveatee shall be the plaintiff in an issue directed pursuant to a petition based on a caveat against bringing land under the Act, beginning with the presumption in favor of the caveator being the plaintiff, which presumption is only displaced on cause shown (see ante, page 80 ).

\section{(6) WITHDRAWAL BY CAVEATOR.}

The caveator may by notice in writing to the registrar withdraw his caveat at any time. ${ }^{74}$ In Alberta the registrar shall forthwith give notice in writing of such withdrawal by mail or otherwise to the caveatee (section 88), and in Manitoba the caveator should notify the caveatee (section 134). The withdraval of the eaveat requires to be witnessed and attested in the same manner as an ordinary instrument, and in Alberta it is specifically provided that

${ }^{72}$ Re McIDermolt Caveat, Newlands, J., (Siask.), mureported, May 3, 1912.

${ }^{73}$ P'limmer Bros. v. St. Maur, 26 N. Z. L. R. 294. Compare l'allis v. Balthasar, 2 W. W. R. 132.

7 Man. 134; Sask. 131; Nlta. 88; Dom. 137. 
where the cavcat itself has been signed by an attorney or agent, the same attorney or agent may withdraw the caveat. In the other jurisdictions while the registrar may in his discretion consider that evidence of authority to withdraw has been satisfactorily shown to him, in the ordinary case the withdrawal must be executed by the careator personally in the ordinary may, or by agent duly authorized by power of attorney.

Where in Nanitoba and Alberta a caveat has been filed by the registrar the caveatee must apply to the court for discharge of the caveat in the prescribed manner in the absence of withdrawal by the registrar himself. ${ }^{75}$

\section{d. Second Caveat.}

Upon the withdrawal, lapse or removal of any careat, the same person may not lodge a further carcat in relation to the same matter unless by leave of a judge. ${ }^{76}$ In Saskatchewan such further careat, apparently, is of exactly the same effect except as regards time of expiration, and carries with it exactly the same rights and powers as a first caveat, but in Nanitoba and Alberta it is intended that such a caveat, if any, shall be temporary in its nature, the order permitting it being required to prescribe the time within which the caveator must proceed upon his caveat. And, further, in Manitoba, the prohibition upon the second careat extends not only thereto, but to the filing of a certificate of lis pendens in respect of any proceedings in court in relation to the same matter. While such a proceeding is not forbidden, this prohibition would secm to bring the lapse of a caveat in Nanitoba in line with the effect of lapse in Victoria, Australia, where such was held to be an abandonment of the claim therein made. ${ }^{77}$ In the

is Man. 141; Alta. 96.

i6 Man. 140; Sask. 132; Alta. 95.

"Howell v. Union Bank of Australia, Lte., 6 N. Z. L. R. S. C. 567. 
other jurisdictions there is nothing to indicate lapse of a caveat as conclusive of abandonment of the claim, although, taken along with the circumstances of each particular case, it may usually be considered as evidence thereof. While the Acts specifically prescribe that no second eaveat should be filed after the lapse, withdrawal or removal of the first, neither can a second caveat making the same claim be filed before such lapse or withdrawal. ${ }^{78}$ In Alberta, since the amendment of 1912 , this point is covered by the wording of the Act. But where the second caveat, though claiming the same land, claims under a different title or interest, there is no reason against filing a second eaveat without special order for that purpose. $^{79}$

\section{e. Effect of Caveat.}

(1) SUMMARY.

The effect of a caveat may be considered in three aspects:

(1) Its effect upon the claim made therein.

(2) The effect as against claims of third persons.

(3) Incidental effects of caveat.

(2) EFFECT ON CLAIM MADE THEREIN.

This first phase, the effect of a caveat upon the claim made therein, that is to say, upon the relations between the parties thereto, may be disposed of very shortly. It has none. By the mere filing of a caveat the interest claimed therein is in itself as between the parties neither improved nor diminished one whit. This follows from the self-evident principle that one party to a bargain cannot by his own act create rights in his own favor thereunder or improve what he has already. ${ }^{80}$ Registration of a caveat is not registration of the instrument

${ }^{78}$ Frost v. Driver, 10 Man. L. R. 209.

${ }^{79}$ Alloway v. Rural Municipality of St. Andrews, I W. L. R. 407; 1 F Man. L. R. 188.

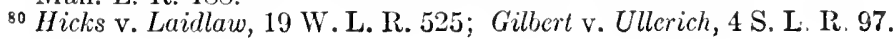


under which it claims so as to render the same operative or more valid than without such a caveat, and you cannot give the effect to an instrument by filing it by way of caveat which it would have if registered under the Act. ${ }^{81}$

(3) EFFECT As AGAINST THIRD PERSONS.

The effect of a caveat as against claims of third persons requires much fuller discussion. As already pointed out, notwithstanding the wording of the forms of caveat as prohibitions, they have in the Canadian systems no statutory effect as injunctions. The effect is only that prescribed by the statutes. In dealing with this effect caveats affecting land only will, for convenience of discussion, be considered. In Manitoba and Alberta, but not in Saskatchewan, caveats claiming an interest in mortgages and incumbrances are permitted, and the principles hele discussed may be applied, so far as applicable to the circumstances, to such caveats. The caveat against bringing land under the new srstem in Manitoba cloes have its well defined and only effect of prohibiting the bringing of land under the new system until it has been disposed of, but it is not under consideration in this section. In case of two caveats in such case no priorities would be affected.

The statutory effect of a caveat is that, so long' as any carcat romains in force, the registrar shall not register any instrument purporting to affect the land in respect to which such caveat is lodged in líanitoba and Alberta, "unless such instrument be "xpressed to be subject to the claim of the caveator," and in Saskatchewan and the Dominion "except subject to the claim of the caveator."'s2 The slight divergence in the wording does not correspond to any

st Pe Elbing, 2 S. L. R. 167, 11 W. I. R. 29.

82 Man. 132; Alta. s7; Nask. 128; Dom. 134. 
actual difference in meaning. In the one case attention seems to be directed to the "instruments," in the other to the register, but, in either case, the practical result is the same, namely, that the memorandum of the caveat is indorsed on the certificate of title to the land in priority to the indorsement of the subsequently presented instrument, which priority gives the caveat its effect. And further, by statute, in Manitoba and Alberta, "registration by way of caveat shall have the same effect as to priority as the registration of any instrument under the Act."

It may be well in the first place to clear up the meaning of registration "subject to the claim of the caveator." This point was carefully argued and fully discussed by the Court of Appeal in Manitoba in O'Brien v. Pearson. ${ }^{84}$ It was there urged by counsel that a person taking a certificate of title subject to a caveat thereby admits the claim set forth in the caveat, which, being so admitted, becomes no longer controversial but an established interest in the land; or, a person taking the benefit of a subsequent registration, such as of a mortgage, thereby admits as against himself the absolute validity of the claim of a prior caveator. The court were unanimous in negativing this proposition. Perdue, J. A., said:

"The intention of this would seem plainly to be, that a transfer or other dealing with the land may be put through by the district registrar, subject to any existing eaveat filed after the first certificate of title has been issued, and that in such case the transferee would take his rights subject to the elaim set out in the eaveat, whatever that claim might be, so that the right of the caveator might be preserved and remain as valid against the transferee as it was against the transferor, but that no additional foree should be given to such claim by making the new certifieate of title subject to it."

And Cameron, J. A., said:

"If, on the other hand, the intention of the legistature was to facilitate the registration of instruments and the issue of

-3 Man. 143; Alta. 97.

3420 W. L. R. $510,1 \mathrm{~W} . \mathrm{W}$. R. 1026. 
certificates, and at the same time to make provision for the preservation of the rights and interests of parties who may have claims against the lands, by virtue of unregistered instruments or otherwise, until such claims shall be ultimately disposed of, then it seems to me the language used is apt and clear, and it appear's to me the legislature had no other object in view. The word 'expressed' as used in both sections 130 and 132 and in reference to this discussion is a significant term. The caveator has no oljection to registration provided it is 'expressed' to be subject to lis claim set out in the caveat, that is, provided that it is made absolutely clear to all parties interested in the title to the lands that the registration does not affect his claim which, thereafter as before, he remains at liberty to establish or defend according to the nature of the proceedings which may be taken." The effect of a caveat, therefore, whatever it may be, is not materially different, on this score, in the Canadian jurisclictions from what it is in the Australian jurisdictions, where, by statute, the registrar shall not during the currency of the caveat make any entry on the register haring the effect of charging or transferring or otherwise affecting the estate or interest protected by the careat.

As regards procedure, it is true, the effect is very different. In Australia a person wishing to acquire a registered interest must try out the question at once, if rights adverse to his are claimed by caveat. In the Canadian jurisdictions he may, as it were, postpone the evil day, but the question remains to be tried out, and by the mere registration subject to a caveat neither the careator nor the person acquiring the interest alters his position either for the better or for the worse upon the merits. As matter of procedure, the carcator in the Canadian jurisdictions may still be entitled to obtain an injunction from the court against registered dealings and

"ask the court to insist that the property shall be held in the hands of the person against whom lie is proceeding for relief until the question involved in the action is disposed of and not become complicated by being transferred to a third person 10-ib involving change of partics and all that." $\$ 5$

sushord V. Bott, 12 IT, L, R. 428. 
But while this effect of a caveat upon other registered dealings may thus be disposed of, or better, thrown back one stage in the inquiry, the important question for discussion is, what is the effect of a caveat, arising by reason of its registration, against other parties claiming competing rights in the same land under unregistered or under subsequent instruments? Several questions may be asked.

Is it mere notice?

If so, to whom is it notice?

Is it more than notice?

If so, to what extent?

Dicta picked out from tice decided cases, separated from the facts of each case, are not conclusire, but are very suggestive as clues to the true view. For example:

"The filing of that careat could have no other effect than to give notice of their claim, even if it hat that effect." 86

"It was gross negligence in the plaintiff:" not to file a caveat." $\$ 6$

"If under the circumstances of the case the mortgagees were allowed to file the caveat, they would, so far as the protection of their claim is concerned, be obtaining practically the registration of the mortgage, and thus doing indirectly hy means of a caveat what was prohibited under the Act without the statutory affidavit." 87

"All the effect that the civeat has is to prevent the registrar passing a title to a tramsferee, or registering an incumbrance or mortgage by or from a registered owner, without putting a memorandum of the caveat upon the eertificatc of ownership or other document. Anel the perron purchasing or taking the mortgage or acquiring the incumbrance is bound to take notice of what the eaveator has clamed in this cavrat and takes his right to the property subject to those rights whatever they may be." 88

(Referring to section 97, Alberta.) "I camnot understand what meaning ean he given to this provicion other that that a careator who reginers his alim meder an agrement to purchase thereby obtains priority for his rlaim over any

${ }^{86}$ Northwest Construction Co. v. Valle, 16 Man. I. R. 201.

${ }^{87}$ Re Ebbing, 11 W. I. R. 29, 2S. L. R. 1tit (Nakk. flill (oumt).

ss Bashford v. Bott, (Sask.) 12 W. I. R. 428. 
other purchaner who registers his claim by way of caveat at a subsequent time, in the same way as a mortgagee who registers his mortgage first acquires priority over one who registers his after."

"The effect of a caveat is to give notice to those dealing with the land that their dealing will be subject to that claim." 90

(But the filing thercof puts the caveators) "in no better position than any simple contract creditor." ${ }^{91}$

"If a caveat were merely notice, it might not, in a case like the present, prevent the subsequent purchaser from getting in the legal title; but by the terms of the Act it is more than a notice. Both the sections I have quoted make the certificate of title subject to the claims of the caveator.'"

"But whaterer" its effect as notice (and I incline to the view that it must be rleemed notice to every person who claims to have acquired, subsequently to its being lodged, any interest in the lands or to have increased or bettered any such interest already held), inamuch as it is the only means provided for the protection of unegistered interests, and it was obviously intended by the legislature thus to afford adequate and sufficient protection for them. I am of the opinion that a caveat, when properly lodged, prevents the acquisition or the bettering or increasing of any interest in the land legal or equitable, adverse to or in lerogation of the claim of the caveator-at all events as it exists at the time when the caveat is lodged.

"Moreover, as a document affecting the transfer of land it caveat is an 'instrument'; and section 81 provides that "Instruments registered in respect of or affecting the same land shall be entitled to priority the one over the other, aecording to the time of registration and not according to the date of (xecution.

Some of the cases from which the foregoing citations are cxtracted are not cases of competing cquities. The facts in those which are such should he noted.

In Northuest Construction Company v. Valle, tom $\left.{ }^{c / i}\right)$ the corporation of the city of Winnipeg, hring registered owner thereof, sold a lot under :urement of sale to defendant Valle. Subsequently

- Bronkinati V. Bum, (11ta.) 15 W. L. R. 661.

('illbert v. Cllerich, (sisk.) $16 \mathrm{~W}$. L. R. 490, 4 S. L. R. 56.

A Gilbert v. Lllerish, 17 II. L. R. 157, 4 S. L. R. 97 (full court).

${ }^{32}$ Alforender v. Gisman, 17 W. L. R. 1St (full court).

Mekillop tert binjafield r. Alexander, 45 S. C. R., at page 582. 
defendant Valle for value assigned his agreement to defendant Wolfe, who gave notice of the assignment to the city. Valle, unknown to Wolfe, was all the time a trustee for the plaintiffs, who, after the sale to Wolfe, filed a caveat. Plaintiff's action to set aside the sale to Wolfe by Valle failed.

In Brooksbank v. Burn, (ante $\left.{ }^{89}\right)$, the defendants, Whitney and Ives, who were registered owners of one piece of land and held a transfer from the registered owners of another, in March, 1907, sold the lands to their co-defendants, Burn and Horne. Default having occurred, an action for specific performance was brought against those purchascrs, and in default of payment, pursuant to decree made, the land was offered for sale and bought in by Whitney and Ives in July, 1909. On September 11, 1909, the plaintiffs purchased the land from the defendants Whitney and Ives, and on 22nd September, 1909, filed a caveat. In November, 1909, defendants Burne and Horne filed a caveat. The sale to defendants Whitney and Ives was set aside in December, 1909, but, in any case, the plaintiffs based their claim on the title of the vendor as registered owners or entitled to become such. It was held by Harvey, C. J., that the plaintiffs' caveat gave them priority and entitled them to specific performance.

In Alexander v. Gesman and McKillop and Benjafield, (ante $\left.{ }^{93}\right)$, Gesman was the owner of land registered in the name of the Canadian Northern Railway and sold by a subsidiary company, under contract then standing in their books in the name of Gesman as purchaser. On November 2nd Gesman sold the land to the plaintiff, Alexander, under ordinary deferred payment contract. On November 4, 1909, Gesman sold the same land to MeKillop \& Benjafield again under such a contract and without notice to them of the prior sale. On November 10, 1909, the plaintiff registered a caveat under his claim. On 
December 14, 1909, the defendants, McKillop and Benjafield, pursuant to their contract and still without actual knowledge of the prior sale, paid Gesman the balance of his "equity" and received from him his original contract with (by some arrangement which (loes not appear) the assignment thereof approved in their favor as of the 28th November, 1909. The Supreme Court of Canada, affirming the Full Court of Saskatchewan, and reversing the trial judge, held that the plaintiff was entitled to succeed in an action for specific performance.

The language of Anglin, J., in the Supreme Court has already been quoted, and the effect of the decision would seem to be, first, that in Saskatchewan, as in the other provinces. but without statutory enactment, registration of a caveat has the same effect as to priority as registration of an instrument, and that, in all three provinces, these words shortly sum up the effect of a caveat. As between equities (and all unregistered doalings are equities) differing only in point of time, that holder of the equity who first legisters a caveat gains priority, and acquires the supcrior equity, whatever the priority would otherwise have been. This agrees with what was held by Harrey, C. J., in Alberta, in Brooksbank v. Burn, supra. Anglin, J., in the Supreme Court expressly puts the case of effect or lack of effect of a caveat against a better equity where he says:

"That the plaintiff"s careat, if it har been lodged only after the defendants har obtained the formal assignment of -their vendor's contract and harl procured the assent of the railway company thereto, would still have sufficed to entitle him to prevent the registration of the defendants as owners incler a conveyance to them from the railway company seems to me improbable, inasmuch as, apart from the provisions of The Lond Tilles Ad, the defendants would then have had a hetere risht to call for the ronveyanee of the legal estate and world, in erputy, he entitled to the legal production of it against the plantill's prior cquitable claim.'.:

[1., at pare 592. Compare drnot an 1 Smith v. Peterson, 2 II. W. R. I . 
This latter view accords with the decision in Northwest Construction Company v. Valle, ante, where the defendant Wolfe had obtained the assignment of Valle's contract from the city of Winnipeg in his favor after which a caveat was filed, but

"at that time the mischief was done and the caveat served no useful purpose."

And the same point was suggested by Harvey, C. J., in Brooksbank v. Burn, supra, where he says:

"If one of the parties claimed through the registered owners, and the other through their unregistered transferees, there would, of course, be other considerations, but that is not the case here."

In Australia as in Canada the effect of a caveat in this respect has been the subject of judicial pronouncement, and to a greater extent. The most recent decision considered appears to be the General Finance Ageney and Guarantee Company of A ustralia, Limited, v. The Perpetual Exceutors and Tintstees Association of Australia, Limited, ${ }^{95}$ where the Full Court of Victoria exhaustively considered the question. There, in July, 1888, Robinson sold to Grant under agreement certain lands not yet registered in Robinson's name, and on August 30, 1888, Grant filed a caveat under his agreement. On 17th September, 1888, the plaintiff made a loan to Robinson on the security of the certificate of title and transfers to him deposited with them. These transfers were then presented for registration and for some reason (not disclosed by the report to one acquainted with Victorian practice through a reading mercly of their Act) Grant's caveat was marked as lapsed, but in February, 1889, when he appears to have aseertained this fact for the first time, he filcl a further caveat. The action was brought by the plaintiffs against the administrator of the estate of Robinson

"27 V. I. R. 739, full court, cital with approval by Anglin, J., in Alexemerer Hekillop and Benjafiedel. 
and against Grant to compel the first named defendant to sign a proper mortgage and Grant to remove his caveat. The action, which failed, was determined as a question of equitable priority and the effect of Grant's first caveat was thus stated by Holroyd, J., for the court, at page 744 of the report:

"It has been argued that a caveat is not notice. In one sense, perhaps, it is not notice. It is not on the ground that a careat is notice that I should consider it proper for any man to search for caveats before he concludes any contraet in respect of land which has been brought under the Act, where there is a possibility of there being an outstanding equitable interest. It would, however, be undoubtedly a prudent thing to do. The effect of the eaveat is this, that a person elaiming any unregistered interest in land which has been brought under the Act ean by lodging it prevent either the registered proprietor of such land or of any ineumbrance thereon, or any other person claiming any interest in such land, from getting any instrument registered which affects the interest elaimed by the eaveator until the caveator has had an opportunity of showing that it would be a fraud on his rights to permit such instrument to be put on the register. The man who lodges a eaveat, as Grant did, prevents any man coming after him from attempting to get priority by saying, as was said in this case, that he had got possession of something which he was pleased to call the title deeds, when in fact they were only certifieates in the names of former owners. The lodging of the eareat is the means pointed out by The Transfer of Land Act to enable a man who has not been and eannot get registered as the proprietor, or as mortgagee or otherwise, to protect his interest, whatever that interest may be. It may be that his interest will not prevail, but he has an opportunity of protecting it, and that is the protection which the dret gives him."

The court referred with complete approval to the decision of A'Beckett, J., in Barnes v. James. ${ }^{96}$ There the facts were that in 1889 James agreed with Barnes to transfer to Barnes a lease about to be granted to him. In April, 1900, the lease in question was granted to James. In July, 1900, James, who throughout was the fraudulent party, all the others heing innocent of mala fides, agreed to transfer the 
lease to the defendant, the Queensland Smelting Company, and on November 16, 1900, executed a transfer thereof to that company. On November 19,1900 , the company filed a caveat. Barnes then brought an action for a declaration of his right against James and the Smelting Company, but failed. A'Beckett, J., said:

"It is open to the plaintiff in such a case to say that the transfer shall not be registered, but he must come with a better case than the defendant,"

and referring to the defendant company,

"no step was omitted by it, by which it could have ascertained the existence of a prior interest in any other person,"

and referring to the plaintiff,

"I cannot say that the plaintiff was negligent, but he might have done more than he did to protect his title by entering it caveat, etc."

The cases in all jurisdictions all point to this, that, in considering the relative equities of competing parties, the filing or omission to file a caveat is an element in their determination, whether the omission to file a caveat be actually termed "negligence" or" not. Or conversely, the omission to search for caveats in acquiring an interest is a factor in determining equities. If to search the register be "a prudent thing" to do, and a party gains by searching and finding nothing, conversely the party who has an unregistered interest and omits to file a caveat so that it may be disclosed to the prudent searcher is imprudent or even negligent. The foregoing extracts (pages 391 and 392) bear out this statement as does also this further statement of the law from the judgment of Anglin, J., in Alexander v. McKillop and Benjafield, ante:

"It was, I think, incumbent not only upon the defendants MeKillop and Benjaficld before completing their purchase, but also uron the ('inadian Northern Railway Company before assenting to the assignment to MrKillop and Benjafickl, to ascertain that no caveat had been lodged against the land, and 
in default of their having done so, they cannot complain if the prior equity of the plaintiff, protected by his caveat, is held to be parimount. As put by Lilly, C. J., in Re Scanlan, ${ }^{97}$ it is a plan practiral precaution for a purchaser $* * *$ to ascertain that there is no caveat (in the registry) before he pays his purchase money * * * People cannot learn too soon that dinalings outside, and without reference to the registry, are hazardous."

And Idington, J., says:

"Alexander had not done anything to taint his right and so far as I can see omitted nothing he was required to do.

"His registration of notice of his claim may not have been requisite on the facts here presented, but was, if I understand the practice, exactly what is usually done by prudent purchasers under a time bargain. And prudent buyers are well adrised in making search for such notice of prior purchase. But though claimed to be here notice to the subsequent purchasers I desire not to express my opinion on that point, for in my view of the case that need not be considered merely from the point of view of notice."

Comparing the Australian view of a caveat as outlined in the case cited and the Canadian view, it is evident that by taking into consideration the omission or otherwise to file and search for caveats as an element in the equities of the parties, the result as to the effect of a caveat will ordinarily be the same under the same facts in the two countries. But in the last analysis there appears to be a radical difference in principle. Thus suppose a case, as may be possible, of two purchasers under contract, where neither fails in any reasonable diligence, and absolutely the only difference in the equities is in point of time. In Australia, in such a case, the first purchaser's interest following the reasoning of the cases cited, would prerail, notwithstanding the second had first registered his caveat. In Canada, the second purchaser would obtain priority by virtue of the registration of his caveat itself. In other words, while in Canada, failing all other tests but that of time, priority in

${ }^{97}$ Re Scanlan, 3 Q. L. J. 43 (full court). 
registration of the caveat gives priority in interest, in Australia under similar circumstances, that party who would have had priority in a court of equity, independently of the Torrens Act, gains priority.

It is apparent that certain expressions of Newlands, J., in the Full Court of Saskatchewan and of Anglin, J., in the Supreme Court of Canada in the leading case under consideration, taken by themselves apart from the facts and other parts of the judgments, seem to give to a caveat an even more sweeping effect than is actually the case if the conclusions reached in the foregoing pages are correct. They seem to indicate that the first man with his caveat has, by virtue thereof, absolute priority of interest. For example, Anglin, J., says:

"I incline to the view that a caveat must be deemed notice to every person who claims to have aequired subsequently to its being lodged any interest in the lands or to have increased or bettered any such interest already held."

Surely it was not intended, for example, that a bona fide registered mortgagee proposing to make further advances, as permitted by his mortgage, should be bound by the subsequent caveat of some one adverse in interest, so as to postpone his further advances to the claim in that caveat. ${ }^{98}$ And again:

"I am of the opinion that a caveat when properly loaged prevents the aequisition or bettering or increasing of any interest in the land legal or equitable adverse to or in derogation of the claim of the caveator-at all events as it exists at the time when the caveat is lodged."

But elsewhere in the same judgment it is intimated that, had McKillop and Benjafield got the approval of the Canadian Northern Railway Company prior to Alexander's caveat, they might have "increased or bettered" their interest (for they had not by any means all the interest in the land

${ }^{98}$ The contrary had been held in Australia, Queenstand, Trustee v. Registrar of Tilles, 5 Q. I.. J. 46, and under The Registry Act in Ontario subsequent registration is not notice. Pierce v. Canada Permanent Mortgage, 25 O. R. 671, 23 O. A. R. 516. 
when they got the railway contract) by making further payments to the registered owners ${ }^{99}$ and could subsequently have got in the actual registered title adversely to Alexander's interest. ${ }^{100}$

The author may venture with some hesitation to sum up the conclusions arrived at in language more comprehensible to the lay reader somewhat as follows: That if upon purehasing an interest in land under a contract or other unregistered instrument, the purchaser ascertains by searches in all places open to him that in the absence of fraud his vendor has the right to sell what he purports to sell, and thereupon the purchaser files his eaveat, he may rest assured that, assuming there is nothing prior to his caveat on the register adverse to him, he has sufficiently protected his interest against any adverse interest existing at the time, or which can arise otherwise than by his own default, or if there be several interests between him and the registered owner, otherwise than by some default on the part of the holder of some of those interests. For it must be remembered that a caveat is in no sense the creation of an interest nor the registration of an instrument and does not in any

93 Rose v. Watson, 10 H. L. C. 671 ; Bannerman v. Green, 1 S. L. R. 394.

Every payment of purchase money on an executory contract is an increasing or bettering of the interest of the purchaser, as said hy the Lord Chancellor in Rose v. Watson, at page 678, "Where the contract is an executory one in this sense, namely, that the ownership of the estate is transferred subject to the payment of the purchase inoney, every portion of the purchase money paid in pursuance of that contract is a part performance and execution of the contract, and to the extent of the purchase money so paid, does, in equity, finatly transfer to the purchaser the ownership of a corresponding portion of the estate," and Lord Cramworth, at page 692, "When instead of paying the whole of his purchase monev, he pays part of it, it would seem to follow as a necessary corollary, that, to the "xtent to which he has paid his purchase money, to that extent the rendor is a trustee for him; in other words, that he acquires a lien exactly in the same way as if upon payment of part of the purchase money the vendor had executed a mortgage to him of the estate to that extent."

1) Arnot and Smith v. Peterson, 2 W. W. R. 1, is an excellent illustration of a superior equity governing priority rather than priority of registration of a ravealt. 
way improve a defect appearing in the title under which the caveator claims. ${ }^{101}$ So that for example, if $\mathrm{A}$, the registered owner, sells by contract to $\mathrm{B}, \mathrm{B}$ to $\mathrm{C}$, and $\mathrm{C}$ to $\mathrm{D}$, and $\mathrm{D}$ files his caveat, $\mathrm{D}$ thereby gains priority over a sale $\mathrm{A}$ may thereafter make to $\mathrm{E}$, but he does nót (except as to receiving notice of proceedings) improve his position any if A subsequently effectually cancels B's contract for default, notwithstanding that $\mathrm{D}$ may be in no default to his direct vendor $\mathrm{C}$.

(4) INCIDENTAL EFFECTS OF CAVEAT.

Having discussed the real and main purpose and effect of a caveat it remains to mention a few incidental effects which have been attributed to the filing: of a caveat. In one case, which, however, depended entirely on the particular facts there found, the filing of a caveat was considered as some evidence of the lack of bona fides of the caveator. ${ }^{102}$ On the other hand the filing of a caveat has been taken as an indication of an intention not to abandon a contract, ${ }^{103}$ and the allowing of a caveat to lapse has been treated as evidence of abandonment. ${ }^{10 t}$ While, it is submitted, such lapse of caveat is not absolute evidence of abandonment, it must be taken to place third parties in the same position as they would have been had such caveat never been filed, whether or not as between the actual parties the claim of the caveator be abandoned.

${ }^{101}$ Re Ebbing, 2 S. I. R. 167; Canadian Pacific Railwayy I. Silzer, 3. S. L. R. 162.

102 Fernie v. Kennedy, 13 W. L. R. 437.

${ }^{103}$ Stewart v. Borm, 19 W. L. R. 166.

${ }^{19:}$ Howell v. Union Bank, Limited, 6 N. Z. L. R. S. C. כ6. 


\title{
CHAPTER XIII
}

\author{
POWERS OF ATTORNEY
}

The Acts provide for the making and filing of powers of attorney by registered owners. In Saskatchewan and Alberta, by a peculiarity in the wording, the sections do not appear to extend to any person except the owner of the land, so that a mortgagee apparently could not authorize any person by power of attorney to deal with his mortgage. In practice they are treated as effective for all purposes. In Manitoba the power is expressly extended to a dealing with a mortgage or incumbrance. ${ }^{2}$ The law upon power's of attorney is not in any way peculiar to the Torrens srstem and is included in the Acts, presumably, owing to the fact that the Acts deal with the registration of titles and not only registration of instruments and are largely directory to the registrar, ${ }^{3}$ and it was therefore necessary that specific rules be laid down touching such important and much used instrumerits as powers of attorney. The instrument must be executed, witnessed and attested in the same manner as any ordinary instrument under the Acts. If the power of attorney be a general one, the instrument is entered in a power of attorney book. and in Saskatchewan is said to be filed only, while if the instrument refers to specific land, a memorandum is made on the certificate of title touching that land. In this latter case it is enacted in Saskatcheran and Alberta that while such power of attorney remains unrevolied, the right of the

1 iask. 104; Alta. 72.

Man. 15,

3 Willize v. Jellett, 26 S. C. R. 2s2; Re Massen and Gibson, 7 Man L. P. 172 . 
owner to transfer or otherwise deal with the land shall be suspended. In Manitoba the right of the owner in such cases will be a matter for the construction of the instrument itself. For powers of attorney no special form is prescribed in Manitoba, and in Saskatchewan and Alberta, notwithstanding a form is given, there is allowed by the Acts themselves the greatest freedom in the matter of form. 


\section{APPENDIX A \\ STATUTES \\ MANITOBA}

The Real Property Act

Being Chapter 148 of the Revicd Statutes of 1902, as a mended by Chanter 38, 1903 (assonted to March 18, 1903); Chapter 50,1904 (assented to February 8, 1904); Chapter 41, 1905 (assented to January 31, 1905); Chipter 74, 1906 (assented to Fobruary 9, 1906); (hapter 75, 1906 (assented to March 16, 1906); Chapte 52, 1908 (assented to February 26i, 1908); and Chapter 49, 1911 (assented to March 24, 1911).

\section{An Act respecting Real Property in the Province of Manitoba.}

Is Majesty, by and with the advice and consent of the Legislative Assembly of Manitoba, enacts as follows:

SHORT TITLE.

1. This Act may be cited as "The Real Property Act." 1 \& 2 Edw. VII, c. $43, \S 1$.

\section{INTERPRETATION.}

2. In this Act, and in all instruments purporting to be made, executed or registered thereunder, unless the context otherwise requires:

(a) The expression "land" means and includes land, messuages, tenements, hereditaments, corporeal and incorporeal, of every kind and deseription, whatever the estate or interest therein may be and whether legal or equitable, together with all paths, passages, ways, watercourses, liberties, privileges and easements, appertaining thereto, and all trees and timber thereon, and all mines, minerals and quarries, unless any such are especially recepted; 
(b) The expressions "owner" and "registered owner" mean and include any person or body corporat registered under this Aet as owner of any estate or interest in land or of any mortgage or incumbrance thereon, whether entitled thereto in his own right or in his representative capacity, or otherwise howsoever;

(c) The expression "lease" includes a sublease, and the expression "lessee" includes a sublessee;

(d) The expression "mortgage" means and includes any charge on land created for sccuring a debt or loan or any hypothecation of such charge;

(e) The expression "mortgagee" means the owner of a mortgage registered under this Act;

(f) The expression "mortgagor" means and includes the owner of land or of any estate or interest in land pledged as security for a debt;

(g) The expression "incumbrance" means and includes any charge or lien on land other than a mortgage or any hypothecation of such charge or lien;

(h) The expression "incumbrancer" means and includes the owner of any land or of any estate or interest in land subject to any incumbrance;

(i) The expression "incumbrancec" means and includes the owner of an incumbrance;

(j) The expression "person of unsound mind" means and includes any person, not an infant, who is incapable, from infirmity of mind, of managing his own affiairs;

(k) The expression "instrument" means and includes any certificate of title, certificate of charge, book, plan or document in writing relating to any dealing with land, or creating any mortgage, incumbrance or lien thereon, or evidencing title thereto, or a duplicate thereof;

(l) The expressions "attorney general" and "provineial treasurer" respectively mean the attomey general of Manitoba and the provincial treasurer of Manitoba;

$(m)$ The expression "valuator" means and includes any person appointed by the Lieutenant Governor in Council under this Act to value land;

(n) The expression "court" means his Majesty's Court of King's Bench for Manitoba;

(o) The expression "judge" means a judge of his Majesty's Court of King's Bench for Manitoba, and includes the chief justice; 
(b) The expression "transmission" applies to every change of ownorship under assignment for benefit of creditors or under foreclosure or sale under mortgage or incumbrance and to crery involuntary change of ownership of land, mortgage or incumbrance;

(q) The expressions "grant," "patent" or "Crown patent" respectively mean and include any grant of Crown land, whether direct from his Majesty or pursuant to the provisions of any statute, and whether such land was held by the Crown in the right of Canada or in the right of any province thereof;

(r) The expression "indorsed" means and includes anything written upon any instrument or other document or in the margin thereof, or at the foot thereof;

$(s)$ The expression "old system" means the system of registration provided by The Registry Act;

$(t)$ The expression "new system" means the system of registration provided by this Act;

(u) Land shall be deemed to be "subject to the new system" while an application is pending to bring such land under the new system and before a certificate of title shall have issued therefor, and land shall be deemed to be "under the new system" after a certificate of title shall have issued therefor;

(v) The expressions "land titles district" and "district" respectively mean a land titles district created or continued under this Act, and the expression "registration district" means a registration district created or continued under The Registry Act and not brought within any land titles district;

(w) The expression "registrar" means a registrar under The Registry Act, and the expression "district registrar" means a district registrar under this Act;

(x) The expression "register" shall mean the volumes kept in a land titles office in which certifieates of title are entered and bound;

(y) Wherever in this Act reference is made to a certificate of title "isued under" this Act" such reference shall be construed to include all certificates of title issued under any Real Property Act previously in force in the Province of Manitoba or any amendments thereto;

(z) Whenever a form in the schedules hereto is directed to be used. such direction shall apply equally to any form to the like effect, or which for the same purpose may be authorized 
under the provisions of this Act; and any variation from such forms, not being a variation in matter of substance, shall not affect their validity or regularity, but they may be used with such alterations as the character of the parties or the circumstances of the case may render necessary. 1 and $2 \mathrm{Edw}$. VII, c. $43, \S 2$.

\section{SCHEDULES-RULES.}

3. The Lieutenant Governor in Council shatl have power from time to time to alter any of the forms in the schedules to this Act, to provide any additional forms that may be deemed necessary, and to alter the rules and regulations set forth in schedule $\mathrm{L}$ to this Act, and to make such rules and regulations as may be deemed necessary or expedient for giving effect to this Act in cases unprovided for, according to its true intent and purpose. $1 \& 2 \mathrm{Edw}$. VII, c. $43, \S 3$.

4. The schedules to this Act, and all additions and amendments thereto hereafter made by the Licutenant Governor in Council or the Court of King's Bench, shall be deemed to be embodied in and to form a part of this Act. 1 \& $2 \mathrm{Edw}$. VII, c. $43, \S 4$.

\section{LAND TITLES OFFICES-DISTRICT REGISTRARS-OFFICERS.}

5. The Lieutenant Governor in Council may constitute such portions of the Province of Manitoba as may seem proper into land titles districts, and change the boundaries thereof from time to time. In each of such districts, at such place as the Lieutenant Governor in Council may appoint, there shall be an office to be called the land titles office for (insert here the name of the district). The Lieutenant Governor in Council may close, in whole or part, any registration district and add to any district any territory taken from a registration district or from another district under this Act. The present districts and offices shall continue until changed under this Act. $1 \& 2 \mathrm{Edw}$. VII, c. $43, \S 5$.

6. Upon the closing of a registration district, and at such times and in such manner as the Lieutenant Gorernor in Council may direct, all books, records and instruments in the possession of a registrar shall be transferred from the possession of such registrar to the possession of the district registrar of the district to which the land affeeted by such books, records and instruments has been transferred. 1 \& 2 Hdw. VII, c. $43, \S 6$.

7. Any district registrar shall have full power to furnish originals or certified copies of all registers, books or instru- 
ments. or of any certified copies of registers, books or instruments in his offiere, affecting lands within the district or under the control of such district registrar, when such lands are, muder this Act, alded to or formed into another district, and all such original or certified copies shall for all purposes be of the same force and effect when deposited in the nffice of the new district as if they were originals and had heen originally registered, deposited or kept in that office. 1 \& 2 Edw. VII, c. $43,57$.

8. For wach district the Licutenant Governor in Council may appoint an official to be called the district registrar, and such clorks and other officials as may be deemed advisable, and may also aproint an official to be known as the registrar general, who shall have such powers and duties in addition to tho- prescribed under this Act as may be assigned to him by the Lieutenant Gorernor in Council. No person whall be appointed a district registrar or registrar general unless he is a barrister or attorney in the courts of the Province of Manitoba of at least five rears' standing. The present district registrars, clerks and other officials shall continue in office until otherwice ordered. All persons appointed under this Act shall hold office during the pleasure of the Lieutenant. Governor in Council. 1 \& 2 Edw. TII, c. $43, \S 8$.

9. The Lieutenant Corrernor in Council may appoint a deputy of the registrar general and one or more deputies of any district registrar appointed under this Act, and each such deputy shall have all the powers and be entitled to perform all the duties of the district registrar or registrar general for whom he is deputy, whether such powers or duties are prescribed by or arise under this Act or any other Act of the I.egislature of this province, and. in case of the death or removal from office or resignation of a district registrar or the registrar generil, such deputy or any person appointed by the Lieutenant Governor in Council, deputy district registrar or deputy registrar general subsequently to such death or removal or resignation, and before the appointment of a new district registrar or registrar general, shall be entitled to act as such deputy with like powers. (1906.) 5 \& $6 \mathrm{Edw}$. VII, $\because 7 t, \S t$.

10. Every district registrar, before he enters upon the rxecution of his office, shall take the oath of office and give security to the satisfaction of the Lientenant Governor in ('ouncil for the due parment orer of all moneys receired by him as such rlistriet registrar. 1 \& 2 Edw. VII, c. 43, \$10. 
11. Each district registrar shall have a seal of office approved by the Lieutenant Governor in Council. 1 \& 2 Edw. VII, c. $43, \S 11$.

12. The district registrar shall keep a book to be called the "day book," in which shall be entered, by its day book number, every instrument which is registered, with the day, hour and minute of filing; and, for the purpose of settling priorities, the time of filing shall be taken as the time of registration. The district registrar in entering memorials upon the certificate of title, and indorsing a memorial upon an instrument registered, shall take the time of filing from the day book as the time of registration. In any land titles office in which a fee book or receiving book is kept as well as a day book, such fee book or receiving book shall be deemed to be a part of the day book, and any entry made therein shall be deemed to be an entry made in the day book. $1 \& 2$ Edw. VII, c. $43, \S 12$.

13. In each district, at the place appointed for a land titles office, the Lieutenant Governor in Council may procure a site and cause a suitable building to be erected thereon or may purchase or rent a building to be used as the land titles office, and properly furnish the same. 1 \& 2 Edw. VII, c. $43, \S 13$.

14. All instruments, books, records, documents, plans and other papers and all registrations made in a registration district prior to the date named for the transfer, as in the sixth section of this Act mentioned, shall continue to have the same effect on and after the said date so named as, but no greater effect than, if this Act, or The Real Property Aet of 1889, or any amendments thereof, or any former Act styled The Real Property Act or any amendments thereof, had not been passed, and no registration heretofore or hereafter made under the old system shall affect any land which, at the time of such registration, was or is subject to or under the new system, so long as such land remains subject to or under the new system; nor shall any registration heretofore or hereafter made under the new system affect any land which is not subject to or under the new system; and no registration marle in any registration district prior to the date when the same or any part thereof became or shall become incorporated in a land titles district or in the office of any land titles district prior to the date when a portion of such district is added to some other district shall, after said date, have the effect of binding any land, other than the land it would have bound 
or affected had that registration district not been brought into a land titles district, or that portion of a land titles district not been added to some other district. When part of is land titles district or registration district is transferred to or becomes part of another land titles district all certificates of julgment registered in such first-named district, prior to such trimsfer, shall cease to form a lien or charge on any land :o transferred upon the expiration of two years from the time of such transfer, unless within said period of two years they are re-registered in the district to which such land has been transferred. 1 \& 2 Edw. VII, c. $43, \S 14$.

15. Except as herein otherwise provided a district registrar shall continue to act as registrar and shall carry out the provisions of The Registry Act in respect of any land under the old system in his district. 1 \& 2 Edw. VII, c. $43, \S 15$.

16. No district registrar, eximiner of titles, officer or clerk in any office under this Act shall, directly or indirectly, act as the agent of any corporation, society, company, person or persons investing money and taking securities on real estate within his district; nor shall such district registrar, examiner of titles, officer or clerk advise, for any fee or reward or otherwise, upon titles to lands or practise as a conveyancer, nor shall he carry on or transact within the office any business or occupation whatever other than his duties under this Act; nor shall such district registrar, examiner of titles, officer or clerk practise as a barrister, attorney or solicitor upon pain of dimisal from office for any offence against this section. $1 \&$ 2 Edw. VII, c. $43, \& 16$.

17. All fees for services rendered by a district registrar uncler this Act or any other Act of the Legislature of this province shall be settled, unless otherwise provided for, by a tariff of fees approved by the Lieutenant Governor in Council, who shall have power to amend the same. The tariffs at present in use in the land titles offices are hereby confirmed subject to amendment, and no service shall be rendered by any official of a land titles office until all such fees fixed for weh sorvice have been paid to the district registrar; but no fees shall be charged to or paid by the Government of Manitoba for any services rendered by a district registrar under this Act to the provincial land commissioner or for any department of the public service. $1 \& 2 \mathrm{Edw}$. VII, c. $43, \S 17 ;(1904) 3$ \& 4 Edw. III, c. $50, \S 1$.

18. The district registrar shall keep a correct account of all sums of money received by him under this Act and under 
The Registry Act and shall pay the same to the provincial treasurer at such times and in such mamner as the provincial treasurer may direet. No official in a land titles office shall be entitled to retain for his use any fee of any kind whatsoever received for work done or information furnished in connection with a land titles office. The penalty for any violation of this section shall be dismissal from office. $1 \& 2$ Edw. VII, e. $43, \S 18$.

19. A distriet registrar shall not, nor shall any person acting under his authority, under this Act or under any order or general rule made in pursuance of this Act, nor shall any surety of such officer, be liable to any action or proceeding for or in respect of any aet bona fide done or omitted to be done in the exercise or supposed exercise of the powers given by this Act or any order, rule or regulation made in pursuance of this Act. $1 \& 2$ Edw. VII, e. $43, \S 19$.

20. Every land titles office shall be kept open on all days except holidays as defined by The Nanitoba Interpretation Act, from the hour of ten o'elock in the forenoon until three o'clock in the afternoon, exeepting Saturdays, and then until one o'clock in the afternoon. Except within the said hours no registration shall be effeeted. $1 \& 2$ Edw. VII, e. $43, \S 20$.

21. When the attendance of a district registrar as a witness for examination under any subpcena, order or summons from any court in this province, whether direeted to him personally or in his official eapacity, is required by any party to any suit, action or proceeding in any such court and such attendance will necessitate the absenee of such district registrar from the eity, town or village in which his office is situate, a proper notice thereof in writing shall in addition to the service of such subpœena, order or summons on the distriet registrar, be served upon or sent to the registrar general so that the same shall be received at his office at least one week before the attendance of such distriet registrar is so required, otherwise such district registrar shall not be bound to attend thereon. A distriet registrar may produce in court any book or instrument from the offiee of any other district registrar or registrar, and such book or instrument shall be decmed to be produced by the proper officer and from the proper custody. $1 \& 2 \mathrm{Edw}$. VII , c. $43, \$ 21$.

MANNER OF BRINGING LAND UNDER NEW STSTEM.

22. Exeept as provided by the next following section, no distriet registrar shall receive any application affecting land not situated in the land titles district for which he acts. $1 \& 2$ Edw. VII, c. $43, \S 22$. 
23. Until the present registration districts of Souris River, thoal Lake, Manchester, Lisgar and Rockwood shall respectively under the provisions of this Act, be added to some existing distriet, or formed into a new district or districts, applieation may be made to bring any land forming part of any such registration district under this Act by filing such application with the clistrict registrar for the land titles distriet of Boissevain in case of land in Souris River, and in other eases with the district registrar for the land titles district of Winnipeg; and the proper district registrar shall thereupon issue to the applicant a certificate of the filing thereof under his hand and seal of office. 1 \& 2 Edw. VII, c. $43, \S 23$.

24. The registrar of the proper registration district shall, upon presentation thereof and payment of the fee of one dollar, register such certificate and such registration shall thereupon have the same effect as regards the land described in such certificate as the filing of an application with the district registrar would have under the thirty-fourth section of this Act, and thereafter the provisions of The Registry Act whall cease to affect such land:

Provided, howerer, that, notwithstanding anything in this Act or The Registing Act contained, in any ease where the value of the land in such application does not exceed two hundred dollars, the registrar of the registration district shatl be entitled to the fee of two dollars and no more for all services rendered by him in connection with such application. $1 \& 2$ Edw. VII, c. $43, \$ 24$.

25. All land which, but for the provisions of this Act or any other Act, would form a part of any of said registration distriets shall hereafter, so far as applicable, be subject to the provisions of this Act, and shall, until it is included in some other land titles district, be dealt with by the district registrar for the land titles district of Boissevain in ease of land which othermise would have been in the registration district of Souris River, hut in other cases by the district registrar of the land titles district of Winnipeg. $1 \& 2$ Edw. VII, c. $43, \$ 25$.

26. The proper district registrar may at any time reject any application heretofore or hereafter made to bring under this Act any land mentioned in the twenty-third and twentyfifth sections of this Act, and upon such rejection shall issue a certificate there of to the registrar of the proper registration district, who, upon payment of the fee of one dollar, shall register such certificate and thereupon the land described in 
such certificate of rejection shall cease to be subject to this Act, and shall immediately become again subject to the provisions of The Registry Act. 1 \& 2 Edw. VII, c. 43, § 26.

27. It shall be the duty of a registrar, upon request in writing of the proper district registrar and upon payment therefor of the fee of ten cents for each instrument, to forward to said district registrar any instrument in his custocly as such registrar. $1 \& 2$ Edw. VII, c. $43, \S 27$.

28. The owner of any estate or interest in land, whether legal or equitable, may, by himself or his duly authorized attorney or agent, apply to the proper district registrar to have his estate or interest or the whole title to the land registered under the new system, but it shall be in the discretion of the district registrar to refuse to entertain such an application unless all persons, other than the applicant, who are interested in the land shall be consenting parties to the application. $1 \& 2$ Edw. VII, c. $43, \S 28$.

29. The Lieutenant Governor in Council may by order direct a district registrar to bring under this Act any land belonging to his Majesty in the right of Mianitoba and the filing with a district registrar of such Order in Council shall in all respects have the same force and effect as the filing of an application to bring land under this Act. 1 \& 2 Edw. VII, c. $43, \S 29$.

30. Contiguous country lands, not exceeding altogether two thousand acres (a road not to be considered a break in the contiguity), or any number of lots under the same plan of subdivision, may be included in the same application; but in no case shall a first or subsequent certificate of title issue for more than fifty lots or for unsubdivided lands which are not contiguous or which contain more than two thousand acres; the provisions of this section shall not apply to cases within the last preceding section. $1 \& 2 \mathrm{Edw}$. VII, c. 43, §30.

31. When land subject to mortgage is brought under the new system all rights, remedies and matters of contract between the mortgagor and mortgagee in relation to such land shall remain intact as if such land were under the old system. $1 \& 2$ Edw. VII, c. $43, \$ 31$.

32. Notwithstanding anything in this Act contained an application shall not be received to bring under the new system an undivided interest in any land, unless an application is also made for all other undivided interests in the same 
land: and no withdrawal or rejection of any application for an undivided interest shall be permitted, unless the application for all other undirided interests in the same land are withdrawn or rejected. 1 \& 2 Edw. VII, c. $43, \S 32$.

33. The father or, if the father be dead, the mother or other guardian of any infant, or the committee or guardian of any person of unsound mind, may apply, on behalf of sueh infant or person of unsound mind to bring land under this Act: and a person holding a power of attorney authorizing the sale of a freehold or other estate in any land may apply in respeet of such land in the name and on behalf of the owner, unless such porrer of attorney expressly prohibits him from $\therefore$ o doing. 1 \& 2 Edw. TII, c. 43, \$ 33.

34. Tpon the filing of an application to bring land under this Act, whether or not the application is made by any person entitled to make it under this Aet, and whether or not it is in any respect in accordance with this Act, such land shall become subject to the new system, and no registration under the old system shall affeet such land unless such application he withdrawn or rejected by the distriet registrar, in either of which events the land shall thereafter until a further application be filed to bring it under the new system be dealt with under the old system. $1 \& 2$ Edw. VII, c. $43, \S 34$.

35. Any person, except a tax sale purchaser, applying to bring land under the new system may in his application, or upon special request in writing addressed to the distriet registrar prior to the drafting of the eertifieate of title, direct the certificate of title for such land, or any part thereof, to be issued in the name of some other person or in the names of limself and some other person; and sueh direction, whether comprised in an application or in a speeial request, shall from the time of its filing with the district registrar have the effect of conveying and transferring to such person or to the applicant and such other perion, as the ease may be, as regards such land, all the estate or interest, whether legal or equitable, which the applicant is entitled to and direets to be transferred, as fully and effectually as if such estate or interest were transferred by deed and such deed were duly registered. 1 \& 2 Edw. VII, e. $43, \$ 35$.

36. An applicant may, upon such terms as to the district registrar seems proper, withdraw his applieation as to the whole or any part of the land comprised therein at any time mrior to the issue of the eertificate of title: 
Provided that, in all such cases, if a caveator shall have been put to expense without sufficient cause by reason of such application, he shall be entitled to receive from the applicant such compensation as a judge on a notice of motion in chamber's may order. 1 \& 2 Edw, VII, e. $43, \S 36$.

37. The district registrar may in all cascs reject the application as to the whole or any part of the land therein comprised, if the applicant fail within in reasonable time to produce the evidence neeessary to make out a good safe holding title, unless the applicant shall adduce satisfactory proof that he is proceeding without unnecessary delay in removing defeets and complying with the requisitions made on the title. $1 \& 2$ Edw. VII, c. $43, \S 37$.

38. On the withdrawal or rejection of such application, the district registrar shall forthwith eause to be entered in the proper abstract book, under the old system, a memorandum stating that such application has been withdrawn or rejected in whole or part; and upon the entry of such memorandum the land thereby affected shall cease to be subject to the provisions of the new system, and shall immediately become again subject to the provisions of the old system. 1 \& 2 Edw. VII, e. $43, \S 38$.

39. In case of the withdrawal or rejection, in whole or in part, of any applieation to bring land under the new system, under which a direction or request has been filed with the district registrar that the certificate of title shall issue to some other person than the applicant, either alone or conjointly with the applieant, the memorandum of withdrawal or rejection, so soon as entered by the district registrar in the abstract book kept under the old system, shall have the effect of re-vesting the land as to which such withdrawal or rejection shall have taken place in the person in whom, had no such direetion or request been filed, it would have remained vested, as fully and effectually as if no such direetion or request had been filed as aforesaid; and no person shall have notice, from such direetion or request having becn filed of any right to such land that may exist between the parties to or named in the direction or request:

(a) Provided, however, that the distriet registrar shall not allow such withdrawal or rejection, except, in the case of a withdrawal, upon the written consent of the person to whom, either alone or conjointly with the applicant, the eertificate of title was directed to issue, and, in the case of at rejection, upon the written consent of the person to whom the 
certificate of title was so directed to issue, or upon the expiration of the time limited in a notice of intention to reject given by the district registrar to him:

(b) Provided, also, that nothing herein contained shall affect the rights as between themselves of any of the parties to such direction or request. 1 \& 2 Edw. VII, c. $43, \S 39$.

40. In case the district registrar shall find that some person other than the applicant has, or appears to have, some right or claim to or against the land in question, he may issue a notice, and cause such person to be served. with a copy thereof, to the effect that a certificate of title will issue for such land pursuant to the application unless the person appearing to have such right or elaim shall, within the time limited by the notice, which time shall in each case be fixed by the district registrar, take proceedings to stop the issue of such certificate of title. 1 \& 2 Edw. VII, c. $43, \S 40$.

41. All notices and proceedings affecting land may be served in the same manner and upon the same persons, officers and functionaries as in suits and proceedings in the Court of King's Bench or under The King's Bench Act. 1 \& 2 Edw. VII, e. $43, \S 41$.

42. Notices and proceedings affecting or intending to affect corporations, whether domestic or foreign, or any unincorporated company, partnership, firm or person, whose chief place of business or head office is without this province, may be served upon any firm, person, company or corporation who, within this province, transacts or carries on any business as the general agent for any such person, partnership, firm, company or corporation; and service upon such agent of any such notice or proceeding shall have the same effect and shall be treated as personal service upon such person, partnership, firm, company or corporation. 1 \& 2 Edw. VII, c. $43, \$ 42$.

43. In any case where, under this Act, notice is required to be served, and it appears that the person to be served has been dead for the space of one year and no will of the deceased has been proved or personal representative appointed to his estate in this province, or in the event of the death of the perconal representative so appointed and the appointment of no other personal representative, such notice may be served in ease of intestacy upon the person or persons who, according to the law as it existed in Manitoba on the thirtieth day 
of June, in the year one thousand eight hundred and eightyfive, would have been the heir or heirs at law of the deceased; or in case of testacy upon the person entitled to or interested in the land by virtue of any devise in the will; and such service shall be as binding, and have the same effect upon the estate of such deceased person and all persons claiming thereunder, as if it had been effected upon a representative to such estate, duly appointed:

Provided that service under this section may be effected in the manner directed or subsequently approved of by the district registrar. $1 \& 2 \mathrm{Edw}$. VII, c. $43, \S 43$.

43a. Any notices under this Act which are required to be published in any newspaper shall also be published in one issue of The Manitoba Gazette, for which publication a fee of three dollars shall be paid. (1906) $5 \& 6$ Edw. VII, c. $74, \S 1 ; 5 \& 6$ Edw. VII, c. $75, \S 5$.

44. In the investigation of titles, every patent which has been issued for ten years or upwards and which remains uncancelled, and as to which the district registrar has no notice that proceedings have been taken to set the same aside, shall be accepted by the district registrar as firal, and it shall not be necessary to inquire whether such patent has been properly issued or not; but in all such cases, if the applicant desires to take advantage of the provisions of this section, the assurance fee to be paid under this Act shall be increased to one-half of one per cent., unless the district registrar shall in special cases otherwise direct. $1 \& 2$ Edw. VII, c. $43, \S 44$.

45. The district registrar, on being satisfied of the due service of all notices that he may think requisite, and that the title to the land is safe holding, may bring such land under the new system and issue a certificate of title therefor to the person who appears to be entitled to the same. 1 \& 2 Edw. VII, c. $43, \S 45$.

TAX SALES.

46. In case of applications under tax sales, the district registrar shall not take notice of any irregularity in the tax sale or in any of the proccedings relating thereto, or inquire into the regularity of the tax sale proceedings or any proceedings prior to or having relation to the assessment of the land, but a certificate from the treasurer of the municipality shall be furnished, showing the years for which there were taxes due and in arrear for which the land was sold at such sale. and the district registrar shall satisfy himself that the saic 
was fairly and openly conducted, and he shall also cause to be served upon all persons appearing to be the persons who, other than the tax purchaser or his assigns, are interested in such land a notice requiring them, within the time limited by such notice, to contest the claim of the tax purchaser, or to redeem the land if it is open to redemption, and in default of a caveat or certificate of lis pendens being filed and in default of redemption, before the registration as owner of the person entitled under such tax sale, all persons so served with notice shall be for ever estopped and debarred from setting up any claim to or in respect of the land so sold for taxes, and the district registrar shall register the person entitled under such tax sale as owner of the land so sold for taxes:

Provided, that the district registrar may, if he shall think proper so to do, in cases where the value of the estate or interest of the person to be served in any parcel of land, in his opinion, does not exceed two hundred dollars, dispense with the service of such notice, but in that event he shall not issue a certificate of title for such land until after the expiration of six months from the date of filing the application. $1 \& 2$ Edw. VII, c. $43, \S 46$.

47. The district registrar in a proper case may order that such notice mentioned in the last preceding section may be served substitutionally, and such substitutional service shall have the same effect as personal service of the notice or proceeding upon the person intended to be affected thereby. 1 \& 2 Edw. VII, c. $43, \S 47$.

48. In case of land under the new system being sold for taxes, the district registrar, on an application of the person entitled under the tax sale, may, without requiring the proceedings necessary under this Act in the case of a lost certificate of title to be taken, dispense with the customary production of the duplicate certificate of title, and cancel the same, in full or partially, as the case may be, by memorial on the certificate of title in the register, and may issue a new certificate of title to the person entitled under the tax sale as owner of said land. The provisions of the forty-sixth and forty-seventh sections hereof shall apply to such application the same as if the application were as to lands not already under the new system. $1 \& 2 \mathrm{Edw}$. VII, c. $43, \S 48$.

POWERS AND DUTIES OF DISTRICT REGISTRARS.

49. The district registrar may exercise the following powers in addition to others conferred under this Act: 
(a) He may enter a eaveat on behalf of his Majesty, or on behalf of any person who may be under any disability, to prohibit the transfer or dealing with any land belonging, or supposed to belong, to the Crown or to any sueh person as hereinbefore mentioned, and also to prohibit the dealing with any land in any case in which it shall appear to him that an error has been made in any certificate of title or other instrument, or for the prevention of any fraud or improper dealing;

(b) He may, by summons, require any person having an instrument in his possession in any capacity to produce before him any instrument in his possession or within his control affecting any land, mortgage or ineumbrance or the title thereto;

(c) He may summon any person whose evidenee may be necessary or material in respect to any matter pending before him to appear and give evidence upon oath respecting such matter, and to produce any instrument or evidence of title before such district registrar or before any other person appointed under an order of such distriet registrar; and such order of a distriet registrar, being under his hand and seal of office, shall be a sufficient authority to the person therein named as a special examiner to administer the oath to and to take the evidence of all such persons as may be summoned by such district registrar to appear for that purpose; and such evidence when so taken by a special examiner shall be transmitted to the proper district registrar and shall be of the same effect as if it had been taken before the district registrar in person;

(d) If it appear to the district registrar that any certificate of title or other instrument has been issued in error or contains any misdescription, or that any entry or indorsement has been made in error on any certificate of title or other instrument, or that any such certificate, instrument, entry or indorsement was fraudulently or wrongfully obtained, he may, whether such certificate or instrument is in his custody or has been produced to him under a summons, so far as practicable without prejudicing rights conferred for value, cancel or correct any error in such certificate of title or other instrument, or in any entry made thereon, or in any memorial, certificate, exemplification or copy of any instrument made in or issued from the land titles office, and may supply entries omitted to be made:

(i) Provided, always, that in the correction of any such error he shall not erase or render illegible the original words, and he shall affix the date upon which such correction was made or entry supplied; 
(ii) And every certificate of title so corrected, and every entry so corrected or supplied, shall have the like validity and effect as if such error had not been made or such entry omitted. $1 \& 2$ Edw. VII, c. $43, \S 49$.

50. In case any person summoned by a district registrar to produce a certificate of title or other instrument refuses to comply therewith, the district registrar may apply to a judge in chambers on notice of motion calling upon such person to appear before a judge and show cause why such certificate or other instrument should not be delivered up to the district registrar to be cancelled or corrected by him; and, if such person, when served with such notice of motion, neglect or refuse to attend before a judge, at the time therein appointed, the judge may issue a warrant authorizing and directing the person so notified to be apprehended and brought before a judge for examination. $1 \& 2$ Edw. VII, c. $43, \S 50$.

51. Upon the appearance before a judge of any person notified or brought up by virtue of a warrant as aforesaid, the judge may examine such person upon oath, and, in case it appear right to do so, may order such person to deliver up such certificate of title or other instrument, as aforesaid, and, upon refusal or neglect by such person to deliver up the same pursuant to such order, may commit such person to the common gaol of any judicial district for any period not exceeding six months, unless such certificate of title or instrument be sooner delivered up, and in such case, or in case such person has absconded so that the notice of motion or warrant cannot be served upon him, the judge may direct the district registrar to cancel or correct the certificate of title or other instrument, or any entry or indorsement thereon, or to substitute or issue such certificate of title or other instrument or make such entry or indorement thereon as the circumstances of the case may require. 1 \& $2 \mathrm{Edw}$. VII, c. $43, \S 51$.

52. In any proceeding respecting land, or in respect of any transaction or contract relating thereto, or in respect of any instrument, caveat, memorial, or other entry affecting land, a judge may by decree or order direct the district registrar to cancel, conrect, substitute or issue any certificate of title, or make any indorcment or entry on any instrument, or otherwice to do every such act and make every such entry as may be necessary to give effect to the judgment, decree or order of the court:

Provided that the district registrar shall not issue any certificate of title by order of the court unless the title of the 
person to whom the certificate of title is directed to issue has been found upon investigation by the district registrar to be a good safe holding title. $1 \& 2 \mathrm{Edw}$. VII, c. $43, \S 52$.

53. Every summons issued by a district registrar may be in the form in schedule $\mathrm{N}$ to this Act or to the like effect, and, in the event of any disobedience of any summons being certified to the Court of King's Bench, it may be enforeed by such court in like manner and by the like proceedings and with a like penalty as subponas of such court. $1 \& 2 \mathrm{Edw}$. VII, c. $43, \S 53$.

54. In the event of a duplicate certificate of title or other instrument being lost or destroyed the district registrar may dispense with the production of the duplicate certificate of title or other instrument upon any dealing; and upon the registration of such dealing the district registrar shall note in the register that no entry of such dealing has been made on the duplicate certificate of title or other instrument, and the registration of such dealing shall thereupon be valid and effectual:

Provided, always, that, before registering such dealing, the district registrar shall satisfy limself that such certificate of title or instrument has not been deposited by way of lien or as security for any loan, and of the reason for its nonproduction, and, in the case of the duplicate certificate of title being lost, shall give at least fourteen days' notice of his intention to dispense with production thereof in such newspaper as he shall think proper. The number of insertions in such newspaper and the form of the notice shall be settled by the district registrar. $1 \& 2$ Edw. VII, c. $43, \S 54$.

55. In the event of a duplicate certificate of title being lost or destroyed, and after proceeding as in the last section set forth, the district registrar may issue a provisional duplicate certificate of title of such land, which provisional certificate shall be an exact duplicate as nearly as may be of the certificate of title bound up in the register, and of every memorandum and indorsement thereon, and shall contain a statement why such provisional certificate is issued; and the district registrar shall at the same time enter in the register notice of the issuing of such provisional certificate and the date thereof and why it was issued; and such provisional certificate shall be available for all purposes and uses for which the duplicate certificate of title so lost or destroyed would have been available, and as valid to all intents as such lost duplicate. $1 \& 2 \mathrm{Edw}$. VII, c. $43, \S 55$. 
ILANS.

56. (1) Any peron subdividing land for the purpose of selling the same in allotments shall deposit with the district registrar a plan in duplieate of such subdivision, and such plan shall be in accordance with the following provisions:

(a) All roark, streets, lanes, passages, thoroughfares, squares or lescres appropriated or set apart for public use shall be awn at surh and distinetly delineated on the plan and have 1 ineasumements marked thereon;

(b) All illotnents into which said land is divided shall be marked with district numbers or letters on the plan;

(c) Each angle of each allotment shall be defined on the ground by the surveror by a post or monument of a durable character and the manner by which each such angle is defined on the ground shall be sliown on the plan:

Provided, however, that upon the request of the owner the registrar general may, subject to such conditions as he may think proper to impose, allow a subdivision to be made and evidenced in the following mamner: Instead of requiring a post or monument at each angle of each allotment, there shall be erected at proper intervals monuments of a more permanent character than have heretofore been used; the said monuments, with the information on the plan showing the location of such monuments, shall be the evidence of the block outlines of such surrey, and the registered plan of such subdivision shall be the evidence of the manner in which each block of land is subdivided into allotments. (1911) 1 Geo. $\mathrm{T}$, c. $49, \S 1$.

(d) The plan shall show distinctly a sufficient number of angular and lineal measurements and astronomic bearings, from which ean be deduced the dimensions and astronomic bearing of each boundary of each and all the allotments into which said land is divided;

(e) The original section or parish lot lines, according to the survey there of by the Dominion Gorernment, or a sufficient number of said lines to show the location and connection of the subdivision therewith, shall be shown on the plan: provicled, however, that, when a connection with the said original survey lines has been sufficiently shown on any previously registered plan, this may not be required;

(f) When the plan is a subdivision of a lot or lots on a former registered plan the district registrar may require that there shall be shown, in a distinct manner on the plan, the numbers or other distinguishing marks of the lot or lots subdivided and the boundary lines of such lot or lots; 
(g) The plan shall be signed by each owner or his duly authorized agent. $1 \& 2$ Edw. VII, c. $43, \S 56$.

(h) Wherever upon any plan of subdivision now filed or registered, or hereafter filed or registered, in any land titles office or registry office in the Province of Manitoba, any portion of such subdivision is shown as a street, lane, avenue, road, highway, park or public square, and is not designated thereon to be of a private nature, the marking or indicating on any such plan of any street, lane, avenue, road, highway, park or public square shall be deemed to be a dedication to the public of such portion thereof for the purpose and object indicated on or to be inferred from such marking on such plan. Nothing herein contained shall affect any case in regard to which litigation is now pending in any court of law in Manitoba, or in which any proceedings have been begun, or any action taken, or anything done of a public character or nature by the original owner of the property affected or anyone claiming through him indicating an intention to assert rights or claims contrary or in opposition to any rights which, but for such adverse claim, the public would have by reason of said plan and the registering or filing thercof. (1908) $7 \& 8$ Edw. VII, c. $52, \S 1$.

(2) On and after the first day of November, 1911, if any person or corporation shall sell or convey or agree to sell or convey any lots or parcels of land, by number or letter according to any plan or subdivision of any property, whether the same has been brought under the operation of this Act or not, before such plan has been registercel according to law, the purchaser of any such lot or parcel of land without knowledge of the non-registration of the plan, or of the necessity for the same, or any person claiming under him, may at his option, on acquiring such knowledge, rescind the contract of purchase and recover back any money paid thereunder with lawful interest and any taxes or other expenses incurred by him in consequence of such purchase, and he shall in such case have a lien on such lot or parcel for all such moneys as against the vendor's interest in the said lot or pareel, but the vendor shall nevertheless be bound by any such contract, deed or conveyance, if the purchaser does not rescind the same. (1911) 1 Geo. V, c. $49, \S 2$.

56a. Before any plan or subdivision of land shall be registered in any land titles office the registrar general may require the outlines of such subdivision to be verified on the grounci by an officer of the land titles office or by an authorized lant? 
surveyor to be designated by the registrar general, and the cost of such verification shall be borne by the applicants for registration of said plan of subdivision. (1908) $7 \& 8 \mathrm{Edw}$. VII, c. 52, § 2 , amending (1906) c. $75, \S 4$.

57. Where in any plan heretofore or hereafter registered there is any omission, clerical error or other defect, the registrar general may on a copy or duplicate of such plan have such omission, error or defect corrected in such manner as to him may seem best, and he shall thereupon enter upon the original plan an order stating in what respect it stands amended by the corrected plan, and shall enter upon the corrected plan an order directing it to be filed with the original plan, and upon such filing the corrected plan shall be deemed to be substituted for the original plan, and thereafter the original plan shall for all purposes be deemed to have been so amended or corrected from the time of its registration, and the description of land in any instrument shall thereafter be construed as if it referred to such corrected plan, but such amendment or correction by the registrar general shall not affect or impair the rights of any person as existing when such amendment or correction is made. $1 \& 2$ Edw. TII, e. $43, \S 57$.

58. All railway corporations shall deposit with the district registrar plans in duplicate of the land taken for their right of way and station grounds, or for any other railway purpose, and such plan shall be in accordance with the following provisions:

(a) The area taken from each quarter section or parish lot, as the case may be, shall be shomn on the plan;

(b) The original section or parish lot lines according to the survey therc of by the Dominion Government shall be shown, and a sufficient number of angular and lineal measurements to define the limits of the land taken for the right of way of such railway, and show their connection with each original section or parish lot through which the railway passes;

(c) When the location of the railway is through land which has been surveyed into allotments and shown on any registered plan, the plan must show distinctly as to all allotments taken in whole or in part for the right of way or station grounds, or for any other purpose for the railway, the lines of such allotment according to such registered plan, and a sufficient number of angular and lineal measurements to show the location and connection of the right of way of such railway with cach such registered allotment; 
(d) The land taken or required shall be defined on the ground by durable posts placed on the southerly or westerly limit thereof, and such posts shall be placed at every change of direction of said limit at the intersection of said limit with the southerly or westerly limit of each Dominion Government road allowance, and the plan shall show the location of these posts. (1911) $1 \mathrm{Geo} . \mathrm{V}, \mathrm{c.} .49, \S 3$.

59. Any bylaw or plan for the opening up of any street, road or highway presented for registration to the district registrar under the provisions of The Municipal Act, shall be in duplicate, and shall be in accordance with the following provisions:

(a) The plan shall exhibit distinctly delineated the width and direction of each course of such street, road or highway and the astronomic bearing of some one or more of the courses shown of the street, road or highway;

(b) The manner by which the street, road or highway is defined on the ground by the surveyor shall be shown on the plan;

(c) The original section or parish lot lines according to the survey thereof by the Dominion Government shall be shown on the plan, and there shall also be shown a sufficient number of angular and lineal measurements to show the location and connection of such street, road or highway with each original section or lot affected by the street, road or highway:

Provided, however, that, when a connection with the said original survey lines has been sufficiently shown on any previously registered plan, this may not be required. 1 \& 2 Edw. VII, c. $43, \S 59$.

60. [Repealed (1908) 7 \& 8 Edw. VII, c. 52 , § 3.]

61. The district registrar may require the owner of any land within his district desiring to deal with the same, and which has or has not theretofore been subdivided, the location of which, in his opinion, is not sufficiently well or accurately defined upon any cxisting registered plan, to file a plan of the same, and so many counterparts as may be required with such information marked thereon as may enable an accurate description to be prepared of the land proposed to be dealt with, and if the owner neglect or refuse to comply with such requirements as aforesaid the district registrar may refuse to proeeed with any matter then pending before him in respect to such land. $1 \& 2$ Edw. VII, c. $43, \S 61$. 
62. The district registrar may require, as to any land within his district proposed to be dealt with, and which has or has not been theretofore subdivided, the location of which in his opinion is not sufficiently well or accurately defined upon any existing registered plan, that a plan of the same and so many counterparts as may be required shall be prepared with such information marked thereon as may enable an accurate description to be prepared of the land proposed to be dealt with; and the expense of any survey which the district registrar shall cause to be made under this section shall in the first instance be defrayed out of the consolidated revenue, but every person who may thereafter apply to be registered as owner or otherwise desires to deal with any land, the description of which can be more accurately drawn from the information shown on the plan of such survey, or which is in any way benefited by such survey, shall, in addition to any other moneys chargeable in such case, pay to the district registrar, to be by him paid into the consolidated revenue, such amount as the district registrar shall deem in his judgment to be an equitable share of such expense to be contributed in respect of such land. $1 \& 2$ Edw. VII, c. $43, \S 62$.

63. All plans other than plans prepared under the provisions of The Manitoba Expropriation Act, intended for filing or registration under this Act must be based on surveys performed with instruments independent of the magnetic needle and shall be certified as accurate by a provincial land surveyor under oath in the form in schedule M hereto, and shall be made in all respects satisfactory to the examiner of surveys. 1 \& 2 Edw. VII, c. $43, \& 63 ;(1908) 7 \& 8$ Edw. VII, c. $52, \S 4$.

64. None of the prorisions of the sections numbered from fifty-six to sixty-three, inclusive of both such numbers, of this Act shall be applicable to plans or surveys of land belonging to his Majesty in the right of Canada. $1 \& 2 \mathrm{Edw}$. VII, c. $43, \S 64$.

[Where a portion of any lot upon any plan of subdivision has been taken and vested in a municipality for a lane the remaining portion of the lot shall be held to be properly described in any instrument presented for registration by giving its number on the plan without specifically excepting therefrom the part of such lot so taken for a lane and such instrument shall be read as if the lane were specifically excepted. (1911) $1 \mathrm{Geo.}$ $V$, c. $49, \$ 9$. 


\section{REGISTRATION OF TITLE.}

65. Every certificate of title shall be deemell and taken to be issued under and for the purpose of this Act as soon as the same shall have been signed and sealed by the district registrar; and every instrument purporting to affect land under the new system shall be deemed to be registered as soon as a memorial there of indorsed thereon shall have been signed and sealed by the distriet registrar. $1 \& 2$ Edw. VII, c. $43, \S 65$.

66. Every certifieate of title shall issue in duplicate in the form in schedule $A$ to this Act, and each duplicate shall have the like force and effect of the other, and each shall be known as the certificate of title; but whenever the expression "duplicate certificate of title" is used such expression shall be held to refer exclusively to the duplicate which is not entered and bound in the register. $1 \& 2$ Edw. VII, c. $43, \$ 66$.

67. Whenever a district registrar is required to make any entry in the register, he shall make a like entry on the duplicate certificate of title unless production there of is dispensed with by him under the provisions of this Act. 1 d 2 Edw. VII, c. $43, \S 67$.

68. In the interpretation of this Act the date of a certifieate of title shall be the date appearing in the body thereof, or the date upon which the last mortgage, incumbrance or lease created under the hand of a registered owner of the land was registered, whichever shall be the later date. $1 \&$ 2 Edw. VII, c. $43, \S 68$.

69. Every certificate of title issued to an executor or administrator or trustee under a will, whether such certificate issued on the first bringing of the land under this Act or upon a transmission or otherwise, shall deseribe the owner as such executor, administrator or trustee, and the will shall be deemed to be embodied in and to form part of the certificate of title; and the executor, administrator or trustee shall, when so described, hold the land in respect of which he is registered upon the trusts and for the purposes to which the same is subject by law, and, before registering any dealing with the land, the district registrar shall satisfy himsolf that such dealing is in aceordance with such trusts or purposes. 1 if 2 Edw. VII, c. $43, \S 69$.

\section{EFFECT OF REGISTRATION OF TITLE.}

70. The land mentioned in any certificate of title granted under this Act shall, by implieation and without any special 
mention in the certificate of title, unless the contrary be expressly deelared, be deemed to be subject to-

(a) Any subsisting reservation contained in the original grant of the land from the Crown;

(b) Any municipal charge, rate or assessment at the date of such certificate, or which may be thereafter imposed on the land, or which has theretofore been imposed for local improvements and which is not then due and payable;

(c) Any unregistered subsisting right of way or other casement, howsoever ereated, upon, over or in respect of the lant;

(d) Any unregistered subsisting lease or agreement for a lease for a period not exceeding three years, where there is actual occupation of the land under the same;

(e) Any mechanics' lien affecting the land;

(f) Any order of attachment, judgment, decree or order for the payment of money against the registered owner of the land, which may have been respectively registered sinee the date of the certificate of title, and which order of attachment, judgment, decree or order has been maintained in force under the provisions of any statute of this province from time to time relating thereto [and to any certificate of lis pendens issued out of any court of competent jurisdiction in this province and duly registered since the date of the certificate of title. (1906) $5 \& 6$ Edw. VII, c. $75, \S 1]$.

(g) All public highways embraced in the description of the land included in any certificate shall be deemed to be excluded;

(h) Any right of expropriation by statute; Act;

(i) The provisions of the seventy-fourth section of this

(j) Caveats affecting the land registered since the date of the certificate of title. $1 \& 2$ Edw. VII, c. $43, \S 70$.

71. Every certificate of title hereafter or heretofore issued under this Act shall, so long as the same remains in force and uncancelled, be conclusive eridence at law and in equity as against his Majesty and all persons whomsoever that the person named in such certificate is entitled to the land described therein for the estate or interest therein specified, subject, however, to the right of any person to show that the land described in such certificate is subject to any of the exceptions or reservations mentioned in the seventieth or seventy-fourth sections of this Act, or to show fraud wherein 
the registered owner, mortgagee or ineumbrancer has participated or eolluded and as against such registered owner, mortgagee or ineumbrancee; but the onus of proving that sueh certificate is so subject, or of proving sueh fraud, shall be upon the person alleging the same. $1 \& 2$ Edw. VII, c. $43, \S 71$.

72. In case more than one certificate of title has been issued in respect of any particular estate or interest in any land, the person elaiming under the prior eertificate shall be entitled to such estate or interest in such land, and that person shall be deemed to hold under a prior certificate who is the holder of, or whose claim is derived direetly or indirectly from the person who was the holder of, the earliest eertificate issued. $1 \& 2 \mathrm{Edw}$. VII, c. $43, \S 72$.

73. The production in any eourt in this provinee of a document purporting to be a eertifieate of title, issued as aforesaid, shall be prima facie proof that such doeument is such certificate of title duly signed and sealed without proof of signature or seal, and that sueh eertificate is in force and uncancelled. $1 \& 2$ Edw. VII, c. $43, \S 73$.

74. Every eertifieate of title shall be void as against the title of any person adversely in aetual occupation of and rightly entitled to the land at the time when sueh land was brought under the new system, and who continues in such occupation. $1 \& 2 \mathrm{Edw}$. VII, c. $43, \S 74$.

75. After land has been brought under this Act no title thereto adverse or in derogation to the title of the registered owner shall be acquired by any length of possession merely. $1 \& 2$ Edw. VII, c. $43, \S 75$.

[In so far as any limitation is imposed by chapter 100 of the Revised Statutes of Manitoba, 1902, on the rights, remedies or powers under mortgages the same shall be held not to apply to mortgagees or incumbrancees in mortgages or ineumbranees heretofore or hereafter made under The Real Propcrly Act except as to liability under covenants for mayment of any moneys secured thereby. This seetion shall be retrouctive. (1908) $7 \& 8$ Edw. VII, e. $52, \$ 6$.

76. No aetion of ejeetment or other action for the recovery of any land under the new system shall lie or be sustained against the registered owner for the estate or interest in respect to whieh he is so registered, except in the following cases, that is to say:

(a) The case of a mortgagee or incumbrancee as against a mortgagor or incumbrancer in default, and in such case a 
mortmagee or incumbrancee shall be entitled to bring such action notwithstanding the provisions of the one hundredth section of this Act;

(b) The case of a lessor as against a lessee in default;

(c) The case of a person deprived of any land by fraud as igainst the person registered as owner through fraud, or as against a person deriving his right or title otherwise than bona fide for value from or through a person so registered through fraud;

(d) The case of a person deprived of any land included in any certificate of title of other land by misdescription of such land or its boundaries, as against the registered owner of such other land, not being a transferee of such other land or deriving from or through a transferce thereof bona fide for value;

(e) The case of a registered owner claiming under the instrument of title prior in date of registration under the provisions of this Act in any case in which two or more certificates of title may be issued under the provisions of this Act in respect to the same land;

$(f)$ For rights arising or partly arising after the date of the certificate of title under which the registered owner claims;

(g) For rights arising under any of the clauses of the seventieth section of this Act. $1 \& 2 \mathrm{Edw}$. VII, c. $43, \S 76$.

77. And in any case other than as aforesaid, the production of the certificate of title shall be held in any court to be an absolute bar and estoppel of any such action as in the last preceding section mentioned against the person named in such certificate of title as seized of, or as owner or lessee of, the land therein described, any rule of law or equity to the contrary notwithstanding. $1 \& 2 \mathrm{Edw}$. VII, c. $43, \S 77$.

\section{REGISTRATIONS.}

78. When land under the new system is intended to be transferred, the registered owner may execute a transfer in the form contained in schedule $B$ to this Act, which transfer shall contain an accurate statement of the estate, interest or easement intended to be transferred or created, and a memorandum of all leases, mortgages or incumbrances to which the same may be subject, and upon the registration of such transfer the duplicate certificate of title shall be delivered up for cancellation in whole or part. $1 \& 2 \mathrm{Edw}$. VII, c. $43, \S 78$. 
79. Any owner of land registered under this Act may make a valid transfer to himself jointly with any other person, and the registered owners may make a valid transfer to one of their number either solely or jointly with some other person, and an executor or administrator may make a valid transfer to himself individually. $1 \& 2$ Edw. VII, c. $43, \S 79$.

80. No words of limitation shall be necessary in any transfer of land in order to convey all or any title therein; but every transfer shall, when registered, operate as an absolute transfer of all such right and title as the transferor had therein at the time of its execution, unless a contrary intention be expressed in such transfer or instrument; but nothing herein contained shall preclude any transfer from operating by way of estoppel. $1 \& 2$ Edw. VII, c. $43, \S 80$.

81. Every instrument presented for registration under the new system shall be registered in the order of time in which the same is presented for that purpose; and instruments registered in respect of or affecting the same estate or interest shall, notwithstanding any express, implied or constructive notice, be entitled to priority according to the time of registration; and the district registrar, upon registration thereof, shall file the same, or a duplicate thereof, in his office; and so soon as registered every instrument shall, for the purpose of this Act, be dcemed and be taken to be embodied in the register as part and parcel thereof, and such instrument when so constructively embodied shall thereupon create, transfer, surrender or discharge, as the ease may be, the lien, estate or interest therein mentioned in the land mentioned in the said instrument. $1 \& 2$ Edw. VII, c. $43, \S 81$.

82. When the memorial of any instrument is entered in the register the district registrar shall record the like memorial on the duplicate certificate or other instrument evidencing title to the land, incumbrance or mortgage intended to be dealt with or in any way affected, unless the district registrar shall dispense with the production of the same; and he shall indorse on every instrument so registered a certificate of the day and minute at which the instrument was presented for registration, and shall authenticate each such certificate by signing his name and affixing his seal thereto; and such certificate shall be received in all courts of law as conclusive evidence that such instrument was duly registered at the time therein mentioned, without proof of the signature or seal of the district registrar. $1 \& 2$ Edw. VII, c. $43, \S 82$. 
83. The district registrar shall have power to reject any instrument appearing to be unfit for registration, and shall not register any instrument purporting to transfer or otherwise deal with or affect land under the new system except in the manner herein provided for registration under the new system, nor unless such instrument be in accordance with the provisions of this Act, as applicable to the new system; but any instrument substantially in conformity with the schedules of this Act, or an instrument of a like nature, shall be sufficient; and no instrument shall be effectual to pass any interest in land under the new system or to render such land liable as security for the payment of money as against any bona fide transferee of such land, until such instrument be registered in accordance with this Act:

Provided, however, that, where an instrument in accordance with the forms in use or sufficient to pass an estate or interest in land under the old system deals with land under the new system, the registrar general may, in his discretion in a proper case, direet the district registrar to register it under the new system, and, when so registered, it shall have the same effect as to the operative parts thereof as, and shall by implication be held to contain, all such covenants as are implied in an instrument of a like nature under the new system; and if it is a mortgage the mortgagee may, for the purpose of foreclosure or sale under the mortgage, elect to proceed either under the provisions of this Act, or as if the land were subject to the old system; but, in ease he proceeds under the provisions of this Aet and the mortgage covers other land not under the new system, he must before cloing so, bring all the land intended to be foreclosed or sold under the new system. $1 \& 2 \mathrm{Edw}$. VII, c. $43, \S 83$.

84. Except as in the last preceding section mentioned and except instruments affecting land without speeific description and mechanies' liens, no instrument shall be registered under the new system unless all the land affected by such instrument be under the operation of the new system and within the same land titles district. $1 \& 2$ Edw. VII, c. $43, \S 84$.

85. Certificates of judgment and attachment presented for registration shall be registered under both the new system and the old system. $1 \& 2 \mathrm{Edw}$. VII, c. $43, \S 85$.

86. Instruments executed by a registered owner and prescnted for registration under this Act shall be accompanied by affidavits as to execution, identity and age, and such other 
evidence as the district registrar may require. $1 \& 2 \mathrm{Edw}$. VII, c. $43, \S 86$.

87. When any instrument is presented for registration and a registered certificate of judgment appears to affect the land described in such instrument, but the applicant for registration claims that the certificate of judgment does not affect the land, or is not equitably entitled to priority over such instrument, notwithstanding the priority of registration of the certificate of judgment, the district registrar may take such evidence under oath or otherwise in the matter as to him may seem sufficient, and may thereupon decicle whether the certificate of judgment does or does not affect the land, or whether the certificate of judgment is or is not entitled to priority over such instrument, and may register the instrument according to such decision, provided that such decision of the district registrar shall be subject to appeal as in other caess. $1 \& 2 \mathrm{Edw}$. VII, c. $43, \S 87$.

88. Where land under this Act is subject to or has as appurtenant thereto or enjoyed therewith any rights, privileges or easements under a party wall agreement, whether the agreement was registered before or after the land was brought under this Act, such rights, privileges or easements and all covenants relating thereto shall be deemed to run with the land, and any instrument registered under this Act shall, without special mention thereof in such instrument, be deemed to be subject to or to carry with it all such rights, privileges, easements and covenants to the same cxtent as if such instruments were made subject to or contained an express assignment or acknowledgment of such party wall agreement and of all rights, privileges, easements and covenants thereunder. $1 \& 2$ Edw. VII, c. $43, \S 88$.

89. In every instrument transferring an estate or interest in land under the new system, subject to mortgage or incumbrance, there shall be implied, unless otherwise expressed, the following covenant by the transferee with the transferor, that is to say: that such transferee shall pay the interest, annuity or rent charge secured by such mortgage or incumbrance, after the rate and at the time specified in the instrument creating the same, and shall indemnify and keep harmless the transferor from and against the principal sum or other moneys secured by such instrument, and from and against all liability in respeet of any of the eovenants therein contained or under this Act implied, on the part of the transferor. $1 \& 2$ Edw. VII, c. $43, \S 89$. 
90. Every instrument signed by an owner or other person claiming through or under him, purporting to pass an estate or interest in land, or to ereate any mortgage or incumbrance, for the registration of which provision is made by this Act, shall, until registered, be deemed to confer upon the person intended to take under such instrument, or others claiming through or under him, a right or elaim to the registration of such mortgage, incumbrance, estate or interest. $1 \& 2$ Edw. VII, c. $43, s 90$.

91. Except in the case of fraud on the part of such person, no person contracting or dealing with, or taking or proposing to take an instrument from, a registered owner shall be required or in any mannel concerned to inquire into or ascertain the circumstances under, or the consideration for which sich owner or any previous owner is or was registered, or to see to the application of the purchase money or of any part thereof; nor shall any person be affected by notice, direct, implied or construetive, of any trust or unregistered interest any rule of law or equity to the contrary notwithstanding and the knowledge that any trust or unregistered interest is in existence shall not of itself be imputed as fraud. $1 \& 2 \mathrm{Edw}$. VII, c. $43, \S 91$.

92. Except as in the sixty-ninth section of this Act mentioned, and except in case of land held in trust for or to be used in connection with any ehurch, the district registrar shall not make any entry in the register containing any notice of trusts, whether expressed, implied or constructive; and, except as in said sixty-ninth seetion mentioned, the describing of an owner as a trustee, whether the beneficiary or object of the trust be mentioned or not, shall not impose upon the district registrar the duty of making inquiry as to the power of the owner in respect of the land, mortgage, incumbrance or charge or the money secured thereby, or otherwise, but (subject to the registration of any caveat) the land, mortgage, incumbrance or charge may be dealt with as if such description had not been inserted. 1 \& 2 Edw. VII, c. 43, § 92.

\section{LEASES.}

93. When land under the new system is intended to be leased or demised for a life or lives, or for any term of years, the owner may execute a lease in the form contained in schedule $\mathrm{C}$ to this Act, sctting forth therein all mortgages, incumbrances and liens to which the land is subject. which lease may be 
registered and a certificate of title for leasehold estate may issue to the lessee. R. S. M., c. $133, \S 90$.

94. In the memorandum of lease, unless a contrary intention appear therein, there shall be implied the following covenants by the lessee, that is to say:

(a) That he will pay the rent thereby reserved at the times therein mentioned, and all rates and taxes which may be payable in respect of the demised property during the continuance of the lease; and

(b) That he will at all times cluring the continuance of the said lease keep, and at the termination thereof yield up, the demised property in good and tenantable repair, accidents and damage to buildings from fire, lightning, storm and tempest, and reasonable wear and tear, excepted. 1 \& 2 Edw. VII, c. $43, \S 94$.

95. In any memorandum of lease, unless a contrary intention appears therein, there shall also be implied the following powers in the lessor, that is to say:

(a) That he may, by himself or his agents, enter upon the demised property and view the state of repair thereof, and may serve upon the lessee, or leave at his last or usual place of abode or upon the demised premises, a notice in writing of any defect, requiring him within a reasonable time, to be therein mentioned, to repair the same;

(b) That in case the rent or any part thereof be in arrear, or in case default shall be made in the fulfilment of any covenant, whether expressed or implied, in such lease on the part of the lessee, and such default shall be continued for the space of two calendar months, or in case the repairs required by such notice as aforesaid shall not have been completed within the time therein specified, such lessor may enter upon and take possession of such demised premises. $1 \& 2$ Edw. VII, e. $43, \S 95$.

96. In any such case the district registrar, upon proof to his satisfaction of lawful re-entry and recovery of po isession by a lessor, shall note the same lyy entry in the register and upon the lease, and the estate of the lessee in such land shall thereupon determine, but without releasing the lessee from his liability in respect of the breach of any covenant in sueh lease expressed or implied. 1 \& 2 Edw. VII, c. 43, \$96.

\section{MORTGAGES AND INCUMBIRANCES.}

97. During the time an application is pending to bring land under this Act any mortgage or incumbrance atfecting 
the land may be filed with the district registrar who may, upon the issue of the certificate of title, indorse thereon a memorandum of such mortgage or incumbrance, and, should more than one mortgage or incumbrance be filed, they shall be entitled to priority in the order in which they have been filed. $1 \& 2 \mathrm{Edw}$. TII, c. $43, \S 97$.

98. Any assignment or mortgage of any mortgage or incumbrance, to which land was subject when it was brought linder this Act, whether such ascignment or submortgage be made before or after the land was brought under this Act, may be made according to the forms in use under the old svitem, and may be registeled under the new system in the same manner as other instruments of a like nature under the new system. 1 \& 2 Edw. VII, c. $43, \S 98$.

99. Whenever any land, mortgage or incumbrance under the new system is intended to be charged or made security in favor of any mortgage, the owner shall execute a memorandum of mortgage in the form contained in schedule $D$ to this Act, or to the like effect; and, whenever such land is intended to be charged with or made security for the payment of an annuity, rent charge or sum of money in favor of any incumbrancee, the owner shall execute a memorandum of incumbrance in the form contained in schedule $\mathrm{E}$ to this Act or to the like effect; and every such instrument shall contain an accurate statement of all mortgages or incumbrances affecting the same. $1 \& 2 \mathrm{Edw}$. VII, c. $43, \S 99$.

100. A mortgage or an incumbrance under the new system shall have effect as security, but shall not operate as a transfer of lind thereby charged, or of any estate or interest therein. 1 \& 2 Edw. TII, c. 43 , $\$ 100$.

101. Nortgages or incumbrances may be transferred by a transfer exceuted in the form contained in schedule $\mathrm{F}$ to this Act, and registered in the same manner as instruments of a similar nature under this Act. A mortgagee may transfer a part of the sum secured by the mortgage, and the part so transferred shall continue to be secured by the mortgage and may be given priority over the remaining part or may be deferred or may continue to rank equally with it under the security of the original mortgage, as may be stated in the instrument of transfer; and the clistrict registrar shall enter on the certificate of title a memorial of the amount of the mortgage so transferred, and how the sum so transferred is to rank. 1 \& 2 Edw. VII, c. $43, \S 101$. 
102. Upon the registration of any transfer or mortgage, of a mortgage, incumbrance or lease, the mortgage or ineumbrance or the estate or interest of the transferor, as set forth in such instrument, with all rights, powers and privileges thereto belonging or appertaining, shall pass to the transferee, and such transferee shall thereupon become subject to and liable for all and every the same requirements and liabilities to which he would have been subject and liable if named in such instrument originally as mortgagee, incumbrancee or lessee of such land, estate or interest. 1 \& 2 Edw. VII, c. $43, \S 102$.

103. By virtue of every such transfer, or mortgage, of a mortgage, incumbrance or lease the right to sue thereupon and to recover any debt, sum of money, annuity or damage thereunder, notwithstanding the same may be deemed or held to constitute a chose in action, and all interest at the time of such transfer in any such debt, sum of money, annuity or damages shall be transferred so as to vest the same in law in the transferee thereof:

Provided always that nothing herein contained shall prevent the court from giving effect to any trusts affecting the said debt, sum of money, annuity or damages, in ease the said transferee shall hold the same as trustee for any other person. R. S. M., c. 133, § 104.

10a. Upon the production of any memorandum of discharge of mortgage or incumbrance, duly exeeuted, discharging the whole or part of such mortgage or ineumbrance or the whole or part of the land comprised in such mortgage or incumbrance from the moneys thereby seeured, the district registrar shall make an entry in the register, noting that sueh mortgage or ineumbrance is discharged wholly or partially or that part of the land is discharged as aforesaid, as the case may require; and; upon such entry being made, such mortgage or ineumbrance shall be released to the extent named in such memorandum of discharge. 1 \& $2 \mathrm{Edw}$. VII, c. $43, \S 104$.

105. Upon proof of the death of the annuitant, or of the occurrence of the event or circumstance upon which, in accordance with the provisions of any memorandum of incumbrance, the annuity or sum of money thereliy secured shall cease to be payable, and upon proof that all arrcars of the said annuity and interest or money have been paid, satisfied or discharged, the district registrar shall make an entry in the register and on the instrument creating such incumbrance, 
noting that such annuity or sum of money is satisfied and discharged; and, upon such entry being made, the land shall cease to be subject to or liable for such annuity or sum of money. 1 \& 2 Edw. VII, c. $43, \S 105$.

106. The mortgagee or incumbrancee upon default in the payment of the principal sum or interest or annuity or any part thereof respectively, at the time mentioned in the mortgage or incumbranee, may enter into possession of the mortgaged or incumbered land by receiving the rents and profits thereof, and may distruin upon the occupier or tenant of the land under the power to distrain hereinafter contained, or may bring action to recover the land either before or after entering into receipt of the rents and profits thereof or making any distress, and either before or after any sale of such land shall be effected under the power of sale aforesaid, in the same manner in which he or they might have brought such action if the money secured by the mortgage or incumbrance had been secured to him or them by an assurance of the legal estate in the land mortgaged or incumbered; and any mortgagee or incumbrancee shall be entitled to foreclose the right of the mortgagor or any person claiming under him to redeem the mortgaged or incumbered land in manner hereinafter provided. 1 \& 2 Edw. VII, e. $43, \$ 106$.

107. Besides his other: remedies, every first mortgagee or incumbrance for the time being shall be entitled, as often as it shall happen that the interest or annuity secured by the mortgage or incumbrance or any part thereof respectively shall be in arrear for twonty-one days and after seven days shall have elapsed from an application to the occupier or tenant for the payment there of, to enter upon the mortgaged or incumbered lind and distrain the goods and chattels of such oceupier or tenant for the arrears of the said interest or annuity, and the distress and distresses then and there found to dispose of in like manner as landlords may do in respect. of distresces for rent reserved upon common demises, and out of the sale moneys to retain the moneys which shall be so in arrear and all costs and expenses oceasioned by such distress and sale:

Provided that no oceupier or tenant shall be liable to pay to any such mortgagee or ineumbrancee a greater sum than the amount of rent which at the time of making such application for payment shall be due from any sueh occupier or tenant; and any amount so paid, as well as any amount which shall be paicl by him to any such mortgagee or 
incumbrancee during the time he may be in receipt of the rents and profits, shall be held to be pro tanto satisfaction of the rent. $1 \& 2 \mathrm{Edw}$. VII, c. $43, \S 107$.

108. In addition to and concurrently with the rights and powers conferred on a first mortgagee, every present and future first mortgagee for the time being of land under this Act, shall, until a discharge from the whole of the money secured or until a transfer upon a sale or order for foreclosure (as the ease may be) shall have been registered, have the same rights and remedies at law and in equity [including the right to sell or foreclose through any competent court-inserted 1906 , c. $75, \S 2$, repealed 1911 , c. $49, \S 7]$ as he would have had or been entitled to if the legal estate in the land or term mortgaged had been actually vested in him with a right in the owner of the land of quiet enjoyment of the mortgaged land until default in the payment of the principal and interest money secured or some part thereof respectively, or until a breach in the performance or observance of some covenant expressed in the mortgage or to be implied therein by the provisions of this Act. Nothing contained in this section shall affeet or prejudice the rights or liabilities of any such mortgagee after an order for foreclosure shall have been entered in the register or shall, until the entry of such an order, render a first mortgagee of land leased under this Act liable to or for the payment of the rent reserved by the lease or for the performance or observance of the covenants expressed or to be implied therein. 1 \& 2 Edw. VII, c. $43, \S 108$.

109. In case default be made in the payment of the principal sum, interest, annuity or rent charge, or any part thereof, secured by any mortgage or incumbrance registered under the new system, or in case default be made in the observance of any covenant expressed in any mortgage or incumbrance or that is herein declared to be implied in such instrument, and if such default be continued for the space of one calendar month or for such longer period of time as may therein for that purpose be expressly limited, the mortgagee or incumbrancro may forthwith, after giving written notice, a copy of which shall be filed in the land titles office, to the said mortgignor or ineumbrancer, his executors, administrators or assigns, and 'very other' person appearing at the time of filing such notice in the land titles office to have any mortgage, incumbrance, or lien upon, or estate, right or interest in or to the lands subsequent to such first named mortgage or incumbrance, of his intention in that bchalf, without any further consent or concurrence 
upon his or their part, enter into possession of the lands and receive and take the rents, issues and profits thereof, and, whether in or out of possession thereof, may make any lease of the same or of any part thereof as he may see fit, and may also in such notice require the mortgagor or incumbrancer and such other interested persons as aforesaid to pay within a time to be specified in such notice the money then due or owing on such mortgage or incumbrance, or to observe the covenants therein expressed or implied, as the case may be, and that all remedies competent will be resorted to unless such default be remedied. 1 \& 2 Edw. VII, c. 43, § 109.

110. After such default in payment or in the observance of any corenant continuing for the further space of one ealendar month from the clate of service of such notice, such mortgagee or incumbrancee is hereby authorized and empowered to sell the land so mortgaged or incumbered, or any part thereof, and all the estate or interest therein of the mortengor or incumbrancer and of the other interested persons referred to in the last preceding section, in such manner as the district registrar may direct, and either altogether or in lots, by public auction or by private contract, or by both such modes of sale, and subject to such conditions as the district registrar may think fit:

Provided that, in case the mortgage or incumbrance contains a provision that the sale may take place without any notice being served on any of the parties, the district registrar may order such sale to take place accordingly. $1 \& 2$ Edw. VII, c. $43, \S 110$.

111. Such mortgagee and incumbrancee may make and execute all such instruments as shall be necessary for the sale or enjoyment of the premises; and all of such sales, contracts, matters and things hereby authorized shall be as valid and effectual as if the mortgagor or incumbrancer and other persons as aforesaid had made, done or exccuted the same; and the receipt in writing of the mortgagee or incumbrancee shall be a suficient discharge to the purchaser of such land, estate or interest, or of any portion thereof, for so much of his purchase money as may thereby be expressed to be received: and no such purchaser shall be answerable for the loss, misapplication or nonapplication, or be obliged to see to the application, of the purchase money by him paid, nor shall he be obliged to inquire as to the fact of any clefault or notice having been made or given as aforesaid, or how the purchase money to arise from the sale of any such land, estate or interest shall 
be applied. Sueh purchase money shall be applied: first, in payment of the expenses oceasioned by such sale; seeondly, in payment of the moneys which may then be due or owing to the mortgagee or incumbraneee; thirdly, in payment of subsequent mortgages, ineumbranees or liens, if any, in the order of their priority; and, fourthly, the surplus, if any, shall be paid to the owner, mortgagor or incumbrancer, as the ease may be. $1 \& 2 \mathrm{Edw}$. VII, e. $43, \S 111$.

112. Upon the registration of any memorandum or instrument of transfer executed by a mortgagee or ineumbrancee for the purpose of such sale as aforesaid, or by a mortgagee selling under the power of sale in any mortgage which affected the land when the first certificate of title issued therefor, the estate or interest of the owner of the land mortgaged or incumbered shall pass to and vest in the purchaser, freed and discharged from all liability on account of such mortgage or ineumbrance and from any mortgage, lien, charge or incumbrance created by any instrument registered subsequent thereto, and the purchaser shall be entitled to receive a certificate of title for the same. $1 \& 2 \mathrm{Edw}$. VII, c. 43 , $\S 112$.

113. Whenever default has been made in payment of the principal or interest moneys secured by a mortgage or incumbrance registered under the new system, and such default shall be continued for six months after the time for payment mentioned in the mortgage or incumbrance, the mortgagee or incumbrancee or his transferee may make applieation in writing to the district registrar for an order of foreclosure; and such application shall state that such default has been made and has continued for the period aforesaid, and that the land mortgaged or incumbered has been offered for sale at publie auetion after a notice of sale served as hereinbefore provided, and that the amount of the highest bid at such sale was not sufficient to satisfy the moneys secured by such mortgage or incumbrance, together with the expenses occasioned by such sale, and that such notice or subsequent notice served upon the same persons declared the intention of the mortgagee or ineumbrancee to make an application for foreclosure in case such sale proved abortive; and such application shall be aceompanied by such proof of the matters stated by the applicant and by such other evidence as the distriet registrar may require; and the district registrar shall appoint a time, and require notice there of to be served on sueh peroons as aforesaid, within which redemption may take place, which 
time shall be not less than one month from the date of service of such last mentioned notice. (1911) 1 Geo. V, c. $49, \S 4$.

(a) Unless the district registrar shall see fit to otherwise order, the notice, whether of intention to sell or to apply for a foreclosure order or the notice appointing a time for redemption shall be served personally on such owner, mortgagor and incumbrancer and other persons interested as aforesaid; but, in ease he or they cannot, after due diligence, be found, the district registrar may direct service of such notice by being left on the mortgaged lands, or by the same being sent through the post office by a registered letter directed to him or them at his or their last known address, or in such other manner as the district registrar may direct. $1 \& 2 \mathrm{Edw}$. VII, c. $43, \S 113$; (1911) 1 Geo. V, с. 49, 4.

114. Upon such application the district registrar may, if he consider it proper, cause notice to be published once in each of three successive weeks in such newspaper or newspapers as the district registrar may direct and in two consecutive issues of the Manitoba Gazette offering such land for private sale and after the expiration of the time appointed under section 113, and after the time for sale mentioned in such advertisement, if there be such advertisement, the district registrar may issue to such applicant an order of foreclosure, mless in the interval a sufficient amount has been obtained by the sale of such land, or paicl by or on behalf of such owner, mortgagor or incumbrancer or other person as aforesaid, to satisfy the principal and interest and other moneys secured and all expenses oceasioned by such sale and proceedings; and every such order of foreclosure under the hand of the district registrar, when entered in the register, shall have the effect of vesting in the mortgagee or his transferee the land mentioned in such order, free from all right and equity of redemption on the part of the owner, mortgagor or incumbrancer, or of any person elaiming through or under him subsequently to the mortgage or incumbrance; and such mortgagee, incumbrancee or transferee shall, upon such entry being made, be deemed a transferee of the land, and become the owner thereof and be entitled to receive a certificate of title for the sams. 1 \& 2 Edw. VII, c. 43, $\S 114 ;(190 j) 4 \& 5 \mathrm{Edw}$. VII, e. 41, 2 ; (1911) 1 Geo. V, ค. $49, \$ 5$.

115. For the purpose of this Act the district registrar, examiner of titles or other officers of the land titles office, shall not have notice of, or be bound by, any proceedings taken by any mortgagee or incumbrancee under his mortgage, 
security or incumbrance for the purpose of foreclosing, selling or otherwise realizing upon his said security or incumbrance, unless such mortgagee or incumbrancee shall have filed a certificate of lis pendens or, in case of proceedings under power of sale, a notice of such proceedings in the land titles office for the district in which the land is situated or registered under the new system. 1 \& 2 Edw. VII, c. 43, $\S 115$.

116. If any mortgagor become entitled to pay off the mortgage money, and the mortgagee be absent from this province, and there is no person in this province authorized to receive the mortgage money and execute a discharge of the mortgage, after the date appointed for the redemption of any mortgage, it shall be lawful for the provincial treasurer to receive such mortgage money with all arrears of interest then due thereon in trust for the mortgagee or other person entitled thereto, and thereupon the interest upon such mortgage shall cease to run or accrue; and the district registrar shall, upon the presentation of the receipt of the said treasurer for the amount of the said mortgage money and interest, and upon proof being made to his satisfaction that such payment satisfies all moneys due and owing upon such mortgage cause an entry to be made in the register discharging such mortgage and such entry shall be a valid discharge of such mortgage and shall have the same force and effect as is hereinbefore given to a like entry when made upon the production of a discharge of mortgage. Such moneys so paid to the provineial treasurer shall be paid over by him to the person or persons entitled thereto, on application. $1 \& 2 \mathrm{Kdw}$. VII, e. $43, \S 116$.

117. In case default has occurred in making any payment due under any mortgage or in the observance of any covenant contained therein and, under the terms of the mortgage, by reason of such default, the whole principal and interest secured thereby shall have become due and payable, the mortgagor may, notwithstanding any provisions to the contrary, and at any time prior to sale or foreclosure under a mortgage, perform such covenant or pay such arrears as may be in default under the mortgage, logether with costs to be taxed by the district registrar, and he shall thoreupon be relieved from the conseguences of nompayment of :o much of the mortgage monxy as may not then have become payable by reac on of lapse of time. I \& 2 Edw. VII, c.43, \$117.

118. In every case where land is subject to a mortgace or incumbrance signed by an owner, the duplicate ecrtificate of 
title shall be deposited with the district registrar who shall retain the same on behalf of all persons interested in the land mentioned in such certificate. The district registrar shall, if desired, furnish to the owner of such mortgage or incumbrance a certificate of charge; and, before any dealing with or discharge of said mortgage or incumbrance is registered, rxcept in the case provided by the one hundred and sixteenth section of this Act, said certificate of charge shall be delivered $u p$ to the district registrar to be cancelled:

Provided, however, that the district registrar may dispense with such production upon satisfactory evidence being produced of the loss or destruction of any such certificate. $1 \&$ $2 \mathrm{Edw}$. VII, c. $43, \S 118$.

\section{TRANSMISSIONS.}

119. Whenever any land, mortgage or incumbrance under the new system becomes the subject of a transmission the person claiming to be entitled to such transmission shall, before the registration of any dealing therewith by him, make application in writing to the district registrar to be registered as owner thereof, and the district registrar may, pursuant to such application, transmit such land, mortgage or incumlorance to such person; and if he become registered as owner thercof as executor or administrator of a deceased person he shall thereupon, in case of mortgage or incumbrance, be invested with all the rights and powers which the deceased owner was possessed of, and the title of the executor or administrator to such land, mortgage or incumbrance shall relate back and take effect as from the date of the death of the deceased owner. $1 \& 2$ Edw. VII, c. 43, § 119.

120. Upon any assignment being made by the owner of any land, mortgage or incumbrance for the benefit of his creditors, the assignee or trustee of such owner may register such assignment and may at any time thereafter make an application to the district registrar to be registered as owner of any such land, mortgage or incumbrance, and the district registrar may, pursuant to such application, transmit any such land, mortgage or incumbrance to such assignee or trustee, who shall thereupon become the owner thereof and shall be invested with all the rights and powers which the assignor was possessed of, and his title shall relate back and take effect as from the date of the assignment; but the district registrar shall not in issuing a certificate of title to such assignee or in any entries he may make regarding any such transmission, 
refer to the fact that the new owner is such assignee or trustee, or that he holds any such land, mortgage or incimbrance for any other than his own absolute use, and for the purpose of any registered dealing therewith he shall be deemed to be the absolute owner thereof. 1 \& 2 Edw. VII, c. $43, \S 120$.

\section{JURISDICTION OF THE COURT.}

121. If any person be dissatisfied with any act, omission, refusal, decision, direction or order of the district registrar, such person may require the district registrar to set forth in writing under his hand the grounds of such act, omission, refusal, direction, decision or order, and such person may then appeal to a judge in chambers by petition, setting forth the particulars and grounds of his dissatisfaction; and thereupon all parties interested including the district registrar and the attorney general, shall be served with such petition, which petition shall state the time and place for the hearing thereof (and at such time and place all parties interested, whether served with, or parties to, the petition or not, may appear and be heard); and the judge, if he shall think proper to do so, may, without making any order in the premises, refer such appeal to the court en banc for decision; and the court or judge shall have jurisdiction to hear the said petition, and shall make such order in the premises as the circumstances of the case may require and as the court or judge may direct, and make such order as to the costs of the parties appearing upon such petition as it or he may see fit. $1 \& 2 \mathrm{Edw}$. VII, c. $43, \S 121$.

122. Upon the hearing of any matter arising under this Act, a judge or the court may summon any person to appear either to give evidence or to be made a party in the cause; and any person interested and the attorney general may appear and be heard before such judge or court, or before any court to which such cause or matter may be taken by way of appeal, and such judge or court may dispose of the matter, and award costs to any of the parties, in such manner as the said judge or court may think proper. $1 \& 2 \mathrm{Edw}$. VII, c. $43, \S 122$.

123. Any order made by such judge or court in any matter arising under this Act shall be subject to appeal or review in the same manner as any other order made by such judge or court; and all paries to the cause and the attorney general shall have the right to appeal. $1 \& 2$ Edw. VII, c. $43, \S 123$. 
124. In the conduct of actions and other proceedings provided for under this Act, there shall be the same rights of appeal, and the same rules and procedure of practice shall apply, as are in force or exist for the time being in respect of actions and other proceedings of a similar nature in the court in which such actions or proceedings may be tried or taken; and such court shall have power to make additional, or to alter, rules and regulations, and to make new, or to alter, forms of proceedings, and from time to time to repeal, alter or vary the then existing rules and regulations, and to make new rules and regulations and forms of proceedings for the practice and procedure of the court in regard to matters which may arise under the provisions of this Act. $1 \& 2$ Edw. VII, c. $43, \S 124$.

125. The court shall have the power to fix and regulate from time to time the fees payable upon all proceedings before the court; and, until the said court shall otherwise order, the fees payable shall be according to the fees payable in respect to proceedings of a similar nature in the court. $1 \& 2$ Edw. VII, c. $43, \S 125$.

126. Repealed (1911) 1 Geo. V, c. $49, \S 7$.

[Nothing contained in this Act shall take away or affect the jurisdiction of any competent court on the ground of fraud, or over contracts for the sale or other disposition of land or over equitable interests therein [ 1 \& 2 Edw. VII, c. $43, \S 126]$ or over mortgages, nor shall anything contained in this Act affect the right of the mortgagee to foreclose or sell through any competent court, which right, it is hereby declared may be excreised in such court. (1906) 5 \& 6 Edw. VII, c. 75, § 3.]

CATEATS AFTER IPPLICATION IS MADE TO BRING LAND UNDER THE NEW SYSTEM.

127. Any person claiming any estate or interest in land described in an application to bring the same under the new system may, at any time before the issue of a certificate of title thereof, file or cause to be filed on his behalf with the district registrar a caveat, in the form in schedule $G$ to this Act, forbidding the bringing of such land under the new system. 1 \& 2 Edw. VII, c. $43, \S 127$.

128. The district registrar, after the receipt of such caveat, shall not bring the land under the new system until such caveat shall have been disposed of. 1 \& 2 Edw. VII, c. 43, $\$ 128$. 
129. After the expiration of one month from the filing thereof, such caveat shall be decmed to have lapsed, unless the person by whom or on whose behalf the same was lodged shall within that time have filed with the district registrar evidence that he has taken proceedings in court to establish his title to the land or his right as set out in such eaveat. $1 \& 2$ Edw. VII, c. $43, \S 129$.

CAVEATS AFTER LAND IS BROUGHT UNDER THE NEW SYSTEM.

130. Any person claiming an estate or interest in land, mortgage or incumbrance under the new system, may file or cause to be filed on his behalf with the district registrar a caveat in the form in schedule $\mathrm{H}$ to this Act, forbidding the registration of any person as transferee or owner of, or of any instrument affecting such estate or interest, or unless such instrument be expressed to be subject to the claim of the caveator. 1 \& 2 Edw. VII, e. $43, \S 130$.

131. Except in the case of a caveat lodged by the district registrar, every caveat lodged against any land, mortgage or incumbrance under the new system shall be deemed to have lapsed upon the expiration of fourteen days after notice given to the caveator to take proceedings in court on his caveat, unless before the expiration of the said period of fourteen days the caveator appears before the court or a judge, or judge in chambers, and gives such undertaking or security or lodges such sum in court as such court or judge may consider sufficient to indemnify every person against any damage that may be sustained by reason of any disposition of the property being delayed, or gives such security or lodges such sum in court as such court or judge may consider sufficient to answer the costs of the caveatee in such proceedings as may be taken under such caveat; but then and in such ease such court or judge may by order direet the district registrar to delay registering any dealing with the land, mortgage or incumbrance for a further period to be specified in such order, or may direct the eaveator to proceed upon his eaveat or may make such other order as may be just. 1 \& 2 Edw. VII, c. $43, \S 131$.

132. So long as any caveat prohibiting the transfer or other dealing with any land, mortgage or ineumbrance remains in force, the district registrar shall not register any instrument purporting to transfer, mortgage or incumber the land, mortgage or incumbrancer in respect to which such 
caveat is lodged, unless such instrument be expressed to be subject to the claim of the caveator. $1 \& 2$ Edw. VII, c. $43, \S 132$.

\section{CAVEATS GENERALLY.}

133. Every caveat filed with the district registrar shall state the name and addition of the person by whom or on whose bchalf the same is filed, and, except in the case of a caveat filed by the district registrar, shall be signed by the caveator, his attorney or agent, and shall state some address or place within the Province of Manitoba at which notices and proceedings relating to such caveat or the subject matter thereof may be served and the nature and particulars of the title, estate, interest or lien under which the claim is made, and shall be supported by an affidavit or statutory declaration stating that in the belief of the deponent the person by whom or on whose behalf the eaveat is filed has a good and valid claim upon the land, mortgage or incumbrance intended to be affected by the same, and that the eaveat is not filed for the purpose of delaying or embarrassing the applicant or owner or any person claiming through him, which affidavit or declaration may be in the form in schcdule $\mathrm{K}$ hereto. $1 \& 2 \mathrm{Edw}$. VII, c. $43, \S 133$; (1908) $7 \& 8$ Edw. VII, c. $52, \S 5$.

The district registrar shall not file any caveat which does not fully meet all the requirements of this section. (1908) $7 \& 8$ Edw. VII, c. $52, \S 5$.

134. The caveator may, by notice in writing to the district registrar, withdraw his caveat at any time; but such withdrawal shall not prejudice the power of the court or a judge to make an order as to payment by the caveator of the costs and damages of the caveatee incurred prior to the receipt by the caveatee of notice in writing of the withdrawal of such caveat. $1 \& 2 \mathrm{Edw}$. VII, c. $43, \S 134$.

135. Any person, other than the district registrar, filing or continuing any caveat wrongfully and without reasonable cause shall be liable to make compensation to any person who may have sustained damage thereby; and such compensation may be recovered by action if the caveator have withdrawn such caveat and no proceedings shall have been taken by the careatec as herein provided, but, if proceedings have been taken by the caveatee, then such compensation shall be decicled by the court or judge before whom proceedings have been taken. 1 \& 2 Edw. VII, c. $43, \S 135$.

136. Every caveat, except a caveat filed by the district registrar, shall be deemed to have lapsed after the expiration 
of the time limited by the preceding sections of this Act as to caveats, so far as applicable respectively, unless the person by whom or on whose behalf the same was lodged shall within that time have filed with the district registrar evidence, to his satisfaction, of proceedings having been taken under his caveat as prescribed by this Act. $1 \& 2$ Edw. VII, c. $43, \S 136$.

137. Notwithstanding anything in this Act contained a caveator may take proceedings under his eaveat at any time after the expiration of the time limited by the preceding sections for so doing, provided he shall do so and furnish evidence there of to the district registrar before he, shall have disposed of the caveat as lapsed. $1 \& 2 \mathrm{Edw}$. VII, c. $43, \S 137$.

138. In the case of any caveat filed, except a careat filed by the district registrar, the applicant or owner may, at any time before the caveator has taken proceedings thereunder, apply to the court or a judge, or a judge in chambers, on motion calling upon the caveator to show cause why such caveat should not be discharged; and upon the hearing of such motion the said court or judge may make such order in the premises, and as to costs, as to such court or judge may seem just. $1 \& 2$ Edw. VII, c. $43, \S 138$.

139. In every case in which a caveat has been disposed of, the district registrar may at once proceed as if no caveat had been filed, unless in the meantime he shall have been served with an order of the court or of a judge staying such proceedings. $1 \& 2 \mathrm{Edw}$. VII, c. $43, \S 139$.

140. After a caveat shall have lapsed or been withdrawn or discharged, it shall not be lawful, except as herein mentioned, for the same person or for anyone on his behalf to lodge a further caveat or file a certifieate of lis pendens in respect of any proceeding in court in relation to the same. matter; but nothing herein contained shall prejuclice the right of the district registrar to enter any careat under the powers vested in him by this Act; and a juctge may, if he thinks proper, upon application made to him for that purpose and upon such terms as to costs or otherwise as he maty consider just, order that a new caveat be filed; and such order shall fix a time within which the caveator must procesed upon such caveat. $1 \& 2 \mathrm{Edw}$. VII, c. $43, \S 140$.

141. In the case of a caveat filed by the district registrar, the applicant or owner may apply to the court or a judge, on notice of motion to be served upon the person on whose behalf such caveat has been filed, for an order that such caveat 
should be withdrawn or discharged; and, in case the person on whose behalf such caveat has been filed is an infant, lunatic, or person of unsound mind, without guardian or committee, the said court or judge may by an ex parte order direct that such notice of motion be served on the official guardian of the court or some other person to be named therein, and may impose upon the applicant such terms as to the costs of such guardian or other person appointed by such order as may seem just; and upon such motion such court or judge may make such order in the premises, either as to dismissing such motion, discharging or withdrawing such caveat or directing any of the parties to commence proceedings, as to the said court or judge may seem just and proper. $1 \& 2 \mathrm{Edw}$. VII, c. $43, \S 141$.

142. At any time before the expiration of the time limited for proceeding upon a caveat, upon application on behalf of the caveator after notice to the caveatee, the court or a judge thereof, for sufficient cause shown and subject to such conditions as may seem proper, may extend the time for proceeding under such caveat for a further period to be specified in the order made upon such application, which order shall forthwith be filed in the land titles office. $1 \& 2$ Edw. VII, c. $43, \S 142$.

143. Registration by way of caveat, whether by the district registrar or by any caveator, shall have the same effect as to priority as the registration of any instrument under this Act; and the district registrar may in his discretion allow the withdrawal of such caveat at any time and the registration, in lieu thereof, of the instrument under which the person on whose behalf such caveat was lodged claims his title or interest, provided such instrument is an instrument that may be registered under this Act; and, if the withdrawal of such caveat and the registration of such instrument be simultaneous, the same priority shall be preserved to all rights under the instrument as the same rights were entitled to under the caveat. 1 \& 2 Edw. VII, c. $43, \S 143$.

144. A caveator may take proceedings prescribed under schedule $\mathrm{L}$ hereto or such other proceedings in court as he may desire to establish his claim under his caveat. 1 \& 2 Edw. VII, c. $43, \S 144$.

145. Any person claiming any estate or interest in land, mortgage or incumbrance subject to or under the new system may, in lien of or after filing a caveat, proceed by way of statement of claim, and may file with the district registrar 
a certificate of lis pendens or other proper evidence of such proceedings. $1 \& 2 \mathrm{Edw}$. VII, c. $43, \S 145$.

\section{ASSURANCE FUND.}

146. Any person sustaining loss or damage through any omission, mistake or misfeasance of the district registrar in the execution of his duties under this Act, and any person deprived of any land, mortgage or ineumbrance or of any estate or interest therein through the bringing of the same under the new system or by the registration of any other person as owner of such land, mortgage or incumbrance, or by any error, omission or misdeseription in any certificate of title, and who by the provisions of this Act is barred or in any way precluded from bringing an action for the recovery of such land, mortgage or ineumbrance or interest therein, may bring an action against the district registrar of the district in which the land is situate for the recovery of damages. If such action be for the recovery of loss or damage arising only through an omission, mistake or misfeasance of the district registrar in the performance of his duties under this Act then such distriet registrar shall be the sole defendant in such aetion; but, if such action be brought for loss or damage arising only from the fraud or wrongful act of some person other than the district registrar, or arising jointly through the fraud or wrongful act of such other person and the omission, mistake or misfeasance of the district registrar, then such action shall be brought against both the district registrar and such other person. In all such actions where there is a defendant other than the district registrar, and damages shall have been recovered and the court shall find that some defendant or defendants other than the district registrar is liable for the loss so sustained or ought to pay the same, final judgment shall not be entered against the district registrar until a judge of the court in which such aetion was brought shall have made an order deelaring that such judgment is not and cannot be satisfied in whole or in part out of the goods or lands of such other defendant or defendants so found liable as aforesaid, and that the amount of such judgment in whole or as to such part thereof as remains unsatisfied, together with costs, should be a judgment against the district registrar defendant, and judgment may thereupon be entered against the district registrar; and upon payment of the amount of such judgment the provineial treasurer shall be entitled to an assignment thereof as against any other such defendant or defendants so liable as aforesaid. The expression "distriet 
registrar" where it occurs in the second, fifteenth, sixteenth, twentieth and twenty-second lines of this section shall include the district registrar and any deputy official or clerk in his office. 1 \& 2 Edw. VII, c. $43, \S 146$.

147. No action shall be brought against a district registrar under the last preceding section unless notice of such action and of the cause therc of shall be served upon such district registrar and the attorney general at least one calendar month before the commencement of such action. 1 \& 2 Edw. VII, e. $43, \S 147$.

148. The provincial treasurer shall pay the amount of any judgment recovered against a district registrar out of the assurance fund provided for by this Act, and, if there shall not be sufficient funds at the credit of the assurance fund to satisfy the judgment, then the amount thereof shall be satisfied out of the public funds of the province. $1 \&$ 2 Edw. VII, c. $43, \S 148$.

149. All actions against a district registrar shall be brought against him by name of office, and shall not abate or be in any way affected by any racancy occurring in the said office or by change of officer. $1 \& 2$ Edw. III, c. $43, \S 149$.

150. No action for recovery of damages under this Act shall lie or be sustained against a district registrar, or against the person by whose fraud, error, omission, misrepresentation, misdescription or wrongful act the person entitled to the land or some estate or interest therein has been deprived thercof, unless such action be commenced within the period of ten years from the date of such deprivation:

Provided, nevertheless, that any person being at the time of such deprivation under the disability of infancy or unsoundness of mind shall bring such action within five years from the date on which such disability shall have ceased, or within ten years from the date of such deprivation, whichever shall be the later date. 1 \& 2 Edw. VII, c. $43, \S 150$.

151. A district registrar shall not under any circumstances be liable for compensation for any loss, damage or deprivation occasioned by the breach by a registered owner of any trust, whether express, implied or constructive. 1 \& 2 Edw. VII, г. $43, \S 151$.

152. In any case where it appears that a district registrar is clearly liable for any loss or damage to any person under any of the provisions of this Aet, and where it appears that 
the claim for loss or damage is a fair and reasonable one, the provincial treasurer may, without an action being first brought, pay the amount of any such claim:

Provided that no such claim shall be paid, unless and until the provincial treasurer shall be authorized to do so by the reports, advising such payment, of the attorney general, the registrar general and the distriet registrar of the district in which the land which is the subject of such claim lies or is registered under the new system. $1 \& 2 \mathrm{Edw}$. VII, c. 43, $\S 152$.

153. It shall in all cases be a bar to the bringing of any action against a district registrar that the plaintiff in such action or the person through or under whom he elaims was served under the provisions of this Act with notice or, not being served with notice, had knowledge that the district registrar was about to bring the land in respect of which the action is brought under this Act, or was about to commit the act through which the plaintiff claims to have been damnified. $1 \& 2$ Edw. VII, c. $43, \S 153$.

154. Upon the first bringing of land under the new sys-. tem there shall be paid one-tenth of one per cent. in case of an original grantee where no transaction or instrument affecting the land has been registered exeept mortgages or leases, but in other cases one-quarter of one per cent. of the value thereof. $1 \& 2 \mathrm{Edw}$. VII, c. $43, \$ 154$.

155. All sums of money received as in the last preceding - section mentioned shall be paid to the provincial treasurer.

(a) The said fund shall be held by the provineial treasurer as trust moneys and may be invested from time to time in such securities as other trust funds of the province may be invested in, or may be utilized by discretion of the Lieutenant Governor in Council for the erection of buildings to be used as land titles offices.

(b) The provincial treasurer shall credit the fund in each year with interest at such rate as may from time to time be directed by the Lieutenant Governor in Comncil.

(c) When the said fund shall have reached the sum of seventy-five thousand dollar's any sums in exeess of said amount may by direction of the Lieutenant Covernor in Council from time to time be transferred to and form part of the consolidated revenue fund of the provinee. 1 \& 2 Edw. VII, c. $43, \S 155$. 


\section{GENERAL PROVISIONS.}

156. No petition, order, affidavit, certificate, registration or other proceeding under this Act shall be invalid by reason of any informality or technical irregularity therein or of any mistake not affecting the substantial justice of the proceeding. $1 \& 2 \mathrm{Edw}$. VII, c. $43, \S 156$.

157. Every covenant and power declared to be implied in any instrument by virtue of this Act may be negatived or modified by express declaration in the instrument or indorsed thereon; and, in any action for a supposed breach of any such covenant, the covenant alleged to be broken may be set forth, and it shall be lawful to allege that the party against whom such action is brought did so covenant, precisely in the same manner, as if such covenant had been expressed in words in such memorandum of transfer or other instrument, any law or practice to the contrary notwithstanding; and every such implied covenant shall have the same force and effect and be enforced in the same manner as if it had been set out at length in such instrument; and, where any memorandum of transfer or other instrument in accordance with the provisions of this Act is executed by more parties than one, such covenants as are by this Act to be implied in instruments of a like nature shall be construed to be several and not to bind the parties jointly. 1 \& 2 Edw. VII, c. 43, $\$ 157$.

158. Any person may under power of attorney authorize any other person to act for him in respect of the transfer or other dealing with any land, mortgage or incumbrance. No power of attorney shall be deemed revoked by act of the party or by death until a revocation thereof shall have been registered with, or notice of death given or become known to, the district registrar with whom the power of attorney or any certified copy thereof is registered. $1 \& 2$ Edw. VII, c. 43, $\S 158$.

159. The owner of any land or any lease, mortgage or incumbrance shall, on the application of any beneficiary or person interested therein, be bound to allow his name to be used by such beneficiary or person in any action, suit or proceeding which may be necessary or proper to bring or institute in the name of such owner concerning such land, lease, mortgage or incumbrance, or for the protection or benefit of the title vested in such owner or of the interest of any such beneficiary or other person; but, nevertheless, such owner 
shall in any case be entitled to be indemnified in like manner as if, being a trustce, he would before the coming into force of this Act, have been entitled to be indemnified in a similar case of his name being used in any such action, suit or proceeding by his cestui que trust. 1 \& 2 Edw. VII, c. $43, \S 159$.

160. In any action, suit or other proceeding affecting any land, mortgage or incumbrance under the new system, or any estate or interest therein, any person who is a party to such action, suit or other proceeding may give in evidence any transfer, mortgage, incumbrance, lease or other instrument affecting the title to such land, estate or interest in dispute, although the same may not be referred to in the certificate of title, or may have been eancelled by the district registrar. $1 \& 2$ Edw. VII, c. $43, \S 16$ ).

161. Every copy of a certificate of title issued under this Act, and every copy of any instrument deposited, filed, kept or registered in any land titles office, together with all memoranda and indorsements thereon, certified as such under the hand and seal of office of the district registrar, shall be received as evidence in any court in this province in the same manner and with the same effect as if the original within such office was produced without proof of the signature or seal of office of the district registrar; and every such eopy shall be admissible in evidence in any court in this province as prima facie proof of the due execution of the original by all persons by whom the instrument purports to have been exeeuted, and whose execution has been verified by an affidavit of execution, indorsed upon or annexed to such original instrument, and of which affidavit a similarly certified copy showing it to have been so indorsed or annexed is produced. $1 \& 2 \mathrm{Edw}$. VII, c. $43, \S 161$.

162. Proceedings under this Act shall not abate or be suspended by death or transmission or ehange of interest; but, in any such event, the district registrar may, upon the application of any person interested, make such order for carrying on, discontinuing or suspending the procecdings as under the circumstances may be just, and may for that purpose issue a certificate of title to a deeeased person. $1 \& 2$ Edw. VII, e. $43, \S 162$.

163. In case any person shall die aftor the execution of any instrument affeeting land, and before registration thereof, the registration of such instrument may nevertheless be proceeded with in accordance with this Act and shall be valid notwithstanding such death. 1 \& 2 Edw. VII, c. 43, \$163. 
164. In case any person who, if not under disability, might have made any application, given any consent, or done any act, or beel a party to any proceeding under this Act, is a minor or a person of unsound mind, the guardian of the minor or committee of the estate of such person of unsound mind may make such application, give such consent, do such act, and be a party to such proceedings as such person might, if free from disability, have made, given, done or been party to, and shall otherwise represent such person for the purposes of this Act. If the minor have no guardian, or the person of unsound mind no committee of his estate, or persons yet unborn are interested, the official guardian ad litem, or such other person as may be appointed for that purpose by the district registrar, may act with like power for such minor, person of unsound mind or person yet unborn, and any notices or proceedings which may be required by the district registrar to be served on a person under any such disability may be served on the guardian or person so appointed by the district registrar for such person under disability; and such service shall be considered as good service and as effectual and binding upon such person under disability as if personally effected upon him while under no disability. 1 \& 2 Edw. VII, c. 43, $\$ 164$.

\section{PENALTIES.}

165. If any person wilfully make any false statement or declaration in any dealing in land under this Act, or suppress or conceal, to assist or join in, or be priry to the suppressing, withholding or concealing from the district registrar of any material document, fact or matter of information, or wilfully make any false declaration required under the authority or made in pursuance of this Act, or if any person fraudulently procure or be privy to the fraudulent procurement of any certificate of title or instrument or of any entry in the register, or of any erasure or alteration of any entry in the register, or if upon requisition made by the district registrar any person refuse or wilfully neglect to produce any instrument or to allow the same to be inspected, or refuse or wilfully neglect to give any information or explanation which he is by this Act required to gire, or knowingly mislead or deceive any pers on hereinbefore authorized to require explanation or information in respect to any land, or the title to any land, in respect to which any dealing or transmission is proposed to be registered, or be a party to, or privy to any fraudulent act whatever in any matter connected with the working of this Act, such perion shall for each such offence be liable to a 
penalty of not less than fifty dollars, nor more than five hundred dollars, and in default of payment, to imprisonment for not less than one month, nor more than six months. $1 \& 2 \mathrm{Edw}$. VII, c. $43, \S 165$.

166. All prosecutions for penalties under this Act may be brought before a police magistrate, or any two justices of the peace, and all penalties when collected shall be paid over to the provincial treasurer. $1 \& 2 \mathrm{Edw} . \mathrm{V} 1 \mathrm{I}, \mathrm{c} .43, \S 166$.

\section{SCHEDULES.}

The following are the schedules referred to in this Act:

Schedule A.-(Section 66.)

CERTIFICATE OF TITLE.

A. B., of is now seized of an estate (state nature of estate), subject to such incumbrances, liens and interests as are notified by memorandum underwritten (or indorsed hereon), in that piece or parcel of land known or described as follows:

In witness whereof I have hereunto signed my name and affixed my seal this

Signed in the presence of day of

\section{District Registrar for}

$1 \& 2$ Edw. VII, с. 43, Sch. A.

\section{Schedule B.-(Section 78.)}

MEMIORANDUMI OF TRANSFER.

I, A. B., of , being registered orwner of an estate (state the nature of estate), subject, however, to such incumbrances, liens and interests as are notified by memorandum underwritten (or indorsed hereon), in all that land described as follows:

do hereby, in consideration of the sum of $\$$, paid to me by E. F., of , the receipt of which sum I hereby acknowledge, transfer to the said E. F. all my estate and interest in the said piece of land. (When a less estate, then describe such less estate.)

In witness whercof I have hereunto signed my name this day of

Signed in presence of

1 \& 2 Edw. VII, e. 43, Sch. B. 


\section{Schedule C.-(Section 93.)}

MEMORANDUM OF LEASE.

I, A. B., of , being registered as owner, subject however, to such incumbrances, liens and interests as are notified by memorandum underwritten (or indorsed hereon), of that land described as follows:

do hereby lease to E. F., of , all the said land, to be held by him, the said E. F., as tenant for the space of years from (here state the date and term) at the yearly rental of dollars, payable (here insert terms of payment of rent), subject to the covenants and powers implied (also set forth any special covenants or modifications of implied covenants).

In witness whereof I have hereunto signed my name this day of

Signed in presence of

$1 \& 2$ Edw. VII, c. 43 , Sch. C.

Schedule D.-(Section 99.)

MEMORANDUM OF MORTGAGE.

I, A. B., of being registered as owner of (here state nature of estate or describe mortgage as case may require), subject, however, to such incumbrances, liens and interests as are notified by memorandum underwritten (or indorsed hereon), in that piece of land described as follows:

in consideration of the sum of dollars lent to me by E. F., of , the receipt of which sum I do hereby acknowledge, covenant with the said E. F.:

First. That I will pay to him, the said E. F., the above sum of dollars on the day of

Second. That I will pay interest on the said sum at the rate of on the dollar in the year by equal payments on the year. day of , and on the day of, in every

Third. (Here set forth special corenants, if any.)

And, for the better securing to the said E. F. the repayment in manner aforesaid of the principal sum and interest, I hereby mortgage to the said E. F. my estate and interest in the land above described (or the said mortgage).

In witness whereof I have hereunto signed my name this day of

Signed by the above-named

A. B. in presence of

1 \& 2 Edw. VII c. 43, Sch. D. 


\section{Schedule E.-(Section 99.) \\ MEMORANDUM OF INCUMBRANCE.}

I, A. B., of , being registered as owner of an estate (state nature of estate), subject, however, to such incumbrances, liens and interests as are notified by memorandum underwritten (or indorsed hereon), in that land described as follows:

and desiring to render the said land available for the purpose of securing to and for the benefit of C. D., of the (sum of money, annuity or rent charge) hereinafter mentioned, do hereby incumber the said land for the benefit of the said C. D. with the (sum, annuity or rent charge) of dollars, to be raised and paid at the times and in the manner following, that is to say:

In witness whereof I have hereunto signed my name this day of

Signed in presence of

1 \& 2 Edw. VII, c. 43 , Sch. E.

\section{Schedule F.-(Section 101.)}

TRANSFER OF LEASE, MORTGAGE OR INCUMBRANCE.

I, A. B., of , being registered owner of a numbered , affecting the following land , subject to such incumbrances, liens and interests as are herein referred to, in consideration of the sum of paid to me by C. D., of , do hereby transfer to the said C. D., the said (lease, mortgage or incumbrance), together with all my rights, powers, title and interest therein.

In witness whereof I have hereunto signed my name this day of

Signed in the presence of

(1911) 1 Geo. V, c. $49, \S 8$.

Schedule $\overline{\text { G.-(Section 12\%.) }}$

CAVEAT FORBIDDING THE LAND TO BE BROUGHT UNDER THE NHW SYSTEM.

To the District Registrar for

Take notice that I (insert name and addition) claim (particularize the estate or interest elaimed) in the land described as in the application of ; and I forbid the bringing of such land under The Real Property Act. I appoint as the place at which notices and proceedings relating hereto may be served.

Dated this day of , 19. 1 \& 2 Edw. VII, c. 43, Sch. G. 


\section{Schedtle H.-(Scction 130.)}

\section{CATEAT FORBIDDING REGISTRATION.}

To the Distr" et Registrar 'or

Take notice that I (insert name and addition) c aim (specify the estate or interest claimed) in (describe land), standing in the register in the name of ; and I forbid the registration of any person or transferee or owner of, or of any instrument affecting the said estate or interest, unless such instrument be expressed to be subject to my elaim. I appoint as the place at which notices and proceedings relating hereto may be served.

Dated this

day of 19 $1 \& 2$ Edw. VII, c. 43, Sch. H.

\section{SCHEdule K.-(Section 133.) AFFIDAVIT IN SUPPORT OF CAVEAT.}

I, A. B., make oath and say (or solemnly declare) as follows:

(1) I am the within named eaveator.

(2) I believe that I have a good and valid elaim upon the said land (mortgage or incumbranee), and I say that this caveat is not being fied for the purpose of delaying or embarrassing any person interested in or proposing to deal therewith.

Sworn before me, etc.

$1 \& 2$ Edw. VII, c. 43, Sch. K.

\section{Schedule L.-(Section 1' ' $^{\prime}$.)}

RULES AND REGLLATIONS FOR PROCEDURE IN THE MATTER OF CATEATS.

1. The eaveator, for the purpose of establishing his claim, may take proceedings by way of petition to the court. Such petition shall be filed with the prothonotary, and shall contain, as conciscly as may be, a statement of the material facts on which the eaveator relies. Such statement shall be divided into paragraphs, numbered consecutively, each paragraph containing as nearly as may be a separate and distinct allegation, and shall state specifically what estate, interest or eharge the caveator claims, and the court or a judge thereof shall, upon the filing of such petition, appoint a time for hearing the same. Such hearing may take place before the court or a judge thereof, or the district registrar, or such other person or persons as the 
said court or a judge may direct; and such hearing may be had partly before one person and partly before one or more persons, as the nature and eireumstances of the case may require and as to such court or judge may seem meet.

2. The eaveator shall eause a copy of such petition to be filed with the distriet registrar; and a copy with notice of the time appointed for hearing shall be served on the caveatee six days at least before the time appointed for the hearing of the said petition.

3. On the day of hearing the eaveatee is personally or by counsel to show eause, and if necessary by affidavit, why the prayer of sueh petition should not be granted.

4. If the caveatee shall not appear on the day appointed for the hearing the court may, upon due proof of the service of sueh petition, make such order in the absence of the caveatce, either for the establishment of the right of the eaveator or as the nature and cireumstanees of the case may recquire, as to the court may seem meet.

5. Upon the hearing of the petition and upon reading the affidavits, if any, filed in support there of and any documents produced to the eourt and hearing what may be alleged on behalf of the caveatee or caveator, the court may, if it shall think fit, dismiss the petition or may make an order establishing the right of the caveator or directing any inquiries to be made or other proceedings taken for the purpose of ascertaining the rights of the parties, and for that purpose may adjourn the hearing and order the petition to be served on any other person or persons the eourt may eonsider necescary; and every person so served shall attend at the adjouned hearing of the petition and be subject to such further order as the court may cause to be made.

6. The court may, if it shall think fit, direct any question of fact brought before it to be decided before a judge thereof, or before a judge and a jury, and for that purpose may direct an issue to be tried wherein the caveator shall be plaintiff and the caveatee defendant, but upon proper eause shown a judge may direet that the issue be tried with the caveatee as plaintiff and eaveator as defendant; and the suid court shall direct when and where the trial of such issue shall take place. And the court may also direct all parties to produce all deeds, books papors and writings in their or in cither of their custody or power on oath before the district registrar or prothonotary, or such other offecers of the court as the court may direct, on a day to be named, and each party shall have liberty to inspect the same and take copies thereof at his own (xpense, and such of them as 
either party shall give notice to be produced at the trial shall be produced accordingly. And the issue may be in the form following:

In the King's Bench.

Manitoba,

The day of

To wit: in the year of our Lord

Whereas A. B. affirms and C. D. denies (here state the questions of fact to be tried), and it has been ordered by the chief justice (or other judge, as the case may be) that the said questions shall be tried by a judge (or a judge and jury as the case may be);

Therefore let the same be tried accordingly.

And in case the parties differ upon the questions to be tried the court may either settle the same or refer them to the registrar of the court.

7. If the court shall find that the caveator is entitled to all or some of the relief claimed by him, the order of the court shall declare what is the estate, interest, lien or claim to which the caveator is entitled; and the court may make such order as the circumstances may require, and shall have power to afford the caveator the same relief as in an ordinary action.

8 . Every order of the court made under these rules shall have the same effect as a judgment or order of the court given or made in any action; and the district registrar shall make such entries in the register and do such things as may be necessary to give effect to the order of the court.

9. If, at the hearing of such petition, it shall appear to the court that for the purpose of justice it is necessary or expedient that an action or suit should be brought, the court may order such action or suit to be brought accordingly, subject to such terms as to the costs or otherwise as may be thought proper.

10. In all proceedings of the court, either by the caveator or caveatee, the court may make such order as to the costs of the proceedings in the court and incidental to filing the caveat as the court shall see fit.

11. The court or a judge thereof may, without prejudice to the exercise of any other power of the court, upon the application of any person interested in any land, make an order restraining for a time, or until the occurrence of an event to be named in such order, or generally until further order, the registration of any dealing with land, and may impose any terms and conditions upon making such order. 
12. The court or a judge thereof may discharge any such order with or without costs, and generally act in the premises in such a manner as the justice of the case requires; and the district registrar, without being a party to the proceedings, upon being served with any order or copy thereof shall obey the same.

13. Unless the petition filed under such caveat shall have been served on all proper parties within thirty days next after it has been filed with the district registrar or within such further time as the judge in chambers may order, any person interested may apply to a judge in chambers for, and such judge in chambers may grant, an order dismissing and discharging such petition and caveat for want of prosecution, and such dismissal shall be deemed to have been a dismissal on its merits unless otherwise ordered.

14. When service of any proceedings under these rules is required to be made upon any person who cannot a ter due diligence be found within the Provinee of Manitoba, a judge in chambers may, in a proper case, order that service of such proceedings may be effected substitutionally in such manner as to such judge may seem proper; and such substitutional service shall have the same effect as personal service upon the person intended to be affected thereby.

15. No failure to comply with any of the rules in this Act made as to any petition shall in the first instance be considered sufficient to dismiss or set aside such petition; but a motion may at any time be made to dismiss such petition for want of prosecution or non-compliance with said rules, and upon the return the judge may make an order that such matter be proceeded with, or such non-compliance amended or remedied, within a time to be specified in the order, and that in default thereof such petition or any proceeding thereunder do stand dismissed; and such judge may, upon such return, make such order as to costs as he may see fit.

16. So soon as an issue has been directed to be tried under this Act, an order that a writ of commission for the examination of witnesses outside the juriscliction of the court may be granted on the application of any party to such issue, pursuant to the principles and practice of the Court of King's Bench, and such examination may be upon interrogatories or virc voce as may seem proper. $1 \& 2 \mathrm{Edw}$. VII, c. 43 , Sch. L.

\title{
Sciiedule M.-(Section 63.)
}

\author{
SURVEYOR'S CERTIFICATE.
}

I, (name of surveyor), of the (place of residence), provineial land surveyor, make oath and say that I was present at and 
did personally superintend the survey represented by this plan, and that the survey and plan are correct.

Sworn before me, etc.

$1 \& 2$ Edw. III, c. 43 , Sch. M.

\section{Schedule N.-(Section 53.) \\ ScMmoNs.}

The Real Property Act.

Province of Manitoba.

In the matter of

The Land Titles District of

To wit:

To

You and each of you are hereby commanded that, all other business and excuses whatsoever ceasing, you do appear personally before the district registrar for the land titles district of , in Manitoba, in the land titles office at

Manitoba, on the day of , A.D. 19, at o'clock in the noon, and so from day to day until the matter herein mentioned be disposed of, and also that you bring with you and produce at the time and place aforesaid (here describe the instrument, etc., to be produced), then and there to testify and show all and singular those things which you or either of you know or the said deed, instrument, lecord, document or writing doth import, of and concerning this matter; and this you, or either of you, shall by no means omit, under a penalty of five hundred dollars, and all other penalties provided by the said Act.

Witness the hand and official seal of the district registrar for the land titles district of at this day of A.D. 19 , in the year of our reign.

[SEAL]

District Registrar for

1 \& 2 Edw. VII, c. 43 , Sch. N. 


\title{
SASKATCHEWAN
}

\section{The Iland Titles Act.}

Being Chapter 41 of the Revised Statutes 1909, as amended by Chapter 12, 1910-11 (assented to March 23, 1911), and Chapter 16, 1912 (assented to Mareh 15, 1912).

\section{An Act respecting Land in the Province of Saskatchewan.}

\author{
SHORT TITLE.
}

1. This Act may be cited as "The Land Titles Act." 1906 , c. $24, \S 1$.

\section{INTERPRETATION.}

2. In this Act unless the context otherwise requires the expression:

1. "Land" means lands, messuages, tenements and hereditaments, corporeal and incorporeal of every nature and description and every estate or interest therein and whether such estate or interest is legal or equitable together with all paths, passages, ways, watercourses, liberties, privileges, easements, mines, minerals and quarries appertaining thereto and all trees and timber thereon and thereunder lying or being unless any such are specially excepted;

2. "Owner" means any person or body corporate entitled to any freehold or other estate or interest in land, at law or in equity, in possession, in futurity or expectancy;

3. "Transfer" means the passing of any estate or interest in land under this Act, whether for valuable comsileration or otherwise;

4. "Transferor" means the person by whom any interest or estate in land is transfered whether for value or otherwise; and the expression "transferee" means the person to whom any interest or estate in land is transfered whether for valur or otherwise;

5. "Mortgage" means atny charge on land created merely" for securing a debt or a loan; [or any hypothecation of such, charge. 1912 , c. $16, \S 1$.] 
6. "Mortgagee" means the owner of a mortgage; and the expression "mortgagor" means the owner or transferee of land or of any estate or interest in land pledged as security for a debt or loan;

7. "Ineumbrance" means any charge on land created or effected for any purpose whatever, inclusive of mortgage, mechanics' liens and executions against lands unless expressly distinguished;

8. "Incumbrancer" means the owner of any land or of any estate or interest in land subject to any ineumbrance; and the expression "incumbrancee" means the owner of an incumbrance;

9. "Lunatie" means any person found by any competent tribunal to be a lunatic;

10. "Person of unsound mind" means any person not an infant who not having been found to be a lunatic has been found on like inquiry to be ineapable from infirmity of mind of managing his own affairs;

11. "Instrument" means any grant, certificate of title, conveyance, assurance, deed, map, plan, will, probate or exemplification thereof, letters of administration or an exemplification thereof, mortgage or incumbrance or any other doeument in writing relating to or affecting the transfer of or other dealing with land or evideneing title thereto;

12. "Pegister" means the register of titles to land kept in aceordance with this Act;

13. "Registration" means:

(a) The loringing of lands under the provisions of this Act;

(b) The entering upon the certificate of title of a memorandum authorized by this Act of any document; and "filing" means the entering in the day book of any instrument;

14. "Memorandum" means the indorsement upon the cretificate of title and on the duplicate thereof of the particulars of any instrument presented for registration;

15. "Certificate of title" means the certificate (form E) granted by the registrar and entered and kept in the register;

16. "Duplicate" or "duplicate certificate" means the duplieate of the certificate of title in the register delivered or issued to the person entitled thereto;

17. "Pegistrar" means a registrar of titles or a deputy or an assistant deputy registrar or a master of titles when acting as registrar; 
18. "Court" means the Supreme Court of Saskatchewan;

19. "Judge" means a judge of the said eourt;

20. "Transmission" applies to change of ownership consequent upon death, lunacy, sale under execution, order of court, assignment for the general benefit of creditors or other act of law, sale for arrears of taxes or upon any settlement or any legal succession in case of intestacy;

21. "Grant" means any grant of Crown land whether in fee or for years and whether direct from his Majesty or pursuant to the provisions of any statute;

22. "Indorsed" and "indorsement" apply to anything written by the registrar upon any instrument or upon any paper attached thereto;

23. "Possession" when applied to persons claiming title to land means also alternatively the reception of the rents and profits thereof;

24. "Form" means a form in the schedule to this Act. 1906 , c. $24, \S 2 ; 1908-9$, c. $9, \S 1 ; 1909$, c. $20, \S 1$.

3. A person shall be deemed to claim under a prior certificate of title who is a holder of or whose claim is derived directly or indirectly from a person who was the holder of an earlier certificate of title granted notwithstanding that such certificate of title has been surrendered and a new certificate of title has been granted upon any transfer or other instrument. 1906, c. $24, \S 3$.

4. Nothing contained in this Act shall take away or affect the jurisdiction of any competent court on the ground of actual fraud or over eontracts for the sale or other disposition of land for which a certificate of title has been granted. 1906, c. $24, \S 4$.

\section{DESCENT OF LAND.}

5. Whenever by any letters patent, transfer, conveyance, assurance or other assignment land or any interest in land is granted, transferred, conveyed or assigned to two or more persons other than executors or trustees in fee simple or for any less estate legal or equitable such persons shall take as tenants in common and not as joint tenants unless an intention sufficiently appears on the face of such letters patent, conveyance, assurance or other assignment that they take as joint tenants. C. O. 1898 , c. 37 .

6. No estate in fee simple shall be ehanged into any limited fee or fee tail but the land whatever form of words is 
used in any transfer, transmission or dealing shall except as hereinafter otherwise provided be and remain an absolute estate in the owner for the time being. 1900, c. $24, \S 7$.

7. Any limitation which heretofore would have created an estate tail shall transfer the absolute ownership or the greatest estate that the transferor had in his land.

\section{MARRIED WOMEN.}

8. Wh'never land is transferred to a man and his wife the trinsfer shall take according to the tenor of the transfer and they hat not take by entireties unless it is so expressed in the transfer. 1906, c. $24, \S 14$.

9. A man may make a valid transfer of land to his wife and a woman may make a valid transfer of land to her husband without in either case the intervention of a trustee. 1906, c. 24, $\$ 15$.

10. The registrar upon application to him by a married woman and upon production of the duplicate certificate of title issued to her prior to marriage accompanied by her affidavit of her marriage giving the date of same, the place where solemnized and her husband's full name, residence and occupation shall make a memorandum of such facts upon the certifieate of title, eancel such existing certificate of title and the duplicate thereof and grant a new eertificate of title to the applicant owner in ber newly acquired name in which her husband's full name, residence and oceupation shall be given and shall issue to her a duplicate certificate. 1906, c. $24, \S 17$.

\section{REGISTRATION DISTRICTS.}

11. For the purpose of this Act there shall be in the Province of Saskatchewan six land registration districts respectively. known as follows:

(a) The Assiniboia Land Registration District composed of that part of Saskatchewan which is bounded as follows: Commencing at the southeast corner of the Province of Saskatchetran, thence northerly along the east loundary of the said province to the north koundary of the twentieth township, thence westerly along the said north boundary of the twentieth townships to the dividing line between the tenth and eleventh ranges west of the second principal meridian, thence northerly along the said dividing line betreen the tenth and eleventh ranges to the north boundary 
of the twenty-sixth township, thence westerly along the north boundary of the twenty-sixth townships to the point where it is first intersected by the east shore of Last Mountain lake, thence southerly along the said east shore of Last Mountain lake to the point where it is first intersected by the dividing line between the twenty-third and twenty-fourth ranges west of the second principal meridian in township twentyfour, thence southerly along the said dividing line between the said twenty-third and twenty-fourth ranges to the southern boundary of the province, thence easterly along the said southern boundary of the province to the point of commencement.

(b) The Yorkton Land Registration District composed of that part of Saskatchewan which is bounded as follows: Commencing at a point in the east boundary of the said province being the point of intersection of the same with the north boundary of the twenticth township, thence northerly along the eastern boundary of the province to the north boundary of the fortieth township, thence westerly along the said north boundary of the fortieth townships to the dividing line between the tenth and eleventh ranges west of the second principal meridian, thence southerly along the said dividing line between the tenth and eleventh ranges to the north boundary of the twentieth township, thence easterly along the said north boundary of the twentieth townships to the point of commencement.

(c) The East Saskatchewan Land Registration District composed of that part of Saskatchewan which is bounded as follows: Commeneing at a point in the east boundary of the said province being the point of intersection of the same with the north boundary of the fortieth township, thenee northerly along the said eastern boundary of the province to the northern boundary thercof, thence westerly along the said northern boundary of the province to the dividing line between the sixth and seventh ranges west of the third principal meridian, thence southerly along the said dividing line between the said sixth and reventh ranges to the point where it is intersected by the south bank of the North Saskatchewan river, thence along the said south bank of the North Saskatchewan river upstream to the point where it is intersected by the 
north boundary of the fortieth township, thence easterly along the said north boundary of the fortieth townships to the point of commencement.

(d) The West Saskatchewan Land Registration District composed of that part of Saskatchewan which is bounded as follows: Commencing at the point where the dividing line between the sixth and seventh ranges west of the third principal meridian is intersected by the south bank of the North Saskatchewan river, thence northerly along the said dividing line between the said sixth and seventh ranges to the northern boundary of the province, thence westerly along the said northern boundary to the western boundary of the province, thence southerly along the said western boundary to the north boundary of the fortieth township, thence easterly along the said north boundary of the fortieth townships to the point where it is intersected by the south bank of the North Saskatehewan river, thence along the said south bank of the North Saskatchewan river downstream to the point of commencement.

(e) The Saskatoon Land Registration District composed of that part of Saskatchewan which is bounded as follows: Commencing at the dividing line between the tenth and eleventh ranges west of the second prineipal meridian at the point where it is intersected by the north boundary of the twenty-sixth township, thence northerly along the said dividing line between the said tenth and eleventh ranges to the north boundary of the fortieth township, thence westerly along the said north boundary of the fortieth townships to the point where it is first interseeted by the south bank of the North Saskatchewan river, thence along the said south bank of the North Saskatehewan river upstream to the point where it is again interseeted by the north boundary of the fortieth township, thenee westerly along the said north boundary of the fortieth townships to the western boundary of the provinee, thence southerly along the said western boundary to the north boundary of the twenty-sixth township, thence easterly along the said north boundary of the twenty-sixth townships to the point of eommencement.

( $f$ ) The Moose Jaw Land Registration District composed of that part of Saskatehewan which is bounded as follows: Commencing at the dividing line between the twenty-third and twenty-fourth ranges west of the 
second principal meridian where it is intersected by the southern boundary of the province, thence northerly along the said dividing line between the said twenty-third and twenty-fourth ranges to the point where it is intersected by the east shore of Last Mountain lakein the twenty-fourth township, thence northerly along the said east shore of Last Mountain lake to the point where it is intersected by the north boundary of the twenty-sixth township, thence westerly along the said north boundary of the twenty-sixth townships to the western boundary of the province, thence southerly along the said western boundary to the southern boundary of the province, thence easterly along the said southern boundary to the point of commencement. 1906 , e. $24, \S 18$.

[The Arcola District is all of the province east of township eleven and south of township twelve. Established 1911.]

Note.-Wherever a dividing line between two ranges is mentioned as the boundary of the district it is understood to mean the surveyed line on the cast boundary of the westerly range and the extension of such line southerly to intersect the north boundary of each township which lies to the south of a correction line and thence casterly along the north boundary of such township to the east boundary thereof.

12. The Lieutenant Governor in Council may from time to time by proclamation as the settlement of the country and the exigencies of the public service require constitute any portion of Saskatchewan a land registration district and declare by what local name the same shall be known and designated and may also change the boundaries of existing districts. 1906 , c. $24, \S 19$.

13. In each registration district at such place as the Lientenant Governor in Council determines there shall be an office called the "land titles office." 1906, c. 24, § 20.

14. The Lieutenant Governor in Council may provide in each registration district at the public expense and may thereafter maintain in a proper state of repair the necessary building or buildings to serve as a land titles office.

(2) Until the actual establishment of an office in any new registration district set apart by Order in Council all registrations made in the offices of the district or districts from which the territory comprising such new district wass set apart 
shall be and are hereby declared always to have been as valid as if made in such new district when fully established. 1906, f. $24, \S 21 ; 1908-9$, c. $15, \S 23$.

15. The attorney general shall from time to time provide all necessary books, forms and such other office requisites as are necessary for use under the provisions of this Act. 1906, c. $24, \S 22$.

OFFICERS.

16. The Lieutenant Governor in Council may from time to time appoint a master of titles whose duties shall be to perform the duties of the master of titles by this Act prescribed and under instructions from the attorney general to inspect the books and records of the several land titles offices and to perform such other duties as he may be directed by the attorney general to perform; and the said master may in the discretion of the attorney general be directed to perform any duty which any registrar is empowered by this Act to perform. 1906, c. $24, \S 23 ; 1909$, с. $20, \S \S 1,2$.

17. No person shall be appointed master of titles unless he is when appointed a barrister and solicitor of at least three rears' standing of the Province of Saskatchewan or one of the other provinces of Canada. 1906, c. $24, \S 24 ; 1909$, c. $20, \S 1$.

18. The business of each land titles office shall be conducted by an officer called the registrar appointed by the Lieutenant Governor in Council with such other officials and clerks as are necessary and as the Lieutenant Governor in Council from time to time appoints.

(2) No perion shall be appointed a registrar unless he is a barrister and solicitor of at least three years' standing of the Province of Saskatchewan or one of the other provinces of Canada. 1906, c. $24, \S 25$.

19. Whenever occasion requires the Lieutenant Governor in Council may from time to time appoint a deputy registrar and one or more assistant deputy registrars to assist a registrar under instructions from the latter.

(2) The deputy registrar may in the event of the illness or absence from office of the registrar perform all the duties required by this Act to be done by the registrar.

(3) In ease of the death, resignation or removal from office of the registrar the deputy registrar shall do and perform all the duties of a registrar under this Act until another registrar is appointed. 1906 , c. $24, \S 26$. 
20. No person shall be appointed a deputy registrar or assistant deputy registrar unless he is a barrister and solicitor of the Province of Saskatchewan or of one of the other provinces of Canada or unless he has been employed for a period of at least three years in a land titles office in Saskatchewan. 1906 , c. $24, \S 27 ; 1909$, c. $20, \S 3$.

21. The master of titles, the registrars, deputy registrars, assistant deputy registrars and other necessary officers shall be attached to the department of the attorney general and be under the control of the attorney general; and their salaries and such incidental expenses of carrying out the provisions of this Act as are sanctioned by this Act or by the Lieutenant Governor in Council shall be paid out of moneys provided by the Legislature of the province and they shall hold office during pleasure. 1906 , c. $24, \S 28 ; 1908$, c. $20, \S 1$.

22. Neither the master of titles nor any registrar, deputy registrar, assistant deputy registrar or clerk in any land titles office shall:

(a) Directly or indirectly act as the agent of any person investing money and taking securities on land within Saskatchewan; or

(b) Advise for any fee or reward or otherwise upon titles to land; or

(c) Practice as a conveyancer; or

(d) Carry on or transact within the land titles office any business or occupation whatever other than his duties as such master, registrar, deputy registrar, assistant deputy registrar or clerk. 1906, c. $24, \S 33 ; 1910$, c. $20, \S 1$.

23. No master of titles, registrar, deputy registrar or assistant deputy registrar or any person acting under authority of a registrar shall be liable to any action or proceeding for or in respect of any act bona fide done or omitted to be done in the exercise or supposed exercise of the powers given by this Act or by any order or general rule made in pursuance of this Act except as hereinafter provided. 1906, c.24, \$34; 1910, c. $20, \S 1$.

24. Each registrar shall have a seal of office approved by the Lieutenant Governor in Council with which he shall seal all certificates of title. 1906, c. $24, \S 35$.

25. The master of titles or any registrar, deputy registrar or assistant deputy registrar within the district to which he is appointed may administer any oath or take any affirmation 
or declaration in lieu of an oath respecting titles to land from anyone cntitled by law to affirm or declare. 1906, c. $24, \S 37$.

26. Every registrar shall when required furnish under seal copies and abstracts of any instruments affecting lands which are deposited, filed or registered in his office and every such certified copy shall be received as evidence in the same manner and with the same effect as if the original was produced. 1906 , c. $24, \S 38$.

27. Every land titles office shall be kept open on all days except Sundays and legal holidays between the hours of ten o'clock in the forenoon and four o'clock in the afternoon during which time either the registrar or the deputy registrar shall be in attendance:

Provided that on Saturdays the said office shall be closed at one o'clock in the afternoon. 1906, c. $24, \S 39$.

\section{BOOKS.}

28. The registrar shall keep a book or books which shall be called the "receiving book" in which he shall enter a record of all instruments received by him.

29. The registrar shall stamp all instruments which are presented to him for registration showing the day, hour and minute of receiving the same and shall immediately enter a record of the same in a receiving book to be kept for that purpose.

(2) The said instruments shall then be examined and if found to be complete and in proper form and fit for registration shall be entered in the day book as hereinafter provided as of the day, hour and minute shown in the receiving book; if the instruments are not found to be complete and in proper form or appear to be unfit for registration the registrar shall have power to reject and return same. 1906 , c. $24, \S 36$.

30. The registrar shall keep a book or books which shall be called the "day book," and in which shall be entered by a short description every instrument relating to lands for which a certificate of title has issued or been applied for which have been found by the registrar to be complete and in proper form with the day, hour and minute of its being given in.

(2) For purposes of priority between mortgagees, transferees and others the time so entered shall be taken as the time of registration.

(3) The registrar in entering memoranda upon the certificate of title embodied in the register and in indorsing a 
memorandum upon the duplicate shall take the time from the day book as the time of registration. 1906, e. $24, \S 40$.

31. Unless required so to do by order of a court or a judge the registrar shall not receive or enter in the day book any instrument until the duplicate certificate of title for the lands affected is produced to him so as to enable him to enter the proper memorandum on such duplicate certificate except as provided in the following section. 1906, c. $24, \S 41$.

32. A duplicate certificate of title for the lands affected need not be produced in the case of:

(a) Executions against lands, eaveats, mechanies' liens, assignments for the general benefit of creditors under The Assignments Act, transfers by a sheriff or by order of a court or a judge; or

(b) Transfers on sales of lands for taxes, maps or plans which do not require to be registered, or certificates or orders of a court or a judge or a certificate of lis pendens under the seal of the court and the hand of the clerk thereof;

(c) A mortgage or other incumbrance created by any person rightfully in possession of land prior to the issue of the grant from the Crown or prior to the issue of transfer from the Hudson's Bay Company or from any company entitled to a grant of such lands from the Crown or to which letters patent from the Crown for such mortgaged or incumbered lands have already issued [but for which no certificate of title has been issued] if there is produced to and left with the registrar with the mortgage or incumbrance an affidavit made by the mortgagor or incumbrancer in form G; and also in the case of lands mortgaged prior to the issue of transfer from the Hudson's Bay Company or other company as aforesaid, a certificate from the land commissioner or other proper offieer of such company that the purehase price of such mortgaged lands has been paid and that the applieant is entitled to a transfer in fee simple therefor from such company. 1906, c. $24, \S 42 ; 1910-11$, e. $12, \S 1$.

(d) A transfer under power of sale in a mortgage given under section 93 of this Act by a mortgagee or an order for foreclosure given under the said section by the registrar. $1910-11$, c. $12, \S 1(2)$. 
33. The registrar shall also keep a book or books which shall be called the "register" and shall enter therein all certificates of title and shall record therein the particulars of all instruments, dealings and other matters by this Act required to be registered or entered in the register and affecting the land included in such certificate of title.

(2) Certinicates of title shall be in form $\mathrm{A}$ in the schedule to this Act and each certificate shall constitute a separate folio of such book. 1906 , c. $24, \S 43$.

34. The registrar shall also keep a book or books to be ralled the "general register" in which he shall enter in alphabetical order under the name of the grantor, every instrument entered in the day book relating to lands in which the land affected thereby is not specifically described with the date of execution thereof, the names of the parties thereto and the day, hour and minute of its receipt by him.

35. The registrar shall also keep a book or books to be called the "execution register" in which he shall enter in alphabetical order under the name of the execution debtor all writs of execution and renewals thereof received by him with the date and amount thereof, the parties thereto and the day, hour and minute of its receipt by him and any other particulars required by this Act.

36. Upon every transfer of ownership the certificate of title of the transferor and the duplicate thereof shall be cancelled in respect of the land so transferred and the certificate of title of the transferee shall thereupon be entered upon a new folio in the register.

(2) The registrar shall note upon the folio of the title of the transferor the number of the folio of the transferee's title and upon that of the transferee the number of the folio of the transferor so that reference can be readily made from one to the other as occasion requires. 1906 , c. $24, \S 44$.

(3) There shall not be included in a certificate of title lands in more than one township. 1912, e. $16, \$ 2$.

\section{REGISTRATION.}

37. Every grant shall be deemed and taken to be registered under the provisions and for the purpose of this Aet so soon as the same has been marked by the reoistrar with the folio and volume on and in which it is embodied in the register.

(2) Every other instrument shall be deemed to be registered so soon as a memorandum of it has been entered in the register 
upon the folio constituted by the existing certificate of title of such land. 1906, e. $24, \S 45$.

38. The registrar shall retain in his office every registered instrument. 1906 , c. $24, \S 46$.

39. Every memorandum entered in the register shall state the nature of the.instrument to which such memorandum relates, the day, the hour and the minute of its registration and the names of the parties thereto and shall refer by number or symbol to such instrument and shall be signed by the registrar. 1906 , c. $24, \S 47$.

40. Whenever a memorandum has been entered in the register the registrar shall make a like memorandum upon the duplicate when the same is presented to him for the purpose and sign and seal such memorandum.

(2) Such memorandum shall be received in all courts of law as conclusive evidence of its contents and that the instrument of which it is a memorandum has been duly registered under the provisions of this Act. 1906 , c. $24, \S 48$.

41. Whenever any land is granted in Saskatchewan by the Crown the letters patent therefor when received by the registrar of the registration district in which the land so granted is situated shall be retained by the registrar in his office; a certificate of title as provided by this Act with any necessary qualification shall be granted to the patentee and a duplicate of such certificate of title shall be issued to the patentee upon the payment of such fees and charges as are fixed or may from time to time be fixed by the Lieutenant Governor in Council:

Provided however that no fees or charges shall be payable upon the issue of a duplicate certificate of title to a person who has obtained a patent under a homestead entry in accordance with the provisions of an Act of the Parliament of Canada known as The Dominion Lands Act, unless at the time such duplicate certificate of title is issued there are instruments registered or filed which incumber or affect the title in which case such duplicate certinicate shall be issued upon the payment. of such fees as are fixed or may from time to time be fixed by the Lieutenant Ciovernor in Council. 1906 , c. $24, \$ \$ 49,50$.

42. The notification to the Hurkon's Bay ('ompany by tha' minister of the interior under the provisions of The Dominion Lands Act of the survey and confirmation of the survey of any township or part of a township shall be accepted by a registrar as equivalent to and be dealt with by him in all respects in the same manner as if the said notification were 
letters patent to and in faror of the said company granting to the said company in fee simple the sections or portions of sections to which they are entitled in such townships or parts of townships under the provisions of The Dominion Lands Act. 1906 , c. $24, \S 51$.

43. A notification to the registrar from the minister of the interior that land described therein has been granted to the Canadian Pacific Railway Company or to any other railway company entitled to Dominion lands under the authority of an Act of Parliament shall be accepted by the registrar and dealt with by him in all respects as if the same were letters patent in favor of such company. 1906, c. $24, \S 52$.

PLANS OF ROADS.

44. Whenever the plan of a surveyed road or trail is forwarded to the registrar of the proper land titles office pursuant to the provisions of The Public Works Act the registrar shall call in the duplicate certificate of title for all patented lands affected thereby in the manner set forth in section 148 of this Act; and upon receipt of same or if the registered owner of such lands refuses or neglects to return the said duplicate certificate of title within thirty days after the demand therefor has been mailed to him by the registrar, the registrar shall proceed to file and register the said plan and shall cancel the area required for the road as shown on the plan from the certificate of title in his office and from the duplicate that may have been or may afterwards be returned to him, and upon being requested so to do by the minister of public works for Saskatchewan shall grant a certificate of title for the road or trail free from all incumbrances, liens, estates or interests whatsoever to his Majesty in the right of the province and shall issue to his Majesty a duplicate of such certificate of title and forward the same to the minister of public works:

Provided that the right and title to all mines and minerals which may be found to exist under such land shall continue to be vested in the said owner and his assigns.

(2) A plan of survey of any drain or water right registered by the applicant for such right when the applicant is the minister of public works for Saskatchewan shall create an easement over or through the land shown to be affected thereby and shall be dealt with in all respects by the registrar as provided in section 73 of this Act. 1906, c. $24, \$ 53 ; 1908$, c. 29 , $\S 2 ; 1909$, с. $20, \S 4$. 
45. If a certificate of title has not been granted for any land affected by a road or trail as shown upon the plan forwarded to the registrar as hereinbefore provided the registrar shall upon granting a certificate of title for such land eancel the area required for the road or trail as shown upon such plan from such certificate of title and from the duplicate thereof when issued and before delivered to the owner; and unless a reservation of such surveyed road or trail is made in the grant from the Crown of such land he shall upon being requested so to do by the minister of public works for the province grant a new certificate of title to his Majesty in the right of the province and shall issue to his Majesty a duplicate of such certificate of title and forward the same to the minister of public works. 1906 , c. $24, \S 54$.

46. Whenever it is made to appear to the satisfaction of the registrar that in any plan heretofore filed by the department of public works of the Northwest Territories or filed and registered as hereinbefore provided manifest technical or other errors have intervened the registrar shall permit such plan to be withdrawn by the department of public works of Saskatchewan and a corrected plan substituted therefor; and the provisions of the next three preceding seetions shall apply to such corrected or substituted plan upon the same being filed and registered. 1906 , c. $24, \S 55 ; 1907$, с. $32, \S 6$.

47. A notification to the registrar from the minister of public works that the land which is deseribed in such notification and which is a part of any road allowance or surveyed road or trail vested in the Crown in the right of the provinee has been closed shall operate as a transfer from the Crown to the person named as transferee in such notifieation or in a transfer attached thereto and shall be aceepted by the registrar and be dealt with by him in all respects as if such notifieation were letters patent in favor of such person.

(2) The notification shall state the nature of the grant and shall specify any mines, minerals, easements or rights which are excepted from the grant.

(3) A notification to the registrar from the minister of public works that the land shown on any plan of road, drain or water right for which a certificate of title in the name of his Majesty in the right of the province has not been issued has been abandoned shall operate as a transfer from the Crown to the registered owner of the land through which the road to be abandoned passes and shall bo aecepted by the registrar and any memorandum which may have been made upon the 
original certificate of title to the land upon the filing of the plan shall be cancelled. 1906 , c. $24, \S 56 ; 1908$, c. $29, \S 3$; $190 \$-9$, с. $9, \$ 2$.

48. Sections 44 to 47 inclusive of this Act shall apply to all plans of roads or trails heretofore filed in any land titles office in Saskatchewan under the provisions of any Act of the Parliament of Canada or of any ordinance of the Northwest Territories or of any Act of the Legislature of Saskatchewan and shall so be dealt with by the registrar. 1906, c. $24, \S 57$.

(2) A copy of any plan made under the provisions of The Northuest Territories Act duly certified by the surveyor general of the department of the interior and by the chief engineer of the department of public works for Saskatchewan shall be accepted and dealt with by the registrar under the provisions of the said sections 44 to 47 . 1910-11, c. $12, \S 2$.

\section{APPLICATIONS TO BRING CNDER THIS ACT.}

49. The owner of any estate or interest in any land whether legal or equitable letters patent for which issued from the Crown before the first day of January, one thousand eight hundred and eighty-seven, or which otherwise had prior to that date passed from the Crown may by himself or his duly authorized agent or attorney apply to have his title registered under the provisions of this Act.

(2) If at the time of the grant of the certificate of title there are no registered incumbrances or conveyances affecting such land the certificate may be granted to the patentee upon payment of such fees as are fixed in that behalf by tariff made from time to time by the Lieutenant Governor in Council, but no fees shall be payable therefor under the provisions of this Act relating to the assurance fund. 1906, c. $24, \S 58$.

50. The application therefor shall be made in writing to the registrar of the registration district in which the land is situate in form B in the schedule to this Act and shall be verified by affidavit of the applicant or some one on his behalf in form $\mathrm{C}$ in the said schedule.

(2) The application shall be accompanied by:

(a) All deeds, if any, in possession of the applicant;

(b) A certificate showing all registrations affecting the title, down to the time when such application is filed, with the copies of any registered documents the original whereof he is unable to produce: 
Provided that it shall not in any case be necessary for any applicant to produce copies of any document the original whereof is at the time of the application of record in the office of the registrar to whom the application is made; nor for the Hudson's Bay Company in the case of any lands the title to which passed to that company before the first day of January, one thousand eight hundred and eighty-seven either by notification made under the provisions of The Dominion Land: Act or by letters patent issued thereunder prior to that date if the application is aceompanied by an affidavit by any officer of the company approved by the attorney general in form D in the schedule to this Act. 1906 , c. $24, \S 59$.

51. Upon the filing of such application, if the applicant is the original grantee of the Crown of the land, and no deed, transfer, mortgage or other incumbrance or instrument or caveat affecting the title thereto appears to have been recorded, or if not the original grantee, all the original title deeds are produced and no person other than the applicant is in actual possession of the land and no eaveat has been filed, the registrar if he entertains no doubt as to the title of the applicant shall grant a certificate of title as hereinafter provided. 1906, c. $24, \S 60$.

52. If there is any mortgage or incumbrance against the land at the date of such application the filing with the registrar of the original mortgage or the instrument creating the incumbrance or a copy of such mortgage or instrument having indorsed thereon or attached thereto a receipt which may be in form $I$ in the schedule to this Act for the payment of the amount thereby secured, signed by the mortgagee or incumbrancee, attested by an affidavit of the witness shall operate as a discharge of the sceurity created by such mortgage or incumbrance. 1906 , c. $24, \S 61$.

53. If any person other than the applicant appears by admission or otherwise to be interested in the land and the applicant desires to have his title registered subject to the interest of such other person and such interest is by virtue of a mortgage, incumbrance, lease or charge created by any other instrument and such instrument is at the time of the application of record in the office of the registrar to whom application is made or if not so of record is then produced to the registrar the registrar may if he entertains no doubt as to the extent and nature of interest or of the title of the applicant register the title and grant a certificate of title and issue a duplieate certificate subject to such interest. 1906, c. $24, \S 62$. 
54. In any case where the person who appears to be intersited in land is a consenting party to an application the registrar may if he entertains no doubt as to the title of the applicant grant a certificate of title subject to the terms of the consent:

Provided that such consent shall be in writing signed by the consonting party in presence of a witness and attested in the manner required by this Act for the attestation of instruments not under seal. 1906, c. $24, \S 63$.

55. In all cases other than those provided for in the last four preceding sections the registrar shall forthwith on giving the applicant a certificate of the filing of his application transmit the application with all evidence supplied to the master of titles to be dealt with as hereinafter mentioned. 1906, c. $24, \S 64: 1908-9$, с. $9, \$ 3 ; 1909$, с. $20, \S 1$.

56. The master of titles shall examine without delay all titles which are submitted to him and for such purpose shall when necessary hear all persons interested or claiming to be interested and shall hear and consider the claims as against the applicant of any person who is in possession of the land; and he shall have and exercise all the powers for compelling the attendance of persons and the production of documents which usually appertain to courts of civil justice and the judges thereof in civil actions brought therein. 1906, c. $24, \S 65$; $1908-9$, , . $9, \S 3 ; 1909$, с. $20, \S 1$.

57. Any person having an adverse claim or a claim not recognized in the application for registration may at any time before the master of titles has approved of the applicant's title file with the registrar a short statement of his claim verified by afficlavit and shall serve a copy thereof on the applicant or his adrocate or his agent. 1906 , c. $24, \S 66 ; 1908-9$, c. 9 , $\S 3 ; 1909$, е. $20, \S 1$.

58. If any adverse claim is filed the master of titles shall proceed to examine into and adjudicate thereon and no certifieate of title shall be granted until such adverse claim has been disposed of. 1906 , c. $24, \S 67 ; 1908-9$, c. $9, \S 3$; 1909, ค. $20, \S 1$.

59. In any case before him the master of titles may direct that notice of the application be published in some newspaper or newspapers in such form and for such period as he thinks expeclient and no order for registration shall be granted by him until after the expiration of at least four weeks from the first publication of the notice if he has directed the same to be published. 1906, c. 24, \$ 6\&; 1905-9, c. 9, \& 3; 1909 ค. 20. 1 . 
60. The master of titles if satisfied with the applicant's title shall thereupon make an order directing the registrar after the expiration of four weeks from the date thereof unless in the meantime the order is appealed from to register the same. 1906 , e. $24, \S 69 ; 1908-9$, c. $9, \$ 3 ; 1909$, c. $20, \S 1$.

61. After the registration of a title the registrar shall make out, sign, officially seal and deliver to the owner or his duly authorized agent a cluplicate of the certifieate of title in the register on which shall be entered all memoranda indorsed on or attached to the certificate of title. 1906, e. $24, \S 70$.

\section{EFFECT OF REGISTRATION}

62. In every instrument transferring, incumbering or charging any land for which a certifieate of title has been granted there shall be implied the following covenant by the transferor or ineumbrancer, that is to say: That the transferor or incumbrancer will do such acts and execute such instruments as in accordance with the provisions of this Act are necessary to give effeet to all covenants, conditions and purposes expressly set forth in such instrument or by this Act cleclared to be implied against such person in instruments of a like nature. 1906 , c. $24, \S 71$.

63. In every instrument transferring land for which a certificate of title has been granted subject to mortgage or incumbrance there shall be implied a covenant by the transferee with the transferor and so long as such transferee shall remain the registered owner with the mortgagee or incumbrancee that the transferee will pay the principal money, interest, annuity or rent eharge seeured by the mortgage or incumbrance at the rate and at the time specified in the instrument creating the same, and will inclemnify and keep harmless the transferor from and against the principal sum or other moneys secured by sueh instrument and from and against the liability in respect of any of the covenants therein contained or under this Act implied on the part of the transferor. 1906, c. $24, \S 72 ; 1909$, с. $20, \S 5$.

64. After a certificate of title has been granted for any land no instrument until registered uncler this Act shall be effectual to pass any estate or interest in any land except a leasehold interest not exceeding three yoars or render such land liable as security for the payment of money except as against the person making the same 1906 , c. $24, \$ 73$. 
65. The owner of land for which a certificate of title has been granted shail hold the same subject (in addition to the incidents implied by virtue of this Act) to such incumbrances, liens, estates or interests as are notified on the folio of the register which constitutes the certificate of title, absolutely free from all other incumbrances, liens, estates or interests whatsoever except in case of fraud wherein he has participated or colluded and except the estate or interest of an owner claiming the same land under a prior certificate of title.

(2) Such priority shall in favor of any person in possession of land be computed with reference to the grant or earliest certificate of title under which he or any person through whom he derives title has held such possession. 1906, c. $24, \S 75$.

66. The land mentioned in any certificate of title granted under this Act shall by implication and without any special mention therein unless the contrary is expressly declared therein be subject to:

(a) Any subsisting reservations or exceptions contained in the original grant of the land from the Crown;

(b) All unpaid taxes;

(c) Any public highway or right of way or other public easement howsoever created upon, over or in respect of the land;

(d) Any subsisting lease or agreement for a lease for a period not excecding three years where there is actual occupation of the land under the same;

(e) Any decrees, orders or executions against or affecting the intercst of the owner in the land which have been filed and maintained in force against the owner;

(f) Any right of expropriation which may by statute or ordinance be vested in any person, body corporate or his Majesty;

(g) Any right of way or other easement granted or acquired under the provisions of The Irrigation Act. 1906, c. $24, \S 76$.

67. After the certificate of title for any land has been granted no instrument shall be effectual to pass any interest therein or to render the land liable as security for the payment of money as against any bona fide transferee of the land under this Act unless such instrument is executed in accordance with the provisions of this Act and is duly registered thereunder. 1906 , c. $24, \S 77$. 
68. No memorandum or entry shall be made upon a certificate of title or upon the duplicate thereof of any notice of trusts whether expressed, implied or construetive.

(2) The registrar shall treat any instrument containing any such notice as if there was no trust and the trustees therein named shall be deemed to be the absolute and beneficial owners of the land for the purposes of this Act. 1906, c. 24, $\S 79$.

69. Every instrument shall become operative aceording to the tenor and intent thereof so soon as registered and shall thereupon create, transfer, surrender, charge or discharge, as the case may be, the land or estate or interest therein mentioned in such instrument. 1906, c. $24, \S 80$.

70. Instruments registered in respect of or affecting the same land shall be entitled to priority the one over the other according to the time of registration and not aceording to the date of execution. 1906, c. $24, \S 81$.

\section{TRANSFERS.}

71. When land for which a certificate of title has been granted is intended to be transferred or any right of way or other easement is intended to be created or transferred the owner shall exeeute a transfer in form $\mathrm{P}$ in the schedule to this Act which transfer may for deseription of the land intended to be dealt with refer to the eertificate of title of the land or shall give such deseription as is necessary to identify the same and shall contain an accurate statement of the estate, interest or easement intended to be transferred or created. 1906, c. $24, \S 82 ; 1909$, c. $20, \S 6$.

72. No words of limitation are necessary in any transfer of any land in order to transfer all or any title therein but every instrument transferring land shall operate as an absolute transfer of all such right and title as the transferor has therein at the time of its exceution unless a contrary intention is expressed in the transfer:

Provided that nothing herein eontained shall preclude any transfer from operating by way of estoppel. 1906, c. $24, \S 83$.

73. Whenever any easement or any ineorporeal right in or over any land for whieh a certificate of title has been granted is created for the purpose of being annexed to or used and enjoyed together with other land for which a ccrtificate of title has also been granted the registrar shall make a memorandum of the instrument ereating such easement or incorporeal right 
upon the folio of the register which constitutes the existing certificate of title of such other land and upon the duplicate thereof. 1906, c. $24, \S 84$.

74. If a transfer purports to transfer the transferor's interest in the whole or part of the land mentioned in any certificate of title the transforor shall deliver up the duplicate certifieate of title of the land and the registrar shall make a momorandrom setting forth the particulars of the transfer upon the luplicate certificate of title and upon the certificate of title in the register cancelling the same either wholly or partially according as the transer purrorts to transfer the whole or part only of the interest of the transferor in the said land. 1906 , с. 24,885 .

75. Cpon every transfer of the land mentioned in a certificate of title the certificate of title to be granted shall be granted by the registrar and a duplicate shall be issued to the transferee on application. 1906 , c. $24, \S 86$.

\section{PLANS.}

76. The registrar may require the owner of any land within his registration district desiring to transfer or otherwise to deal with the same under the provisions of this Act to furnish the registrar with a map or plan of the land having the several measurements marked there on certified by a Saskatchewan land surveyor and prepared upon one of the following scales:

(a) If the land prorosed to be transferred or dealt with is of less area than one acre then the map or plan shall be on a scale not less than one inch to two chains;

(b) If the land is of greater area than one acre but not exceeding five acres then the map or plan shall be on a scale not less than one inch to five chains;

(c) If the land is of greater area than five acres but not exceeding eighty acres then the map or plan shall be on a scale not less than one inch to ten chains.

(2) The owner shall sign the plan and attest the accuracy of the same in the manner hereinafter provided for the attestation of all instruments.

(3) If the owner neglects or refuses to comply with the requirements aforesaid the registrar shall not proceed with the registration of the transfer or dealing until the requirements are complied with.

(4) Subsequent subdivisions of the same land may be delineated upon a duplicate of the map or plan of the same so 
furnished if such map is upon a suffieient scale in accordance with the provisions herein contained; and the correctness of the delineation of each subdivision shall be attested in the manner preseribed for the attestation of an original map.

(5) Where parts of different legal subdivisions are included in the same transfer the map shall represent the whole of the legal subdivisions and shall indicate the location of the land to be transferred:

Provided that this shall not be necessary in the case of lots in a eity, town or village the plan of which has heen registered. 1906 , e. $24, \S 87$; 1909 , e. $20, \S 7$.

77. Any plan which has been prepared in arcordince with the provisions of any Act of the Parliament of Canada or of any ordinance of the Northwest Territories or any Act of the Legislature of Saskatehewan and which has been lodged or filed with the registrar under or in accordance with the provisions of any of said Aets or ordinanees shall be dealt with and recognized by him in so far as it is capable of being dealt with and recognized as if it had been prepared and filed or registered under and in aceordance with the provisions of this Act. 1906 , c. $24, \S 88$.

78. Any map or plan attested by the signature of the superintendent general of Indian affairs or his deputy and certified by a Dominion land surveyor to be a true copy of a plan of survey lodged or filed in the department of Indian affairs of lands deseribed as "Indian lands" in The Indian Act shall be dealt with and recognized in accordince with the provisions of this Act by the registrar of the district in which the said lands are situated when the said map or plan has been lodged or filed with him notwithstanding that The Indiun Act does not expressly authorize the said map or plan to be so lodged or filed. 1906 , e. $24, \S 89 ; 1909$, c. 20, $\$ 7 ; 1910-11$. e. $12, \S 3$.

79. Any owner subdividing land and liying the sime out as a town plot shall register a map of such town plot and shall deposit with the registrar three copies thereof and the registral shall indorse thereon a certificate showing the number of stech map and the date of registration and shall deliver one ropy of the same to the minister of public works for saskatchewan, retain the original and one of the copies in the land titles office and return one copy to the owner.

(2) Such map shall be made on a scale of not less than on. inch to four chains and shall how: 
(a) The number of the section, township and range or the number of the river lot or the name of the district or reservation, as the case may be, in which the land lies; and

(b) The number of the meridian west of which the said range, river lot, district or reservation is situated;

(c) All boundary lines of the section or sections, river lot, district or reservation within the limits of the land shown on the said map;

(d) All roads, streets, passages, thoroughfares, squares or reservations appropriated or set apart for public use with the courses and widths thereof respectively;

(e) The length and width of all lots;

(f) The courses of all division lines between the respective lots within the said town plot; and

(g) The courses of all streams or waters within the limits of the land included in the map.

(3) The lots shall be marked with distinct numbers or symbols.

(4) Fvery such map shall be signed by every owner or his agent and certified in form $X$ in the schedule to this Act by a Saskatchewan land surveyor whose respective signatures shall be duly witnessed and attested in the manner herein provided for the attestation of instruments to be registered under this Act.

(5) The registration in the land titles office of the plan of the subdivision in lots or blocks of any land shall vest the title to all streets, lanes, parks or other reserves for public purposes shown on such plan in his Majesty in the right and to the use of his Province of Saskatchewan; and no change or alteration in the boundaries of any street, lane, park or public reserve shall be made without the consent of the minister of public works having been first obtained:

Provided that the right and title to all mines and minerals which may be found to exist under such streets, lanes, parks or public reserves shall continue to be rested in the said owner and his assigns.

(6) No plan of subdivision of any land within the corporate limits of any city or town shall be registered unless it conforms to the regulations made or to be made by the council of such city or town with regard thereto and provided that such regulations and any amendments thereof or additions thereto have first been approved by the minister of public works; or in case no such regulations have been made then unless it conforms 
in all respects to the regulations of the department of public works with regard thereto and unless the chief engineer of the department of public works has indorsed thereon his certifieate that such plan of subdivision conforms in all respects to the regulations of the department of public works with regard thereto; and no plan of subdivision of any land outside the corporate limits of a city or town shall be registered unless the chief engineer of the department of public works has indorsed thereon his certificate that such plan of subdivision conforms in all respects to the regulations of the department of public works with regard thereto. 1906 , c. $24, \S 90 ; 1908$, c. $29, \S 5$; $1908-9$, c. $9, \S 4 ; 1909$, c. $20, \S \S 7,8 ; 1910-11$, c. $12, \S 4$; 1912 , c. $16, \S 3$.

80. In no case shall any plan or survey although filed and registered be binding on the person so filing or registering the same or upon any other person unless a sale, mortgage, incumbrance or lease has been made according to such plan or survey.

(2) In all cases cancellation in whole or in part or amendments or alterations of any such plan or survey may be ordered to be made at the instance of the person filing or registering the same or of any person deriving a title through him of any land shown on such plan or survey by a judge if on application for the purpose duly made and upon hearing all parties concerned it is thought fit and just so to order and upon such terms and conditions as to costs and otherwise as may be deemed expedient. $\quad 1906$, c. $24, \S 91$.

\section{LEASES.}

81. When any land for which a certificate of title has been granted is intended to be leased or demised for a life or lives or for a term of more than three years the owner shall execute a lease in form $J$ in the sehedule to this Act and every such instrument shall for description of the land intended to be dealt with refer to the certificate of title of the land or shall give such other description as is necessary to identify the land.

(2) The owner of any estate leased or demised to him or to the person from whom he claims a title for a life or for lives or for a term of more than three years in any land for which the grant from the Crown has been registered may apply to have his title registered and when any lease under the provisions of this Aet is registered the registrar shall retain possession of the duplieate certificate of title on behalf of all persons interested in the land covered by such lease; and the registrar 
shall if desired furnish either to the lessor or lessee or to both a certificate of the registration of the lease in form $L$ in the schedule to this Act.

(3) A right for the lessee to purchase the land therein described may be stipulated in the instrument.

(4) In case the lessee pays the purchase money stipulated and otherwise observes his covenants expressed and implied in the instrument the lessor shall be bound to execute a transfer to such lessee of the land and to perform all necessary acts by this Act prescribed for the purpose of transferring the land to the purchaser.

(5) No lease of mortgaged or incumbered land shall be valid and binding against the mortgagee or incumbrancee unless the mortgagee or incumbrancee has consented in writing to the lease prior to the same being registered or subsequently adopts the same. 1906 , c. $24, \S 92 ; 1908$, c. $29, \S 6 ; 1908-9$, c. $9, \S 5$.

82. In every lease unless a contrary intention appears therein there shall be implied covenants by the lessee:

(a) That he will pay the rent thereby reserved at the times therein mentioned and all rates and taxes which may be payable in respect of the demised land during the continuance of the lease;

(b) That he will at all times during the continuance of the lease keep and at the termination thereof yield up the demised land in good and tenantable repair, accidents and damage to buildings from fire, storm and tempest or other casualty and reasonable wear and tear excepted. 1906, c. $24, \S 93$.

83. In every lease unless a different intention appears therein there shall also be implied powers in the lessor:

(a) That he may by himself or his agents enter upon the demised land and riew the state of repair thereof and may serve upon the lessee or leave at his last or usual place of abode or upon the demised land a notice in writing of any defect requiring him within a reasonable time to be therein mentioned to repair the same in so far as the tenant is bound so to do;

(b) That in case the rent or any part thereof is in arrear for the space of two calendar months or in case default is made in the fulfilment of any covenant whether expressed or implied in such lease on the part of the lessce and is continued for the space of two calendar 
months or in case the repairs required by such notice as aforesaid are not completed within the time therein specified the lessor may enter upon and take possession of the demised land. 1906, e. $24, \S 94$.

84. In any such case the registrar upon proof to his satisfaction of lawful re-entry and recovery of possession by a lessor or his transferee by a legal proceeding shall make a memorandum of the same upon the certificate of title and upon the duplicate there of when presented to him for that purpose and the estate of the lessee in such land shall thereupon determine but without releasing the lessee from his liability in respect of the breach of any corenant in the lease expressed or implied.

(2) The registrar shall cancel the lease if delivered up to him for that purpose. 1906 , c. $24, \S 95$.

85. Whenever in any lease made under this Act the forms of words in column one of form $\mathrm{K}$ in the schedule to this Act and distinguished by any number therein are used the lease shall be taken to have the same effect and be construed as if there had been inserted therein the form of words contained in column two of the said form and distinguished by the same number:

Provided that it shall not be necessary in any such lease to insert any such number.

(2) Every such form shall be deemed a covenant by the covenantor with the covenantee and his transferees binding the former and his heirs, executors, administrators and transferees.

(3) There may be introduced into or annexed to any of the forms in the first column any expressed exeeptions from the same or expressed qualifications thereof respectively and the like exceptions or qualifications shall be taken to be made from or in corresponding forms in the second column. 1906, e. 21 , $\S 96$.

86. Whenever any lease or demise which is required to be registered by this Act is intended to be surrendered and the surrender thereof is effected otherwise than through the operation of a surrender in law upon the production of the surrender in form M in the schedule to this Act to the registral he shall make a memorandum of the surrender upon the certificate of title in the register and upon the duplicate certifieate:

Provided that no lease subject to mortgage or incumbranee shall be surrendered without the consent of the mortgagee or incumbrancec. 
(2) When the memorandum has been so made the estate or interest of the lessee in the land shall vest in the lessor or in the person in whom having regard to intervening circumstances, if any, the land mould have vested if the lease had never been executed. 1906 , c. $24, \S 97$; 1909, c. $20, \S 9$.

\section{MORTGAGES AND INCUMBRANCES.}

87. Whenever any land for which a certificate of title has becn granted is intended to be charged or made security in favor of any mortgagee the mortgagor shall execute a mortgage in form $\mathrm{E}$ in the schedule to this Act or to the like effect.

(2) Whenever any such land is intended to be charged with or made security for the payment of an annuity, rent charge or sum of money other than a debt or loan in favor of any incumbrancee the incumbrancer shall execute an incumbrance in form $\mathrm{F}$ in the schedule of this Act or to the like effect. $1910-11$, c. $12, \S 6$.

(3) Every such instrument shall contain an accurate statement of the estate or interest intended to be mortgaged or incumbered and shall for description of the land intended to be dealt with refer to the certificate of title on which the estate or interest is held or shall give such other description as is necessary to identify the land.

(4) A memorandum of the mortgage or incumbrance shall be made upon the certificate of title in the register and upon the duplicate certificate. 1906, c. $24, \S 98 ; 1909$, c. $20, \S 10$.

88. There may be filed in the office of the registrar any mortgage or other incumbrance created by any person rightfully in possession of land prior to the issue of the grant from the Crown or prior to the issue of the transfer from the Hudson's Bay Company or from any company entitled to a grant of such lands from the Crown or to which letters patent from the Crown for such mortgaged lands have already issued if there is produced to and left with the registrar with the mortgage an affidavit made by the mortgagor in the form $G$ in the schedule to this Act and also in the case of lands mortgaged prior to the issue of transfer from the Hudson's Bay Company or other company as aforesaid a certificate from the land commissioner or other proper officer of the company that the purchase price of such mortgaged lands has been paid and that the mortgagor is entitled to a transfer in fee simple therefor from such company.

(2) The registrar shall on registering the grant or transfer of lands so mortgaged enter in the register and indorse upon 
the duplicate certificate of title before issuing it a memorandum of the mortgage or incumbrance.

(3) When so entered the mortgage or incumbrance shall be as valid as if made subsequent to the issue of the grant or to the issue of the transfer from the Hudson's Bay Company or from any company entitled to a grant of such lands from the Crown or to which letters patent from the Crown for such lands may have issued, as the case may be.

(4) If more than one mortgage or incumbrance are filed they shall be registered in the order of time in which they have been filed in the said office. 1906, c. $24, \S 99$.

89. Nothing in this Act eontained shall entitle a settler who is entered for a homestead or homestead and pre-emption under the provisions contained in The Dominion Lands Act to mortgage the land entered for by him as a homestead or preemption prior to issue of a patent to him therefor. 1906, c. $24, \S 100 ; 1908$, c. $29, \S 7 ; 1908-9$, c. $9, \S 6$.

90. When any mortgage or incumbrance is registered under the provisions of this Act the registrar shall retain possession of the duplicate certificate of title on behalf of all persons interested in the land covered by such mortgage or incumbrance; but the registrar shall if desired furnish to the owner of such mortgage or incumbrance a certificate of charge which may be in form $Z$ in the sehedule to this Act. 1906, c. $24, \S 101$.

91. A mortgage or incumbrance under this det shall have effect as security but shall not operate as a transfer of the land thereby charged. 1906 , c. $24, \S 102$.

92. A mortgagee or ineumbrance of lands may from time to time either upon the written request of the owner or in case there is at such time or times any default existing under such mortgage or incumbrance without such request, apply for and obtain insurance against actual loss or injury to growing crops by hail of the crops then growing on the land subject to such mortgage or incumbrance and the cost of such insurance paid by the mortgagee or ineumbrancee shall be added to the principal sum owing under and by virtue of such mortgage or ineumbrance and shall be repayable with interest at the then next ensuing date set for payment of any instalment of principal or interest under such incumbrance. $1908-9$, c. $9, \$ 8$.

93. Proceedings to enforee payment of moneys secured by mortange or incumbrance or to enforce the observance of the covenants, agreements, stipulations or conditions contained 
in any mortgage or incumbrance or for the sale of the lands mortgaged or incumbered or to foreclose the estate, interest or claim of any person, in or upon the lands mortgaged or incumbered as also proceedings to redeem or discharge any land from any such mortgage may be had and taken in the supreme Court of Saskatchewan under the practice and procedure of the said court.

(2) In case default is made in payment of the principal sum, interest, annuity or rent charge or any part thereof secured by any mortgage or incumbrance registered under this Act or in case default is made in the observance of any covenant expressed in any mortgage or incumbrance or herein declared to be implied in such instrument and in ease such default continues for the space of one calendar month or for such longer period of time as may therein for that purpose be expressly limited the mortgagee or incumbrancee may pursuant to any covenant in that behalf contained in the mortgage forthwith after giving written notice a copy of which shall be filed in the land titles office in which the mortgage is registered to the said mortgagor or incumbrancer, his executors, administrators or assigns and to every other person appearing by the records of such land titles office at the time of filing such notice in the land titles office to have any mortgage, incumbrance or lien upon or estate, right or interest in or to the lands subsequent to such first named mortgage or incumbrance of his intention in that behalf without further consent or concurrence upon his or their part enter into possession of the lands and receive and take the rents, issues and profits thereof and whether in or out of possession thereof may make any lease of the same or of any part thereof as he may see fit and may also in such notice require the mortgagor or incumbrancer and such other interested persons as aforesaid to pay within a time to be specified in such notice the money then due or owing on such mortgage or incumbrance or to observe the covenants therein expressed or implied as the case may be and that all remedies competent will be resorted to unless such default be remedied.

(3) After such default in payment or in the observance of any covenant continuing for the further space of two calendar months from the date of service of such notice such mortgagee or incumbrancee is hereby authorized and empowered pursuant to any power of sale contained in the said mortgage to sell the land so mortgaged or any part thereof and all the estate and interest therein of the mortgagor or incumbrancer and of the other interested parties referred to in the last preceding subsection in such manner as the registrar may direct 
and either altogether or in lots by public or private contract or by such modes of sale and subject to such terms and conditions as to expenses or otherwise as the registrar may think fit.

(4) Such mortgagee or incumbrancee may make and execute all such instruments as shall be necessary for the sale and enjoyment of the premises; and all such instruments shall be as valid and effectual as if the mortgagor or incumbrancer and other persons as aforesaid had made, done or executed the same and the receipt in writing of the mortgagee or incumbrancee shall be a sufficient discharge to the purchaser of such land, estate or interest or of any portion thereof for so much of his purchase money as may thereby be expressed to be received, and no such person shall be answerable for the loss, misapplication or nonapplication or be obliged to see to the application of the purchase money by him paid nor shall he be obliged to inquire as to the fact of any default or notice having been made or given as aforesaid or how the purchase money to arise from the sale of any such land, estate or interest shall be applied. Such purchase money shall be applied: firstly, in payment of the expenses occasioned by such sale; secondly, in payment of the moneys which may then be due or owing to the mortgagee or incumbrancee; thirdly, in payment of the subsequent mortgages, incumbrances or liens, if any, in the order of the priority; and fourthly, the surplus, if any, shall be paid to the owner, mortgagor or incumbrancer, as the case may be.

(5) Upon the registration of any instrument executed by a mortgagee or incumbrancee for the purpose of such sale as aforesaid the estate or interest of the owner of the land mortgaged or incumbered shall pass to and rest in the purchaser freed and discharged from all liability on account of such mortgage and of any mortgage, lien, charge or incumbrance created by any instrument registered subsequent thereto and the purchaser shall be entitled to receive a certificate of title for the same.

(6) Whenever default has been made in payment of the principal or interest secured by a mortgage or incunbrance and such default shall be continued for six months after the time for payment mentioned in the mortgage or incumbrince the mortgagee or incumbrancee or his transferee may make an application in writing to the registrar for an order for foreclosure and such application shall state that such dofanlt has been made and has continued for the period aforesaid, that the land mortgaged or incumbered has been offered for sale 
at public auction under the provisions of this Act, that the amount of the highest bid at such sale was not sufficient to satisfy the moneys secured by such mortgage or incumbrance together with the expenses occasioned by such sale and that such notice or subsequent notice served upon the same persons declared the intention of the mortgagee or incumbrancee to make an application for foreclosure in case such sale proved abortive; and such application shall be accompanied by such proof of the matters stated by the applicant and by such other evidence as the registrar may require.

(7) Unless the registrar shall see fit to order otherwise the notice, whether of intention to sell or to apply for a foreclosure order, shall be served personally on such owner, mortgagor or incumbrancer and such other persons interested as aforesaid; but in case he or they cannot after due diligence be found the registrar may direct service of such notice by leaving the same on the mortgaged lands or by mailing the same in a sealed envelope by registered post directed to him or them at his or their last known address or in such other manner as the registrar may direct.

(8) Upon such application the registrar may if he considers it proper cause notice to be published once in each of three consecutive wecks in such newspaper or newspapers as the registrar may direct and in two consecutive issues of The Saskatchewan Gazette offering such land for private sale; and the registrar shall appoint a time not less than one month from the date of the first of such advertisements or in case there is no advertisement not less than one month from the date of such application, upon and after which he may issue to such applicant an order of foreclosure unless in the interval a sufficient amount of money has been obtained from the sale of such land or paid by or on behalf of such owner, mortgagor or incumbrancer or other person as aforesaid to satisfy the principal and interest and other moneys secured and all expenses occasioned by such sale and proceedings; and every such order of foreclosure under the hand of the registrar when entered in the register shall have the effect of vesting in the mortgagee or his transferee the land mentioned in such order free from all right and equity of redemption on the part of the owner, mortgagor or incumbrancer or any person claiming through or under him subsequently to the mortgage or incumbrance; and such mortgagee, incumbrancee or transferee shall upon such entry being made be cleemed a transferee of the land and become the owner thereof and be entitled to receive a certificate of title for the same. 
(9) Where a mortgagor is entitled to redeem he shall have the power to require the mortgagee instead of giving the receipt or discharge in form $I$ in the schedule to this Act to transfer the mortgage to any third party as the mortgagor directs and the mortgagee shall be bound to transfer such mortgage to such third party in form Q of this Act. 1908-9, c. 9, $\$ 7$.

(10) In case default has occurred in making any payment due under any mortgage or in the observance of any covenant contained therein and under the terms of the mortgage by reason of such default the whole principal and intcrest secured thereby shall have become due and payable, the mortgagor may notwithstanding any provisions to the contrary and at any time prior to sale or foreclosure under a mortgage perform such covenant or pay such arrears as may be in default under the mortgage together with costs to be taxed by the registrar and he shall thereupon be relieved from the consequences of such default. 1910-11, c. $12, \S 7$.

94. Upon the production of any mortgage or incumbrance having indorsed thereon or attached thereto a receipt or acknowledgment in form I in the schedule to this Act signed by the mortgagee or incumbrancee and proved by the affidavit of an attesting witness discharging the whole or any part of the land comprised in such instrument from the whole or any part of the principal sum or annuity secured thereby or upon proof being made to the satisfaction of a juclge of the payment of all or part of the moneys due on any mortgage or incumbrance and the production to the registrar of a certificate signed by the judge to that effect the registrar shall make an entry on the certificate of title noting that such mortgage or incumbrance is discharged wholly or partially or that part of the land is discharged as aforesaid as the case requires:

Provided that the registrar may register such receipt and make such entry without the production of any mortgage or incumbrance if satisfied that there is no such mortgage or incumbrance that could be produced by the mortgigor.

(2) Upon such entry being so made the land or the estate or interest in the land or the portion of the land mentioned or referred to in such indorsement as aforesaid shall eeise to be subject to or liable for such principal sum or ammity or, as the case may be, for the part there of mentioned in such entry as discharged. 1906, c. $24, \S 104$.

95. Upon proof of the death of the annuitant or of the event or circumstance upon which in accordance with the 
provisions of any incumbrance the annuity or sum of money thereby secured ceases to be payable and upon proof that all arrears of the said annuity and interest or money have been paid, satisfied or discharged or upon the order of the judge the registrar shall make a memorandum upon the certificate of title in the register and on the duplicate certificate that such annuity or sum of money is satisfied and discharged and shall eancel such instrument.

(2) Upon such memorandum being made the land shall cease to be subjeet to or liable for such annuity or sum of money. 1906 , с. $24, \S 105$.

96. If any mortgagor becomes entitled to pay off the mortgage money and the registered mortgagee is absent from Saskatchewan and there is no person authorized by registered power of attorney to give a reeeipt to the mortgagor for the mortgage money after the date appointed for the redemption of any mortgage the judge on application to him and proof of the faets and of the amount due for principal and interest upon the mortgage may direct the payment into a chartered bank having a branch or ageney in the registration district of the mortgage money with all arrears of interest then due thereon to the credit of the mortgagee or other person entitled thereto.

(2) If there is no branch or agency of any chartered bank in the district payment shall be made into a chartered bank having a branch or agency in Saskatchewan. 1906, c. 24, § 106.

97. The registrar shail upon presentation of the judge's order and of the receipt of the manager or agent of the bank for the amount of the said mortgage money or interest make a memorandum upon the certificate of title in the register describing such mortgage, stating the day, hour and minute on which such memorandum is made.

(2) Such memorandum shall be a valid discharge of the mortgage.

(3) The registrar shall when such order and receipt are presented to him send a notice of the fact to the mortgagee hy letter addressed by mail to his last known place of abode.

(4) The registrar shall indorse on the duplicate certificate of title and also on the mortgage whenever those instruments are produced to him the several particulars to be indorsed upon each of such instruments respectively.

(5) After payment as aforesaid of any mortgage money and interest the interest upon the mortgage shall cease to run 
or acerue and the mortgagee entitled thereto shall not recover any further sum in respeet of such mortgage than the amount so paid. 1906, c. $24, \S 107$.

98. Mortgages, incumbrances and leases of land for which a certificate of title has been granted may be transferred by a transfer executed in form $Q$ in the schedule to this Act.

(2) The transfer shall be registered in the same manner as mortgages, incumbrances and leases are registered.

(3) Transferees shall have priority aceording to the time of registration. 1906, c. $24, \S 108$.

(4) In case of a mortgage by a mortgagee of his estate or interest in a mortgage the person in whose favor such charge is ereated shall be deemed the transferee of such estate or interest and shall have all rights and powers as such subject to the provisos and conditions expressed in the instrument creating the charge or implied therein by virtue thereof. 1912 , c. $16, \S 4$.

99. Any mortgagee may transfer a part of the sum secured by the mortgage by a transfer exeeuted in form $R$ in the schedule to this Act and the part so transferred shall continue to be secured by the mortgage and may be given priority over the remaining part or may be deferred or may continue to rank equally with it under the security of the origind mortgage as stated in the transfer.

(2) The registrar shall enter on the certificate of title and on the duplicate certificate a memorandum of the amount of the mortgage so transferred, the name of the transferee and how the sum. so transferred is to rank and shall notify the mortgagor of the facts. 1906, c. $24, \S 109$.

100: Upon the registration of a transfer of any mortgage, incumbrance or lease the estate or interest of the transferor as set forth in such instrument with all rights, powers and privileges thereto belonging or appertaining shatl pass to the transferee; and such transferee shall thereupon become subject to and liable for all and every the same requirements and liabilities to which he would have been subject and liable if named in such instrument. 1906, c. 24, \&110.

101. By virtue of every such transfer the right to sue upon any mortgage or other instrument and to recover any debt, sum of money, annuity or damages thereunder and all interest at the time of such transfer in any such debt, sum of money, annuity or damages thereunder shall be transferred so as to vest the same in law in the transferee thercof: 
Provided that nothing herein contained shall prevent the court from giring effect to any trusts affecting the said debt, sum of money, annuity or damages in case the said transferee shall hold the same as trustee for any other person. 1906, c. $24, \S 111$.

102. In every mortgage there shall be implied against the mortgagor remaining in possession a covenant that he will repair and licep in repair all buildings or other improvements ereeted and made upon the land and that the mortgagee may at all convenient times until the mortgage is redeemed be at liberty with or without surveyors or others to enter into or upon the land to view and inspect the state of repair of the buildings or improvements. 1906, e. 24, § 112.

103. Whenever in a mortgage made under this Act the form of words in column one of form $\mathrm{H}$ in the schedule to this Aet and distinguished by any number therein are used such mortgage shall be taken to have the same effect and be construed as if there had been inserted therein the form of words contained in eolumn two of the said form and distinguished by the same number; but it shall not be necessary in any such mortgage to insert any such number.

(2) Every such form shall be deemed a covenant by the mortgagor with the mortgagee and his transferee binding the former and his heirs, exeeutors, administrators and transferees; and there may be introduced into or annexed to any of the forms in the first column any expressed exceptions from the same or expressed qualifieations there of respectively and the like exception or qualification shall be taken to be made from or in the corresponding forms in the second column. 1906 , e. $24, \& 113$.

\section{POWERS OF ATTORNEY.}

104. The owner of any land may authorize and appoint any person to act for him or on his behalf with respect to the transfer or other dealing with such land or with any part there of in accordance with the provisions of this Act by executing a power of attorney in form $N$ in the schedule to this Act or as near thereto as circumstances permit or in any form heretofore in use for the like purpose in which the land is not specifically mentioned and described but is mentioned and reforred to in general terms any of which forms of power of attorney the registrar shall file or register as the cireumstances of the ease may require. 
(2) If the land referred to in any form of power of attorney is specifically and properly described the registrar shall make a memorandum upon the certificate of title and upon the duplicate certificate of the particulars therein contained and of the time of its registration.

(3) Until such power of attorney in which the land referred to is so specifically described is revolied by a revocation in form $\mathrm{O}$ in the schedule to this Act the right of the owner to transfer or to otherwise deal with the land shall be suspended.

(4) The execution or registration of a general power of attorney shall not in any way affect the right of the owner to transfer or otherwise deal with his land. 1906, c. $24, \S 114$.

105. The registrar is hereby empowered to recognize for the purpose for which it was executed in so far as it concerns any land in his district belonging to the person who executed it any power of attorney which is in the general form referred to in the last preceding section and which has heretofore been or shall hereafter be deposited, filed or registered in any land titles office in any registration district.

(2) Where an original power of attorney in any form mentioned in the last preceding section las heretofore been or shall hereafter be deposited, filed or registered in one land titles office a copy thereof certified as such by the registrar in whose office it is of record may be accepted by any other registrar in lieu of the original and be recognized by him for the purpose for which the original power of attorney was executed in so far as it affects any land in the district of the last mentioned registrar belonging to the person who executed it. 1906 , c. $24, \S 115$.

106. The registrar shall keep a book in convenient form in which shall be entered according to the respective dates of the receipt thereof in his office a record of all powers of attorney or duly certified copies of powers of attorney deposited, filed or received in his office.

(2) Such book shall be kept in alphabetical order so as to show the names of all persons whose lands are or are intended to be affected by such powers and the day, hour and minute of their receipt by him. 1906 , c. $24, \S 116$.

107. Any such power of attorney may be revoked by a revocation in form $\mathrm{O}$ in the schedule to this Act.

(2) The registrar shall not give effect to any transfer or other instrument signed pursuant to sueh power of attorney after the registration of a revocation of such power unless executed prior to such revocation. 1906, c. $24, \$ 117$. 
TRANSMISSION.

108. Whenever the owner of any land for which a certificate has been granted dies such land shall subject to the provisions of this Act vest in the personal representative of the deceased owner.

(2) Such personal representative shall before dealing with such land make application in writing to the registrar to be registered as owner and shall produce to the registrar the probate of the will of the deceased owner or letters of administration or the order of the court authorizing him to administer the estate of the deceased owner or a duly certified copy of the said probate, letters of administration or order, as the case may be, and shall deposit with the registrar a sworn copy thereof, and thereupon the registrar shall enter a memorandum there of upon the certificate of title.

(3) For the purposes of this Act the production of the probate of a will granted by the proper court of any province or territory of Canada or of the United Kingdom of Great Britain and Ireland resealed under the direction of a judge of a surrogate court and the deposit with the registrar of a sworn copy thereof shall be sufficient. 1906 , c. $24, \$ 118 ; 1907$, c. 32 , $\S 9 ; 1908$, c. $29, \S 8$.

109. Upon such memorandum being made the executor or the administrator, as the case may be, shall be deemed to be the owner of the land.

(2) The registrar shall note the fact of the registration by a memorandum under his hand on the probate of the will, letters of administration, order or other instrument. 1906, c. 24, $\S 119$.

110. The title of the executor or administrator to the land shall relate back and take effect as from the date of the death of the deceased owner. 1906 , c. $24, \S 120$.

111. The duplicate certificate of the title issued to the deceased omner at the time of the making of the application shall be delivered up to be cancelled or be proved to have been lost or destroyed and the registrar shall grant to the executor or administrator as such a new certificate of title and issue to him a duplicate certificate. 1906 , c. $24, \$ 121$

112. Whenever any mortgage, incumbrance or lease affecting land for which a certificate of title has been granted is transmitted in consequence of the will or intestacy of the owner thereof the probate of the will of the deceased owner 
or letters of administration or the order of the court authorizing a person as aforesaid to administer the estate of the deceased owner or a certified copy of the said probate, letters of administration or order, as the case may be. accompanied by an application in writing from the executor or administrator or such other person as aforesaid claiming to be registered as owner in respect of such estate or interest shall be produced to the registrar and a sworn copy thereof deposited with him and the registrar shall thereupon make a memorandum upon the certificate of title and upon the duplicate thereof of the date of the will and of the probate or of the letter's of administration or order of the court as aforesairt, the date, hour and minute of the production of the same to him and of such other particulars as he deems necessary. 1906, c. 24, 123; 1908, c. $29, \S 9$.

113. Upon such memorandum being made the executor or administrator or such other person, as the case may be, shall be deemed to be the owner of the mortgatge, incumbrance ol lease.

(2) The registrar shall note the fact of the registration by memorandum under his hand on the letters of administration, probate or order. 1906 , c. $24, \S 124$.

114. Any person registered in place of a deceased owner shall hold the land in respect of which he is registered upon the trusts and for the purposes to which the same is applicable by this Act or by law and subject to any trusts and equities upon which the deceased owner held the same; but for the purpose of any registered dealings with such land he shall be deemed to be the absolute and beneficial owner thereof. 1906 . c. $24, \S 125$.

115. Any person beneficially interested in any such land may apply to a court or judge having jurisdiction to have the same taken out of the hands of the trustee having chirge by law of such land and transferred to some other person or persons; and the court or judge upon reasomable cause being shown shall name some suitable person or persons as owner of the land; and upon the person or persons so named accepting the ownership and giving approved security for the due fulfilment of the trusts the court or a juclge mav order the registrar to cancel the certificate of title to the trustee and to grant a new certificate to the person or persons so mamed. 1906, c. $24, \S 126$.

116. The registrar upon the production of such order shall cancel the certificate of title to the trustee after making thereon 
and upon the duplicate thercof a memorandum of the appointment by order of the court or judge of such person or persons as owncrs and shall grant a new certificate of title to such new trustce and issue to him a duplicate certificate of title. 1906, c. $24, \S 127$.

117. Upon any assignment under the provisions of The Assignments Act being made by the owner of any land (for which a certificate of title has been granted), mortgage or incumbrance for the benefit of his creditors the assignee of such owner may file such assignment and may at any time thereafter make an application to the registrar to be registered as owner of any such land, mortgage or incumbrance and the registrar may pursuant to such application transmit any such land, mortgage or incumbrance to such assignee who shall thereupon become the owner thereof; and from and after the receipt by the registrar of such assignment the registrar shall not permit any dealings with any such lands, mortgage or incumbrance by the person making such assignment nor shall he register any transfer, mortgage, lease or any other instrument made or executed by such person affecting the same or any part thereof:

Provided howerer that the provisions of this section shall not affect any lands of the person making such assignment which are exempt from seizure or sale under execution or other legal proceeding under any law in force in the province at such time but with respect to lands so exempt the registrar shall permit the person making such assignment to deal with the same as if such assignment had not been filed upon such person furnishing to the registrar within thirty days after the filing of such assignment a description in writing of the lands claimed to be so exempt which description shall be signed by such person and attested by a witness and shall state that the lands described therein are claimed to be exempt as aforesaid and such description shall be accompanied by the written consent or approval of the assignee (and satisfactory in form to the registrar) to the effect that the assignee agrees that the lands contained in such description and claimed to be so exempt are exempt or in lieu of such consent by the assignee the same shall be accompanied by an order of the judge declaring the lands so described or such portion there of as the judge thinks proper to be so exempt. 1906, c. $24, \S 128$.

\section{EXECUTIONS.}

118. The sheriff or other duly qualified officer after the lelivery to him of any exccution or other writ then in force 
affecting land if a copy of such writ has not already been delivered or transmitted to the registrar shall on payment to him by the execution creditor named therein of fifty cents together with the amount of the registrar's fee forthwith deliver or transmit by registered letter to the registrar a copy of the writ and of all indorsements thereon certified under his hand and seal of office, if any, together with such registration fee.

(2) Such writ shall bind the land covered thereby only from the time of the receipt of a certified copy thereof by the registrar for the registration district in which such land is situated.

(3) From and after the receipt by the registrar of such copy no certificate of title shall be granted and no transier, mortgage, incumbrance, lease or other instrument executed by the execution debtor of such land shall be effcctual except subject to the rights of the execution creditor under the writ while the same is legally in force.

(4) The registrar on granting a certificate of title and on registering any transfer, nortgage or other instrument executed by the execution debtor affecting such land shall by memorandum upon the certificate of title in the register and on the duplicate issued by him express that such certificate, transfer, mortgage or other instrument is subject to such rights.

(5) Every writ received by the registrar of any district at the expiration of two years from the date of the receipt thereof shall cease to bind or affect the land of the execution debtor in such district unless before the expiration of such period of two years a renewal of such writ is filed with the registrar in the same manner as the original is required to be filed with him. 1906 , c. $24, \S 129 ; 1908$, c. $29, \S 10$.

119. The registrar shall keep a book in convenient form in which shall be entered according to the dates when respectively received a record of all copies of writs received by him from the sheriff or other officer; and such book shall be kept indexed showing in alphabetical order the names of the persons whose lands are affected by such writs with the day and hour and minute of such receipt. 1906, c. $24, \S 130$.

120. Upon the satisfaction or withdrawal from his hands of any writ the sheriff or other duly qualified officer shall forthwith transmit to the registrar a certificate under his official seal, if any, to the effect that such writ has been satisfied or withdrawn; and upon the expiration of a writ of exccution or upon the production and delivery to the registrar of such 
a certificate or of a judge's order showing the satisfaction or withdrawal of the writ as against the whole or any portion of the land so bound the registrar shall make a memorandum upon the certificate of title of such expiration or to the effect so certified or shown if a certificate of title has been issued for such land and whether a certificate of title has been issued or not upon or opposite to the entry of the writ in the book to be kept under the provisions of the next preceding section.

(2) Thenceforth such land or portion of land shall be deemed to be absolutely released and discharged from the writ. 1906, c. $24, \S 131$.

\section{SIIERIFF'S SALE.}

121. No sale by a sheriff or other officer as aforesaid under process of law of any land for which a certificate of title has been granted shall be of any effect until the same has been confirmed by the court or a judge.

(2) When any such land is sold under process of law the registrar upon the production to him of the transfer of same in form $\mathrm{S}$ in the schedule to this Act with proof of the due execution thereof and with an order of the confirmation of such sale indorsed upon the transfer or attached thereto shall after the expiration of fou weeks after receiving the same unless such registration is in the meantime stayed by the order of the court or judge register the transfer, cancel the existing certificate of title wholly or in part if less than the whole of the land comprised therein be sold, grant a certificate of title to the transferee and issue to him a duplicate certificate.

(3) In case the registration shall have been so stayed the registration shall not be made except according to the order and direction of the said court or judge. 1906, c. $24, \S 132$.

122. A transfer of such land so sold under process of law or for arrears of taxes as hereinafter provided shall not be registered after a period of two months from the date of the order of confirmation unless the period be extended by order of the court or a jurlge filcd with the registrar.

(2) Such transfer if not registered within that period or within the time fixed by such order shall cease to be valid as against the owner of the land so sold and any person or persons claiming by, from or through him. 1906, e. $24, \S 133 ; 1908$, c. $29, \S 11$.

123. The application for confirmation of a sale of such land so made under any process of law may be made by the sheriff or other officer making the sale or by any person interested 
in the sale on notice to the owner unless the judge to whom the application is made dispenses with such notice.

(2) If the sale is confirmed the costs of confirmation shall be borne and paid out of the purchase money or as the judge directs.

(3) In case the sale is not confirmed the purchase money paid by him shall be refunded to the purchaser and the judge may make such order as to the costs of all parties to the sale and of the application for its confirmation as he thinks just. 1906, c. $24, \S 134$.

\section{SALE FOR TAXES.}

124. When any land for which a certificate of title has been granted is sold for taxes the purchaser may at any time after the sale lodge a caveat against the transfer of the land.

(2) Upon the completion of the time allowed by law for redemption and upon the production of the transfer of the land in form $\mathrm{S}$ in the schedule to this Act with proof of the due execution thereof by the proper officer and a judge's order confirming such sale the registrar shill after the expiration of four weeks from the delivery to him of the transfer and judge's order of confirmation register the transferee as absolute owner of the land so sold and shall cancel the certificate of title in whole or in part as the ease requires, shall grant a new certificate of title to the transferee and issue to the purchascr a duplicate certificate unless the registration has in the meantime been stopped by order of a judge. 1906, c. $24, \S 135$.

CAVEATS.

125. Any person claiming to be interested in any land under any will, settlement or trust deed or under any instrument of transfer or transmission or under any unregistered instrument or under an execution where the execution ereditor seeks to affect land in which the execution debtor is interested beneficially but the title to which is registered in the name of some other person or otherwise may lodge a caveat with the registrar to the effect that no registration of any transfer or other instrument affecting the said land shall be made and that no certificate of title therefor shall be granted until such caveat has been withdrawn or has lapsed as hereinafter provided unless such instrument or certificate of title is expressed to be subject to the claim of the caveator as stated in such caveat:

Provided that no caveat which has heretofore been or that may hereafter be lodged shall be deemed to be insuffieient for 
the purposes of the lodgment thereof merely upon the ground that the interest claimed therein is not shown to be derived from the registered owner of the land affected. 1912, c. 16, $\S 5$.

(2) On, from and after the first day of January, 1910, no caveat may be lodged with the registrar which has annexed thereto or indorsed thereon or which refers to or is founded upon a writing or any part thereof within the meaning of the Act respecting Lien Notes and Conditional Sales of Goods or any written order, contract or agreement for the purchase or delivery of any chattel or chattels. $1910-11$, c. $12, \S 8$.

(3) Every such writing and every such written order, contract or agreement for the purchase or delivery of any chattel or chattels made or entered into on, from and after the first day of January, 1910, shall on, from and after the said day whether or not it is the subject-matter of a claim by way of caveat under the provisions of this Act be in so far as it affects or purports to affect land in Saskatchewan absolutely null and void to all intents and purposes whatsoever anything contained in any Act to the contrary notwithstanding.

(4) If by inadvertence, accident or the non-performance of duty on the part of the registrar or otherwise howsoever a caveat is lodged with the registrar contrary to the provisions of this section such lodgment shall nevertheless be absolutely null and void to all intents and purposes whatsoever. 1906, c. $24, \S 136 ; 1909$, c. $20, \S 11$.

126. A caveat shall be in form $\mathrm{T}$ in the schedule to this Act and shall be verified by the oath of the caveator or his agent and shall contain an address within Saskatchewan at which notices may be served. 1906 , c. $24, \S 137 ; 1912$, c. 16 , $\S 6$.

127. Upon the receipt of a caveat the registrar shall enter the same in the day book and shall make a memorandum thereof upon the certificate of title of the land affected by such caveat and shall forthwith send a notice of the caveat through the post office or otherwise to the person against whose title the caveat has been lodged.

(2) In the case of a caveat before registration of a title under this Act the registrar shall on receipt thereof enter the same in the day book. 1906 , c. $24, \S 138$.

128. So long as any caveat remains in force the registrar shall not enter in the register any memorandum of any transfer or other instrument purporting to transfer, incumber or other- 
wise deal with or affect the land in respect to which such caveat is lodged except subject to the claim of the caveator. 1906 , c. $24, \S 139$.

129. The owner or other person claiming any interest in such land may by summons call upon the caveator to attend before a judge to show cause why the caveat should not be withdrawn; and the said judge may uron proof that such last mentioned person has been summoned and upon such evidence as the judge requires make such order in the premises as to the said judge seems fit. 1906 , c. $24, \S 140 ; 190 \$-9$, c. $9, \S 9$.

130. Subject to the provisions of the preceding section such caveat shall continue unless and until it is removed as hereinafter set forth, namely: The owner or other person elaiming any interest in such land may require the registrar by notice in writing which shall be in form $\mathrm{I}$ in the schedule to this Act to notify the caveator at his address for service as set forth in the caveat that such caveat shall lapse at the expiration of thirty days from the mailing of such notice by the registrar unless within said thirty days the caveator shall file with the registrar an order made by the judge providing for the continuing beyond the said thirty days of said caveat and in the event of such order not being filed with the registrar within the said thirty days such careat shall lapse and shall be treated as lapsed by the registrar; the notice hereinbefore provided to be given by the registrar shall be by registered letter. 1906 , c. $24, \S 141 ; 1908-9$, с. $9, \S 10$.

Provided, however, that whenever the registrar is satisfied that any interest in such land other than the interest therein of the caveator is protected by such caveat he may refuse to notify the caveator as required by this section and in such case the removal of such caveat shall be subject only to the provisions of section 129 hereof. 1912, c. $16, \$ 7$.

131. The caveator may by notice in writing to the registrar withdraw his caveat at any time; but notwithstanding such withdrawal the court or judge may order the payment by the caveator of the costs of the caveatee incurred prior to such withdrawal. 1906, c. $24, \S 142$.

132. A memorandum shall be made by the registrar upon the certificate of titie and upon the duplicate certificate of the withdrawal, lapse or removal of any eaveat or of any order made by the court or a judge in connection therewith.

(2) After such withdrawal, lapse or removal it shall not be lawful for the same person or for any one on his behalf to 
lodge a further caveat in relation to the same matter unless by leave of the judge. 1906, c. $24, \S 143$.

133. Any person lodging or continuing any caveat wrongfully and without any reasonable cause shall be liable to make compensation to any person who has sustained damage thereby.

(2) Such compensation with costs may be recovered by proceedings at law if the caveator has withdrawn such caveat and no proceedings have been taken by the caveatee as herein provided.

(3) If proceedings have been taken by the caveatee then the compensation and costs shall be determined by the court or judge acting in the same proceedings. 1906 , c. $24, \S 144$.

\section{ATTESTATION OF INSTRUMENTS.}

134. Every instrument executed within the limits of Saskatchewan except instruments under the seal of any corporation, caveats, orders of a court or judge, executions or certificates of any judicial proceedings attested as such requiring to be registered under this Act shall be witnessed by one person who shall sign his name to the instrument as a witness and who shall appear before the master of titles or the registrar or deputy registrar of the registration district in which the land is situated or before a judge, notary public, commissioner for oaths or a justice of the peace in and for Saskatchewan and make an affidavit in form $U$ in the schedule to this Act. 1906 , c. $24, \S 145$; 1909 , c. $20, \S 1$.

135. Every instrument executed without the limits of Saskatchewan except grants from the Crown, orders in council, instruments under the seal of any corporation or caveats required to be registered under the provisions of this Act shall be witnessed by one person who shall sign his name to the instrument as a witness and who shall appear and make an affidavit in form $U$ in the schedule to this Act before one of the following persons:

(a) If made in any province in Canada before a judge of any court of record, any commissioner authorized to take affidavits in such province for use in any court of record in Saskatchewan or before any notary public under his official seal; or

(b) If made in Great Britain or Ireland before a judge of the Supreme Court of Judicature in England or Ireland or of the Court of Sessions or of the Judiciary Court in Scotland or a judge of any of the county 
courts within his county or the mayor of any city or incorporated town under the common seal of such city or town or before any commissioner in Great Britain or Ireland authorized to take affidavits therein for use in any court of record in Saskatchewan or a notary public under his official seal; or

(c) If made in any British colony or possession out of Canada before a judge of any court of record, the mayor of a city or incorporated town under the common seal of such city or town or notary public under his official seal; or

(d) If made in any foreign country before the mayor of any city or incorporated town under the common seal of any such city or town or before the British consul, vice consul or consular agent residing therein or before any judge of any court of record or a notary public under his official seal. 1906, c. $24, \S 146$.

\section{EJECTMENT.}

136. No action of ejectment or other action for the recovery of any land for which a certificate of title has been granted shall lie or be sustained against the owner under this Act in respect thereof except in the case of:

(a) A mortgagee as against a mortgagor in default;

(b) An incumbrancee as against an incumbrancer in default;

(c) A lessor as against a lessee in default;

(d) A person deprived of any land by fraud as against the owner of such land through fraud or as against a person deriving otherwise than as a transferee bona fide for value from or through such owner through fraud;

(e) A person deprived of or claiming any land included in any grant or certificate of title of other land by misdescription of such other land or of its boundaries as against the owner of such other land;

(f) An owner claiming under an instrument of title prior in date of registration under this Act in any case in which two or more grants or two or more certificates of title or a grant and certificate of title are registered under this Act in respect to the same land.

(2) In any case other than aforesaid the production of the duplicate certificate of title or a certified copy of the certificate 
of title shall be an absolute bar and estoppel to any such action against the person named in such certificate of title as owner or lessee of the land therein described. 1906, c. $24, \S 147$.

\section{DAMAGES.}

137. After a certificate of title has been granted for any land any person deprived of such land in consequence of fraud or by the registration of any other person as owner of such land or in consequence of any fraud, error, omission or misdescription in any certificate of title or in any memorandum thereon or the duplicate thereof or otherwise, may:

(a) If the land has been included in two or more grants from the Crown; and

(b) In any other case;

bring and prosecute an action at law for the recovery of damages against the person upon whose application the erroneous registration was made or who acquired title to the land in question through such fraud, error, omission or misdescription.

(2) Except in the case of fraud or error occasioned by any omission, misrepresentation or misdescription in the application of such person to be registered as owner of such land or in any instrument executed by him, such person shall upon a transfer of such land bona fide for value cease to be liable for the payment of any damages which but for the transfer might have been recovered from him under the provisions hereinbefore contained.

(3) Such damages with costs may in such last mentioned case be recovered out of the assurance fund hereinafter provided for by action against the registrar as nominal defendant. 1906 , c. $24, \S 148$.

138. Except in the case of misdescription of the land or its boundaries anything in this Act to the contrary notwithstanding no bona fide purchaser or mortgagee under this Act of land for valuable consideration shall be subject to action for recovery of damages as aforesaid or to action of ejectment or to deprivation of land in respect of which he is registered as owner on the ground that his transferor or mortgagor has been registered as owner through fraud or error or has derived from or through a person registered as owner through fraud or error. 1906 , c. $24, \S 149$.

139. If the person against whom the action for damages is directed to be brought as aforesaid is dead or cannot be found within the province an action for damages may be brought 
against the registrar as nominal defendant for the purpose of recovering the amount of the said damages and costs against the said assurance fund.

(2) In any such case if final judgment is recovered and also in any case in which damages are awarded in any action as aforesaid and the sheriff makes a return of nulla bona or certifies that any portion thereof with costs awarded cannot be recovered from such person the provincial treasurer upon receipt of a certificate of the judge before whom the said action was tried shall pay the amount of such damages and costs as are awarded or the unrecoverable balance thereof, as the case may be, and shall charge the same to the account of the said assurance fund. 1906, c. $24, \S 150$.

140. Any person sustaining loss or damage through any omission, mistake or misfeasance of the master of titles or a registrar or any of his officers or clerks in the execution of their respective duties under the provisions of this Act and any person deprived of any land by the registration of any other person as owner thereof or by any error, omission or misdescription in any certificate of title or in any memorandum upon the same or upon the duplicate certificate thereof and who by the provisions of this Act is barred from bringing an action of ejectment or other action for the recovery of the land may in any case in which remedy by action for recovery of damages hereinbefore provided is barred bring an action against the registrar as nominal defendant for the recovery of damages.

(2) If the plaintiff recovers final judgment against such nominal defendant the judge before whom such action is tried shall certify to the fact of such judgment and the amount of the damages and costs recovered and the provincial treasurer shall pay the amount thereof out of the assurance fund aforesaid to the person entitled on production of an exemplification or certified copy of the judgment rendered.

(3) Notice in writing of every such action and the cause thereof shall be served upon the attorney general of Saskatchewan and also upon the registrar at least thrce calendar months before the commencement of such action. 1906, c. 24, $\S 151$.

141. If in any such action judgment is given against the plaintiff or the plaintiff discontinues or the action is dismissed he shall be liable to pay the full costs of defending the action and the same when taxed shall be levied in the name of the 
nominal defendant by the like process of execution as in ordinary eivil cases. 1906 , e. $24, \$ 152$.

142. No action for recovery of damages sustained through deprivation of land shall lie or be sustained against the registrar or against the assurance fund aforesaid unless the same is commenced within the period of six years from the date of such deprivation:

Provided that any person under the disability of infancy, lunacy or unsoundness of mind may bring the action within six years from the date on which the disability ceased. 1906 , c. $24, \S 153$.

143. The plaintiff in the action within six years from the date on which such disability ceased and the plaintiff in any such action at whatever time it is brought and the plaintiff in any action for the reeovery of land shall be nonsuited in any case in which it appears to the satisfaction of the judge before whom such action is tried that the plaintiff or the person through or under whom he elaims title had notice by personal service or otherwise was aware of such delay and wilfully or collusively omitted to lodge a caveat or allowed the caveat to lapse. 1906 , e. $24, \S 154$.

144. Whenever any amount has been paid out of the said assurance fund on account of any person the amount may be recovered from him or if dead from the estate of such person by action against his personal representatives in the name of the registrar.

(2) Upon such suit a certificate signed by the provincial treasurer of the payment out of such assurance fund shall be sufficient proof of such debt. 1906, c. $24, \S 155$.

145. Whenerer any amount has been paid out of the assurance fund on account of any person who has abseonded or who camnot be found within Saskatchewan and has left any* real or personal fotate within the same upon the application of the registrar and upon the production of a certificate signed by the provincial treasurer that the amount has been paid in satisfaction of a judgment against the registrar as nominal defendant and on proof of service of the writ in any of the modes provided by the ordinary procedure in Saskatchewan a judge may allow the registrar to sign judgment against such person forthwith for the amount so paid out of the said assurance fund together with the costs of the application.

(2) snch judgment shall be final subjeet only to the right to have such judgment opened up as may be provided in 
relation to ordinary procedure in Saskatchewan in cases of judgment by default.

(3) The judgment shall be signed in like manner as a final judgment by default in an adverse suit and execution may issue immediately. 1906, c. $24, \S 156$.

PETITION, REFERENCE, SUMMONS, ETC.

146. If any person is dissatisfied with any aet, omission, refusal, decision, direction or order of a registrar such person may require the registrar to set forth in writing under his hand the grounds of such act, omission, refusal, decision, direction or order and such person may then apply to the master of titles by petition setting forth the grounds of his dissatisfaction.

(2) The master of titles having caused the registrar to be served with a copy of the petition shall have jurisdiction to hear the said petition and to make such order in the premises and as to the costs of the parties appearing upon the petition as the cireumstanees of the ease require. 1906, c. $24, \S 158$; $1908-9$, е. $9, \S 3 ; 1909$, с. $20, \S 1$.

147. The registrar may:

(a) Whenever a question arises with regard to the performance of any duty or the exereise of any function by this Act conferred or imposed upon him; or

(b) Whenever in the exereise of any duty of a registrar a question arises as to the true construetion or validity or effect of any instrument or as to the persons entitled or as to the extent or nature of the estate, right or interest, power or authority of any person or class of persons; or

(c) Whenever a question arises as to the mode in which any entry or memorandum ought to be made in the day book or register or upon any certificate of title or duplicate thereof; or

(d) Whenever a question arises as to any doubtful or uncertain right or interest stated or elaimed to be dealt with by a registrar;

refer the same in form $\mathrm{V}$ in the schedule to this Act to the master of titles.

(2) The master of titles may upon the same being referred allow any of the parties interested to appear before him and summon any other of such persons to appear and show eause either personally or by adrocate in relation thereto. 
(3) The master of titles having regard to the persons appearing before him whether summoned or not shall decide the question or direct any proceedings to be instituted for that purpose and direct the particular form of entry or memorandum to be made as under the circumstances appears to be just. 1906 , с. $24, \S 159 ; 1908-9$, с. $9, \S 3 ; 1909$, c. $20, \S 1$.

148. If under section 44 or any of the other provisions of this Act the registrar requires a duplicate certificate for the purpose of making any memorandum thereon or for the purpose of wholly or partially cancelling the same or if it appears to the satisfaction of the registrar:

(a) That any duplicate certificate or other instrument has been issued in error or contains any misdescription of land or boundaries; or

(b) That any entry, memorandum or indorsement has been made in error or omitted from any duplicate certificate or other instrument; or

(c) That any such duplicate certificate, instrument, entry, memorandum or inclorsement has been fraudulently or wrongfully obtained; or

(d) That any such duplicate certificate or instrument is fraudulently or wrongfully retained;

he may by written demand in form $\mathrm{W}$ in the schedule to this Act to be served upon such person or to be mailed to his last known post office address within Saskatchewan require the person to whom such duplicate certificate or instrument has been so issued or by whom it has been so obtained or is retained to deliver up the same for the purpose of being cancelled, corrected or completed as the case requires.

(2) In case such person refuses or neglects to comply with such requisition or cannot be found the registrar may apply to a judge to issue a summons for such person to appear before him and show cause why such duplicate certificate or other instrument should not be delivered up to be cancelled, corrected or completed as aforesaid.

(3) If such person when served with the summons personally or in the mode directed in such summons neglects or refuses to attend before the judge at the time therein appointed the judge may issue a warrant authorizing and directing the person so summoned to be apprehended and brought before the said judge for examination. 1906, c. $24, \S 160$.

149. Upon the appearance before a judge of any person summoned or brought up by virtue of a warrant as aforesaid 
the judge may examine such person upon oath and in case it appears right so to do may order such person to deliver up the duplicate certificate or other instrument as aforesaid.

(2) Upon refusal or neglect by such persun to deliver up the same pursuant to the order or to be put under oath or to be examined or to answer any question touching the matter after being sworn the judge may commit such person to the nearest common jail for any period not exceeding six months unless the duplicate certificate or other instrument is sooner delivered up or sufficient explanation is made why the same cannot be done.

(3) In such case or in case such person has absconded so that summons cannot be served upon him as hereinbefore directed or in case a period of three months from the time of mailing the said demand in said form $W$ to such person has elapsed before the duplicate certificate or other instrument has been returned to the registrar the judge may direct the registrar to cancel or correct or complete the certificate of title, duplicate certificate or other instrument in his possession or any memorandum thereon relatiug to the land and to substitute and issue if necessary a duplicate certificate or other instrument or make such memorandum as the circumstances of the case require and the registrar shall obey such order. 1906, c. 24, $\$ 161$.

150. In any proceeding respecting land or in respect of any transaction or contract relating thereto or in respect of any instrument, caveat, memorandum or entry affecting land the judge by decree or order may direct the registrar to cancel, correct, substitute or issue any duplicate certificate or make any memorandum or entry thereon or on the certificate of title and otherwise to do every act necessary to give effect to the decree or order. 1906, c. $24, \S 162$.

\section{ASSURANCE FUND AND FEES.}

151. Before the registrar shall perform any duty to be by him performed under any of the provisions of this Act he shall except as herein otherwise provided clemand and receive the proper fee or fees therefor as fixed and settled by tariff made from time to time by the Lieutenant Governor in Council and demand and receive for the assurance fund upon the registration of every grant of incumbered land and upon every absolute transfer of land one-fifth of one per cent. of the value of the land transferred if such value amounts to or is less than five thousand dollars and one-tenth of one per cent. on the additional value when such value exceeds five thousand dollars. 
(2) Upon every subsequent transfer he shall demand and receive upon the increase of value since the granting of the last certificate of title one-fifth of one per cent. if the increase is not more than five thousand dollars and one-tenth of one per cent. on any excess over such five thousand dollars. 1906, c. $24, \$ 163$.

152. The value shall be ascertained by the oath or affirmation of the applicant, owner or person acquiring such land or of such other person as the registrar believes to be acquainted with the value of the land and whose oath or affirmation the registrar is willing to accept.

(2) If the registrar is not satisfied as to the correctness of the value so sworn to or affirmed he may require such applicant, owner or person acquiring the land to produce a certificate of the value under the hand of a sworn valuator appointed by the registrar or a judge which certificate shall be received as conclusive evidence of the value for the purpose aforesaid. 1906, c. $24, \S 164$.

153. Each registrar shall keep a correct account of all sums of money received by him in accordance with the provisions of this Act including the assurance fund and shall pay the same to the provincial treasurer at such times and in such manner as are lirected by the Lieutenant Governor in Council. 1906, c. $24, \S 165$.

154. The assurance fund shall be held by the provincial treasurer as trust moners and may be invested from time to time in such securities as may he approved by the Lieutenant (ioveruor in Council.

(2) The provincial treasurer shall credit the fund in each year with interest at such rate as may from time to time be clirected by the Lieutenant Governor in Council.

(3) When the said fund shall have reached the sum of seventy-five thousand dollars any sum in excess of said amount may by clirection of the Licutenant Governor in Council from time to time be transferred to and form part of the consolidated revenue fund of the provinee. 1906 , c. $24, \S 166$.

155. The assurance fund shall not under any circumstances be liable for compensation for any loss, damage or deprivation occasioned:

(a) By the breach by the owner of any trust whether expreserl, implied or constructive; nor 
(b) In any case in which the same land has been included in two or more grants from the Crown; nor

(c) In any case in which loss, damage or deprivation has been occasioned by any land being included in the same certificate of title with other land through misclescription of the boundaries or parcels of any land; unless it is proved that the person liable for compensation and damages is dead or has absconded from the province or has been adjudged insolvent or the sheriff has certified that he is not able to realize the full amount and costs awarded in any action for such compensation;

(d) By reason of the improper use of the seal of any corporation or company or by reason of the registration of any instrument exer!ited by any person under any legal disability unless the fact of such disability was disclosed on the instrument by virtue of which such person was registered as owner.

(2) The said fund shall be liable for such amounts only as the sheriff fails to recover from the person liable an aforesaid. 1906 , c. $24, \S 167 ; 1909$, c. $20, \S 12$.

156. The government of Saskatchewan may accept and receive from the government of Canada such portion of the assurance fund formed under the Act of the Parliament of Canada known as The Territories Real Property Act and continued as the assurance fund by the Act of the Parliament of Canada known as The Land Titles Aet 1894 as the said government of Canada or Governor in Council of Canada may assign, transfer or pay over to the government of Saskatchewan and for the purpose of carrying the provisions of this section into effect the Lieutenant Governor in Council may by order provide for the adjusting of all questions arising between the government of Saskatchewan and the government of Canada in connection with the assignment, transfer or payment over of such portion of the said assurance fund as aforesaid including the giving or executing on behalf of the province all such contracts of indemnity or otherwise as may be found necessiry or expedient. 1908, с. 29, \$12.

CANCELLATION OF CERTIFICATE OF TITLE.

157. Upon the application of any owner of several parcels of land held under separate certificates of title or under one certificate of title and the delivery up of the duplicate or duplicates thereof to him the registrar may cancel the existing 
certificate or certificates of title granted as also the duplicate so delivered up and grant to the owner a single certificate of title for all the parcels of land or several certificates of title each applying to one or more of the parcels in accordance with the application.

(2) Upon each of such respective certificates of title so granted shall be entered a memorandum of each and every incumbrance, lien, charge, mortgage or other instrument affecting such parcel or parcels of land setting forth the occasion of the cancellation and referring to the certificate of title so granted.

(3) The registrar shall issue to the applicant one or more duplicate certificates as the case requires. 1906, c. $24, \S 168$.

158. The registrar in the case of a partially cancelled certifcate of title shall return the duplicate to the transferor after the memorandum partially cancelling the same has been made thereon and upon the certificate of title in the register:

Provided that whenever required by the owner of an unsold portion of land in any partially cancelled certificate of title or where such a course appears to the registrar more expedient he may grant to such owner a certificate of title for such portion of which he is the owner upon the delivery of the partially cancelled duplicate certificate of title to the registrar to be cancelled and retained. 1906 , c. $24, \S 169 ; 1908$, c. 29 , $\S 13$.

\section{LOST OK DESTROYED CERTIFICATE OF TITLE.}

159. Upon the production to the registrar of satisfactory proof by statutory declaration of the person to whom a duplicate certificate has been issued or some one having knowledge of the facts of the accidental loss or destruction of the duplicate certificate so issued the registrar may after having entered in the register the facts so proven issue a fresh duplicate certificate in lieu of the one so lost or destroyed noting upon the same why it is so issued:

Provided that unless the registrar is satisfied as to the loss or destruction of the duplicate certificate so issued and that notice of intention to issue another duplicate certificate in lieu of such alleged lost or destroyed certificate in a newspaper or otherwise is unnecessary no such fresh duplicate certificate shall be issued until the registrar shall for four weeks:

(a) Publish a notice of his intention to issue such fresh certificate in the newspaper published nearest to the land described in the register or if more newspapers than one are published in the same locality then in one of such newspapers; and 
(b) Post up such notices in a conspicuous place in the land titles office. 1906, c. $24, \S 170$.

INFANTS, IDIOTS, LUNATICS.

160. Whenever any person who if not under disability might have made any application, given any consent, done any act or been party to any proceeding under this Act is an infant, idiot or lunatic the guardian or guardians of the estate of such a person may make such application, give such consent, do such act and be party to such proceeding as such person if free from disability might have made, given, done and been party to and shall otherwise represent such person for the purposes of this Act.

(2) Whenever there is no guardian of the estate of any such person aforesaid being infant, idiot or lunatic or whenever any person the guardian of whose estate if he were idiot or lunatic would be authorized to act for and represent such person under this Act is of unsound mind and incapable of managing his affairs but has not been found an idiot or lunatic under inquisition a court or a judge may appoint a guardian or guardians of such person for the purpose of any proceedings under this Act and from time to time change such guardian. 1906 , c. $24, \S 171$.

161. The judge on application for that purpose on behalf of any person who is under the disability of infancy, lunacy or unsoundness of mind may by order directed to the registrar prohibit the transfer of or dealing with any land belonging to any such person. 1906, c. $24, \S 172 ; 1908$, c. $29, \S 12$.

\section{NOTICE, IOINT OWNERSHIP.}

162. No person contracting or dealing with or taking or proposing to take a transfer, mortgage, incumbrance or lease from the owner of any land for which a certificate of title has been granted shall except in case of fraud by such person be bound or concerned to inquire into or ascertain the circumstances in or the consideration for which the owner or any previous owner of the land is or was registered or to see to the application of the purchase money or of any part thereof nor shall he be affected by notice direct, implied or constructive of any trust or unregistered interest in the land any rule of law or equity to the contrary notwithstanding.

(2) The knowledge that any trust or unregistered interest is in existence shall not of itself be imputed as fraud. 1906, c. $24, \S 173$. 
163. Upon the transfer to two or more persons as joint owners of any land for which a certificate of title has been granted to be held by them as trustees it shall be lawful for the transferor to insert in the transfer or other instrument the words "no survivorship" and the registrar shall in such case include such words in the duplicate certificate issued to such joint owners pursuanc to the transfer and in the certificate of title.

(2) Any two or more persons so registered as joint owners of any land held by them as trustees may by writing under their hand authorize the registrar to enter the words "no survivorship" upon the duplicate certificate and also upon the certificate of title.

(3) In either case aforesaid after such entry has been made and signed by the registrar it shall not be lawful for any less number of joint owners than the number so entered to transfer or otherwise deal with the land without obtaining the sanction of the court or of a judge by an order on motion or petition. 1906 , c. $24, \S 174$.

164. Before making any order as aforesaid the court or judge shall if it seems requisite cause notice of intention of making such order to be properly advertised and in such case appoint a period of time within which any person interested may show cause why the order should not be made; and thereupon the said court or judge may order the transfer of the land to any new owner or owners solely or jointly with or in the place of any existing owner or owners or may make such order in the premises as the court or a judge thinks just for the protection of the persons beneficially interested in the land or in the proceeds thereof.

(2) Upon such order being deposited with the registrar he shall make a memorandum there of upon the certificate of title and upon the duplicate certificate; and thereupon the person or persons named in the order shall be the owner or owners of the land. 1906 , с. $24, \S 175$.

\section{SUEMISSION TO JUDGE OR MASTER OF TITLES.}

165. Whenever any matter is under this Act submitted to a judge or the master of titles and the judge or the master of titles deems it advisable that parties interested should be notified of the time and place when and where a hearing of the matter so submitted should be held and no special provisions are made therefor in this Act or if there are any such special provisions and the judge or the master of titles shall be 
of the opinion that the notice required thereby to be given is not sufficient he may direct:

(a) That notice of such time and place be given; and

(b) That such notice shall be served personally upon such persons as he may direct or be left at their usual place of abode; or

(c) That such notice shall be posted at such place or places and for such periods as he may name; or

(d) That such notice be published in such newspaper or newspapers as he may designate and for such time as he may direct; and

(e) That such notice may be given in any one or more or in all the methods above specified. 1906, c. 24 , $\S 176 ; 1908-9$, с. $9, \S 11 ; 1909$, с. $20, \S 1$.

166. Whenever this Act directs that persons interested shall be heard or shall receive notice and such parties are not within the jurisdiction or cannot be found so as to be personally served the judge or the master of titles or the registrar having jurisdiction in the matter, as the case may be, may direct that any party without the jurisdiction may be served personally or in either case may direct substitutional service within or without the jurisdiction in such manner as he deems expedient or that publication of notice in such manner as he may direct may be sufficient service. 1906, c. 24. § 177; $1908-9$, с. $9, \S 12 ; 1909$, с. $20, \S 1$.

\section{EVIDENCE AND PROCEDURE.}

167. Every covenant and power declared to be implied in any instrument by virtue of this Act may be negatived or modified by express declaration in the instrument.

(2) In any action for an alleged breach of any such implied covenant the covenant alleged to be broken may be set forth and it shall be lawful to allege precisely in the same manner as if the covenant had been expressed in words in the transfer or other instrument any law or practice to the contrary notwithstanding that the party against whom the action is brought did so covenant.

(3) Every such implied covenant shall have the same force and effect and be cnforced in the same manner as if it had been set out at length in the transfor or other instrument.

(4) When any transfer or other instrument in accorlance with this Act is executed by more parties than one such covenants as are by this Act to be implied in instruments of a like 
nature shall be construed to be several and not to bind the parties jointly. 1906, c. $24, \S 178$.

168. The owner of any land for which a certificate of title has been granted or of any lease, mortgage or charge affecting the same shall on application of any beneficiary or person interested therein be bound to allow his name to be used by such beneficiary or person in any action, suit or proceeding which it may be necessary or proper to bring or institute in the name of such owner concerning such land, lease, mortgage or charge or for the protection or benefit of the title vested in such owner or of the interest of any such beneficiary or person:

Provided that such owner shall in any case be entitled to be indemnified in like manner as a trustee would before the first day of January, one thousand eight hundred and ninety-five, have been entitled to be indemnified in a similar case of his name being used in any such action, suit or proceeding in name by his cestui que trust. 1906, c. 24, § 179.

169. Every certificate of title and duplicate certificate granted under this Act shall except:

(a) In case of fraud wherein the owner has participated or colluded; and

(b) As against any person claiming under a prior certificate of title granted under this Act in respect of the same land; and

(c) So far as regards any portion of the land by wrong description of boundaries or parcels included in such certificate of title so long as the same remains in force and uncancelled under this Act;

be conclusive evidence in all courts as against his Majesty and all persons whomsoever that the person named therein is entitled to the land included in the same for the estate or interest therein specified subject to the exceptions and reservations implied under the provisions of this Act. 1906, c. 24, $\S 180$.

170. In any suit for specific performance brought by an owner of any land for which a certificate of title has been granted against a person who has contracted to purchase the land without notice of any fraud or other circumstances which according to this Act would affect the right of the transferor the duplicate certificate of title of the owner shall be evidence that the owner has a good and valid title to the land for the estate or interest therein mentioned or described. 1906, c. $24, \S 181$. 
171. Proceedings under this Act shall not abate or be suspended by any death, transmission or change of interest but in any such event a judge may make such order for earrying on, discontinuing or suspending the proceedings upon the application of any person interested as under the circumstances he thinks just and may for such purpose require the production of such evidence and such notices to be given as he thinks necessary. 1906, c. $24, \S 182$.

172. Whenever in any action, suit or other proceeding affecting land for which a certificate of title has been granted it becomes necessary to determine the fact whether the transferee, mortgagee, incumbrancee or lessee is a purchaser or transferee, mortgagee, incumbrancee or lessee for valuable consideration or not any person who is a party to the action, suit or other proceeding may give in evidence any transfer, mortgage, incumbrance, lease or other instrument affecting the land in dispute although the same is not referred to in the certificate of title or has been cancelled by the registrar. 1906, c. $24, \S 183$.

173. Whenever by virtue of this Act a judge, the master of titles or the registrar having jurisdiction in the matter, as the case may be, is required or authorized to hold an inquiry proof of the matters relevant to the inquiry may be made before him by affidavit:

Provided that the judge, the master of titles or the registrar having jurisdiction in the matter, as the case may be, may whenever he deems it expedient require the personal attendance of any person before him to testify as to the matters of any such inquiry or of the deponent to any affidavit to be cross-examined upon his affidavit. 1906, e. 24, § 184; $1908-9$, c. $9, \S 12 ; 1909$, c. $20, \S 1$.

174. Whenever the judge or the master of titles, as the case may be, so requires any person or deponent to appear before him in person he may issue a summons under his hand requiring such person or deponent to appear before him at a time and place to be speeified to testify as to what he may know concerning the matters in question or to be crossexamined, as the case may be.

(2) If such person or deponent fails to attend at the time and place specified upon due proof under oath that such person or deponent has been duly served with the said summons and that proper conduct money according to the tariff of fees provided for the attendance of witnesses at trials in civil causes in the supreme court and any law in force in 
Saskatchewan has been paid or tendered to him the judge or the master of titles, as the case may be, may issue his warrant directed to the sheriff of any judicial district directing him to apprehend such person or deponent and bring him before the said judge or the master of titles, as the case may be, for examination and to keep him in his custody until he is so eximined.

(3) The sheriff shall obey the said warrant according to the tenor thereof and shall be entitled to the same fees for executing such warrant as he would be entitled to for executing a process issued out of the said supreme court.

(4) The costs incidental to any such inquiry shall be in the discretion of the judge or the master of titles, as the case may be, and shall be taxed by the local registrar of the court in which the inquiry was held as nearly as may be according to the tariff provided for cirrl causes in the said court.

(5) Judgment shall be signed in such court for such costs in favor of the party to whom they are awarded by the judge or the master of titles, as the case may be, and execution may be issued for the recovery thereof out of said court as upon an ordinary judgment therein. 1906 , c. $24, \S 185 ; 1908-9$, c. 9 , $\S 13 ; 1909$, c. $20, \S 1$.

175. Whenever any proceeding is taken under this Act whether by motion or summons or by the filing with or the delivery to the registrar of a caveat, mechanics' lien or copy of an execution against lands or other such proceeding and any party to such proceeding or the person in whose behalf or against whose interest such careat, lien or execution has been so filed or delivered is not a resident in the province a judge may upon the application of a party to such proceeding or interested therein or affected by such caveat, lien or execution grant an order requiring such non-resident to give security for the costs of the applicant of such order in prosecuting or resisting such proceedings or in removing or maintaining such careat, lien or execution.

(2) It may be a term of such order that in default such proceeding may be deemed granted or dismissed or such caveat, lien or execution may be deemed remored or maintained.

(3) such order may also provide for a stay of proceedings.

(4) The practice and procedure for obtaining such order and giving such security shall be as nearly as may be the same as upon an application for security for costs in civil causes in the said supreme court 
(5) The judge may order the costs incident to such application or order taxed to be recovered as is provided for costs in subsections (4) and (5) of the last preceding section. 1906, c. $24, \S 186$.

176. The court or judge or the master of titles, as the case may be, may order costs to be paid by or to any person or party to any proceeding under this Act:

Provided that any applicant under this Act shall be deemed liable prima facie to pay all costs, charges and expenses incurred by or in consequence of his application except in a case where parties object whose rights are suffieiently secured without their appearance or when any costs, charges or expenses are incurred unnecessarily or improperly. 1906 , c. $24, \S 187$; $1908-9$, с. $9, \S 13 ; 1909$, c. $20, \S 1$.

177. The judge may by order directed to the registrar prohibit the dealing with any land in any case in which it appears to him that an error has been made by misdescription of such land or otherwise in any certificate of title or other instrument or may make an order directed to the registrar for the prevention of any other improper dealing. 1906, c. 24, $\S 188$.

178. Any order of the court or a judge or the master of titles, as the case may be, may be cnforced in the same manner and by the same officials and process as orders are usually enforced by the procedure and practice of the supreme court and shall be obeyed by every registrar and acting registrar when directed to him. 1906 , c. $24, \$ 189 ; 1908-9$, c. $9, \$ 13$; 1909 , c. $20, \S 1$.

\section{AFFIDAVITS.}

179. In all matters before the court or a juclge or the master of titles, as the case may he, where proof is required the same may be taken by affidavit or by vira roce evidence as may be ordered by the court or a judge or the master of titles, as the case may be. 1906 , с. 24,$8190 ; 1908-9$, с. $9, \$ 13$; 1909 , c. $20, \S 1$.

180. Affidavits shall be sulject to the practice governing afficlavits in the supreme court. 1906, c. $24, \$ 191$.

APPWAL.

181. An appeal shall lie hy a registrar or person directly interested therein from any order or decision of a judge or the master of titles marle or given under the provisions of this 
Act to the supreme court sitting en banc within the prescribed time in the same manner and with the same incidents in and with which judgments and orders of that court by a single judge may be appealed from.

(2) The practice and proceedings relating to appeals in the said court including costs and payment thereof and the enforcement of judgments on appeal shall adapted to the circumstances apply. 1906 , c. $24, \S 192 ; 1908-9$, c. $9, \S 14 ; 1909$, c. $20, \S 1$.

182. The said court sitting as the court of appeal may by order of court provide and from time to time change a tariff of costs payable for all services and proceedings under this Act.

(2) Unless and until so provided for the tariff of costs relating to actions in the supreme court where the title to lands is in question shall apply adapted to the circumstances. 1906, c. $24, \S 193$.

\section{FORMS.}

183. The Lieutenant Governor in Council may from time to time whenever it is necessary so to do add to or otherwise vary any of the forms in the schedule to this Act or may cause to be adopted any other form or forms which he considers applicable to any special case or class of cases for which a form has not been provided in the schedule to this Act. 1906, c. 24 . $\S 194$.

GENERAL.

184. No petition, order, affidavit, certificate, registration or other proceedings under this Act shall be invalid by reason of any informality or technical irregularity therein or of any mistake not affecting the substantial justice of the proceedings. 1906 , c. $24, \S 195$.

185. If in any matter before a judge under this Act the judge considers proper he may refer the same to the court en banc and such court may either dispose of the matter or refer it back to the judge with such direction as the court en banc may think fit. 1906 , c. $24, \S 196$.

186. Every owner or mortgagee of any land for which a certificate of title has been granted shall deliver to the registrar a memorandum in writing of some post office address within the province to which it shall be sufficient to mail all notices that under this Act are required to be sent to an owner or mortgagee.

(2) Every owner shall if required by the registrar so to do before the delivery of any duplicate sign a receipt therefor in 
his own handwriting or otherwise furnish the registrar with his signature so as to prevent personation as far as possible.

(3) Every owner or mortgagee shall from time to time notify the registrar of any change in his post office address: Provided that the registrar may proceed without such memorandum of address. 1906, c. 24, \& 197.

187. A purchaser, mortgagee or incumbrancee for valuable consideration shall not be affected by the omission to send any notice by this Act directed to be given or by the non-receipt thereof. 1906 , c. $24, \S 198$.

188. The Lieutenant Governor in Council may in cases herein provided for make such rules and regulations as he may deem necessary for giving effect to this Act and carrying out the provisions thereof according to its intent and meaning. 1906, c. $24, \S 199$.

189. The registrar may require evidence that any person making a transfer, mortgage, incumbrance or lease is of the full age of twenty-one years. 1906, c. $24, \S 200$.

190. All proceedings taken under any former law and regulation shall be taken up and continued under this Act when not inconsistent therewith and all penalties and forfeitures may be recovered and all proceedings had in relation to matters which have happened before the coming into force of this Act in the same manner as if the said former law or regulation was still in force, following the provisions of this Act as far as they can be adapted to the said former law or regulation.

(2) All orders, regulations and rules made under any such former law shall continue good and valid in so far as they are not inconsistent with this Act until they are annulled or others made in their stead. 1906, c. 24, $\$ 202$.

191. Nothing in this Act contained shall affect any act done or any right or right of action existing, accruing, acerued or established or any proceedings commeneed in a civil causc before the coming into force of this Act; and all rights, estates and interests existing in any person under or by virtue of any former law in force in Saskatchewam relating to titles to real property shall be and are hereby prescrved so far but so far only as they are consistent with the provisions of this Act. 1906, c. $24, \S 203$. 


\section{FOKM A.}

(Section 33 (2)

Certificate of Title.

I'rovince of Saskatchewan.

Registration District.

This is to certify that $A$. B., of is now the owner cf an estate (describe the estate) of and in (describe the property), subject to the incumbrances, liens and interests notified by memorandum underwritten or indorsed hereon, or which may hereafter be made in the register.

In witness whereof I have hereunto subscribed my name and affixed my official seal this day of , 19 . [L.S.]

\section{(And if subject to mortgage, say:)}

The title of $A . B$. is subject to mortgage, dated the day of , made by $A$. B. to $W$. B. to secure (here state the amount secured, the rate of interest per cent. per annum and the respective dates from which the principal and interest are secured) payable as therein mentioned.

(If mortgage is discharged, say:)

The above mortgage No. is discharged this day of $\quad, 19$, (here state the distinguishing letter or number of the reaister and the number of the folio therein).

(And, if subject to a lease, say:)

The title of $A$. B. is subject to a lease, dated the day of , made hy A.B. to Y.Z. for the term of rears.

(When the transfer is absolute, say:)

This certficate of title is cancelled and a new certificate of title No.

, issued this day of 19 . 
FORM B.

(Section 50)

Application to Bring Land Under the Operation of "The Land Titles Act."

To the Registrar of Registration District:

I (insert name and addition), hereby apply to have the land hereinafter described brought under the operation of The Land Titles Act. And I declare:

1. That I am the owner (or agent for , the owner) of an estate in fee simple in possession (or of an estate of freehold in possession for my life, or otherwise os the case may require) in all that piece of land, being (here describe the land).

2. That such land, including ail buildings and other improvements thereon, is of the value of dollars, and no more.

3. That there are no documents or evidences of title affecting such land in my possession, or under my control, other than those included in the schedule hereto.

4. That I am not aware of any mortgage or incumbrance affecting the said land or that any other person has any estate or interest therein at law or in equity, in possession, remainder, reversion or expectancy (if there be any add: other than as follows, and set the same forth).

5. That the said land is now occupied (if unoccupied prefix un to occupied; if occupied, add by whom, and state the name and addition of the occupant and the nature of his occupancy).

6. That the names and addresses so far as known to me of the occupants of all lands contiguous to the said land are as follows:

7. That the names and addresses so far as known to me of the owners of all lands contiguous to the said land are as follows:

(If the certificate of title is not to be granted to the applicant, add): And I direct the certificate of title to be granted in the name of (insert name and addition).
Dated this day of 19.

Made and subscribed at in the presenee of 


\section{FORM C.}

(Section 50)

\section{Affidavit of Applicant.}

Province of Saskatchewan,

\section{To wit:}

I, of make oath and say:

1. That I am the applicant named in the application hereto annexed.

2. That the several statements contained in the said application are true to the best of my knowledge and belief.

Sworn before me at the

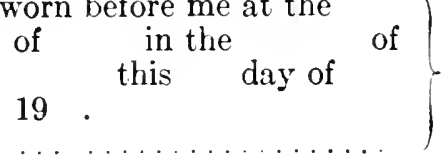

Signature.

FORM D.

(Section 50)

Affidavit Concerning the Hudson's Bay Company's LANDS.

Province of Saskatchewan, To wit:

I, of the of in the of make oath and say:

1. I am an officer of the Hudson's Bay Company entitled to make this affidavit by the authority and under the approval of the attorney general.

2 . Title to the lands mentioned in the accompanying application now produced and shown to me, and marked with the letter "A," passed to the said company by notification under the provisions of of The Dominion Lands Act (or by letters patent issued on-stating date-as the case may be).

3. The said company is at the date of this affidavit absolutely entitled to the said lands in fee simple and has not incumbered the same in any way whatsoever.

4. And the said lands are not subject to any execution and are not chargeable with any arrear: of municipal taxes, rates or assessments.

Sworn before me at

of this day of


FORM E.

(Section 87)

Mortgage.

I, A. B. (insert name as in certificate of title and addition), being registered as owner of an estate (here state nature of interest), in that piece of land deseribed as follows: (here insert description) containing acres, be the same more or less (here state rights of way, privileges, easements, if any, intended to be conveyed along with the land, and, if the land dealt with contains all included in the original grants, refer thereto for description of parcels and diagram. Otherwise set forth the boundaries and accompany the description by a diagram), in consideration of the sum of dollars lent to me by $E . F$. (here insert description), the receipt of which sum I do hereby acknowledge, covenant with the said $E . F$. :

Firstly.-That I will pay to him, the said $E$. F., the above sum of dollars on the day of

Secondly.-That I will pay interest on the said sum at the rate of on the dollar, in the year, by equal payments on the day of , and on the day of in every year.

Thirdly.-(Here set forth special covenants, if any.)

And for the better securing of the said $E . F$. the repayment in manner aforesaid, of the prineipal sum and interest, I hereby mortgage to the said $E . F$. my estate and interest in the land above described.

In witness whereof, I have hereunto signed my name this day of 19 .

Signed by the above named $A$. B. as mortgagor in the presence of ...........

Signature of Mortgagor.

(For form of transfer of mortgage see form Q.)

FORM F.

\section{(Section 87 (2)}

INCUMBRANCE.

I, A. B (insert name as in certificate of title and addition), being registered as owner of an estate (state nature of estate), subject, however, to such mortgages and incumbrances as are notified by memorandum underwritten (or indorsed hereon), in that pieee of land deseribed as follows: (here insert description) 
containing acres more or less (here state rights of way, privileges, easements, if any, intended to be conveyed along with the land, and if the land dealt with contains all included in the original grant or certificate of title, refer thereto for description of parcels and diagrams, otherwise set forth the boundaries and accompany the description by a diagram), and desiring to render the said land available for the purpose of securing to and for the benefit of $C . D$. of (description) the (sum of money, annuity or rent charge) hereinafter mentioned; do hereby incumber the said land for the benefit of the said $C$. D. with the (sum: annuity or rent charge) of , to be paid at the times and in the manner following, that is to say: (Here state the times appointed for the payment of the sum, annuity or rent charge intended to be secured, the interest, if any, and the events in which such sum, annuity or rent charge shall become and cease to be payable, also any special covenants or powers and any modification of the powers or remedies given to an incumbrancee by this Act.) And subject as aforesaid the said $C . D$. shall be entitled to all powers and remedies given to an incumbrancee by The Land Titles Act.

Signed by the above named , in the presence of

Signature of Incumbrancer.

(Insert momorandum of mortgages and incumbrances.)

FORMI G.

(Scctions $32(c)$ and $s 8$ )

Affidatit to be Filed with a Mortgage or Incumbrance.

Province of Saskatehewan, To wit:

I, (name of mortgagor or incumbrancer) of the of in the make oath and say:

1. That I am the mortgagor (or ineumbrancer) named in the hereunto annexed instrument bearing date the and made in fivor of against (describe the lands mortgaged or incumbercd).

2. That I have paid the full purchase price for the said land and hold therefor the receipt of the excuted by their tuly authorized agent at and am entitled to a transfer in fee simple from the said 
3. That the grant from the Crown has not yet been issued (or the transfer from the company has not yet been received, as the case may be) but that I am the person rightfully in possession of the said land and entitled to ereate the said mortgage (or incumbrance) under section 88 of The Land Titles Act.

4. That said land hereby mortgaged (or incumbered) is neither a homestead, purchased homestead nor a pre-emption under The Dominion Lands Act.

Sworn before me at the

$\begin{array}{ll}\text { of } & \text { on the } \\ \text { of } & 19\end{array}$ day

Signature.

FORM $\mathrm{H}$.

(Section 103)

Short Covenants in Mortgage.

COLUMN ONE.

COLUMN TWO.

1. Have a good title to the said land.

2. Have the right to mortgage the land.
1. And also that at the time of the execution and delivery hereof I am and stand solely, rightfully and lawfully seized of a good, sure, perfect, absolute, and indefeasible estate of inheritance in fee simple of and in the lands, tenements, hereditaments and all and singular other the premises hereinbefore described with their and every part of their appurtenances and of and in every part and parcel thereof without any manner of trusts, reservations, limitations, provisos or conditions, except those contained in the original grant thereof from the Crown or any other matter or thing to alter, eharge, change, incumber or defeat the same.

2. And also that I now hare in myself good right, full power and lawful and absolute authority to convey the said lands, tenements, hereditaments and all and singular other the premises herchy conveyerl or hereinbefore men- 
tioned or intended so to be, with their and every of their appurtenances unto the said mortgagee, his heirs, executors, administrators and assigns in manner aforesaid and according to the true intent and meaning of these presents.

3. And that on de-

3 . And also that from and after default the mortgagee shall have quiet possession of the land.

4. Free from all incumbrances. fault shall happen to be made of or in the payment of the said sum of money in the said above proviso mentioned or the interest thereof or any part thereof or of or in the doing, observing, performing, fulfilling or keeping of some one or more of the provisions, agreements or stipulations in the said above proviso particularly set forth contrary to the true intent and meaning of these presents and of the said proviso then and in every such case it shall and may be lawful to and for the said mortgagee, his heirs, executors, administrators and assigns peaceably and quietly to enter into, have, hold, use, occupy, possess and enjoy the aforesaid lands, tenements, hereditaments and premises hereby conveyed or mentioned or intended so to be with their appurtenances without the let, suit, hindrance, interruption or denial of me, the said mortgagor, my heirs or assigns or any other person or persons whomsoever.

4. And that free and clear and freely and clearly acquitted, exonerated and discharged of and from all arrears of taxes and assessments whatsoever due or payable upon or in respect of the said lands, tenements, hereditaments and premises or any part thereof, and of and from all former conveyances, mortgages, rights, annuities, debts, judgments, executions and recognizances, and of and from all 
manner of other charges or ineumbrances whatsoever.

5. Will execute such further assurance of the land as may be requisite.
5. And also that from and after default shall happen to be made of or in the payment of the said sum of money in the said proviso mentioned or the interest thereof or any part of such money or interest or of or in the doing, observing, performing, fulfilling or keeping of some one or more of the provisions, agreements or stipulations in the said above proviso particularly set forth, contrary to the true intent and meaning of these presents and of the said proviso, then and in every such case I, the said mortgagor, my heirs and assigns and all and every other person or persons whosoever having or lawfully elaiming or who shall or may have or lawfully claim any estate, right, title, interest or trust of, in, to or out of the lands, tenements, hereditaments and premises hereby conveyed or mentioned or intended so to be with the appurtenances on any part thereof by, from, under or in trust for me the said mortgagor shall and will from time to time and at all times thereafter at the proper costs and charges of the said mortgagee, his heirs, exeeutors, administrators and assigns make, do, suffer and execute or cause or procure to be made, done, suffered and executed all and every such further and other reasonable act or acts, deed or deeds, devices, conveyances and assurances in the law for the further, better and more perfectly and absolutely conveying the said lands, tenements, hereditaments and premises with the appurtenanees unto the said mortgagee, his heirs, executors, administrators and assigns, as by the said mortgagee, his heirs, executors or his or their solicitor, 
shall or may be lawfully and reasonably devised, advised or required, so that no person who shall be required to make or execute such assurances shall be compelled for the making or executing thereof to go or travel from his usual place of abode.

6. Have done no act to incumber the land.

6. And also that I, the said mortgagor, have not at any time heretofore made, done, committed, executed or wilfully or knowingly suffered any act, deed, matter or thing whatsoever whereby or by means whereof the said lands, tenements, hereditaments and premiseshereby conveyed or mentioned or intended so to be or any part or parcel thereof, are, is or shall or may be in any wise impeached, charged, affected or incumbered in title, estate or otherwise howsoever.

\section{FORMI.}

(Sections 52 and.93)

Receipt or Achnowledgient of Payment of Mortgage or Other Incumbrance.

I, C. D., the mortgagee (incumbrancee or assignee as the case may be) do acknowledge to have received all the moneys lue or to become due under the within written mortgage (or incumbrance, as the case may be) and that the same is wholly discharged.

In witness whereof I have hereunto subscribed my name this day of 19

Signed by the above named

$C . D$. in the presence of

Signature.

\section{FORMI J.}

(Section 81)

L.EASE.

I, A. B. (insert name as in certificutc of title and addition), being registered as owner, subject, however, to such mortgages 
and incumbrances as are notified by memorandum underwritten (or indorsed hereon), of that piece of land described as follows: (here insert description) containing acres more or less (here state rights of way, privileges, easements, if any, intended to be conveyed along with the land, and if the land dealt with contains all included in the original grant or certificate of title or lease refer thereto for description and diagram, otherwise set forth the boundaries by metes and bounds) do hereby lease to $E$. F. of (here insert description), all the said land to be held by him, the said $E$. F., as tenant, for the space of

years, from (here state the date and term), at the yearly rental of dollars, payable (here insert terms of payment of rent) subject to the covenants and powers implied (also set forth any special covenants or modifications of implied covenants).

I, E. F., of (here insert description), do hereby accept this lease of the above described land, to be held by me as tenant, and subject to the conditions, restrictions and covenants above set forth.

Dated this day of $\quad 19$.

Signed by the above named $A$. B. as lessor, and E. F. as lessee, in the presence of

Signature of lessor.

Signature of lessee.

(Here insert memorandum of mortgages and incumbrances.)

FORM K.

(Section 85)

\section{Short Covenants in Lease.}

COLUMN ONE.

1. Will not without leave assign or sublet.
COLUMN TWO.

1. That I, the said lessee, my (xiceutors, administrators or transferees will not during the said term transfer, assign or sublet the land and premices hereby leased or any part thereof or otherwise by any act or decel procure the said land and premises or any part thereof to be trinsforred or sullet, without the consent in writing of the lessor or his transferees first had and obtained. 
2. Will fence.

2. That I, the said lessee, my executors, administrators or transferees will during the continuance of the said term erect and put upon the boundaries of the said land, or on those boundaries on which no substantial fence now exists, a good and substantial fence.

3. Will cultivate.

3. That I, the said lessee, my executors, administrators or transferees will at all times during the said term cultivate, use and manage in a proper husbandlike manner all such parts of the land as are now or shall hereafter, with the consent in writing of the said lessor or his transferees, be broken up or converted into tillage and will not impoverish or waste the same.

4. Will not cut timber.

5. Will not carry on offensive trade.
5. That I, the said lessee, my executors, administrators or transferees will not at any time during the said term use, exercise or carry on or permit or suffer to be used, exercised or carried on in or upon the said premises or any part thereof any noxious, noisome or offensive art, trade, business, occupation or calling, and no act, matter or thing whatsoever shall at any time during the said term be done in or upon the said premises or any part thereof which shall or may be or grow to annoyance, nuisance, grievance, damage or any disturbance of the occupiers or owners of the adjoining lands and properties. 
FORM L.

(Section 81 (2)

Certificate of Lease.

Lease No.

Land Registration District

This is to certify that a lease made by

who was at the time of the registration of the said lease the registered owner of the land thereby demised to of all the lands described in the said lease No. for the term of years from the day of 19 at an annual rental of $\$$

payable was duly registered in the land titles office for the land registration district at on the day of 19 at o'clock in the noon.

Dated at the Land Titles Office at this day of 19 .

Registrar.

\section{FORM M.}

(Section 86)

Surrender of Lease.

In consideration of dollars to me paid by lessor (or his assigns, as the case may be) I do hereby surrender and yield up from the day of the date hereof unto the lease (describe the lease fully) and the term therein created.

Dated the day of 19 .

Signed by the above named in the presence of

Signatuie.

\section{FORM N.}

\section{(Section 10.4)}

Power of At'Torney.

I, A. B., being registered owner of an estate (here state nature of the estate or interest), subject, however, to such incumbrances, liens and interest as are notified by memorandum underwritten (or indorsed hereon), (here refer to 
schedule for description and contents of the several parcels of land intended to be affected, which schedule must contain reference to the existing certificate of title or lease of each parcel) do hereby appoint $C . D$. attorney on my behalf to (here state the nature and extent of the powers intended to be conferred, as to sell, lease, mortgage, etc.), the land in the said schedule described and to execute all such instruments, and do all such acts, matters and things as may be necessary for carrying out the powers hereby given and for the recovery of all rents and sums of money that may become or are now due or owing to me in respect to the said lands, and for the enforcement of all contracts, covenants or conditions binding upon any lessee or occupier of the said lands, or upon any other person in respect of the same, and for the taking and maintaining possession of the said lands, and for protecting the same from waste, damage or trespass.

In witness whereof I have hereunto subscribed my name this day of , , 19

Signed by the above named

$A$. B. in the presence of

signature.

FORMI O.

(Sections 104 (3) and 10\%)

Revocation of Power of Attonney.

I, A. B., of , hereby revoke the power of attorney given by me to dated the day of, 19, and recorded in the land titles office at for the land registration district, on the day of, 19, as Number

In witness whereof I have hereunto subscribed my name this day of, 19 .

Signed by the above named

A. B. in the presence of

Signature.

FORMI P.

(Section $\mathrm{r} 1$ )

Transfer.

I, A. B., being registered owner of an estate (state the nature of the estate) in all that certain tract of land containing acres, more or less and being (part of) section

township 
range in the (or as the case maybe), (here state rights of way, privileges, easements, if any, intended to be conveyed along with the land and if the land dealt with contains all included in the original grant refer thereto for description of parcels and diagrams; otherwise set forth the boundaries and accompany the description by a diagram), do hereby in consideration of the sum of dollars paid to me by E.F., the receipt of which sum I hereby acknowledge, transfer to the said $E$. $F$. all my estate and interest in the said piece of iand. (When a lesser estate describe such lesser estate.)

In witness whereof I have hereunto subscribed my name this day of, 19 .

Signed by said $A . B$. in the presence of

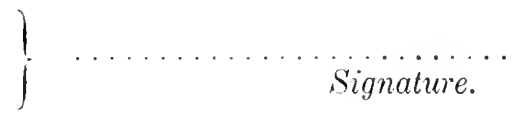

FORM Q.

(Sections 93, 98 and Form E)

Transfer of Mortgage, Incumbrance or Lease.

I, $C$. D., the mortgagee (incumbrancee or lessee, as the case may be), in consideration of dollars this day paid to me by $X$. Y. of , the receipt of which sum I do hereby acknowledge, hereby transfer to him the mortgage (incumbrance or lease, as the case may be), (describe the instrument fully) together with all my rights, powers, title and interests therein.

In witness whereof I have hereunto subseribed my name this day of, 19 .

Signed by the said the presence of

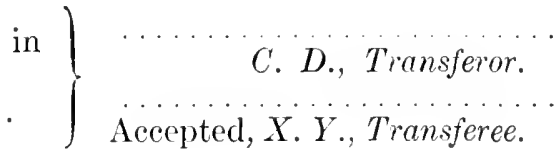

FORM R.

(Section 99)

Transfel of Part of Moltagali on Incumbranct.

I, C. D., the mortgagee (or incumbrancee, or as the case may be), in consideration of dollars this day paid to me by $X$. $Y$. of , the receipt of which sum I do hereby acknowledge, herehy transfer to him dollars of the mortgage (or 
incumbrance, as the case may be), (describe the instrument fully) together with all my rights, powers, title and interest therein and the sum so transferred shall be preferred (or deferred or rank equally, as the case may be) to the remaining sum secured by the mortgage (or ineumbrance).

In witness whereof I have hereunto subscribed my name this day of, 19 .

Signed by the said

presence of

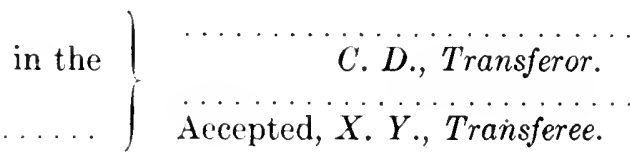

FORM S.

(Section 121 (2)

Transfer of Jand Under Process of Law.

I, of , the person appointed to execute the process hereinafter mentioned in pursuance of a writ dated the day of , one thousand nine hundred and and issued out of (insert name of court), a court of competent jurisdiction in an action wherein

is the plaintiff, and the defendant, which said

is registered as the owner of

the land hereinafter described, subject to the mortgages and ineumbrances notified hereunder, do hereby, in consideration of the sum of paid to me, as aforesaid, by $E$. $F$., (insert addition) transfer to the said $E$. F., all that piece of land (here insert a sufficient description of the land and refer to the debtor's certificate of title or grant). and

Dated the day of one thousand nine hundred

Signed by the above named presence of in the

Mortgages and incumbrances referred to (state them). 
FORM S.

(Section 124 (2)

Transfer of Land on Sale for Taxes.

I, of , by virtue of authority vested in me to sell lands for arrears of taxes by do hereby, in consideration of the sum of paid to me by E.F. (insert addition) transfer to the said $E . F$. all that piece of land, being (here insert a sufficient description of the land, and refer to the certificate of title). and

Dated the day of one thousand nine hundred

Signed by the above named in the

presence of

Signature with official seal.

$\mathrm{Or}$

FORMIS.

Transfer of Land Under Decree or Order of a Court of Competent Jurisdiction.

I (insert name), in pursuance of a decree (or order) of (insert name of court), a court of competent jurisdiction, dated the day of one thousand nine hundred and , and entered in the register, vol. fol. hereby transfer to $E . F$. (insert addition) subject to the mortgages and incumbrances notified hereunder, all that piece of land being (here insert a sufficient description of the land and refer to the certificate of title or grant).

Dated the day of one thousand nine hundred and

Signed by the above named

presence of in the

Mortgages and incumbrances referred to (state them).

Signature with official seal.

Oi

FORMS S.

Transfer of Lease, Mortgage or Ineymbranee, Under Decree or Order of a Court of Competent Jirisdiction.

I (insert name), in pursuance of a decree (or order) of (insert name of court), a court of competent jurisdiction, 
dated the day of one thousand nine hundred and , and entered in the register, vol. fol. , hereby transfer to E.F. (insert addition) subject to the mortgages and incumbrances notified hereunder, the lease (or mortgage or incumbrance, as the case may be) granted by in favor of of (or upon) all that piece of land (here insert description of the land according to the description in the lease, mortgage or incumbrance, and refer to the registered instrument). and

Dated the day of one thousand nine hundred

Signed by the above named in the presence of

Signature with official seal.

Mortgages and incumbrances referred to (state them).

$$
\begin{gathered}
\text { Or } \\
\text { FORM s. }
\end{gathered}
$$

Transfer of Lease, Mortgage or Incumbrance Under Process of LaW.

I, of , the person appointed to execute the writ hereinafter mentioned (or otherwise as the case may be), in pursuance of a writ of fieri facias, tested the day of one thousand nine hundred and , and issued out of (insert name of court) a court of competent jurisdiction in an action wherein is the plaintiff and the defendant, which said is registered as the owner of a lease (mortgage or incumbrance, as the case may be) numbered of (or upon) the land hereinafter described subject to the mortgages or incumbrances notified hereunder, do hereby in consideration of the sum of paid to me as

aforesaid by $E$. $F$. (insert addition) transfer to the said $E$. $F$. the lease (mortgage or incumbrance) granted by to and in favor of dated the day of, to, in and over (here describe the land according to the description in the lease, mortgage or incumbrance, and refer to the registered instrument). and

Dated the day of one thousand nine hundred

Signed by the above named in the 
FORM T.

(Section 126)

Caveat.

To the Registrar

Take notice that I, A. B., of (insert description) claiming (here state with particulars the nature of the estate or interest claimed and the grounds upon which such claim is founded) in (here describe land and refer to cortificate of title) forbid the registration of any transfer or other instrument affecting such land or the granting of a certificate of title thereto except subject to the claim herein set forth.

My address is:

Dated this day of $\quad 19$.

Signature of Caveator or his Agent.

I, the above named $A . B$. (or $C$. D., agent for the above A. B.) of (residence and description) make oath and say:

1. That the allegations in the above caveat are true in substance and in fact, to the best of my knowledge, information and belief.

2. That the claim mentioned in the above caveat is not to the best of my knowledge, information and belief founded upon a writing or a written order, contract or agreement for the purchase or delivery of any chattel or chattels within the prohibition contained in subsection (2) of section 125 of The Land Titles Act.

Sworn before me at in the this day of 19 .

signature.

FORM U.

(Sections 194 and 195)

Affidavit of Attestation of an Instrunient.

Province of Saskatchewan, To wit:

I, A.B. of , in the make oath and say:

1. That I was personally present and did see named in the within (or annexed) instrument, who is personally 
known to me to be the person named therein, duly sign and execute the same for the purposes named therein;

2 . That the same was exeeuted at the in the and that I am the subscribing witness thereto;

3. That I, know the said and he is in my belief of the full age of twenty-one years.

Sworn before me at

in the this

day of $\quad 19$.

Signature.

FORM $\mathrm{V}$.

(Section 1.4\%)

Reference by Registrar to the Master of Titles.

(Place and Date.)

In the matter of The Land Titles Act.

In the matter of the registration of transfer (or as the case may be) A. B. to C. D.

The registrar under the provisions of The Land Titles Act hereby refers the following matter to the master of titles, to wit:

(Here state briefly the difficulty which has arisen.)

The parties interesterl so far as the registrar knows or has heen informed are: (Here give the names.)

Signature.

(Official seal)

Registrar.

FORM W.

(Section 1.48)

Demand to Return Certificate of Tithe.

To (name of ouner or whoever is custodian of eertificate):

Iou are hereby required to forward to the land titles offiee certificate of title No. in favor of (insert ouner's name) for (deseription of land) as the same is required by me pursuant to the provisions of The Land Titles Act for the purpose (purpose for which certificate is required and whether or not by direction of a judge). 
Your attention is called to the provisions of sections 148 and 149 of the said Act and the penalty therein provided for neglect or refusal to comply with this demand.

Dated at 19

$$
\text { Registrar, A.B., } \quad \text { District. }
$$

\section{FORM X.}

\section{(Section 79 (4)}

I, Saskatchewan land surveyor, do solemnly declare that this plan accurately shows the manner in which the land included therein has been surveyed and subdivided by me and that the said plan is prepared in accordance with the provisions of The Land Titles Act.

Dated at 19 .

Signed in the presence of
A. B.,
Saskatchewan Land Surveyor.
FORM Y.

(Section 130)

To.........................

\section{Sir,--}

Under the provisions of section 130 of The Land Titles Act I hereby notify you that the caveat filed by you on the day of 19 against the following land, namely: shall lapse at the expiration of thirty days from the mailing of this notice unless within the said thirty days you file with me an order of the judge continuing said caveat beyond the said thirty days.

Yours, 


\section{FORM Z.}

(Section 90)

Certificate of Charge, Mortgage or Incumbrance.

Land Registration District.

Mortgage or Incumbrance No. Cert. of Title No.

This is to certify that a mortgage (or incumbrance) made by who was at the time of the registration of said mortgage (or incumbrance) the registered owner of the land thereby mortgaged (or incumbered) for the sum of dollars in favor of affecting all the land described in said mortgage (or incumbrance) No. was duly registered in the land titles office for the land registration district at on the day of 19 , at o'clock in the noon and that no registered mortgages or incumbrances affecting the said lands are entitled to priority over the said mortgage (or incumbrance) except the following, that is to say:

Dated at the Land Titles Office at this day of 19 . 


\section{ALBERTA}

\section{The Land Titues Act}

Being Chapter 24 of the Statutes of Alberta, 1906 (assented to May 9, 1909), as amended by Chapter 5, 1907 (assented to March 15, 1907); Chapter 20, 190 S (assented to March 5, 1908); Chapter 4, 1909 (assented to February 25, 1909); Chapter 5, 1909 (assented to February 25, 1909); Chapter 2, 1910 (assented to December 16, 1910); and Chapter 4, 1911-12 (assented to February 16, 1912).

HIS MAJESTY, by and with the advice and consent of the 1 Legislative Assembly of the Province of Alberta, enacts as follows:

1. This Act may be eited as "The Land Titles Act."

2. (a) The expression "land" means lands, messuages, tenements, and hereditaments, corporeal and incorporeal, of every nature and description, and every estate or interest therein, and whether such estate or interest is legal or equitable, together with all paths, passages, ways, watercourses, liberties, privileges, easements, mines, minerals, and quitries appertaining thereto, and all trees and timber thereon and thereunder lying or being, unless any such are specially excepted.

(b) The expression "owner" means any person or body corporate entitled to any freehold or other estate or interest in land, at law or in equity, in possession, in futurity or expectancy.

(c) The expression "transfer" means the passing of any estate or interest in land under this Aet, whether for valuable consideration or otherwise.

(d) The expression "transferor" means the person by whom any interest or estate in land is transferred, whether for value or otherwise, and the expression "transferee" means the person to whom any interest or estate in land is transferred whether for value or otherwise. 
(e) The expression "mortgage" means any charge on land ereated merely for seeuring a debt or loan.

(f) The expression "mortgagee" means the owner of a mortgage; and the expression "mortgagor" means the owner or transferor of land, or of any estate or interest in land pledged as security for a debt or a loan.

(g) The expression "incumbrance" means any charge on land created or effected for any purpose whatever, inclusive of mortgage, mechanics' liens, when authorized by statute or ordinance, and executions against lands. unless expressly distinguished.

(h) The expression "incumbrancer" means the owner of any land or of any estate or interest in land subject to any incumbrance; and the expression "incumbrancee" means the owner of an ineumbrance.

(i) The expression "lunatic" means any person found by any competent tribunal or commission de lunatico inquicendo, to be a lunatie.

j) The expression "person of unsound mind" means any" person not an infant who, not having been found to be a lunatic, has been found on like inquiry to be ineapable, from infirmity of mind, of managing his own affairs.

(k) The expression "instrument" means any grant, certificate of title, conveyance, assurance, deed, map, plan, will, probate or exemplification of will, letters of administration, or an exemplification thereof, mortgnge or incumbrance, or any other document in writing relating to or affecting the transfer of or other dealing with land or evidencing title thereto.

1) The expression "register" means the register of titles to land kept in aceordance with this Act.

(m) The expression "registration" means (1) the bringing of lands under the provisions of this Act; and (2) the entering upon the certifieate of title of a memorandum authorized by this Act of any document; and "filing" means the entering in the day book of any instrument.

i) The expression "memorandum" means the indorsement upon the certificate of title and on the duplicate copy thereof of the particulars of any instrument presented for registration. 
(o) "Certificate of title" means the certificate (form E) granted by the registrar and entered and kept in the register; "duplicate" or "duplieate certificate" means the duplicate, delivered or issued to the person entitled thereto, of the certifieate of title in the register.

( $p$ ) The expression "registrar" means inspect or of land titles offices, when acting as registrar, a registrar of titles, a deputy registrar or an assistint deputy registrar. $1911-12$, c. $4, \S 15$.

(q) The expression "territories" means the Northwest Territories, the district of Keewatin and all other territories of Canada.

(r) The expression "court" means any court authorized to adjudicate in the province in civil matters in which the title to real estate is in question.

(s) The expression "court of appeal" means the court of appeal herein constituted.

( $t$ ) The expression "judge" means an official authorized in the province to adjudicate in civil matters in which the title to real estate is in question.

(u) The expression "transmission" applies to change of ownership consequent upon death, lunacy, sale under execution, order of court, or other act of law, sale for arrears of taxes or upon any settlement or any legal succession in case of intestacy.

(v) The expression "grant" means any grant of Crown land, whether in fee or for years, and whether direct from his Majesty or pursuant to the provisions of any statute.

(w) The expressions "indorsed" and "indorsement" apply to anything written upon any instrument or upon any paper attached thereto by the registrar.

$(x)$ The expression "possession" when applied to persons claiming title to land means also alternatively the reception of the rents and profits thereof.

(y) The expression "affidavit" includes an affirmation when made by a person entitled to affirm.

3. For the purposes of this Act there shall be in the province two land registration districts, respectively known and described as follows: (1) "North Alberta Land Registration District," being composed of all that portion of the Province of Alberta which lies to the north of the ninth (9th) eorrection line. (2) "South Alberta Land Registration Iistrict," being 
composed of all that portion of the Province of Alberta which lies to the south of the ninth (9th) correction line.

4. The Lieutenant Governor in Council may, from time to time by proclamation, as the settlement of the country and the exigencies of the public service require, constitute any other portion of the province a land registration district and declare by what local name the same shall be known and designated, and may also change the boundaries of existing districts.

5. The Lieutenant Governor in Council may provide in each registration district at the public expense, and may thereafter maintain, in a proper state of repair, a building of stone or brick, or partly of brick and partly of stone, to serve as the office of the registrar, and as the place of deposit and preservation of registers and other record books, certificates, instruments and documents connected with the registration of titles; and may fit up the said office with such fireproof safes and other secure places as are necessary.

6. In each registration district at such place as the Lieutenant Governor in Council determines there shall be an office to be called the "land titles office."

7. The Lieutenant Governor in Council may from time to time appoint an inspector of land titles offices whose duties shall be, under instructions from the attorney general, to inspect the books and records of the several land titles offices, and to perform such other duties as he may be directed by the attorney general to perform; and the said inspector may, in the discretion of the attomey general, be directed to perform any duty which any registrar is empowered by this Act to perform; but no person shall be appointed inspector of land titles offices unless he is when appointed a barrister, solicitor or adrocate of at least three years' standing of one of the provinces of Canada.

8. The business of each land titles office shall be conducted by an officer to be called "the registrar" appointed by the Lieutenant Governor in Council, with such assistants and clerks as are necessary and as the Lieutenant Governor in Council from time to time appoints.

(2) Every registrar now acting in the province under the provisions of the Act of the Parliament of Canada known as The Land Titles Act 189\%, or hereafter to be appointed shall hold office during pleasure; but hereafter no person shall be appointed registrar unles he is a barrister, solicitor or advocate 
of at least three years' standing of one of the provinces of Canada.

9. The Lieutenant Governor in Council may from time to time appoint a deputy registrar and one or more assistant deputy registrars, who shall be known as first, second or third deputy registrar or as the case may be, to assist a registrar under instructions from the latter and perform such duties as he shall from time to time assign to each of them.

(b) The deputy registrar may, in the event of illness or absence of the registrar, perform all the duties required by the Act to be done by the registrar;

(c) In the case of death, resignation or removal from office of the registrar, the deputy registrar shall do and perform all the duties of a registrar until another registrar is appointed. As amended 1911-12, c. 4, §15 (2).

10. The inspector of land titles offices, the registrars, deputy registrars, and other necessary officers shall be attached to the attorney general's department, and be under the control of the attorney general, and their salaries, and such incidental expenses of carrying on this Act as are sanctioned by this Act or by the Lieutenant Governor in Council shall be paid out of moneys provided by the Legislative Assembly for that purpose.

11. The inspector of land titles offices and every registrar, deputy registrar and assistant deputy registrar before he enters upon the execution of his office shall take before some judge or stipendiary magistrate in the province the oath of office in the form A in the schedule to this Act. As amended 1911-12, c. $4, \S 15$ (3).

12. Before the inspector of land titles offices or any registrar or deputy registrar or assistant deputy registrar is sworn into office he shall furnish to his Majesty security in a penal sum of not less than one thousand dollars for the true and faithful performance by the said inspector of land titles offices, registrar or deputy registrar or assistant deputy registrar of his duty in respect of all things directed to be done by or required of the said inspector of land titles offices, registrar, or deputy registrar or assistant deputy registrar respectively, by this Act to any law in that bchalf; and the said security shall, in the discretion of the attorney general, be either a joint and several bond of the inspector of land titles offices, registrar or deputy registrar or assistant deputy registrar, as the case may be, and of two sureties, or a guarantec bond of a guarantee company duly approved by the Lieutenant Governor in Council. As amended 1911-12, e. 4, \$15 (4). 
(2) Such bond or guarantee shall be in duplicate and shall be subject to the approval of the Lieutenant Governor in Council.

13. When the security to be so furnished is the joint and several bond of the inspector of land titles offices, registrar or deputy registrar or assistant deputy registrar, as the case may be, and two sureties, the same shall be executed under the hands and seals of the obligors in the form $B$ in the schedule to this Act, and the sureties shall justify under oath in the form $\mathrm{C}$ in the said schedule; and the execution of the said bond shall be duly verified by the affidavit of a subscribing witness in the form $D$ in the said schedule; and with the affidavits appended shall then be forthwith transmitted to the provincial secretary to be filed in his office. As amended 1911-12, c. 4, §15 (5)

14. The inspector of land titles offices and any registrar or deputy registrar or assistant deputy registrar shall when required by the attorney general furnish such further or other security as is deemed expedient. As amended 1911-12, c. 4, § 15 (6).

15. Each registrar shall have a seal of office, approved by the Lieutenant Governor in Council, with which he shall seal all certificates of title, and he shall stamp all instruments which are presented to him for registration, showing the day, hour and minute of receiving the same.

16. The inspector of land titles offices or any registrar or deputy registrar or assistant deputy registrar within the district to which he is appointed may administer any oath or take any affirmation or declaration in lieu of an oath respecting titles to land from any one entitled by law to affirm or declare. As amended 1911-12, c. $4, \S 15(7)$.

17. Every registrar shall when required furnish under seal exemplifications, copies and abstracts of any instruments affecting lands which are deposited, filed or registered in his office, and every such exemplification or certified copy shall be received as evidence in the same manner and with the same effect as if the original was produced.

(2) Every registrar shall when requested furnish under seal an abstract in form EE, showing in whose name any parcel of land stands, the number of the certificate of title and the instruments registered against the said land. Added 1911-12, c. 4, $\S 15(8)$.

(3) Every registrar shall when requested furnish a general registrar's certificate under seal in form FF. Added 1911-12, c. $4, \S 15(9)$. 
18. Neither the inspector of land titles offices, nor any registrar, deputy registrar or assistant deputy registrar or clerk in any land titles office shiall directly or indirectly act as the agent of any person investing money and taking securities on land within any registration district, nor shall the inspector of land titles offices, nor any registrar, deputy registrar or clerk advise, for any fee or reward or otherwise, upon titles to land, nor practise as a conveyancer, nor shall he carry on or transact within the land titles office any business or occupation whatever other than his duties as such inspector, registrar, deputy registrar or clerk. As amended 1911-12, c. 4, \& 15 (9).

19. Every land titles office shall be kept open on all days (except Sundays and legal holidays) between the hours of ten o'clock in the forenoon and four o'clock in the afternoon, except on Saturdays, when the said offices shall be closed at one o'clock in the afternoon during which times either the registrar or his deputy registrar shall be in attendance.

20. The registrar shall keep a book or books which shall be called the "day book," and in which shall be entered by a short description every instrument relating to lands for which a certificate of title has issued or been applied for which is given in for registration, with the day, hour and minute of its so being given in; and for purposes of priority between mortgagees, transferees and others the time so entered shall be taken as the time of registration; and the registrar in entering memoranda upon the certificate of title embodied in the register and in indorsing a memorandum upon the duplicate shall take the time from the day book as the time of the registration.

(2) Unless required so to do by order of a court or a judge the registrar shall not receive or enter in the day book any instrument until the duplicate certificate of title for the lands affected is produced to him so as to enable lim to enter the proper memorandum on such duplicate certificate, except executions against lands, caveats, mechanics' liens, transfers by a sheriff or municipal officer, or by order of a court or a judge, transfers on sales of lands for taxes, maps or plans which do not require to be registered, or certificates or orders of a, court or a judge, and except a morterage or other incumbrance created by any person rightfully in possession of land prior to the issue of the grant from the ('rown, or prior to the issue of transfer from the Hudson's Bay Company or from any company entitled to a grant of such lands from the Crown or to which letters patent from the (rown for such mortgaged lands have already issued, if there is produced to and left with 
the registrar, with the mortgage an affidavit made by the mortgagor in the form $\mathrm{P}$ in the schedule to this Act, and also in the case of lands mortgaged prior to the issue of transfer from the Hudson's Bay Company or other company as aforesaid a certificate from the land commissioner or other proper officer of such company that the purchase price of such mortgaged lands has been paid and that the applicant is entitled to a transfer in fee simple thereof from such company.

21. The registrar shall also keep a book or books which shall be called the "register" and shall enter therein all certificates of title, which shall be in the form $\mathrm{E}$, shall constitute a separate folio of such book, and the registrar shall record therein the particulars of all instruments, dealings and other matters by this Act required to be registered or entered in the register and affecting the land included in such certificate of title.

22. Every grant shall be deemed and taken to be registered under the provisions and for the purposes of this Act so soon as the same has been marked by the registrar with the folio and volume on and in which it is embodied in the register, and every other instrument shall be deemed to be registered as soon as a memorandum of it has been entered in the register upon the folio constituted by the existing grant or certificate of title of such land.

23. Instruments registered in respect of or affecting the same land shall be entitled to priority the one over the other according to the time of registration and not according to the date of execution; and the registrar, upon registration thereof, shall retain the same in his office, and so soon as registered every instrument shall become operative according to the tenor and intent thereof, and shall thereupon create, transfer, surrender, charge or discharge, as the case may be, the land or the estate or interest therein mentioned in the instrument.

24. Every memorandum entered in the register shall state the nature of the instrument to which such memorandum relates, the day, the hour and the minute of its registration, and the names of the parties thereto, and shall refer by number or symbol to such instrument, and shall be signed by the registrar.

25. Whenever a memorandum has been entered in the register the registrar shall make a like memorandum upon the cluplicate when the same is presented to him for the purpose, and the registrar shall sign and seal such memorandum, which shall be received in all courts of law as conclusive evidence of its 
contents and that the instrument of which it is a memorandum has been duly registered under the provisions of this Act.

26. Whenever any land is granted in the province by the Crown and the letters patent therefor have been forwarded -from the office whence the same are issued to the registrar of the registration district in which the land so granted is situated, the registrar shall retain the letters patent in his office; and a certificate of title, as provided by this Act, with any necessary qualification shall be granted to the patentee:

Provided that in no case shall a first or subsequent certificate of title issue for more than fifty lots or for lots in more than one subdivision or for unsubdivided lands which are not contiguous, or which contain more than six hundred and forty acres. As amended 1911-12, c. 4, § 15 (10).

(2) Where a person has obtained a patent under a homestead or under a homestead and pre-emption entry or under half-breed land scrip or military bounty land scrip in accordance with the Act of Parliament of Canada known as The Dominion Lands Act, and amendments thereto, a duplicate of such certificate of title shall be issued to such party free of all fees and charges by this Act provided to be paid and in the case of other patentees such duplicate certificate of title shall be issued upon the payment of such fees as are fixed or may from time to time be fixed by the Lieutenant Governor in Council.

(3) The notification to the Hudson's Bay Company by the minister of the interior under the provisions of The Dominion Lands Act of the survey and confirmation of the survey of any township or part of a township shall be accepted by a registrar as equivalent to and dealt with by him in all respects in the same manner as if the said notification were letters patent to and in favor of the said company granting to the said company in fee simple the sections or portions of sections to which they are entitled in such townships or parts of townships under the provisions of The Dominion Lands Act.

(4) A notification to the registrar from the minister of the interior of Canada that the land described therein has been granted to the Canadian Pacific Railway Company or to any other railway company entitled to Dominion lands under authority of an Act of the Parliament of Canada shall be accepted by the registrar and doalt with by him in all respects as if the same were lettress patent in favor of such company.

(5) The owner of any estate leased or demised to him or to the person from whom he claims a title, for a life, or for 
lives, or for a term of more than three years, in any land for which the grant from the Crown has been registered, may apply to have his title registered and to have a certificate of title issued to him therefor under the provisions of this Act.

(6) A notification received by the registrar from the minister of public works of the abandonment by the Crown of any roads or road allowances or trails which now are or which may hereafter be vested in the Crown in the right of the province, shall have the same effect as a patent issued by the Crown to the person in such notification mentioned as transferee and shall be so treated by the registrar. The notification shall state the nature of the grant and shall specify any mines, minerals, easements or rights which are excepted therefrom.

(7) In case any land is expropriated or any street or portion of a street is closed by hylaw of any municipality pursuant to any ordinance of the Territories or Act of the Legislature of Alberta, a judge of the supreme court may direct that such bylaw be registered in the land titles office for the land registration district in which the land or the street or portion of a street affected lies, and upon the bylaw being registered the registrar upon payment of the proper fees shall give a certificate of title to the municipality for the land expropriated or the land comprised in the street or portion of the street closed by the bylaw; provided that the judge before directing the registration of any such bylaw may direct notice of the application of the municipality to be given to such persons as he deems interested therein. Added by 1907, c. 5, § 19.

27. The owner of any estate or interest in any land whether legal or equitable, letters patent for which issued from the Crown before the first day of January, one thousand eight hundred and eighty-seven, or which otherwise had prior to that date passed from the Crown, may apply to have his title registered under the provisions of this Act.

(2) If at the time of the grant of the certificate of title there are no registered incumbrances or conveyances affecting such land, the certificate may be granted to the patentee upon payment of such fees as are fixed in that behalf by tariff made from time to time by the Lieutenant Governor in Council, but no fees shall be parable therefor under the provisions of section one hundred and seventeen of this Act.

28. The application therefor shall be made in writing in the form $F$ in the schedule to this Act to the registrar of the registration district in which the land is situated; shall be verified by the affidavit in the form $G$ in the schedule to this 
Act of the applicant or some one on his behalf and shall bo accompanied by:

(a) All deeds in possession of the applicant, if any;

(b) A certificate showing all registrations affecting the title, down to the time when such application is filed, with copies of any registered documents the original whereof he is unable to produce;

(c) A certificate from the sheriff showing that there is no execution in his hands against the applieant's lands;

(2) But in no case shall it be necessary for any applieant to produce copies of any documents under the foregoing provisions of this section if the originals of such documents ar of record at the time when the application is made, in the office of the registrar to whom the application is made; provided that it shall not be necessary for the Hudson's Bay Company, in the ease of any lands the title of which has passed to that company before the first day of January one thousand eight hundred and eighty seven, either by notification made under the provisions of subclause seven of clause twentytwo of The Dominion Lands Act, or by letters patent issued thereunder prior to that date to produce to the registrar any of the certificates mentioned in this section, if the application is accompanied by an affidavit, to be made by any officer of the company approved by the attorney general, in the form $\mathrm{H}$ in the schedule of this Aet.

(3) For the purpose of such application all transfers of lancl executed in the manner in which transfers are required to be executed under this Act shall be taken to be effectual to vest. the title to such land in the transferee therein mentioned.

29. Upon the filing of such application, if the applicant is the original grantee of the Crown of the land and no deed, transfer, mortgage or other incumbrance or instrument or caveat affecting the title thereto appears to have been reeorded, or if not the original grantee, all the original title deeds are produced and no person other than the applicant is in actual possession of the land and no eaveat has been registered. the registrar if he entertains no cloulbt as to the title of the applicant shall grant a eertificate of title as hereinafter providect.

(2) If there is any mortgage or incumbrance against the land at the date of the said application, the filing with the registrar of the original mortgage or the instrument creating the incumbrance or a copy of such mortgage or instrument having indorsed thereon or attached thereto a receipt for the payment of the amount thereby secured signed by the 
mortgagee or incumbrancee, attested by an affidarit of the witness, shall operate as a discharge of the security created by such mortgage or incumbrance.

(3) Such receipt may be in form $I$ in the schedule to this Act.

(4) If any person other than the applicant is admitted or appears to be interested in the land, then if such interest is by virtue of a mortgage, incumbrance, lease, or charge created by any other instrument and the instrument is at the time of the application of record in the office of the registrar to whom the application is made, or, if not of record, the instrument is produced to the registrar, and if the applicant desires to have his title registered, subject to the interest of such other person, the registrar, if he entertains no doubt as to the extent and nature of such interest or of the title of the applicant may register the title and grant a certificate of title and issue a duplicate certificate of title subject to such interest.

(5) In any case where the person who is admitted or appears to be interested in land is a consenting party to an application, the registrar may, if he entertains no doubt as to the title of the applicant, grant a certificate of title, subject to the terms of the consent, provided that the consent shall be in writing by the consenting party in presence of a witness and attested in the manner provided for by this Act.

30. In all cases other than those provided for in the last preceding section, the registrar shall forthwith, having given the applicant a cortificate of the filing of his application, transmit the application, with all evidence supplied, to the judge to $b x$ dealt with as hereinafter mentioned.

31. The judge shall examine, without delay, all titles which are submitted to him, and for such purposes shall when necessitry hear all persons interested and shall hear and consider the claims as against the applicant of any person who is in possession of the land; and he shall have and exercise all the powers for compelling the attendance of persons and the production of documents which usually appertain to courts of civil justice and the judges thereof in civil actions brought therein.

32. Any person having an adrerse claim or a claim not recognized in the application for registration may at any time before the judge has approved of the applicant's title file with the registrar a short statement of his claim, verified by affidavit, and shall serve a copy thereof on the applicant, his adrocate or agent. 
33. If any adverse claim is filed the judge shall proceed to examine into and adjudicate thereon, and no certificate of title shall be granted until such adverse claim has been disposed of.

34. In any case before him the judge may direct that notice of the application be published in some newspaper or newspapers in such form and for such period as the judge thinks expedient and no order for registration shall be granted by him until after the expiration of at least four weeks from the first publication of the notice, if he has directed the same to be published.

35. The judge if satisfied with the applicant's title shall thereupon make an order directing the registrar, after the expiration of four weeks from the date thereof, unless in the meantime the order is appealed from, to register the same.

36. After registration of a title the registrar upon application by the owner or his duly authorized agent shall make out, sign, officially seal and deliver to him a duplicate of the certificate of title in the register on which shall be entered all memoranda indorsed on or attached to the certificate of title.

37. Upon every transfer of land mentioned in a certificate of title the certificate of title to be granted shall be granted by the registrar and a duplicate shall be issued to the transferee on application.

38. Every owner or mortgagee of any land for which a certificate of title has been granted shall deliver to the registrar a memorandum in writing of some post office address within the province to which it shall be sufficient to mail all notices that under this Act are required to be sent to an owner or mortgagee; and every owner or mortgagee shall from time to time in likc manner notify the registrar of any change in his address; and every owner shall, if required by the registrar to do so, before the delivery of any duplicate, sign a receipt therefor in his own handwriting or otherwise furnish the registrar with his signature so as to prevent personation as far as possible:

Provided that the registrar may proceed without such memorandum of address.

39. Every certificate of title shall be made on a separate folio of the register, and upon every transfer of ownership the certificate of title of the transferor and the duplicate 
thcrcof shall be cancelled and the certificate of title of the transferee shall thereupon be entered upon a new folio in the register; and the registrar shall note upon the folio of the title of the trinsferor the number of the folio of the transferee's title and upon that of the transferee the number of the folio if the transferor so that reference can be readily make from wne to the other as occasion requires.

\section{EFFECT OF REGISTRATION.}

40. In every instrument transferring, incumbering, or charging any land for which a certificate of title has been granted, there shall be impiied the following covenant by the transferor or incumbrancer, that is to say: That the transferor or incumbrancer will do such acts and execute such instruments as in accordance with the provisions of this Act are necessary to give effect to all covenants, conditions, and purposes expressly set forth in such instrument or by this Act declared to be implied against such person in instruments of a like nature.

41. After a certificate of title has been granted for any land, no instrument until registered under this Act shall be effectual to pass any estate or interest in any land (except a leasehold interest for three years or for a less period) or render such land liable as security for the payment of money; but upon the registration of any instrument in the manner hereinbefore prescribed the estate or interest specified therein shall pass, or, as the case may be, the land shall become liable as security in manner and subject to the covenants, conditions and contingencies set forth and specified in such instrument or by this Act declared to be implied in instruments of a like nature.

42. The owner of land for which a certificate of title has been granted shall hold the same subject (in addition to the incidents implied by virtue of this Act) to such incumbrances, liens, estates or interests as are notified on the folio of the register which constitutes the certificate of title absolutely free from all other incumbrances, liens, estates or interests whatsoever, except in case of fraud wherein he has participated or colluded and except the estate or interest of an owner claiming the same land under a prior certificate of title granted under the provisions of this Act or granted under any law heretofore in force relating to title to real property.

(2) Such priority shall, in favor of any person in possession of land, be computed with reference to the grant or earliest 
certifieate of title under which he or any person through whom he derives title has held such possession.

43. The land mentioned in any eertificate of title granted under this Act shall by implication and without any speeial mention therein, unless the contrary is expressly cleclared, be subject to:

(a) Any subsisting reservations or exceptions contained in the original grant of the land from the Crown;

(b) All unpaid taxes;

(c) Any public highway or right of way or other public easement, howsoever ereated upon, over or in respect of the land;

(d) Any subsisting lease or agreement for a lease for a period not exceeding three years, where there is actual oceupation of the land under the same;

(e) Any decrees, orders or executions against or affecting the interest of the owner of the land which have been registered and maintained in force against the owner;

(f) Any right of expropriation which may by statute or ordinance be vested in any person, body corporate, or his Majesty;

(g) Any right of way or other easement granted or acquired under the provisions of any Aet or law in force in the provinee.

44. Every certificate of title granted under this Act shall (except in case of fraud wherein the owner has partieipated or colluded) so long as the same remains in force and uncancelled under this Act be conclusive evidence in all courts as against his Majesty and all persons whomsoever that the person named therein is entitled to the land included in the same, for the estate or interest therein speeified, subject to the exceptions and reservations mentioned in the next preceding section/exeept so far as regards any portion of land by wrong deseription of boundaries or parcels included in such certificate of title and exeept as against any person claiming under a prior certificate of title granted under this Act or granted under any law heretofore in force relating to titles to real property in respeet of the same land; and for the purpose of this section that person shall be decmed to elaim under a prior certificate of title who is holder of or whose claim is derived directly or indirectly from the person who was the holder of the earliest certificate of title granted, notwithstanding 
that such certificate of title has been surrendered and a new certificate of title has been granted upon any transfer or other instrument.

45. A purchaser, mortgagee, or incumbrancee for valuable consideration shall not be affected by the omission to send any notice by this Act directed to be given or by the nonreceipt thereof.

46. After the certificate of title for any land has been granted no instrument shall be effectual to pass any interest therein or to render the land liable as security for the payment of money as against any bona fide transferee of the land under this Act unless such instrument is executed in accordance with the provisions of this Act and is duly registered thereunder; and the registrar shall have power to decide whether any instrument which is presented to him for registration is substantially in conformity with the proper form in the schedule to this Act or not and to reject any instrument which he may decide for any reason to be unfit for registration. As amended 1911-12, с. 4, § 15 (11).

47. No memorandum or entry shall be made upon a certificate of title or upon the duplicate thereof of any notice of trusts, whether expressed, implied or constructive; but the registrar shall treat any instrument containing any such notice as if there was no trust; and the trustee or trustees therein named shall be deemed to be the absolute and beneficial owners of the land for the purposes of this Act.

TRANSFERS.

48. When land for which a certificate of title has been granted is intended to be transferred, or any right of way or other casement is intended to be created or transferred, the owner may execute a transfer in the form $\mathrm{J}$ in the schedule to this Act, which transfer shall, for description of the land intended to be dealt with, refer to the certificate of title of the land or shall give such description as is sufficient to identify the same and shall contain an accurate statement of the estate, interest or easement intended to be transferred or created and a memorandum of each lease, mortgage and other incum. brance to which the land is subject.

49. Whenever an easement or any incorporeal right in or over any land for which a certificate of title has been granted is created for the purpose of being ammexed to or used and 
enjoyed together with other land for which a certificate of title has also been granted, the registrar shall make a memorandum of the interest creating such easement or incorporeal right upon the folio of the register which constitutes the existing certificates of title of such other land and upon the duplicate thereof.

50. If a transfer purports to transfer the transferor's interest in the whole or part of the land mentioned in any certificate of title, the transferor shall deliver up the duplicate certificate of title of the land and the registrar shall make a memorandum thereon and upon the certificate of title in the register cancelling the same, either wholly or partially, according as the transfer purports to transfer the whole or part only of the interest of the transferor in the said land, and setting forth the particulars of the transfer.

51. The registrar, upon cancelling any certificate of title either wholly or partially, pursuant to any transfer, shall grant to the transferee a certificate of title of the land mentioned in the transfer and issue to the transferee a duplicate thereof; and the registrar shall retain every transfer and cancelled duplicate certificate of title; but in the case of a partially cancelled certificate of title the registrar shall return the duplicate to the transferor after the nemorandum partially cancelling the same has been made thereon and upon the certificate of title in the register; or may whenever required thereto by the owner of an unsold portion of land in any partially cancelled certificate of title, or where such a course appears to the registrar more expedient, grant to such owner a certificate of title for such portion of which he is the owner, upon the delivery of the partially cancelled duplicate certificate of title to the registrar to be cancelled and retained.

52. In every instrument transferring land, for which a certificate of title has been granted, subject to mortgage or ineumbrance, there shall be implied the following covenant by the transferee both with the transferor and the mortgagee, that is to say: That the transferee will pay the prineipal money, interest, annuity or rent charge secured by the mortgage or incumbrance, after the rate and at the time specified in the instrument creating the same, and will indemnify and keep harmless the transferor from and against the principal sum or other moneys seeured by such instrument and from and against the liability in respect of any of the covenants therein contained or under this Act implied, on the part of the transferor. 
53. The registrar may require the owner of any land within his registration district desiring to transfer or otherwise deal with the same under the provisions of this Act to have the same surveyed by an Alberta land surveyor and to furnish to the registrar a plan of such survey made on tracing linen in black India ink, having the several ineasurements made thereon, and freprared upon one of the following scales:

(a) If the land proposed to be transferred or dealt with is of less area than one acre, then the map or plan shall be on a scale not less than one inch to two chains;

(b) If the land is of greater area than one acre, but not exceerling five acres, then the map or plan shall be on a scale not less than one inch to five chains;

(c) If the land is of greater area than five acres, but not excecding eighty acres, then the map or plan shall be on a scale not less than one inch to ten chains.

(2) The plan shall be signed by the owner and certified by the Alberta land surveyor who made the survey represented by such plan in form $\mathrm{C} C$ in the schedule to this Act, and the signature of both owner and surveyor shall be witnessed and attested in the manner hereinafter provided for the attestation of all instruments.

(3) The plan shall show all the original boundaries of the section, settlement lot or surveyed parcel of land of which the land desired to be dealt with is a part, with all angular and linear measurements thereof and all information as to the original monuments found on the ground which are necessary to establish the true position of such boundaries; provided, however, that if, in the opinion of the surveyor to the land titles office, it is not necessary to show all the said original boundaries in order to clearly determine the accurate position of the land desired to he dealt with, it shall be sufficient to show only such information in regard to said boundaries as he may determine to be necessary.

(4) If the owner neglects or refuses to comply with the requirements aforesaid the registrar shall not proceed with the registration of the transfer or other instrument until the requirements are complied with.

(5) Any plan which has been prepared in accordance with the provisions of any Act of the Parliament of Canada from time to time known as The Railuay Act or of any other Act of the Parliament of Canada, and which has been lodged or filed with the registrar under or in accordance with the said provisions, thall be dealt with and recognized by him in so far as it is capable of heing dealt with and recornized, as if it had been prepared and 
filed or registered under and in aceordance with the provisions of this Act.

(6) Any map or plan attested by the signature of the superintendent general of Indian affairs or his deputy and certified by a Dominion land surveyor to be a true copy of a plan of survey lodged or filed in the department of Indian affairs, of lands described as "Indian Lands" in the Act of the Parliament of Canada known as The Indian Act, shall be dealt with and recognized in accordance with the provisions of this section by the registrar of the land registration district in which the said lands are situated when the said map or plan has been lodged or filed with him, notwithstanding that The Indian Act does not expressly authorize the said map or plan to be so lodged or filed. 1911-12, e. $4, \S 15$ (12).

53a. All railway corporations shall deposit with the registrar of the land registration district within which such lands are situated plans in duplicate of the land required for their right of way and station grounds, or for any other railway purpose, before being granted certificates of title therefor, and such plan shall be in accordance with the following provisions:

(a) The plan shall be made on tracing linen in black India ink and vermilion red, and certified by a Dominion land surveyor in the form $\mathrm{HH}$ or by an Alberta land surveyor in the form $\mathrm{CC}$, in the schedule to this Aet, according as the land dealt with is Dominion or patented land, and the signature of such surveyor shall be duly witnessed and attested in the manner provided for the attestation of instruments to be registered under this Act;

(b) The area taken from each quarter section, settlement lot, or parcel of land, as the case may be, shall be shown on the plan;

(c) The original boundaries of sections, settlement lots and parcels of land, together with the information as to monuments on which the position of such lines was determined by the surveyor on the ground, shall be shown on the plan; and a sufficicnt number of angular and linear measurements to clefine the limits of the land taken for the right of way of such railway and to show their connection with each such original boundary shall also be shown;

(d) The land required for right of way shall be defined on the ground by iron posts placed on the southerly or westerly limit thereof, and such posts shall be placed at 
every change of direction of said limit and at the intersection of said limit with the southerly or westerly boundary of each road allowance or, where there is no road allowance, of each section, settlement lot or other surveyed pareel, whenever for any reason it is not possible to place such posts on the southerly or westerly limit of a right of way they shall be placed on the northerly or easterly limit thereof, and the plan shall show the location of these posts and, in the ease of those placed on seetion, settlement lot or other land boundaries, the distance measured along such boundary, from such posts to the nearest monument or post on such boundary;

(e) When the location of the railway is through land which has been subdivided and of which a plan has been registered under section 124 of this Act, the railway plan must show distinctly, as to all allotments taken in whole or in part for the right of way or station grounds or for any other railway purpose, the lines of such allotments according to such registered plan, and a sufficient number of angular and linear measurements to show the location and connection of the part required by the railway with the external boundaries of each allotiment;

(f) The plan shall show the land required for right of way, station grounds, or other railway purposes colored red;

(g) Notwithstanding anything in this seetion the registrar may accept transfers of land for right of way and station grounds referring to any plan prepared prior to the first clay of January, 1911, and signed by a Dominion land surveyor, or prepared subsequently to the said first day of January, 1911, and signed by an Alberta land surveyor, filed in his office on or before the first day of March, 1912, pursuant to The Railway Act of Canada. or The Railway Act, being chapter 8 of the Statutes of Alberta, 1907, if in his opinion the lands to be transferred are clearly and sufficiently defined and the centre line properly tied into the land boundaries of the section or other pareel of land, and all information and measurements necessary to locate the said lands upon the ground are shown upon the said plan. Added $1911-12$, c. $4, \S 15$ (13). 


\section{LEASES.}

54. When any land for which a certificate of title has been granted is intended to be leased or demised for a life or lives, or for a term of more than three years, the owner shall execute a lease in the form $\mathrm{K}$ in the schedule to this Act, and cvery such instrument shall, for description of the land intended to be dealt with, refer to the certificate of title of the land, or shall give such other description as is necessary to identify the land; and a right for the lessee to purchase the land therein described may be stipulated in the instrument; and in case the lessee pays the purchase money stipulated, and otherwise observes his covenants expressed and implied in the instrument, the lessor shall be bound to execute a transfer to such lessee of the land, and to perform all necessary acts by this Act prescribed for the purpose of transferring the land to the purchaser:

Provided always that no such lease of mortgaged or incumbered land shall be valid and binding against the mortgagee or incumbrancee unless the mortgagee or incumbrancee has consented to the lease prior to the same being registered, or subsequently adopts the same.

55. In every such lease, unless a contrary intention appears therein, there shall be implied the following covenants by the lessee, that is to say:

(a) That he will pay the rent thereby reserved at the times therein mentioned, and all rates and taxes which may be payable in respect of the demised land during the continuance of the lease;

(b) That he will at all times during the continuance of the lease keep and at the termination thereof yicld up the demised land in good and tenantable repair, accidents and damage to buildings from fire, storm and tempest or other casualty and reasonable wear and tear excepted.

56. In every such lease unless a different intention appears therein there shall also be implied the following powers in the lessor, that is to say:

(a) That he may, by himself or his agents, enter upon the demised lands and view the state of repair thereof, and may serve upon the lessee, or leave at his last or usual place of abode, or upon the demised land, a notice in writing of any defeet, requiring him within a reasonable time, to be therein mentioned, to repair the same, in so far as the tenant is bound to do so; 
(b) That in ease the rent or any part thereof is in arrear for the space of two calendar months, or in case default is made in the fulfilment of any covenant, whether expressed or implied in such lease, on the part of the lessee, and is eontinued for the spaee of two ealendar months, or in ease the repairs required by such notice, as aforesaid, are not completed within the time therein specified, the lessor may enter upon and take possession of the demised land.

57. In any such case the registrar, upon proof to his satisfaction of awful re-entry and reeovery of possession by a lessor, or his transferee by a legal proceeding, shall make a memorandum of the same upon the certifieate of title and upon the duplicate thereof when presented to him for that purpose, and the estate of the lessee in such land shall thereupon determine, but without releasing the lessee from his liability in respect of the breach of any covenant in the lease, expressed or implied, and the registrar shall cancel the lease if delivered up to him for that purpose.

58. Whenever in any lease made under this ${ }^{\circ}$ Act the forms of words in eolumn one of the form $\mathrm{L}$ in the schedule to this Act, and distinguished by any number therein, are used the lease shall be taken to have the same effect and be construed as if there had been inserted therein the form of words contained in column two of the said form and distinguished by the same number; and every such form shall be deemed a eovenant by the covenantor with the covenantee and his transferees, binding the former and his heirs, executors, administrators and transferees; but it shall not be necessary in any such lease to insert any such number; and there may be introduced into or annexed to any of the forms in the first column any expressed exeeptions from the same, or expressed qualifications thereof respectively, and the like exceptions or qualifications shall be taken to be made from or in corresponding forms in the second column.

59. Whenever any lease or demise which is required to be registered by this Act is intended to be surrendered and the surrender thereof is effeeted otherwise than through the operation of a surrender in law, upon the production of the surrender in the form $M$ in the sehedule to this Aet to the registrar he shall make a memorandum of the surrender upon the certifieate of title in the register and upon the duplieate certificate; and when the memorandum has been so made the estate or interest of the lessee in the land shall vest in the lessor or in the person 
in whom, having regard to intervening circumstances, if any, the land would have vested if the lease had never been executed:

Provided that no lease subject to mortgage or incumbrance shall be surrendered without the consent of the mortgagee or incumbrancee.

\section{MORTGAGES AND INCUMBRANCES.}

60. Whenever any land for which a certificate of title has been granted is intended to be charged or made security in favor of any mortgagee, the mortgagor shall execute a mortgage in form $\mathrm{N}$ in the schedule to this Act, or to the like effect; and whenever any such land is intended to be charged with or made security for the payment of an annuity, rent charge or sum of money, in favor of any incumbrancee, the incumbrancer shall execute an incumbrance in the form $O$ in the schedule to this Act, or to the like effect; and every such instrument shall contain an aceurate statement of the estate or interest intended to be mortgaged or incumbered, and shall, for description of the land intended to be dealt with, refer to the certificate of title on which the estate or interest is held or shall give such other description as is necessary to identify the land; and a memorandum of the mortgage or ineumbrance shall be made upon the certificate of title in the register anct upon the duplicate certificate. As amended 1911-12, c. 4, $\S 15(14)$.

(2) Provided that there may be filed in the office of the registrar any mortgage or other incumbrance created by any person rightfully in possession of land prior to the issue of the grant from the Crown or prior to the issue of the transfer from the Hudson's Bay Company or from any company entitled to a grant of such lands from the Crown or to which letters patent from the Crow for such mortgaged lands have already issued, if there is produced to and left with the registrar with the mortgage an affidavit made by the mortgagor in the form $P$ in the schedule to this Act, and also in the case of lands mortgaged prior to the issue or transfer from the Hudson's Bay Company or other company as aforesaid at certifieate from the land commissioner or other proper officer of the company that the purchase price of such mortgaged lands has been paid and that the mortgagor is entitled to a transfer in foe simple therefor from such eompany; and the registrar shall, on registering the grant of lands so mortgaged, enter in the register and indorse upon the chuplicate certificate of titlo before issuing it a memorandum of the mortgage or 
incumbrance; and when so entered the mortgage or incumbrance shall be as valid as if made subsequent to the issue of the grant or to the issue of the transfer from the Hudson's Bay ('ompany or from any company entitled to a grant of such lands from the Crown or to which letters patent from the Crown for such lands may have issued, as the case may be; and if more than one mortgage or incumbrance are filed they shall be registered in the order of time in which they have been filed in the said office.

(3) Provided, however, that nothing in this Act contained shall entitle a settler, who has entered for a homestead, or homestead and pre-emption under the provisions contained in The Dominion Lands Act, to mortgage the land entered for by him as a homestead or pre-emption prior to issue of a patent to him therefor; it being hereby declared that notwithstanding anything contained in this Act such mortgage is in the nature of an assignment or transfor which is prohibited by the said Act. As amenderl 1909, c. 4, § 11 (1).

61. A mortgage or incumbrance under this Act shall have effect as security but shall not operate as a transfer of the land theretsy charged.

62. Procecdings to enforce payment of moneys secured by mortgage or incumbrance, or to enforce the observance of the covenants, agreements, stipulations or conditions contained in any mortgage or incumbrance, or for the sale of the lands mortgaged or incumbered, or to foreclose the estate, interest or claim of any person in or upon the land mortgaged or incumbered, as also proceedings to redeem or discharge any land from any such mortgage or incumbrance, shall be had and taken in the Supreme Court of the Northwest Territories or any court hereafter constituted exercising within the province the jurisdiction, powers and authority at the date of the passing of this Act cxercised therein by the Supreme Court of the Northwest Territories under the practice and procedure of the said court.

63. Upon the production of any mortgage or incumbrance having indorsed thereon or attached thereto a receipt or acknowledgment in the form I in the schedule to this Act, signed by the mortgagee or incumbrancee, or where it is stated in the mortgage or incumbrance that the money has been advaneed on joint account by the surviving mortgagee or incumbrancee and proved by the affidavit of an attesting witness, discharging the whole or any part of the land comprisel in such instrument from the whole or any part of the 
principal sum or anmuity secured thereby, or upon proof being made to the satisfaction of a judge of the payment of all or part of the moneys clue on any mortgage or incumbrance, and the production to the registrar of a certificate signed by the judge to that effect, or upon the production of a receipt or acknowledgment in the said form I, accompanied by evidence satisfactory to the registrar of the loss or destruction of the mortgage or incumbrance the registrar shall thereupon make an entry on the certificate of title noting that such mortgage or incumbrance is discharged, wholly or partially, or that part of the land is discharged, as aforesaid, as the case requires; and upon such entry being so made the land or the estate or interest in the land or the portion of the land mentioned or referred to in such indorsement as aforesaid shall cease to be subject to or liable for such principal sum or annuity, or, as the case may be, for the part thereof mentioned in such entry as discharged. As amended 1911-12, c. $4, \S 15$ (15).

64. Upon proof of the death of the annuitant, or of the occurrence of the event or circumstance upon which in accordance with the provisions of any incumbrance the annuity or sum of money thereby secured ceases to be payable, and upon proof that all arrears of the said annuity and interest or money have been paid, satisfied, or discharged, the registrar shall, upon the order of a judge, make a memorandum upon the certificate of title in the register that such annuity or sum of money is satisfied and discharged and shall cancel such instrument, and upon such memorandum being made the land shall cease to be subject to or liable for such annuity or sum of money, and the registrar shall in any or either such case as aforesaid indorse on the duplicate certificate of title a similar memorandum whenever such duplicate certificate of title is presented to him for that purpose.

65. If any mortgagor becomes entitled to pay off the mortgage money, and the registered mortgagee is absent from the province and there is no person authorized by registered power of attorney to give a receipt to the mortgagor for the mortgage money after the date appointed for the redemption of any mortgage, the judge on application to him and proof of the facts and of the amount due for principal and interest, upon the mortgage may direct the parment into a chartered bank having a branch or agency in the district, or if not in the district in the provinee, of the mortgage money, with all arrears of interest then due thereon, to the eredit of the mortgagee or other person entitled thereto; and thereupon the interest upon the mortgage shall caise to run or acerue. 
(2) The registrar shall upon presentation of the judge's order and of the reeeipt of the manager or agent of the bank for the amount of the said mortgage money and interest make a memorandum upon the certificate of title in the register discharging such mortgage, stating the day, hour and minute on which such memorandum is made.

(3) Such memorandum shall be a valid discharge of the mortgage.

(4) The registrar shall, when such order and receipt are presented to him, send a notice of the fact to the mortgagee by letter addressed by mail to his last known place of abode.

(5) The registrar shall indorse on the duplicate certificate of title and also on the mortgage whenever those instruments are produced to him the several particulars to be indorsed upon each of such instruments respectively.

(6) After payment as aforesaid of any mortgage money and interest the mortgagee entitled thereto shall not recover any further sum in respect of such mortgage than the amount so paid.

66. Mortgages, incumbrances and leases of land for which a certifieate of tit'c has been granted may be transferred by a transfer executed in the form $Q$ in the schedule to this Act, and the transfer shall be registered in the same manner as mortgages, incumbrances and leases are registered; and transferees shall have priority according to the time of registration.

(2) Any mortgagee may transfer a part of the sum secured by the mortgage by a transfer exeeuted in the form $R$ in the schedule to this Act, and the part so transferred shall continue to be seeured by the mortgage and may be given priority over the remaining part or may be deferred or may continue to rank equally with it under the security of the original mortgage, as stated in the transfer; and the registrar shall enter on the certificate of title a memorandum of the amount of the mortgage so transferred the name of the transferee, and how the sum so transferred is to rank, and shall notify the mortgagor of the facts.

67. Upon the registration of a transfer of any mortgage, incumbrance or lease, the estate or interest of the transferor, as set forth in such instrument, with all the rights, powers and privileges thereto belonging or appertaining, shall pass to the transferee, and such transferee shall thereupon become subject to and liable for all and every the same requirements 
and liabilities to which he would have been subject and liable if named in such instrument.

68. By virtue of every such transfer the right to sue upon any mortgage or other instrument, and to recover any debt, sum of money, annuity or damage thereunder, and all interest at the time of such transfer in any such debt, sum of money, annuity or damages, shall be transferred so as to vest the same in law in the transferee thereof:

Provided always that nothing herein contained shall prevent the court from giving effect to any trusts affecting the said debt, sum of money, annuity or damages, in case the saill transferee shall hold the same as trustee for any other person.

69. In every mortgage there shall be implied against the mortgagor remaining in possession a covenant that he will repair and keep in repair all buildings or other improvement. erected and made upon the land, and that the mortgagee may at all convenient times until the mortgage is redeemed be at liberty, with or without surveyors or others, to enter into or upon the land to view and inspect the state of repair of the buildings or improvements.

70. Whenever in a mortgage made under this Act the form of words in column one of the form s in the said scheclule to this Aet, and distinguished by any number therein is uscel, such mortgage shall be taken to have the same effect and bo construed as if there had been inserted therein the form of words contained in column two of the arid form and distinguished by the same number; and every such form shall be deemed a covenant by the covenantor with the covenanter and his transferees, binding the former and his heirs, excentor: administrators and transferees; lut it shall not be necessary in any such morigage to insert any such number; and there may be introduced into or annexed to any of the forms in the first column any expressed exceptions from the same or expressed qualifications thercof respectively, and the like "xeeptions or qualifications shall be taken to be made from or in the corresponding forms in the fecond column.

71. In every case where land is subject to a mortgage or incumbrance signed by the ownere, the duplicate certificate of title shall be deposited with the registral who shall retain the same on behalf of all pereons interesterl in the land mentionet in such eertificate. 'The registrar shall if drired furnish to the owner of such mortgage or incomblance a certificate of charge in form GG hereto; antl before any instrument dealin? 
with or discharging the said mortgage or ineumbrance is registered, except in the ase provided for by section 65 of this Act, said certificate of charge shall be delivered up to the registrar to be cancelled:

Provided, however, that the registrar may dispense with such production upon satisfactory evidence being produced of the los or clestruction of any such certificate. As amended $1911-12, \therefore 4, \S 15(16)$.

\section{POWERS OF ATTORNEY.}

72. 'The owner of any land may authorize and appoint any person to act for him or on his behalf with respeet to the transfer or other dealing with such land or with any part thereof, in accordance with the provisions of this Act, by exeeuting a power of attorney in the form $\mathrm{T}$ in the schedule to this Act or as near thereto as eircumstances permit, or in any form heretofore in use for the like purpose in which the land is not speeifically mentioned and deseribed but is mentioned and referred to in general terms, any of which forms of power of attorney the registrar shall register, and if the land referred to in any form of power of attorney is speeifieally and properly described, the registrar shall make a memorandum upon the eertificate of title and upon the duplicate certificate of the particulars therein contained and of the time of its registration; and until such power of attorney in which the land referred to is so specifically described is revoled in the manner provided by the next following section, the right of the owner to transfer or to otherwise deal with the land shall be suspended:

Provided that the exeeution or registration of a general power of attorney shall not in any way affect the right of the owner to transfer or otherwise deal with his land.

73. Any such power of attorney may be revoked by a revoeation in the form $U$ in the schedule to this Act; and the registrar shall not give effect to any transfer or other instrument signed pursuant to such power of attorney after the registration of a revocation of such power.

74. Wherever the owner of any land for which a certifieate of title has been granted dies such land shall subject to the provisions of this Act rest in the personal representative of the deceased owner.

(2) Such personal representative shall before dealing with such land make application in writing (exeeuted by himself or his solicitor) to the registrar to be registered as owner and shall produce to and leave with the registrar the duplicate certificate 
of title for the lands in respect of which the application is made and probate of the will of the deceased owner, or letters of administration, or the order of court authorizing him to administer the estate of the deceased owner or a notarial copy of the will of the deceased made in notarial or authentic form, executed within the Province of Quebec, the original of which is filed in any notarial office, or a duly certified copy of the said probate, letters of administration or order, as the ease may be; for the purpose of this Act the probate of a will granted by the proper court of any province of the Dominion of Canada, or of the United Kingdom of Great Britain and Ireland, or an exemplification thereof, shall be sufficient, if the same shall have been resealed with the scal of the court in the province of Alberta having jurisdiction in such matters.

(3) The registrar shall thereupon enter upon the said certificate of title and upon the duplicate thereof a memorial of the application for transmission. the date of the probate, letters of administration, order of the court or notarial will, the date and hour of the production to him of the same and such other particulars as he may deem necessary and shall also note the fact of registration by the usual memorandum under his hand on the said probate, letters of administration, order or notarial will.

(4) Upon such memorandum being made the executor or administrator, as the case may be, shall be deemed to be the owner of the land and the registrar shall cancel the said certificate of title in the name of the deceased owner, and grant to the executor or administrator aforesaid, as such, a new certificate of title and issue to him a duplieate certificate.

(5) The title of the executor or administrator to the lands shall relate back and take effeet from the date of the death of the deceased owner.

(6) If the certificate of title for the land has not been granted to the deceased owner the personal representatives before being entitled to be registered under this section shall bring the land under this Act in the ordinary way. 1911-12, c. $4, \S 15(17)$.

75. Whenever any mortgage, incumbrance or lease affecting land, for which a certifieate of title has been granted, is transmitted in consequenec of the will or intestaey of the owner thereof, the probate of the will of the deceased owner, or letters of administration, or the order of the court authorizing a person as aforesaid to administer the estate of the decased owner or a notarial copy of the will of the deceased made in a notarial or authentic form, exceuted within the Province of 
Queber, the original of which is filed in any notarial office, or in office copy of the saitl probate, letters of administration. or order, as the case may be, accompanied by an application in writing from the exerutor or administrator, or such other perion as aforestid, elaiming to be registered as owner in respect of such estate or interest, shall be produced to and left with the registrar, who shall thereupon make a memorandum upon the certificate of title and upon the duplicate thereof of the late of the will and of the probate, or of the letters of adminitration, or order of the court as aforesaid, the date, hour and minute of the prodnction of the same to him, with such other particulars as he deems necessary. As amended 1911-12, ( $4.515(18)$.

(2) Tpon such momorandum being made, the executor, or administrator, or weh oflur perion, as the case may be, shall he deemed to be the owner of the mortgage, incumbrance or loase: and the ragistrar shal note the fact of the registration by menorantum unker his hand on the letters of administration. probate or order as aforesaid.

75. Any perzon registered in place of a deceased owner thall loold the land in respect of which he is registered upon the trusts and for the purposes to which the same is applicable by this Act or by law, and subject to any trusts and equities upon which the deceased owner held the same; but for the purpose of any registered dealings with such land he shall he deemed to be the absolute and beneficial owner thereof.

(2) Any person beneficially interested in any such lani may apply to a court or judge having jurisdiction to have the same taken out of the hands of the trustee having charge by law of such land and transferred to some other person or persons; and the court or judge, upon reasonable cause being shown, shall name some suitable person or persons as owner of the land; and upon the person or persons so named accepting the ownership and giving approved security for the due fulfilment of the trusts, the court or a judge may order the registrar to cancel the certificate of title to the trustee, and to grant a new certificate of title to the person or persons so named.

(3) The registrar, upon the production of the order, shall cancel the certificate of title to the trustee after making thereon and upon the duplicate there of a memorandum of the appointment $l y$ order of the court or judge of such person or person: as ownors, and shall grant a new certificate of title to such new trustee and iscue to him a cluplicate certificate of title. 


\section{EXECUTIONS.}

77. The sheriff, or any duly qualified officer, after the delivery to him of any execution or other writ affecting land, if a copy of such writ has not already been delivered or transmitted to the registrar, shall, on payment to him of fifty cents by the execution creditor named therein, provided that said writ is in force, forthwith ${ }^{3}$ deliver or transmit by registered letter to the registrar a copy of the writ and of all indorsements thereon certified under his hand and seal of office, if any; and no land shal be bound by any such writ until the receipt by the registrar for the registration district in which such land is situated of a copy thereof, either prior to this Act, under the law then in force or subseciuent hereto; but from and after the receipt by him of such copy no certificate of title shall be granted and no transfer, mortgage, incumbrance, lease or other instrument executed by the execution debtor of such land shall be effectual except subject to the rights of the execution creditor under the writ while the same is legally in force; and the registrar on granting a certificate of title and on registering any transfer, mortgage, or other instrument executed by the debtor affecting such land, shall by memoranda upon the certificate of title in the register and on the duplicate issued by him express that such certificate, transfer, mortgage, or other instrument is subject to such rights:

Provided that every writ or renewal there of shall cease to bind or affect land at the expiration of two years from the date of the receipt there of by the registrar of the district in which the land is situated unkess before the cxpiration of such period of two years a renewal of such writ is filed with the registrar in the same manner ats the original is recpured to be filed with him;

Provided further that all writs of execution or renewals thereof now in the hands of the registrars of land registration districts under any law heretofore in force relating to title to real property shall be and be taken to have been effectual to bind or affect the land only during the period of two yeatrs from the date of such writ or renewal thereof.

(2) The registrar shall keep a book in convenient form in which shall be entered according to the dates when respectively received a record of all copies of writs received by him from the sheriff or other officer as aforesaid whether so rescived prior to this Act or subsecuent thereto; and such book shall be kept indexed showing in alphabetical order the names 
of the persons whose lands are affected by such writs with the day and hour and minute of such receipt.

78. Upon the satisfaction or withdrawal from his hands of any writ, the sheriff or other duly qualified officer shall on payment to him of fifty cents forthwith transmit to the registrar a certificate under his official seal, if any, to that effect, and upon the production and delivery to the registrar of such certificate, or of a judge's order, showing the expiration, satisfaction or withdrawal of the writ as against the whole or any portion of the land so bound, the registrar shall make a memorandum upon the certificate of title to that effeet if the land has been brought under the provisions of this Act, and, if not, upon or opposite to the entry of the writ in the book to be kept under the provisions of the next preceding seetion; and thenceforth such land or portion of land shall be flecmed to be absolutely released and discharged from the writ. As amended $1909, \therefore 4, \$ 11(2)$.

\section{SHERIFF'S SALES.}

79. No sale by a sheriff or other officer as aforesaid, under process of law, of any land for which a certificate of title has been granted shall be of any effect until the same has been confirmed by the court or a judge; but when any such land is sold under the process of law, the registrar, upon the production to him of the transfer of the same in the form $V$ in the schedule to this Act, with proof of the due exeeution thereof, and with an order of the confirmation of such sale indorsed upon the transfer or attached thereto, shall after the expiration of four wecks after receiving the same register the transfer, cancel the existing certificate of title wholly, or in part if less than the whole of the land comprised therein be sold, grant a certificate of title to the transferee, and issue to him a duplicate certifieate in the prescribed form, unless such registration is in the mantime stayed by the order of the court or judge, and in such case the registration shall not be made except aecording to the order and direction of the said court or judge.

80. A transfer of such land so sold under process of law or for arrears of taxes as hereinafter provided shall be registered within a period of two months of the date of the order of confirmation, unless in the meantime this period be extended by order filed with the registrar of the court or a judge; and shall cease to be valid as against the owner of the land so sold and any person or persons claiming by, from or through him, if not registered within that period, or within the time fixed by such order 
81. The application for confirmation of a sale of such land so made under any process of law may be made by the sheriff or other officer making the sale or by any person interested in the sale, on notice to the owner, unless the judge to whom the application is made dispenses with such notice; and if the sale is confirmed the costs of confirmation shall be borne and paid out of the purehase money, or as the judge direets; but in case the sale is not confirmed the purchase money paid by him shall be refunded to the purchaser; and the judge may make such order as to the eosts of all parties to the sale and of the application for its confirmation as he thinks just.

\section{SALE FOR TAXES.}

82. When any land for which a crertificate of title has been granted is sold for taxes the purchars may at any time after the sale lodge a caveat against the transfer of the land; and upon the completion of the time allowed by law for redemption and upon the production of the transfer of the land in the prescribed form for tax sales in the form $V$ in the sehedule to this Act, with proof of the due execution thereof by the proper officer and a judge's order eonfirming such sale, the procedure for obtaining which shall be the same as herembefore provided in case of a sheriff's sale, the registrar shall, after the expiration of four weeks from the delivery to him of the transfer and judge's order of confirmation, register the transferee as absolute owner of the land so sold and shall cancel the certificate of title in whole or in part as the ease recuires, grant a new certificate of title to the transferee, and shall issule to the purchaser a duplicate certificate, unless the registration has in the meantime been stopped by order of a judge.

83. Upon production to the registrar of a duplieate certificate of title issued to a female, accompanied with a statement in writing of her marriage giving the date of such marriage, the place where solemnized, and her husband's full name with his residence and occupation, verified by oath or affirmation and the production of a certificate of the marriage by the person who solemnized the same, and such further (vidence as the registrar may require, or upon prorluction to the registrar of such evidence as would be sufficient to astablish the marriage? in any court in the province and on an application to the registrac to grant a new certificate of title, he shall file the same and at once cancel the existing eertificate of title, as also the duplicate, and shall make a memorandum of each of the facts; and the registrar shall thereupon grant a new eertificate of title to the applicant owner in her newly acfuiref surname in which her 
husband's full name, residence and occupation shall be given and shall iscue to her a duplieate certificate. As amended 1911-12, c. 4. 15 (19).

83a. Upon any assignment being made by the owner of any land, mortgage or incumbrance for the benefit of his creditors, the assignce or trustee of such owner may register such assignment and may at any time thereafter make an application to the registrar to be registered as owner of any such land, mortgage, or ineumbrance, and the registrar may, pursuant to such application, transmit any such land, mortgage or incumbrance to such asignee or trustee, who shall thereupon become the owner thercof and shall be invested with all the rights and powers which the assignor was possessed of, and his title shall relate back and take effect as from the date of the assignment; hut the registrar shall not, in issuing a certificate of title to such assignee or in any entries he may make regarding any such tranmission. refer to the fact that the new owner is such assignee or trustee, or that he holds any such land, mortgage or incumbrance for any other than his own absolute use, and for the purpose of any registered dealing therewith he shall be leemed to be the abolute omer threof. 1909 , c. $5, \$ 9$.

\section{CATEATS.}

84. Any person claiming to be interested under any will, settlement or trust cleed, or any instrument of transfer or transmission or under an unregistered instrument or under an execution where the execution creditor seeks to affect land in which the execution debtor is interested beneficially but the title to which is registered in the name of some other person or otherwise howsoerer in any land, mortgage or incumbrance, may caus to be fited on his behalf with the registrar a caveat in form 11 in the seheclule to this Act against the registration of any perion as transferee or owner of, or of any instrument affecting, such sitate or interest, unless such instrument be (xpresed to be subject to the claim of the caveator.

85. Every caveat filed with the registrar shall state the name and acldition of the person by whom or on whose behalf the same is filed and exeept in the case of a caveat filed by the registrar as hercinafter provided shall be signed by the areator, his atomey or agent and shall state some address or place within the province at which notices and proceedings rating to surb caveat or the subject matter thereof may be served and the nature of the intorest claimed and the grounds upon which such claim is founded and shall he supported by 
an affidavit that in the belief of the deponent the person by whom or on whose behalf the caveat is filed has a good valid claim in respect of the land, mortgage or incumbrance intended to be affected by the same, and that the eaveat is not filed for the purpose of delaying or embarrassing the applicant, or owner, or any person claiming through him, which affidavit or declaration may be in the form $\mathrm{X}$ in the scheclule to this Act. As amended 1911-12, c. 4, §15 (20).

86. Upon the receipt of a caveat the registrar shall enter the same in the day book and shall make a memorandum thereof upon the certificate of title of the land affected by such caveat and shall forthwith send a notice of the caveat and of the interest claimed thereunder through the post office or otherwise to the person against whose title the careat has been lodged; but in the case of a caveat before registration of title under this Act the registrar shall on receipt thereof enter the same in a book to be kept by him in which shall be entered all instruments affecting land as to which no title has yet issued.

87. So long as any caveat remains in foree the registrar shall not register an instrument purporting to affect the land, mortgage or ineumbrance in respect to which such caveat is lodged, unless such instrument be expressed to be sulject to the claim of the caveator.

88. The caveator, or in case the caveat is signed by his attorney or agent, such aftorney or agent may by notice in writing to the registrar withdraw his caveat at any time, and the registrar shall forthwith give notice in writing of such withdrawal by mail or otherwise to the caveatee. As amended $1911-12$, c. $4, \S 15(21)$.

89. Except in the case of a cavent lodged by the registrar, as hereinafter provided, every caveat loclged agimst any land. mortgage or incumbrance shall be deemed to have lapsed after the expiration of sixty days after notice, proved to the satisfaction of the registrar, has been cither server as process is usually served or sent by registered mail in the form $\mathrm{I}$ in the schedule to this Ant on to like cffect to the eaveator at or to the address stated in the caveat to take proceedings in court on his raveat, muless before the expiration of the said period of sixty days the caveator takes proceedings in court by originating summons subject to the provisions of The Judicature Ordinance of the Northwest Territories, or otherwise, to substantiate the title, estate, interest, or lien claimed by his 
caveat and a judge's order in such proceedings has been filed with the registrar continuing such eaveat:

Provided that the court or judge may upon an ex parte application shorten the said period of sixty days to such period as he shall specify in such order, and a copy of such order shall be served or mailed with the notice in this section referred to.

90. At any time before the expiration of the time limited for procecding upon a careat upon application to be made by way of summons to a judge, the judge for sufficient cause shown, and subject to such conditions as may seem proper, may extend the time for proceeding upon such caveat for a further period to be speeified in the order made upon such application.

91. In the case of a caveat filed, except a caveat filed by the registrar as hereinafter provided, the applicant or owner may at any time apply to the court or a judge by originating summons, subject to the provisions of The Judicature Ordinance of the Northwest Territories, calling upon the caveator to show cause why such caveat should not be discharged; and upon the hearing of such application the said court or judge may make such order in the premises and as to costs as to such court or judge may seem just.

92. In any proceedings in respect of a eaveat the court or judge may order that the caveator give such undertaking or security as such court or judge may consider sufficient to indemnify every person against any damage that may be sustained by reason of any disposition of the property being delayed, or to answer the costs of the caveatee, and may direct the registrar to delay registering any instrument dealing with the land, mortgage or incumbrance during such time as the order of such court or judge provides, or may direct the caveator to take further proceedings by action or otherwise upon his caveat, or may make such other order as may be just.

93. In any proceedings taken in consequence of the filing of a careat if it be made to appear to the court or judge that the caveator, or person on whose behalf the caveat has been filed by the registrar, as hereinafter provided, claims an interest in the land, mortgage or incumbrance by virtue of any contract in writing for the sale and purchase of such land, mortgage or incumbrance, signed by the vendor thereof or by his lawfully authorized agent or by virtue of an assignment of such contract, duly attested in the manner provided for in seetions 102 and 103 of this Act, and that there has been no default under the terms of such contract, or if any default has been made that 
such default has been eured before the return of the applieation to the court or judge then the eourt or judge may, and unless it otherwise appear's to be a case in which the caveat should be removed, shall refuse to order the removal of such eaveat.

(2) An assignor of such a contract may apply to remove a caveat filed by his assignee in cases in which default has been made under any covenant or agreement entered into by such assignee.

94. Any person, other than the registrar, filing or continuing any eaveat without reasonable cause shall be liable to make compensation to any person who may have sustained elamage thereby; and such compensation may be recovered by action if the caveator have withdrawn such caveat and no proceedings have been taken by the caveator or eaveatee as herein provided, but if such proceedings have been taken then such compensation shall be decided by the court or judge in such proceedings whether the eaveat has been withdrawn or not.

95. It shall not be lawful, except as hereafter mentioned, for the same person, or for any one on his behalf, to file more than one caveat in respect of the same matter: but nothing herein contained shall prejudies the right of the registrar to enter any eaveat under the power's vested in him by this Aet; and a judge may, if he thinks proper, upon application made to him for that purpose and upon such terms as to costs or otherwise as he may consider just, order that a new areat be filed, and such order shall fix a time within which the eaveator must proceed upon such caveat. As amended 1911-12, c. 4, \$15 (22).

96. In the ease of a caveat filed by the registrar as hereinafter provided the applieant or owner may apply to the court or a juelge by originating summons as provided for by The Judicature Ordinance of the Northwest Territories to be served upon the person on whose behalf such caveat has been filed for an order that such caveat be withelrawn or discharged; and in ease such person on whose behalf such caveat has been filed is an infant, lunatic or person of unsound mind, without guardian or committee, such court or juclge may by an ex parte order direct that surh summons be served on the official guardian, or some other person to be named therein, and may impose upon the appliciant such terms as to the costs of such guardian or other person appointed by such order as may seem just; and upon such applieation such court or juelge may make such order in the premises, rither dismising such application, discharging or withelpawing such caveat, or directing any of the parties to commence proceselings by action 
or otherwise as to the said court or judge may seem just and proper.

97. Registration by way of caveat, whether by the registrar or by any caveator, shall have the same effect as to priority as the registration of any instrument under this Act, and the registrar may in his discretion allow the withdrawal of such caveat at any time and the registration in lieu thereof of the instrument under which the person on whose behalf such caveat was lodged claims his title or interest, provided such instrument is an instrument that may be registered under this Act; and if the withdrawal of such caveat and the registration of such instrument are simultaneous, the same priority shall be preserved to all rights under the instrument as the same rights were entitled to under the caveat.

98. Any person elaiming an interest in any land, mortgage or incumbrance, may in lieu of, or after fling a caveat, proceed hy way of action to enforce his claim.

99. Upon the withdrawal, lapse or removal of any caveat, or upon the making of any order by the court or judge in connection therewith, a memorandum of such withdrawal, lapse, removal or order, as the case may be, shall be made by the registrar upon the certificate of title and upon the duplicate rertificate thercof.

100. The registrar may file a eaveat on behalf of his Majesty, or on behalf of any person who may be under any disability, to probibit the transfor or dealing with any land belonging or supposed to belong to the Crown or to any such person, and also to prohibit the dealing with any land in any case in which it shal appear to him that an error has been made in any certificate of title or other instrument, or for the prevention of any fraud or improper dealing.

101. Any contract in writing for the sale and purchase of any land, mortgage or incumbrance shall notwithstanding anything to the contrary therein contained be assignable, and any assignment of any such contract shall operate according to its terms to transfer to the assignee therein mentioned all the right, title and interest of the assignor both at law and in reguity subject to the conditions and stipulations in such assignment contained:

Provided, however, that nothing herein contained shall affert any rights at law or in equity of the original vendor or owner of the land, mortgage or ineumbrance, until notice in writing of such assignment has been either sent to him by registered mail or served upon him in the way process is usually 
served; and the notice mentioned in section 86 hereof shall be deemed to be such notice.

(2) This section shall apply to written agreements, or contracts in writing, for the sale and purchase of any land, mortgage or incumbrance entered into before as well as after, the passing of this Act.

\section{ATTESTATION OF INSTRUMENTS.}

102. Every instrument executed within the limits of the province other than the notifications referred to in seetion 26 , subsection 6 hereof, instruments under the seal of any corporation, caveats, orders of a court or judge, executions, or certificates of any judicial proceeding, attested as such, requiring to be registered under this Act, shall be witnossed by one person who shall sign his name to the instrument as a witness, and who shall appear before the inspector of lancl titles offices or the registrar or deputy registrum of the registration district in which the land is situated, or before a judge, stipendiary magistrate, notary public, commiscioner for taking affidavits, or a justice of the peace in or for the province, and make an affidavit in the form $\mathrm{Z}$ in the schedule to this Act.

(2) Any document executed by a corporation, notwithstanding anything to the contrary in the Act, statute, charter or memorandum and articles of ascociation incorporating such corporation, shall for the purpoves of this Act be dremed to be sufficiently executer if sealed with the corporate seal of such corporation and counterigned by at least one offic's" of the corporation.

103. Every instrument cxecuted withont the limits of the province, other than grants from the Crom, Order in Council, instruments under the seal of any rorporation, or caveats required to be registered under the provisions of this Aet, shall be witnessed by one person who shall sign his name to the instrument as a witness, and who hall appear before on of the following perons and make an afficlavit in the said form $\mathrm{Z}$ :

(a) If made in ainy province of Canata, before a judge of any court of record, any commisioner authorized to take affidavits in such province for use in any court of recorel in this provinee, or before any notary public uncler his official seal. As amended 1907, c. $5, \$ 19(2) ; \mathrm{or}^{\prime}$

(b) If made in Grait Britain or Ircland, before a juclge of the Supreme Court of Judicature in England or 
Ireland, or of the Court of Sessions or of the Judiciary Court in Scotland, or a judge of any of the county courts within his county, or the mayor of any city or incorporated town under the common seal of such city or town, or before any commissioner in Great Britain or Ircland, authorized to take affidavits therein for use in any court of record in the province, or a notary public under his official seal; or

(c) If made in any British colony or possession out of Canada, before a judge of any court of record, the mayor of any city or incorporated town under the common seal of such city or town, or notary public under his official seal; or

(d) If made in any foreign country, before the mayor of any city or incorporated town, under the common seal of any such city or town, or before the British consul, vice consul or consular agent residing therein, or before any judge of any court of record or a notary public under his official seal:

Provided that the court or a judge may, upon being satisfied of the due execution of any instrument, whether such instrument has been executed within or without the limits of the province, authorize the registration of the same, notwithstanding that the proof of such execution may be defective under the provisions of this or of the next preceding section hereof.

REMEDIAL PROCEEDINGS.

\section{Ejectment.}

104. No action of ejectment or other action for the recovery of any land for which a certificate of title has been granted shall lie or be sustained against the owner under this Act in respect thereof, except in any of the following cases, that is to say:

(a) The case of a mortgagee as against a mortgagor in default;

(b) The case of an incumbrancec as against an incumbrancer in default;

(c) The case of a lessor as against a lessee in default;

(d) The case of a person deprived of any land by fraud as against the owner of such land through fraud, or as against a person deriving title otherwise than as a transferee bona fide for value, from or through such owner through fraud; 
(e) The case of a person deprived of or claiming any land included in any grant or certificate of title of other land by misdeseription of such other land or of its boundaries, as against the owner of such other land;

(f) The case of an owner claiming under an instrument of title prior in date of registration under this Act, or under the provisions of any law heretofore in foree in any case in which two or more grants, or two or more certificates of title, or a grant and certificate of title, are registered under this Act or under any such law in respect to the same land.

(2) In any case, other than as aforesaid, the production of the certificate of title or a certified copy thereof shall be an absolute bar and estoppel to any such action against the person named in such certificate of title as owner or lessee of the land therein deseribed.

105. After a certifieate of title has been granted therefor any person deprived of any land in consequence of fraud or by the registration of any other person as owner of such land, or in consequence of any fraud, error, omission, or misclescription in any certifieate of title or in any memorandum thereon or upon the duplicate thereof, may, in any case in which the land has been included in two or more grants from the Crown, bring and prosecute an action at law for the recovery of damages against such person as a judge appoints, and in any other case against the person upon whose application the erroneous registration was made, or who acquired title to the land in question through such fraud, error, omission, or mislescription:

Provided always that except in the case of fraud or error occasioned by any omission, misrepresentation, or misdescription in the application of such person to be registered as owner of such land, or in any instrument executed by him, such person shall, upon a transfer of such land bona fide for value, cease to be liable for the payment of any damages which but for the transfer might have been recovered from him under the provisions hereinbefore contained, and such damages, with eosts, may in such last mentioned case be recovered out of the assurance fund hereinafter provided for, hy artion against the registrar as nominal defendant.

106. Nothing in this Act contained shall be so interpreted as to leave subject to action for recovery of damages as aforesaid, or to action of ejectment, or to deprivation of land in respect to which he is registered as owner, any purchaser or 
mortgagee bona fide for valuable consideration of land under this Act on the plea that his transferor or mortgagor has been registered as owner through fraud or error or has derived title from $\mathrm{Oi}^{\mathrm{i}}$ through a person registered as owner through fraud or error, except in the case of misdescription as mentioned in section one hundred and four.

107. If the person against whom the action for damage: is directed to be brought as aforesaid is dead or cannot be found within the province, an action for damages may be brought against the registrar as nominal defendant for the purpose of recovering the amount of the said damages and costs against the said assurance fund; and in any such case, if final judgment is recovered and also in any case in which damages are awarded in any action as aforesaid and the sherifl makes a return of nulla bona or eertifies that any portion thereof. with costs awarded, camnot be recovered from such person. the provincial treasurer upon receipt of a certificate of the judge before whom the said action was tried shall pay the amount of such damages and costs as are awarded or the unrecovered balance there of as the case may be and shall charge the same to the account of the said assurance fund.

108. Any person sustaining loss or damage through any omission, mistake, or misfeasance of the inspector of land titleoffices or a registrar, or any of his officers or clerks, in the "xecution of their repective duties under the provisions of this Aret, and any peroon deprived of any land by the registration of why other peron as owner thereof or by any error. onission or misdescription in any certifieate of title or in any memorandum upon the same or upon the duplicate certificate thercof, and who, by the provisions of this Act, is barred from bringing an action of rjectment o" other action for the recovery of the land, may in any case in which remedy by action for recovery of damages hereinbefore provided is barred, bring an action against the registrar as nominal defendant. for recovery of damages; and if the plaintifi recovers final jurlgment against such nominal defendant the judge before whom such action is tried shall certify to the fact of such judgment and the amount of the damages and costs recovered and the provincial treasurer shall pay the amount thereof to the perion entitled on production of an exemplification or certified copy of the judgment rendered and shall charge the same to the account of the said assuranee fund:

Provided always that notice in writing of every such action. and the cause thereof, shall be served upon the attorney general. 
and also upon the registrar, at least three calendar month before the commencement of such action.

109. If in any such action judgment is given in favor of the nominal defendant, or the plaintiff discontinues or becomes nonsuited, the plaintiff shall be liable to paty the full costs ot defending the action; and the same when taxed shall bx levied in the name of the nominal defendant by the like proces of execution as in ordinary ciril cases.

110. No action for recovery of damages sustained through deprivation of land shall lie or be sustained against the registrar or against the assurance fund aforesaid umless the same in commenced within the period of six years from the date of such deprivation:

Provided, nevertheless, that any person under the disability of infancy, lunacy or unsoundness of mind may bring the action within six years from the date on which the disibility ceased; and the plaintiff in the action within six years from the date on which such disability ceased, and the plaintiff in any such action at whatever time it is brought, and the plaintift in any action for the recovery of land shall be nonsuited in any case in which it appears to the satisfaction of the judge before whom such action is tried that the plaintiff or the person through or under whom he claims title had notice by personal service or otherwise was aware of such delay and wilfully or collusively omitted to lodge a caveat or allowed the caveat to lapse.

111. Whenever any amount has been paid out of the said assurance fund on account of any person the amount may be recovered from him, or if dead, from the estate of such person, by action against his personal representatives, in the name of the registrar; and a certificate signed by the provincial treasurer of the payment out of the said assurance fund shall be sufficient proof of such debt; and whenever any amount has been paid out of the assurance fund aforesaid on account of any person who has abseonded or who cannot be found within the province and has left any real or personal estate within the same, a judge upon the application of the registrar and upon the production of a certificate signed by the provincial treasurer that the amount has heen paid in satisfaction of a judgment against the registrar as nominal defendant, and proof of service of the writ in any of the modes provided by the ordinary procedure in the provinee, may allow the registrar to sign judgment against such person forthwith for the amount so paid out of the said assuranere fund, together with the cost of the application; and such jurlgment shall be final, subjer 1 
only to the right to have such judgment opened up, as may be provided in relation to ordinary procedure in the provinee, in cases of judgment by default, and the judgment shall be signed in like manner as a final judgment by default in an adverse suit and execution may issue immediately; and if the person has not left real or personal estate within the province sufficient to satisfy the amount for which execution has issued as aforesaid, the registrar may reeover such amount, or the unrecovered balance thereof, by information against such person at any time thereafter in the Supreme Court of the Northwest Territories or such other court as may hereafter be constituted, exercising within the province the jurisdiction, powers and authority at the date of the passing of this Act exereised therein by the Supreme Court of the Northwest Territories, at the suit of the attorney general.

112. If any person is dissatisfied with any act, omission, refusal, decision, direction or order of a registrar such person may require the registrar to set forth, in writing under his hand, the ground of such act, omission, refusal, decision, direction or order, and such person may then apply to a judge of the Supreme Court of Alberta by petition, setting forth the grounds of his dissatisfaction; and the judge, having caused the registrar to be served with a copy of the petition, shall have jurisdiction to hear the said petition and to make such order in the premises and as to the costs of the parties appearing upon the petition as the circumstances of the case require. As amended 1908 , c. $20, \S 15$.

113. Whenever a question arises with regard to the performance of any duty or the exereise of any function by this Act conferred or imposed upon a registrar, or whenever in the exercise of any cluty of a registrar a question arises as to the true construction or legal validity or effect of any instrument, or as to the persons entitled, or as to the extent or nature of the estate, right or interest, power or authority of any person or class of persons, or as to the mode in which any entry or memorandum ought to be made in the day book, or register, or upon any certificate of title or duplicate thereof, or as to any doubtful or uncertain right or interest stated or claimed to be dealt with by the registrar, he may refer the same in the form $\mathrm{AA}$ in the schedule to this Act to a judge of the Supreme Court of Alberta who may allow any of the parties interested to appear before him and summon any other of such persons to appear and show eause, either personally or by counsel, attorney-at-law or adrocate, in relation thereto; and the judge 
having regard to the persons appearing before him, whether summoned or not, shall decide the question or dircet any proceedings to be instituted for that purpose and direet the particular form of entry or memorandum to be made as under the circumstances appears to be just. As amended 1908, e. 20, $\S 15$.

114. If it appears to the satisfaction of a registrar that any duplicate certificate or other instrument has been issued in error or contains any misdescription of land or boundaries, or that any entry, memorandum or indorsement has been made in error on or omitted from any duplicate certifieate or other instrument, or that any such duplicate eertificate, instrument, entry, memorandum or indorsement has been fraudulently or wrongfully obtained, or that any such duplieate certificate or instrument is fraudulently or wrongfully retained, or if under any of the provisions of this Act the registrar requires a duplieate certificate for the purpose of making any memorandum thereon or for the purpose of wholly or partially cancelling the same, he may by written demand, in the form $\mathrm{BB}$ in the sehedule to this Act, to be served upon such person or to be mailed to his last known post office address within the province, require the person to whom such duplicate certifieate or instrument has been so issued or by whom it has been so obtained or is retained, to deliver up the same for the purpose of being eancelled, corrected or completed as the ease requires; and in case such person refuses or negleets to comply with such requisition, or cannot be found, the registrar may apply to a judge to issue a summons for such person to appear before him and show cause why such duplieate certifieate or other instrument should not be delivered up to be cancelled, corrected or completed as aforesaid, and if such person, when served personally or in the mode direeted in such summons with the summons, neglects or refuses to attend before the judge at the time therein appointed the judge may issue a warrant authorizing and direeting the person so summoned to be apprehended and brought before the said judge for examination.

(2) If it appears to the satisfaction of the registrar that any duplicate certificate of title or other instrument has been issued in error or contains any misdescription, or that any entry or indorsement has been made in error on any certifieate of title or other instrument, or that any such certificate, instrument, entry or indorsement was fraudulently or wrongfully obtained, he may, whether such certificate or instrument is in his custody or has been produeed to him in answer to a demand, so far as practicable without prejudicing rights conferred for value, 
cancel or correct any crror in such certificate of title or other instrument, or in any cntry made thereon or in any memorial, certificate, exemplification or copy of any instrument made in or issued from the land titles office, and may supply entries to be made:

Provided always that in the eorrection of any such error he shall not erase or render illegible the original words, and he shall affix the date upon which such eorrection was made or entry supplied. 1911-12,1.4, \$15 (23).

(3) Erry certifite of title so corrected, and every entry so correctod on -ipplied. hall have the like validity and effect as if -nch reror li: in not bren made or such entry omitted. 1911-12. (c. $4,5,520$.

115. Tron the appearunce before a judge of any person -tummoned or brought up by virtue of a warrant as aforesaid the julge may examine such person upon oath and in case it appears right so to to may order such person to deliver up the duplicate certificate or other instrument as aforesaid; and upon refusal or neglect by sich peron to deliver up the same, pursuant to the order, or to be put under oath, or to be examined, or to answer any puestion touching the matter after being swom. may commit such person to the nearest common jail for any period not execeling wix months, unless the duplicate certificate or other ins:trument is sooner delivered up or suffirient explanation is made why the same cannot be done, and in such rase, or in ease such person has absconded so that summons cannot be served upon him as hereinbefore directed. or in rase a period of three months from the time of mailing the said demand to such person has elapsed without the duplirate cortificate or other instrument having been returned to the registrar, the judge may dircet the registrar to canesl or correct or complete the duplicate certificate or other instrument in his rosession or any memorandem thereon relating to the land and to substitute and issue if neessary a duplicate certifieate or other instrument or make such memorandum as the rircumstances of the "ase require. and the registrar shall ohey -wh orkt. As amented 1909, e. 4, s 11 (3).

116. In any proceeding reperting land or in respect o" any transaction or contract relating thereto, or in respect of any instrument, caveat, momoundum or entry affecting land, the juclge by decere or ordes may direet the registrar to cancel. correct, sulstitute, or i-we any duplicate certificate, or make any memortindum or entry thercon or on the certificate of title and otherwise to do every act nreessary to give effect to the deeree or order. 
ASSURANCE FUND AND FEES.

117. Before the registrar shall perform any duty to be by him performed under any of the provisions of this $\mathrm{A} t$ he shall, except as herein otherwise provided, demand and receive the proper fees or fee therefor as fixed and settled by tariff made from time to time by the Licutenant Governor in Council; and demand and receive for the assurance fund upon every absolute transfer of land a ter the isue of the first certificate of title therefor, where the land was not incumbered at the time of registering the grant, one-fifth of one per cent. of the value of the land trans erred if such value amounts to or is less than five thousand dollar's, and one-tenth of one per cent. on the additional value, when such value exceeds five thousand dollar ; and upon every subsequent transfer he shall demand and receive upon the increase of value since the granting of the last certificate of title one-fifth of one per cent. if the increase is not more than five thousand dollars, and onctenth of one per cent. on any excess over such fire thousand collars.

(2) The value shall be aseertained by the oath or affirmaion of the applicant, owner or person acquiring such land, or of such other person as the registrar belicves to be acquainted with the value of the land and whose oath or affirmation the registrar is willing to aceept; and if the registiar is not satisfied as to the correctness of the value so sworn to or affirmed he may require such applicant, owner or person acquiring the land to produce a certificate of the value, under the hand of a sworn valuator appointed by a judge, which certificate shall be received as conelusive evidence of the value for the purpose aforesaid.

118. Each registrar shall keep a correct account of all sums of money received hy him in accordanee with the provisions of thi : Act and shall pay the same to the provincial treasurer at such times and in such manner as directed by the Licutenant (Governor in Council.

119. The government of the province may aceept and receive from the government of Canala or from the Covernor in Council of Canada such portion of the assuranee fund formed under the Act of the Parliament of Camalia known as The T'erritories Real Properiy Act and continued at the assurance fund by the Act of the Parliament of ('andela known as The Land Titles Act 18\% 1 , as the said gorernment of Canada or Governor in Council of Canada may assign, transfer or pay over to the government of the provine and for the purpose 
of carrying the provisions of this section into effect the Lieutenant Governor in Council may by order provide for the adjusting of all questions arising between the government of the provinee and the government of Canada in connection with the assignment, transfer or payment over of such portion of the said assurance fund as aforesaid including the giving or executing on behalf of the provinee all such contracts of indemnity or otherwise as may be found necessary or expedient.

120. The assurance fund herein provided for shall be formed by the provincial treasurer from the amounts paid to and received by him for that purpose by and from the registrars as hereinbefore provided and by investing the same together with all interest and profits accrued thereon from time to time in securities approved of by the Lieutenant Governor in Council:

Provided that the said assurance fund may be invested in securities or obligations of the Province of Alberta. As amended 1909, e. 5, § 9 .

(2) When the said fund shall have reached the sum of $\$ 75,000$ any sum in excess of said amount may, by direction of the Lieutenant Governor in Council, from time to time be transferred to and form part of the consolidated revenue fund of the province. $1911-12$, c. $4, \S 15$ (24).

121. The assurance fund shall not under any circumstances be liable for compensation for any loss, damage or deprivation oceasioned by the breach by any owner of any trust, whether expressed, implied or constructive; nor in any ease in which the same land has been included in two or more grants from the Crown; nor shall the assurance fund be liable in any case in which loss, damage or deprivation has been oceasioned by any land being included in the same eertifieate of title with other land, through misdeseription of the boundaries or parcels of any land, unless in the ease last aforesaid it is proved that the person liable for compensation and damages is dead or has abseonded from the provinee or has been adjudged insolvent, or the sheriff has certified that he is not able to realize the full amount and costs awarded in any action for such compensation; and the said fund shall be liable for sueh amounts only as the sheriff fails to recover from the person liable as aforesaid.

122. Upon the applieation of an owner of several parcels of land held under separate certificates of title, or under one certificate of title, and the delivery up of the duplicate certificates therefor to him, the registrar may cancel the existing 
certificate or eertifieates of title granted, as also the cluplicate certifieates so delivered up, and grant to the owner a single certificate of title for all the parcels of land, or several certifieates of title each applying to one or more of the pareels, in accordance with the applieation; upon which eertificates of title respectively shall be entered a memorandum of each and every incumbrance, lien, eharge, mortgage or other instrument affecting such pareel or pareels of land, setting forth the oceasion of the cancellation and referring to the certifieate of title so granted; and thereupon the registrar shall issue to the applicant one or more duplicate eertifieates as the case requires:

Provided that no one eertificate issued to any person under this section shall include or refer to a greater area than six hundred and forty aeres of land.

123. Upon production to the registrar of satisfactory proof by statutory declaration by the person to whom a duplieate eertificate has been issued or by some one having knowledge of the facts, of the aceidental loss or destruction of the duplicate certificate so issued, the registrar, having in the newspaper published nearest to the land described in the register, or if more newspapers than one are published in the same locality then in one of such newspapers, and in a conspicuous place in the land titles office for four weeks, published a notice of his intention to do so, may, having entered in the register the facts as proven, issue a fresh duplicate certificate in lieu of the one so lost or destroyed, noting upon the same why it is so issued:

Provided that the publication of such notice in a newspaper as above provided, or of any notice, may be dispensed with if the registrar is satisfied as to the loss or destruction of the duplieate eertificate so issued and that notice of the issue of another duplieate certificate in lieu of such lost or destroyed certificate in a newspaper or otherwise is unnecessary.

124. (1) Any owner subdividing land, for which a certifieate of title has been granted, for the purpose of selling or conveying the same in allotments shall deposit with the registrar a plan in triplicate, on traeing linen not exceeding twent $y$-nine inches in width, of the land on a scale of not less than one inch to every four chains, and the seale shall be marked on the plan; the plan shall be a fair speeimen of draughtsmanship, to the satisfaction of the examiner of surveys, and shall not be aceepted if any part of the lettering thereon has been done by means of rubber stamps or machine printing; the plan shall show in black India ink the boundaries, numbers and other distinguishing marks 
of the lots laid out thereby, and shall show the number of the cection, township and range or the number of the river lot, or the name of the district or reservation, as the case may be, in which the land lies, also the number of the meridian west of which the said range, river lot, district or reservation is situated, is well as all boundary lines of the quarter section, section, sections or river lot, which contain the subdivided land shown on the said plan; the plan shall show all monuments, posts or marks hy which the outside boundaries of the land shown on the plan are determined: where the plan is a subdivision of a lot or lots on a forner plan, it shall show in orange ink or in scarlet vermilion paint the numbers or other distinguishing marks of the lot or lots subdivided and the boundary lines of such lot or lots; the plan shall also show distinetly all roads, streets, passages, thoroughfares, squares or reservation appropriated or set apart. for public lise. with the courses and widths thereof respectively, the length and witth of all lots, and the courses of all division lines between the respective lots within the same, together with such other information as is required to show distinctly the position of the land being subdivided; each lot shall be marked with a distinet number or symbol: and the plan shall further show the courses of all streams of water within the limits of the land included in the plan; and every plan shall be signed by the owner or his agent, or where the oriner is a corporation by the whef offeer of the rorporation, and eertified in black India ink in the form ('C in the schedule to this Act by an Alberta land surveyor, whose respective signatures shali be duly witnessed and attested in the manner hereinbefore provided for the attestation of instruments to be registered under this Act. One tripliate of the plan shall forthwith be transmitted by the registrar to the department of public works. 1910, c. $2, \S 12$ (3).

(2) The registrar before filing a plan may require evidence to be given explaining any seeming discrepancy between the measurements on the plan and the description of the land in the registere or the measurements on any former plan, or may require evidence on any other matter which he considers requires to he explained. 1909 , c. 4 , s $11(-1)$.

(3) In no case thall any plan or surver, although filed and registered, be binding on the person so filing or registering the same, or upon any other person unless a sale, mortgage, ncumbrance or leas has been made aecording to such plan or survey; and in all cases cancellation in whole or in part or amondments or alterations of any such plan or survey may he orilered to be made at the instinee of the person filing or registering the same or of any person deriving title through 
him of any land shown on such plan oi survey by a judge, if on application for the purpose duly made and upon hearing all parties concerned it be thought fit and just so to ordel and upon such terms and conditions as to costs and otherwise as may be deemed expedient and the judge may make such order as to the vesting or revesting of any land included in such plan as he may think fit:

Provided that the provisions of this section shali apply to any plan which was formerly filed or registered in the land titles office for any registration district in the Northwest Territories now within the province of Alberta, whether a certificate or certificates of title have been granted or not for the land shown on such plan, or for any part of such lands. 1909 , c. $4, \S 11$ (4).

(4) No plan of sulddivision of any land shall be registered unless it conform in all respects to the regulations of the department of public works with regard thereto. 1907, c. 5, \$19(3); 1909 , c. $4, \S 11$ (4); 1911-12, c. $4, \S 15(2.5)$.

(5) The registrar shall not accept transfers or mortgages of parcels of land within the limits of any plan registered in the land titles office under this section, unless the boundaries of such parcels are delimited on the plan, or until a new plan shall have been registered under this section showing the said boundaries and distinguishing the said parcels by numbers or letters, if, in his opinion, the registration of such transfer would have the effect of nullifying the provisions of the preceding subsection. 1910, c. $2, \S 12(4) ; 1911-12$, c. $4, \S 1 j(2 \tilde{)})$.

(6) No plan of subdivision of any incumbered land shall be registered unless the same be approved and signed by the incumbrancee or incumbrancees. $1911-12$, c. $4, \$ 15$ (25).

(7) No lots shall be sold under agreement for sale or otherwise according to any townsite or suludivision plan until ifter the same has been duly registered in the land titles office for the registration district in which the land shown on said plin is situate, providing that this soction shall not apply to any plan now in existence and approved by the ministor. 1911-12, c. 1 , $\$ 15(25)$.

\section{ROAD ALLOWANCLS.}

125. In the following six sections the word "road" shall le, unless the context otherwise repuires, taken to mean and to refer to any old trail which existed prior to the subdivision of the land which it erosses into sections or any road allowanee diversion or now road. 
126. Upon the filing in the land titles office of the plans of surveys of any road as provided for in The Public Works Act, the lands shown on such plans so far as the same are not Dominion lands shall vest in the Crown in the right of the province, subject to the right of any person who has acquired any interest in the said lands, so far as the same are taken for any road allowance diversion or new road, to compensation for such interest.

(2) The Crown shall not be entitled to any mines or minerals, whether solid, liquid or gaseous, which may be found to exist within, upon or under any land vested in the Crown under the provisions of this section, unless the same are expressly purchased, and the title to any such mines or minerals shall in no wise be affected by the filing of any plans of survey as provided herein. 1911-12, c. $4, \S 15$ (26).

127. The provisions of The Public Works Act with regard to the allowance of compensation for lands required for public works and the provisions as to procedure in the said Act contained with regard thereto shall obtain in all applications for compensation made under this Act.

128. Whenever the plan of the survey in paragraph 126 hereof mentioned is forwarded to the registrar of the proper land titles office by the publie works department the registrar shall call in the duplicate certifieates of title for all patented lands affected thereby, in the manner set forth in section 114 of this Act, but if the registered owner refuses or neglects to return the duplieate certificate of title within thirty days after the demand has been mailed to him the registrar shall proceed to file the plin and shall eancel the area required for the road as shown on such plan from the original certificates in his office and from the duplicates that may have been or may otherwise be returned to him and shall issue a certificate of title for the road to his Majesty in the right of the province and forward the duplicate thereof to the minister of public works.

129. If a certificate of title has not been issued for any lands affected by a road, as shown by the plan which has been forwarded to the registrar by the public works department pursuant to the provisions of this Act, the registrar shall cancel the area required for the road as shown on such plan from the eertificates of title as they are issued and from the duplicates before they are delivered to the owners and shall issue new certificates of title for the area so cancelled, as provided in 
the preceding section hereof, unless the grant of the land is issued subject to the road shown on the plan.

130. Where in any plan filed as mentioned in section 126 hereof or heretofore filed by the department of public works of the Northwest Territories or of the province it is made to appear to the satisfaction of the registrar that manifest, technical or other error has intervened, the registrar may permit such plan to be withdrawn and a correct plan substituted therefor; and the provisions of sections 126 to 129 both inclusive hereof shall apply to such corrected or substituted plan upon the same being filed:

Provided, however, that where a certificate or certificates of title to the land shown upon the plan which it is desired to withdraw has or have been issued to the Crown no such plan shall be withdrawn until such certificate or certificates shall have been returned to the registrar who shall eancel the same and issue another certificate or other certificates of title in the place and stead thereof to his Majesty in the right of the province for the land shown upon such corrected or substituted plan; and the effect of said cancellation and reissue (and the effect of said withdrawal and substitution in eases in which no certificate of title has been issued to the Crown of the lands shown upon the plans so withdrawn) shall be to revest in the person or persons from whom such lands may have been divested by the plan that is so withdrawn or.in his or their heirs, executors, administrators or assigns, such part of the lands so divested as is not shown upon the corrected plan so substituted, and the registrar shall so notify such person or persons and shall cancel the cancellation if any made by him upon the original certificate of title in his office and upon the duplicate thereof when it is returned to him and shall cancel out of the original certificate and duplicate the area shown upon the corrected and substituted plan so filed.

131. Every covenant and power declared to be implied in any instrument by virtue of this Act may be negatived or modified by express declaration in the instrument; and in any action for a supposed breach of any such covenant the covenant alleged to be broken may be set forth and it shall be lawful to allege that the party against whom the action is brought did so covenant, preciscly in the same manner as if the covenant had bocn expressed in words in the transfer or other instrument, any law or practice to the contrary notwithstanding; and every such implied covenant shall have the same force and effect and be cnforced in the same mamer as if it had been set out at length in the transfer or othor instru- 
ment; and when any transfer or other instrument in accordance with this Act is exccuted by more parties than one such covenants as are by this Act to be implied in instruments of a like nature shall be construed to he sereral and not to bind the parties jointly.

132. The owner of any land for which a certificate of title has been granted or of any lease, mortgage or charge affecting the same, shall on applieation of any beneficiary or person interested therein be bound to allow his name to be used by such beneficiary or person in any action, suit or proceeding which it may be necessary or proper to bring or institute in the name of such owner concerning such land, lease, mortgage or chorge, or for the protection or benefit of the title vested in such owner, or of the interest of any such beneficiary or person; but nevertheless such owner shall in any case be entitled to be indemnified in like manner as, if being a trustee, he would hefore the passing of this Act have been entitled to he indemnified in a similar case of his name being used in any whe action, suit or proecedings by his cestui que trust.

133. Whenever any person who if not under disability might have made any application, given any consent, done any atet, or been party to any proceedings under this Act, is a minor, irliot or lunatic, the guardian or committee of the estate, respectively, of such a person may mike such application, give such eonsent, do such act, and be party to such proceeding as such person if free from disability might have made, given, done and been party to, and shall otherwise represent such person for the purposes of this Act; and whenever there is no guardian or committee of the estate of any such person aforesaid being infant, idiot or lunatic, or whenever any person, the committee of whose estate if he were idiot or lunatic, would be authorized to act for and represent such person under this Act, is of unsound mind and ineapable of managing his affairs but has not been found an idlot or lunatic under inquisition, a court or a judge may appoint a guardian of such person for the purpose of any proceedings under this Act, and from time to time change such guardian. And wherever the court or a judge sees fit it or he may appoint a person to act as the next friend of a married woman for the purpose of any proceeding inder this Act, and from time to time remove or change such next friend.

134. Whenever in any action, suit, or other proceeding affecting land for which a certificate of title has been granted it lecomes necessary to determine the fact whether the trans- 
feree, mortgagee, incumbrancee, or lessee, is a purchaser, transferee, mortgagee, incumbrancee, or lesse for valuable consideration or not, any person who is party to the action, stit or other proceeding may give in evidence any transfer, mortgage, incumbrance, lease or other instrument affecting the land in dispute, although the same is not referred to in the certificate of title or has been cancellech by the registrar.

135. Except in the case of fraud no person contracting or dealing with or taking or proposing to take a transfer, mortgage, incumbrance or lease from the owner of any land for which a certificate of title has been grantert chall bre bound or concerned to inquire into or ascertain the circrumstances in or the consideration for which the owner or any previous owner of the land is or was registered or to see to the application of the purchase money or of any part thercof, nor shall he be affected by notice direct, implied or constructive, of any trust or unregistered interst in the land, any rule of law or equity to the contrary notwithstanding; and the knowlecige that any trust or unregistered interest is in existence shall not of itself be imputed as fraud.

136. In any suit for specific performance brought by an owner of any land for which a certificate of title has been granted against a person who has contracted to purchase the land not having notice of any fraud, or other circumstances which according to this Act would affect the right of the transferor, the duplicate certificate of title of the owner shall be evidence that the owner has a good and valicl title to the land for the estate or interest therein mentioned or described.

137. Upon the transfer of any lant for which a certifieate. of title has been granted to two or more persons as joint owner's. to be held by them as trustres, it shall be lawful for the transferor to insert in the transfer or other instrument the word "no survivorship"; and the registrar shall in such case include such words in the duplicate ertificate issued to such joint owners pursuant to the transfer and in the eertifieate of title: and any two or more persons so registered at joint owners of any land held by them as truster's may hy writing under their hand authorize the registrar to enter the words "ne survivorship" upon the duplicate certificate and also upon the certificate of title; and after surh entry has been made and signed loy the registrar in either such "asce as aforesaid it shall not be lawful for any less number of joint owners than the number so entered to transfor or otherwise deal with the land without obtaining the sanction of the cont or of a jurlge hy an order on motion or pretition. 
138. Before making any order as aforesaid the court or judge shall, if it seem requisite, cause notice of intention so to do to be properly advertised, and in such case appoint a period of time within which any person interested may show cause why the order should not be made; and thereupon the said court or judge may order the transfer of the land to any new owner or owners, solely or jointly with or in the place of any existing owner or owners, or may make such order in the premises as the court or judge thinks just for the protection of the persons beneficially interested in the land or in the proceeds thereof; and upon such being deposited with the registrar he shall make a memorandum thereof upon the certificate of title and upon the duplicate certificate when the same is produced to hin; and upon such memorandum being made the person or persons named in the order shall be the owner or owners of the land.

139. Nothing contained in this Act shall take away or affect the jurisdiction of any competent court on the ground of actual fraud or over contracts for the sale or other disposition of land for which a certificate of title has been granted.

140. The Lieutenant Governor in Council shall from time to time provide the necessary books, forms, and other office requisites and shall make such rules and regulations as are necessary to carry out the provisions of this Act; and shall also make such rules and regulations as to him appear necessary for giving effect to this Act, in cases unprovided for, according to its true intent and purpose.

141. Proceedings under this Act shall not abate or be suspended by any death, transmission or change of interest, but in any such event a judge may make such order for carrying on, discontinuing or suspending the proceedings, upon the application of any person interested, as under the circumstances he thinks just, and may for such purpose require the production of such evidence and such notices to be given as he thinks necessary.

142. No petition, order, affidarit, certificate, registration or other proceeding under this Act shall be invalid by reason of any informality or technical irregularity therein or of any mistalie not affecting the substantial justice of the proceedings.

(2) Affidavits for use in applications to register title, or in any matter other than the execution of instruments, may be made before any person authorized to take affidarits for use in the Supreme Court of the Northwest Territories, or any 
court hereafter constituted exercising within the provinee the jurisdiction, powers and authority at the date of the passing of this Act exercised therein by the Supreme Court of the Northwest Territories; and in all matters before a judge or the court where proof is required the same may be taken by affidavit sworn as aforesaid or by riva roce evidence as may be ordered by the judge or court.

(3) Affidavits shall be subject to the practice at the datc of the passing of this Act governing affidavits in the Supreme Court of the Northwest Territories.

143. The inspector of land titles offices shall not, nor shall any registrar, deputy registrar, or any person acting under authority of a registrar, be liable to any action or proceeding for or in respect of any act bona fide done or omitted to be done in the exercise or supposed exercise of the powers given by this Act, or any order or general rule made in pursuance of this Act.

144. Whenever any matter is under this Act submitted to a judge by a registrar or by any other person or authority and the judge deems it advisable that parties interested should be notified of the time and place when and where a hearing of the matter so submitted should be held, and no special provisions are made therefor in this Act, or if there are any such special provisions and the judge shall be of opinion that the notice required thereby to be given is not sufficient, he may direct notice of such time and place to be given and he may direet that such notice be served personally upon such persons as he may direct or be left at their usual place of abode, or he may direct that such notice shall be posted at such place or places and for such periods as he may name, or he may direct that such notice be published in such newspaper or newspapers as he may designate and for such time as he may direct, and he may direct that such notice may be given in any one or more or in all the methods above specified.

(2) Whenever this Act directs that persons interested sball be heard or shall reserve notice and sueh parties are not within the jurisdietion or eannot be found so ats to be personally served, the judge may direet that any party without the jurisdietion may be served personally, or in cither case may direct substitutional servies within or without the jurisdietion to be made in such manner as he may direct or he may direct that publication of notice in such mammer as he may direct may be sufficient service. 
145. The registrar shall, in all cases of transfers, mortgages, incumbrances or leases, be entitled to require satisfactory evidence that the person making such instruments is of the full age of twenty-one years.

146. Whenever by virtue of this Act a judge is required or anthorized to hold an inquiry, proof of the matters relevant to the inquiry may be marle before him by affidavit, which may be sworn before any judge of any court, notary public, ju-tice of the peace or commisioner for taking affidavits, having authority or juricliction within the place where the oath is alministered:

Provided always that the judge may, whenever he deem: it expetient $s 0$ to do, require the personal attendance of any person lufore him to testify as to the matters of any such incuing or that any deponent to any affidarit shall attend in peron before him to be cros-cxamined upon his affidavit.

(2) Hhenercer the judge so requires any person or deponent to :tplear before him in person he may issue a summons under his hant and seal requiring such person or deponent to appear before lim at a time and place to be specified to testify as to what he may know concerning the matters in question. or to be eross-examined as the ase may be; and if such person or denonent fails to attend at the time and place specified, upon due proof under oath that such person or deponent has been duly served with the said summons and that proper conduct money has been paid or tendered to him (which conluct money shall be according to the tariff of fees provided for the attendance of witnesses at trials in civil causes in the supreme Court of the Northwest Territories or any court hereafter constituted exercising within the province the jurisliction, powers and authority at the date of the passing of this Act exercised therein by the supreme Court of the Northwest Territories) the judge may issue his warrant directed to the sheriff of any judicial district, directing him to apprehend wch person or deponent and bring him before the said judge for examination and to keep him in his custody until he is so examined; and such sheriff shall obey the said warrant according to the tenor thereof. And the sheriff shall be entitled to the same fees for rxecuting such warrant as he would be "nitied to for executing a proeess issued out of such court.

(3) The costs incidental to any such inquiry shall be in the diverotion of the judge, and shall be taxed by the clerk of the court in the district in which the inquiry was held as nearly as may be according to the tariff provided for civil causes in the said court; and judgment shall be signed in such court 
for such costs in favor of the party to whom they are awarded by the judge, and execution may be issued for the recovery thereof out of the said court as upon an ordinary judgment therein.

(4) Whenever any procceding is taken under this Act, whether by motion or summons, or by the filing with or the delivery to the registrar of a caveat, mechanics' lien, or copy of an execution against lands, or other such procceding, and any party to such proceeding, or the person in whose behalf or against whose interest such caveat, lien or execution has been so filed or delivered is not a resident of the province, a judge may, upon the application of a party to such proceeding or interested therein or affected by such caveat, lien or execution, grant an order requiring such non-resident to give security for the costs of the applicant for such order in prosecuting or resisting such proceedings or in removing or maintaining such caveat, lien or execution; and it may be a term of such order that in default such proceeding may be deemed granted or dismissed, or such caveat, lien or execution may be deemed removed or maintained; and such order may also provide for a stay of proceedings. The practice and procedure for obtaining such order and giving such security shall be as nearly as may be the same as upon an application for security for costs in civil causes in the said supreme court, or such other court as hereinbefore mentioned, and the judge may direct payment of the costs incident to such application or order to be taxed and recovered as is provided in the case of the costs mentioned in subscction (3) of this section.

APPEAL.

147. An appeal shall lie by the inspector of land titles offices, a registrar, or person directly interested therein, from any order or decision of a judge made or given under the provisions of this Act to the Supreme Court of the Northwest 'Territories sitting en banc, or to any other court sitting en banc hereafter constituted, exercising within the province the jurisdiction, powers and authority at the date of the passing of this Act exercised therein by the Supreme Court of the Northwest Territories, within the prescribed time, in the same manner and with the same incidents in and with which judgments and orders of that court by a single judge may be appealed from; and the practice and proceedings rolating to appeals in the said court inchuding costs and payment thereof and the enforcement of judgments on appeal shall, adapted to the circumstances, apply. 
148. If in any matter before a judge under this Act the judge considers proper he may refer the same to the court en banc, and such court may either dispose of the matter or refer it back to the judge with such direction as the court en banc may think fit.

149. The court or judge may order costs to be paid by or to any person party to any proceeding under this Act, regard heing had to the following provisions:

That any applicant under this Act is liable prima facie to pay all costs, charges and expenses incurred by or in consequence of his application, except in a case where parties object whose rights are sufficiently secured without their appearance, or when any costs, charges or expenses are incurred unnecessarily or improperly.

150. Any order of the court or a judge may be enforced in the same manner and by the same officials and process as orders are usually enforced by the procedure and practice of the Supreme Court of the Northwest Territories, or of any court hereafter constituted exercising within the province the jurisdiction, powers and authority at the date of the passing of this Act exercised therein by the Supreme Court of the Northwest Territories and shall be obeyed by every registrar and acting registrar when directed to him.

151. The said court sitting as the court of appeal may, by order of court, provide (and from time to time change) a tariff of costs payable for all services and proceedings under this ict; but unless and until so provided for the tariff of costs relating to actions at the date of the passing of this Act of the Supreme Court of the Northwest Territories where the title to lands is in question shall apply, adapted to the circumstances.

152. The Lieutenant Governor in Council may from time to time, whenever it is necessary so to do, add to or otherwise vary any of the forms in the schedule to this Act, or may cause to be adopted any other form or forms which he considers applicable to any special case or class of cases for which a form has not been provirled in the schedule to this Act.

153. All officers, persons, bodies politic or corporate acting under the provisions of any law or regulation heretofore in force in the province with relation to titles to real property shall continue to act as if appointed under this Act until others are appointed in their stead; and all proceedings taken under such former law or regulation shall be taken up and continued under this Act when not inconsistent therewith, and all penalties 
and forfeitures may be recovered and all proceedings had in relation to matters which have happened before the coming into force of this Act in the same manner as if the said former law or regulation was still in force, pursuing the provisions of this Act as far as they can be adapted to the said former law or regulation.

(2) All orders, regulations and rules made under any such former law shall continue good and valid in so far as they are not inconsistent with this Act until they are annulled or others made in their stead.

154. Nothing in this Act contained shall affect any act done or any right or right of action existing, accruing, accrued or established or any proceedings commenced in a civil cause before the coming into force of this Act; and all rights, estates and interests existing in any person under or by virtue of any former law in the province relating to titles to real property shall be and are hereby preserved so far but so far only as they are consistent with the provisions of this Act.

155. The registration or filing of all instruments effected, and all certificates of title granted uncler any law heretofore in force relating to titles to real property shall have the same effect and be regarded and dealt with in the same way as though such registrations or filings had been effected and such certificates of title granted under the provisions of this Act:

Provided, however, that the assurance fund established under the provisions of this Act shall not be liable in respect to any claims arising out of the registration or filing of such instruments or the granting of such certifieates.

156. This Act shall come into force upon the proclamation thereof by the Lieutenant Governor.

\section{SCHEDULE.}

\section{FORM A.-(Section 11.)}

Form of Inspector's, Registrar's and Deputy Registrar's OATH OF OFFick.

Province of Alberta, District of

To Wit:

I, (name and describe deponent) having been appointed to the office of inspector of land titles office (or registrar or deputy registrar) in and for the (name of registration district, ctc.) do 
swear (or affirm, as the case may be) that I will well, truly and faithfully perform and execute all duties required of me relating to the said office so long as I continue therein, and that I have not given, directly or indirectly, nor authorized any person to give any money, gratuity or reward whatsoever for procuring the said office for me.

Sworn before me at the
of the in the day of A.D. 19 .
(Signature of inspector, registrar or deputy registrar.)

FORMI B.-(Section 13.)

\section{Form of Bond of Inspector, Registrar and Deptty REgistraR.}

Province of Alberta, District of

To Wit:
Know all men by these presents that I, (insert name and addition to the principal) of the in the Province of Alberts of the Dominion of Canada, hereinafter called "the principal," and we (insert names and additions of the sureties) of the of , in the of and of the of in the " hereinafter called "the sureties," are respectively" held and firmly bound unto our Sorereign Lord the King, his Heirs and Successors, in the respective penal sums following, that is to say: "the principal" in the sum of dollars of lawful money of Canada, and each of the "sureties" in the sum of dollars of like lawful money, to be paid to our said Sovereign Lord the King, his Heirs and Successors; for which said respective payments, well and faithfully to be made, we jointly and severally, each for the other bind ourselves, and our respective heirs, executors and administrators, firmly by these presents, sealed with our respective seals.

Dated this day of in the year of our Lord one thousand nine hundred and Majesty's reign. and in the year of his:

Whereas "the prineipal," having been appointed to the office or employment of is required by law to give security to the C'rown for the due performance of the duties appertaining thereto; and "the sureties" have consented to become his sureties for such his performance of the said duties; and this: bond is given in pursuance of The Land Titles Act.

Now the condition of this obligation is, that if "the prin(ipal" faithfully discharges the duties of the said office and 
duly accounts for all moneys and property which may come into his custody by virtue of the said office this obligation shall be void, otherwise the same shall remain in full force and effect. Signed and sealed and delivered in the presenee of

(Signatures and Seals.)

\section{FORM C.-(Section 13.)}

Affidavit of Justification by a Surety.

Province of Alberta, District of

To Wit:
I, , one of the sureties in the above (or within) bond or obligation named make oath (or affirm, as the case may be) and say as follows:

1. I am seized and possessed to my own use of real (or real and personal) estate, in the of in Canada, of the actual value of dollars, over and above all charges upon or incumbrances affecting the same.

2. My post office address is as follows: (insert $i t$ ). Sworn before me at the

$\left.\begin{array}{c}\text { of } \begin{array}{c}\text { in the } \\ \text { of this day of }\end{array} \\ \text { A.D. } 19 \quad \text {. }\end{array}\right\}$

(Signature.)

FORM D.-(Section 13.)

Affidavit of Attestation of Bond.

Provinee of Alberta,

District of

To Wit:
I, of the of , in the of , make oath and say that I was personally present and did see

(one of, or as the case may be) the obligor in the above (or within) bond or obligation named, duly exeeute the said instrument by signing, sealing, and, as his act and deed (or their respective acts and deeds, as the case may be), delivering the same; and that I am a subscribing witness to such exeeution.

Sworn before me at the

$$
\begin{aligned}
& \text { of this day of } \\
& \text { of } 19 \text {.D. } 19 \text {. }
\end{aligned}
$$

(Signature.)

(A separate affidavit in this form will be made by a witness to the execution by such obligor, if the same person does not witness the execution by all of them.) 


\title{
FORMI E.-(Section 21.)
}

Certificate of Title.

\author{
Canadia \\ Provine of Alberta, \\ Registrution District
}

This is to certify that $A$. B. of

is now the owner of an estate (describe the estate) of and in (describe the property) subject to the incumbrances, liens and interests notified by memorandum underwritten or indorsed hereon, or which may hereafter be made in the register.

In witness where of I have hereunto subscribed my name and affixed my official seal this day of A.D. 19

And if subject to a mortgage, say:

The title of $A$. B. is subject to mortgage, dated the day of , made by $A . B$. to W. B. to secure (here state the amount secured, the rate of interest per cent. per annum and the respective dates from which the principal and interest are secured) payable as therein mentioned. [If mortgage is discharged, say: "The above mortgage No. , is discharged this day of A.D. 19 " (here state the distinguishing letter or number" of the register and the number of the folio therein.)]

And if subject to a lease, say:

The title of $A . B$. is subject to a lease, dated the day of , made by $A$. B. to $Y$. $Z$. for the term of years.

When the transfer is absolute, say:

This certificate of title is cancelled and a new certificate of title No. , issued this day of

A.D. 19 .

(Signature.)

\section{FORMI F.-(Section 28.)}

Appication to Bring Land Under the Operation of The LaNd Titles ACT.

To the Registrar of Registration District:

I (insert name and addition), hereby apply to have the land hereinafter described brought under the operation of The Land Titles Act. And I declare:

1. That I am the owner (or agent for , the owner) of an estate in fee simple in possession (or of an estate of freehold in possession for my life or otheruise as the case may require) in all that piece of land, being (here describe the land). 
2. That such land, including all buildings and other improvements thereon, is of the value of dollars and no more.

3. That there are no documents or evidences of title affecting sueh land in my possession, or under my control, other than those included in the schedule hereto.

4. That I am not aware of any mortgage or incumbrance affecting the said land, or that any other person has any estate or interest therein at law or in equity, in possession, remainder, reversion or expectaney (if there be any add: other than as follows: and set the same forth).

5. That the said land is now occupied (if unoccupied, prefix un to occupied, if occupied, add by whom, and state the name and addition of the occupant and the nature of his occupancy).

6. That the names and addresses so far as known to me of the oceupants of all lands contiguous to the said land are as follows:

7. That the names and addresses so far as known to me of the owners of all lands contiguous to the said land are as follows:

If the certificate of title is not to be granted to the applicant, add: And I direct the certificate of title to be granted in the name of (insert name and addition.)]

Dated this day of 19 .

Made and subscribed at

in the presence of

(Signature.)

\section{FORM G.-(Section 28.)}

Sehedule of Documents Referred to. AfFidavit.

Province of Alberta,

Distriet of

To Wit:

I.

of

make oath

1. That I am the applicant named in the applieation hereto annexed.

2. That the severa! statements contained in the said application are true, to the best of my linowlodge and belief.

Sworn before me at the

of in the , this of A.D. 19 
FORM H.-(Section 28.)

\section{Affidavit Concerning the Hudson's Bay Company's} LANDS.

Province of Alberta,

District of

To Wit:

I, of the of
in the of , make'
oath and say:

1. I am an officer of the Hudson's Bay Company entitled to make this affidavit by the authority and under the approval of the attorney general of Alberta.

2. Title to the lands mentioned in the accompanying application now produced and shown to me, and marked with the letter "A," passed to the said company by notification under the provisions of subelause 7 of clause 22 of The Dominion Lands Act (or by letters patent issued on-stating date-as the case may be).

3. The said company is, at the date of this affidavit, absolutely entitled to the said lands in fee simple and has not incumbered the same in any way whatsoever.

4. And the said lands are not subject to any execution, and are not chargeable with any arrears of municipal taxes, rates or assessments.

Sworn before me at the

$\left.\begin{array}{cc}\begin{array}{c}\text { of } \\ \text { of }\end{array} & \text { in the } \\ \text { day of } & \text { A.D. } 19\end{array}\right\}$

(Signature.)

\section{FORMI I.-(Section 29.)}

Receipt of Achnowledgment of Patment of Mortgage OR OTHER INCUMBrance.

I, C. D., the mortgagee (incumbrancee or assignee as the case may be) do acknowledge to have received all the moneys due or to become due under the within written mortgage (or incumbrance, as the case may be) and that the same is wholly discharged.

In witness whereof I have hereunto subseribed my name this day of, 19 .

Signed by the above named

$C . D$., in the presence of

(Signature.) 


\section{FORM J.-(Section 48.)}

\section{TRANSFER.}

I, A. B., being registered owner of an estate (state the nature of estate) subject, however, to such incumbrances, liens and interests as are notified by memorandum underwritten (or indorsed hereon) in all that certain tract of land containing acres more or less, and being (part of) section township - range, in the (or as the case may be), (here state rights of way, privileges, easements, if any, intended to be conveyed along with the land and if the land dealt with contains all included in the original grant refer thereto for descriptions of parcels and diagrams; otherwise set forth the boundaries and accompany the description by a diagram) do hereby, in consideration of the sum of dollars paid to me by $E$. F., the receipt of which sum I hereby acknowledge, transfer to the said $E$. $F$. all my estate and interest in the said piece of land. (When a lesser estate describe such lesser estate.)

In witness whereof I have hereunto subscribed my name this day of , 19

Signed by said $A . B$. in the presence of

(Signature.)

FORM K.-(Section 54.)

\section{LEASE.}

I, A. B., being registered as owner, subject, however, to such mortgages and incumbrances as are notified by memorandum underwritten (or indorsed hereon), of that piece of land (describe it), part of section township

range , (or as the case may be), containing acres, more or less (here state rights of way, privileges, easements, if any, intended to be conveyed along with the land, and if the land dealt with contains all included in the original grant or certificate of title or lease, refer thereto for description and diagram, otherwise set forth the boundaries by metes and bounds) do hereby lease to $E . F$. of (here insert description), all the said land, to be held by him, the said E. F. as tenant, for the space of years, from (here state the date and term), at the yearly rental of dollars, payable (here insert terms of payment of rent), subject to the covenants and powers implied (also set forth any special covenants or modifications of implied covenants). 
I, E.F. of (here insert description), do hereby accept this lease of the above described land, to be held by me as tenant. and subject to the conditions, restrictions and covenants abore set forth.

\title{
Dated this day of
}

signed by the above named

A. B. as lessor, and E.F.

as lessee, in presence of

(Signature of lessor.)

(Signature of lessee.)

(Here insert memorandum of mortgages and incumbrances.)

\author{
FORM L.-(Section 58.) \\ Short Covenants in Lease. \\ COLUMN ONE. \\ COLUMN TWO.
}

1. Will not, without leave 1. The covenantor, his execin writing, assign or sublet. utors, administrators, or transferees, will not, during the said term, transfer, assign or sublet the land and premises herebyleased, or any part thereof, or otherwise by any act or deed procure the said land and premises, or any part thereof, to be transferred or sublet, without the consent in writing of the lessor or his transferees first had and obtained.

2. Will fence.

2. The covenantor, his executors, administrators, or transferees, will during the continuance of the said term erect and put upon the boundaries of the said land, or on those boundaries on which no substantial fence now exists, a good and substantial fence.

3. Will cultivate.

3 . The covenantor, his executors, administrators, or transferees, will, at all times during the said term, cultivate, use 
and manage in a proper husbandlike manner, all such parts of the land as are now or shall hereafter, with the consent in writ ng of the said lessor or his transferees, be broken up or converted into tillage, and will not imporerish or waste the same.

4. Will not cut timber.

4. The covenantor, his executors, administrators, or transferees will not cut down, fell, injure or clestroy any living timber or timberlike tree standing and being upon the said land, without the consent in writing of the said lessor or his transferees.

5. Will not carry on offensive trade.

5. The covenantor, his executors, administrators, or transferees will not, at any time during the said term, use, exercise, or carry on, or permit or suffer to be used, exercised or carried on, in or upon the said premises, or any part thereof, any noxious, noisome or offensive art, trade, business, occupation or calling; and no act, matter or thing whatsoever shali at any time during the said term be done in or upon the said premises, or any part thereof, which shall or may be or grow to the annoyance, nuisance, grievance, damag* or any disturbance of the occupiers or owners of the adjoining lands and properties.

FORM M.-(Section 59.)

In consideration of dollars to me paid by (lessor or his assigns, a.: the case may be) I do hereby surrender and yield 
up from the day of the date hereof unto the lease (describe the lease fully) and the term therein created.
Dated the day of
A.D. 19 .

signed by the above named

in the presence of

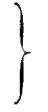

(Signature.)

\section{FORM N.-(Section 60.)}

\section{Mortgage.}

I, $A$. B., being registered as owner of an estate (here state nature of interest), subject, however, to such incumbrances, liens and interests as are notified by memorandum underwritten (or indorsed hereon) of that piece of land (description), part of section township, range, (or as the case may be) containing acres, be the same more or less (here state rights of way, privileges, easements, if any, intended to be conveyed along with the land, and if the land dealt with contains all included in the original grants refer thereto for description of parcels and diagrams; otherwise set forth the boundaries and accompany the description by a diagram), in consideration of the sum of dollars lent to me by E.F. (here insert description), the reccipt of which sum I do hereby acknowledge, covenant with the said $E . F$. :

Firstly.-That I will pay to him, the said E.F., the above sum of dollars, on the day of

Secondly.-That I will pay interest on the said sum at the rate of on the dollar, in the year, by equal payments on the day of and on the day of in every year.

Thirdly:--(Here set forth special covenants, if any.)

And for the better securing of the said $E$. F . the repayment in manner aforesaid of the principal sum and interest, I hereby mortgage to the said E.F. my estate and interest in the land above described.

In witness whereof, I have hereunto signed my name this day of 19 .

signed by the above named

$A$. B. as mortgagor, in the presence of

(Signature of mortgagor.)

(Insert memorandum of mortgages and incumbrances.) 


\section{FORM O.-(Section 60.)}

\section{INCUMBRANCE.}

I, A. B., being registered as owner of an estate (state nature of estate), subject, however, to such mortgages and incumbrances as are notified by memorandum underwritten (or indorsed hereon), of that piece of land of (description) part of section , township , range , (or as the case may be) containing acres, more or less (here state rights of way, privileges, easements, if any, intended to be conveyed along with the land, and if the land dealt with contains all included in the original grant or certificate of title, refer thereto for description. of parcels and diagrams, otherwise set forth the boundaries and accompany the description by a diagram), and desiring to render the said land available for the purpose of securing to and for the benefit of $C$. D., of (description) the (sum of money, annuity or rent charge) hereinafter mentioned, do hereby incumber the said land for the benefit of the said C.D., with the (sum, anmuity or rent charge) of , to be paid at the times and in the manner following, that is to say: (Here state the times appointed for the payment of the sum, annuity or rent charge intended to be secured, the interest, if any, and the cuents in which such sum, annuity or rent charge shall become and cease to be payable, also any special covenants or powers, and any modification of the powers or remedies given to an incumbrance by this Act): And subject as aforesaid, the said $C$. $D$. shall be entitled to all powers and remedies given to an incumbrancee by The Land Titles Act.

Signed by the above named

in the presence of

(Signature of incumbrancer.)

(Insert memorandum of mortgages and incumbrances.)

(This form, P, although struck out by subsection 5 of section 11 of The Statute Law Amendment Act (Part I), 1909 , is still the form used under subsection 2 of section 60 of The Land Titles Act.)

\section{FORM P.-(Section 60 (2.)}

Affidavit to be Filed witi a Mortgage or Incumbrance.

I, (name of mortgagor or incumbrancer, as the case may be) of the of of make oath and say:

(1) I am the mortgagor (or incumbrancer, as the case may be), named in the hereunto annexed instrument, bearing date 
the and made in favor of lands mortgaged or incumbered).

against (describe the

(2) The grant from the Crown of the said land has not yet been issued, but I claim to be the party rightfully in possession of the said land and to be entitled to create the said mortgage (or incumbrance) and that particulars of my possession and title to the said land are as follows: (Here must be given such information as will satisfy the registrar as to the mortgagor's or incumbrancer's right to create the mortgage or incumbrance, and in the case of such mortgagor or incumbrancer of land entered for by him as a homestead or pre-emption under the provisions in that bchalf contained in "The Dominion Lands Act," that he has been recommended for patent and received his certificate or recommendation in accordance with the said provisions).

Sworn before me

this day of

(Signature.)

\section{FORM Q.-(Section 66.)}

Transfer of Mortgage, Incumbrance or Lease.

I, C. D., the mortgagee, (incumbrancee or lessee, as the case may be), in consideration of dollars, this day paid to me by $X . Y$., of the receipt of which sum I do hereby acknowledge, hereby transfer to him the mortgage (incumbrance or lease, as the case may be, describe the instrument fully), together with all my rights, powers, title, and interest therein.

In witness whereof I have hereunto subscribed my name this day of

Signed by the said

in presence of 19 .

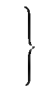
C. D. (Transferor.)
X. Y. (Transferee.)

\section{FORM R.-(Section 66 (2.)}

\section{Transfer of Part of Mortgage Incumbrance.}

I, C.D., the mortgagee, (incumbrancee or lessee, as the case may be) in consideration of dollars this day paid to me by $X Y$., of , the receipt of which sum I do hereby acknowledge, hereby transfer to him dollars of the mortgage (or incumbrance, as the case may bc, describe the instrument fully), together with all my rights, powers, title, and interest therein, and the sum so transferred shall be preferred (or deferred or 
rank equally, as the case may be) to the remaining sum secured by the mortgage (or incumbrance).

In witness whereof I have hereunto subscribed my name this day of 19 .

Signed by the said

in presence of

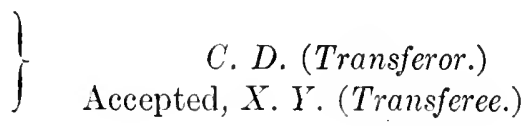

FORM S.-(Section 70.)

Short Covenants in Mortgage.

COLUMN ONE.

1. Has a good title to the said land.

2. Has the right to mortgage the land.
COLUMN TWO.

1. And also, that the said mortgagor at the time of the sealing and clelivery hereof, is, and stands solely, rightfully and lawfully seized of a good, sure, perfect, absolute and indefeasible estate of inheritance, in fee simple, of and in the lands, tenements, hereditaments and all and singular other the premises hereinbefore described, with their and every part of their appurtenances, and of and in every part and parcel thereof, without any manner of trusts, reservations, limitations, provisos or conditions, except those contained in the original grant thereof from the Crown, or any other matter or thing to alter, charge, change, incumber or defeat the same.

2. And also, that the said mortgagor now hath in himself good right, full power and lawful and absolute authority to mortgage the said lands, tenements, hereditaments, and all and singular other the premise: hereby mortgaged or hereinbefore mentioned or intended so to be with their and every of their appurte- 
3. And that on default the (mortgagee) shall have quiet possession of the land. nances unto the said mortgagee, his heirs, executors, administrators and assigns in manner aforesaid, and according to the true intent and meaning of these presents.

3. And also, that from and after default shall happen to be made of or in the payment of the said sum of money, in the said above covenant mentioned, or the interest thereof, or any part thereof, or of or in the doing, observing, performing, fulfilling or keeping of some one or more of the covenants in this mortgage particularly set forth, contrary to the true intent and meaning of these presents, then and in every such case, it shall and may be lawful to and for the said mortgagee, his heirs, executors, administrators, and assigns, peaceably and quietly to enter into, have, hold, use, occupy, possess, and enjoy the aforesaid lands, tenements, hereditaments and premises, hereby mortgaged or mentioned or intended so to be, with their appurtenances, without the let, suit, hindrance, interruption or denial of him the said mortgagor, his heirs, or assigns, or any other person or persons whomsoever.

4. Free from all incumbrances.
4. And that free and clear and freely and clearly acquitted, exonerated and discharged of and from all arrears of taxes and assessments whatsoever due or payable upon or in respect of the said lands, tenements, 
hereditaments and premises, or any part thereof, and of and from all former eonveyanees, mortgages, rights, annuities, debts, judgments, exeeutions and reeognizances, and of and from all mamer of other charges or incumbrances whatso ever.

5. Will execute sueh further assuranees of the land as may be requisite.
5. And also, that from and after default shall happen to be made of or in the payment of the said sum of money in the said covenant mentioned, or the interest thereof, or any part of such money or interest or of or in the doing, observing, performing, fulfilling or keeping of some one or more of the covenants in this mortgage particularly set forth, contrary to the true intent and meaning of these presents and of the said eovenants then and in every such case the said mortgagor, his heirs and assigns, and all and every other person or persons whosoever having, or lawfully claiming, or who shall or may have or lawfully elaim any estate, right, title, interest or trust of, in, to or out of the lands, tenements, hereditaments and premises hereby mortgaged, or mentioned, or intended so to be, with the appurtenanees or any part thereof, by, from, under or in trust for him the said mortgagor, shall and will, from time to time, and at all times thereafter, at the proper costs and charges of the said mortgagee, his heirs, executors, administrators and assigns make, do, suffer and execute, or cause or procure to be made, done, suffered 
and executed, all and every such further and other reasonable act or acts, deed or deeds, devices, conveyances and assurances in the law for the further, better and more perfectly and absolutely conveying the said lands, tenements, hereditaments and premises, with the appurtenances unto the said mortgagee, his heirs, executors, administrators and assigns, as by the said mortgagee, his heirs, executors or his or their counsel learned in the law, shall or may be lawfully and reasonably devised, advised or required, so as no person who shall be required to make or execute such assurances shall be compelled, for the making or executing thereof, to go or travel from his usual place of abode.

6. Has done no act to incumber the land.
6. And also, that the said mortgagor hath not at any time heretofore made, done, committed, executed or wilfully or knowingly suffered any act, deed, matter or thing whatsoever whereby or by means whereof, the said lands, tenements, hereditaments and premises hereby mortgaged or mentioned or intended so to be, or any part or parcel thereof, are, is or shall or may be in any wise impeached, charged, affected or incumbered in title, estate, or otherwise howsoever.

\section{FORM T.-(Section r.}

Power of AtTorner.

I, A.B. being registered owner of an estate (here state nature of the estate or interest), subject, however, to such incumbrances, 
liens and interests as are notified by memorandum underwritten (or indorsed hereon), (here refer to schedule for description and contents of the several parcels of land intended to be affected, which schedule must contain reference to the cxisting cortificate of title or lease of each parcel) do hereby appoint $C$. D. attorney on my behalf to (here state the nature and extent of the powers intended to be conferred, as to sell, lease, mortgage, ctc.) the land in the said schedule described, and to execute all such instruments, and do al such acts, matters and things as may be necessary for carrying out the powers hereby given and for the recovery of all rents and sums of money that may become or are now due or owing me in respect to the said lands, and for the enforcement of all contracts, covenants or conditions binding upon any lessee or occupier of the said lands, or upon any other person in respect of the same, and for the taking and maintaining possession of the said lands, and for protecting the same from waste, damage, or trespass.

In witness whereof I have hereunto subscribed my name this day of 19 Signed by the above named $A$. $B$. in the presence of

(Signature.)

\section{FORM U.-(Section 33.)}

\section{Revocation of Power of Attorney.}

I, A. B., of hereby revolie the power of attorney given by me to dated the day of, 19 , and recorded in the land titles office at for the land registration district, on the day of, 19, as No.

In witness whereof I have hereunto subseribed my name this day of 19 .

Signed by the above named

$A$. B. in the presence of

(Signature.)

FORM V.-(Section 79.)

Transfer of Land under Process of Lati.

I, , of , the person appointed to execute the process hereinafter mentioned, in pursuance of a writ dated the day of , one thousand ninc hundred and and issued out of (insert name of court), a court of eompetent jurisdietion, in an action wherein is the plaintiff, and 
the defendant, which said is registered as the owner of the land hereinafter described, subjeet to the mortgages and incumbrances notified hereunder, do hereby in consideration of the sum of paid to me, as aforesaid, by $E$. F. (insert addition) TRANSFER to the said $E . F$. all that piece of land (here insert a sufficient description of the land, and refer to the debtor's certificate of title or grant). and
Dated the
day of
one thousand nine hundred

Signed by the above named

in presence of

(Signature with official seal.)

Mortgages and incumbrances referred to. (State them.)

$$
\text { Or }
$$

FORM V.-(Section 82.)

Transfer of Land on Sale for Taxes.

I, of , by virtue of authority vested in me to sell lands for arrears of taxes by do hereby in consideration of the sum of paid to me by E.F. (insert addition) TRANSFER to the said $E . F$. all that piece of land being (here insert a sufficient description of the land, and refer to the certificate of title). and

Dated the day of one thousand nine hundred

Signed by the above named

in presence of

(Signature with official seal.)

\section{Or}

FORMI V.-(Section 79.)

Transfer of Iiease, Mortgage or Incumbrance Under Process of LAw.

I, , of

the person appointed to execute the writ hereinafter mentioned (or otherwise, as the case may be), in pursuance of a writ of fieri facias, tested the day of one thousand nine hundred and and issued out of (insert name of court), a court of competent jurisdiction, in an action wherein is the plaintiff and the defendant, which said is registered as the owner of a lease (mortgage or incumbrance, as the case may be) numbered of (or upon) the land hereinafter described, subject to the mortgages or 
incumbrances notified hereunder, do hereby, in eonsideration of the sum of paid to me as aforesaid, by $E$. F. (insert addition) TRANSFER to the said E.F. the lease (mortgage or incumbrance) granted by to and in favor of dated the day of to, in and over (here describe the land according to the description in the lease, mortgage or incumbrance, and refer to the registered instrument).

and

Dated the day of , one thousand nine hundred

Signed by the above named

in presence of

(Signature with official seal.)

$\mathrm{Or}$

FORM V-(Section 79.)

Transfer of Land under Decree or Order of a Court of Competent Jurisdiction.

I (insert name), in pursuance of a decree (or order) of (insert name of court), a court of competent jurisdietion, dated the day of one thousand nine hundred and, and entered in the register, vol. , fol. , hereby TRANSFER to $E$. $F$. (insert addition), subjeet to the mortgages and incumbrances notified hereunder, all that piece of land being (here insert a sufficient description of the land and refer to the certificate of title or grant).

and

Dated the day of , one thousand nine hundred

Signed by the above named

in presence of

(Signature with official seal.)

Mortgages and ineumbranees referred to. (State them.)

\section{$\mathrm{Or}$ \\ FORM V.-(Section 79.)}

Transfer of Lease, Mortgage or Incumbirance, under Decree or Order of a Court of Competent Julisdiction.

I (insert name), in pursuance of a decree or order of (insert name of court), a court of competent juriscliction, dated the day of , one thousand nine hundred and and entered in the register, vol., fol., hereby' TRANSFER to $E . F$. (insert addition) subject to the mortgages and incumbrances notified hereunder, the lease (or mortgage or 
incumbrance, as the case may be) granted by in favor of of (or ul on) ail that piece of land (here insert description of the land according to the description in the lease, mortgage or incumbrance, and refer to the registered instrument). and

Dated the day of , one thousand nine hundred Signed by the above named in presence of

(Signature with official seal.)

Mortgages and incumbrances referred to. (State them.)

FORMI W.-(Section 84.)

Caveat Forbidding Registration.

To the Registrar for

Take notice that I (insert name and addition of caveator) claim (specify the estate or interest claimed) in (describe land and refer to certificate of title), standing in the register in the name of ; and $I$ forbid the registration of any person as transferee or owner of, or of any instrument affecting the said estate or interest, unless such instrument be expressed to be subject to my claim. I appoint as the place at which notices and proceedings relating hereto may be served.

Dated this day of, 19 .

(Signature of caveator or his agent.)

\section{FORM X.-(Section 85.)}

Affidarit in Support of Caveat.

I (the cavcator or his agent), make oath and say (or solemnly declare) as follows:

(1) I am the within named caveator (or agent for the above named caveator).

(2) I believe that I have (or the said caveator has) a good and valid claim upon the said land (mortgage or incumbrance) and I say that this caveat is not being filed for the purpose of delaying or embarrassing any person interested in or proposing to deal therewith.

Sworn before me, etc.

(Signature.) 


\section{FORM Y.-(Section 89.)}

Notice to Caveator to take Procendings on Caveat.

Take notice that the eaveat lodger by you in the land titles office for the clistrict of on the day of

19 , forbidding the registration of any person as transferee or owner of or of any instrument affecting the estate or interest claimed in your eaveat in respect of (describe land and refer to certificate of title) unless such instrument be expressed to be subject to your elaim, will cease to have any effeet after the expiration of sixty days (or such shorter time as the judge mays order) next ensuing the date at which this notice is served or sent to you by registered mail, unless in the meantime you take proeeedings in court on your eaveat. This notice is giren pursuant to section 89 of The Land Titles Act.

Dated at the clay of 19 .

To (the caveator).

at (address stated in the caveat).

(Signature of person giving the notice.)

FORM Z.-(Section 102.)

Affidavit of Attestation of an Instrument.

I, $A . B$., of , in the , make oath and say:

(1) I was personally present and did see named in the (within or annexed) instrument, who is personally known to me to be the person named therein, duly sign and execute the same for the purposes named therein;

(2) That the same was executed at the in the and that I am the subseribing witness thereto;

(3) That I know the said and he is in my belief of the full age of twenty-one year's.

N.B.-Where an instrument is executed by an attorney under the provisions of section 72 , paragraph 3 may be omitted.

Sworn before me at

in the

day of

, this

A.D. 19 .

(Signature.)

FORM AA.-(Section 11.3.)

Reference by Rigistizar to the Jubir.

(Place and date.)

- In the matter of the registration of transfer (or as the case may be) $A$. B. to $C$. D. 
The registrar under section one hundred and thirteen of The Land Titles Act hereby refers the following matter to the judge, to wit: (Here state briefly the difficulty which has arisen.)

The parties interested, so far as the registrar knows or has been informed, are: (Here give the names.)

(Official seal.)

(Signature),

Registrar.

FORM BB.-(Sections 114 and 115.)

Demand to Return Certificate of Title.

To (name of owner or whoever is custodian of certificate).

You are hereby required to forward to the land titles office certificate of title No. , in favor of (insert owner's name) for (description of land) as the same is required by me pursuant to the provisions of The Land Titles Act for the purpose (purpose for which certificate is required and whether or not by direction of a judge).

Your attention is called to the provisions of sections 114 and 115 of the said Act, and the penalty therein provided for neglect or refusal to comply with this demand.

$$
\begin{aligned}
& \text { A. B., } \\
& \text { Registrar, }
\end{aligned}
$$

District.

\section{FORM CC.-(Section 124.)}

I , Alberta land surveyor, do solemnly declare that the survey represented by this plan has been made by me in accordance with the provisions of The Alberta Survey; Act, and that this plan is correct and true to the best of my knowledge and belief, and is prepared in accordance with the provisions of The Land Titles Act.

of
Dated at
this
day of
19 , in the presence

\section{FORM EE.-(Section 17 (2.)}

The Land Titles Act.

\section{Land Titles Office.}

Alberta Land Registration District. $\operatorname{Re}$

I hereby certify that on this day of A.D. 191 , at o'clock m., certificate of title No. 
stood in the name of

for the above land subject to the following registered instruments only:

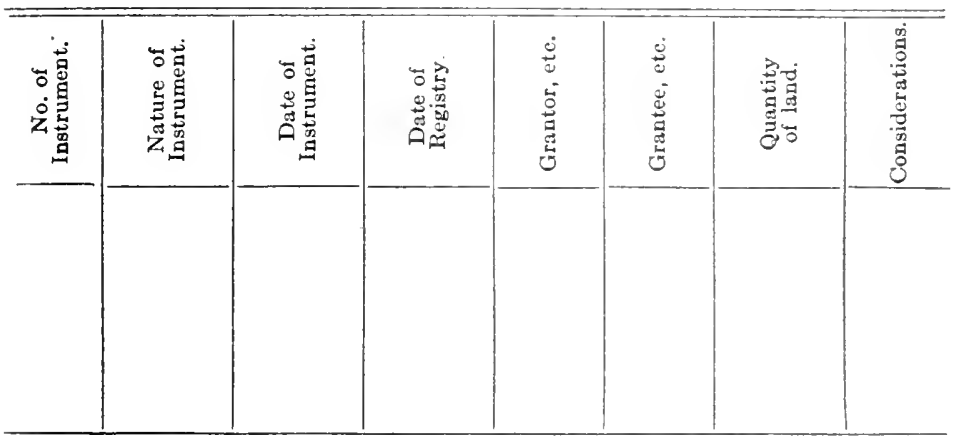

Registrar, Alberta Land Registration District.

FORM FF.--(Section 17 (3.)

Land Titles Office.

Alberta Land Registration District.

I hereby certify that on this day of A.D. 191 at o'clock m., there are no decrees, orders or executions entered in the execution register of the above office, and no instrument referring generally to lands entered in any other register of such office, which affects lands of excepting:

Registrar, Alberta Land Registration District.

FORM GG.--(Section 71.)

Alberta Land Registration District.

Certificate of Charge.

Mortgage or Incumbrance.

Mortgage or Incumbrance No.

Application No.

Assignment No.

Certificate of Title No.

This is to certify that a made by to for the sum of dollar's affecting was duly registered in the land titles office at Alberta, on the day of A.D. 19 , at o'clock m., and that no 
registered mortgages or incumbrances affecting the said lands are entitled to priority over the said that is to say:

Dated at the Land Titles Office at day of

A.D. 191 except the following,

\section{Alberta Land Registration District.}

FORMI HH.-(Section 53a.)

I, a Dominion land surveyor, do solemnly declare that the survey represented by this plan has been made by me and that the said plan is correct and true to the best of my knowledge and belief and is prepared in accordance with the provisions of The Land Titles Act.

Dated at presence of

this

day of

, 19 , in the 


\section{APPENDIX B}

\section{TARIFFS}

MANITOBA.

TARIFF OF FEES UNDER THE REAL PROPERTY ACT.

The following shall, on, from and after the fifteenth day of February, A.D. 1911, be the tariff of eharges to be eharged by each district registrar under said The Real Pioperty Act:

FEES ON APPLICATION.

The fees to be paid on application to bring land under the Act shall be as follows, inelusive of contribution to assurance fund:

Where the value of the land does not excecd $\$ 500 \ldots \ldots \$ 5.00$

On each $\$ 500$ value thereafter, or fraction thereof, add $\$ 1$ until value reaches $\$ 3,000$.

On each $\$ 500$ value thereafter, or fraction thereof, add $\$ 3$ until value reached is $\$ 5,000$.

On each $\$ 1,000$ value thereafter, or fraetion thereof, add $\$ 3$.

When the applicant is the original grantee from the Crown, and there is no eloud on the title and no transaction affects the land other than leases, mortgages, fi.fas., certificates of judgment or other eharges or liens, the fees shall in all cases be one-half of the above named fees.

When the land has been sold by a sheriff under $f i$. $f a$., or under power of sale in a mortgage, or has been in question in any suit or proeeeding in equity, a further fee upon the following seale shall be charged for cach mortgage sale, or for each suit or proceceding which it shall be necessary for the examiner to inquire into:

When the value of the land does not exceed $\$ 500, \ldots .2 .00$

On eaeh additional $\$ 1,000$ value thereafter, or fraction thereof, until the value raches $\$ 4,500 \ldots \ldots \ldots \ldots, 1.00$

When the value excereds $\$ 4,500 \ldots \ldots \ldots \ldots \ldots \ldots$. 7.00 
For examination of each document in support of an application in excess of ten, 20 cents. This fee not to be charged upon any document examined under last clause in power of sale, sheriff or equity proceedings.

For filing with the application, each mortgage, conveyance, release or other link in the chain of title, except patent or discharge of mortgage............\$ 2.00

For filing each patent or discharge of mortgage...... 1.00

Each direction or request to issue a certificate of title to any person other than the applicant.

\section{FEES ON TRANISMISSIONS.}

The fees to be paid on all transmissions will be as follows: When the value of the land does not exceed $\$ 500$.

When the value of the land does not exceed $\$ 1,000$.

When the value of the land does not exceed $\$ 1,500 \ldots 10.00$

When the value of the land does not exceed $\$ 2,000 \ldots 12.00$

On each $\$ 1,000$ thereafter, or fraction thereof, add. .

\section{REGISTRATIONS.}

Registering transfer of land (ineluding fee for certificate of title, and fee for tax and other searches).........

Registering a mortgage, incumbrance or charge or transfer thereof (including certificate of charge), where the money secured does not exceed $\$ 5,000 \ldots \ldots \ldots \ldots$

On each $\$ 1,000$, or fraction thereof, up to $\$ 10,000$, a further fee of $\$ 1$; and on each $\$ 1,000$, or fraction thereof, over $\$ 10,000$, a further fee of 50 cents, until the total registration fee shall reach $\$ 25$.

On registration of mortgages by corporations, executors or administrators, or on registration of transfers of land to or from corporations, executors or administrators, the district registrar may, in his discretion, charge an additional fee of not less than $\$ 1$ nor more than $\$ 10$ for investigation of evidence.

Registering each power of attorney.

Registering a lease (exclusive of fee for leasehold certificate)

Registering or filing any mechanies' lien, lis pendens, order, decree, certificate of judgment or any discharge of any mechanics' lien, certificate of judgment, mortgage or charge. 
Registering any instrument other than those herein provided for ........................... \$ 2.00

FILINGS.

Filing each caveat..................... 2.00

Filing each discharge, lapse, withdrawal or merger of caveat ............................... 1.00

Filing petition on caveat.................... 1.00

Each filing of evidence of proceeding on eareat...... 1.00

Filing proceedings under power of sale ........... 2.00

Filing notice of intention to exercise power of sale.... 2.00

PLANS.

For registration of each plan, exclusive of field inspection and extra certificate of title:

Lots 1 to $10 \ldots \ldots \ldots \ldots \ldots \ldots \ldots \ldots \ldots$

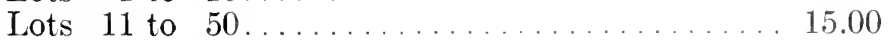

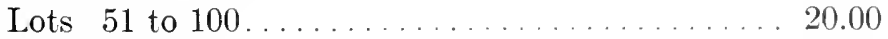

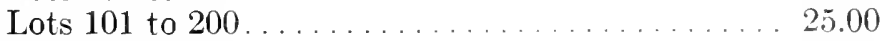

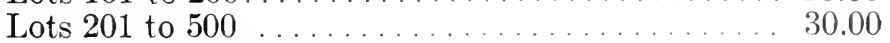

Lots 501 to $1,000 \ldots \ldots \ldots \ldots \ldots \ldots \ldots \ldots \ldots . .35 .00$

Lots 1,001 to $2,000 \ldots \ldots \ldots \ldots \ldots \ldots \ldots \ldots .45 .00$

For each additional 500 lots, or fraction thereof, after first 2,000 lots, add ...................... 5.00

For examination and field inspection of subdivision plans, to be paid upon deposit of plan for examination, minimum fee........................... 10.00

For plans containing 40 lots and over, each lot in first $100 \quad .25$

Each lot after first $100 \ldots \ldots \ldots \ldots \ldots \ldots \ldots \ldots . .10$

All lots over one acre in area shall be counted as equivalent to as many lots as there are acres.

Should it be found necessary, on account of errors in the survey or plan, to make further examination or inspection, the actual cost of the same will be charged.

Registration or order cancelling or varying plan.

Every blue print copy of plan, or part of plan, 25 cents a square foot.

Minimum fee.......................... 1.00

District registrar's certificate on same........... 1.00

For all other services of surveyor, per hour ........ 2.00

Receiving plan of railway right of way for deposit . . . 1.00 
Receiving plan of railway right of way for filing, for each mile of right of way shown on plan...........

GENERAL.

Each extra certificate of title................. 1.50

Each withdrawal of any application............. 2.00

Each certificate of charge or of registration of mortgage

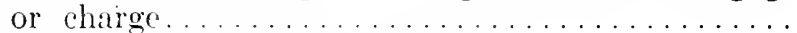

Certified copy, first folio of 100 words.

For every folio, or part of folio, after the first. . . . . . . .10

Each summons....................... .50

Examination of each witness, per hour........... 2.00

Entering notice of marriage or death. . . . . . . . . 2.00

For entry of survivor or other persons as proprietors in case of joint tenancy . . . . . . . . . . . . . . . .

Merger of any estate or incumbrance.

Entering satisfaction or lapse of certificate of judgment or mechanics' lien.

Every entry in the register, for which no other fee is provided

Each extra memorial, whether in the register or on any instrument

Each search.

Taxation of costs, per hour. . . . . . . . . . . . . .

Each redemption certificate.

On payment out to tax purchaser of redemption moneys, 2 per cent. of the money paid out.

On each correction in a certificate of title.

Carbon copies of certificate of title for assessors, actual cost of furnishing same not to exceed 5 cents each.

Fee on lost certificate of title, exclusive of provisional certificate when required.

On not ces issued by a district registrar for each person to be served.

On rejection of each instrument presented for registration, to be charged in the discretion of the district registrar.

Each order made by a district registrar or registrar general

Each fiat of registrar general.

Each fiat of district registrar for filing second caveat... .

Each approval of registrar general or district registrar under The Devolution of Estates Act.............

On reiease of any document from holdup file, a district registrar may, in his discretion, charge a fee up to but not exceeding. 


\section{TARIFFS-SASKATCHEWAN}

SASKATCHEWAN.

TARIFF OF FEES UNDER THE LAND TITLES ACT.

Regina, Friday, August 31, 1906.

His Honour the Lieutenant Governor by and with the advice of the Executive Council has been pleased to order that the fees to be exacted by each registrar of a land registration district or by his deputy or the acting registrar (as the case may be) in the event of the death or absence from office of the registrar for the services to be done and performed by a registrar under and by virtue of the provisions of The Land Titles Act or of any Act or Acts passed in ameridment thereof shall be those which are set out in the tariff of fees below:

1. For each certificate of title and duplicate if there are any instruments in the registrar's hands which incumber or affect the land as mentioned in sections 41, 42 and 43 , including all fees for registration, searches and memorandums

And also assurance on sworn value.

2. Each certificate of title issued in accordance with an application made under the provisions of section 49 , where at the time of the issue of such certificate the patent is the only instrument in the hands of the registrar affecting the land, shall be issued and a duplicate thereof shall be delivered or mailed to the person or company entitled thereto for a fee of. .

3. For a certificate of title on an application to bring land under the Act in cases other than those provided for by the last item, which shall include the fees to be paid to the assurance fund, and for the duplicate certificate of title and abstract and all filings, searches and inspections:

(a) Where the value of the land does not exceed $\$ 500$

(b) Where the value is over $\$ 500$ and up to $\$ 1,000 \ldots$

(c) For each additional $\$ 500$ or the fraction thereof until the value reached is $\$ 5,000$ andd......... And for each additional $\$ 1,000$ thereafter or fraction thereof add.

(See, lowever, item No. 8.)

4. For registering a transfer and issuing a certificate of title thereon and duplieate thereof and including fees for memorandums, searches and inspections: 
(a) Where the value of the property does not exceed $\$ 500$ including fees payable to the assurance fund

(b) Where the value of the property is over $\$ 500 \ldots$ And in addition the fees payable to the assurance fund.

(See, however, items Nos. 8 and 11).

5. For a certificate of title on a transmission however effeeted including fees for duplicate thereof and for registration, searehes and all other services connected therewith, but not including fees payable to assurance fund

If the land transmitted is included in more than one certificate of title, for entering memorandum on each certificate of title and duplieate thereof, after the first certificate

(See, however, item No. 8.)

6. For new certificate of title to register female owner on her marriage including duplicate thereof and all filings, memorandums and services connected therewith.

7. For certificate of title issued on any other instru-

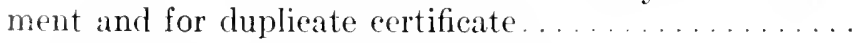

8. If more than one certificate of title is required upon the same instrument, for each certificate with duplicate thereof after the first certificate.

9. For registering or filing any lease (exclusive of the fee of $\$ 2$ for certificate of lease), inortgage, incumbrance or eharge, surrender or power of attorney, including all memorandums, searches and other services connected therewith

(See, however, item No. 11.)

(a) For filing first mortgage or incumbrance before issue of grant. .

Also the fees to be paid under item No. 1 for issuing certificate of title, etc., and assurance on sworn value.

(b) For every mortgage or incumbrance after the first

10. For registering or filing any mechanies' lien, certificate, order or deeree of a court or judge, or any assignment or diseharge wholly or partially of a mortgage, incumbrance or charge; or a satisfaction of an annuity or any other instrument affecting land other than those 
particularly specified in this tariff; including all memorandums, searches and other services connected therewith

(See, however, item No. 11.)

11. When any instrument registered deals with or affects land in more than one certificate of title, for each memorandum after the first memorandum..........

12. For each abstract respecting land included in one certificate of title, or respecting each quarter section for which certificate of title has not been granted, including all charges for searches and certificates.............

13. For filing each caveat and for preparing and mailing notices in connection therewith.......... 2.00

14. For notice, form $Y$ under section $130 \ldots \ldots \ldots .1 .00$

15. For entering withdrawal, lapse or removal of caveat ........................... 1.00

16. For each search for each parcel of land or for

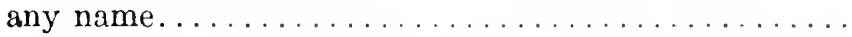

17. For a certificate as to decrees, orders or executions including one search for one name.

And for each additional name.

18. For each certificate of charge.

19. For each map or plan registered, including new certificate of title and duplicate thereof.

(See, however, items Nos. 8 and 11.)

20. For each map or plan deposited under any Railway Act or any other Act than The Land Titles Act....

21. For registering or filing writ of fieri facias or a satisfaction, withdrawal or expiration thereof, including all memorandums and other services connected therewith.

22. For the production of each instrument filed or registered

23. On rejection of each instrument presented for registration, to be charged in discretion of registrar .

24. For copy of or extract from any registered instrument or instruments otherwise in the custody of the registrar, per folio of 100 words.

(For certificate see item 26.)

25. (a) For copy of every mas or tracing attached to or indorsed on any document............

(b) For copy of each maj, or plan filed, registered or deposited in the land titles office up to and

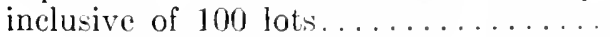

And for each atditional lot over 100 . 
(c) And for each copy or tracing showing one block of lots or of one or more lots in one block on any such map or plan. . . . . . . . . . . . . . \& $\$ 2.00$

26. For each certificate, signed by the registrar, deputy registrar or acting registrar and authenticated by the registrar's official seal and not otherwise provided for

27. For taking each affidavit or solemn declaration. .

28. For entering executor or administrator or an assignee under The Assignments Act as transferee or proprietor of a mortgage on a transmission..........

29. For entering survivor or other person as proprictor in the case of a joint proprietorship..........

30. For each certificate and reference to a court or judge, excepting a reference made under section 147 of The Land Titles Aet.......................

31. For attending a court or judge on reference or on hearing of any petition or on any proceeding or on producing any document on any application or proceeding before a court or judge for each hour...............

32. For a certificate of title or duplicate issued to replace one worn out, filled up, destroyed or lost........

(a) Where a certificate of title or duplicate thereof has been lost or destroyed, for perusing proof of loss, settling notice for publication and for all other services excepting new certificate of title.

33. For consolidating two or more certificates of title.

34. For filing claim of excmption under section 117 .

35. For reading proof of lawful re-entry and recovery of possession and making memorandum of same as required by section $84 \ldots \ldots \ldots \ldots \ldots \ldots \ldots$

Note-In addition to the above fees there is payable to the assurance fund, on the registration of every grant of incumbered land, on the registration of the first transfer after the issue of a certificate of title where the land was not incumbered, on the increased value of the land in every subsequent transfer, and on the filing of a first mortgage or incumbrance before issue of grant, one-fifth of one per cent. on the sworn value up to $\$ 5,000$ and one-tenth of one per cent. on any excess orer such $\$ 5,000$.

Note-There shall not be included in a certificate of title lands in more than one township.

Note-No charge shall be milde for any services whatever under this tariff rendered to or for the government of Saskatchewan. 
No charge shall be made upon the issue of a ecrtificate of title to a homestead patentee under the provisions of The Dominion Lands Act unless at the time of issue the title is incumbered and in that event the fees shall be as hereinbefore provided.

JoHN A. ReID, Clerk Executive Council.

\section{SUPPLEMENTARY TARIFF OF FEES UNDER THE LAND TITLES ACT.}

Regina, Wednesday, February 17, 1909.

Under the provisions of The Land Titles Act His Honour the Lieutenant Governor by and with the advice of the Executive Council has been pleased to order that the fees to be exacted by each registrar of a land registration distriet or by his deputy or the acting registrar (as the ease may be) in the event of the death or absence from office of the registrar for the services in connection with proceedings for sale and foreclosure of mortgages to be done and performed by a registrar shall be those which are set out in the following table of fees, namely:

Registration Fees on Sale and Foreclosure of Mortgages Under The Land Titles Act.

Inspecting notice of exercising power of sale in mortgage and instructions as to service. . ........... \$ 2.00

Instructions as to advertising and sale of property. . 3.00

Fee on every other application to registrar for instruetions during proceedings.

Registration of transfer from mortgagee and transmission (including the issue of certificate of title)..... 5.00

And in addition fees payable to the assurance fund.

Order of registrar for foreclosure and transmission, including certifieate of title................. 10.00

Joln A. RRID, ('lerk Exccutive Council.

\section{SOLICITORS' FEES ON SALE AND FORECLOSURE PROCEEDINGS}

Under The Land Titles Act chargeable against the mortgaged property or proceeds of sale and allowed only to solicitors authorized to practise in Saskatchewan.

(As approved by the attorney general for use by registrars.)

For the following services when rendered and no others: 
Drawing, serving and filing notice of exercising power of sale, inclusive of all instructions and attend-

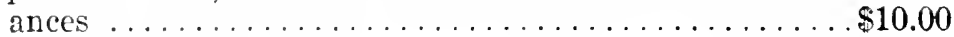

Advertising sale and all services in connection therewith, including all attendances, revising proof, etc. 15.00

On sale of mortgaged premises under power of sale including all instructions, attendance at sale and all other attendances and services up to completion of sale, including the drawing of transfer............25.00

Actual and necessary disbursements, when verified by statutory declaration, including auctioneer's fees which should not be more than $\$ 15.00$ for ordinary sale. 
ALBERTA.

\section{TARIFF OF FEES UNDER THE LAND TITLES ACT.}

His Honour the Lieutenant Governor, by and with the advice of the Executive Council, has been pleased to order that the tariff of fees under The Land Titles Act approved of by Order in Council No. 564, 1906, and other Orders in Council amending the same, be repealed, and that the tariff of fees hereto annexed be substituted therefor and that the fees to be exacted by each registrar of a land registration district or by his deputy or the acting registrar (as the case may be), in the event of the death or absence from office of the registrar, for the services to be done and performed by a registrar under and by virtue of the provisions of The Land Titles Act, or of any Act or Aets passed in amendment thercof, shall be those which are set out in the said tariff of fees.

\section{Land Titles Act.-Tariff of Fees.}

By Order in Council passed the twenly-second day of February, A.D. 1912, the tariff of fecs in force uncler Order in Council dated the 12th day of October, 1906, and ameinding Orders is repealed and the following tariff substituted:

\section{Fees on Grants from the Croun.}

1. Each certifieate of title for land granted to a person or eompany who has obtained a patent under a homestead or under a homestead and pre-emption entry, or under half-breed land scrip or military bounty land scrip, in accordance with the Dominion Lands Act and amendments thereto shall be issued, and a duplicate thereof shall be delivered or mailed to the person or company entitled thereto, free of charge.

2. In the case of other patentees the fec payable upon the issue of each certificate of title and duplicate, including the delivery or mailing thereof, to the person or company entitled thereto, shall be.....

Fees on Application to Bring Land under the Act.

3. Each certifieate of title issued in aecordance with an applieation made under the provisions of seetion 27 of the said Act, where at the time of the issue of sueh certificate the patent is the only instrument in the hands 
of the registrar affecting the land, shall be issued, and a duplicate thereof shall be delivered or mailed to the person or company entitled thereto for a fee of

4. For certificate of title on an application to bring land under the Act in cases other than those provided for in the last item, which shall include the fees to be paid to the assurance fund, and for the duplicate certificate of title and abstract and all filings, searches and inspections:

(a) Where the value of the land does not exceed $\$ 500$

(b) Where the value is over $\$ 500$ and up to $\$ 1,000$. .

(c) For each additional $\$ 500$ or fraction thereof until the value reached is $\$ 5,000$, add........ And for each additional $\$ 1,000$ thereafter or fraction thereof, add.

(See, however, item No. 38.)

\section{Fees on Transmissions.}

5. For certificate of title on a transmission, including fees for duplicate thereof and for registration, searches and all other services connected therewith, but not including fees payable to assurance fund...............

If the land transmitted is included in more than one certificate of title, for entering memorandum on each certificate of title and duplicate thereof after the first certificate

$$
\text { (See, however, item No. 38.) }
$$

6. For entering executor or administrator as transferee or proprietor of a mortgage on a transmission.....

7. For entering survivor or other person as proprietor in the case of a joint proprietorship..........

8. For new certificate of title to registered female owner on her marriage, including duplicate thereof, and all filings, memorandums and services connected therewith

9. For a certificate of title to an assignee for the benefit of creditors, including duplicate thereof........

\section{Fees for Registration or Filing.}

10. For registering a transfer and issuing a certificate of title thereon and duplicate thereof and including fees for memorandums, searehes and inspections:

(a) Where the value of the property does not exceed $\$ 500$, including fees payable to assurance fund. 
(b) Where the value of the property is over $\$ 500 \ldots \$ 4.00$ And in addition the fees payable to the assurance fund.

(See, however, items Nos. 13 and 38.)

11. For registering or filing any lease (exclusive of the fee of $\$ 2.00$ for leasehold certificate of title), mortgage, incumbrance, or charge, surrender or power of attorney, including all memorandums, searches and other services connected therewith..............

(See, however, item No. 13.)

(a) For every such mortgage or incumbrance after

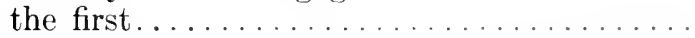

12. For registering or filing any cortificate, order or decree of a court or judge, or any assignment or discharge wholly or partially of a mortgage, incumbrance or charge; or a satisfaction of an annuity, or any other instrument affecting land other than those particularly specified in this tariff, but not including mechanics' liens, including all memorandums, searches and other services connected therewith.........................

(See, however, item No. 13.)

13. When any instrument registered deals with or affects land in more than one certificate of title, for each memorandum after the first memorandum..........

14. For filing each caveat and for preparing and mailing the notices in connection therewith........ 2.00

15. For entering withdrawal of caveat........ 1.00

16. For every extra memorial required to be mide in connection with the filing or withdrawal of a caveat. .

17. For registering or filing writ of fieri facias or a satisfaction or withdrawal thereof, including all memorandums and other services connected therewith .....

\section{Plans.}

18. For registration of each plan of suludivision, exclusive of extra certificates of title.

And a further fee for each lot or separite parcel into which the land is proposed to be subetividerl, as shown

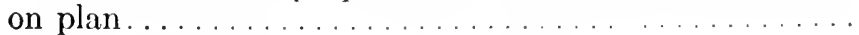

19. Registration of order cancelling or varying plan

20. Receiving plan profile or book of reference of railway right of way, required to be deposited under any

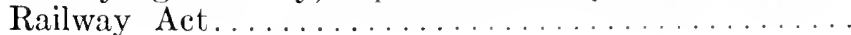


21. Receiving plan of railway right of way for filing under The Land Titles Act, for each mile of right of way shown on plan.

22. Every blue print copy of plan or part of plan

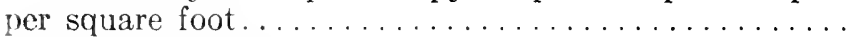

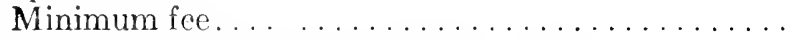

District registrar's certificate on same ..........

23. For all other services of surveyor per hour......

24. For each map or plan deposited under any other Act than The Land Titles Act or Railway Act.........

\section{General.}

25. For taking each affidarit or solemn declaration. .

26. For each search for each lot or parcel oî land or

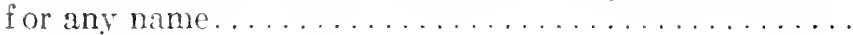

$2 \bar{i}$. For a certificate as to decrees, orders or executions, inc.uding one search, for one name..........

And for each additional name................ .50

28. For each certificate of charge............... .50

29. For each abstract respecting land included in one certificate of title, or respecting each quarter section for which certificate of title has not been granted, including all charges for searches and certificates............

Provided that where the entries on such abstract exceed five in number an additional fee of ten cents for all such additional entries shall be charged.

30. For production of each instrument filed or registered

31. For returning the documents of title deposited in support of an application on withdrawal or rejection of any application for certificate of title............

32. For certified copy of or extract from any registered instrument or instrument otherwise in the custody of the registrar, per first folio of 100 words............

For every folio, or part of folio after first.........

33. For each certificate and reference to a court or judge, excepting a reference madc under section 113 of The Land Titles Act.

34. For attending a court or judge on reference or on hearing of any petition or on any proceeding or on producing any document on any application or proceeding before a court or judge, for each hour. 
35. For a certificate of title or duplicate issued to replace one worn out, filled up, destroyed or lost. .

(a) Where a certificate of title or duplicate there of has been lost or destroyed, for perusing proof of loss and settling notice for publication and for all other services, excepting new certificates of title.

36. For consolidating two or more certificates of title.

For each memorial of cancellation after the first two.

37. For certificate of title issued on any instrument not otherwise provided for, and for duplicate certificate.

38. If more than one certificate of title is required upon the same instrument, for each certificate with duplicate thereof after the first certificate.

39. On each correction in a certificate of title, including examination of the evidence.

40. On rejection of each instrument presented for registration, to be charged in the discretion of the registrar

41. For each certificate signed by the registrar, deputy registrar or acting registrar and authenticated by the registrar's official seal, and not otherwise provided for...

\section{ASSURANCE FUND FEES.}

Note-In addition to the above fees there is payable to the assurance fund on the registration upon every absolute transfer of land after the issue of the first certificate of title therefor, one-fifth of one per cent. of the value of the land transferred if such value amounts to or is less than five thousand dollars, and one-tentl of one per cent. on the additional value where such value exceeds five thousand dollars; and upon every subsequent transfer upon the increase of value since the granting of the last certificate of title one-fifth of one per cent. if the increase is not more than five thousand dollars, and one-tenth of one per cent. on any excess over such five thousand dollars, such valuation in each case to be ascertained by the oath or affirmation of the applicant, owner, or person acquiring the land, or of such other pereon as the registrar believes to be acquainted with the value of the land and whose oath or affirmation he is willing to accept. 


\section{APPENDIX C \\ ADDTTIONAL PRACTICE FORMS}

No. 1-Notice to Adverse Party.

Application No.

The Real Property Act.

Land Titles Office, District of

ha applied to bring the land described at the foot hereof under the above Statute, and the district registrar has directed notice of the application to be served on you, and has appointed days from such service, after which time, unless a caveat has been lodged forbidding the same the land will be brought under the operation of the said Act by issuing a certificate of title to the applicant. or to whom he may appoint, and you will thereafter be for ever estopped and debarred from setting up any claim to, $0^{-}$in respect of said land.

Dated at the Land Titles Office at this day
of LAxd Referred To

Distrirt Registrar.

\section{No. 2-Affidavit of Maker of an Instrument.}

\begin{tabular}{c|c} 
Canada: & I, \\
Province of & .
\end{tabular}

To wit:

make oath and say:

1. That I am the within named and that I am of the full age of twenty-one years.

2. That I am the registered owner (or the person entitled to be registered as the owner $)^{1}$ of the within described lands.

Sworn before me at the

of in the Province

of this day of

A. D. 191 .

1 Commissioner in

1 One or the other alternative must be sworn positively. 
No. 3-Notice of Exercising Power of Sale.

To

\section{The Real Property Act. ${ }^{1}$}

I (or we) hereinafter called the mortgagee(s) hereby give you notice that I (or we) demand payment of the sum of dollars $(\$ \quad)$ with interest on at the rate of per centum per annum from the day of A.D. 19 , due to me (or us) under a certain mortgage under The Real Property Act made by to dated the day of A. D. 19 , and registered in the Land Titles Office for the District of on the day of

A.D. 19 , as No. for securing payment of dollars and interest thereon as therein mentioned on all and singular th certain parcel or tract of land and premises situate, lying and being

default having been made in the payment of the money secured by said mortgage for the space of one calendar month.

And take notice that I (or we) the said mortgagee(s) intend without any further consent or concurrence on your part forthwith to enter into possession of the said lands and to receive and take the rents, issues and profits thereof and whether in or out of possession thereof to make any lease of the same or any part thereof as I (or we) may see fit.

And further take notice that unless payment of the said mortgage money and interest together with subsequent interest and the cost of these proceedings, be made within one ${ }^{2}$ calendar month from your being served with this notice, I (or we) the said mortgagee(s) will proceed to sell and dispose of the said lands in accordance with the provisions of The Rcal Property Act and the amendments thereto and that all remedies competent will be resorted to and all the rights, powers and privileges granted to or conferred upon the said mortgagee(s) under and by virtue of the said Act and amendments thereto and the said mortgage will be exereised.

And take notice that in the erent of the said mortgaged land being offered for sale by public auction and the highest bid at such sale not being sufficient to satisfy the moneys secured by said mortgage together with all expenses occasioned by such sale, then I (or we) the said mortgagee(s) will after such default shall have continued for six months after the time

1 In Saskatchewan "Land Titles Act" for "Real Property Act" throughout in this and the following forms.

2In Saskatchewan "two." 
mentioned in said mortgage for payment make an application in writing to the district registrar for an order for foreclosure.
Dated at
this
day of
A. D. 19 .
(.Mortgagee's name)
Per

Solicitors.

\section{ISo. 4-Directions for Sale.}

In the Matter of The Real Property $A c t^{1}$ and in the Matter of a liortgage from to registered in the Land Titles Office at as No.

1. Sale to be held at in the Province of day the day of A.D. at at the hour of o'clock m. ${ }^{2}$

2. ( ) insertions of the advertisement in the a newpaper published in the town of in the issues of the weeks commencing

3. Fo:ters to be securely fixed in conspicuous places throughout the following torns and villages:

in

in

4. Posters to be forwarded by registered mail at least weeks prior to the date of sale to all parties served with notice of exercising power of sale. ${ }^{3}$
Approved this
day of
A. D. .

Registrar.

\section{No. 5-Conditions of Sale.}

\section{The Real Property Act.}

In the Natter of a Mortgage Sale of the property described in the annexed advertisement, sold by the order of (hereinafter called the vendor) by virtue of the power of sale contained in mortgage dated the day of $A$ D. ,
made by to Land Titles Office for Land Registration District as No.

${ }^{1}$ In Saskatchewan "Land Titles Act."

2 In Saskatchewan if sale is not to be held on "Mountain Standard Time" insert "Central Time."

3 These conditions should be submitted complete to be amended by registrar if he sees fit. 
Conditions of Sale.

1. The highest bidder shall be the purchaser, and if any dispute arise between two or more bidders, the property shall be put up again at a former bidding. No person shall advance at any bidding less than ten dollars, and no bidding shall be retracted. The property will be put up subject to a sealed reserve price which will be opened only when bidding ceases, and before the property is knocked down to a purchaser. If the highest bid is equal to or greater than the reserve price, the property will be knocked down to such highest bidder but if the highest bid is not equal to the reserve price the property will be offered again at the reserve price and not sold for less.

2. The purchaser shall immediately after the sale pay in cash to the vendor's solieitors or agent a deposit of twenty per centum on the amount of his purchase money, in part payment of the purchase money, and execute the subjoined agreement to complete the purchase according to these conditions.

3. The remainder of the purchase money shall be paid, and the purchase eompleted within thirty days from the day of sale in either of the two following modes at the option of the purchaser:

(a) The remainder of the purchase money shall be paid in cash to the vendor's solicitors, at

(b) Or the purchaser shall pay in eash at the said place, a sum which together with the said deposit and a mortgage for $\$ \quad$ will be equal to the amount of the purchase money, said mortgage for $\$$ to be a first mortgage on the said premises, executed by the purehaser and all other necessary parties securing payment of such balanee payable as follows, viz.:

with interest at the rate of per eentum per annum ( yearly) until the whole of the said money is paid with compound interest. such mortgage to be according to the form usually adopted by the vendor.

4. The (applieation for transmission) ${ }^{2}$ conveyance and mortgage shall be prepared by the vendor's solieitors but the purchaser shall pay all expenses (thereof and in connection with the exccution and registration thereof, and $)^{2}$ in connection with registering the purchaser as the owner of the property.

5. The purchaser shall pay interest at the rate aforcsaid, on the whole of the unpaid purchase money from the date hercof

1 This is not a case of transmission in Saskatchewan

2 Inappropriate to Saskatchewan under the prescnt tariff. 
until eompletion of the purchase, or the vendor shall have the option of taking the rents and profits of the said lands in lieu of interest as aforesaid, until the said purehase is completed, but without prejudice to the rights of the vendor herein.

6. Upon payment of the remainder of the purchase money in one of the modes preseribed in paragraph 3 the vendor will deliver to the purchaser transfer under power of sale and other documents in support of such transfer sufficient to enable the purchaser to become the registered owner of the property described in the mortgage, but in the event of his being unable so to do the vendor shall not be liable to the purehaser otherwise than for the return of the moneys paid by the purchaser without any interest, costs or other compensation whatever.

7. The property is sold subject to taxes for the current year and subject to all exceptions and reservations contained in the original grant from the Crown. (And set out registered prior incumbrances if any).

S. If the purchaser shall fail to comply with the above conditions, or any of them, the said deposit shall be absolutely forfeited to the vendor, who may thereupon sue the purchaser for the balance of the purchase money, and resell the said property in such manner and on such terms as he shall think fit, and any defieiency which may result from such resale after deducting all costs, eharges and expenses attending such resale shall be borne by the purehaser at the present sale, and shall be recoverable by the rendor as and for liquidated damages. It shall not be necessary for the vendor to tender a conveyance or mortgage to the said purchaser.

At the sale by auction made this day of the property comprised in the advertisement hereto annexed

was the highest bidder for and declared to be the purchaser of the same at the price of dollars, and he has paid the sum dollars by way of deposit and in part payment of the purchase money, and hereby agrees to complete the said purchase according to the above conditions and on behalf of the above named vendor hereby confirms the said sale and acknowledges the receipt of said deposit.
Dated at
this
day of
A. D. 19 . 


To Wit. $\quad \begin{aligned} & \text { I, of the of } \\ & \text { in the Province of } \\ & \text { oath and say: }\end{aligned}$, make

1. I was personally present and did see the within instrument duly signed and executed by the part thereto, for the purposes named therein.

2. The said instrument was executed at

3. I know the said part and that of the full age of twenty-one years.

4. I am a subseribing witness to the said instrument.

Sworn before me at

in the Province of this

A. D. 19

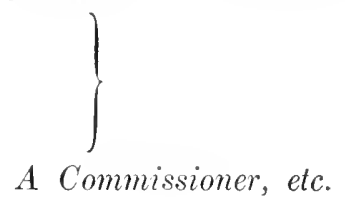

\section{Declaration of Auctioneer.}

I, of the of , in the Province of , do solemnly declare:

1. I have for some time past been engaged in the business of and am a duly licensed auctioneer at the of and $I$ have had considerable experience in the mode of selling land and house property.

2. I attended at the time and place mentioned in the advertisement hereto annexed marked " $\mathrm{A}$ " at and offered for sale by public auction the lands and premises deseribed in the said advertisement, and that the result of such sale is as follows:

3. The said sale was conducted by me in a fair, open and proper manner, and according to the best of my skill and judgment.

4. There were about persons present at the said sale.

And I make this solemn declaration, consciontionsly believing it to be true, and knowing that it is of the same force and effeet as if made under oath and by virtue of The Canada Evidence Act.

Declared before me at in the Provine' of this day of
A. D. 19

.
A Commissioner, etc. 


\section{Declaration of Fitness of Auctioneer.}

I, of the of , in the Province of
do solemnly declare:
1. I have for some time past known and been well acquainted with of the of, auctioneer, during a portion of which time he has carried on business as an auctioneer at the said of

2. I am acquainted with several persons who have employed the said as an auctioneer, and I have been informed by them and believe that he has given entire satisfaction relative to the business entrusted to him as such auctioneer by such parties.

3. The said is a person of ability and of considerable experience as an auctioneer, and in my opinion is a fit and proper person to be employed for the conduct of the sale herein.

And I make this solemn declaration, conscientiously believing it to be true, and knowing that it is of the same force and effect as if made under oath and by virtue of The Canada Evidence Act.

Declared before me at
in the Province of
this day of
A. D. 19

A Commissioner, etc.

No. 6-Poster.

\section{The Real Property Act.}

Mortgage Sale of Valuable (Farm) Property.

Under and by virtue of the powers of sale contained in a certain mortgage which will be produced at the time of the sale on the land hereinafter described

There will be offered for sale by public auction at (Hotel) in the (Village of) (Province) on the day of 19 , at the hour of o'clock Mountain (Central) time, the following property, namely: (Here insert full description of property).

Terms of sale to be 20 per cent. cash at the time of sale and the balance according to the terms and conditions to be made known at the time of the sale or upon application to the vendor's solicitors. 
The above property will be sold subject to a sealed reserved bid and free from all ineumbrances save taxes for the current year.

The vendor is informed that the above property is situate about miles from the Town of and that

acres have been brought under cultivation. (Description of improvements may be inserted here.)

For further particulars and conditions of sale apply to

Dated at

this day of

Vendor's Solicitor.

No. 7-Transfer Under Power of Sale.

\section{The Real Property Act.}

Whereas by a certain mortgage made under The Real Property Act dated the day of A. D. and duly registered in the Land Titles Office for the on the day of A. D. under No. did mortgage the lands and premises hereinafter particularly described unto for securing the payment of the sum of dollars and interest as therein mentioned.

And whereas default was made in the payment of the said mortgage pursuant to the terms thereof for more than one calendar month.

And whereas in pursuanee of the provisions of The Real Property Act and of the power of sale in said mortgage written notice of the intention of the mortgagee to sell the said lands and premises has been duly served on the said and all other parties entitled to such notice, and more than one calendar month having elapsed after service of said notice without payment of the amount demanded, the mortgigee in exercise of the said power of sale cansed the said lands and premises to be offered for sale by public auction on the day of
A. D.
at

And whereas at the said sale

of

in the Province of was the highest bidder for and became the purehaser of the said land at the said sale for the sum of dollars.

Now therefore being registered as owner of said mortgage on an estate in fee simple in possession (subject however to such incumbrances, liens and interests as are notified

'In Saskatchewan "two." 
by memorandum underwritten or indorsed hereon) in all th piece or parcel of land known and described as follows:

doth hereby in exereise of the said power of sale conferred upon by the said mortgage, and The Real Property Act and all other powers thereunto enabling in consideration of the said sum of dollars paid to by the said (the receipt of which sum is hereby acknowledged) transfer unto the said all that the said piece of land.

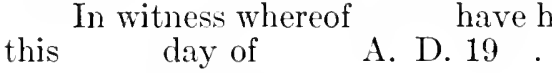

Signed in presence of

$$
\begin{aligned}
& \begin{array}{l|l}
\text { To wit: } & \text { I, of the of } \\
\text { in the Province of } \\
\text { make oath and say: }
\end{array}, \\
& \begin{array}{l}
\text { To wit: } \quad \begin{array}{l}
\text { I, of the of } \\
\text { in the Province of } \\
\text { make oath and say: }
\end{array},
\end{array}
\end{aligned}
$$

name

1. That I was present and did see the within named transferor execute the within transfer for the purposes named therein.

2. That I know the said and that of the full age of twenty-one years.

3. That the said transfer was exeeuted at the and that I am a subscribing witness thereto.
Sworn before me at in the Provinee of this disy of A. D. 19 .

A Commissioner, etc.

$$
\text { To wit: } \quad\left\{\begin{array}{l}
\text { I, of the of } \\
\text { in the Province of } \\
\text { make oath and say: }
\end{array}\right.
$$

1. That I am the within named transferor and that I am of the full age of twenty-one years.

2. That I am the registered owner of the within mentioned mortgage.

Sworn before me at in the Province of this day of A.D. 19 .

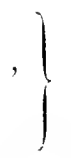

A Commissioner, etc. 
No. 8-Application for Transmission.

\section{[Heading as in Form 4.]}

To the registrar of the

Land Registration District:

I, in the Province of , hereby apply to be registered by transmission as owner of the land hereinafter described, and I declare:

1. That I am the owner of an estate in fee simple in

under purehase of the same when exposed for sale at public auction under the power of sale in mortgage No. made by , in favor of

2. That such land including all buildings and other improvements thereon is of the value of dollars and no more.

3. That there are no documents or evidences of title affeeting sueh land in my possession or uncler my control other than as follows:

4. That I am not aware of any mortgage or incumbrance affeeting the said land or that any other person has or claims to have any estate or interest therein at law or in equity, in possession, remainder, reversion, or expectancy, save (a mortgage by myself to , to be registered immediately after the registration of myself as owner of the said land, or as the case may be).

5. That I am of the full age of twenty-one years.

Dated this day of , A. D. 19 .

Made and subscribed at in the presence of

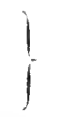

I, of , in the Province of , the applicant above named, make oath and say:

1. That the several statements contained in the said applieation are true to the best of my knowledge, information and belief.

Sworn before me at in the Province of this dity of A. D. 19

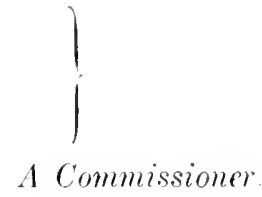




\section{No. 9-Release and Receipt by Subsequent Incumbrancer.}

\section{[Heading as in Form 4.]}
A. B., of the
of
in the Province of

hereby represents and warrants to $C . D$. that he is the subsequent incumbrancee under a certain mortgage on the said land, duly l'tistered in the Land Titles Office for the Land Registration District on the

No. for the sum of $\$$ day of

as owing and unpaid under the said mortgage the sum of \$

And the said $A . B$. further represents and warrants to the said $C . D$. that he is entitled as said registered incumbrancee to whatever surplus moneys have been realized by the sale of said lands after payment of prior incumbrances up to the said sum of $\$$, the amount of his claim under said mortgage.

said , of the sum of $\$$ of said amount due and owing.

And the said $A$. B. hereby acknowledges said amount as correct and does hereby release and discharge $C . D$. from all claims, reckonings and accounts in respect of the said sale and all acts and deeds done by the said $C . D$. thereunder.

In witness whereof the said $A$. B. has hereunto set his hand and seal this day of

Signed, sealed and delivered

in the presence of

\section{[Affidavit of execution.]}

Note.--If the claimant is an execution creditor in Saskatchewan this clause is suggested:

And the said $A . B$. does further warrant and guarantee that he has a valid charge against the said land by virtue of the said execution notwithstanding any right, claim or protection which the said mortgagor might have under the Exemptions Act being Cap. 47, R. S. S. 1909 and the said $A$. B. does hereby agree to save harmless and indemnify the said $C . D$. against all claims and demands of any person or persons whatsoever by reason of the Eaid execution and any exemption claimed thereunder.

No. 10-Application for Final Order of Foreclosure.

$$
\text { [Heading as in Form 4.] }
$$

To the District Registrar of the

Land Registration District:

$A$. B. (mortgagce) does hereby apply for a final order of 
foreclosure under the provisions of The Real Property Act and amendments thereto, and under and by virtue of the said final order of foreclosure to be registered as owner of the land hereinafter described, and declares:

1. That the said A.B. claims to be entitled to final order of foreclosure and to be registered as aforesaid under and by virtue of a certain mortgage made by $\mathrm{X}$. $Y$. (give full description and address and occupation of mortgagor).

2. That the land referred to is described as follows: (give full description of land).

3. That there are no documents or evidences of title affecting such land in his possession or under his control other than those included in the schedul' hereto.

4. That he is informed that the said land is now occupied by

5. That he is the mortgagee mentioned in the said mortgage.

6 . That the said mortgage was given to secure the repayment of the sum of $\$$ lent to the mortgagor $X$. $Y$. by the said mortgagee, and there is now llue and owing by him to the said mortgagee the sum of $\$$

7. That default oceurred under the said mortgage on the day of 19 , when a payment of $\$$ for principal and $\$$ for interest was not made by the mortgagor $X . Y$. nor any person or persons on his behalf, and that such default has continued to this date.

8. That the said property was offered for sale subject to an upset price of $\$$ in the Province of on the day of 19 , by C.D., a duly licensed auctioneer after notice of excreising power of sale had been duly served as required by The Real Property Act.

9. That the said sale proved abortive, the hichest bid being that of of the post office of , his bid being for the sum of $\$$

10. That the notice of exereising power of sale hercinbefore referred to declared the intention of the mortgagees to make an application for an order of foreclosure in ease such sale proved abortive.

11. That the said $A . B$. is not now, nor since the date of mortgage has not, nor has any per: on or per-ons by his orler, for his use or on his behalf been in posiession of the said laud and premises comprised in such mort gage or any part thercof, nor in receipt of the rents and profits issuing out of same or any part thereof. 
12. That the said $A$. B. knows of no reason why he should not be entitled to a final order of foreclosure and to be registered as owner.

In witnes; whereof the said $A . B$. has hereunto subscribed his name and affixed his seal this Signed, sealed and delivered । in the presence of day of

A. D. 19

\section{[Affiderit of cxecution.]}

\section{No. 11- - Eeclaration of Default.}

[Heading as in Form 4.]

\section{(anada:}

Province of

To wit:

I, A. B., of , in , do solemnly declare as follows:

1. That $I$ am the above mortgagee (or that I am the agent of the above named mortgagee, and have charge of the books and papers of the said mortgagee, and have a knowledge of the matters herein deposed to).

2. That default was made in payment of the moneys sceured by said mortgage to be paid on the day of and default continued thereunder for the space of one calendar month and to the present time and still continues and there is now owing theremder the sum of $\$$ in accordance with the statement attached hereto.

3. That in pursuance of the powers in said mortgage contained, the said lands were offered for sale by publie atuction on, 19 , when said lands were sold to for

4. That the said sale to the said was a bona fide sale in every respect, and that the said did not at the date of the sale or at any subsequent time stand in any fiduciary capacity to the mortgagee.

And I make this solemn declaration conscientiously believing it to be true and knowing that it is of the same force and effect as if made under oath and hy virtue of The Canadr Evidence Act.

Declared before me at the , in the Province of this day of A. D. 191 .

A Commissioner in. etc.

Paragraphs 3 and 4 are to be used only where the dectaration is being used in support of a transfer under power of sale. 


\section{No. 12-Notice of Application for Final Order of} Foreclosure.

\section{[Heading as in Form 4.]}

To C.D. and to whom it may concern:

$A$. B. hereby gives you notice that default has heen made in payment of principal and interest secured by a certain mortgage under The Real Property Aet made by C. D. of in the Province of , to the said A.B.. dated the for the day of Land Registration District on the registered office the sum of $\$$, as No. for securing the repayment of on the following property situate in the Province of namely: (here insert description) and that such default has continued for more than six months after the time for payment mentioned in the said mortgage.

And the said $A, B$. hereby gives you further notice that the said land in pursuance of the power of sale contained in the said mortgage and of The Real Property Act and amendments and further in pursuance of the notice of exercising power of sale which has been duly served on you was offered for sale by public auction under the provisions of The Renl Property Act and amendments thereto at , on the day of 19 , and the amount of the highest bid at such sale was not sufficient to satisfy the moneys secured by the said mortgange, together with the expenses occasioned by such sale, and the said sale has therefore proved abortive.

And you are hereby given notice that $A$. B., the mort gagee, has made an application in writing to the district registrar of the Land Registration District for an order for the foreclosure of the said mortgage and unless you tender the amount due under the said mortgage and the expensess in "onnection with the said abortive sale and of this applieation to the mortgagee or to his solicitors, on or tefore one month from the service (or mailing) ${ }^{2}$ of this notire the said order for the final foredosure of the said mortgage will be granted.
Dated at in the Provinee of
this
day of $; 19$. A. B.

By his solicitors.

In Saskatchewan service is directed by maiting. 


\section{No. 13-Discharge of Mortgage.}

\section{The Real Property Act.}

Province of

Canada:

To the registrar of<smiles>[TlH][TlH]</smiles>

I,

the mortgagee do acknowledge to have received all the moneys due or to become due under a certain mortgage made by of in the to which mortgage bears date the day of A. D. 191 , and was registered in the Land Titles Office for the said Land Registration District at o'clock m., on the day of A. D. 191 , No. , book , folio

That such mortgage has been assigned

And that the person entitled by law to receive the money, and that such mortgage is therefore discharged.

In witness whereof I have hereunto subscribed my name this day of A. D. 19 .

Signed by the above named in presence of

[Affidavit of Execution.]

No. 14-Mortgage of a Mortgage.

The Real Property Act.

I, A. B., (insert nome and occupation of mortgagee), being registered owner of a certain mortgage of that piece of land described as follows: (here insert description), which mortgage was made by (insert name of original mortgagor) and is dated the day of and registered in the Land Titles Office for the Land Registration District on the day of as No. , in consideration of the sum of $\$$, lent to me by E.F. (insert occupation and description) the receipt of which sum I do hereby acknowledge, covenant with the said E. $F$.

Firstly-that I will pay to him the said $E . F$, the above -um of $s$ 
Secondly-that I will pay interest on the said sum at the rate of per cent. per annum by payment on the day of and on the day of in every year, etc.

Thirdly-(here set forth special covenants).

And for the better securing to the said E.F. the repayment in the manner aforesaid of the principal sum and interest, I hereby mortgage to the said $E$. $F$. all my right, title and interest in the mortgage atove described.

In witness whercof I have hereunto signed my name this day of 19 .

Signed by the above named in the presence of

[Attach affidavit of execution.]

No. 15-Requisition to Registrar to Serve Notice pursuant to Section 130 Saskatchewan.

The Land Titles Act.

To the registrar of the Land Registration District.

I, $A$. B., being registered owner of (or claiming an intere tas

in) that certain parcel of land described as follows: (here describe land), hereby require you by notice in writing, pursuant to Form $\mathrm{Y}$ of The Land Titles Act, to notify the caveator in a certain caveat filed against the above land on the day of as No. , at his address for service as set forth in such caveat, that such caveat shall lapse at the expiration of thirty days from the mailing of such notice by you unless within the said thirty days the caveator shall filc with you an order made by a judge providing for the continuing beyond the said thirty days of the said caveat.

In witness where of I have hereunto set my hand this day of A. D. 19

Signed in the presence of

[Attach affidavit of execution.] 


\section{APPENDIX D \\ CONVEYANCING FORMS}

Form 1-Agreement for Sale.

Prepared with special reference to the interests of the vendor.

1. Memorandum of Agreement made in duplicate this day of, 19 between $A$. B., of the of , in the Province of , hereinafter called "the vendor," of the first part, and $C . D$., of the of , in the Province of , hereinafter called "the purchaser," of the second part.

Witnesseth that the vendor has agreed to sell to the purchaser and the purchaser has agreed to buy from the vendor the following land, situate in the Province of , namely: together with all the privileges and appurtenances thereto belonging at and for the price or sum of dollars of lawful money of Canada, payable at in the manner and on the days and times hereinafter mentioned, that is to say: with interest at the rate of per cent. per annum, to be computed from the date hereof and to be paid yearly on each day of and after the date hereof on so much principal money as from time to time remains unpaid until the whole principal money and interest is paid, whether before or after the same becomes due; but after default interest at the rate aforesaid shall acerue and be payable from day to day.

2. And the purchaser covenants with the vendor that he will well and truly pay or eause to be paid to the said vendor the said sums of money together with interest thereon at the rate aforesaid on the days and times and in the manner above mentioned and will also pay and discharge all taxes, rates and assessments including local improvement rates wherewith the said land may be charged from and after the , and that on default of payment of any instalment of interest, such interest shall at once become principal and bear interest at the rate aforesaid, which interest shall be payable from day to day and 
shall itself bear interest at the rate aforesaid if not paid prior to the next gale day, it being agreed that all interest as well upon principal as upon interest is to be compounded at each day mentioned for payment of interest.

3. And the purchaser further agrees that he will forthwith insure and during the continuance of this agreement keep insured against loss and damage by fire and tempest each and every building now or hereafter ereeted on the said land in their full insurable value in some insurance company to be approved of by the vendor, and will not do or suffer anything to be done whereby the said poliey or policies may he vitiated, and will pay all premiums and sums of money necessary for such purposes as the same shall become due, and will assign and deliver over unto the said rendor the policy or polieies of insurance and the receipt or receipts thereto appertaining, and if the purchaser shall neglect to keep the said buikdings or any of them insured as aforesaid, or pay the said premimns or deliver such receipts, then it shall he lawful for the said rendor to insure the said buildings in the manner aforesaid and all moneys so expended together with all costs and expenses incurred in connection therewith as between solicitor and client shall be deemed to be seeured hereby and charged upon the said land and shall without demand therefor with interest at the rate aforesaid compounded from the time or times of adrancing the same be repaid by the present purchaser to the vendor on demand. Evidence of the renewal of such insurance shall be produced to the vendor at least three days before the insurance then existing shall expire, otherwise the vendor may insure as above provided.

4. And that all moneys received by virtue of any policy or policies may at the option of the vendor cither be forthwith applied in or towards substantially rebuilding, reinstating and repairing the said premises or in or toward payment of the last instalment of principal falling due under and by virtue of these presents, and in case of a surplus in or toward payment of the instalment next preceding in point of time of payment and so on until the whole of the principal heremder shall le paid, and in case of a surplus then in or toward payment of the interest.

5. And the purchaser further aspers to insure in cach year during the existence of this agrecment the crops grown on the said land against damage by hail in their full insuralle value in some insurance company approved of by the vendor, and to pay all premiums and sums of money necestary for such purpose and to assign and deliver over to the said vendor the policy or policies of insurance and the receipt or receipts thereto 
appertaining; and that all moneys received by virtue of any such policy or policies as aforesaid shall be applied in payment to the vendor of principal and interest due under this agreement as specified in the next preceding paragraph in the case of fire insurance.

6. And that forthwith on the happening of any loss or damage by fire or by hail or tempest the purchaser will at his own expense furnish all the necessary proofs and do all necessary acts to enable the vendor to obtain payment of the insurance money.

7. In consideration whereof and on payment of the said sums of money with interest as aforesaid in the manner aforesaid, the vendor doth covenant, promise and agree to and with the purchaser to transfer to the purchaser the said parcel of land with the appurtenances as aforesaid, subject to the conditions and reservations contained in the original grant from the Crown which transfer shall be prepared by the vendor's solicitors at the expense of the purchaser.

8. The purchaser shall immediately after the execution of this agreement have the right to possession of the said premises, but must get possession at his own expense.

9. And it is further agreed between the parties hereto that until the completion of the purchase the purchaser shall hold the said premises as tenant to the vendor from the day of the execution hereof at a yearly rental equivalent to, applicable in satisfaction of and payable at the same time as the instalments of (principal and $)^{1}$ interest upon the principal hereinbefore provided to be paid, the legal relation of landlord and tenant being hereby constituted between the vendor and the purchaser:

Provided, and it is hereby agreed that should the vendor become entitled to exercise his right of distress hereby conferred the purchaser hereby expressly waives on the levying of such distress, all irregularities whether as to the time, place or manner or otherwise.

10. And that the purchaser shall not be entitled to call for the production of any abstract of title or proof or evidence of title or any deeds, papers or documents relating to the said property other than those which are in the possession of the vendor.

1 The words "principal and" should be omitted whenever the yearly instalment of principal and interest, the rent reserved, would together amount to a sum grossly in excess of the fair rental value of the land. This would be strong evidence of a want of bona fides in the creation of the tenaney between the parties. See Independent Lumber Co. v. David, 19 W. L. R. 3S7, 1 W. W. R. 134. 
11. And it is further agreed that in default of payment of the said moneys and interest, or any part or parts there of on the days and times aforesaid, or of performance or fulfilment of any of the stipulations, covenants, provisos and agreements on the part of the purchaser herein contained, the vendor shall be at liberty to determine and put an end to this agreement and to retain any sum or sums paid thereunder as and by way of liquidated damages in the following method, that is to say: by mailing in a registered package a notice ${ }^{2}$ signed by or on behalf of the vendor intimating an intention to determine this agreement, addressed to the purchaser at rost office, or in case of approved assignment to the post office address of the assignee named in such assignment, or by delivering the said notice to the purchaser or approved assignee personally, and if at the end of twenty days from the time of mailing or delivery thereof the amount due be not paid, then this agreement shall without further notice become void and be at an end, and all rights and interests herehy created or then existing in favor of the purchaser or derived under this agreement shall thereupon cease and determine, and the lands hereby agreed to be sold shall revert to and revest in the vendor without any further fleclaration of forfeiture or notice or act of re-entry, and without any other art by the vendor to be performed, and without any suit or legal proceedings to be brought or taken, and without any right on the part of the purchaser for any compensation for moneys paid under this agreement, and the said purchaser shall forthwith deliver up quiet and peaceable possession of the said lands to the vendor. ${ }^{3}$

${ }^{2}$ Notice of cancellation must comply strictly with the provisions of the agreement under which it is given. March Bros. and Wells v. Banton, 20 W. L. R. 322; Stewart v. Borm, 19 W. L. R. 166.

${ }^{3}$ The courts of Alberta and Manitoba have held that the provisions of a similar clause in an agreement for sale are in the nature of a penalty. In the absence of evidenee of laches or abandonnent of the contract, even after notice given pursuant thereto, if the purchaser is ready and willing to make good his default, sperific pesformanee will be deereed; in any event the vendor will be ordered to return the instalments already pairl. The tendeney of the courts of these provinces is to relieve from the effects of this clause and forcelosure procecdings are advisable rather than cancollation. Struart v. March, $17 \mathrm{~W}$ L. R. 522; Whilla v. Riverviow Really ('o., 14 W. L. R. 359 In Saskatchewan, unless fraud or mistake intervenes a purehaser must abide by his agreement. The servire of a notire of cancellation on default rescints the contract. Whether payments already made will be returned to the purehaser drpends upoin his ability to make out a case for the exercise of the equitable juriseliction of the court. Where the purchaser has been guilty of lithes or other rireumstances are present, which in the opinion of the court render it inequitable 
12. And it is further agreed between the parties hereto that upon reduction of the vendor's elaim hereunder to dollars the purchaser may ask for and in such ease the vendor shall furnish to the purchaser a transfer in accordance with the terms and provisions above mentioned upon the purchaser executing in favor of the vendor a first mortgage on the said lands and premises free from all incumbrances, the same to provide for the payment of the balance of the purchase money in accordance with the provisions herein contained, and to contain a corenant by the purchaser for the insurance against fire to the amount of not less than the full insurable value of all buildings and against hail as above, such mortgage to be satisfactory to the vendor's solicitors and to be prepared by the vendor's solicitors at the expense of the purchaser and the expense of registering the sime and of the necessary searches; solicitor's fees and disbursements incurred with regard to the same shall be borme by the purchaser.

13. And it is further agreed that upon the purchaser or those claiming under him committing any act of waste upon the said lands or doing any other thing whereby the value of the said lands may be diminished, or failing to remain in actual personal possession of the said land, or making default in any of the covenants or provisions herein contained, the whole purchase money and interest hereby secured shall at the option of the vendor forth with without notice become due and payable.

14. And it is further agreed that time is to be considered of the essence of this contract and that all the covenants and agreements herein contained on the part of the purchaser shall be binding upon his executors, administrators (successors) and assigns and shall inure to the benefit of the vendor, his executors, administrators and assigns; and in case there are two or more purchascrs the covenants herein contained on their part shall $\mathrm{be}_{\mathrm{s}}^{\mathrm{s}}$ deemed to be joint and several; and wherever the singular or the masculine is used throughout this agreement, the same shall be construed as meaning the plural or the feminine, or a body corporate where the context or the parties hereto so require.

to order the retum of instalments paid, the clause will be strictly enforced. Steele v. MeCarthy, 7 W. L. R. 702; Hole v. Wilson, 16 W. L. R. 352; Banton v. Mareh Bros. and Wells, 16 W. L. R. 337. See, also, the following as to this clause generally: Great West Lumber Co. v. Willins, 7 W. L. R. 166; Moodie v. Ioung, 8 W. L. R. 310; Hall v. Turnbull, 10 W. L. R. 536; Dalzill v. Homeseekers Land Co., 16 IV. L. R. 525; Exema v. Cherry, 18 W. L. R. 6t5; Hicks v. Laidlaw, 19 W. L. R. 525; Mareh Bros. and Wells v. Banton, 20 W. L. R. 322 (S. (.. Can.). 
15. No assignment of this agreement shall be valid unless the same shall be for the entire interest of the purchaser and shall be approved and countersigned by the vendor; and no agreement or conditions or relations between the purchaser and his assignee, or any other person acquiring title or interest from or through the purchaser shall preclude the vendor from the right to convey the premises to the said purchaser on the payment of the unpaid portion of the purchase money which may be due hereunder, unless such assignment be approved and countersigned by the vendor as aforesaid, and these conditions shall not in any way be affected or changed by the vendor receiving payment of any portion of such purchase money from any assignee not approved as aforesaid. ${ }^{4}$

In witness whereof the parties hereto have set their hands and seals the day and year first above written.

Signed, sealed and delivered

in the presence of

Purchaser.

Post Office.

Province.

\section{Form 2-Agreement for Sale.}

Prepared with special referencu to the interests of the purchaser.

Memorandum of Agreement ${ }^{5}$ made this

day of

A. D. 19 , between A. B., of , in the Province of , hereinafter called "the vendor," of the first part, and C.D., of , in the Province of , hereinafter called "the purchaser," of the second part.

Witnesseth that the vendor agrees to sell to the purchaser and the purchaser agrees to buy from the vendor that certain piece of land situate in the Province of , being , at and for the price or sum of dollars, being at the rate of dollars per , payable in the following manner, that is to say: dollars in cash or before the exceution

${ }^{4}$ This clause has been interpreted to mean that in order that an assignment may be valid as against the vendor it must have received his approval; in the event of an assignment without his alproval, he may ignore the same and convey directly to the original purchisser, notwithstanding the assignment. In such a case the purchisser would nevertheless hold the property as trustec for the assignees. Shawyer Massey Co. v. Bennett, 12 W. I. R. 249; affirmed by the Supreme Court of Canada, $! 4$ W. L. R. 106; steuturt v. Borm, 19 W. L. R. 166; MeKillop and Benjafield v. Alexunder, (S. (. Cin.) 20 W. I. R. 850.

- See notes to Form 1. 
and delivery of these presents (the receipt whereof is hereby acknowledged).

The surm of $\$$

The sum of $\$$

The sum of $\$$

The sum of $\$$

The sum of $\$$ on or before the on or before the on or before the on or before the on or before the day of
day of
day of
day of
day of

19

together with interest on so much of the said purchase money as shall from time to time remain unpaid, whether before or after due, at the rate of per centum per annum payable yearly on or before each day of . All arrears of interest whether upon principal or upon interest to become principal and bear interest as such.

And the purchaser covenants and agrees to and with the vendor that he will pay all taxes. rates and other charges and assessments wherewith the said land may be charged from and after the day of , 19 , and that he will at the request of the vendor insure and keep insured during the currency hereof in favor of the vendor all buildings now or hereafter erected upon the said land.

In consideration whereof and upon payment of the said sums of money with interest thereon at the days and times and in the manner aforesaid the vendor covenants to convey to the purchaser the said parcel of land free from incumbrances, subject only to the reservations and conditions contained in the original grant from the Crown.

The purchaser shall be entitled to the possession of the said lands forthwith upon the execution hereof:

Provided that upon the vendor's claim herein being reduced to dollars the purchaser is to have the privilege of asking for and the vendor will furnish to the purchaser a transfer in accordance with the terms and provisions above mentioned upon the purchaser executing in favor of the vendor a first mortgage uron the said land and premises, free from incumbrances, the same to provide for the payment of the balance of the purchase money upon the terms above set out.

And it is further agreed that if the purchaser shall at any time make any default under this agreement and such default shall continue for thirty days, the vendor shall be at liberty to cancel the same in the following manner, that is to say: by mailing in a registered letter addressed to the purchaser at

post office, or in case of assignment to the assignee at his post office address named in such assignment, a notice declaring his intention to cancel this agreement and at the expiration of thirty days from the mailing of said notice, unless such default 
be sooner remedied this agrcement shall thereupon without further notice become null and roid and the purchaser and all claiming under him shall forthwith deliver up quist and peaceable possession of the said land to the vendor or his agent. ${ }^{1}$

And it is further agreed that these presents and all herein contained and the benefit of all covenants and provisos contained herein shall be binding upon the parties hereto, their and each of their executors, administrators and assigns, and if there be more than one vendor or purchaser shall be jointly and severally binding and in such case the singular shall he read as plural and the masculine as feminine herein wherever the context so requires.

In witness whereof the parties hereto have hereunto set. their hands and seals the day and date first above written.

Signed, sealed and delivered

in the presence of

\section{Form 3-Agreement for Sale, Share of Crop.}

Memorandum of Agreement, made in cluplieate the day of , in the year of our Lord, one thousand nine hundred and , between $A . B$, of , in the Province of , hereinafter ealled "the vendor," of the first part, and $C . D$, of , in the Province of, hercinafter called "the purchaser," of the second part.

Witnesseth that in consideration of the conditions and stipulations herein contained, and the payments to be made as hereinafter specified, the strict performance of each and every of the said covenants and stipulations as well as the making of the said payments being hereby expressly declared a condition precedent, and of the essence of this agrecment, the vendor agrees to sell to the purchaser, and the purchaser agrees to buy from the vendor, the following lands and premises, that is to say:

at and for the price or sum of 8 , payahle at, as

1 See notes to cancellation clause in Form 1. This chanse gives the purchaser sixty days in which to remedy his dofoult. "This agreement contains no provision for aecrleration of payments on default. Tender to the vendor of the amount of arrears and interest within sixty days would restore the parties to their original position. Moneys paid on account of contract could be recovered unless the purrebiscres dofault was of such a nature as to justify the vendor in conclumling that he had repudiated or abandoned the contract. 
to cash payments, and as hereinafter more particulary set forth as to crop payments, at the times and in the manner following, that is to say: the sum of $\$$ on the execution of this agrecment (the receipt whereof is hereby acknowledged), (here insert further cash payments if any) and the balance of $\$$ by crop payments in annual instalments as hereinafter specified.

2. And the purchaser covenants to pay interest on the unpaid balance of the purchase price at the rate of per cent. per annum, to be computed from the date hereof, and payable annually on the day of in each and every year until the full amount of principal has been fully paid and satisfied, whether before or after due; but after default, interest at the rate aforesaid shall aecrue and be payable from day to day.

3. And the purchaser further eorenants and agrees that on default of payment of any instalment of interest, such interest shall at once become principal and bear interest at the rate aforesaid, which interest shall be payable from day to day and shall itself bear interest at the rate aforesaid; it being agreed that all interest, as well upon principal as upon interest, is to be compounded on the date hereinbefore fixed for the payment of interest, in each and every year during the curreney of this agrcement.

4. The balance of the purchase price and interest is to be paid in the following manner:

The purchaser covenants and agrees in each and every year during the term of this agreement after the year 19 to deliver at his own expense, in the name of the vendor, at an elevator or in cars at the option of the vendor, at, in the Province of , one-half of the entire crop of grain grown on the said land in each and erery year during the said term, from the threshing machine, until the net sums realized by the vendor on the sale of such crops shall fully pay and satisfy the said balance of the purchase price, together with interest as aforesaid. The proceeds of the sale of the rendor's share of the erop shall be applied by the vendor on the amount remaining due under this agreement, first, on account of interest and the balance (if any) in the reduction of the unpaid principal money. It is, however, further understood and agreed that all sums not then paid under this agreement shall, in any event, become due and payable in cash at the expiration of years from the date hereof.

5. The purchaser further covenants and agrees that he will break and backset in a good and husbandlike manner 
during the season of 19 , at least

acres on the above described premises, and a further quantity of uncultivated, arable land upon said premises to be broken and backset in the same manner during the proper seasons as follows: acres in 19 , acres in 19 , and acres in 19 , until not less than acres of said land shall have become broken up, all of which breaking shall be done in the respective years before the day of

6. The said purchaser further agrees that at the proper season of 19 , and in each and every year thereafter during the continuance of this contract, he will seed in wheat or such other grain as the vendor may consent to in writing, at his own expense all the land upon the said described premises that may be broken previously to that year, unless some part of the said land be left to summer fallow as below provided; that he will properly care for, harvest and thresh said crops in due season and at his own expense, each year's crop to be threshed not later than the day of during the currency of the year in which it is grown.

7. And the purchaser further agrees that he vill give the vendor or his duly authorized agent at least five days' notice in writing of the time when he will commence to thresh, and similar notice prior to delivering grain as aforesaid.

8. And the said purchaser further agrees that he will furnish and deliver to the vendor immediately after the grain, or any part thereof, is threshed, a certificate to be executed by the owner or manager of the threshing machine which threshes such grain, showing in detail the date when such grain was threshed and the number of bushels of the different kinds of grain threshed, and that the charges for threshing such grain have been paid in full; and that not later than the day of in each year he will furnish to the venclor his statutory declaration verifying the certificate or rertificates as aforesaid and the threshing of all the grain grown on the said land in the current year.

9. The purchaser agrees to carefully watch for, and at his own expense to kill and destroy all noxious weeds which may grow upon said premises during the term of this agreement, and especially to pull and burn all mustard plants whereever and whenever they may be discovereel and to kill and destroy all Russian thistles before they have gone to seed, or, if by oversight any such thistles have gone to seed, whether such seed is ripe or not, to remove all such plants from their place of growth and burn them without scattering the seed. 
10. The purchaser agrees to fall plow in each season at least acres of stultle land on said rremises before the day of , and to spring plow before the day of next following the remainder of such stubble land, unless the rendor shall consent in writing that some part of such stubble land be left orer to summer fallow, and the purchaser agrees to do all summer fallowing in proper season and manner according to the best methods of cultivation.

11. And that he will on or before the first day of in each year produce and leave with the vendor a receipt or receipts for the payment of all liens, rates, taxes or charges upon the said land for the current year, and that in default of his doing so the rendor may pay any such liens, rates, taxes or charges, and in case such payment or payments is or are made by the rendor the amount or amounts so paid, together with all costs and expenses incurred in connection therewith, as between solicitor and client. shall be deemed to be secured hereby and charged upon the said land, and shall, without demand therefor, be payable forthwith with interest at the contract rate.

12. In the event of default in the payment of any sum hereinbefore mentioned, or in the event of default being made in payment of any crop payment, or in any building, cultivation or insurance condition hereinafter mentioned, the whole purchase money at the option of the rendor, without notice, shall immediately become due and payable in cash.

13. The crop payments aforesaid shall become due and be payable by the purchaser to the vendor on the day in each year during the currency of this agreement on which the purchaser commences to thresh his crop. No sum whaterer is to be credited by the vendor in reduction of either interest or purchase money until the date or dates on which he actually personally receives the net proceeds of the sale of the grain received by him by way of crop payment.

14. For fire, tempest and hail insurance covenants, see paragraphs $3,4,5$ and 6 , Form 1 .

15. For covenant to convey on performance of conditions, see paragraph 7 , Form 1.

16. The purchaser shall immediately after the execution of this agreement have the right to possession of the said premises, but must get possession at his orn expense.

17. It is further agreed between the parties hereto that during the currency hercof the purchaser shall hold the said premises as tenant to the vendor from the date of execution hereof at a yearly rental of one-half share of the crop grown 
upon the said land, delivered as aforesaid, applicable in satisfaction of the principal and interest as herein provided, the legal relation of landlord and tenant being hereby constituted between the vendor and purchaser:

18. Provided that if any of the goods and ehattels of the purchaser or his approved assignee shall be at any time seized under any mortgage, lien or agrecment, or be seized or be taken in execution or in attachment by any ereditor of the purchaser or such assignee, or if the purchaser or sueh assignee shall make any assignment for the benefit of creditors, or hecome bankrupt or insolvent and shall take the benefit of any act that may be in force for bankrupt or insolvent debtors, or if any writ of execution shall issue against the goods or chattels of the purchaser or such assignee out of any court, the then current year's rent shall immediately become due and parable without notice; and it is further agreed that should the vendor become entitled to exercise his right of distress incident to the tenancy hereby ereated the purchaser herebr expresty wrives on the levying of such distress all irregularities, whether as to time, place or manner, or otherwise.

19. And the purchaser shall not be entitled to call for the production of any abstract of title, or eridence of title, or any deeds, papers or documents relating to the said property other than those which are in the posicssion of the rendor.

20. For cancellation clause, see paragraph 11, Form 1.

21. For covenant against waste, and for per-onal possession by purchaser, paragraph 13 , Form 1 .

22. For covenant binding executors, administrators and assigns. etc., see paragraph 14, Form 1.

23. For provisions as to asignment of contract, see paragraph 15, Form 1.

In witness whercof the parties hereto have hereunto set their hands and seals the day and year first above mitten.

Signed, sealed and delivered

In the presence of

Purchaser.

P'ost Oflice.

Province.

Special Clauses for Agreements of Sale.

Erection of House and Stable.

And the purchaser hereby agrees and linds himself that he will on or before the day of , A. D. 19 , erect a 
habitable dwelling house and stable upon the said land and insure the same in the manner herein provided.

\section{Fixtures.}

And it is hereby declared and agreed that all erections, buildings and improvements hereafter put upon the said lands shall (in addition to other fixtures thereon) thereupon become fixtures and a part of the realty.

\section{INSPECTION.}

Provided that upon default by the purchaser of any covenant on his part herein contained or upon and after default in payment of any of the moners hereby secured or payable under these present srom time to time, the vendor shall be entitled to send his inspector or agent to inspect and report upon the value, state and condition of the said land at the purchaser's expense and all expenses incurred and paid in so doing together with all costs and charges between solicitor and client which the vendor may ineur or pay in enforcing or attempting to enforee all or any of the remedies and powers given hereby or subsisting, whether the proceedings taken prove abortive or not, shall form and be a charge upon the said land and payable forthwith to the vendor with interest at the contract rate from the time of the payment of the same.

\section{REPAIRS, ETC.}

And the purchaser covenants with the vendor that the vendor may at such time or times as he may deem necessary and without the concurrence of any person make such arrangements for the repairing, finishing and putting in order any building or improvements on the said land and for inspecting, taking care of, leasing, collecting the rents of and managing generally the said property as he may deem expedient, and all reasonable expenses, costs or eharges, including an allowance for the time and service of any agent of the vendor or other person appointed for any of the above purposes shall be forthwith payable to the vendor and shall be a charge upon the said property and shall bear interest at the eontract rate.

\section{Existing Tenancies.}

And it is agreed that the said land is sold subject to existing tenancies as follows: 


\section{Subdivision.}

And the vendor agrees that the purchaser may subdivide the said property into blocks and lots, each block to contain

lots of feet each; and further agrees to do all acts and exeeute all instruments necessary for the registration of a plan of the said property as aforesaid and providing for the necessary streets and lanes according to the regulations governing the registration of such plans, it being understood and agreed that all expenses of and ineidentals to such subdivision are to be borne by the purehaser.

\section{Form 4-Notice of Cancellation.}

To post office of

Pursuant to the terms of a certain agreement for the sale of the property hereinafter referred to, dated the A. D. 19 , between $A . B$., of , in the of , as vendor and $C . D$., of , in the of , as purchaser (and assigned to , of the of , in the of by assignment dated the day of , A. D. 19) which said agreement is in respect of the followinglands, namely:

in the Province of

You are hereby notified that default has been mate in the payment of the sum of $\$$ dollars principal and interest (or as the case may be) falling due under the said agreement on the day of , A. D. 19, (or in the performance of the following covenant, setting out the same).

And you are hereby further notified that if payment of the said sum of $\$$ dollars be not made (or the said covenant be not performed) within twenty days from the date of the mailing of this notice the said agrecment shall without further notice become void and be at an end and all rights and interests thereby created and now existing in favor of the purchasere or derived from him, under the said agreement, shall theroupon cease and determine and the property above refferred to shall revert to and revest in the vendor without any further declatration of forfciture or notice or act of re-cutry and withont any other act by the vendor or suit or legal procerelings; and any sum or sums paid under the said agreement shall be retained liy the vendor as and by the way of licuidated damages without any right of rompensation on the part of the purchaser or those claiming under 
him, and the purehaser and those claiming under him shall forthwith deliver up quiet and peaceable possession of the said lands to the vendor.
Dated at
in the
of
this
day of ,A. D. 19 .

Vendor.

\section{(Registered.)}

This notice is adapted to the agreement for sale, Form 1 herein, and can safely be nsed only where the cancellation clause in pursuance of which the notice is given is the same as in that agreement. A notice of cancellation must comply strictly with the terms of the particular agreement under which it is given. March Bros. and Wells v. Banton, 20 W. L. R.

322.

\section{Form 5-Declaration of Posting Notice of Cancellation.}

\author{
Canada: \\ Province of \\ To wit:
}

1. I did on
I, clare:

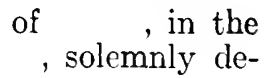

day of
, A. D. 19 personally deposit in his Majesty's office at, in the Provinee of a duplicate of the notice of cancellation annexed hereto, the same being inclosed in a fully prepaid registered envelope addressed to at the post office of , in the of

2. 'That now produced and shown to me and marked "Exhibit A" to this my declaration is the registration receipt for the said envelope.

3. And I make this solemn declaration conscientiously believing it to be true and knowing it to be of the same force and effect as if made under oath and by virtue of The Canada Evidence Act.

Deelared before me at the of

Province of in the day of, A. D.

A Commisioner or Notary Public in and for

\section{Form 6-Option to Purchase Land.}

Agreement made this day of ,A. D. 19 , between $A . B$., of , in the Province of , hereinafter ralled "the vendor," of the one part, and $C . D$., of , in the Province of , hereinafter called "the purchaser," of the ther part. 
Whereas the vendor alleges that he is the owner of the piece or parcel of land situate in the Province of and being composed of

This agreement witnesseth that the vendor in consideration of the sum of $\$$ dollars ${ }^{1}$ (the receipt whereof is hereby acknowledged) hereby offers and agrees to sell to the purchaser, his executors, administrators or assigns, free from incumbrances the said property hereinbefore described for the sum of $\$$ on the following terms, namely, $\$$ dollars in cash forthwith upon the acceptance of this offer and the balance ${ }^{2}$

with interest at the rate of computed from the day of A. D. 19 , on so much of the purchase price as from time to time remains unpaid until the whole purchase price and interest has been fully paid.

This offer is to remain open until the hour of twelve o'clock noon of the day of , A. D. 19 , and is to be irrer ocable until the said mentioned date, and if accepted on or before the said date shall thereupon constitute a binding agreement of purchase and sale; the purchaser to examine the title at his own expense within ten days from the date of acceptance. The vendor not to be bound to produce or show any evidences of title except such as are in his possession.

This offer may be accepted by a letter clelivered to the vendor, or mailed postage prepaid and registered, addressed to the vendor at, in the of, and deposited in the post office on or before the day of , A. D.19.

Time shall be of the very essence of this option.

In witness where of the vendor has hereunto set his hand and seal on the day and year first abore written.

Signed, sealed and delivered

in the presence of

1 An "option" unsupported by consideration and not under seal is no more than an offer revocable at any time before acceptance. Where there is actual consideration the anount thereof is generally immaterial. There are, however, American cases holding that a recited consideration of one dollar, either stipulated or paid is insufficient. Where the option is under seal, but without consideration and is attempted to be withdrawn before acceptance there is some conflict of authority as to the effect to be given to the seal in an action for specific performance. The seal at common law renders the offer irrevocable and this rule would probably be followed by a court of equity, It is, however, advisable in unilateral agreements of this nature that some real consideration pass. See 36 Cyc. pp. 626, 627.

2 All the terms of the agrcement must be fully set out. 


\section{Form 7-Listing Agreement.}

(With authority to sell.)

Agreement made this between $A$. B., of first part and C.D., of the second part.

Witnesseth, that in consideration of the services hereinafter mentioned and to be performed by the party of the second part, the party of the first part hereby nominates, authorizes and appoints the said party of the second part his sole agent to sell for him the following property situate in the Province of and being composed of , for the sum of $\$$ dollars [net to the party of the first part] ${ }^{1}$ on the following terms:

And the party of the first part agrees to pay to the party of the second part all money in excess of the above named sum for which the party of the second part may sell the said property.

[And the party of the first part agrees in the event of a sale as aforesaid by the said party of the second part to pay him the said party of the second part a commission of per cent. of the sclling price of the said land, the same to be deducted from the cash payment.] ${ }^{2}$

And that the party of the second part shall have until the day of , A. D. 19 , to sell the said property on the above named terms, until which date this contract is to be irrevocable.

The party of the first part reserves the right to effect a sale of the said property on his own account, but in case of such sale agrees to pay to the party of the second part one-half of the regular commission of five per cent., and further agrees under penalty of forfeiting the entire regular commission as aforesaid to the party of the second part to immediately notify him of such sale.

And in case a sale is made to anyone who is induced by the party of the second part or his bona fide agent to enter into negotiations or communications which result in such sale, then the party of the first part agrees to pay to the party of the second part five per cent. of the price for which the said property is sold.

When a purchascr shall have been found by the party of the second part, if by reason of defective title or otherwise by the

1 Words in brackets are not'to be inserted if alternative clause providing for remuneration of agent is used.

${ }^{2}$ This elause is to be used as alternative to the elause preceding it. 
default of the party of the first part the sale is not perfected, the commission of the party of the second part equivalent to the difference between the price agreed upon by such purchaser and the net price to the vendor hereinbefore mentioned (or the agent's commission of per cent. as the case may be) shall have been earned and become payable forthwith by the party of the first part to the party of the second part.

And the party of the second part hereby agrees at his own expense to list the said property and advertise the same for sale and use all reasonable diligence to effect a sale thereof.

In witness whereof the parties have hereunto set their hands and seals.

Signed, sealed and delivered

in the presence of

\section{Form 8-Assignment of Agreement for Sale.}

\section{(By the Purchaser.)}

This Indenture, made in duplicate this in the year of our Lord one thousand nine hundred and between $A . B$., of part, and C.D., of part, and $X . Y$. of part.

Whereas the party of the first part, by agreement dated the day of , one thousand nine hundred and agreed to purchase the land hereinafter mentioned from the party of the third part, and in and by such agreement covenanted with the party of the third part to pay the purchase money mentioned in the said agreement.

And whereas the party of the first part is desirous of assigning his interest in the said land to the party of the second part.

And the party of the second part has agreed, in consideration of such assignment being aceepted by the party of the third part, to give his personal covenant to the party of the third part to carry out and fulfil all the covenants and conditions in the said agreement by the party of the first part agreed to be done, paid or performed.

And the party of the first part, in consideration of the party of the third part accepting the said assigmment, has agreed that this assignment or the acceptance thereof by the party of the third part shall not in any way affect the rights of the party of the third part to enforce the covenants of the party of the 
first part in the said agreement contained against him or his representatives.

Now this indenture witnesseth that in consideration of the premises and of the sum of dollars now paid by the party of the second part to the party of the first part (the receipt where of is hereby by him acknowledged) the party of the first part hath granted, bargained, sold, assigned, transferred and set over, and by these presents doth grant, bargain, sell, assign, transfer and set over unto the party of the second part, his cxecutors, administrators and assigns for ever, all the estate, right, title, interest, claim and demand whatsoever, both at law and in cquity, of him the party of the first part, of, in and to that certain parcel or tract of land and premises situate, lying and being

subject to the payment of the balance due and accruing due uncler the hereinbefore in part recited agreement, together with all interest to the party of the first part in the said agreement so far as the same relates to the above described land.

To have and to hold the same with all and every benefit that may or can be derived from the said described land unto the party of the second part, his executors, administrators and assigns for ever.

And the party of the second part, in consideration of the party of the third part accepting this assignment, which acceptance may be without formal execution hereof by him, hereby covenants and agrees to and with the said party of the third part, his executors, administrators and assigns to pay the several sums of purchase money and interest in the said hereinhefore in part recited agreement contained, on the days and times when the same shall become due, and to do and perform all other acts and things which the party of the first part in the said agreement covenanted with the party of the third part to do.

And the party of the first part, for the consideration aforesaid, hereby covenants that the execution of this agreement or the acceptance thereof by the party of the third part shall not in any way releasc him from his obligations to perform the said hereinbefore in part recited agreement, and all covenants and conditions therein contained by him agreed to be done and performed.

Wherever the singular and masculine are used throughout this indenture, the same shall be construed as meaning the plural or the feminine when the context or the parties hereto so require.

In witness whereof, etc. 
Form 9-Assignment of Agreement for Sale.

(By the endor.)

This Indenture, made in duplicate the

day of

A.D. 19 , between A. B., of , in the Province of hereinafter called "the assignor" of the first part, and C. D., of in the Province of, hereinafter called "the assignee" of the second part, and 'X. Y., of, in the Province of , hereinafter called "the purchaser" of the third part.

Whereas by articles of agreenent dated the '- day of A. D. 19 , and made between the above named assignor of the first part therein and the above named purchaser of the second part therein, the said assignor agreed to sell and convey unto the said purchaser, who therein agreed to purchase from the said assignor the lands therein and hereinafter described for the sum of - dollars subject to the conditions and covenants in the said articles of agreement contained.

And whereas there is still owing and unpaid under the said articles of agreement the sum of dollars, together with interest thereon at the rate of per eent. per annum from the day of ,A. D. 19 , which moneys and interest are under said agreement payable to the assignor in addition to all other sums payable under said agreement.

And whereas the said assignor has agreed to grant and assign the said articles of agreement and all his interest therein and in the said lands, and ail moneys still owing and unpaid under the said articles of agrecment unto the said assignee.

Now therefore this indenture witnesseth that in consideration of the premises and of the sum of dollars of lawful money of Canada now paid by the assignee to the said assignor (the receipt whereof is hereby ly him acknowledged) he the said assignor doth hereby grant, assign and set over unto the said assignee, his executors, administrators and assigns, the said articles of agreement, all moneys due, owing or payable thereunder, and all the right, title and interest of him the said assignor thereunder and thercin.

And this indenture further witnesseth that for the consideration aforesaid, he the said assignor by these presents doth grant, bargain, sell, assign, transfer and set over unto the said assignee, his executors, administrators and assigns for ever, all and singular that certain parcel or tract of land and premises situate, lying and being in the Province of and being composed of 
To have and to hold the said lands and premises unto and to the use of the said assignee, his executors, administrators and assigns for ever, subject to the terms, covenants and conditions contained in the said articles of agreement.

And the said assignor hereby covenants with the said assignee that there is now due or accruing due and unpaid under the said articles of agreement to the said assignor in addition to all other sums payable thereunder, the said sum of dollars together with the interest thereon at per cent. per annum from the day of , A. D. 19, and that he has done no act nor permitted any act to incumber the said lands save and except as mentioned in said agreement, and has not done or permitted any act and has been guilty of no omission or laches whereby the said articles of agreement have become in part or entirely in anywise impaired or invalid, and he has not released, assigned, hypothecated or discharged, nor has any covenant, eondition or proviso contained therein been discharged or waived, nor any breach or non-performance thereof been waived or condoned, and that he will upon request do, perform or execute every act necessary to enforce the full performance of the eovenants and other matters contained in the said articles of agreement, and for the purpose of enforcing all rights of the assignor in said agreement, the said assignor hereby nominates, constitutes and appoints the said assignee his true and lawful attorney, irrevocable, to use the name of the said assignor in securing the enforcement of all such rights, and doth hereby authorize the assignee to convey the said lands or the interest of the assignor therein named to the purehaser or such other person, including the assignee, as may become entitled to a conveyance thereof.

And the said assignor doth further, for himself, his executors, administrators and assigns, eovenant, promise and agree to and with the said assignee, his executors, administrators and assigns, that in the case of default by the purchaser in payment of any sum or sums of money which shall become due or owing under the said articles of agreement, that he will forthwith on demand well and truly pay or cause to be paid to the said assignee, his exceutors, administrators or assigns any sum or sums so in default.

And he doth further covenant and agree that the giving or extending of time for the payment of any sum or sums of money payable under the said articles of agreement, or for the performance of any condition or covenant contained therein, by the said assignee to the said purchaser or any other person shall not be a waiver or release or discharge in any way to the assignor of this covenant. 
And the said purchaser doth hereby acknowledge having received notice of the assignment herein contained and doth acknowledge and admit that the amount owing by him under the said articles of agreement is as hereinbefore set out.

And the said purchaser doth further covenant, promise and agree to and with the said assignee that he will pay or cause to be paid to the assignce the said sum of money still owing and unpaid under the said articles of agreement on the days and times and in the mamner therein set forth, and that he will keep, observe and perform all corenants, provisos and agreements in said agreement contained.

Wherever the singular and the masculine are used throughout this indenture, the same shall be construed as meaning the plural or the feminine where the context or the parties hereto so require.

In witness whereof, etc.

\section{Form 10-Lease over Three Years, Crop Payment.}

1. I, A. B., of , in the Province of , hereinafter called "the lessor," being registered as owner, subject however, to such mortgages and incumbrances as are notified by memorandum underwritten or indorsed hereon of that piece or parcel of land known and described as follows:

do hereby lease to C.D., of , in the Province of , farmer, all the said lands together with all erections, buildings, barns, stables or other houses thereupon erected, standing and being, or hereafter during the said term to be erected, standing or being, together also with all ways, paths, passages, watercourses, privileges, and advantages whatsoever, to the said premises belonging or in any way appertaining to be held by the said lessee as tenant for the space of years from the day of , A. D. 19 , and from thenceforth next ensuing fully to be completed, yielding and paying therefor yearly and every year during the sairl term hereby granted unto the lessor the clear yearly rent hereinafter mentioned, namely, the share or portion of the whole crop of the different kinds and qualities which shall be grown upon the demised premises in each and every year during the said term subject to the covenants and powers implied and the special covenants hereinafter mentioned.

2. The said lessee hereby covenants, promises and agrees to and with the said lessor that he will at all times during the said term cultivate and manage in a proper and husbandlike 
manner all such parts of the land as are now and shall hereafter be broken up, or converted into tillage and shall not impoverish or waste the same.

3. That he will at his own expense and in a proper and husbandlike manner during the season of 19 , seed, harvest and thresh acres of the cultivated portion of the said land with and acres of the cultivated portion of the said land with , and will during the said year summer fallow acres of the said land, and also during the said year in a proper and husbandlike manner, and in its due and proper season, break, backset and otherwise properly cultivate at least acres of the said land.

4. That he will during the year 19 , and each succerding year thereafter cluring the continuance of this lease either put into crop or summer fallow either the whole or so much of the demised premises as has been or shall hereafter be brought under cultivation as the lessor may direct, but so that in any case each part of the said land shall be summer fallowed once in three years, and will during the year 19 , and in each succeeding year thereafter during the term hereby granted in a proper and husbandlike manner and in its due and proper season break, backset and otherwise properly cultirate atleast acres of the unbroken arable land on the demised premises until all the said arable land shall have been brought under cultivation.

5. That he will each year during the continuance of this lease seed, harvest and thresh at his own cost and expense all the grain grown on the said land, the lessor's share to be delivered to him on the day of the threshing, which is to take place not later than the day of in each year, and is to be hauled at the expense of the lessee to such elevator in the of as whe lessor may direct and there stored in the name of the lessor for his use absolutely.

6 . That he will properly bluestone the seed grain for the demised premises in each year of the said term.

7. That he will furnish at his own cost and expense all the labor, horses and machinery necessary for the proper seeding, harvesting and marketing of the crop to be grown as aforesaid.

8. That he will furnish and deliver to the lessor immediately after the grain or any part thereof is threshed a certificate to be executed by the owner or manager of the threshing machine which threshes such grain showing in detail the date when such grain was threshed and the number of bushels of the different kinds of grain threshed and that the charges for threshing such grain have been paid in full, and that not later than the day of in each year he will furnish 
to the lessor his statutory declaration verifying the certifieate or certificates as aforesaid and the threshing of all the grain grown on the said land in the current year.

9. That he will not at any time during the said term use, exercise or carry on, in or upon the said premises or any part thereof, any noxious, noisome or offensive arts, trade, business, oceupation or ealling, and no act, matter or thing whatsoever shall at any time during the said term be done in or upon the said premises or any part thereof which shall or may be grown to annoyance, nuisance, grievance, damage or any disturbance of the owners of the said land or the owners or oecupiers of the adjoining land and property.

10. The purchaser agrees to carefully watch for and at his own expense to kill and destroy all noxious weeds which may grow upon the said premises during the term hereby granted, and especially to pull and burn all mustard plants wherever and whenever they may be diseovered, and to kill and destroy all Russian thistles before they have gone to seed, or if by oversight any such thistles have gone to seed. whether such seed is ripe or not to remove all such plancs from their places of growth and burn them without scattering the seed.

11. That he will not during the said term transfer, assign or sublet the land and premises hereby leased or any part thereof, or otherwise by any act or deed procure the said land and premises or any part thereof to be transferred or sublet without the eonsent in writing of the lessor first had and obtained.

12. That he will pay all rates and taxes and charges which may be payable in respect of the demised land during the continuance of this lease.

13. And it is further agreed that if the term hereby granted shall be at any time seized or taken into execution or in attachment by any creditor of the said lessee, or if the said lessee shall make any assignment for the benefit of his creditors or beeome bankrupt or insolvent or shall take the benefit of any act that may be in foree for bankrupt or insolvent debtors, or in ease execution shall issue against the goods of the lessee from any court having jurisdiction in the Province of the then current rent shall immerliately become due and payable, and the said term shall immediately become forfeited and void.

14. And that the terms lessor and lessee shall inelude the executors, administrators and assigns of each of them, and that the singular number in these presents if the context or the parties so require shall be eonstrued to mean the plural or the maseuline the feminine. 
15. And the lessor does hereby covenant with the lessee that upon payment of the rent and performance of the covenants herein contained on the part of the said lessee he shall and may peaceably and quietly enjoy the said lands during the said term without any molestation, hindrance or disturbance from or by the said lessor or anyone claiming under him.

16. And the lessor further promises and agrees to and with the lessee to pay to the said lessee the sum of $\$$ dollars per acre for every acre of the said land broken by the lessee as hereinbefore provided:

17. Provided always and it is hereby expressly agreed that, if the rent hereby reserved, or any part thereof shall be unpaid for fifteen days after any of the days on which the same ought to have been paid, although no formal demand shall have been made thereof, or in case of the breach or non-performance of any of the covenants or agreements herein contained on the part of the lessee, his executors, administrators or assigns, then and in either of such cases it shall be lawful for the lessor at any time thereafter into and upon the said demised premises or any part thereof in the name of the whole to re-enter and the same to have again, repossess and enjoy as of his or their former estate, anything hereinafter contained to the contrary notwithstanding.

1S. And I, the said do hereby accept this lease of the above described land to be held by me as tenant subject to the conditions, restrictions and covenants above set forth.

In witness whereof the parties hereto have hereunto set their hands and seals this signed by the above named as lessor and as lessee in the prescrice of

\section{Form 11-Lease over Three Years. Cash Payment.}

1. I, A.B., of , in the Province of , hereinafter called "the lessor," being registered as owner subject, however, to such mort gages and incumbrances as are notified by memorandum underwritten or indorsed hercon of that piece or parcel of land known and described as follows:

In consideration of the rents, covenants, conditions and agreements hereinafter reserved and contained on the part of the lessee to be paid, observed and performed have demised and leased and by these presents do demise and lease unto C.D., the lessee all the said lands, together with all erections and buildings, dwellings, barns, stables and other houses 
thereupon erected, standing and being or hereafter during the said term to be ereeted, standing or being; and together also with all ways, paths, passages, watercourses, privileges and advantages whatsoever to the said premises belonging or in any way appertaining to be held by the said lessee as tenant for the space of

$$
\text { years from the day of }
$$

A. D. 19 , and from thenceforth next ensuing fully to be completed, yielding and paying therefor, yearly and every year during the said term hereby granted, unto the lessor the elear yearly rent or sum of $\$$ dollars of lawful money of Canada on the day of the month of subject to the covenants and powers implied and the special covenants hereinafter mèntioned.

2. The said lessee covenants with the said lessor that he will during the said term pay unto the said lessor the rent hereby reserved in the manner herein mentioned without any deduction whatsoever.

3. Insert eovenant as to cultivation. Paragraph 2, Form 10.

4. And that he will properly bluestone the seed grain for the demised premises in each year of the said term.

5. See Paragraph 9. Form 10.

6. See Paragraph 10, Form 10.

7. See Paragraph 11, Form 10.

8. See Paragraph 12, Form 10.

9. The lessee further covenants and agrees with the lessor that he will during the year 19 , and each suceeeding year thereafter during the continuance of the term hereby granted in a husbandlike and proper manner and in its due and proper season break, backset and otherwise properly eultivate at least acres of the unbroken arable land on the demised premises until all the said arable land shall have been brought under cultivation or until the expiration of this lease.

10. And the lessor hereby agrees to pay to the said lessee the sum of $\$$ dollars per aere for every aere of the said land broken as aforesaid, the same to become due and payable on the days and dates hereinbefore fixed for the payment of the rent.

11. And the lessee covenants and agrees that he will summer fallow in a proper and husbandlike manner and in the proper season the eultivated portion of the said land so that in any case each part thereof will be summer fallowed once in three years.

12. See Paragraph 13, Form 10.

13. See Paragraph 14, Form 10.

14. See Paragraph 15, Form 10.

15. See Paragraph 16, Form 10.

16. See Paragraph 17, Form 10.

17. See Paragraph 18, Form 10. 


\section{Form 12-Lease of Farm. Cash or Share of Crop not over Three Years.}

Memorandum of Agreement made in duplicate this day of , A. D. 19 ,

Between $A$. B., of , in the Province of after called "thelessor," of the first part and C.D., of , in the Province of , hereinafter called "the lessee," of the second part.

Witnesceth: that in consideration of the rents, covenants and agreements hereinafter reserved and contained on the part of the said lessee. to be paid, kept, observed and performed, he the said lessor hath demised and leased and by these presents doth demise and lease unto the said lessee all that certain parcel or tract of land, situate, lying and being in the Province of and being composed of together with all ways, paths, passages. watercourses, privileges and advantages whatsoever to the said premises belonging or in any way appertaining, together, also, with all buildings now or hereafter to be erecterl on the said land during the continuance of the term hereby granted.

To have and to hold the said premises for and during the term of to be computed from the day of A. D. 19 , and from thenceforth ensuing fully to be completed and ended. Yielding and paying. (For cash lease proceed as in Form 11 and for lease share of crop as in Form 10.)

In witness where of the said parties have set their hands and seals the day and year first above written.

Signed, sealed and delivered

in the presence of

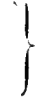

\section{Form 13-Lease of House.}

This Indenture, made the between $A$. B., of, , in the Province of after called "the lessor," of the first part, and C.D., of in the Province of , hereinafter called "the lessee," of the second part.

Witnesseth that in consideration of the rents, covenants and agreements hereinafter reserved and contained on the part of the said lessee, his executors, administrators and assigns, to be paid, observed and performed, he the said lessor hath demised and 
leased and by these presents doth demise and lease unto the said lessee, his executors, administrators and assigns, all that certain piece or parcel of land situate and being in the Province of in the Dominion of Canada and being composed of

together with all the rights, privileges and appurtenances whatsoever to the said premises belonging or appertaining.

To have and to hold the said demised premises with the appurtenances, unto the said lessee, his executors, administrators or assigns, for and during the term of to be computed from the day of , A D. 19, and from thenceforth next ensuing fully to be completed and ended, yielding and paying therefor and every during said term hereby granted unto the said lessor, his heirs, executors, administrators or assigns, the sum of dollars in lawful money of Canada to be payable on the following days and times, that is to say: on the day of in each during the said term, the first of such payments to become due and be made on the day of next.

And the said lessee covenants with the said lessor to pay rent as hereinbe ore provided, and that the said lessor may enter and view the state of repair of the said premises, and that the said lessee will not assign or sublet the term hereby demised without leave in writing and will not carry on any business that shall be deemed a nuisance on said premises, and that he will during the said term keep and at its expiration leave the premises in good repair (reasonable wear and tear and accidents by fire or tempest excepted).

And also that if the term hereby granted shall at any time be seized or taken in execution or in attachment by any ereditor of the said lessee, or if the said lessee shall make any assigmment for the benefit of creditors, the said term shall immediately become forfeited and void, and the full amount of the current rent shall be at once due and payable. And also that if the said premises are destroyed or so much injured as to become unfit for occupation by fire or other casualty not caused by wilful default or neglect of the said lessee, his executors, administrators or assigns, the said term hereby demised shall cease, and the current rent shall be duly apportioned and the due proportionate part thereof shall be at once due and payable:

Provided always that if the said rent hereby reserved or any part thereof be in default, or if a breach or default shall be made in any of the covenants hercin contained by the said lessee, his executors, administrators or assigns, then and in every such case it shall be lawful for the said lessor, his heirs, executors, 
administrators or assigns into and upon the said premises or any part thereof in the name of the whole to re-enter and the same to have again, repossess and enjoy as if these presents had never been executed.

And the lessor covenants with the said lessee, his heirs, executors, administrators or assigns paying the rent hereinbefore reserved and keeping all the covenants herein contained shall and may from time to time and at all times during the said term peaceably and auietly enjoy the said premises hereby demised without molestation or hindrance.

In witness whereof, etc.

\section{Form 14 - Lease of Apartments or Office Suite.}

This Indenture made in plicate this day of 19

Between A.B., of , in the Province of , hereinafter called "the lessor," of the first part, and C.D., of in the Province of , hereinafter called "the lessee," of the second part.

Whereas the said lesor is the registered orner of the lands and premises hereinater described and hath agreed to lease the same to the said lessee upon the terms and conditions hereinafter set out.

Now therefore this indenture witnesseth that in consideration of the rents. covenants and agreements hereinafter reserved and contained on the part of the lessee, his executors, administrators, (successors) and assigns, to be paid, observed and performed, the said lessor hath demised and leased and by these presents doth demise and lease unto the lessee for use and occupation as, and for no other purposes, all those certain premises known as in the building known as of situate upon lots , in the Province of , in the

To have and to hold the said demised premises for and during the term of years, and thereafter as a monthly tenant to be computed from the day of, and from thenceforth next ensuing and fully to be complete and ended.

riclding and paying therefor during the said term hereby granted unto the said lessor the sum of paid as follows, that is to say, the sum of per annum, to be in advance on the day of each and every month.

And the said lessee corenants with the said lessor that he will during the said term pay unto the said lesor the rent hereby reserved in the manner herein mentioned without any deduction whatsoever. 
And also will during the said term, well and sufficiently repair, maintain and keep the said demised premises in good and substantial repair and all fixtures and things thereto belonging, or which at any time during the said term shall be erected or made therein by the lessor when, where, and so often as need shall be, reasonable wear tear and damage by fire, lightning and tempest only excepted.

And also he will not during the said term transfer, assign or sublet the said premises hereby leased or any part thereof, or otherwise by any act or deed procure the said premises, or any part thereof, to be transferred, assigned or sublet, without the consent in writing of the lessor first had and obtained.

And also he will not at any time during the said term use, exereise, or carry on, in or upon the said premises or any part thereof, any noxious, noisome, or offensive arts, trade, business, occupation, or ealling, and no act, matter or thing whatsoever, shall at any time during the said term be done in or upon the said premises or any part thereof which shall or may be, or grow to annoyance, nuisanee, grievance, damage or any disturbance of the occupiers or owners of the said ing land and property

And also will at the expiration, or other sooner termination of the said term, peaceably surrender and yicld up to the lessor the said premises hereby leased with all fixtures erected or made by the lessor therein in good and substantial repair and condition, reasonable wear, tear and damage by fire, lightning and tempest only exeepted.

And it is hereby agreed, that it shall be lawful for the said lessor, or his agents, at all reasonable timos during the said term, to enter upon the said leased premices and view the state of repair thereof and he may serve upon the said lessee, or leave at his last or usual place of abode, or upon the said leased premises, a notice in writing of any defect requiring him within a reasonable time, to be therein mentioned, to repair the same in so far as the tenant is hound to to so. The said lessce will forthwith, upon receipt of such notice, well and suffieiently repair and make good accordingly, reasonable wear, tear and damage by fire, lightning and tempest exeepterl:

Provided always and it is hereby expressly agreed that if and whenever the rent herelyy reserved, or any part thereof, shall be unpaid for fifteen days after any of the days on which the same ought to have been paid, although no formal demand shall have been made therefore, or in ease of the breach or nonperformance of any of the covenants or agreements herein contained on the part of the lessee, or in ease the said premises or 
any part thereof become and remain vacant and unoccupied for a period of fifteen days or be used by any other person or persons for any other purpose than as above provided, without the written consent of the lessor, then and in either of such cases, it shall be lawful for the lessor at any time thereafter into and upon the said demised premises, or any part thereof, in the name of the whole, to re-enter and the same to have again, repossess and enjoy as of his former estate, anything herein contained to the contrary notwithstanding.

And the lessee further covenants that if the term hereby granted shall be at any time seized or taken in execution or in attachment by any of the creditors of the lessee, or if the lessee, shall make an assignment for the benefit of creditors, or becoming bankrupt or insolvent, shall take the benefit of any act that may be in force for bankrupt or insolvent debtors, the then current rent, together with the rent for three months thereafter, shall immediately become due and payable, and the said term shall at the option of the lessor immediately become forfeited and roid.

And the lessor covenants with the lessee, that he paying the rent hereby reserved and pcrforming the covenants hereinbefore on his part contained, shall and may peaceably possess and enjoy the said leased premises for the term hereby granted without any intcruption or disturbance from the lessor, or any other person lawfully claiming under him.

The lessor covenants with the lessee, that the lessor will during the term between the first day of October and the first day of May provide suitable means for heating and furnish heat for the said premises up to a reasonable temperature for the reasonable use thereof by the said lessee, except during the making of repairs; but should the lessor make default in so doing he shall not be liable for indirect or consequential damage or damages for personal discomfort or illness.

And the lessee for himself, his (agents, clerks) servants and all other persons seeking communication with him, shall be entitled in common with the other tenants to the free use of the stairway passage from the street to the said premises at all reasonable times.

And the lessee for himself, his (agents, clerks) servants, and other persons as aforesaid, shall be entitled in common with the other tenants of the building, to use the rater closets and lavatories in the said building, and the lessor will at all times keep the same clean and in good working order and supplied with water from the public mains, save at such times as the general supply of water may be turned off from the public mains; and in case the pipes affording the said supply be injured or 
become filled up, or otherwise incapable of affording the same, the lessor will forthwith commence repairing or cleaning and within a reasonable time have the necessary repairs effected or the said pipes cleaned out, so as to enable such supply to be continued:

Provided that if such injury or filling up shall happen by reason of the negligence of the lessee, his (agents, clerks or) servants, the lessee shall pay the expenses of the necessary repairs.

If the lessee shall require any additional water supply in the premises hereby demised, he shall pay for the same any additional cost charged the lessor by reason thereof; or in case of a meter being placed in the building, shall pay at a rate to be arranged.

The lessee covenants with the lessor that he will pay all electric light charges in connection with the premises hereby leased.

And the lessor agrees to place a directory in the door or passage by which entry is made from the public street to the premises, with room thereon for the name of the lessee and the number of his (offices or) apartments to be inserted thereon at the expense of the lessee, in plain letters, subject to the approval of the lessor; and the lessee shall have the right to use said board or tablet for the purpose aforesaid.

The rules and regulations in regard to the said building annexed hereto, shall during the said term in all things be observed and performed by the said lessee and his (agents, clerks or) servants

The said lessee shall give to the lessor prompt written notice of any aceident or other defect in the water pipes, heating apparatus, plumbing work, electrie light or other wires of the said premises.

The lessor shall not be liable for any damage to any property at any time in the said premises or building from steam, water works, rain, or snow which may leak into or issue or flow from any part of the said building, of which the premises leased are part, or from the pipes or plumbing works of the same or other place or quarter.

The lessee shall be liable for any damage done by reason of water being left running in the said premises.

And it is hereby further agreed by and between the said lessor and lessee that in the event of such partial or total destruction by fire or other casualty, of the said premises, or of the cntry, passage or stairway leading thereto as shall ronder such premises untenantable, or prevent reasonable convenient access thereto, the rent hereby reserved shall at once cease to 
acerue and become payable until the said premises, entry, pascage or stairway shall be rebuilt or restored to their former condition, but the lessee shall forthwith pay to the lessor the proportionate part of the then current rent accruing to the time of such part al or total destruction, and in the case of total destruction of the said premises, the lessee or the lessor may, within one month after such destruction, on giving notice thereof in writing to the other of them, terminate this lease.

And the said lessee doth hereby accept this lease of the above described premises to be held by him as tenant and subject to the conditions, restrictions and covenants above set forth.

Wherever herein the words "lessor" and "lessee" are used in and after the paragraph on the first page hereof beginning "And the said lessee corenants with the said lessor" the word "lessor" shall be construed and read as being "the lessor, his executors, administrators, (successors) and assigns," and the word "lessee" as being "the lessee, his executors, administrators (successors) and a-signs," and the singular shall be read as plural and the masculine as feminine or a body corporate whenever the context or the parties hereto so require.

In witness where of the parties hereto have hereunto set their hands and seals.

Signed, sealed, etc.

\section{RULE AND REGLLATIONS.*}

1. The sidewalk, entry passages, and stairway shall not be obstructed by any tenants, or used by them for any other purpove than for ingress and egress from and to their respective offices.

2. The floors, skylights and windows, which reflect or admit light into the passagerays, or into any place in the building, shall not be covered or obstructed by any of the tenants; and no awnings shall be put up orer any window without the sanction of the lessor. The water closets and other water apparatus shall not be used for any purpose other than those for which they were constructed and no swcepings, rubbish, rags, ashes or other substance shall be thrown therein; any damage resulting to them from misuse shall be borne by the tenant who or whose servants, clerks or agents shall cause it.

3. No sign, advertisement or notice shall be inseribed, painted or affixed on any part of the outside of the building,

* Such of these rules and regulations as may be suitable may be annexed to and made a part of the foregoing lease. 
unless of such color, size and style, and in such places upon or in said building as shall be first designated by the lessor and indorsed hereon, and the lessee on ceasing to be tenant of the demised premises will, before leaving the same, cause any sign as aforesaid to be removed or obliterated at his own expense and in a workmanlike mamner.

4. Directory boards and interior signs or glass doors will be painted for the tenants by the lessor, the costs of the painting to be charged to the tenant.

5. All awnings or shades over and outside of the windows desired by the tenants shall be erected at their own expense; they must be of such shape, material, eolor and make as may be preseribed by the lessor and shall be put up inder the direction of the lessor or his agents.

6. All tenants must observe strict care not to allow their windows to remain open so as to admit rain or snow. For any injury caused to the property of other tenants, or to the property of the lessor, by such earelessness, the tenant neglecting this rule will be held responsible.

7. No additional loeks shall be placed upon any door of the building without the written consent of the lessor, which shall be indorsed hereon.

8. No tenant shall clo, or permit anything to be done, in the said premises, or bring or keep anything therein which will in any way inerease the risk of fire or the rate of fire insurance on the building or on property kept therein, or obstruct or interfere with the riglits of other tenants, or in any way injure or annoy them, or conflict with the laws relating to fires, or with the regulations of the fire department, or with any insurance policy upon the building, or any part there of, or conflict with any of the rules and ordinances of the Board of Health, or with any statute or munieipal bylaw.

9. Nothing shall be placed on the outside of window sills or projections.

10. The water shall not be left rumning unless in actual use in the leased premises; spikes, hooks, screws or nails shall not be put into the walls or woorlwork of the building.

11. The lescor shall in all cases retain the power to prescribe the weight and proper position of safes, and all damages done to the building by taking in and putting out a safe, or by a salfe during the time it is on the premises, shall be made good and paid for by the tenant who has caused the safe to be taken in or put out.

12. In order that the leased premises may be kept in a good state of preservation and eleanliness, the lessor will employ a earetaker who shall attend to, sweep, dust and otherwise keep 
elean, in a reasonable manner, the hallways of the said building and the outside or general offices of the said leased premises and each tenant shall during the continuance of his lease permit the earetaker of the lessor to take charge of and clean the outside or general offices of the said leased premises, the inside or private office or offices in each case shall be kept clean by the tenant, and any sweepings therefrom placed in the outside or general office after six o'elock in the afternoon will be removed by the earetaker. No tenant shall employ any person other than the caretaker for the purpose of such cleaning or taking care of such premises. It is understood and agreed that the lessor shall be in no way responsible to any tenant for the loss of property from the leased premises however oceurring, or any damage done to the furniture or other effects of the tenant by the caretaker or any of his employees.

13. The lessor shall have the right to enter the premises at reasonable hours to examine the same and make such alterations and repairs as he shall deem necessary for the safety and preservation of the said building, and also to exhibit the said premises to be let and to put upon them the notice "To Let" which shall not be removed by any tenants during the three months previous to the expiration of the lease of the premises.

14. No rooms or room shall be occupied as sleeping or lodging apartments at any time without the written consent of the lessor or agent, and no cooking shall be done upon the leased premises without the consent of the lessor indorsed hereon.

15. The tenants, their elerks or servants and occupants of these demised premises shall not make or permit any improper noises in the building, or use any musical instrument or do anything that will annoy or disturb or interfere in any way with the other tenants, or those having business with them.

16. Nothing shall be thrown by the tenants, their clerks or servants, out of the windows or down passageways or skylights of the building.

17. No animals shall be allowed upon or kept in the leased premises.

18. If the tenants desire telegraphic or telephonic conneetions the lessor will direct the electricians as to where and how the wires are to be introduced, and without such directing no boring or eutting for wires will be permitted. If the tenants desire to use gas or electric light for lighting their premises, they must arrange with the lessor for the supply thereof, and no pipe or electric wire will be permitted which has not been ordered or authorized in writing by the lessor and if the lessor supply lighting the accounts therefor will be paid with the rent. 
19. The lessee shall not ereet any partition of any kind whatever, and shall not hang any curtain, blind or awning that will obstruet light from entering the halls and passages without the consent of the lessor first had in writing.

20. The lessor may lock the entrance door on street at eleven o'clock each evening and keep it locked until a reasonable hour the next morning, and the lessee shall be entitled to one key of the entrance door, and shall be responsible for the safekeeping of the same to the lessor.

21. The lessor shall have the right to make such other and further reasonable rules and regulations as in his judgment may from time to time be needful for the safety, care and cleanliness of the premises, and for the preservation of good order therein, and the same shall be kept and observed by the tenants, their clerks and servants.

\section{Lease, Special Covenants In.}

\section{Premises now in Good Repair.}

And the lessor covenants with the lessee that the said premises and appurtenances are now in good and substantial repair, and that the lessor will repair any damage arising from the lack of repair at this present time upon reasonable notice to him by the lessee.

\section{Lessee's Admission as to State of Repair.}

The lessee admits and agrees that the plumbing work and drains in and about the said premises are now in a sanitary and satisfactory condition, and that the premises are now clean and in a good state of repair.

\section{Alterations and Additions.}

And that the lessee will not during the said term make or suffer any alterations or additions to or ereet any new buildings upon the said premises without having first submitted a plan or specification thereof to the lessor and obtained his approval thereof in writing.

\section{Right to Enter and Exinbit Premises.}

And that the lessee will permit the lessor or his agents to make such repairs to and alterations in the said premises as he shall deem necessary, and to exhilit the said premises to any prospective tenant or purchaser, and will permit all persons having written authority therefor to view the said premises at all reasonable hours. 


\section{Lessor may Follow Goods of Tenant.}

And the lessee further agrees that if he leaves the said premises leaving any rent owing and unpaid the lessor may seize and sell the goods and chattels of the lessee at any place to which the lessee or any other person may have removed them, whether on or off the demised premises.

\section{Lessee may Purchase.}

And the lessor covenants that he will, upon request to him by the lessee at any time within from the date hereof, sell the said premises to the lessee for the sum of $\$$. dollars on the following terms: $\$$ dollars in cash at the time of the sale and the balance with interest on the unpaid portion of the said purchase price at the rate of per cent. per annum.

And that upon payment by the lessee of the full amount of the purchase price and interest as aforesaid he, the said lessor, will convey the said premises to the lessee, or his administrators, executors or assigns.

\section{Renewal of Lease.}

And the lessor covenants with the lessee that if the lessee duly and regularly pays the said rent and performs all and every the covenants, provisos and agreements herein contained on the part of the said lessee to be paid and performed, the lessor will upon the request and at the cost of the lessee months previous to the expiration of the term hereby granted, grant to the lessee a renewed lease of the said premises for a further term of years at the same rent and subject to the same covenants, provisos and agreements as are herein contained.

\section{Payment of Thaes, etc., By Lessor.}

The said lessee covenants with the said lessor that on failure of the said lessee to pay the amount that may be due from time to time by him for taxes, electric light, gas or water for the said premises for fifteen days after the same becoming due, the lessor may pay the amount or amounts thereof and charge the same as rent against the said lessee, and the same shall become due and payable by the lessee to the lessor forthwith, and the lessor shall have all the rights and powers of collecting the same together with the costs of such collection as between solicitor and client in the same manner and to the same extent as if the amount so paid was due and owing for rent of the said premises. 


\section{Form 15-Surrender of Lease.}

This Agreement, made this day of A. D. 19 between $A . B$., of (lessee) of the one part, and $X . Y$., of (lessor) of the other part.

Witnesseth that in consideration of the sum of $\$$ dollars now paid by the said $X$. $Y$. to the said $A$. B., the receipt whereof is hereby acknowledged, the said $A$. B. does hereby assign and surrender unto the said $X$. $Y$., his executors, administrators and assigns, the lands and premises described in a certain lease affecting in the Province of , and bearing date the day of A. D. 19 , and the unexpired residue of the term created by the said lease.

In witness whereof the parties hereto have hereunto affixed their hands and seals the day and year first above written.

Signed, etc. 
APPENDIX E

\title{
LEADING CASES
}

\section{Gibbs (Appellant) v. Messer and Others (Respondents).}

\author{
(JUNE 24, 1891.) \\ Victoria-Transfer of Land-Forged Deed- \\ Registration-Effect Of.
}

The Transfer of Land Act 1866, No. 301, established a register of titles and incumbrances, and provided that every person who purchases bona fide and for value from the registered proprietor and enters his deed of transfer or mortgage on the register shall thereby acquire an indefeasible right, notwithstanding the infirmity of his author's title; and seetion 144 provides, any person deprived of land by a fraudulent operation under the Aet, may in certain events recover damages from the registrar of titles. An agent of land forged a transfer of land to a fictitious purchaser, and obtained a certificate of title from the registrar, and, professing to act for such purchaser, obtained a loan from the respondents by means of a forged mortgage from such purehaser, a memorial of which was entered by the registrar;

Held, that the duty of ascertaining the identity of the principal for whom the agent acted rested on the mortgagees, and that damages were not reeoverable from the registrar under seetion 144 of the Act; that the eertificate of title and memorial of mortgage must be caneelled, and certificates of title substituted by the registrar in the name of the true owner.

This was an appeal from a judgment of the Supreme Court of the Colony of Victoria, affirming a judgment of Webb, J., which ordered that the appellant, as registrar of titles, should pay to the respondent Mary Stuart Messer, the plaintiff in the action, out of the assurance fund established by the Transfer of Land Statute, her costs of the action and all moneys from time to time paid by her for interest in respect of an alleged mortgage for $£ 3,000$, under which the respondents Thomas McIntyre and Gilbert Burn McIntyre claimed to be mortgagees, and also all moneys necessarily paid by her for principal, interest, and costs to redeem the mortgage.

The question to be determined on appeal was whether a registered proprietor of land under the Transfer of Land Statute (Act No. 301) can be said to have been deprived of land within the meaning of the 144th section of the statute, and ought consequently to be held entitled to compensation out of the 
assurance fund, where a forged transfer from the registered proprietor has purported to have been made to a non-existent person uncter a fictitious name, which name, in pursuance thereof, has been entered on the register as the name of the proprietor of the land, and a forged mortgage has subsequently been executed in the name of such fictitious person as mortgagor to a person who bona fide advances money on the security of the land.

The facts are stated in the judgment.

On the 18th of August, 1887, Webb, J., delivered judgment in favor of the respondent Mary stuart Messer, the plaintiff in the action, and the full court affirmed the judgment of Webb, J.

From this judgment the present appeal was brought.

Sir H. Davey, Q. C.. Finlay, Q. C., and Garner, for the appellant. The plaintiff in the action was not deprived of land within the meaning of the 14tth section of the statute. An action against the registrar of titles to recover compensation out of the assurance fund can be brought only when there was originally some person upon whose application the land was improperly brought under the operation of the Aet. There was no such person in the present ease. The alleged person upon whose application the erroneous registration was made was a fictitious person. The whole procedings upon which the names of the respondents Thomas MeIntyre and Cilbert Burn MeIntyre were entered on the register as proprietors were a nullity, and passed no title to such respondents. It would be contrary to public policy that persons should be relieved of the obligation of ascertaining whether a party with whom they are dealing as the agent of a principal has a prinripal.

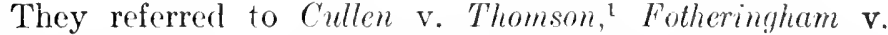
Archer, ${ }^{2}$ Hassett v. The Colonial Bemk, Oakden v. Gibbs, ${ }^{4}$ and Ogle v. Aedey. ${ }^{5}$

Rigby, Q. C., and Sargant, for the responelent Messer.

The Attorney General (Sir R. Webster, (Q. C.), and Rashleigh, for the respondents $M$ (antyre.

The mortgage was mate loy Cresswell under the assumel name of Cameron, as registered proprietor of the lanel within the meaning of the statute. The mortgagres hald a right to

15 V. L. R. Eq. 147

25 W. W. \& $\Lambda^{\prime}$ B. 95.

37 V.I. R. 301.

48 V. L. R. 380.

${ }^{5} 13$ V. I. R. 467. 
rely upon the certificates as evidence of title. The mortgagees were imnocent purchasers for value, without any notice, actual or constructive, at the time of making the mortgage of any claim by the plaintiff or fraud. A remedy is provided for the plaintiff out of the assurance fund by the 144th section of the statute.

They referred to In re The Hercules Insurance Company, Sharman's Case, ${ }^{6}$ and In re The Mercantile Credit Association, Richardson's Case. ${ }^{7}$

LoRD WATSON delivered their lordships' judgment: 8

This appeal depends upon the eonstruction of the Transfer of Land Statute, No. 301 of 1866, which established a register of titles and incumbrances for the Colony of Victoria, in order "to give certainty to the title to estates in land, and to facilitate the proof thereof, and also to render dealings with land more simple and less expensive."

The facts of the case, so far as they bear upon the question which we have to decide, may be shortly stated. The

*252 plaintiff* Mrs. Messer, who resides in Scotland, was entered in the register as proprietor in fee simple, free from incumbrances, of certain parcels of land in the district of Hamilton.

In the year 1884, she was joined by her husband, who left behind him in the colony, in the custody of Charles James Cresswell, a solicitor at Hamilton, her duplicate certificates of title, and also a power of attorney, by which she had authorized her husband to sell, mortgage, or otherwise dispose of the lands.

During their absence from the colony Cresswell forged a transfer of the lands by Mr. Messer, as his wife's attorney, to "Hugh Cameron, of North Hamilton, County of Dundas, grazier." It is admitted that there was no such person as the transforee in existence. Cresswell then, representing himself to be agent for Hugh (ameron, produced the transfer, dated the 11th of August, 1885, along with Mrs. Messer's certificate of title, to the registrar, who cancelled each folio in which her name was entered, registered Hugh Cameron as proprietor upon a now folio, and issued the ustal duplicate certificate in lis name.

Sill profesing to act as agent for Hugh Cameron, Cresswell next arranged with the defendants, the McIntyres, for a loan of $\$ 3,000$, to be secured by mortgage. He wrote with

641 L. J. R. (1. 580: L. R. 13 Hq. 586.

74 L. J. R. ('h. 252; L. R. 19 Eq. 558.

8 The Lord Chan"ellor (Lerd Halsbury), Lord Watson, Lord Hobhouse, Lord Hersmell, Lord Macmighten, Iord Morris and Lord Shand.

Note: Star-paging refers to (1s:1) 1. C. 248 
his own hand a deed of mortgage, bearing the date of 10 th of October, 1885, purporting to be executed by Cameron, he himself being the subscribing witness, whose attestation is required by the statute. Upon the faith of that document the Mintyres paid the money to Cresswell, who forthwith appropriated it to his own purposes. When they presented their mortgage for registration, the registrar declined to enter it until he was satisfied that the Hugh Cameron registered as proprietor was not identical with a person of the same name who had recently been made bankrupt. They accordingly obtained from Cresswell a statutory declaration, purporting to be sworn by his client Hugh Cameron before himself as a commissioner of the Supreme Court of the colony for taking affidavits, to the effect that the declarant had never been made insolvent, or taken the benefit of any Act relating to bankruptey or insolvency. Upon production of that evidence the registrar duly entered a memorial of the mortgage in the folio containing Hugh Cameron's certificate of title.

*Mr. Messer returned to the colony in July, 1886, *253 when these frauds were discovered, and Cresswell absconded, leaving no assets. The present suit was then brought by Mrs. Messer against (1) the registrar, (2) the McIntyres, as mortgagees of Hugh Cameron, and (3) Cresswell. It prays for an order for the callingin and cancellation of the certificates in the name of Hugh Cameron, and also for the issue to the plaintiff of new certificates of title, free from the incumbrance of the McIntyres' mortgage; and alternatively, in the event of the mortgage being held to constitute a valid incumbrance upon her title, for a declaration that the plaintiff shall be at liberty to redeem, and that the moneys necessary therefor be paid by the registrar out of the assurance fund created by the Act.

It is clear that the registration of the name of Hugh Cameron, a fictitious and non-existing transferee, cannot impede the right of the true owner, Mrs. Messer, who hat been therelyy defrauded, to have her name restored to the register. Accordingly, in the absence of Cresswell, who has not appeared to defend, the controversy between the litigant parties has been mainly, if not wholly, confined to the question whether the mortgage is or is not an incumbrance affecting Mrs. Messer's title. If the mortgage is valid, their lordships see no reason to doubt that Mrs. Mesier has been deprived of an interest in her land, in consequence of fratud, within the meaning of section 144, and that, failing recovery from Cresswell (against whom she has taken all the proceedings which the clause requires) 
she is entitled to receive the amount payable for its redemption out of the assurance fund. On the other hand, if the mortgage does not constitute an incumbrance upon her title, Mrs. Messer will obtain a full measure of relief, and can have no claim against the fund.

Mr. Justice Webb, the judge of first instance, sustained the validity of the mortgage, but ordered that the plaintiff should be at liberty to redoem, and that the defendant, the registrar, should pay to her, out of the assurance fund, her costs of the action, all moneys from time to time paid by her for interest in respect of the mortgage, and also all moneys necessarily paid by her for principal, interest, and costs in order to its redemption. His decision was affirmed on appeal by the *254 full court, with the *ariation that the plaintiff was found liable in costs to the mortgagees, to be added to her own costs of suit, and repaid to her by the registrar out of the assurance fund.

The registrar has appealed to this board from the judgment of the full court. In the course of the argument it was maintained on his behalf that the protection given by the statute to proprietors of a mere interest in land, such as is created by a statutory mortgage, which does not operate as a tran fer of the legal estate, is less extensive than the protection afforded to proprietors of the land itself. Their lordships do not find it necessary to determine that point, although, prima fucie. it does not appear to have been the intention of the Act to confer the same kind and degree of security upon all persons who, transacting in roliance on the register, acquire either moprietary rights or mere interests in land, in good faith and for valuable consideration. They assume, for the purposes of this cace, that the statute, in that respect, makes no disinction between these two classes of proprietors; and that the McIntyres mortgage is not liable to impeachment upon gromels which would have been unaviling against a transfer of the land obtained by them, in similar cireumstances, from the same author.

Their lordships do not propose to criticise in detail the varivis enactments of the statute relating to the validity of registered rights. The main object of the Act, and the legislative scheme for the attaimment of that object, appear to them to be equally plain. The ohject is to save persons dealing with registered proprietors from the trouble and expense of going behind the register, in order to investigate the history of their author's title and to satisfy themselves of its validity. That end is accomplished by providing that erery one who purchases, bona fide and for value, from a registered proprietor, and enters 
his deed of transfer or mortgage on the register, shall thereby acquire an indefeasible right, notwithstanding the infirmity of his author's title. In the present ease, if Hugh Cameron had been a real person whose name was fraudulently registered by Cresswell, his certifieates of title, so long as he remained undivested by the issue of new certificates to a bona fide transferee, would have been liable to eancellation at the* *255 instance of Mrs. Messer; but a mortgage exeeuted by Cameron himself, in the knowledge of Cresswell's fraud, would have constituted a valid incumbrance in faror of a bona fide mortgagee. The protection which the statute gives to persons transacting on the faith of the register is, by its terms, limited to those who actually cleal with and derive right from a proprictor whose name is upon the register. Those who deal, not with the registered proprietor, but with a forger who uses his name, do not transact on the faith of the register; and they eamnot by registration of a forged deed acquire a valid title in their own person, although the fact of their being registered will enable them to pass a valid right to third parties who purchase from them in good faith and for onerous consideration.

The diffienty which the mortgagees in this case have to encounter arises from the cireumstance that Hugh Cameron was, as Mr. Justice Wobb aptly deceribes him, a "myth." His was the only name on the register, and, having no existence, he could neither execute a transfer nor a mortgage. The mortgagees have endeavored to surmount that difficulty by arguing that, in the circumstanees of the case, Cresswell must be held to have been de jure, if not de facto, the proprietor whose name was on the register: and that their mortgage executed by him in the name of Hugh Cameron, is therefore as valid as if Cresswell's own name had been on the register, and he, and not Cameron, had been the apparent mortgagor. That argument found favor with both courts below.

The views entertained by the learned judges have been very elearly explained by Mr. Justice A'Beckett, who, in delivering the judgment of the full bench, said: "We, therefore, feel no doubt that the certificate of title on which the mortgagees advaneed their money, though brought into existence by the forgery of the defendant Cresswell, was as efticacious in their favor as if it had issued upon an honest and regular transaction. That certifieate described Hugh Cameron as the proprietor, and the mortgagees harl the right to rely uron the certificate as evidence of his title to an indef easible estate in the land mortgaged to them. It now appears that no such person as Mr. Hugh Cameron described in the certifieate in 
*256 fact existed; and the appellants* contend that a mortgage purporting to be by this fictitious person, and affecting land alleged to be his, is a mortgage of non-existent interesta mere abstraction which cannot derogate from the rights of the true ownel-and that the mortgage is therefore worthless. This contention appears to us to be answered by the view put forward in the statement of claim inferentially admitted by the registrar of titles, and sustained by the evidence, that Charles James Cresswell had, for the purpose of dealing with this land, assumed the name of Hugh Cameron. It was he who signed the transfer to Fugh Cameron as transferee, and who signed the mortgage to the defendants McIntyre as mortgagor, and he produced the eertificate of title of Hugh Cameron for the purpose of having the mortgage registered upon it. Upon these facts we think that, in favor of the mortgagees, he should be regarded as the proprietor of the land with whom they dealt on the faith of the certificate evidencing his title."

The opinion thus expressed appears to recognize the principle that a mortgagee advancing his money on the faith of the registor. eamnot get a good security for himself except by transacting with the person who, aceording to the register, is the proprictor having title to create the incumbrance. So far their lordships agree; but they do not coneur in the inferences which the learned judges have drawn from the facts in evidence with respect to the position of Cressuell throughout these transactions and his true relation to the name entered on the register as that of the proprietor. They are unable, upon the facts proved, to affirm that Cresswell "assumed" the name of Hugh C'ameron for the purpose of dealing with Mrs. Messer's land. A man cannot, with any propricty, be said to assume a name, or in other words an alias, unless he aets personally under that name, or asserts it to be his own designation. Nothing could be farther from Cresswell's purpose than his assumption of the name of Hugh Cameron; on the contrary, the mainspring of his fraudulent device consisted in representing Hugh Cameron to be a real porson, a grazier, who had no connection with himself beyond that of an ordinary client.

In pursuanee of that device he professed to transact with

*257 the MeIntyres in the capacity of *Cameron's law agent, he attested what purported to be Cameron's signature to their deed of mortgage, and he gave them a document, used by them in order to obtain regist ration of their right, which bore that Hugh Cameron had appeared personally before him, and had signed the document in his presence, after making oath to the verity of its contents. The McIntyres must, in these cireumstances, have understood Cresswell and Hugh Cameron to be 
distinct individualities. They nowhere alleged the contrary; and if they had even suspected that Hugh Cameron was only another name for Cresswell, they would not have been justified in completing the transaction without inquiry. The MeIntyres eannot, therefore, as matter of faet, be held to have dealt on the faith of the certifieate as evidencing the proprietary title of Cresswell.

The truth is that Hugh Cameron was in no sense an alias of Cresswell, but a fiction or puppet ereated by him in order that he might appear to be an individual having a separate and independent existence. The reasoning of the learned judges fails to appreciate the difference between these two things. If Cresswell had, as they sairl he did, "assumed" the name of Hugh Cameron, and had used it frautulently he would not have been a forger. His fraud, in that rave, woukl have lain in the representation that Hugh Cameron was his own designation, and he would, no doubt, have been amenable to the criminal law in respect of such fraud. But, in first registering a fictitious Hugh Cameron as proprictor of the lanel and then executing and delivering a mortgage in the name of Hugh Cameron, Cresswell represented the mortgagor to be a peron other than himself and committed the crime of forgery. The real character of the criminal acts perpetrated hy Cresswell differs in no respect from what it would have been had Hugh Cameron been a real person, whose name was put upon the register by him and used hy him in a forged dered creating an incumbrance.

Although a forged transfer or mortgage, which is roid at eommon law, will, when duly entered on the register, become the root of a valid title in a bona fide purchaser by foreing the statute, there is no enaetment which makes indefeasible the *registered right of the transferec or mortgagee under *258 a null deed. The Melntyres cannot bring themselves within the protection of the statute, because the mortgage which they put upon the registrer is a mullity. The result is unfortunate, bint it is due to their having dealt, not with the registered proprietor, but with an agent and forger, whose names was not on the register, in reliance upon his honesty. In the opinion of their lordships, the duty of ascertaining the identity of the principal for whom an agent professes to act with the person who stands on the register ats proprietor, atul of seeing that they get a genuine derel axerented by that principal, reste with the mortgagees themselves; and if they alerent at forgery they must bear the conseguences.

Their lordships will humbly atelvise her Mitjesty to reverse both judgments below, and, in linu thereof, (1) to declare that 
the mortgage purporting to be executed by Hugh Cameron to the defendants McIntyre is invalid, and does not constitute an incumbrance upon the title of the plaintiff, Mrs. Messer; (2) to direct the defendant Richard Gibbs to cancel the two certificates of title issued in the name of Hugh Cameron and entered in folio: 346,585 and 346,596 of the register book vol. 1733, and also the memorial of the said mortgage entered in these folios and to substitute therefor two certificates of title to the same lands respectively, in the name of the plaintiff; (3) to order the defendants MeIntyre to pay to the plaintiff her costs of suit in both courts below; (4) to order the defendant Charles James Cresswell to pay to the defendant Richard Gibbs his costs in those courts and here, and also pay to the defendants McIntrre all such costs either incurred by them or paid by them to the plaintiff as hereby provided. The defendants MeIntyre must pay to the plaintiff, Mrs. Messer, her costs of this appeal.

Solicitors-Freshfields and Williams, for appellant; St. Barbe, Sladen and II ing, for respondent Messer; Watson and Malleson, for the MeIntyres.

Assets Co. v. Mere Roihi and others; Assets Co. v. Wiremu Pere and another (Consolidated Appeal). Assets Co.v. Panapa Waihopi and others; Assets Co. v. Ii Pere and others (Consolidated Appeal). Assets Co. v. Teira Ranginui and others; Assets Co. v. Heni Tipuna and others (Consolidated Appeal).

(August 3, 4, 5; November 1, 2, 3, 4, 7, 9, 1904; and March 1, 1905.)

\section{New Zealand-Land Legislation-Registered Title.}

A registered title to land in New Zealand is, in the absence of fraud conelusive, and defects in procedure eannot affect such title. The fraud which nust be proved in order to invalidate the title of a registered purchaser for value, whether he buys from a prior registered owner or from a person claiming under a title certified under The Native Land Acts, must be brought home to the person whose registered title is impeached or to his agents. Fraud by persons from whom he claims does not affeet him unless knowledge of it is brought home to him or his agents.

These were three consolidated appeals from judgments of the Court of Appeal for New Zealand, reported in $21 \mathrm{~N}$. Z. L. R. 691 and 22 N. Z. L. R. 1, 37. 
The facts and numerous statutory provisions are stated in the judgment of the board.

Coram Lord Macnaghten, I.ord Davey, Lord Robertson, Lord Lindley, and Sir Arthur Wilson.

First named appeals from a decree of the Court of Appeal (October 29, 1902) in favor of the respondents, declaring the proceedings of the Native Land Court, the provisional register in the land transfer office, the Governor's warrant, and the certificate of title issued there $n$, to be void, and ordering the certificate of title issued thereon to be delivered up to the district land registrar at Gisborne to be cancellerl, and the register to be amended accordingly, with costs

Second appeals from a decree of the same court (November 8, 1902) declaring; that the appcllants were trustees of the lands in suit for the resjondents, who were entitled to mesne profits for such period since June 18, 1879, as was not barred by limitation.

Third appeals from a decree (October 29, 1902) declaring that the instruments by which the appellants claimed were void, and that the registration thereof upon the provisional register and the certificate of title issued to the appellants were also void, and that the certificate should be delivered up to the district land registrar at Cisborne to be eancelled, and that both registers should be amended aceordingly. Nesne profits were also directed to be recovered.

The respondents in all three appeals are aboriginal natives of New Zealand. The respondents to the first appeal claimed to be owners according to native custom of a block of land called Waingaromia No. 3, as found in their favor on Mareh 22, 1876 , by the Native Iand Court, which ordered that a memorial of ownership be issued. But at the time of such finding they alleged that no approved plan of the land within the meaning of sections 33,71 and 83 of The Native Land Court Act of 1873 , was *in existence, nor was any memo- *179 rial of ownership under section 47 actually issued therefor until 1889. The appellants, on the other hand, alleged that one Cooper purchased the block from the native owners by a memorandum of transfer of December 9, 1876, and on December 28, 1876, obtained an order in frechold tenure under the Act of 1873 , and on Fobruary 5, 1877, provisionally registered this order undor The Land Transfer Act of 18\%4. In April, 1889, they, as mortgagees from Cooper, obtained from the Native Land Court (the (hief Judge signing for John Rogan, a retired jurlge) a memorial of ownership in favor of the respondents anterlated March 22, 1876, caused to be

Note: Star-i)aging refers to (1905) A. C. 176 
indorsed thereon the certificate provided by sections 61 and 75 of The Native Land Act 1873 , and the order in freehold tenure all dated December 28, 1876 and in favor of Cooper, and caused the memorial with its indorsements to be provisionally registered. They then obtained from the Governor of the colony a certificate of title issued to Cooper, and from Cooper a transfer to themselves of the lands in suit, and from the district land registrar a certificate of title thereto Two suits were then brought, which, so far as material to this appeal, were for the same object-namcly, to have the certificate of title called in and cancelled, or to have the appellants declared trustces for the plaintiffs.

The respondents to the second appeal claimed to be owners according to native custom of a hlock of land called Waingaromia No. 2, declared to be such by a memorial of ownerShip dated March 22, 1880, issued by the Native Land Court, and that they had neither sold to the appellants nor done any act whereby they ceased to be owners, nor had the memorial been cancelled or destroyed in accordance with law. The Native Land Court had, however, on February 19, 1877, issued a similar memorial. although at that time no approved plan sufficient to give the court jurisdiction was in existence. The said Cooper had on the previous January 9, obtained a memorandum of transfer, and on June 28, 1877, an order in freehold tenure of the lands in suit, and caused it to be provisionally $r$ gistered. These proceedings the respondents alleged had been annulled by order of the Governor in January, *180 1879, $i$. e., prior to *Iarch 22. 1880; but the liquidators of the Glasgow Bank, as assignees of Cooper, caused the certificates and order in freehold tenure required by sections (61 and 75 of The Native Land Act 1873, to be indorsed on the momorial of March, 1850 and obtained a certificate of title from the district land registrar dated August 28, 1882 . On August 15, 1883, they aloo registered The Glasgow Bank Act 188 , which vested the land in them.

The respondents to the third appeal claimed that they and o hers had been found to be owners of the block Rangatira by a memorial of ownership dated May 21, 1875, issued by the Fative Land Court and that after partition an order had been made on May 12, 1886, under The Native Land Division Act 1882, declaring them to be owners of Rangatira No. 2 (the lands in : uit), which order also directed that a Crown grant should issue to them. The $m$ morial was then cancelled, but the order of 1886 is still subsisting, and is provisionally registered. Immediately after this registration the appellants obtained the registration of certain deeds of sale 
uncer which they derived title alleged to have be $n$ made by the !espondents, and on October 23, 1895, obtainerl a certificate of title rom the district land registrar. The history of the transaction between the dates of May 21, 1875, and May 12, 1886 , as given in the appellants' case, paragraphs 8 to 12 , found by their lordships to be correct, is as follows: The block was leased after the earlier date to cer ain sheep farmers, who in 178 assigned their lease to the firm Kinross and Graham. In that year and subsequently the respondents and others signed memoranda of transfer of their interests to the firm. These, after inquiry duly made, were indorsed by a trust commissioner as approved under The Native Lands Frauds Prevention Act 1881. Thereafter the firm remained in possession without payment of rent. In 1883 the lease and the rights under the memoranda of transfer vested in the Cilasgow Bank by t:ansfer from the firm to the liquidators and in the appellants by virtue of The Gla gow Bank Act of 1SS2. In 1886, after due inquiry by the Land Court, the order of that date was made. The Crown grant was drawn up but lay in the Native Land Court owing to *non-payment *181 of fees. These were paid in 1895. In July of that year a duplicate was constituted a folium of the provisional register of the district land registrar at Gisborne. At the same time the memoranda of transfer to Kinross and Graham, the transfer from them to the appellants direct, were registered hereon. $\mathrm{Th}$. Governor then isued his warrant for a certificate of title to the sellers, and the registrar issued his certificate of title to the appellants.

In all thrce cases the Count of Appea' deci ed for the respondents

Haldane, K. C., H. D. Bell, Northcote, and Smith Clark, for the appellants, contended in the first appeal that they were entitled to judgment against both sets of respondents. The evidence showed that they were bona fide purehasers for valuable consideration of the lands in suit. They bought from the registered proprietors thereof. They heeame themsolvos after their purchase in their turn registered proprietors thereof in good faith without notice of any adverse claim to the vendors' title by the respondents or any other person, and without any notice of any mistake, irregularity or fraud on the part of any person in relation to the said land. The certificate of title issued to them on registration is under such circumstances conclusive evidence of their ijth', and bars the respondents' suit. See Land Transfer Act 18\%O, section 19, subsection 5; sections 20, 35, 40, 46, 129; Land Transfer Act 1885, secetions 
55, 56, 66, 189 and 190 . The appellants do not come within the exceptions specified in section 56, and under sections 189 and 190 their title cannot be attacked on the ground of any infirmity affecting the title of their transferor. The scheme of these Acts is to render the certificate of title conclusive rvidence thereof. Sce, also, The Native Land Act 1873, sertions 75 and 76 . The certificate to the appellants was issued under the authority of a warrant from the Governor, which has, by virtue of section 12 of The Land Transfer Act 188.;, the orce and effect of a Crown grant, which cannot be impeached except by proceedings in the nature of a scire facias.

As registered proprietors, whether on the provisional

*182 or completed register, the appellants have a *title which is unchallengeable except for direct fraud committed by themselves; as bona fide purchasers from registered proprictors their title is abolute. Under section 43 of The Land Transfer Act 1885, all dealings recorded on the pro is onal register have when transferred to the final register the same effect as if they had been originally recorded on the final register.

With regard to the contention that registration in this case was invalid because of the invalidity of the orders made by the Native Land Court, which authorized the issue of the Clown grant, they contended that all the procedure prescribed by The Native Land Acts in the matter of purchase of lands from natives had been substantially followed, and that the Native Land Court had investigated all matters relating to the ascertainment and transfer of the native title, and had decided them farorably to the appellants. The order of freehold tenure on which the Governor acted in granting his warrant and the district registrar acted in giving his certificate of title was unimpeachable, and at any rate could not be examined into or disregarded by the registrar. As an order of the Native Land Court it is the record of a court of exclusive jurisdiction, conclusive in another court in a collateral proceeding, and not to be cluestioned by officials in the registry office acting under the Transfer Acts. Nor can it now be set aside and the registration cancelled as if it were a nullity. The objections to the procedure are not substantial, and lapse of time has cured them. The appellants and their predecessors have since 1876 been in continuous possession of the lands in suit throughout the whole of the proceedings alleged to be irregular. They have expended large sums of money on improvements, and greatly increased its value as productive pastoral estate, with the knowledge of, but without objection by, the respondents. It was not till 1897 that a caveat was entered and hostilities commenced. In 1900 actions were brought by natives named 
in the memoranda of ownership of March, 1876, against the appellants, and in previous years by certain other natives in respect of neighloring blocks of land. They were regarded as representative actions and friled. *See, *183 as regards two of these actions which have been reported, Matai v. Assets Co; Hami Tikitili v. Assets Co. ${ }^{2}$ Reference was made as to the effect of registration under the Land Transfer Acts and as to the validity of tran-fers under the Native Land Acts to Paraone v. Mattheus;" Gibhs v. Messer ;' Creditors' Trustee of Arelatera v. Wallier; $;^{5}$ Attorney General v. Tipae. ${ }^{6}$ The Land Transfer Acts are expressed in very nearly the same terms in all the Australian colonies as in New Zealand. In South Australia (see Bonnin r. Andrew's ${ }^{7}$ it has been held that sections 55, 56, and 65 of the Land Aet of 188.5 , proteet the appellants' title even if they were the first holders of a certificate of title, instead of holding the still stronger position of bona fide registered transferees from registered holders. Further, if the respondents have sustained any loss or damage by the registration of the appellants, their remedy was in an action against the registrar general. See Land Transfer Act 18\%0, section 133, and the Aet of 1885, section 178. They are barred from the present action by 3 and 4 Will. 4, c. 27 , and, having lain by so long whilst the appellants, believing the property to be their own, expended money thereon, eannot now be allowed to assert any title.

It was also contended in all the appeals that any failures which there might have been to observe all details of procedure in the Land Court under the Native Land Acts were so trivial as not to invalidate the appellants' title, and were errop: 10 which the appellants were not parties and of which they had no notice.

Further, it was contended with regard to these irregularities in the Native Land Court proeedure that they were not proved. As regards the first appeals, it was contended that the map "approved as a sketch plan" produced to the court in 1876 , was an approved map in terms of The Vative Land Act 1873 , sections 33 and 71 . The order for a memorial of ownesship was a competent order. The absence of a memorial of ownership *following upon the order was *18t not proved, and its existence ought to be presumed.

1 (1887) 6 N. Z. L. R. 35!!.

$2(188.3)$ 18 N. \%. L. R. 226.

3 (1858) 6 N. Z. L. R. 74t; and on appeal (1889) 7 N. Z. L. R. 528.

4 (1891) A. C. 248.

5 (1881) 3 N. Z. L. R. (C.A.) 91

6 :1887) 6 N.T.L.R. 157.

7 (18.5) 12 S. A. L. R. 153 . 
Its absence, however, would not nullify the subsequent order of freehold tenure of December 28, 1876 , in favor of Cooper. That was a valid order, the registration of which on the provisional register entitled subsequent purchasers from Cooper to the benefit of all the provisions of the Act of 1885 . See sections 56, 189 and 190. It was contended also that the signature of Macdonald, C. J., on behalf of Rogan, J., retired, was effectual under section 67 of The Native Land Court Act 1886 .

As regards the second appeals the same general contentions applied, and in particular it was urged that the order of freehold tenure in favor of Cooper of June 28, 1877, was a valid order, and that the registration thereof upon the provisional register, followed by the registration on the permanent register of the liquidators of the Glasgow Bank, entitled subsequent purchasers to the benefit of The Land Transfer Act of 1885 .

As regards the third appeals, they contended that the indor'ing as approved of the memoranda of transfer by the trust commissioner was equiralent to a confirmation by the court in terms of The Native Land Court Act 1894, $\$ 57$; that these memoranda at the time of execution related to land which was customary land within the meaning of that expression as interpreted by The Vative Land Court Act of 1894, and that the transfers thereof having been duly confirmed within the meaning of section 73 of that Act were properly accepted by the registrar as being interests in eustomary land which were claimed prior to the coming into operation of that Act. Aceordingly his issue of a certificate in October, 1895, to the apellants was in conformity with section 14 of The Land Transfer Act 1885, and section 73 of The Native Land Court Act 1894. By force of this latter section each native owner became the individual owner of his share under the Land Transfer Act subject to all equities affecting his estate or interest. Then the transfer by each native to the appellants having been indorsed under section 57 must be deemed to have been confirmed by the Native Land Court, to have been validated as an effective alienation, and to have authorized registration.

IV. N. Recs, E. Bray, and II. Wimpfheimer, for the

*185*respondents, contended that they were owners of all the lands subject to the three sets of appeals. In reference to the first block, they are owmers according to native custom and have never alienated it. They were owners in 1876 when the Native Land Court purported to adjudicate to that effect. But at the time of that adjudication and of the antecedent hearing it was found by the appellate court that there was no approved plan of the land in existence within the meaning of sections 33, 71 and 83, of The Native Land Court Act 1873. Nor was 
any memorial of ownership under seetion 47 of The Native Land Act 1873, and executed with the roquired formalities, issued until 1889. There was no power under this latter Act to issue an interlocutory order for a memorial of ownership. That memorial always lies at the root of native transferable title. Until this ease it has never been asserted that, prior to the issue of a memorial, native title is capable of transfer. Aceordingly the memorandum of transfer and order in frechold tenure in favor of Cooper in 1876, under which the appellants claim, were, if proved to have been made, absolutely void as against the respondents, and inoperative to convey any rights to Cooper. There was no power to take those steps, which were no doubt the preseribed proeesses of transfer, until after a memorial of ownership had been property issued, for until that was done the natives had no title transferable to Europeans. The Native Land Court never made the inquiries required by sections 59,60, 61, 75 and 83 of The Native Land Act 1873, concerning any transfer from the respondents or their eo-owners. Nor did it ever make any order in freehold tenure of the land under the authority of that Act, or which could possess any force or validity thereunder. At the time when the memorandum and transfer were alleged to have been made, there were many infant native owners for whom no trustees had been appointed under the Maori Real Estate Management Act 186\%, and under sections 54 and 55 of The Native Land Aet 18\%3, and among these infants were many of the respondents. Thus, even if the lands had become transferable by virtue of a valid memorial, they had not been effectively transferred. Accordingly it followed that the provisional * registration in February, 1877, of *186 the said order of freehold tenure under The Land Transfor Act 1874 , was also void and conferred no rights upon Cooper. So also his transfer to the appollants. The memorial of ownership first obtained in 1889 and antedated, and the indorsements thereon of certificates and order in frechold tenure and provisionally registering the same were all void against the respondents, who knew nothing of tho transaction, and frandulent within the meaning of The Land Transfer Act 18\%0, and its amendments, and of the later Act of 1885 . All these proceedinge were not to be classed as moro irregularitios capablo of being cured, as the appellants contend, by lapse of time. They are of a mature to destroy the jurisdiction of the Native Land (ourt, whosenthority and proceedings must be strictly regulited by the Acts which establish it. Accordingly the appellants were not at regards this pareel of land in the position of registered bona fide purchasers for value from a registrered proprictor. 
In reference to the second block, there was, besides the objections already stated, the additional objection that, as the result of an order of the Governor in January, 1879, all proceedings before taken in the Native Land Court were annulled, the provisional register was vacated, and all entries thereon cancelled. See section 59 of The Native Land Act 1873, and section 12 of the Land Act of 1874. The respondents rely on the memorial of ownership thereafter issued to them in March, 1880, which has never been cancelled or destroyed in accordance with law. It was pending this order and the proceedings which led up to it that Cooper assigned to the liquidators of the bank by memorandum of transfer dated June 18, 1879. After the order the only steps taken were that the appellants and their vendors procured, without the knowledge of the respondents, indorsements thereon, under sections 51 and 75 of The Native Land Act $18 \% 3$, of the certificates required thereby, and also of an order of freehold tenure in favor of Cooper, under which and without any Governor's warrant their vendors, the liquidators of the Glasgow Bank, obtained a certificate of title, subsequently transferred to the appellants by force of The Glasgow Bank Act 1882 These certificates and order were indorsed, not merely *187 without* the respondents' knowledge, but without any examination by the Native Land Court under sections $59,60,61$ and 75 of the natives interested.

In reference to the third block, the respondents' atle was und $r$ an order dated May 12, 1886 of the Native Land Court made unde" The Native Land Dirision Act 1882, declaring them to be owners thereof, and cancelling a previou= memorial of ownership in their favor issuerl under The Native Land Act $18 \% 3$, and dated May 11,1875 . relating (inier alia) to the same block. The appellants were holders of a lease dated March 1 , 1875 , from the respondents and others, owners of a block of land which included tho:e in suit. Registration proceedings were taken, and on October 23, 1895, the appellants ohtained their certificate of title without the krowledge or consent of the respondents. They wrongfully ol, tained it, and accordingly wre rightly held by the appellate court to be trustees there of for the respondents; for the beneficial title was in them subject only to the appellants' lease. The resondents have never parted with their title under the order of 1856 . The deeds of sale under which the appellants claim were not valid alienations, and did not authorize registration.

The same general observations apply to all three easesthat the appellants were not bona fide remistered owners, and their title was vitiated by fraud, in obtaining orders of freehold tenure in violation of established legal procedure; in obtaining 
the property of the respondents by roid and ineffectual deeds; in Cooper obtaining and retaining title to land obtained by a void order. The orders were void as not complying with the statute; the persons conveying had no title to convey; the deeds were void and ineomplete; and the absence of memorials of ownership showed that there was under the Native Land Acts no title in the respondents which they were capable of transferring to Europeans. The evidence pointed to collusion between Cooper and the offieials of the Native Land Courts. Reference was made to Nireaha Tamaki v. Baker ${ }^{8}$ Paraone v. Matthews, ${ }^{9}$ approved in Solicitor General v. Mere *Tini; $;^{10}$ Public Trustee v. Registrar General of ${ }^{*} 188$ Land; ${ }^{11}$ Ex parte Davy; $;^{12}$ Rutu Pcehi v. Davy $;{ }^{13}$ Attorney General v. Tipae ; ${ }^{14}$ In re Olirae Block; ${ }^{15}$ Hami Tikitiki v. Assets Co., ${ }^{16}$ Moore v. Public Trustee. ${ }^{17}$ The lands in suit had never been brought under the Land Transfer Acts from time to time in force, and consequently the appellants cannot elaim title under those Acts. The order of freehold tenure, if duly made by the Land Court in the due exercise of its jurisdiction, would have brought them under the Transfer Acts, but, as already shown, the memoranda of transfer and the memorials of ownership did not romply with the provisions of The Native Land Act of 1879, and in consequence the whole of the proceedings before the Native Land Court relating to the land the subject of those informal proceedings were coram non judice and void. Further reference on this point was made to Kawatini v. Kinross $;^{18}$ Buchanan v. Ngatuere $;^{19}$ Poaka v. Ward $:^{20}$ In re Okirae Block. ${ }^{15}$

Bell replied.

LORD LINDLEY delivered the judgment of their lordships:

The substantial question raised in each of these three appeals is whether the Assets Company, Limited, has acquired a good title, as against the plaintiffs, who are natives, to certain

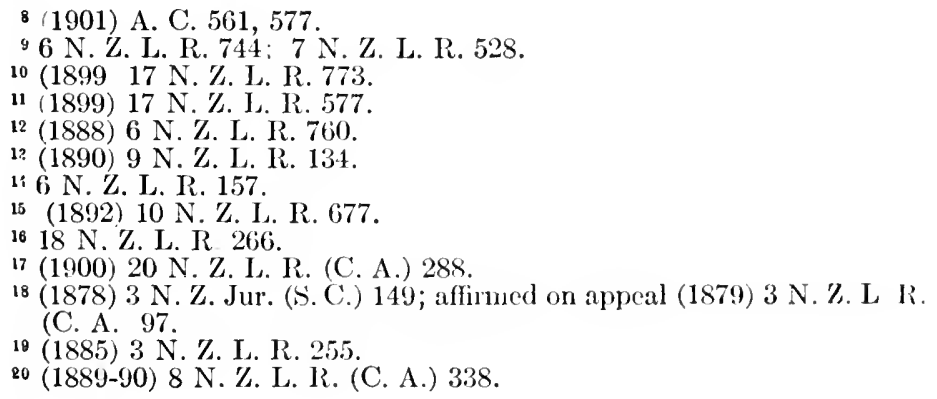


lands in New Zealand. The natives have long been out of possesion. The Astets Company is and has been for many vears not only in possession but also registered in the land registers of the colony as owner of the lands in dispute. The appeals arise out of actions brought in the Supreme Court by a few natives to recover portions of land which formerly belonged to them and many others. In form the actions are not for recovery of possession, but for the rectification * 18 ) of the register and for mesne profits. But whether *the substance or the form of the actions is regarded, it is obvious that it is for the plaintiffs to establish their claim, and not for the Assets Company to prove their title as if they were themselyes plaintifis out of possession.

The lands in question in the first appeal are known as Waingaromia No. 3; those in question in the second appeal as Waingaromia No. 2; and those in question in the third appeal as Rangatira No. 2.

The title of the Assets company is derived historically through one Cooper, who many years ago bought the lands in quastion from the natives. The sales to him were carreid out in the Native Land court. Orders and other documents necesary to enable the Ascets company to be registered as owner under The Land Transfer Acts were obtained, and the Assets Company was registered accordingly as its titles were completed. The company's title as registered owner is impeached by the plaintiffs in all three cases on two groundsnamely, firist, that the registration of the company as owner was procured by fraud; and secondly, that such registration was invalid by reaton of tor invalidity of the orders of the Native Land Court on whicis warrants of the Covernor, having the the effect of ('rown grants, were issued, on which warrants the registration was fonded.

Before dealing with the facts relied upon for the purpose of establishing these rontentions, it will be convenient to examine the statutes relating to the land registry, and to ascertain the legal effect of registration, for if this effect is what the As-ets (ompany contends there is an end of the natives' claim. The Asorts Company contends that, in the absence of fraud by the company or its agents, registration is conclusive, and confers a good title on the company; and that defects in the proceedings in the Native Land Court, even if proved, camot affect the title of the company, although such defects may possibly cntitle the natives to compensation for any injury caused to them ly improper registration. The question thus raised is one of the greatest importance in the colony, and, unfortu- 
nately, there is a difference of opinion upon it amongst the members of the Supreme Court.

*The system of land registry in New Zealand was *190 introduced in 1860; and from 1870 to 1885 it was governed by The Land Transfer Act of 1870 and Acts amending it passed in 1871,1874, 1880 and 1885 , when it was repealed, but re-enacted with amendments and additions.

The Land Transfer Act of 1870 was, shortly, to the following effect. Sections 7 and 19. In every district there was a district land registrar (section 7 ), whose duty it was to examine into the title of every person applying for registration, and if satisfied with the title he was to issue a certificate of title and to register it. Sections 19, 23 and 37 . His certificate, duly authenticated under his hand and seal, was made evidence in all courts of law and equity (seetions 39 and 139) of the particulars therein set forth, and of their being entered in the register book; and except in cases after provided the certificate was conclusive evidence that the person named in it was entitled to the land mentioned in it for the estate or interest therein mentioned, and no certificate could be impeached on the ground of want of notice or of insufficient notice of the application to bring the land under the provisions of the Act, or on account of any error, omission. or informality in such application or in the proceedings pursuant thereto by the district land registrar. Sections 23, 37, 39 and 139.

In connection with this enactment it is material to notice that on registration the applicants' documents of title had to be given up to the registrar to be cancelled and kept in the office. Sections 22 and 23.

The excepted cases mentioned in the clause referred to above were fraud, prior certificates or registered grants, omitted or misdescribed easements and errors in descriptions of pareels or boundaries. Sections 46 and 129. There was, morcover, another exception in favor of persons adversely in possession when the land was brought under the provisions of the Act, and continuing up to the time of granting the certificate. Section 139.

As regards fraud, it was provided (section 119) that, except in cases of fraud, no person dealing with a registered propriet or need inquire into the circumstances in, or the consideration for, which he or any previous registered proprictor beeame registered, nor see to the application of purchise-money, nor be affected *with notice, direct or constructive, of any trust *191 or unregistered interest; and knowledge of any such trust or interest was not of itself to be imputed as frand. 
It was further provided (seetion 129) that no aetion for possession or other action for the reeovery of any land should lie against the registered propriet or for the estate or interest in respect of which he was registered, exeept in eertain specified eases; and except in these cases the produetion of a registered grant or certificate was an absolute bar to any such action against the registered proprietor, any rule of law or equity to the contrary notwithstanding. The only exeepted ease which need be mentioned was thus expresed: "the case of a person deprived of any land by fraud as against the person registered as proprietor of : rch land through fraud, or as against a person deriving otherise than as a transferee bona fide for value from or through a person so registered through fraud." Section 129 .

The other excepted eascs above referred to do not require further attention.

There was power (scetion 19 , subsection 4 ) to rectify the register, and to state eases (section 116) for the opinion of the supreme court. Land Transfer Aet $1870, \S 19$, cl. $4, \S 116$. The provisions relating to these matters were re-east in the Act of 1885 and may be passed over.

Light is thrown on the general scheme of the Act by the provisions relating to the land assurance fund. Seetions $3 \tilde{5}$ and 130. A schedule of charges to be paid by persons applying for registration is given at the end of the Act, and these eharges form the fund. Any person deprived of any land in eonsequence of any fraud, or through the bringing of sueh land under the provisions of the Aet, or by the registration of any other person as propriet or, or in eonsequence of any error, omission, or misdeseription in any certificate of title, or in any entry or memorial in the register book, might bring an action for damages against the person upon whose applieation sueh land was brought under the provisions of the Act or such erroneous registration was made, or who aequired title through fraud, error, omission, or misdescription. This was qualified in eertain eases of a transfer to a bona fide purchaser for value by making the assurance fund bear the damages sustained. This provision,

*192 taken in *eonnection with those already referred to, went far to show that, exeept in the excepted eases, the registered eertificate was to be enelusive, and that the remedy of persons wrongfully deprived of their property was to obtain damages from the wrong-doer.

So the matter stood under the Aet of 1870 .

The Land Transfer Act of $18 \% 1$ (sections 8 and 12) introdueed a provisional register for dealings with Crown lands before grants for them were obtained and before certifieates of title under the Act of 1870 eould be issued. The temporary receipts 
and memorials issued under this Act were made evidence, but it was enacted at the end of section 9 that the estate or interest of a registered proprietor of land on the provisional register should be indefeasible only against the person named in the original receipt and all percons claiming through, under, or in trust for him. This shows pretty plainly what the effect of being on the permanent register was understood to be.

The Land Transfer Act $18 \%$ q provided for the registration of instruments affecting land granted under the Native Land Acts, but for which no Crown grant had been issued. The machinery of the provisional registry was made applicable to these cases; but otherwise the Act is not important.

The Land Transfor Act of $1 S S O$ (sections 7 and 9), merely extended the Act of 1870 to some cases to which that Act did not originally apply.

The Land Transfer Act of 1885 consolidated and amended the previous Acts; and although it was not in force when the property in dispute was being dealt with in the Native Land Court, it was in operation when the Assets Company was registered as owner. The system of registration already deseribed was continued, but some important provisions were added, and many of the clauses of the previous Acts were revised and altered. The following are those sections which are important on the present occasion.

Section 10 describes the land subject to the provisions of the Act. It includes: "All land which has already in any manner become subject* to the prorisions of "The Land *193 Transfer Act 1870,' or any Act amending the same, or of 'The Land Registry Act 1860.'"

"All land hereafter alienated, or contracted to be alienated from the Crown in fee."

"All land in respect of which any order shall hereafter be made under the provisions of any Native Land Act in force for the time being which shall have the effect of vesting such land in any person in frechold tenure."

All the lands in dispute in these appeals appear to their lordships clearly to come within this section 10 . The certificatcs of title issued under the Act of 1870 , scetions 33, and the issue of the Ciovernor's warrants make this point plain.

Section 12 of The Land Transer Act 1885, makes a certificate of title issued on the Governor's warrant equivalent to a Crown grant, and section 13 makes the warrant conchusive evidence to the registrar of the matters required to be stated therein.

The mode of applying for certificates of title is much the same as before; and the old title deeds are to be delivered up 
and cancelled as leefore. The sections relating to this subject aud the forms in schedule 2 , strongly confirm the view that the lanks in dispute come withinsection 10. Section 17 et seq. and schedule 2.

The old provisions respecting the register and the duty to keep it are reprodiced, and a certificate of registration is conchusive evidence of registration. No instrument not registered is effectual to pass any estate or interest in land under the provisions of the Act, but upon the registration of any instrument in mammer described the estate or interest specified in such in trument shall pass according to its terms. Sections 31 . 35 and 36.

The old enactments relating to provisional registration are concolidated, and provision is made for transferring to the regiter the momorials and entries on the provisional register as roon as they are tinally completel. Fections 42,43 and 44.

section 45 enacts that, subject to any special provisions in the Act, all its provisions shall, so far as circumstances will admit, apply to land on the provisional register and to the registration of instruments and other matters affecting the same. This lets in a number of important sections * 194 making the register* conclusive (for example, sections $55,67,189$ and 190), lut it is provided that the estate or interest of a proprietor on the provisional register shall be indefeasible only against the peron named in the original receipt or order and those claiming through, unrler, or in trust for lim. This reproduces the last part of section 9 of the Act of 1871 before referred to. As in the Act of 1870 , so in The Land Transfer Act 1885, section 55, the register is made enclusive evidenes of the title of the registered proprietor, except in atses of frand, prior certificates of title or registreel grants, omiscions or misclescriptions of easements, and wong dexcription of pareds or boundaries, to which must be added adverse claimants in posession at the time of bringing the land under the Act and continuing in such posession at the time of isuing the certificate. Section 67 .

Cartificates of title duy sisned and saled are made conchuse (ridence of title as in the Act of 1870 , sections 39 and 139-eections 65 and 66 of the Act of 1885.

The protertion thus afforded is strengthened, as in the Act of 1870 , by the preservation in section 56 of the enactment against hinging actions against registered proprictors-that is, section 129 of 1870 , alreacly noticed.

Further protection is afforded by the reproduction of rection 119 of the Act of 1560 relating to notice and knowledge of unregistered interests, and there is a new clause specially 
protecting bona fide purchaser or mortgagees from registered proprietors. Rections 189 and 190.

The provisions relating to the correction of certificates of title and of the register have becn re-east, and the powers of the registrar in this respect have hren enlarged. Subject to regulations nuter the Act, he is empowered to correct errors and supply omissions, and to recpure errtificates of title or other instruments to hadelivered up to be ancelled or corrected if issued in error, or if they eontain any misdeseription of land or boundaries, or if fraudulently or wrongfully obtained. Sections 68 and 69. He an apply to the Supreme Court to compel people to appear before him and to delisor up documents as required. Sections 70 and 71 . Appeals lie from his decisions to the supreme Court. Section 191, etc. Large, however, as these powers are, it has* heen clecided that *195) they cannot be excrised to the prejurlice of a registered

bona fide purchascr. Hacarthy and Collins, In re (1901).21 Their lordships bave not to consider his power, but they doubt whether the registrar can set aside a Crown grant or its statutory equivalent; they are disposed to think that his power to rectify is limited to some fraud or other cause intervening after the Crown grant or equivalont instrument which originally brought the liand on the register.

There does not, moreover, appear to be any power conferred on the supreme court to rancel oi correct any certificate of title or entry on the register unless applied to by the registrar or on appeal from him, except where land or some, estate or interest therein is recorred by some proceceling in that court from a registered proprietor. Fection 73 . In such a tase, if the proceeding is not expresty barred-that is, if, having regard to section $5(0$, the plaintiff is entitled to recoverthe Supreme Count or judge ain clirret the registrar to cancel a certificate or entry and to substitute another for it.

These provisions confer upon the supleme ('oult jurlis- diction to cntretain such actions, and to make such orders as those which give rise to these appeals, if tho plaintiffs are entitled to recover the land. Whother those orders have been rightly made is a difforent question.

The provisions relating to the insurance found are alio reproduced, but are considerably altered and extrublod. Iand Transfer Act 188.), soctions $177 \mathrm{et} \mathrm{sey.} \mathrm{Any} \mathrm{person} \mathrm{sustaining} \mathrm{loss}$ through any omision, mistake, or misfeasanes of the registrar or any of his officers, and any person deprived of any land through its being brought under the $A$ ot, or by the registration

21 (1901) 19 N. Z. L. R. 545. 
of any other person as proprietor, or by any error in any certificate of title or in any entry or memorial of the register, or who has sustained any loss by the wrongful inclusion of land in any ecrtificate, and who by that Act is barred from bringing an action for possession or other action for the recovery of the land, may obtain compensation out of the fund. Provision is also made for the recovery by the registrar of any money paid out of the fund as compensation for loss *196 occasioned by fraud. Certain cases are excluded* from compensation out of the fund, but they are not material on the present occasion. Actions for the recovery of compensation ont of the fund are barred after the lapse of six years, with an extension in case of disability. Sections 178, 182, 185 and 187.

The acquisition by Europeans of lands held by natives under their native customs was regulated by The Native Land Act 187\%. The procedure to be followed is there fully set out-Native Land Act 1873, $\$ 33$ and 47. The proceedings commenced by bringing in a claim for investigation of the native title; and if the title of the natives was found satisfactory a memorial of their ownership was drawn up and signed by the judge, and sealed with the seal of the court and enrolled. It might be appealed against; but, subject to appeal, a certified copy of the memorial signed by a judge of the court and sealed with its seal was not only evidence of the facts stated in it, but was made "conclusive of the ownership of the land described therein according to native custom." Sections 58 and 51 . Leases for not more than twenty-one years could then be granted, but native land could not be otherwise dealt with except under the direction of the court. Sections 48, 59,60 and 87 . Section 87 is express on this point. In the case of a sale, a memorandum of transfer by the sellers to the purchasers was signed and submitted to the judge, and it was his duty to satisfy himself that everything was in order, and that the proposed sale was fair to the natives, and that the consideration was adequate and was paid. The memorandum of transfer was an important document, but it was not binding even as an agreement. Section 87 . On being satisfied that all was right, the judge was to draw up a certificate of the completion of the sale, and indorse it on the memorial of ownership with a declaration as thereinafter mentioned to the effect that the purchaser should thenceforth hold the land as freehold. Section 61 . This document was then to be sent by the judge to the Covernor with a recommendation for a Crown grant. By section 75 the judge of the Native Land Court was authorized by an order signed by him and under the seal of the 
court, to declare that the land should be held for the future in freehold tenure, and it was enaeted that such land should be held as freehold accordingly, anything thereinbefore provided notwithstanding, and ${ }^{*}$ from the date of such order ${ }^{*} 197$ the native title over the land comprised in such order should be extinguished; and the Governor was empowered at any time thereafter to issue a Crown grant for any such land. The effect of such an order, commonly called an "order of freehold tenure," was not to transfer the title of the natives, but to extinguish it, and to confer a new right on the purchaser.

This Aet of 1873 was followed by several amending Aets, and was repealed by The Native Land Court Act 1886.

Their lordships do not consider it necessary at present to allude further to the Native Land Aets. The important matters to be Lorne in mind are: First, that The Native Land Act 1873, was passed after The Land Transfer Act 18\%0, and that orders made by judges of the Native Land Court would have to be acted on by district land registrars; and secondly, that the Native Land Court was specially ereated to watch over and protect the natives against being unfairly dealt with by Europeans in transactions relating to lands; and that the jurisdietion of that court to sanction sales, and make orders vesting lands in purehasers for estates of freehold eannot be denied. How far errors in procedure affeet the validity of orders made by the court in the exereise of its jurisdiction is one of the questions raised by these appeals.

Their lordships' attention was ealled to many decisions on the Native Land Acts and the Land Transfer Acts, and some of them are important. The memorial of ownership, which is a very important document, and the root for future purroses of the title of the natives mentioned in it, has been held to be conclusive. Okirae Block, In re (1892). ${ }^{22}$

A memorandum of transfor has been held to have no operation as a transfer or as an agreement until approved by the Native Land Court, but after such approval it hecomes binding. Kotarepaia Block, In re (1S84), ${ }^{23}$ Areliatera Te Wera (Trustee) v. Wallier (1S\$4), ${ }^{24}$ and Paraone v. Matthex's (1SS9). ${ }^{25}$

Orders of frechold tenure have giren rice to differenees of* opinion. There areserral decisions to the effeet $* 198$ that, as between private individuals, they are conclusive in favor of bona fide registered purchasers-namely, Attorney

2210 N. Z. L. R. S. C. 677.

${ }^{23} 3$ N. Z. L. R. S. C. 51.

243 N. Z. L. R. A. C. 91 .

${ }^{25} 6$ N. Z. L. R. 744; Ib. vol. 7, 528. 
General v. Tipae (1887), ${ }^{26}$ Matai v. Assets Co. (1887), ${ }^{27}$ Hami Tilitiki v. Assets Co. and Distriet Land Registrar (1899), ${ }^{23}$ and Public Trustee v. Registrar General of Land (1899), ${ }^{29}$ mentioned below. Indered, except the decisions under appeal their lordships have found no case to the contrary. There are cases, however. in which orters of the Native Land Court have been impeached and hed void. and great reliance was placed upon them by the councel for the respondents. They were as follows:

In Te Raihi v. Grice (1886j), , $^{30}$ the Native Land Court made an orker. and then cancelled it and made another on which :) ('rown grant issued. The Supreme Court, in an action to which the attorney general was a party, declared the Crown grant roid on the ground that the order on which it was obtained was roid, the Native Land ('ourt having had no power to "ancer its first order. This case turned on an Act of 1867 , and not on any of the statutes which have to be considered on the present occasion. No registered title was in question then.

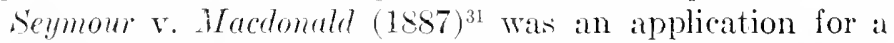
mandamus which was very properly refused. The last part of the headnote-namely, that the crifificate, if granted, would he invalid - loes not appear in the judgment, and ean only mein that the applieant for it rouk not property make use of it.

Poata v. Whard $(1889,1890)^{32}$ was an application for a prolilition to stay a partition amongst natives. There was no question of registered title. But the court held that the proper ateps to obtain a partition had not been taken and a prohibition was granted.

Faraone v. Mutheus was really a case of fraud, and might have been shortly disposed of on that ground.

*19y Thr *defendants knew they hard no title when they got on the register. The rase, however, was deciled on the groment that the proceedings were null and void rather than on the ground of fraud.

Solicito General v. Mere Tini (1899) was a somewhat similar case, but the Crown there applied to have a certificate of title followed by registration cancelled. This case does not show that if the suit had been between private individuals it would havensereded.

${ }^{26} 6$ N. Z. L. R.S. C. 157 .

27 6 N.'Z. L. R. S. C. 359

24 S N. \%. L. R. 226.

? 17 N. Y. L. R. 577.

34 + N. Z. L. R. A. C. 219.

1 5) N.Z. L. R. A. C. 167.

28 N. Z. I. R. 338.

:3 17 N. Z. L. R. 773. 
Rutu Peehi v. Da'y (1890 $)^{34}$ was a decision on points of law raised before trial. The district land registrar was a party, anel compensation out of the assurince fund was claimed. It is obvious that this involved a much wider incuiry than an action against a registered owner; and in that very case no decision was given to the prejudice of the only bond fide purchaser.

Public Trustee v. Registrer General of Land was, again, an application for compensation out of the assurance fund on the ground that the Crown had been wrongfulty deprived of certain reserve lands vested in it. The title of the registered purchaser was admitted to be unimpeachable.

No one of these cares can be regarderl as a dear decision adverse to the Assets (company on these anpeats moser fraud be established against it.

The Assets Company procured itself to be registoresl in the following way:

As regards the lands known as Waingaromia No. 3, the company produced to the listrict lanel registrar a warrant from the Ciovernor of the colony on May $7,1889$.

As regards Wainguromia No. 2, the company bought from the liquidators of the (ilakgow Bank, who were alrearly on the register, and produced an Imperial Act of Parliament vesting the assets of the bank in the company.

As regards Rangatira No. 2, the Assets Company produced sertificates of title from the Native Land Court and Crown grants, and it wat provisionally registered. Its title depends* on The Tative Land C'onit Let 1894, which *200 has no application to the othere cases.

As regards Waingaromia No. 3, the Asisets ('ompany rely primarily on the absenere of frand and on the conchusivenesis of their registered title. The raise other alefeness if their main

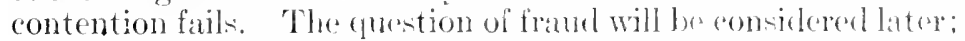
but apart from framel the respondents eontend that the watriant was invalid beratue it wat founded on an invaliel order of freeshold tenure; that this order was invalid lecentes it wats fomedrel on an invaliel memoramben of trans fer from the matives that this was invalid because it was not fommeded on any memorial of title, but only on an oreler for a memoriat; and that this oreler

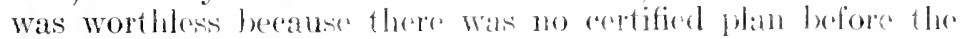
court when the order was misle.

The alleged invalielity of the memorandem of transtere itself is based on evirlenee of ireegularities in the signatures to it. It is alleged that some natives who were interested did not sign it, and that others who wre minors were not properly representerl.

349 N.\%. I. R. . . C. 131. 
and other irregularities are suggested. Having regard to the lapse of time and the long undisturbed possession and to what subsequently took place, their lordships think they ought not to entertain objections of this character to the memorandum of transfer. They must assume that Judge Rogan performed his statutory duty and satisfied himself that the memorandum was substantially in order.

The objection to the order of freehold tenure made by him is more serious. It is admitted that what is described as a sketch plan was before the court, and that it was in all particulars idcntical with the plan which was afterwards approved by the proper officer, except that it was not certified. The judge could not therefore then make a memorial of ownership; and in making his order for a memorial, which was dated December 27,1876 , he made a note in pencil- "Order not signed to stand over till plan is certified to." It is not denied by the appellants that the judge could not make an order of freehold tenure until a memorial of omnership had been signed and enrolled upon which the order could be indorsed. And their lordships think that Judge Rogan's order of frechold

*201 tenure must* be regarded as provisional only until the plan should be certified. The important point for observation is that the judicial proceedings bx fore Judge Rogan were complete; and upon the production of the plan, with the proper certificate on it, nothing more was required than the purely ministerial act of signing the formal documents necessary for carrying into effect the result of the proceedings before the judge. No further exercise of judicial discretion was required, and on production of the certificate to the plan Judge Rogan might have signed the formal documents at any time.

Chief Judge Macdonald had express statutory power conferred upon him in 1886 to act for Judge Rogan and to complete what he had left uncompleted; and it appears to their lordsnips that Chief Judge Macdonald had jurisdiction to do what he did. Native Land Court Act, $18 \& 6, \$ 67$; and see sections 52 to 64 and 115 to 117 . It will be remembered that Cooper, or those claiming under him, had throughout been in possession. This, no doubt, was the reason why Chief Judge Macdonald thought it right to antedate his orders. Their lordships do not overlook the fact that Chief Judge Macdonald was correcting a mistake made by Judge Brookfield in 1884 when he ordered a Crown grant or certificate of title to be issued to the natives. This order, which was ncver sioned, must have been made in ignorance of Cooper's position. The respondents attach importance to this order, and in fact rely uron it as showing their title to sue. This, however, places them in a 
difficulty, for Judge Brookfield's order presupposes a memorial of ownership in the natives and would be worthless without itNative Land Division Act 1882, \$10-and yet the only memorial they had to rely upon was the order for one made by Judge Rogan in 1876, which they now contend was itself worthless.

But realizing as their lordships do the difficulties arising from Judge Rogan's failure to complete the course of procedure preseribed by the Native Land Acts, their lordships are of opinion that the registered title of the Assets Company to Waingaromia No. 3 can only be impeached for fraud. It was strenuously contended by counsel for the natives that the *proceedings in the Native Land ('ourt were not *202 only irregular, but that the irregularities were of such a nature as to affect the jurisdiction of the Native Land Court and to render its proceedings and its order of freehold tenure absolutely null and void on the ground that it was coram non judice. The same contention assumed another shape when relied on to show that the lands in question were never brought under The Land Transfer Act 18S5, so as to render its provisions applicable to them.

Their lordships have very carefully considered the judgments delivered in the Court of Appeal upon this part of the case, as well as the very able and exhaustive arguments of the learned counsel for the native claimants, but their lordships are unable to concur in the view taken by the majority of the court and they eoncur in that taken by Mir. Justice Williams, who dissented from the judgment. The sections making registered eertificates conelusive evidence of title are too elear to be got over.

In dealing with actions between private individuals, their lordships are unable to draw any distinetion between the first registered owner and any other. A registered bona fide purchaser from a registered owner whose title might be impeached for fraud has a better title than his vendor, even if the title of the latter could be impeached by the Crown. The reasons for arriving at this conclusion are so clearly given by Mr. Justice Williams that their lordships do not think it necessary to do more than adopt them and supplement them by a few remarks on some of the arguments addressed to them and to which they are unable to assent. It is to be observed that in Solicitor General v. Mere Tini the title of the first registered owner was suecessfully impeached by the Crown. But in Public T'rustee v. Registrar General, his title was admitted to be unimporehable. These cases are noticed above.

Their lordships are not prepared to hold that a Crown grant, or a warrant, or a certificate having the statutory effect 
of the Crown grant can be impeached except at the *203 instance* of the (rown, or at any rate in an action to which the (rown is a party. The power of the Crown to set aside its own grant, or its equivalent, has not to be considered on the present occasion, and their lordships do not therefore express any opinion upon it.

It by no means follows that errors in procedure, even in matters which in one sense affect jurisdiction, need be noticed, or ought to be noticed, by other persons whose duty it is to act on orders brought to them. It is not their duty to attend to such matters; if it were, their action would be paralyzed. What they have to look to is the order; and if that is good on the face of it, it is their duty to act upon it; and it must be treated as a sufficient foundation for what they do. Not only are they protected from liability if the order turns out to have been improperly obtained, but, if what they do under it is made conclusive on questions of title, a title which might be otherwise impeachable must be treated as valid.

The cases of Matai v. Assets Co., supra, Alridge, In re (1893),35 and Hami Tilitilit v. Assct.s Co.. supra, were decided and, in their lordships opinion, rightly decided on this principle. Having regard to the Lind Transfer Aets and the Native Land Acts, their lordships are of opinion that it was not the duty of a clistrict land registrar to examine into the validity of a Crown grant, nor to inquire how a Governor's warrant had been obtained, nor to inculire into the proceedings in the Native Land court culminating in an order of freehold title. The dets how that these doeuments may be assumed to have been propery obtained and may be safely acted upon by the district land registrars and by other persons acting in good faith.

The difference between want of jurisdiction over persons and subject matter and wrong procedure in a court having such juriscliction will be found discussed in Pemberton v. Hughes (1599),,$^{36}$ where the Court of Appeal in England had to consider the validity of a divorce in Florida alleged to be coram non judice and void by reason of errors in procedure. The

*204 Court* of Appeal held that such matters ought not to be regarded by a foreign tribumal ealled upon to recognize the Floricka receree.

It is said that Gibbs v. Messer (1891 $)^{37}$ shows that registered titles may not be conclusive even in favor of a bona fide registered purchaser from a registered owner. The ease no doubt loes show that such a case may oceur. The case was one of

os 15 N. Z. L. R. 361.

${ }^{36} 6$ s. J. Ch. 281; (1899) 1 Ch. 781.

s; 60 L. J. P. C. 20 ; (1891) A. C. 248. 
fraud and forgery. A transfer from a registered ownel to a non-existent person had been fraudulently procured and registered, and a fietitious transfer from that fictitious transferee to a bona fide mortgagee was afterwards registered. In a suit by the first registered owner against the registrar, the registered mortgagee, and the perpetrator of the fraud, the name of the first registered owner was ordered to be restored to the register by this board. The supreme Court of Vietoria had beld that the true owner had lost her moperty, hut was entitled to damages out of the compensation fund. The appeal was by the registrar from this decision. This boarel held that as there was, in fact, neither any transeree from the first registered owner, nor any transferor to the registered mortgagee, there was nothing to deprive the first registered owner of her property-nothing, in fact, on which the subsequent registrations could operate; and those registrations were accordingly ordered to be cancelled. Iord Watson, in his observations on the protection given to bona fide purchasers, points out that a bona fide purchaser from a registered owner is in a botter position than a first registerel owner whose title may be impeached for fraud. But there is nothing in his judgment in favor of the view that an original registered owner claiming through a real person does not got a good titlo against every one exeept in the cases specially mentioned in the Act, fraud being one of them.

Then it is contended that a registered owner may hold as trustee and be compelled to exerute the trusts subject to which he holds. This is true; for, although trusts are kept off the register, a registered owner may not be beneficially entitled to the lands registered in his name. But if the alleged cestuique trust is a rival clamant, who can prove no trust apart* from his own alleged ownership, it is plain that to *205 treat him as a cestui que linst is to destroy all hemefit from registration. Here the plaintiffs sot up an adverse tit leand nothing alse; and to hold in their faror that there is any resulting or other trust entitling them to the property is, in their lorelships oprinion, to do the very thing which legistration is eseigned to prevent. Their lordships amnot give offect to the ingenious arguments addressed to them on this point. Nor and they adopt the case of bolicitor General r. Mere Tini as an authority which ought to be followed in these appeals.

The conclusions thus alliverl at really elispose of all there appesals, exe(e)t so far as they are liased on fraut. But before dealing with the eharges of frame their lorelships will shortly allucle to the special grounds relicel upon in the sereond and third appeals. 
In Waingaromia No. 2, the liquidators of the Glasgow Bank, who claimed through Cooper, were registered as owners on the provisional register, and in August, 1882, they obtained a certificate of title from the district land registrar.

By an Imperial statute (45 \& 46 Vict. e. $152, \S \S 3$ and 4 , and 2nd schedule), The City of Glasgow Bank (Liquidation) Act 1882 , all the assets of the Glasgow Bank were vested in the Assets Company on their obtaining a discharge from the liquidators for the purchase money and on the recording of such discharge as mentioned in the Act. The purchase money was to be paid on or before October 1,1882, but it was not in fact all paid before December, 1882, and the statutory vesting did not take effect until then. On August 15, 1883, the Glasgow Bank Act was produced to the district land registrar, and he indorsed on the liquidators' certifieate of title a transfer to the Assets Company and registered it. The Act resting the assets in the company vested them (section 4) "subject to the existing charges, debts, engagements and liabilities specifically affecting the same in the hands of , he bank or the liquidators," and the court below has held that these words had the effect of overriding or controlling the Land Transfer Acts of the colony. Their lordships *206 are unable to concur in this view. There is nothing in* the Glasgow Bank Act to show that interference with the Colonial Land Acts was ever contemplated, still less that those Acts were to be overridden. The general vesting clause, when applied to lands in the Colony, must be read so as to work in harmony with the Colonial Aets, and in effect as conferring upon the Assets Company the right to procure themselves to be registered aceording to the laws of the colony; and if that registration gave them rights in the colony beyond what they might have without it, there is nothing in the Imperial Act to deprive them of those rights.

Then it was ingeniously argued that these particular lands were not bought from the liquidators on the faith of their being registered owners, and that the Land Transfer Acts did not therefore apply. But although the agreement to buy the assets of the Glasgow Bank in block was not based on the Colonial Land Transfer Acts, the completion of the purchase of these particular lands was based upon them, and nothing more can be reasonably required.

In 1883 the Land Transfer Acts in force in the colony were the Act of 1870 and the Acts amending it. But the reasons for which registration under the Act of 1885 confers a good title apply also to the Aets in foree in 18S3; and although the liquidators were only themselves entered as owners on the provisional register, a good transferable title had been acquired by them. 
and the subsequent registered title of the Assets Company cannot be disturbed.

Passing now to Rangatira No. 2, the Assets Company rests its title on the fact that in October, 1895 , it obtained a certificate of freehold title under The Land Transfer Act 1885, and is registered as owner under that Act. The title is impeached for fraud and for irregularities in the Native Land Court, and especially for the invalidity of the memoranda of transfer from natives, on which the title is founded. Fraud is denied, and will be passed over for the present. Their lordships have already expressed their view of the conclusiveness of the register. but as the objection to the validity of the transfers was argued at great length and prevailed in the Court of Appeal, their lordships think it right to express their opinion upon it. The history of the ease is complicated. It is fairly and correctly stated in the appellants' case, paragraphs 8 to 12 , and their lordships do not think it necessary to repeat it in fletail. The* important points are that in 1875 the lands *207 in question were brought by the natives under the Native Land Acts, when a memorial of ownelship was issued to them. Their title was then investigated and determined. They obtained a statutory title, and ceased to hold solely by their old eustom or usage. In the same year (1875) the natives granted a lease for twentyone years. Afterwards, between 1878 and 1853, most of the natives signed memoranda of transfer of all their interests to the then lessees. These memoranda of transfer are those now impeached. No orders of freehold tenure followed them. But in May, 1886, they were produced to, and approved and indorsed by, the trust commissioner, and his cluty was, by the Act of 1881 (Native Lands Frauds Prevention Act of 1881, \$\$ 4, 6 and 15), to protect the natives in their dealings with Europeans to see that everything was fair, and that the purchase money was really paid. Without his certificate no transaction with the natives could be registered. No rent was ever paid to the vendors after this. In 1886 partition proceedings were pending between the natives; and the lands known as Rangatira No. 2 were allotted to tho ze adult natives who had sold their interests as above mentioned, and in May, 1886 , an order was made for the issue of a Clown grant of this block to those scllers. Other blocks were allotted to the other natives, and Crown grants were ordered to be issued to them; and the memorial of ownership issued in 1875 was then cancelled. All this was done before August, 1886, when two im! o:tant Acts were passed. Mr. Graham, who represented the purchasers, was a consenting party to all these proceedings, which were really taken not only to 
effect a partition between the natives, but also to facilitate the completion of the purchaser's title.

These orders for Crown grants were made, but were retained in the office, as the fees for them were not paid.

Then the Native Land Court Act 1S86, and the Native Land Administration Act 18S6, were passed. The former Act, by section 115, repealed The Native Land Act 1879, but en*20s acted that* incompleted procedure might be completed either under the new Act or under the old. This Act was amended in 1888 and 1889.

By The Native Land Administration Act 1886, section 24, further provision was made for the proteetion of natives and for the completion of incompleted transactions. This Act did not come into operation until January, 1887. Native Land Act $1888, \S 3$.

The Asrets Company did not complete its title under either of these Aets.

So matters stood when The Native Land Court Act 1894 was passed. At that time the lease and interests of the native sellers, which had been bought as above stated, had become vested-first in the liquidator's of the Glasgow Bank, and afterwards in the Assets Company, by virtue of the Imperial statute which has been already referred to; and in July, 1895, the company obtained the registration on the provisional register of the transfers from the natives and its other documents of title; and in October following obtained, first, a warrant from the Gov'rnor for the issue of a certificate of title to the native soller's; and lastly, from the district land registrar, a certificate of the company's ownership under the Act of 1885, and registration of the company as owner accordingly.

The contention of the Assets Company is that the Act of 1894 cured all defects and enabled it to aequire a complete title and to procure itself to be registered as owner. The contention on the other side is that the transfers had become pure waste paper, and that there was no title to register.

It will be convenient first to consicler the Aet of 1894 (The Native Land Court Act 1894). It repealed The Native Lands Frouds Prevention Act 1881, to which reference has already been made, and also the several Native Land Court Acts of 1886,1888 and 1889.

The Aet of 1894 enacts (section 57 ) that every instrument indored by a trust commissioncr as approved in terms of the Act of 1881 is to be deemed to have been eonfirmed by the court within the meaning of the Act of 1894, and no further confirmation is required. By section 73 all land which was *209 customary* land when the Act of 1894 came into 
operation (and by section 2 Rangatira No. 2 was such land) became subject to The Land Transfer Act 1885 (already referred to), and every native owner of such land, subject to all equities affecting his interest therein and to all existing restrictions on alienation thereof, is to be deemed the propriet or thereof under the said Act for an estate in fee simple in possession. Further, by the same section 73 any person elaiming to have acquired an interest in any such land by virtue of any alienation prior to the coming into operation of the Act of 1894 may apply to the eourt to have such alienation confirmed, and upon confirmation thereof the claimant becomes entitled to be registered under the Act of 1885 as proprietor of the estate or interest aequired.

This latter part of section 73 above referred to cannot mean that cases that fall within section 57 , and which require no confirmation, are to be again confirmed. The latter part of section 73 can only apply to incomplete transactions not approved and certified by the trust commissioner. This being the case, their lordships are unable to see why section 57 does not apply to these memoranda of transfers from the natives which the trust commissioner did approve and certify, and their lordships can see nothing substantially wrong in the procedure which resulted in the registration of the company.

To treat the memoranda of transfer as waste paper appears to their lordships to go a great deal too far. They wore not valid as transfers, but they were the first step for obtaining such transfers, and entitled the parties to take the neeessary procecdings for eompleting them.

The repeal of the Act of 1873 led to difficulties which do not appear to have been removed by subsequent legislation prior to 1894 . This is apparent from Poaka v. Ward, already referred to. The Act of 1894 was apparently passed to remedy them.

The true effect of the Act of $1894, \$ \$ 57$ and 73 , was, in their lordships' opinion, to entitle all the selling natives to their shares in the lands sold, but subject to all equities affecting the same. These equities included the right of the

Assets* Company to have the transfers which had been *210 approved by the trust commissioner carried out and completed. There may have been irregularities in the procedure adopted; but their lordships are of opinion that the Aet of 1894 put matters right, and that there was nothing wrong in substance, nothing to affect the validity of the final cortificate and registration of the company as owner.

Passing now to the question of fraud, their lordships are unable to agree with the court of Appeal. Sections 46, 119, 129 and 130 of The Land Transfer Act 1870, and the corresponding 
sections of the Act of 1885-namely, sections 55, 56, 189 and 190-appear to their lordships to show that by fraud in these Acts is meant actual fraud - that is, dishonesty of some sort; not what is called constructive or equitable fraud-an unfortunate expression and one very apt to mislead, but often used, for want of a better term, to denote transactions having consequences in equity similar to those which flow from fraud. Further, it appears to their lordships that the fraud, which must be proved in order to invalidate the title of a registered purehaser for value, whether he buys from a prior registered owner or from a person claiming under a title certified under the Native Land Acts, must be brought home to the person whose registered title is impeached or to his agents. Fraud by persons from whom he claims does not affect him unless knowledge of it is brought home to him or his agents. The mere fact that he might have found out fraud if he had been more vigilant and had made further inquiries which he omitted to make does not of itself prove fraud on his part. But if it be shown that his suspicions were aroused, and that he abstained from making inquiries for fear of learning the truth, the case is very different, and fraud may be properly ascribed to him. A person who presents for registration a document which is forged, or has been fraudulently or improperly obtained, is not guilty of fraud if he honestly believes it to be a genuine document which can be properly acted upon.

In dealing with colonial titles depending on the system of registration which they have adopted, it is most important that the foregoing principles should be borne in mind, for *211 if they ${ }^{*}$ are lost sight of that system will be rendered unworkable. Their lordships are keenly alive to the necessity of vigilanceto protect natives against unfair and oppressive dealings on the part of Europeans; but on the other hand it is equally important not to disturb registered titles of bona fide purchasers, especially when accompanied by long possession and large outlays.

It was urged by counsel that the decision of this board in Gibbs v. Messer shows that it is not in all cases essential to bring fraud lome to the registered owner. This is true, but the case is not really in point. As already explained in Gibbs v. Messer two bona fide purchasers were on the register, and the case turned on the non-existence of any real person to accept a transfer and get registered himself, and then to make a transfer to somrone else. Morcover, forgery is more than fraud, and gives rise to considerations peculiar to itself.

In the first appeal. Waingaromia No. 3, the fraud charged is fraud by the Assets Company in obtaining a warrant from the 
Governor and a certificate of title from the district land registrar.

In the second appeal, Waingaromia No. 2, various frauds on the natives are charged against Cooper and the liquidators of the Glasgow Bank, who purchased from him. There is no definite charge of fraud by the Assets Company. The only charge against the company is that the company obtained from the district land registrar an indorsement of the transfer from the liquidators to the company, and that the obtaining of that indorsement was fraudulent and roid as against plaintiffs.

In the third appeal, Rangatira No. 2 , the fraud charged is, again, that frauds were committed by other pcople and that the obtaining and retaining by the company of a certificate of title from the district land registrar was fraudulent and void as against the plaintiffs.

The evidence of fraud by the company entirely break down. The evidence shows that in all these cases the agents of the Assets Company in the colony took to the registrar and got* him to register certain documents which, accord- *212 ing to their purport and effect, entitled, and which they believe did in fact entitle, the company to be registered as owners. There is no evidence whatever of any fraudulent statement made by the company's agents to the registrar nor of any bribery, corruption, or dishonesty in the matter.

Their lordships cannot help thinking that the equitable doctrines of constructive fraud have weighed too much with the Court of Appeal and have induced it to impute fraud to the Assets Company although no dishonesty by the company or its agents, or by the liquidators of the City of Glasgow Bank, was really established. Nor is there any proof whatever that the liquidators or the Assets Company dishonestly refrained from making inquiries which an honest purchaser would have made.

The conclusions thus arrived at dispose of all these appeals. Their lordships do not therefore think it necessary to give any opinion on several other defences to these actions which were raised in the Court of Appeal and relied uron by comnel for the appellants in their arguments before this loard. Their lordships refer to the defences based on the defretive title in the plaintiffs, the absence of other parties, the Statute of Limiations, the effect of long possession and large outlays on the lands sought to be recovered, and the effect of decisions in former unsuceessful actions by natives suing on behalf of themsclves and others. Their lord-hips lase their judgment on the conelusiveness of the registered title in the absence of fraud.

In upholding the title of the appellants on this broad ground it is satisfactory to find that their lordships are not 
disturbing, but upholding, the views which had been until recently taken and acted upon in the colony for many years in actions brought against bona fide purchasers on the register. The same view has been taken in South Australia, as is shown by Bonnin v. Andrews (1878). ${ }^{38}$

The conclusion of the whole matter is that their lordships will humbly advise his Majesty to allow these appeals *213 and to *reverse the judgments appealed from, with costs, and to enter judgment in each action for the defendants, the Assets Company, with costs, and the costs of each appeal must be borne by the respondents thereto.

Solicitors-A. E. Baker, for appellants; Baker and Nairne, for respondents.

8812 S. A. L. R. 153. 


\section{APPENDIX F}

\section{INDEX TO STA'TU'TES}

Abstract,

form of........................ . 533

Address,

to be given by parties

528,563

Administrator, See "Executor."

Adverse possession,

gives no title to land under new system . . _ . . 429

prevails against first certificate of title .... . . 429

rules as to, under mortgages............ 429

Affidavits,

include affirmation.................. 553

may be made before registrar, master or inspector. . — $\quad 473,556$

Alberta, of execution. See "Attestation of Instruments."

528,606

Land Titles Act. .......... . ... . ... 551

Annuity,

discharge of .

$437,497,575$

Appeal,

general right to.

Application to bring land under Act,

$446,527,609$

form of.

Assignment for benefit of creditors, exemptions under.

531,614

504,584

included in transmission. .

Assurance fund,

action against, in Manitoba.

106, 467

affidavit of value for.....

amount payable to

518,597

bar by reason of notice.

$453,517,597$

breach of trust, not liable for.

claims under former Aets, not liable for

disability, action against in case of

disposal of .

double grants, liability in case of .

improper use of corporate scal.

limitation of actions against.

misdescription, non-liability for . .

payment of claims without action.

payment of judgments against.

recovery against person primarily liable

$453,514,593$

$452,518,598$

….. 611

$452,549,593$

$153,518,598$

519,598

. . 519

452

519,598

. . 453

452

514,593

remedy over against person primarily liable. $\quad 574,593$

Attestation of instruments,

affidavit of, form of...

547,631

before whom sworn. . .......

510,589

required, when, ..

$432,510,589$ 
Bona fide purchase", Bond, right to damages against...........

of inspector, registrar, etc., form of .

Bringing land under the Act, See, also, "Bringing Land Under New System." adverse claimant to file claim..... 482,562 application for. . requirements of 559,560 submissi n to judge 480,560 consent by interested party.......................... 482 discharge of mortgage on ........ . . . . . . . .481, 562 notice to adverse claimants. . . . . . . . . . . . . . . .482, 563 title, in simple cases. exanination of, by judge by master of titles.

where julge satisfied.

where master of titles satisfied.

Bringirg land under new system, See, also, "Bringing Land Under the Act."

application for.

by a person holding power of attorney.

cavert against. See "Caveat."

conscnt of interested parties....

contractual rights under mort gage remain intact

direction to issue title to third person..

good safe holrling title to be produced

in Souris River, ete

manner of

notice to other persons interested

nimber of acres or lots in application.

of person of unsound mind or infant.

provincial land.

service of notice............ 416

"subject to the new system". . $\quad \ldots \ldots .444$

tax sales, application under. . . . . . 417

undivided interests.......... . . . . . . 413

where title satisfactory . . . . . . . . . . 417

withdrawal of application... .... . . . . . 414

costs of raveator on ..................... 415

withdrawal or rejection, proceedings by district registrar on ..... 415 where direction in favor of third party filed . . . . . . . . 415

\section{Canadian Pacific Railway Company,}

issue of certificate of title to.

\section{Caveat,}

address for sorvice in

$448,508,584$

affidavit in support of.

$448,508,585$

form of

after dat of rertificate, excepted from certificate.

$460,547,630$

against bringing land under new system

for'm of

$\ldots \ldots 428$

lapse of,

$\ldots 459,547$

arainst rogistation, form of .

by district registrar.

by registrar 
Caveat, continued

caveator, costs of on withdrawal of application.

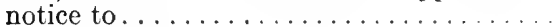

form of .

$447,509,585$

549,631

contrary to Act null and void ................. 508

damages for wrongful filing $\ldots \ldots \ldots \ldots \ldots \ldots \ldots \ldots \ldots \ldots \ldots \ldots \ldots \ldots$

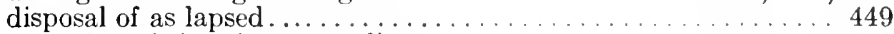

extension of time for proceedings... . . . . . . . . . . . . 450

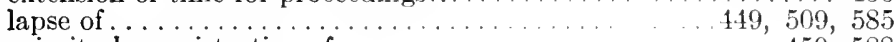

priority by registration of . . . . . . . . . . . . . . 450,588

proceedings under........................ 450

registered owner, need not show interest from . . . . . . . . . 507

registration of instruments under which caveator claims.....450, 588

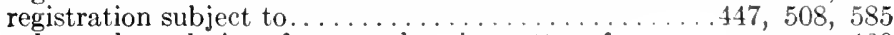

rules and regulations for procedure in matter of . . . . . . . . . 460

second, or lis pendens forbidden . . . . . . . . . . . 449, 509, 587

summons to discharge..................449, 509, 586

under contract for sale and purchase . . . . . . . . . . . . 586

under lien note forbidden . . . . . . . . . . . . . . . . . 508

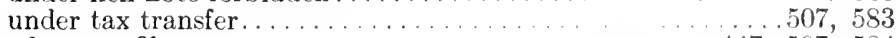

who may file.............. 447, 507, 584

withdrawal of ........... $\quad .148,509,585$

Certificate of charge, ........... $\quad 144,493,577$

form of ............ . . . . . . . . . . . . 633

Certificate of title,

See, also, "Duplicate Certificate of Title."

address in ................ . 528,563

bar to action for recovery of land... . . 430, 591

cancellation of on transfer....... . . . . . . 476,563

conclusive evidence of title ...... $428,484,524,564,565$

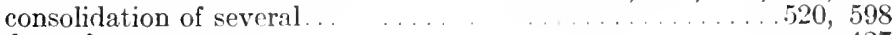

date of .................... . . . . 427

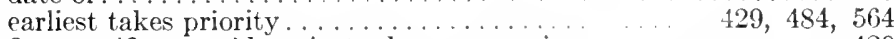

first certificate void against adverse occupier . . _ . . . . . . 429

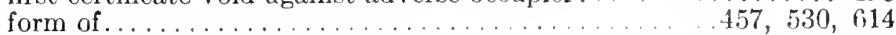

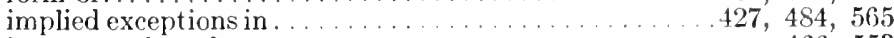

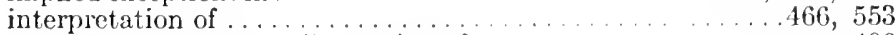

"issued under this Act," meaning of . . . . . . . . . . . . . 406

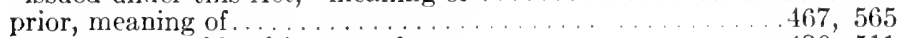

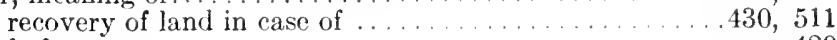

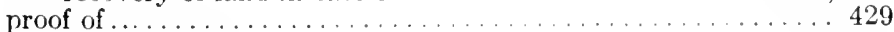

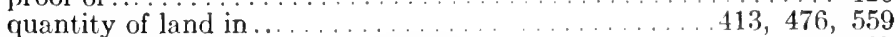

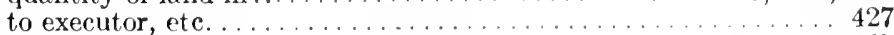

two or more owners take as tenants in common............. 467

when issued.................. . . . . . 427

Confirmation, of transfer under process of law . $\quad 506,582$

Contract, assignable..................... . . 588

Copies,

certified, by registrar, as cvidence

$455,474,556$

Corporations,

Costs, seal of, improper use of

judge or master of titles may order . . $\quad \ldots \ldots 527,610$

scale of ......................... 628,610

security for, by non-resident..........526, 609 
Court,

jurisdiction, as to fraud, contracts, etc $\ldots \ldots \ldots \ldots .446,467,606$

in sale and foreclosure. . . . . . . . . . .439, 446, 493, 574

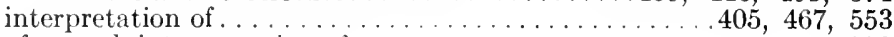

of appeal, interpretation of .................... 553

Covenants, implied,

See "Implied Covenants"

Damages,

See, also, "Assurance Fund."

against assurance fund when primary right barred

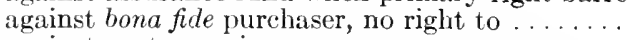

against party causing same................ 512, 591

limitation of period of commencement of action. . . . .452,514, 593

notice of delay . . . . . . . . . . . . . . . . . . . . 514, 593

omission to file caveat ................453, 514, 593

through mistake of official . . . . . . . . . . . 451, 513, 592

notice of action................... 452, 513, 592

where party liable dead, etc . . . . . . . . . . . . 512, 592

Day book,

time in, settles priorities . . . . . . . . . . . . . 409, 474, 557

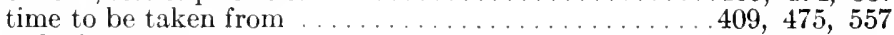

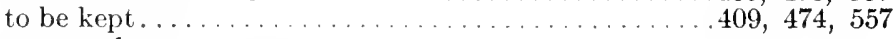

Decree or order,

excepted from certificate of title...........428, 484, 565

District registrar,

See, also, "Registrar."

action against, not abated by vacancy or change in office ... . . . 452 notice of . . . . . . . . . . . . . . . . . . . . . . 452

appointment of . . . . . . . . . . . . . . . . . . . . 408

attendance on subpona, etc ................. 411

carries out Registry Aet ...................... 410

caveat by ............................ 419

certified copies by ....................... 455

correction of error, fraud, etc., by . . . . . . . . . . . . . 419

deputies of ............................. 408

interpretation of ......................... 406

manner of making corrections. . . . . . . . . . . . . . . . 419

notice, to approve manner of service of . . . $\ldots \ldots \ldots \ldots \ldots .417$

not liable for bona fide act . . . . . . . . . . . . . . . 411

not to accept fee............................... . . 411

not to act as conveyancer, ete. . . . . . . . . . . . . . 410

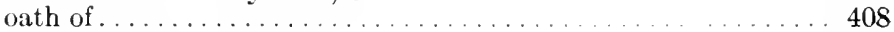

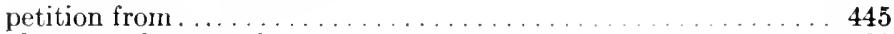

plan, may have made...................... 426

may require owner to file before dealing. . . . . . . . . 425

powers and duties of . . . . . . . . . . . . . . . . . . . 418

production of book from other office................ 411

qualifications of ........................ 408

security given by . . . . . . . . . . . . . . . . . . . 408

summons, to give evidence..................... 419

to produce instrument, ete . . . . . . . . . . . . . 419

takes evidence of priority of instrument over judgment . . . . . 433

Duplicate certificate of title,

See, also, "Certificate of Title."

bar to action for recovery of land . . . . . . . . . . . 511, 591

delivery, to new owner after transfer ..............486, 563

to owner on land being brought under Act........483, 588 
Duplicate certificate of title, continued

delivery up to registrar on transfer.

demand to return

form of . .

486,567

$419,516,595$

entry to be made on unless dispensed with $.548,632$

evidence in specifie performanee action

$427,475,557$

interpretation of... 524,605

lost or destroyed, proceedings in case of . . 466,553

memorandum of registration on

$+21,520,599$ conclusive evidence. . .

$431,477,558$

$431,477,558$

production dispensed with in Alberta ............ . . 557

in Saskatehewan .............................. 475

provided for......................... 427, 483, 4\$6, 563

retained, where land leased ......................... 489

where land mortgaged ......................444, 493, 577

returned on partial cancellation.............. 520,567

summons to deliver up . . . . . . . . . . . . . . . . . . . . 419

upon first certificate of title................... 483,563

Easement,

ereated by transfer ........................ 485, 566

excepted from certificate of title . . . . . . . . . . . . . 428

indorsement on certificate of title........ 485, 566

public, exeepted from certifieate of title .............. 484

statutory, excepted from certificate of title....... .484, 565

Ejectment,

Error, action for. See "Recovery of Land."

correction of, by registrar.

judge may correct.

$419,516,595$

manner of correction

$420,517,596$

\section{Estoppel,}

operation of transfer by.

431,485

Evidence,

by affidavit. .

525,608

cancelled instrument as. .

$455,525,605$

certified copies as...

eross-examination on affidavit

$455,474,556$

525,608

432

Execution, affidavit of . .

form of

476

Execution register,

provided for...

\section{Executions,}

binding effect of .

505,581

505,581

484,565

excepted from certificate of title

$.505,581$

expiration of...

filing of .

504,581

operation of . .

505,581

satisfaction or withdrawal of . .

505,582

Executor,

application for transmission by .

502,578

503,580

application to remove...........

$427,503,579$

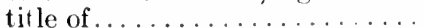

$444,502,579,580$

transfer to himsclf . . .

431

transmission of mortgage to

$.502,579$ 
Expropriation, right of, excepted from certificate of title........428, 484, 565

Fee book, to be liept. .

Fee tail, abolished .... . ..................... 467

Fees, court may fix $446,528,610$ Filing,

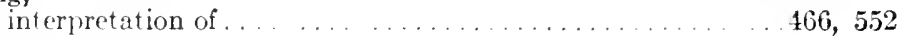
Form, interpretation of $409,529,610,611$

Former Acts and registrations continued Forms, alteration of, by order in council $407,528,610$ en borlied in Act . . . . . . . . . . . . . . . . . . . . . . . 407 variations in . . . . . . . . . . . . . . . . . . 406

Fraud, affects dealings.

$434,521,605$ correction by registrar, in ease of . $419,516,595$ linow ledge is not $434,521,605$ recovery of land in ease of .

$430,511,590$ vitiates conclusiveness of certifieate of title.

$428,524,565$

General register, certificate, form of . . . . . . . . .

to be furnished .............. . 556 provided for...................... 476

Grant, double, assurance fund not liable.

fees on registration of interpretation of ...................... issue of eertifieate of title on

Guardian, when registered......

519,598

477,559

$406,467,553$ 477,559 $\ldots 476,558$ of infant, powers of .

$456,521,604$

Highway, publie, excepted from eertificate of title... $\quad 428,484,565$

Hudson's Bay Company, affidavit coneerning lands, form of . . . bringing land ranted prior to 1886 under 532,616 issue of eertificate of title to. 1880 under Ast.

Implied covenants, construed as several, not joint

$454,523,604$ in leases...............

$435,450,571$ in mortgage, to repair.

in transfers, ete. . $433,483,564,577$ may be negatived pleading to execute further necessary instruments

Incumbrance, to indemnify against mortgage.

$454,523,603$ $454,523,603$ ....483, 564 $\lfloor 33,483,567$ Sfe, alsn, "Mortgage." form of . $159,533,621$ interpretation of $405,466,552$ Incumbrance ${ }^{\circ}$, interpretation of . 
I ncumbrancer,

Indorsed,

interpretation of $\ldots \ldots \ldots \ldots \ldots \ldots \ldots \ldots \ldots, 466,552$

interpretation of $\ldots \ldots \ldots \ldots \ldots \ldots \ldots \ldots \ldots, 467,553$

Indorsement,

Infant, interpretation of

467,553

bringing land of, under system... ... . . . 414

Inquiry, guardian of, may take step..... ... $\quad 456,521,604$

practice on .................. . . . $\quad 625,608$

Inspector of land titles offices (Alberta),

appointment and duties of . .............. 554

not liable for bona fide act . ............ . . . . . 607

oath and security of .................. 555

\section{Instrument,}

description in, need not except land .....

interpretation of ................ $405,466,552$

not registerable to defeat plan regulations.... ........601

operation, against bona fide transferee on registration ....432, 484, 566 only against maker before registration...........483, 564 operative on registration................431,485, 558,564 priority according to time of registration .........431,485, 558 rejection where unfit for registration . . . . . . . .432, 474, 566 stamped by registrar.................... 474,556 substantial conformity with schedules recquired for registration . . . 432 unregistered, confers right to registration. . . . . . . . . 434 when deemed registered . . . . . . . . . . $427,476,55 \mathrm{~s}$

Irregularity, Technical,

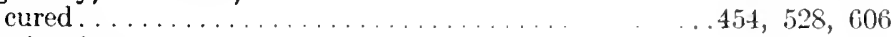

Irrigation Act,

rights acquired under, excepted from certifieste of title . . . . . 484

Joint owners,

Judge,

indorsement of certificate.............522, 605

amendment of plans by ....................489, 600

appeal from order of, on petition...........445, 527, 609

enforcement of orders of . ............. . . . . . . 527, 610

inquiry before, practice on ................... 525, 608

interpretation of ..................... 405, 467, 553

order of, prohibiting dealings ................... 527

power of, to cancel, correct, etc.............. 420,517, 594

reference to court en banc, by........................528, 610

registrar to examine order of. ....................... 420)

summons to appear or give evidence by .......... . 415

warrant to apprehend by . . . . . . . . .

Judgment,

excepted from certificate of litle ................. . . 428

lien in new district ceases in two years. .............. . 410

priority to, granted to instrument.......... . . . . 433

Land,

registration of certificate of .......... . . . . . 432

interpretation of $\ldots \ldots \ldots \ldots \ldots \ldots \ldots 4,465,551$

Land titles district,

boundaries of, in Alberta . . . . . . . . . . . . . 553

in Saskatchewan ... . . . . . . . . 
Land titles district, continued erection and alteration of $\ldots \ldots \ldots \ldots \ldots \ldots \ldots \ldots 407,471,554$

Lease, instrument not to contain land in more than one........... 432

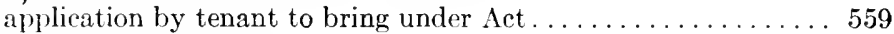

certificate of, form of ........................... 541

certificate of registration of ......................... 490

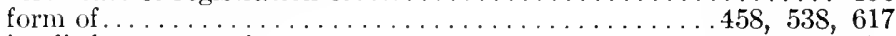

implied covenants in ..................435, 490, 571

interpretation of ............................. 405

mortgagee to consent......................490, 571

not exceeding three years, excepted from certificate of title.....

$428,484,565$

provided for ........................434, 489, 571

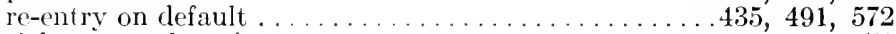

right to purchase in ......................490, 571

short forms in .....................491, 539, 572, 618

surrender of . . . . . . . . . . . . . . . . . . 491, 572

\section{Limitation,}

form of .......................... 541,619

words of, abolished ......................431, 485

Lis pendens,

certificate of, excepted from certificate of title........... 428

duplicate not required produced for registration . . . . . . . . 475

Lunatic,

in ease of mortgage proceedings . ..................... 443

committee of, powers of $\ldots \ldots \ldots \ldots \ldots \ldots \ldots 456,521,604$

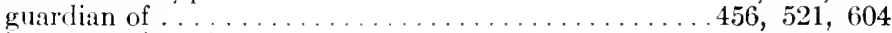

Manitoba,

interpretation of . . . . . . . . . . . . . .

Real Property Act............................ 403

Married woman,

entireties abolished. . . . . . . . . . . . . . . . . . . . . . . 468

husband and wife may mutually transfer................ 468

new certificate of title on marriage ...............468, 583

Master of titles,

appeal from............................ 527

deals with applications for bringing land under Act . . . . . . . 482

duties of ................................. 472

enforeement of order of ...................... 527

not liable for bona fide act $\ldots \ldots \ldots \ldots \ldots \ldots \ldots \ldots \ldots, 473$

not to act as conveyaneer, ete .................. 473

petition to ................................. 515

qualification of . . . . . . . . . . . . . . . . . . 472

summons by . . . . . . . . . . . . . . . . . . . . . . 525

Mechanics' lien, excepted from certificate of title..................428

Memorandum, interpretation of $\ldots \ldots \ldots \ldots \ldots \ldots \ldots \ldots \ldots \ldots \ldots \ldots, 552$

Misdescription, assuranre fund not liable for, except in eertain cases.......519, 598 correction of, by registrar...................419, 516, 595 damages in case of ..................... 451, 512, 591 recovery of land in ease of ................430, 511, 591

Mortgage, renders certificate of title inconclusive..........430,524, 565

acceleration clause in, relief from. 
Mortgage, continued

by homesteader forbidden.

493,574

certificate of charge for. .

$444,493,577$

form of

$.550,633$

certificate of satisfaction by judge.

497,575

discharge of

497,574

form of.

538,616

distraint under.

... 438

filed.

492,573

form of affidavit with

534,621

filing during application to bring under new system

435,492

foreclosure, under.

$438,493,574$
$\ldots .441,495$

after abortive sale

form of

$458,533,620$

has effect as security but not transfer.

$436,493,574$

implied covenant in, to execute further necessary instrument. .483, 564 to indemnify against in transfer.

$433,483,567$

interpretation of

$405,465,552$

notice of intention to exercise rights under

439,494

of mortgage.

436,499

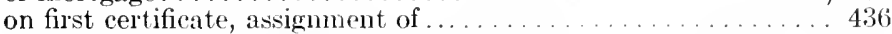

payment where mortgagor out of province

$443,498,575$

possession under.

438,494

proceedings in court under

493,574

recovery of land under.

retention of duplicate certificate in case of

438

short forms of eovenant in.

$444,493,577$

title of executor to

$500,535,577,623$

transfer of

503,580

form of

$436,499,576$

rights arising on.

$459,543,622$

$437,499,577$

transmission to executor.

502,579

Mortgage of mortgage .

436,499

rights arising on ..

437,499

Mortgagee,

entry into possession by .

executes instrument to proteet sale under mortgage

440,495

first, has rights of holder of legal estate. .

439

special rights of entry and distress of

$43 \mathrm{~s}$

493

hail insurance by

interpretation of

$405,466,5,52$

proceedings in supreme court by

493

rights when land brought under new system

413

sale by

Mortgagor,

inplied covenant to execute further necessary instruments.. 483, 564

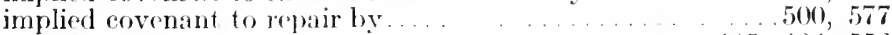

interpretation of ........ $\ldots 45,466,552$

may requide transfer to third ialty instead of discharge. . . . . . 497

relief from aceoleration clatuse. . . . . . . . . . . . . . 443, 497

New districts,

transfer of records to. . . . . . . . . . . . . . . . . 407

New system,

all land in any one instrument to Jo under . . . . . . . . . . 432

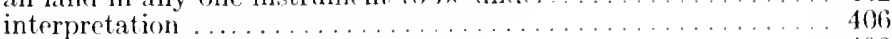

"subject to the," interprotation of . . . . . . . . . . . . 406

"under the," interpretation of ...................... 406 
Notice, Notices,

unless fraudulent, does not affect dealing.........434, 521, 605

of action against registrar $\ldots \ldots \ldots \ldots \ldots \ldots \ldots \ldots 42,513,592$

of application for foreclosure, service of . . . . . . . . . 442,496

omission to give not to affect parties. . . . . . . . . . . .529, 566

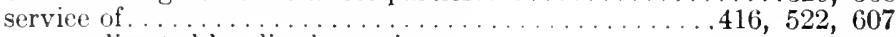

as direeted by district registrar . . . . . . . . . . . . 417

on agent within jurisdiction. .................. 416

on person deceased over one year . . . . . . . . . . 416

to be published in Manitoba Gazette................. 417

Occupier,

distress by mortgagee on ........................ 438

Offices,

land titles, establishment of ............407, 471, 554

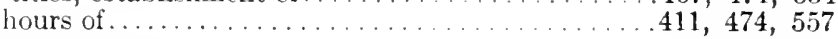

Old system,

instrument registered under new system . . . . . . . . . . . 432

Owner,

interpretation of . . . . . . . . . . . . . . . . . 406

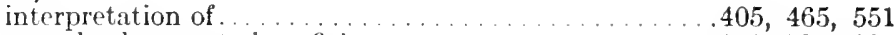

must lend name to beneficiary. . . . . . . . . . . 454, 524, 604

Party wall agreement,

rights under, run with land _ _ . . . . . . . . . . 433

Patent,

interpretation of ......................... 406

ten years old or over on investigation of title.......... 417

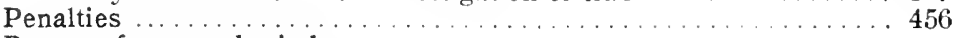

Person of unsound mind, bringing land of, under new system _............ 414 committee of, may take steps … . . . . . . $456,521,604$ interpretation of...

Personal representative, See "Executor."

Petition, Plans,

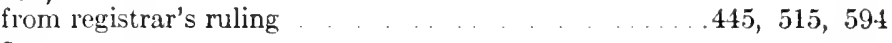

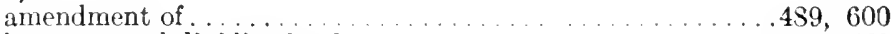

by owner subdividing land . . . . . . . . . . . . . . 457

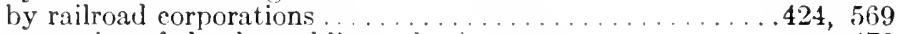

correction of plan by public works department . . . . . . . 479

dedication of streets by ........................ 423

defect in, correction of by registrar ................ 424

for opening street, etc., under The Municipal Act . . . . . . . 425

incumbrancee must sign . . . . . . . . . . . . . . . . . . . 601

instruments may not defeat regulations regarding . . . . . . . .601

may be required by distriet registrar . . . . . . . . 425, 486, 568

not binding unless sales under................489, 600

of Dominion government lands exempted from rules . . . . . . . 426

of drain or water right....................... . . . . . . . .

of road, before issue of certificate . . . . . . . . . . . . 479

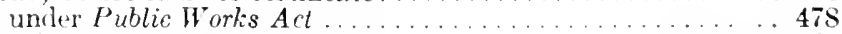

of suldivision, requirements as to ...........

registration required before sale of land under …...423, 568

required, prior to agreement of sale . . . . . . . . . . . 601

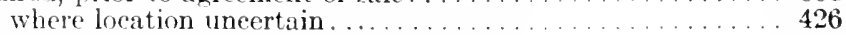

requirements of department of public works............ 601 
Plans, continued

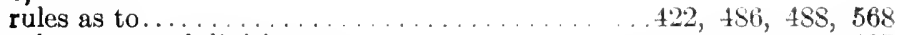

subsequent subdivisions on ................... 487

surveyor's certificate, form of ...........463, 549,632, 634

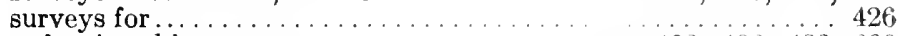

to be signed by owner................ $423,486,488,600$

under special Acts................. . 487

verification of by officer of land titles office... . . . 423

vest streets, etc., in Crown................ 488

\section{Possession,}

interpretation of .... $\quad \ldots \ldots \ldots \ldots \ldots \ldots 46,553$

Power of attorney,

authorized...

authorizing bringing land under new system

$454,500,578$

book of record of .

.. 414

form of record of ..................... 501

form of ........................ 541,626

in case of death ........................ 454

ordinary form accepted................. 501,578

revocation of . . . . . . . . . . . $51,57 . \ldots \ldots \ldots \ldots$

form of . . . . . 542, 627

specific ..................... 501,578

\section{Proceedings,}

abatement of .

$455,525,6(k)$

Receiving book,

to be kept..

\section{Recovery of land,}

References, action for, eases of

409,474

$429,511,594$

by registrar.

515,594

form of .

548,631

\section{Register,}

interpretation of.

Registrar,

to be kept......

$406,466,552$

$+76,558$

See, also, "District Registrar."

abstracts by................. 474,556

appointment and qualification of ....... 472,554

calling in duplicate certificate, ineorrect instrument, etr . . . 516, 595

certified copies by ...................... . . . 74,556

corrections by ........ ........... . . 595

deputy and assistants.............. _ _ $\quad 472,555$

examination of instrumen ${ }^{+} \mathrm{s}$ by ............ 474,566

forwards copies to district registrar. .............. 413

interpretation of ................... $405,466,553$

may require evidence as to age ........... . 529, 608

not liable or bona fide act. . . . . . . . . . . . . .473, tion

not to act as conveyancer, etc............

oath of offie:

408,555

petition rom.

reference by.

re ec'ion of instruments by.

$445,515,594$

$.515,594$

474,566

sec rity of .

555

Registrar general,

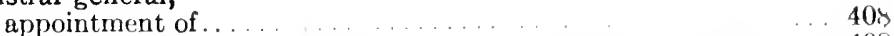

deputy of ..................... 408

may correct plan .. $\quad 424$ 
Registrar general, continued

may require certification of plan . . . . . . . . . . . . . . 423

qualification of .............................. 408

\section{Registration,}

affidavits of execution, identity and age............ 432

eaveat against. See "Caveat."

contents of memorandum of .

477,558

embodiment of instrument in register on ...............441

indorsement of on instrument .................. 431

indorsement on duplicate certificate upon........431, 477, 558

in new districts carried on in old .................. 471

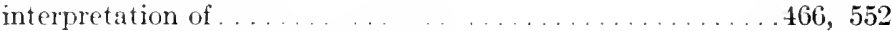

irregularity in cured... $\quad \ldots \ldots \ldots \ldots \ldots . \ldots 45,528,606$

operation of instrument on . . . . . . . 431, 483, 486, 558, 564

against bona fide transferee on ........ . . . 432, 484, 566

order of

priority according to thine of . . . . . . . . . . . . . $431,485,558$

proof of ................. 431, 477, 558

rejection of instrument presented for . . . . . . . 432, 474, 566

valicl after death of maker of instrument.. . . . . . . . . . . . 455

Reservations,

in Crown grant, excepted from certificate of title . . . 428, 484, 565

\section{Right of way,}

excepted from certificate of title ................ . . . . . 28

public, excepted from ecrtifieate of title. $\quad \ldots \ldots 4 \$ 4,565$

statutory, excepted from certificate of title........... 565

Road allowance,

abandonment of ..... _ _ . . . . . . . 560

closing by notification. $\quad \ldots \ldots .479$

transfer of ............. 479

under Public Works Act ... . . . . . . . 602

Rules and regulations,

of Lieutenant Governor in Council . . . . 529, 606

\section{Sale for taxes,}

caveat under.

507,583

confirmation of transfer. .

507,583

form of transfer

545,628

time of registration of transfer.

507,583

Sale under power,

advertisement of private sale.

442,496

distribution of proeceds.

441,495

in mortgage.

440,494

without notice

... 440

purchaser's rights on sale.

440,495

rinsfer to purchaser, rights under

441,495

Saskatchewan,

Land Titles Act . . ... . . . . . 465

Seal,

of registrar.....

$.409,473,556$

Sheriff,

confirmation of sate by . ............... . . . . 506,582

Short covenants,

in lease.

in mort gage. 
Streets,

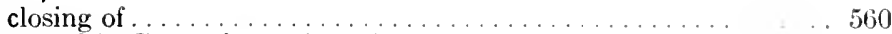

vested in Crown by registration of plan ... . . . . . . . . . 488

Subdivision plans,

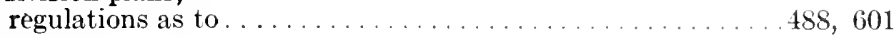

\section{Summons,}

by distriet registrar . . . . . . . . . . . . . . . . . . . . . 419

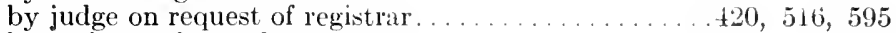

by registrar, form of ........................ 464

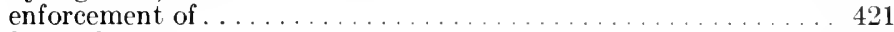

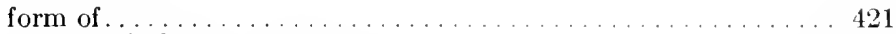

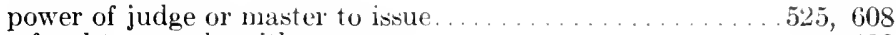

refusal to comply with ...................... 420

\section{Tariffs,}

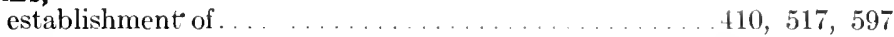

Taxes,

unpaid, excepted from certificate of title........428,484,565

Tax sale purchaser,

may not direct issue of title to third person .......... 414

Tax sales,

applications to bring land under new system under ........ 417

value of land under $\$ 200 \ldots \ldots \ldots \ldots \ldots \ldots \ldots \ldots \ldots \ldots . \ldots \ldots$

where land already under new sysicent............ 418

\section{Territories,}

interpretation of . . . . . . . . . . . . . . 553

Transfer,

delivery up of duplicate certificate to permit registration. . .4\$6, 567

executor to himself . . . . . . . . . . . . . . . . . 431

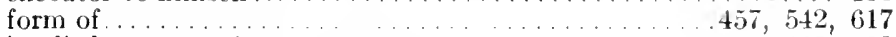

implied rovenant in .. $\quad \ldots \ldots \ldots \ldots \ldots \ldots \ldots \ldots 33,483$

interpretation of . . . . . . . . . . . . . . . . 465,551

of joint interests among themselves. . . . . . . . . . . . . 431

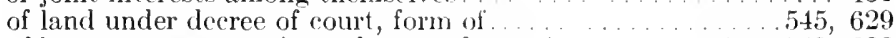

of lease, mortgage or incumbrance, form of . . . . . $459,543,622$

under decree of court, form of . . . . . . . . . . . . .

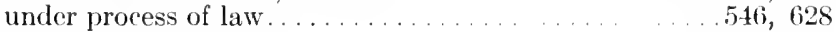

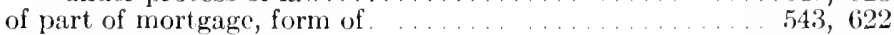

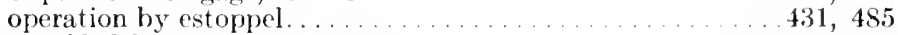

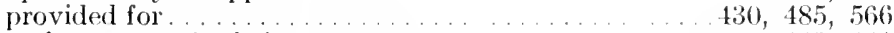

under power of sale in 1hortgage . . . . . . . . . . . .440, 441

under process of law. . . . . . . . . . . . . . . . . . . . .

form of ... $\quad .544,627$

time for registration of . . . . . . . . 506, 583

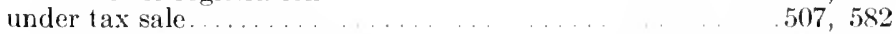

form of . $\quad . \ldots \ldots \ldots \ldots .628$

words of limitation not required ..... . . . . . 431, 485

\section{Transferee,}

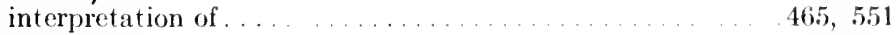

\section{Transferor,}

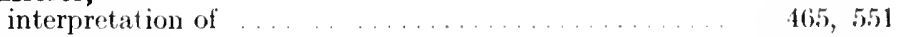

\section{Transmission,}

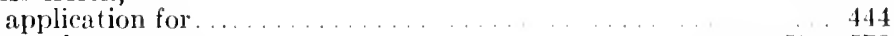

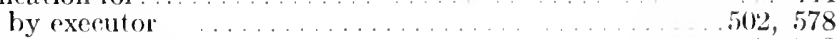

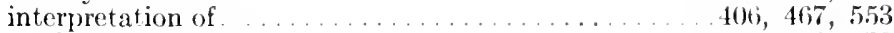

on death . . . . . . . . . . . . . . 502,578 
Trustee,

application to remove. . . . . . . . 503,580

Trusts,

$452,518,598$

assurane fund not liable for breach of

$\ldots \ldots, 434$

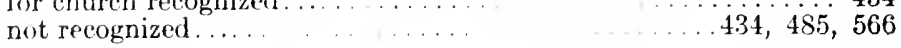

Valuator,

interpretation of 


\section{APPENDIX G \\ GENERAL INDEX}

Nore. $-(n)$ placed after a page number indicates reference to a foot note.

Absolute fee,

registration of, in British Columbia.

Abstract of title,

vendor not required to produce same on a sale.

Acceleration,

defeated by statute.

Action for damages,

against whom brought. .

Address for service, omission of, in caveat fatal .

Adjoining owners, unregistered, rights of inter se

Adverse possession, for full statutory period before reeognition..

"merely" in section 75, Manitoba..... . . . . 145

nature of possession required......... . . . . . 146

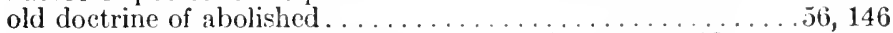

person in should oppose other application for first certifieate. . . 56

rights of, against first certificate ..... . . . . 142

against registered owner . .................... 143

rights under, excepted on first certificate of title in British Columbia ......... 55 in Manitoba..................... 55

in Ontario.................. 58

rights under, in other jurisdictions . . $\quad \ldots \quad 56$

runs from date of existing certificate. . 145

Advertising,

in sale under power. . . . . . . 330

Affidavit, defeetive, invalidates caveat..... 78

Affidavit of execution, party to instrument disqualified. . 113

solicitor of the grantee, by ...... 114

sworn before whom.......

technieal irregnlaritios in... $115,189,190$

where requisitt ........... 111

Affidavit of value,

registrar to be satisfied with. $\quad 206$

Agreement for sale,

See "Contraet of Sale."

Agreement to give mortgage,

equitable inort gager. . .

not permissible as special covenant in incumbranees. 286

Allodial ownership,

corresponding to ownership of personal property. 
Application for transmission, with transfer under power of sale . . . . . . . . . . 336

Application to bring land under system, agent of owner in Alberta and Dominion, by .......... 70

specific authority generally requirer ......... 70

amount of land in .................. 71

dealings with land pending. ...... . . . . . . . 73

directions to convey to other party in ... . . . . . . . 72

disposal of documents filed upon … ‥

full disclosure in ............................ 72

meaning of "possession" in . . . . . . . . . . . . . 71

title required to be shown ... _ . . . . . . . . . . 64, 74

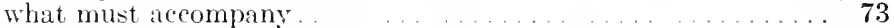

who may make. ......................... 70,71

Assignment for general benefit of creditors,

absolute ownership of assignee. . . . . . . . . . . . 270

indorsement of executions on transmissions under . . . . . . 140

inoperative against subsequently acquired property ....270, 271

priorities against execution ereditors. . . . . . . . . . . 270

priority over unregistered instrument, no _ . . . . . 192, 193

Assigns,

proceedings on ................. . . . 269

seizure of goods of by mortgagee . . . . . . . 303

Assurance fund,

absent in certain Acts...... . . . . . . 202

action against, limitation of .... . . . . 219

payment of claims without . . . . 227

pleadings in ........... . . 217

amounts collected under................ 206

established in British Columbia in 1s9s ..... 26

liability of $\ldots \ldots 207$

direct ............220, 221

for damages uncollectable. . . . . . . . . . . . . 212

for improper new duplicate without negligence... . . . . 60

for registration of court order withont jurisdiction . . . . . . 96

in Manitoba...................... . . . 225

in Saskatchewan, Alberta and the Territories . . . . . . . 207

instruments executed by corporations. . . . . . . 49,95

primary and secondary........ 207, 208

relieved by negligence of party $\ldots \ldots 214$

where none for damage. . . . 212

nature of ........... 202

protection of, limit to............. 102

on liringing land uniter system $\quad \ldots \ldots 66$, 85

sources of . . . . . . . . . . . . . 205

Attachment, order of, excepted from eertificate of title in Manitohit $\ldots \ldots \ldots, 51$

Attestation of instruments,

corporation, lyy $\ldots \ldots 112$

party thereto, by $\quad \ldots \ldots \ldots 113$

requirement of ..... . . . . 111

Attorney General's Department,

controls arlministration of systems.... . . . 34

Attornment,

clause rreates tenancy by estoppel only . . . . . . . 293

distress under............ . . . . 303

in mortgage...... . . . . . . . . 293 
Australia,

decisions in, recognized in Canada ...........

Beneficiaries,

rights of, against personal representative. . . . . . . . . 24!

Bills of Sales Act, English, irregularities in registration under . . . . . . . . . . . . . 190

"Binds,"

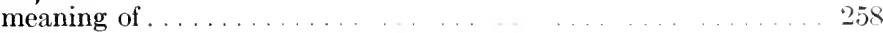

Books,

caveat book ........... ........... . . 41

day book......... . . . . . 43

deposit book......... . 46

fee book.............. $\quad . .44$

generally............ 43

general register......... 46

land index................ 46

power of attorney book. . . . . . . . 46

transfer journal.................... 44

Bringing land under the system,
adverse possessor, rights of preserved . . . . .

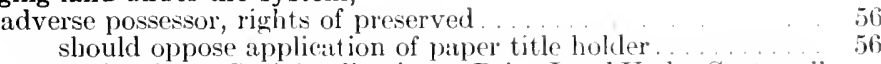

application for. See "Application to Bring Land Under System."

assuranee fund to be protected on ... . . . . . . . . . . 66, 85

complicated titles outside of Manitoba.............. . . 86

consideration of extraneous evidence... $\ldots \ldots \ldots . . \ldots .65$

definition of . . . . . . . . . . . . . . . . 61

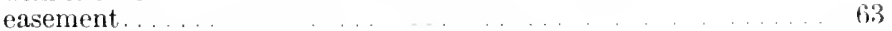

estates less than fee simple. . . . . . . . 62

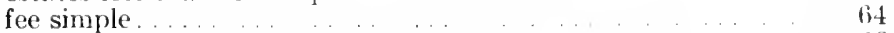

interests which may be brought under. ... 63

leaseholds............... . . . . . . . . 61

not otherwise registerable interest $\quad .64,74$

onee under, alway's under. . . . . . . . . . 62

possession, on evidence of ... . . . . . . . . . . 66 i

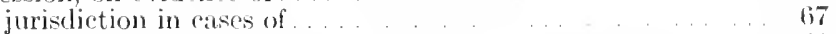

prior to first certificate, land not under... . . . . . 199

registrar, duties of as to examining title ... . . . . 74

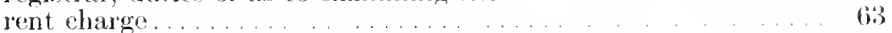

rights of third parties in their absenee guarderl. . . . . 75

simple cases, granting of rentificates in... . 7.1

undivided interests.

unpatented land . . . . . . 63

British Columbia,

approach of legislation to true Torrens system... . . 26

indefeasible and absolute fors in ........... 25

introduction of 'lorrens system into....... 24

\section{Caveat,}

See, also, "Caveat agamst Bringing Lamd I ndor System."

address for servier in

against bringing land under system. See "Caveat Against Bringing Land Indor System."

agent, anthority of to filc.....

general rulo dotermining .. . 376

by crstui que trust. ... . . . . . . . 3665

by registrar. See "Catveats by Rrgistrar."

cestuis que trustent shombl filo... 178 
Caveat, continued

claiming under execution.

effect of. See "Effect of Caveat."

excepted from certificate of title in Manitoba.

form and contents of ...................... 371

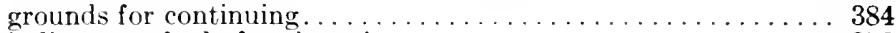

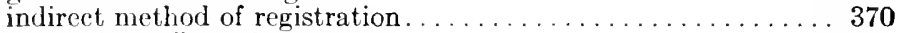

injunction, effect of as . . . . . . . . . . . . . . . . 374

irregularities in, different rule from other cases. . . . . . . . . . 191

justifies court proceedings to distribute surplus . . . . . . . . . . . . 340

lapse of. See "Lapse of Caveat."

as abandonment of claim ................. 386

nature of claim to be stated ... . . . . . . . . . . . . 372

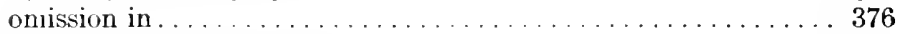

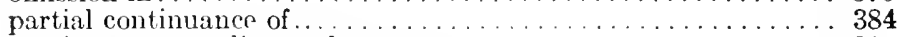

parties to proceeding under. . . . . . . . . . . . . . . 385

petition under, differing from caveat, dismissed . . . . . . . 381

priorities of . . . . . . . . . . . . . . . . . . . 394

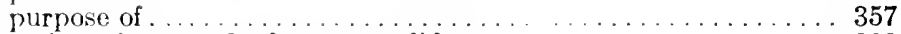

registration merely does not validate... . . . . . . . . . 382

right to file prior to patent . . . . . . . . . . . . . . . . 358

second, without permission ineffectual.............. 381

summons under, not a trial. . . . . . . . . . . . . . . . 383

merits heard on ....................... 383

technical objections not fatal..... . . . . . . . . . . 382

under adverse possession . . . . . . . . . . . . . . . 365

under elaim by creditor under 13 Eliz. . . . . . . . . . . 366

under claim to proceeds of sale.... . . . . . . . . . . . 365

under deposit of title deeds . . . . . . . . . . . . . . . . 365

under lien note, forbidden.................... 370

under mortgage before recommendation for patent ....... 370

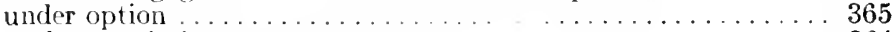

under restrictive covenants . . . . . . . . . . . . . 364

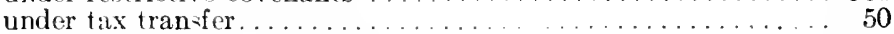

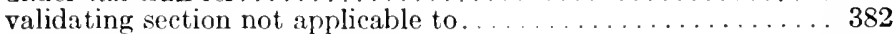

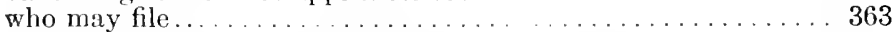

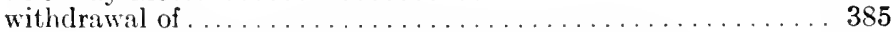

written instrument only ground for in Saskatchewan . . . . . . 366

Caveat against bringing land under system,

See, also, "Caveat."

absence of, not proof of title . . . . . . . . . 85

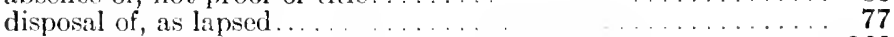

duration of . . . . . . . . . . . . . . . . . 360

generally........................... 77

lapse of, may be waived by caveatee . . . . . . . . . . . 360

on withdrawal of application ..... . . . . . . . . . 360

neglect to file, relieves assurance fund . . $\ldots \ldots \ldots \ldots . \ldots 213$

proceedings after disposal of . . . . . . . . . . . . . . . 84

second caveat after dismissal of petition. $\quad \ldots \ldots \ldots \ldots .79,84$

special necessity of, in Manit oba. . . . . . . . . . . . 358

statutory effeet of, as injunction. . . . . . . . . . . . . . 37,36

strict compliance with statute in .............. 78

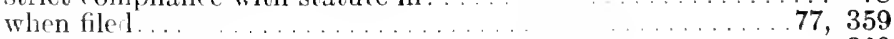

who may file. . . . . . . . . . . . . . . . . . 360

Caveat by registrar,
jurlge's order in place of in Saskatchewan. . . . . . . . . . 362

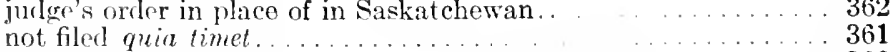

tromination of . . . . . . . . . . . 362

where filed . . . . . . . . . . . . . 361 
Careat, second,

Caveator,

See "Second Caveat."

lien of

130,131

may obtain injunction. . . . . . . . . . 390

must show chain from registered owner . . . . . . . . . . 373

nature and particulars of claim required ............... 372

rights in distribution of surplus proceeds of sale . . . . . . . 339

served with notice of exercising power of sale . . . . . . . . 321

si nature by agent........................... 375

Certificate of title,

accuracy of description of land in............ . 58

back of, indorsement of incumbrances on ...... . . . 58

indorsements on in Manitoba.................... 58

conclusiveness of, absolute except in case of fraud $\quad 162,163$

exceptions to........................ 153

in favor of bona fide purchaser ............. . . 162

in favor of all persons...................... 91

deposit of, as equitable mortgage............ 275

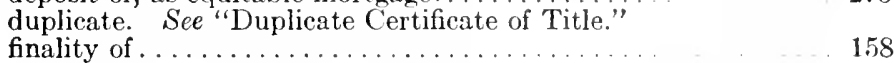

first, proceedings under mortgages on ......... $\quad 318$

generally .......................... 46

indorsements on each, equivalent to certificate..... 91

initials may be rejected in ..................... 47

limitation of estate in.................... 47

literal meaning of ...................... 47

owner, address of in . . . . . . . 58

full name of in ................... 47

not enabled to defeat his own contracts....... 164

rights arising after date of .............. . 198

rights not included in........... 48,49

Coleridge, L. C. J.,

comments on Torrens system. . 15

Company,

See "Incorporated Company."

Conditions of sale,

$\mathrm{E}_{\mathrm{a}}$ depreciatory............... 327

7 prior incumbrances in ........... 330

$r$ under power............... 326

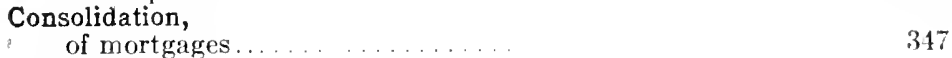

Contract of sale,

damages where land under system..

enforcrable under system...................139, 178, 199

equitable interests in land under system established by .........

exceptions and reservations under Acts not implied in ... . . 152

executory, effect of notice of equity on ............... 175

payment under, notwithstanding subsequent registration . . . . 193

priority to exceution or judgment. ............... 179, 192

uncnforceable for a time in South Australia.... 127

vendor, duty of as to registration.......

not required to produce abstract. .

Conveyancing practice,

as regards land under system.......

duty of vendor on registration.. 
Conveyancing practice, continuel

production of abstract. ...................... 150

reservations and exceptions.................... 152

Corporations,

Costs,

See "Incorporated Company."

against Crown ............................. 83

security for, in petition proceedings . . . . . . . . . . . 83

on issue . . . . . . . . . . . . . . . . . 83

Courts,

juriselietion in foreclosure assumed by . . . . . . . . . . . 312

jurisciction of................................ 146

statutory preservation of .................. 147

to reopen statutory foreclosure.................. 345

mortgage proceerlings through . . . . . . . . . . . . . . 295

operate by order on owner in Australia ................. 149

Covenants,

registrar not necessary party to proceedings in Canada....... 149

action on, always in supreme court . . . . . . . . . . . . 314

extinguishert by foreclosure... _ . . . . . . . 316

implied, are assignable........ . . . . . . . . . 238

for payment cause merger.

in foreclosure order.... . . . . . . . . . 315

in mort gage. . . . . . . . . 28. 287, 348

in transfer.... .............. 235

in mortgage, action on. $\quad \ldots \ldots \ldots \ldots 314$

Covenants for title,

transfer, none impliert in $\quad \ldots \ldots \ldots \ldots . \ldots 230$

Creditors' Relief Act,

Crown,

Torrens Aets subject to ... _ ...... 140

Damages,

bound by limitations of system. _ . . . . . . . 69

Siee, also, "Action for Damages."

artion against assurance fund .............221, 225

hat of other remedies as ground for $\quad \ldots, 222$

defences to 212, 224, 226

limitation of .......................... 219

actual, refuired to revover from assurance fund $\ldots \ldots .218,227$

effert of system on common law rule... . . . . . . . . 150

measure of value of land in action for $\ldots \ldots 218,219$

Day book,

comnon to all juristictions........ . . . ......... . 43

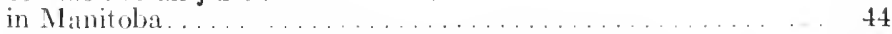

only instrumentis fit for registration to be entered in ........ 44

time of entry in, fixes priority ... . . . . . . . . . . 44

Decrees or orders, rourt will not make roving decree $\ldots \ldots \ldots \ldots \quad \ldots \ldots .53,54$

Deed, excepted from certificate of title ... . . . . . . . 51

distinet from transfer. . . . . . . . . . . . . . . . 230

effect of transfer as . .......................... . $23 \pm$

Default, possession of, required under old systems $\ldots \ldots \ldots{ }_{7}$

length of, required for sale proceedings $\ldots \ldots \ldots \ldots \ldots \ldots .325$

Deposit of certificate of title,

as equitable mort gage. . . . . . . . . . . . . . . . . 275

statutory equitable mortgage in Ontario. 
Deposit of title deeds,

as equitable mortgage under system

creates interest in land... . . . . . . . 209

Deprivation of land,

by dual grants or certificates...... . 198

by misdescription. . . . . . . . . 196

contrasted with disposition of land. $\quad 209$

date of .................... 219

distinguished from loss or damage.... 221

meaning of, restricted .... 209

mortgaging is, pro tanto ... . . . . . 209

recovery in case of fraud........ 195

Description,

accuracy of, required in certificate of title. 58

in instrument.................. 109

in instrument must show all exceptions... 109,110

Directions for sale,

alteration of ........... 331

registrar's discretion on ... . . . . . . . . . . . . . . . . . .

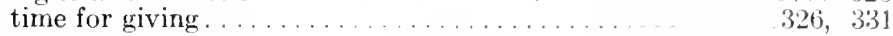

Disability,

transfer by person under, liabilty of assuranee fun! 216

Discharge of mortgage,

assignment in place of

351

by judge's certificate........... 350

mortgagor absent from provinee............. 351

requisites of ........ . . 350

Discretion,

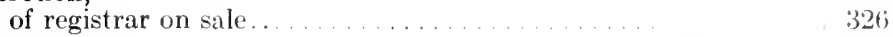

Distress,

contractual right extended beyond mortgagor's goods 302

limited to goods of mort gagor or assigns. . . . . .30;3

independently of courts ... 296, 297

right of mortgagee... $\quad 291$

under attornment clause.. 293

Distribution of proceeds,
caveator's rights. . . . . 3i39)

Creditors' Relief ict applies to.

doubts arising on ............... 340

mortgagee may require striet proof in ..... :33.

mortgages introvening between executions. . . . 33:9

nothing to excoution crectitor where land exempt 330

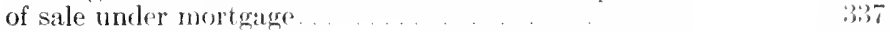

rolease by claimants... . . 310

stayed to let in caveator....... 340

District registrar,

Sce "Registrar."

Drminion Lands Act,

mortgage by homestearler prohibited by. . 281

Duplicate certificate of title,

custorly of .......... I1ti

distinguished from arertificate. 59

holder reguired to deliver up

loss of, ind issur of new. .... (i)

$\begin{array}{ll}\text { production of, dispensed with } & 116\end{array}$

may determine priority . 116

reguiled . . . . . . 115 


\section{D uplicate certificate of title, continued}

reason for . . . . . . . . . . . . . . . . . . . . 58

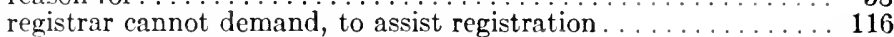

right of correction on impounded . . . . . . . . . . . . . . 200

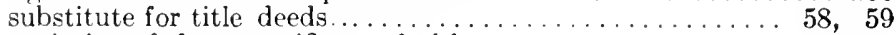

variation of, from certificate of title........... 59,60

Duress,

when ceases to be such................... 59

actual fraud by . . . . . . . . . . . 170

Easemeat,

acquired under Irrigation Act excepted from certificate in Sas-

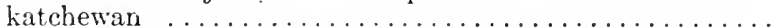

acquired under statute excepted from certificate in Alberta. . . . .

created by use of transfer form ..................... 233

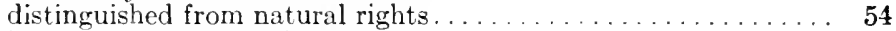

in gross, not existent in law................... 55

over unregistered land cannot be brought under system........ 63

public, excepted from certificate of title ............ 54

unity of ownership extinguishes................ 54

Effect of caveat,

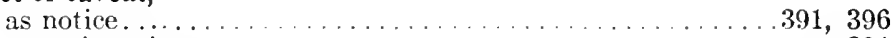

as registration $\ldots \ldots \ldots \ldots \ldots \ldots \ldots \ldots \ldots \ldots \ldots \ldots \ldots \ldots \ldots \ldots$

"bettering" or "increasing" interest, prevents . . . . . . . . . 399

claim not admitted by taking subject to . . . . . . . . . . . 389

evidence of lack of bona fides..................... 401

generally . . . . . . . . . . . . . . . . . . . . . . . . 400

in Canada and Australia compared . . . . . . . . . . . . 398

injunction not as . . . . . . . . . . . . . . . . . . . 388

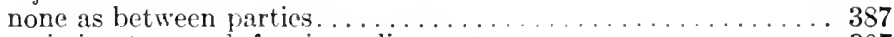

omission to search for, is negligence... . . . . . . . . . . 397

on equities, equal and unequal. ................. 394

Ejectment,

"subject to the claim of the caveator" . . . . . . . . . . . 389

recovery of land under Act is . . . . . . . . . . . . . . 194

Eng!ish legislation,

Acts of 1875 ineffective $\ldots \ldots \ldots \ldots \ldots \ldots \ldots \ldots \ldots$

summary of Acts and reports. . . . . . . . . . . . . 9

Equitable estates,

abolition of, under system. . . . . . . . . . . . . . . . 128

cause of complexity in titles. . . . . . . . . . . . . . . . .

conferred by unregistered instruments................. $\ldots \ldots$

equitable rights, distinguished from . . . . . . . . . . 131, 134

in registered land . . . . . . . . . . . . . . . . . . . . . . 137

necessary under system . . . . . . . . . . . . . . 132

not identical with "unregistered" interests . . . . . . . . . . 137

personal right only under the system.... . . . . . . . . 127

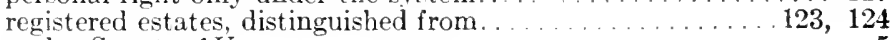

under Statute of $U$ ses. . . . . . . . . . . . . . . . . . 5

Equitable interest,

See "Equitable Estates."

not bound by execution. .... . . . . . . . . . . . 261

Equitable mortgage,

agrcement to give mortgage. . . . . . . . . . . . . 275

compared with incumbrance. . . . . . . . . . . . . . . 349

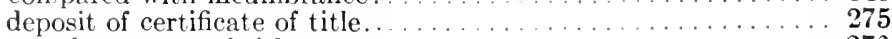

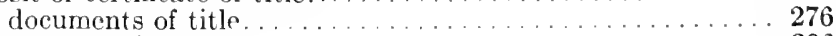

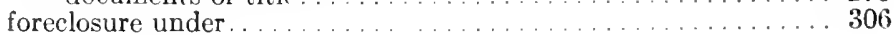


Equitable mortgage, continued

generally.................... . 274

transfer absolute in form . .................. . . 278

Equitable mortgagee,

right to sell under........................ 278

registered transferee may be . . . . . . . . . . . . . . . 137

Equitable priority,

registrar cannot determine ..................... 97

except in certain cases in Manitoba................ 100

Equitable relief,

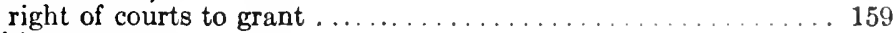

Equities,

Equity,

prevail against registered interest only where fraud ..... 164, 165

Error,

principles of, in Torrens system................. 346

\section{Escheat,}

correction of, by registrar . . . . . . . . . . . . . 199

Estates in land,

125,126

estate for life........................ 1

in fee simple..........................

tail................................. 1

abolished ............................ 48

limitation of, in eertifieate of title ................ 48

none in registered land except on registration........... 129

origin in feudal system ....................... 1

Examiner of titles,

provided in British Columbia ......... . . . . . . . 37

in Manitoba.......................... 37

Exceptions and reservations,

See "Reservations and Exceptions."

Execution,

binds registered interests only.............. 261

confirmation of sheriff's sale under........... 268

contraet takes priority to ....................... 179

costs of withdrawal or satisfaction of .... . . . . . 268

diserepaney in names in ................... 267

distribution on sale under, pro rata............... 264

where ineumbrances intervene.............. 264

exeepted from eertificate of title .................. 51

"filing" distinguished from "registering" . . . . . . . . . . . 266

indorsed c $n$ certificate of title notwithstanding exception ...... 51

renewal, satisfaction or withdrawal of ................ 267

sale under................................. 256

time for presentation of transfer ......... . . . . . 268

transfer, unregistered, takes priority to .... . . . . 265

writ of . . . . . . . . . . 267

filing of, as a seizure . . . . . . . . . . . . . 259

lien of . .................... 257

Execution creditor,

cannot share in proceeds after mortgage sale . $\ldots \ldots \ldots .339$

under expired writ ................... 339

has not priority over unregistered dealing. . . . . 179, 192, 265

rights of, in distribution where mortgages intervene. $\quad \ldots \ldots .33 !$

Executors and administrators,

See "Personal Representative." 
Exemptions,

claim for, against assignee for benefit of creditors . . . . . . . 270

Expropriation,

Fee book, statutory right of, excepted from certificate of title.

in Manitoba.

Fees of solicitors, dependent in England on folios.................... 6

Feudal system, foundation of English land law . . . . . . . . . . . . . . 1 seisin under, displaced . . . . . . . . . . . . . . . . . . . .

Filing, transfer under.

distinet from registration.

included in registration in Manitoba.

Forced sale,

price not conclusive evidence of value ... . . . . . . . . . . . 219

Foreclosure,

action on the covenant after.

final order of, effect of

generally

inappropriate word under Torrens system .

in Manitoba, originally none ............ 310

jurisdietion of courts in . . . . . . . . . . . . . . . . 306 assumed ............................ 312

notice of application $\quad \ldots \quad \ldots \ldots \ldots \ldots \ldots \ldots 342$

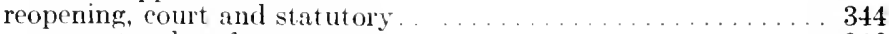

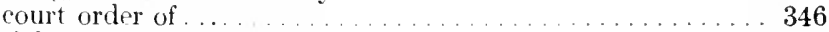

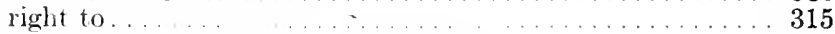

subsequent to abortive sale under power. . . . . . . . . . . 342 applieation for . . . . . . . . . . . . . . . . . . 342 requisites to ... . . . . . . . . . . . . . 342

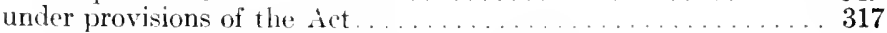

Forgery, of mortgages indorsed on first certificate........... 318

acceptance of forged instrument viewed as negligence....... 214

fraud distinet from . . . . . . . . . . . . . . . . . . . . 168

may pass good title to third person. . . . . . . . . . . . . . 192

to unregistered grantee ... . . . . . . . . . . . . . . . . . . . 192

Forms,

rights under . . . . . . . . . . . . . . . . . . 191

compliance with, necessity of ................ 103, 104

instrument combining two, not registerable ........... 108

Fraud,

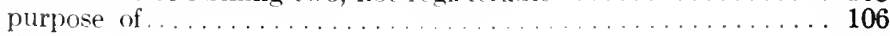

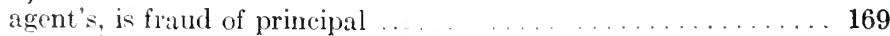

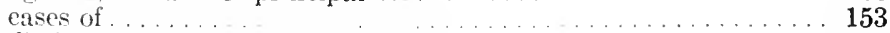

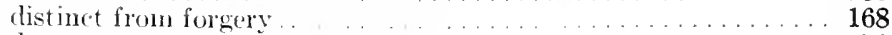

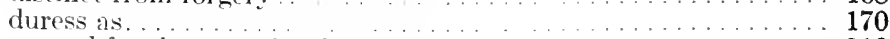

ground for damages for deprivation . . . . . . . . . . . 210

hearsay notice not ground of ................... 154

in equity not necessarily fraud under system. .......... 171, 172

invalidity of eourt order not ground of . . . . . . . . . . . 169

irregularities, notice of, not necessarily. . . . . . . . . . 172

knowledge of improper act as . . . . . . . . . . . . . . 154

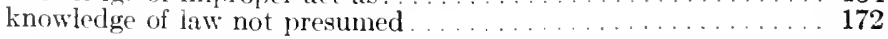


Fraud, continued

means actual moral fraud.

must be brought home to registered owner .

$161,167,173$

notice and fraud.

167,169

recovery of land by person deprived by

165,171

195

registrar's duty on notice of

101

relying on accidental betterment is

168,169

sole ground of equitable claim against registered owner . . . . 164

taking bona fide on a forgery is not . . . . . . . . . . 192

undue influence as ............. . . . . 170

General law,

voluntary and fraudulent transfers identical in effeet ... . . . 154

rights preserved under system...

365

General statement of law, governed by facts of each case

Guaranteed titles,

in United States, compared with Torrens titles

$160(n)$

Guardian,

205

may make application to bring land under system ... .... 71

Hail insurance,

by mortgagee. ........... . . . 348

Highways, public,

excepted from certificate of title... 51

Holmested, George S.

address on Torrens system. .

writes on Torrens system, 1876. ... 18

Homestead, mortgage of, prohibited.

Implied covenants,

See "Covenants."

Incorporated company,

assumption that seal properly affixed

112

dealings by, assurance fund protected in saskatchewan.. $\quad 217$

duty of person taking from.

216

execution of instruments by.

seal of .

verification of execution

Incumbrance,

analogy to equitable mortgage. .

cannot include agreement to give niortgitge. $\quad 286$

differeness from mort gage. . . . . 349

remedies under..... $\quad 349$

sale and foreclosure proceedings under.

use of ................ 349

Indefeasible fee,

Infant, registration of, in Britisl Columbia

transfer by, liability of assurance fund $\quad 216$

Injunction,

caveator may obtain.....

390

Inspector of land titles offices,

powers and duties of, in Alluret:

in Nortliwest Territori . 36

Instrument,

delivery up for correction. .

examination of, for registration... $\quad 92$

fitness of, for registration........ 103

description in, to show all exceptions... . . . . . 109, 110 
Instrument, continued

embodiment of unregisterable instrument invalidates...... 103

identity of parties in ....................... 109

must be capable of registration against all property therein . . 109

of dual nature not registerable.................. 108

to be complete in view of future registrations....... 110, 111

variance from forms in ................... 103

may be referred to as evidence after registration............ 91

memorandum of incumbrances in. necessity for... . . . . . . 240

old system, registerable in Manitoba ................. 92

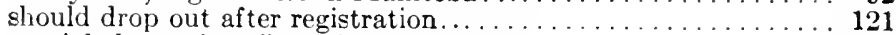

special clauses in, effect of registration on ............. 183

validity of duty of registrar as to . . . . . . . . . . . . . 93

Interests in land,

include equitable interests. . . . . . . . . . . . . . . . 208

Irregularities,

affidavits of execution, in ....................... 115

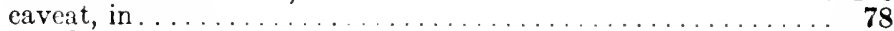

cured by statute.......................... 187

petitions in Manitoba, in . . . . . . . . . . . . . . 79

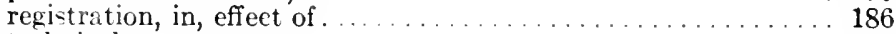

technical .............................. 189

Irrigation Act,

Issue,

right of way or easement under, protected in Saskatehewan . . . . 57

confined strictly to question to be tried . . . . . . . . . . . 83

determines nothing but question tried .............. 83

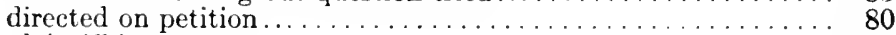

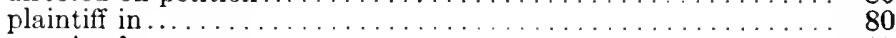

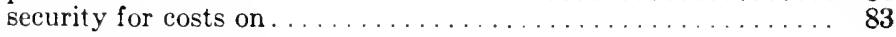

Judge of superior courts,

acting as persona designata, limitation of powers of . . . . . . 42

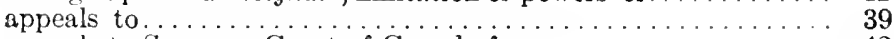

appeals to Supreme Court of Canada from . . . . . . . . . 42

cannot hear new evidence on appeal. . . . . . . . . . . 40

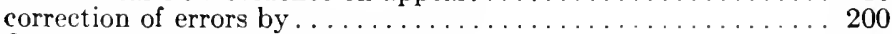

does not extend to local master..................... 42

duties on applications to bring under new system . . . . . . . 76, 86

limitation of powers of, on eaveat applications . . . . . . . . 384

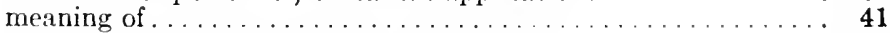

order of, in place of caveat by registrar ... . . . . . . . 362

powers of, in an action....................... 201

Judgment,

technical rules, not strictly bound by . . . . . . . . . . . . 42

See, also, "Execution."

binds equitable interests in Manitoba. . . . . . . . . . 264

defeated by prior unregistered transfer . . . . . . . . . . . . 265

excepted in Lanitoba from certificate of title .......... 51

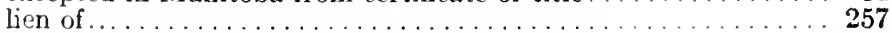

registrar may decide priorities . . . . . . . . . . . . . 266

sale under............................ 256

Layse of caveat,
by effluxion of time $\ldots \ldots \ldots \ldots \ldots \ldots \ldots \ldots \ldots \ldots \ldots$

by effluxion of time $\ldots \ldots \ldots \ldots \ldots \ldots \ldots \ldots \ldots \ldots \ldots \ldots \ldots \ldots \ldots \ldots \ldots \ldots \ldots \ldots \ldots \ldots \ldots \ldots$
summons. $\ldots \ldots \ldots \ldots \ldots \ldots \ldots$

claim not supported by case made .................. 382

evidence of abandonment of claim. . . . . . . . . . . . 401

non-compliance with Act fatal. . . . . . . . . . . . . 381 
Lapse of caveat, continued

notice by person interested................ 379

not recognized in Manitoba............ . 379

notice by registrar terminating. . . . . . . . . . 377

not continued after thirty days......... . 378

summons continuing.............. 378

where rights of third parties involved . . . . . . 379

who may require service.............. 377

technical objections to continuing. . . . . . 380

Lapse of time,

Land, terminating caveat .................. 377

interpretation of . . . . . . . . 63

Lease and release,

common form of conveyance............. 5

Leases,

by mortgagee under Acts . . . . . . . . . . . . . . . . 346

form of ........................... 352

not exceeding three years excepted from certificate of title . 51

not required under seal. ..................... 352

option by executor in . . . . . . . . . . . . . 251

option of purchasing. . . . . . . . . . . . . . . . . . 354

by executor ...................... 354

right of mortgagee to make. . . . . . . . . . . . . . . . . 294

in Saskatchewan.................. . . . . . . 298

statutory covenants in unregistered . . . . . . . . . . . . 352

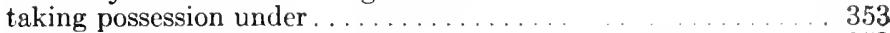

termination of .................... . . . . 353

unregistered, give right of action . . . . . . . . 179

Legal estate,

distinguished from registered estate ........ . 123

in first mortgagee in Manitoba . . . . . . . . . 299-301

under Statute of Uses ..................... 4,5

Letters of administration,

Lien,

as evidence of intestacy ................... 65

none on land under unregistered mortgage ........ 130

Lien note,

caveat under, prohibited ............ 370

Limitation, technical words abolished............................ 232

words of, dispensed with............. 230

Limitation of actions,

against assurance fund in Manitoba.............
in Saskatchewan, Alberta and the Territories

Lis pendens,

doctrine of ....................... 15

excepted from certificate of title in Manitoba

right to file under Land Tilles Act $1894 \ldots . . .158$

Local improvement rates,

excepted from certificate of title in Manitoba...

incumbrance in Ontario . . . . . . . . . . . . 50

Lunatic,

dealings with estate of . . . . . . . . . 271

service of notice on ................ $32 \%$

Manitoba,

inauguration of Torrens system in . . . . . . . . . 
Mason, J. Herbert,

address on Torrens system by .................. 10

second address on Torrens system by .............. 14

Master of titles,

appeal to the Supreme Court of Canada from, eventual. . . . . . 43

constituted appellate tribunal $\ldots \ldots \ldots \ldots \ldots \ldots \ldots \ldots \ldots \ldots . \ldots \ldots$

duties of, in cases of applications to bring under system.......76, 86

powers and duties of, in Saskatchewan............. 35

Mechanics' !ien,

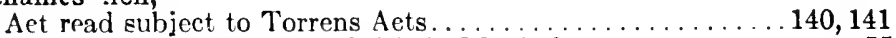

excepted from certifirate of title in Manitoba........... 55

priority of, none outside of Manitoba............... 55

valid on increased value against mortgagee ............ 141

Memorandum of registration,

evidence that instrument completely registered ... . . . . . . . 110

Mierger,

except in case of land in more than one distriet......... 110

of mortgage on transfer . . . . . . . . . . . . . . . . 237

Minor,

registrar eannot receive evidence of intention to determine... . . 238

service of notice on ......................... 323

Misdescription,

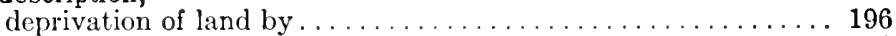

in case of bona fide transferee . . . . . . . . . . . . . . . 198

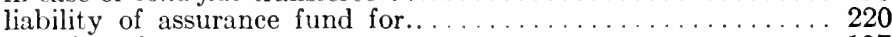

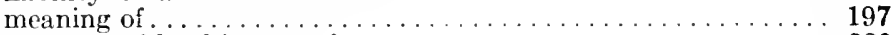

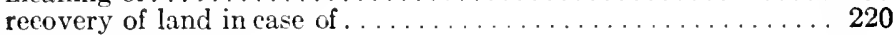

Mortgage,

aeceleration clause in . . . . . . . . . . . . . . . . . 347

action on the covenant.................... 314

agreements to give....................... 275

by homesteader prohibited ................... 281

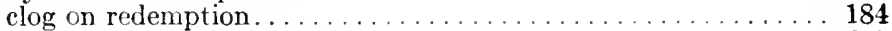

consolidation........................ 347

discharge of. Sce "Discharge of Mortgage."

equitable. See "Equitable Mortgage."

continues to exist...................... 274

foreelosure of, reopening statutory . . . . . . . . . . . 345

in Saskatchewan, Alberta and the Territories. . . . . . . . 307

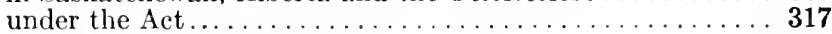

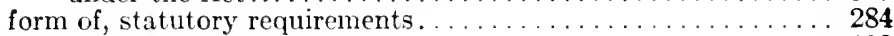

further advanees under ... . . . . . . . . . . . . . . . 193

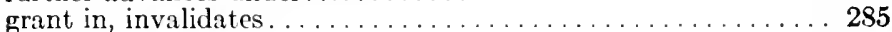

implied covenants in ...................... 287

to repair in . . . . . . . . . . . . . . . . . . . . 348

implied covenant of transferee to assume. . . . . . . . . . 236

legal, term obsolete under system ................. 274

of mortgage. See "Mortgage of Mortgage."

re-demise to mortgagor under first mortgage in Manitoba ..... . 300

rights by implication in ....................... 290

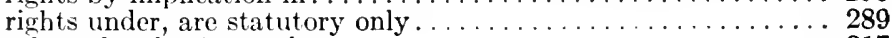

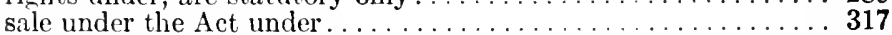

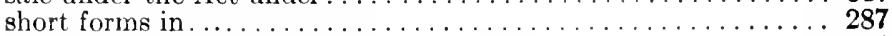

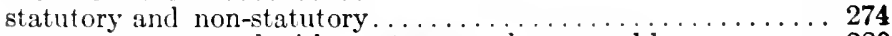

statutory, compared with mortgage under general law....... 280

tacking ............................... 347 
Mortgage, continued

technical objections cleared in Míanitoba.... ...... 299

transfer absolute in form as ...................... . . 278

right of court to declare......................... 279

under system, treated as under general law . . . . . . . . . 282

Mortgage of mortgage,

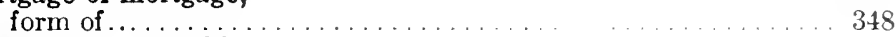

rights conferred by ............................ 348

Mortgagee,

distribution of surplus by, proof of claims in . ........... 338

duty of, on exercising power of sale.................... 327

exereise of all rights through courts only ........... 294, 295

express trustee of surplus proeeeds of sale... . . . . . . . . 337

first, in Manitoba, special position of . ............... 299

treated as holding legal estate...... . . . . . . . . 299

from personal representative. ...................... 251

has rights preseribed by statute only ... _ _.... 289

insuranee against hail by .......... . . . . . . 348

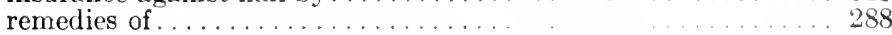

responsible for identity of mortgagor … 216, 217

right in Saskatchewan to make leases. . . . . . 298 to take possession . . . . . . . . . . . . . . . . 298

right to bid ...................... . . 329

to distrain ............... 291, 293

to make leases ...................... 294

to sell, nature of . . . . . . . . . 292

to take possession............... 293

rights of, by implication.............. 290

on own motion................... 291

under system and general law compared.. 283

Mortgagor,

loses right of redemption upon sale....... 333

Negligence,

of registrar, assurance fund liable without any . . 223

omission to file caveat as................. 213,391

to search as. .................... 213,397

where defenec to action against assurance fund. $\quad 212,227$

Notice,

bar to action against assurance fund in Manitoba...

fraud in equity not necessarily fraud under system. $\quad 171,172$

of application for foreclosure .................. . 342

of irregularities, not necessarily cause of fraud... 172

personal service of, unless otherwise specified... $\quad 375$

postpones rights of party receiving............ 155

registration not, to all the world ................ 193

when fraud ........................... 165

Notice of action,

in case of action against assurance fund in Manitoba........ 227

in Saskatchewan, Alberta and the Territories..........224

Notice of exercising power of sale,

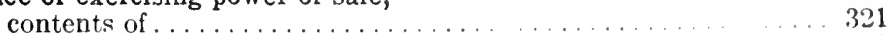

filing of . . . . . . . . . . . . . . . . . . . 322

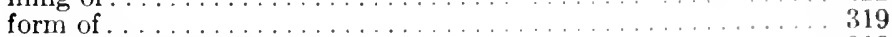

parties to be served ............................... 319

assigns to be served ..................................... 320

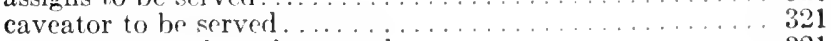

covenantor need not be served ...................... 321 
Notice of exercising power of sale, continued mortgagor who has sold need not be served. . . . . . . . 320

subsequent ineumbrancees to be served............. 321

service of ............................. 322

shortening of period of default required . . . . . . . . . . 325

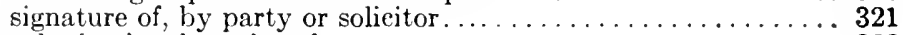

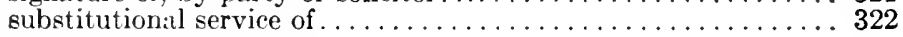

Nova Scotia Land Titles Act,

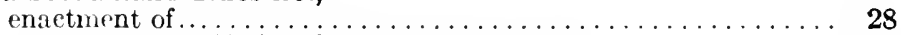

possessory, qualified and absolute titles under ............. 29

recognition of trusts in .................... 29

Occupier, lueaning of ........................... 302

Old system, instruments under, when registerable under new system. . . . . . 92

Ontario,

land titles system, based on English Act..............

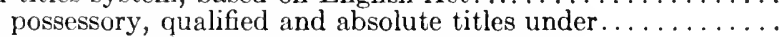
registry systems in ...................... 17

Option,

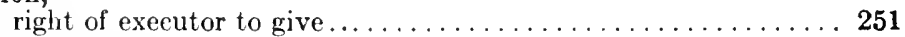

Order of court,

not to be questioned by registrar. . . . . . . . . . . 96

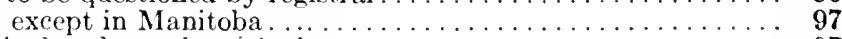

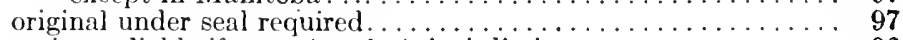

Owner,

registrar liable if no prima facie jurisdiction............ 96

See, also, "Registered Owner."

absolute, distinguished from owner of estate. . . . . . . . 229

Parties, unregistered owners strangers to one another ............... 181

effect of registration on instruments between ........... 180

Party wall agreement, mutual transfer of easement . . . . . . . . . . . . . . 233

Patents,

where sent.

Payment into court,

of surplus proceeds of mortgage sale............. 340

Personal representative,

approval of sales by, in Manitoba............... 35

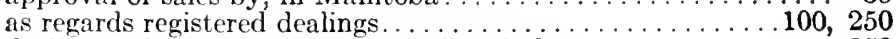

dealings subjeet to general law in Manitoba.............. 253

description as such more than mere addition. . . . . . . . . 255

duty toward benefieiaries. . . . . . . . . . . . . . . 139, 249

may transfer to himself . . . . . . . . . . . . . . . . 255

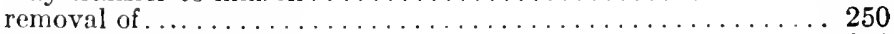

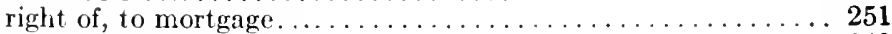

Petition,

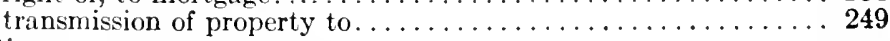

admissibility of new evidence on ............... 40

allegation in, that caveat not disposed of as lapsed ........ 77

allegations in ........................ 79

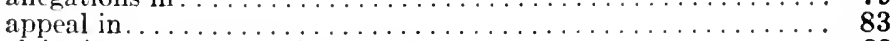

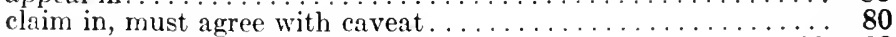

commission to examine witness on $\ldots \ldots \ldots \ldots \ldots \ldots \ldots \ldots .62,83$

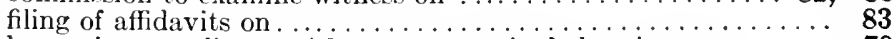

less strict compliance with statute required than in caveat ..... 79 
Petition, continued

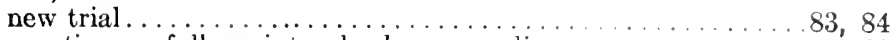

practice on, follows interpleader proceedings.......... 82

proceedings on hearing of ......................... 80

production of documents on ....................... 83

second caveat on dismissal of . . . . . . . . . . . . 84

second, where allowed ....................... 84

security for costs on ........................ 82

to judges in jurisdictions other than saskatchewan … 39,40

Plaintiff,

to master of titles in Saskatchewan ............... 35

\section{Possession,}

who should be on issue $\ldots \ldots \ldots \ldots \ldots \ldots \ldots \ldots \ldots \ldots . \ldots \ldots 2$

proceedings under caveat ............ $\quad 385$

action for, under mortgage......... _ . . . . 313

mortgagee taking under Acts.............. 316

title by. See "Title by Possession."

under mortgage. See "Mortgagee."

Possessory title,

analogous to entry on provisional register in New Zealand ..... 66

distinguished from title by possession................ 66

meaning under Ontario Act................... 27

Power of attorney,

insufficient, effect of registration under............. 187

liability of party taking under to search............. 216

person holding, may apply to bring land under system in Manituba 71

requisites of .................................. 402

\section{Power of sale,}
special, suspends dealings.
402,403

See, also, "Sale under Power."

contractua!, not effective as special covenant.... . 286, 292

not conferred by section 108, Manituba........... 301

under mortgage by way of transfer........... . 278

Practice of conveyancers,

as guide to examination of title under Act ......... 65

Principal and agent,

fraud of principal is fraud of agent............. 169

Private sale,

after abortive sale under mortgage ........... . . . 343

Proceedings, legal, meaning of, under system $\ldots \ldots \ldots \ldots \ldots \ldots \ldots \ldots \ldots \ldots \ldots$

\section{Purchaser,}

at sale under power, rights of .

332

where proceedings defective. . . . 334, 335

bona fide, from holder through fraud .................. 196

claiming under unregistered inst rument protected, unless fraudu-

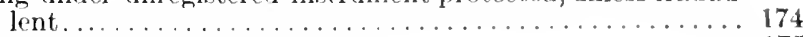

protecterl, af ter registration onl . . . . . . . . . . . . . 175

Qualifications,

from inception of contract.............. 176, 177

on first certificate of title....................... 69

Qualified titles,

meaning of, in Ontario...................... 27

Receiver,

appoint ment of, under mortgage................. 316

Recovery of land,

remedies for. 
Rectification of register,

action for.

Redemption,

on tax transfer

Reference,

informal, to registrar general in Manitoba............ 40

new evidence not admissible on . . ................ 40

to judge as persona designata in provinces other than Manitoba 39, 40

to master of titles in Saskatchewan ............... 35

Registered estate,

defeated by possession for statutory period $\ldots \ldots \ldots \ldots \ldots \ldots 144$

definition of ........................... 122

distinguished from legal and equitable estates........... 123

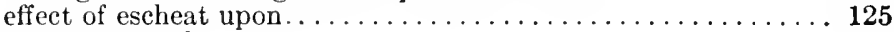

permanency of . ......................... 124

Registered owner,

certificate of title, full name and description of owner required in. . 47

correction of name of owner in ............... 47

post office address of owner and mortgagee in . . . . . . 47

grounds of proceedings against. . . . . . . . . . . . . 164

qualifications of title of $\ldots \ldots \ldots \ldots \ldots \ldots \ldots \ldots \ldots \ldots \ldots, 48$

Registrar,

action for rectification of register, not party to . . . . . . 201

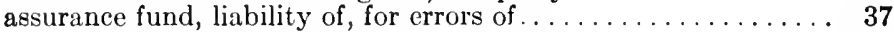

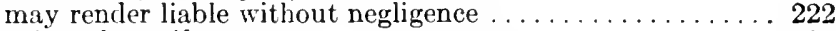

correction of manifest error . . . . . . . . . . . . . . . . 199

determines prima facie validity of instruments .......... 39

priority over judgment in Manitoba . . . . . . . . . . . 38

discretion of, on sale.................... 326

duplicate certificate of title, cannot demand to permit registration 116

duties of, as regards outside information ..........75, 100, 101

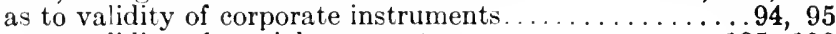

as to validity of special covenants ............185, 186

in examining title on first application ............ 74

on applications to bring complicated titles under system . . . 76

duty of, as regards dealings of a personal representative . . . . . . 2253

in Manitoba......................... 253

in Saskatchewan, Alberta and the Territories......... 254

equitable rights, cannot determine but with three exceptions.....

$97,100,137$

examination of instruments by ............... 92

examines title on application to bring land under system ..... 37

general duty to administer the Act ............... 36

greater discretion in examining first title than subsequent instru-

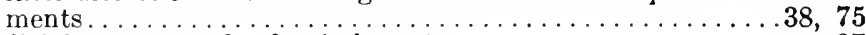

judicial powers confined strictly to Act $\ldots \ldots \ldots \ldots \ldots \ldots \ldots \ldots, \ldots \ldots \ldots$

ministerial and discretionary functions of $\ldots \ldots \ldots \ldots \ldots \ldots 37,93$

not necessary party to proceedings in Canada............ 149

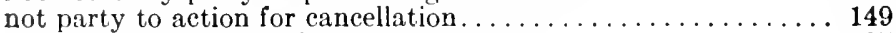

not to extend Acts for beneficial purposes............ 37

personal liability, protection from ................. 36

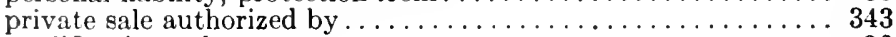

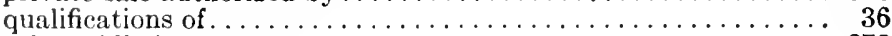

refuses idle instruments . . . . . . . . . . . . . 272

Registrar general,

powers of, in Manitoba.................... 35 


\section{Registration of deeds,}

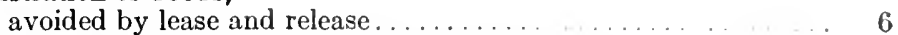

distinguished from registration of title ............... 8

Registration of instruments,

by whom to be effected . . . . . . . . . . . . . . . . . 151

classification of .......................... 90

covering land under old and new systems, invalid.......... 189

distinetion as to, under Torrens and other systems $\ldots \ldots \ldots \ldots 89$

effect of as new certificate of title . ................. 91

effeet of on special covenants in ...................121, 183

fixing of time of ........................... 90

intelligibility as test of fitness for .................... 104

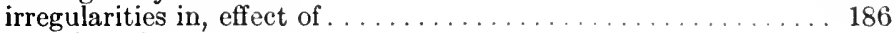

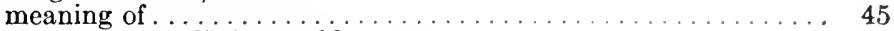

not notice to all the world . . . . . . . . . . . . . . . 193

operation given to special clauses .................121, 183

right to, conferred by unregistered instrument........... 180 includes right to requisites for .................60 $(n)$

special importance of, in Torrens system . . . . . . . . . . 89

when instrument deemed registered ................... 45

where land in more than one district ................. 110

Registration of title,

change in nature of estate caused by ................ 122

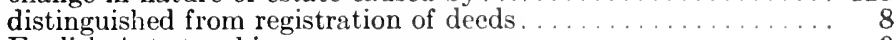

English Acts touching. ......................... 9

first, literal meaning of . . . . . . . . . . . . . . . . . . 122

same as subsequent....................... 120

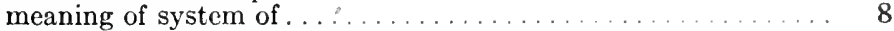

Rejected instruments,

duty of registrar toward ....................... 44

noted in fee book in Manitoba.................... 44

treated as if never received . ......................... 44

Remedies of mortgagee, See "Mortgagee."

Rent charge, may be brought under system. .................... 63

Repair, covenant to, by mortgagor..................... 348

Reservations and exceptions, contained in original grant, always exeepted from certificate of title ..................................... 49

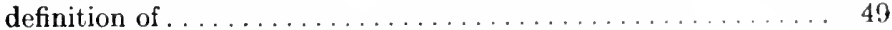
statutory, do not extend to contracts between parties......49, 152 to be set out fully in instruments for registration.......... 110

Reserve bid, on sale under power

Restrictive covenants,

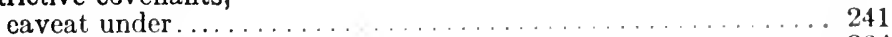

right to .............................. 364

equitable interest ereated by ...................... 244

in instruments. ..................................... 240

where no other land involved................... 244, 245

Right of way,

acquirel under Irrigation Acl, protected in Saskatchewan . . . . 57

under statute, protected in Alberta ................. 57 
Right of way, public,

excepted from certificate of title ................ 54

in all cases in Manitoba........................... 54

Sale,

in gross, not protected as an easement............. 55

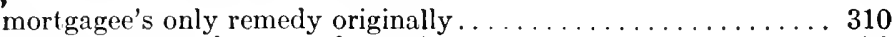

under mortgage by way of transfer . . . . . . . . . . . . . 278

Sale by the court,

under mortgage . . . . . . . . . . . . . . . . . . . . . . . . . 304

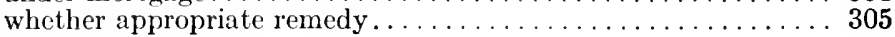

Sale under power,

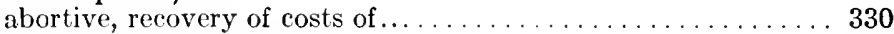

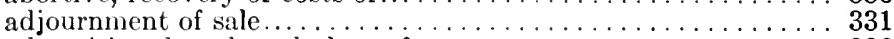

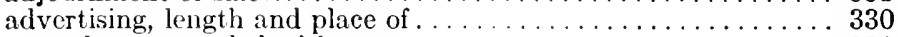

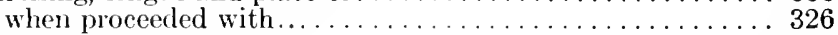

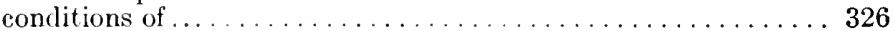

defective proceedings, effect of $\ldots \ldots \ldots \ldots \ldots \ldots \ldots \ldots 33,334$

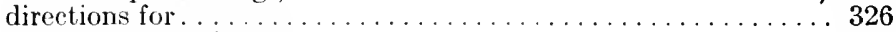

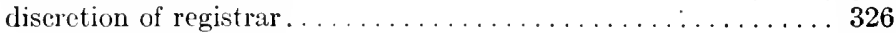

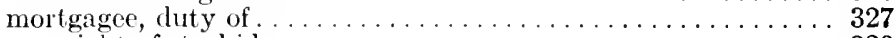

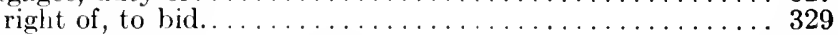

mortgages indorsed on first certificate, of . . . . . . . . . 318

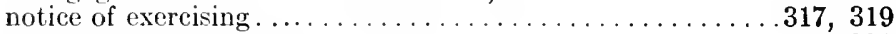

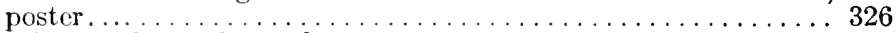

private sale not favored . . . . . . . . . . . . . . 331

procedure not governed by special covenants........... 286

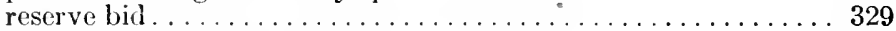

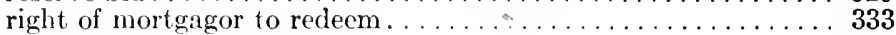

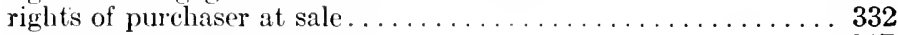

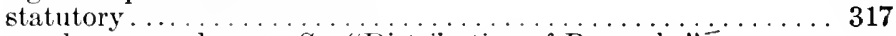

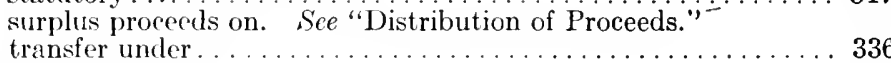

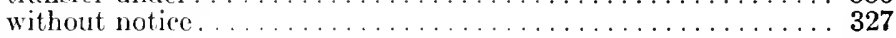

Search,

neglect to, relieves assurance fund............... 213

Second caveat,

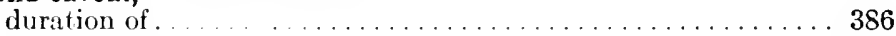

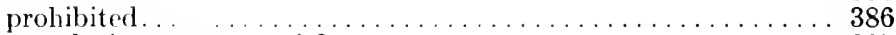

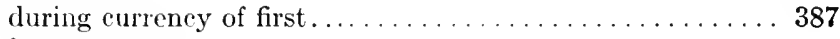

Security for costs,

on petition .......................... 82

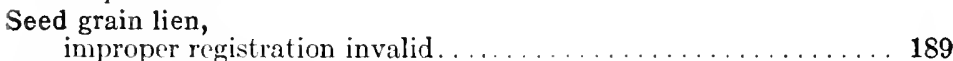

Service,

of notice of exercising power of sale, when complete........ 325

Settlement, none under Canadian Acts

Short forms, ill mortgages..

Special clauses, registration giving operation to . . . . . . . . . . . . 183, 184

Special covenants,

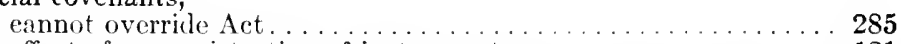
effert of, on registration of instruments.............. 121 ineffective to regulate service of notice of exercising power of sale.. 323 in mortgages, not to conflict with inst rument ............ 285 
Statute of Limitations,

not repugnant to Torrens Acts. . . . . . . . . . . . . . . 143

Sub-infeudation,

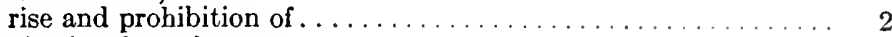

Substitutional service,

Tacking,

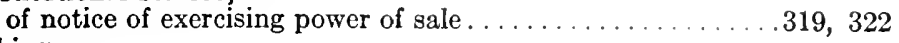

Taxes,

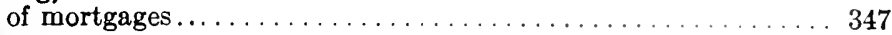

arrears required to be paid on transfer in Manitoba......... 51

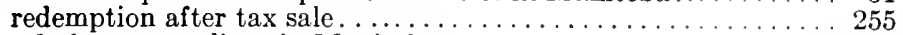

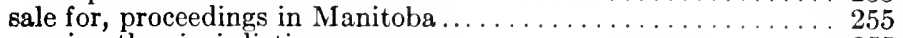

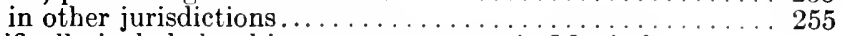

specifically include local improvement rates in Manitoba . . . . . . 50

unpaid taxes and tax transfers....................... 256

unpaid taxes excepted from certificate of title........... 50

Tax transfer,

treated as including tax transfers............50, 256

caveat under............................ 50

Title,

treated as excepted from certificate of title..........50,256

See "Title by Possession."

examination of, before registry systems. . . . . . . . 6,11

investigated sixty years back ....................... 6

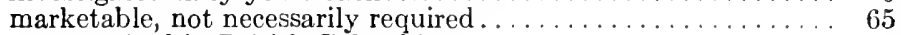

required in British Columbia......................... 64

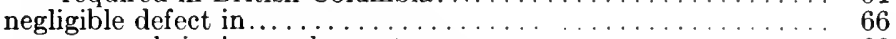

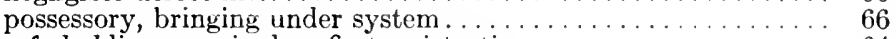

safe holding, required on first registration............. 64

Title by possession,

See, also, "Adverse Possession."

acquisition of, does not remove land from system .......124, 125

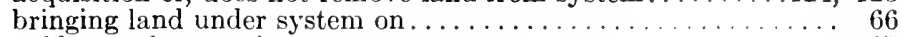

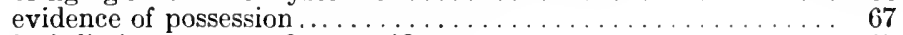

jurisdiction to grant first certificate on . . . . . . . . . . 67

Title deeds,

duplicate certificate of title takes place of ........... 59

Torrens, Sir Robert,

originates South Australian system..............9, 13

Torrens system,

Act overrides other Acts ... . . . . . . . . . . . . . . . . 139

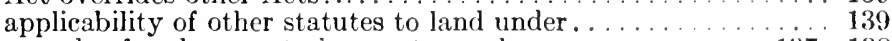

as code of real property law, not complete............ 137, 138

Canada Land Law Amendment Association advocates in Canada

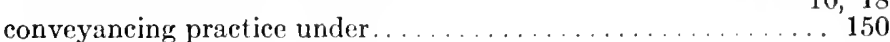

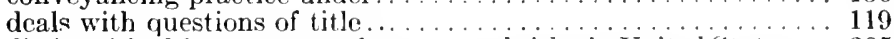

distinguished from system of guaranteed titles in United States. . . 205

evils designed to remedy . . . . . . . . . . . . . . . . 8

first advocated in Canada ................... 10

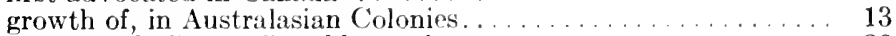

Holmested, George S., address of on . . . . . . . . . . . 20

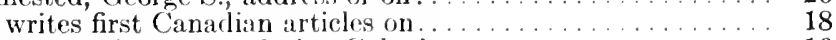

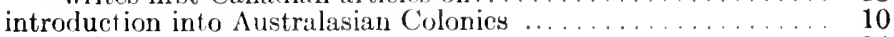

British Columbia ......................... 24

Manitoba........................... 19

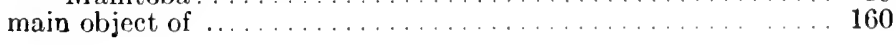




\section{Torrens system, continued}

modeled on Shipping Acts $\ldots \ldots \ldots \ldots \ldots \ldots \ldots \ldots \ldots \ldots$

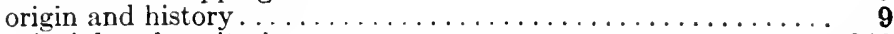

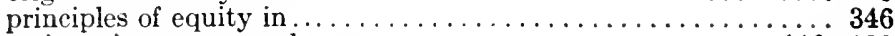

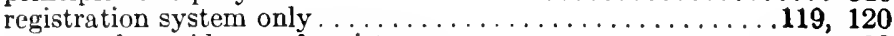

statutes for guidance of registrars $\ldots \ldots \ldots \ldots \ldots \ldots \ldots \ldots \ldots, 98 \ldots \ldots \ldots \ldots$

two main objects of ....................... 138

Torrens system in Western Canada,

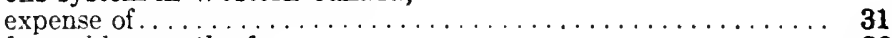

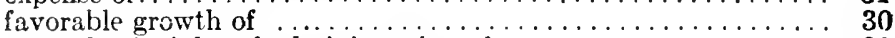

general principles of administration of $\ldots \ldots \ldots \ldots \ldots \ldots \ldots, 32$

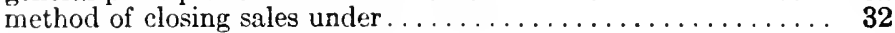

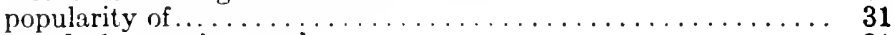

speed of operations under...................... 31

Transfer,

absolute in form as equitable mortgage $\ldots \ldots \ldots \ldots \ldots \ldots 278$

contrasted with deed $\ldots \ldots \ldots \ldots \ldots \ldots \ldots \ldots \ldots \ldots \ldots \ldots \ldots$

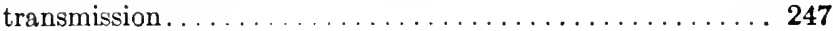

equivalent to quit claim . . . . . . . . . . . . . . 230

estoppel, operation by ....................... 230

execution of, before transferor registered owner ......... 230

memorandum of incumbrances in ............... 239

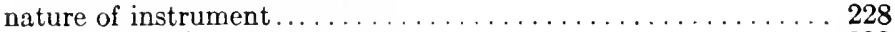

not creation of new estate . . . . . . . . . . . . . 233

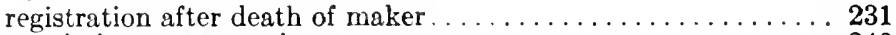

restrictive covenants in ................... 240

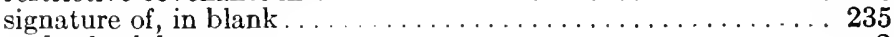

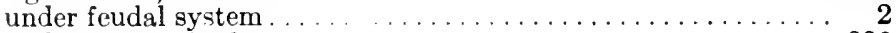

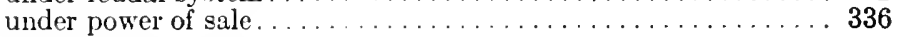

Transferee,

implied covenant with mortgagee . . . . . . . . . . . . 237

responsible for identity of transferor . . . . . . . . . . 215

Transferor, death of, before registration of transfer $\ldots \ldots \ldots \ldots \ldots \ldots$

Transmission,

cases of.

$.246,271$

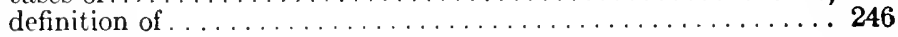

Trustee Acts, read in conjunction with Torrens Acts . . . . . . . . . 140

Trustee Relief Act,

Trusts, payment into court under, by mortgagee . . . . . . . . . . 340

breach of, no ground against assurance fund in Manitoba. . . 227

in Saskatchewan, Alberta and the Territories......... 219

doctrine of, under Statute of Uses . . . . . . . . . . . . . . 4

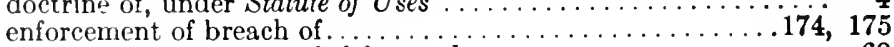

in Crown grant not carried forward $\ldots \ldots \ldots \ldots \ldots \ldots \ldots \ldots$

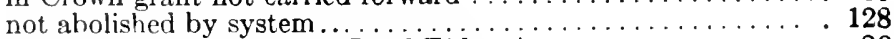

recognized by Nova Scotia Land Titles Act................ 29

Undivided interests, will not be brought under system in Manitoba $\ldots \ldots \ldots \ldots .64,71$

Undue influence, is actual fraud.

United States,

growth of Torrens system in

registry systems in 
Unregistered instruments,

effeet of, between parties same as when registered . . . . . . . 178

between themselves ....................... 181

establish no lien on land ...................... 130

holder may treat certificate of title as unimpeachable . . . . . . . 192 jurisdiction of eourt to establish liens under...........130, 131

Unregistered interests,

actual rights in land . . . . . . . . . . . . . . . . . 149

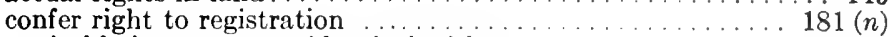

equitable interests, not identical with ............... 137

exist under English Act ........................ 28

Ontario Act............................. 28

memorandum of, on first certificate of title ........... 88

nature of ........................... 126

unenforceable where notice of breach of trust ....... 174, 175

unregistered estate, equivalent to .................. 133

when may prevail against certificate of title ............. 164

Uses, Statute of,

complexity of conveyancing under ................ 5

Court of Chancery defeats....................... 4

effect of, on conveyanees...................... 3

legal and equitable estates under................. 5

rise of trusts from ......................... 4

Voluntary transfer,

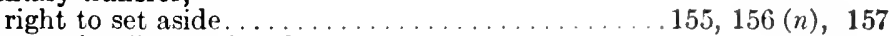

Volunteer,

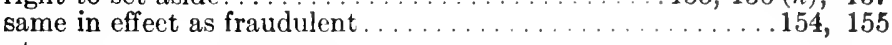

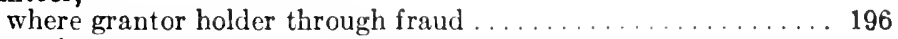

Written instrument,

required as foundation of caveat in Saskatchewan ........ 366 


\section{APPENDIX $\mathrm{H}$}

\section{A TABULAR SUMMARY OF TORRENS TITLE LEGISLATION IN MANITOBA, SASKATCHEWAN, ALBERTA AND THE NORTHWEST TERRITORIES.}

\section{Province of Manitoba.}

1885. 48 Vict. chapter 28.-The Real Property Act of 1885. Went into force July 1, 1885. Consolidated and repealed by The Real Property Act of 18.99 .

1886. 49 Vict. chapter 28.- "An Act to amend The Real Property Act of 1885 , and for other purposes."

1887. 50 Vict. chapter 11.- "An Act to further amend The Real Property Act of 1885, and the Act amending the same."

1883. 51 Viet. chapter 21.- "An Act to further amend The Real Property Act of 1885, and for other purposes."

1888. 51 Vict. chapter 22.- "An Act to amend The Real Property Act of $18 S 5$ and amending Acts."

1889. 52 Vict. chapter 16.- "An Act respecting Real Property in the Province of Manitoba." Cited (section 1) as The Real Property Act of 18s9. Consolidates and repeals (sections 2, 18, 152) all the foregoing Acts. This Act was itself with amendments consolidated by R. S. M. (1891) chapter 133.

1890. 53 Vict. chapter 5.- "An Act to amend chapter 16 of 52 Vict. being 'An Act respecting Real Property in the Province of Manitoba." "

1891. 54 Vict. chapter 6.- "An Act to amend chapter 16 of 52 Vict., being 'An Act respecting Real Property in the Province of Manitoba and amendments."'

1891. Revised Statutes of Nanitoba, chapte: 133.-The Real Property Act (section 1) consolidates The Real Property Att of $18 S 9$ and amending Arts.

1894. 57 Vict. chapter 30.- "An Act to amend The Real Property Act." (R. S. M. chapter 133.)

1896. 59 Vict. chapter 24.- "An Act to amend The Real Property Act." (R. S. M. chapter 133.)

1897. 60 Vict. chapter 30.- "An Act to amend The Real Property Act." (R. S. M. chapter 133.)

1898. 61 Vict. chapter 45.- "An Act to amend The Real Property Act." (R. S. M. chapter 133.)

1900. 63 \& 64 Vict. chapter 47.- "An Act respecting Real Property in the Province of Manitoba." (Amending and eonsolidating R. S. M. chapter 133 and anendments thereto. Cited as The Real Property Act.)

1901. 1 Edw. VII, chapter 42.- "An Act to amend The Real Property Act, being chapter 47 of $63 \& 64$ Vict."

1 Edw. VII, chapter 43.- "An Act to amend The Real Property Act."

1902. 1 \& 2 Edw. VII, chapter 43 (March 1, 1902)._."An Act respecting Real Property in the Province of Manitoba." (Amending and Consolidating R. S. M. chapter 133 and amendments thereto. Cited as The Real Property Act.) 
1902. Revised Statutes of Manitoba 1902, chapter 148.--"An Act respecting Real Property in the Province of Manitoba." (In force March 6, 1903.)

1903. 3 Edw. VII, chapter 3S. - "An Act to amend The Real Property Act."

1904. 3 \& 4 Edw. VII, chapter 50. - "An Act to amend The Real Property Act."

1905. 4 \& 5 Edw. VII, chapter 41. - "An Act to amend The Real Property Act."

1906. 5 \& 6 Edw. VII, ehapter 74.- "An Act to amend The Real Property Act."

5 \& 6 Edw. VII, chapter 75.- "An Aet to amend The Real Property Act."

1908. 7 \& 8 Edw. VII, chapter 52.- "An Act to amend "The Real Properly Act."

1911. 1 Geo. V, chapter 49.- "An Act to amend The Real Property Act."

\section{Dominion of Canada.}

(Territories, ineluding the districts now comprising the Provinces of Saskatchewan and Alberta.)

1878. Bill introduced by the Hon. David Mills, Minister of the Interior, to apply the Torrens system to the Northwest Territories.

1883. Bill for the same purpose by Mr. Dalton MeCarthy, Q. C., read a first time in Commons, April 12th.

1884-85. Bill for the same purpose by Hon. Sir Alexander Campbell, Minister of Justice, earricd through the Senate and read a first time in Commons.

1886. 49 Vict. chapter 26 (D).- "An Act respecting Real Property in the Territories." Cited (section 1) as The Territories Real Property Act. Repealed and re-enacted by R. S. C. chapter 51 .

1886. Revised Statutes of Canada (R. S. C.) chapter 51.--Re-enacting the preceding Act. Repealed by Land Tilles Act 1894.

1887. $50 \& 51$ Vict. ehapter 30 (D). - 'An Act to amend The Revised Statutes, chapter 51, respecting Real Property in the Tcrritories." Repealed by Land Titles Act 1894.

1888. 51 Virt. chapter 20 (D).- "An Aet to further amend chapter 51 of The Revised Statutes of Canadal, The Territorics Real P'reperty Act." Repealed by Land Titles Act, 1894 .

1894. $57 \& 58$ Vict. chapter 28 (D).- "An Act to consolidate and amend the Acts respecting Land in the Territories." Cited (section 1) as The Land Titles Act 189\%. Repeals (by section 146) R. S. C. (1886) chapter 51; 50 and 51 Virt. chapter 30 ; and 51 Viet. ehapter 20. In this Act "Territorics" means 'The Northwest Territories, the District of Kcewatin, and all Territories of Canada. Section $2(q)$.

1897. $60 \& 61$ Vict. chapter 30.- "An Act to amend The Land Titles Act 1894."

1898. 61 Virt. chapter 32.- "An Act further to amend The Land Titles Act 1894."

1899. $62 \& 63$ Virt. chapter 17.- " $\Lambda \mathrm{n}$ Act to further amend The Land Titles Act 1894."

1900. 6.3 \& 6.t Vict. chapter 21.-An Act to amend The Land Titles Act 189\%."

1902. 2 Edw. VII, chapter 17.- "An Act to amend The Land Titles Ast 1894." 


\section{DOMINION OF CANADA, continued}

1904. 4 Edw. VII, chapter 19.- "An Act to amend The Land Titles Act 1894."

1905. 4 \& 5 Edw. VII, chapter 18.- "An Act to amend The Land Titles Act 1894."

\section{Province of Saskatchewan.}

1906. Chapter 24.- "An Act respecting Land in the Province of Saskatchewan." (Cited as The Land Titles Act. Came into force September 8, 1906.)

1907. Chapter 32 , $\S \S 5,6,7,8,9$ and 10 of The Statute Law Amendment Act $19 n \%$.

1908. Chapter 29.-."An Act to amend The Land Titles Act."

1908-09. Chapter 9.- "An Act to amend The Land Titles Act."

1909. Chapter 20.- "An Act to amend The Land Titles Act."

1909. Revised Statutes of Saskatchewan 1909, chapter 41.- "An Act resperting Land in the Province of Saskatchewan." (Cited as The Land Titles Act. In force March 15, 1911.)

1910-11. Chapter 12.-"An Act to amend The Land Titles Act."

1912. Chapter 16.- "An Act to amend The Land Titles Act."

\section{Province of Aleerta.}

1906. Chapter 24._- An Act respecting Real Property in the Province of Alberta." Cited as The Land Tilles Art.

1907. Chapter 5, § 20, of "An Act to amend The Statute Law."

1908. Chapter $20, \S 15$. "An Act to amend The Statute Law."

1909. Chapter 4, \$ 11, of "An Act to amend The Statute I aw, Part I.",

1909. Chapter 5, $\$ 9$, of "An Act to amend The Statute Law, Part II."

1910. (Second Session.) Chapter 2, \& 12, of The Statute Law Amendment Act.

1911-12. Chapter 4, $\S 15$, of "The Statute Law Amendment Act."

\section{Dominion of Canada. (Territories.)}

1906. Revised Statutes of Canada 1906, chapter 110, The Land Tilles Ad (In force January 31,1907 .)

1908. 7 \& 8 Edw. VII, chapter 41._- "An Act to amend The Land Titles Act."

1910. $9 \& 10$ Edw. VII, chapter 36._."An Act to amend The Land Titles Act." 
The following shall, on, from and after the fiftentl tay of February, A.D. 1911, be the tariff of charges to be eharged ly ealch district registrar under said "The Real Property Act":

\section{FEES ON APPLITATON.}

The fees to be paid on application to bring land under the Act shall be as follows, inclusive of contribution to Assurance Fund:

Where the value of the land does not exeed $\$ 500 \ldots \ldots \ldots .5 .00$

On each $\$ 500$ value thereafter, or fraction thereof, ardd $\$ t$ mutil value reaches $\$: 3,000$.

On each $\$ 500$ value thercafter, or fraction thereof, ald $\$ 3$ until value reached is $\$ .5,(1000$.

On each $\$ 1,000$ value thereafter, or fraction thereof, add $\$ 3$.

When the applieant is the original guarantee from the Crown, and there is no rloul on the title and no transaction affects the land other than leases, mortgages, fi-fas, certificates of judgment or' other' charges or liens, the fees shall in all cases be one-half of the ahove-named fees.

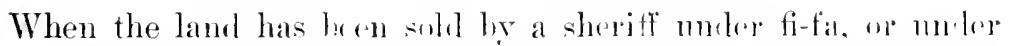
power of sale in al mortange, or has been in puestion in any snit or procesting in ecpuity, a further fee nu n the following seake shall be wharesel for carch mortgalge sale, or for each suit or proceseding which it shall be necessary for the examiner to inquire into:

When the value of the land does not "xeeed $\$ 500 \ldots \ldots \ldots$

On each additional $\$ 1,000$ value thereafter, or fraction thereof, until the value reaches $\$ 4,600 \ldots \ldots \ldots \ldots \ldots \ldots . \ldots \ldots$

When the value exceets $\$ 1,500 \ldots \ldots \ldots \ldots \ldots \ldots \ldots \ldots .7 .00$

For examination of earh document in support of an applieation

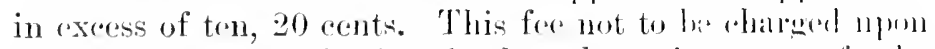

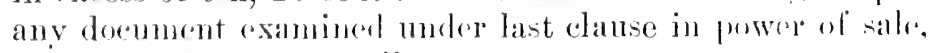
sheriff or equity procendings.

For filing with the alphiration, ranch mortgage, converamer, release or other link in the ehain of title, exeept patent or discharge of mortgage $\ldots \ldots \ldots \ldots \ldots \ldots \ldots \ldots$

For filing each patent or discharge of mortgage ........... 


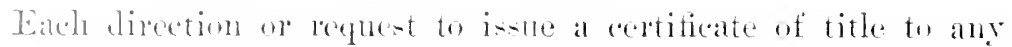

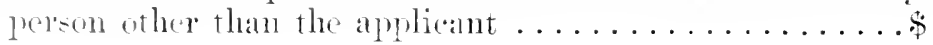

FEES OX TRAXSMISTIUSS.

The fees to be pairl on all transmisions will he as fullows:

Then the ralne of the land does not exced \$ $500 \ldots \ldots \ldots \$ 5.00$

When the ralue of the land lues not exered $\$ 1.000 \ldots \ldots .8 .00$

When the ralue of the lamel dues nut exceed $\$ 1.500 \ldots \ldots .10 .99$

When the value of the land lese not exceed \$2.000 . . . . 12.00

On each $\$ 1,000$ thereafter, or fraction the reof. ald..... 2.00

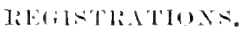

Fegistering tran-for of land (inchuling for for certificate of title, and tee for tax and other salpelest.........

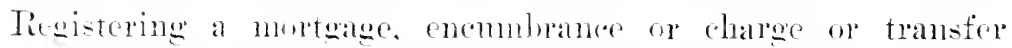
thereof (inchuding eeptiticats of (harese), where the money

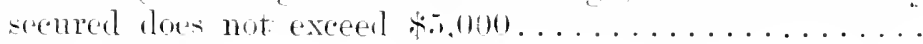

On each $\$ 1$, 000 , or fraction thereof. 113 to $\$ 10,000$, a further fee of $\$ 1$; and on each $\$ 1$.0010), w traction thereot, orer $\$ 10,000$, a further fer of 50 ents. until the total registrattion fee shall reach $\$ 25$.

On registration of morteages by anpolation- axecontors or anministrator's, or on registration of transfers of land to or from corperations. executers on alministraters. the distriet

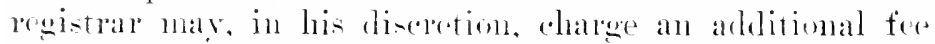
of not lese than $\$ 1$ nor more than $\$ 10$ tor inrestigation of eridence.

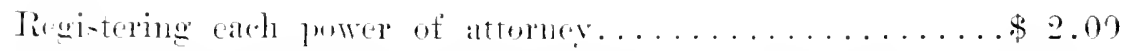

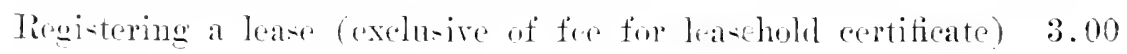

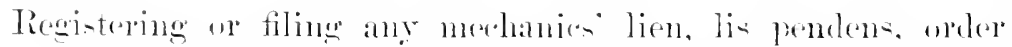

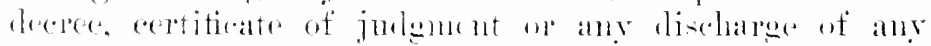

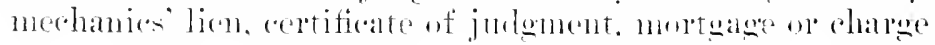

Regitering an instrument other than those herein provided for 2.00

Flloldis.

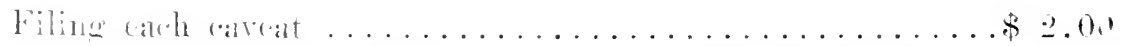

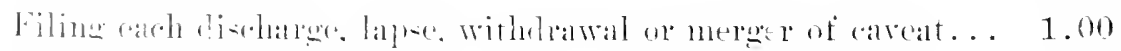

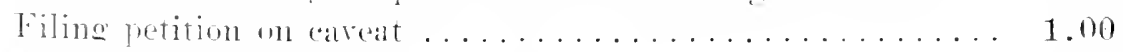

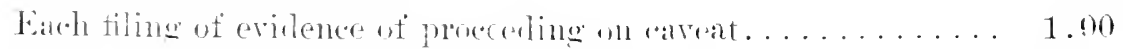

Filing proceding moler purer of -ille............. . .00

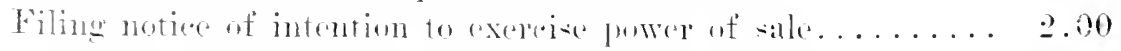






